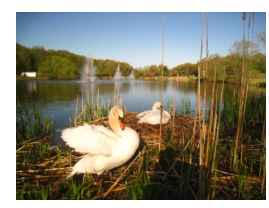

Western Michigan University Medieval Institute Publications/Arc Humanities Press

$10-2-2015$

\title{
A Bibliographical Guide to the Study of the Troubadours and Old Occitan Literature
}

Robert A. Taylor

Follow this and additional works at: https://scholarworks.wmich.edu/mip_rmemc

Part of the European History Commons, European Languages and Societies Commons, French and Francophone Literature Commons, Medieval History Commons, Medieval Studies Commons, and the Other Spanish and Portuguese Language and Literature Commons

\section{Recommended Citation}

Taylor, Robert A., "A Bibliographical Guide to the Study of the Troubadours and Old Occitan Literature" (2015). Research in Medieval and Early Modern Culture. 2.

https://scholarworks.wmich.edu/mip_rmemc/2

This Reference is brought to you for free and open access by the Medieval Institute Publications at ScholarWorks at WMU. It has been accepted for inclusion in Research in Medieval and Early Modern Culture by an authorized administrator of ScholarWorks at WMU. For more information, please contact wmuscholarworks@wmich.edu.

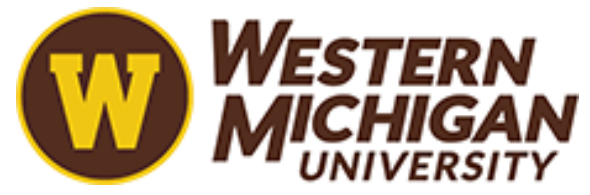


? A Bibliographical Guide

MEDIEVAL to the Study of the Troubadours and Old Occitan Literature

Robert A. Taylor 


\section{Bibliographical Guide to the Study of the Troubadours and Old Occitan Literature}


Medieval Institute Publications is a program of The Medieval Institute, College of Arts and Sciences

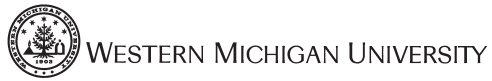




\title{
Bibliographical Guide to the Study of the Troubadours and Old Occitan Literature
}

\author{
Robert A. Taylor
}

MEDIEVAL INSTITUTE PUBLICATIONS

Western Michigan University

Kalamazoo 
Copyright (C) 2015 by the Board of Trustees of Western Michigan University All rights reserved Manufactured in the United States of America This book is printed on acid-free paper.

\section{Library of Congress Cataloging-in-Publication Data}

Taylor, Robert A. (Robert Allen), 1937-

Bibliographical guide to the study of the troubadours and old Occitan literature / Robert A. Taylor.

pages $\mathrm{cm}$

Includes index.

Summary: "This volume provides offers an annotated listing of over two thousand recent books and articles that treat all categories of Occitan literature from the earliest enigmatic texts to the works of Jordi de Sant Jordi, an Occitano-Catalan poet who died young in 1424. The works chosen for inclusion are intended to provide a rational introduction to the many thousands of studies that have appeared over the last thirty-five years. The listings provide descriptive comments about each contribution, with occasional remarks on striking or controversial content and numerous cross-references to identify complementary studies or differing opinions" -- Provided by publisher.

ISBN 978-1-58044-207-7 (Paperback : alk. paper)

1. Provençal literature--Bibliography. 2. Occitan literature--Bibliography. 3.

Troubadours--Bibliography. 4. Civilization, Medieval, in literature--Bibliography.

I. Title. II. Title: Troubadours and old Occitan literature.

Z7033.P8T39 2015

[PC3301]

016.849'1040902--dc23

2015004437

ISBN 978-1-58044-215-2 (clothbound : alk. paper)

eISBN 9781580442084 


\section{Contents}

Preface $\quad$ xix

$\begin{array}{ll}\text { Sigla/Abbreviations/Symbols } & \text { xxiii }\end{array}$

I. Reference Works

1. Bibliographies

1.1. General Bibliographies 1

1.2. Annual or Periodic Bibliographies 2

1.3. Specialized Bibliographies $\quad 2$

1.4. Linguistic Bibliographies 3

1.5. Bibliographical Theory 3

2. Alphabetized Reference

2.1. Dictionaries

2.2. Concordances 5

2.3. Encyclopedias 6

3. Aids to Research

3.1. Electronic Resources 8

3.2. Indexes, Databases, Checklists 9

3.3. History of Occitan Scholarship, Reception Studies, Medievalism 11

[See also listings under V. Related Fields.]

$\begin{array}{ll}\text { 3.3.1. État-présent Studies } & 11\end{array}$

$\begin{array}{lr}\text { 3.3.2. Sociopolitical Forces and Scholarship } & 12\end{array}$

$\begin{array}{ll}\text { 3.3.3. Medievalism: Legends and Popularizing Studies } & 13\end{array}$

3.4. Research in Progress, Goals for the Future 14

4. Collective Research Publications

$\begin{array}{ll}\text { 4.1. Periodicals } & 16\end{array}$

4.2. Conference Proceedings (Professional Organizations) 17

4.3. Congress and Colloquium Proceedings 19

4.4. Collective Publications: Mélanges/Festschrift Volumes 21

5.1. Practical Guides

5.2. Philological Research 24 
6. Manuscript Sources

6.1. The Chansonniers: General Studies

6.2. Individual Chansonniers

6.3. Editing Theory and Practice

7. Anthologies

[For musical anthologies, see 13.2; for anthologies of trobairitz poetry, see 14.3.]

7.1. Troubadour Lyric Anthologies

7.2. Comprehensive Anthologies (Lyric, Non-Lyric, and Prose) 37

7.3. Contre-texte Anthologies

7.4. Specialized Anthologies

8. Attribution Studies

8.1. General

\section{Literary Criticism (Lyric)}

9. Orientation

9.1. Guides to the Field

9.2. Sociohistory

9.2.1. General Studies

9.2.2 Courts and Patronage

9.2.3 Politics and Poetry

9.3. Literary History (Overview: Lyric, Non-Lyric, Prose)

9.4. Introduction to Occitan Lyric Poetry

10.1. General Studies

$$
\text { 10. Origins }
$$

10.2. Arabic Theory

10.3. Latin Theory

10.4. Popular Theory (Indigenous Sources)

11. The Love Ethic: Definition of Fin'amors

11.1. General Studies of the Love Ethic

11.2. Themes of Troubadour Poetry (Motifs, Images, Topoi)

11.3. Vocabulary, Terminology of Fin'amors 
12.1. General

12. Genres of Troubadour Lyric

12.2. Canso

12.3. Sirventes

12.3.1 Mala Canso

12.4. Tenso, Partimen $\quad 80$

12.5. Pastorela

12.6. Alba $\quad 83$

12.7. Salut d'amor $\quad 87$

12.8. Sestina 89

12.9. Planh 91

12.10. Descort

12.11. Minor Genres (Balada, Cobla, Comjat, Dansa, Devinalh, 94 Enueg/plazer, Estampida, Estribot, Gap, Porquiera, Other Minor or Fictious Genres, Escondig)

13. Music

13.1. General Studies

13.2. Musical Anthologies 103

13.3. Manuscript Sources, Transmission $\quad 105$

$\begin{array}{ll}\text { 13.4. Structural Analysis } & 106\end{array}$

$\begin{array}{ll}\text { 13.5. Performance } & 107\end{array}$

$\begin{array}{ll}\text { 13.6. Contrafacture } & 111\end{array}$

13.7. Text/Melody Relationship 113

$\begin{array}{ll}\text { 13.8. Single Poets and Works } & 116\end{array}$

13.9. Electronic Resources for Musicology 119

13.10. Discography 119

14. The Trobairitz

14.1. Medieval Women

14.2. General Studies of Trobairitz 122

14.2.1. Annotated Bibliography 122

$\begin{array}{lr}\text { 14.2.2. Encyclopedias } & 122\end{array}$

$\begin{array}{ll}\text { 14.2.3. Introductory Studies } & 123\end{array}$

$\begin{array}{ll}\text { 14.2.4. Specialized Studies } & 124\end{array}$

14.3. Anthologies of Trobairitz Poetry 126

14.3.1. Complete Anthologies 126

$\begin{array}{lr}\text { 14.3.2. Specialized Anthologies } & 128\end{array}$

$\begin{array}{ll}\text { 14.4. Feminist, Gender Criticism } & 128\end{array}$

14.5. Establishing the Trobairitz Corpus 130

14.6. Real Women or Fictitious? 132

14.7. Distinguishing Features of Trobairitz Poetry 134

14.8. Individual Trobairitz 136 
viii Contents

15. Critical Approaches to Literary Analysis

15.1. General Studies of Critical Methodology

15.2. Formalistic Analysis

15.3. The Debate: Orality versus Literacy

15.4. Psychocritical Approach

15.5. Rhetorical Analysis, Metrics, Versification 149

$\begin{array}{ll}\text { 15.6. Intertextuality } & 154\end{array}$

15.7. Trobar Clus

159

15.8. Plurilinguistic, Hybrid-Language Texts

161

15.9. Electronic Analysis (Methodology, Practical Applications)

$$
\text { IV. Literary Criticism (Non-Lyric) }
$$

16. General Studies of Non-Lyric Literature

17.1. General Studies

$\begin{array}{lr}\text { 17.2. Two Medical Charms } & 166\end{array}$

$\begin{array}{lr}\text { 17.3. Bilingual Alba } & 168\end{array}$

$\begin{array}{ll}\text { 17.4. Latin Farci } & 169\end{array}$

$\begin{array}{ll}\text { 17.5. Passion of Augsburg } & 170\end{array}$

$\begin{array}{ll}\text { 17.6. Passion of Clermont-Ferrand } & 171\end{array}$

$\begin{array}{ll}\text { 17.7. Boeci } & 172 \\ 17.8 . \text { Sainte Foy (Canso de Sancta Fides) } & 173\end{array}$

17.8. Sainte Foy (Canso de Sancta Fides) 173

$\begin{array}{ll}\text { 17.9. Two Harley Lyrics } & 175\end{array}$

$\begin{array}{ll}\text { 17.10. Alexandre } & 176\end{array}$

$\begin{array}{ll}\text { 17.11. Life of St. Leger } & 177\end{array}$

$\begin{array}{ll}\text { 17.12. Sponsus } & 178\end{array}$

17.13. Two Poems to the Virgin ("Versus Limousins") 179

$\begin{array}{lr}\text { 18.1. General Epic } & 180\end{array}$

18.2. Aigar e Maurin $\quad 182$

18.3. Canso d'Antiocha 183

18.4. Roman d'Arles 184

$\begin{array}{ll}\text { 18.5. Brendan } & 185\end{array}$

18.6. Canso de la Crozada 186

$\begin{array}{lr}\text { 18.6.1. Bibliography } & 186\end{array}$

$\begin{array}{lr}\text { 18.6.2. Editions } & 186\end{array}$

$\begin{array}{ll}\text { 18.6.3. General Studies } & 187\end{array}$

18.7. Daurel e Beton 191

18.8. Ferabratz 193

18.9. Girart de Rossilhon 194 
19. Narrative Literature

19.1. General Studies

19.3. Andrieu de Fransa (André de France)

19.5. Blandin de Cornualha (et Guillot Ardit de Miramar) 209

19.6 Castia-gilos

19.7. Esther (Roman de la Reine Esther)

19.9. Filomena (Roman de Notre Dame de la Grasse)

19.12. Guilhem de la Barra (Las aventuras de mosenher G. de la Barra)

19.14. Judici d'amor (So fo el temps c'om era jais, or En

20. Dramatic Literature

20.1. General Studies

20.3. Esposalizi de Nostra Dona (Sancta Maria Verges et de Jozep)

\section{Didactic Literature}

22.1. General Studies 
22.5. Ensenhamens: General Studies 260

22.5.1 Cabra joglar, Fadet joglar, Gordo 261

22.5.2. Ensenhamen au cavayer (Qui comte vol aprendre) 262

22.5.3. Ensenhamen alla dama (El termini d'estiu) 262

22.5.4. Ensenhamen del escudier (El temps de nadalor) and Ensenhamen de 263 la donzela (En aquel mes de mai)

22.5.5. Ensenhamen del guarso (L'autrier mentre ques ieu m'estava) 264

22.5.6. Ensenhamen d'onor (Aissi co.l tesaurs es perdutz) 264

22.5.7. Razos es e mesura 264

22.5.8. Abrils issi' e mays intrava 265

22.5.9. Ensenhamen au jongleur (Si tot non es enquistz) 266

22.6. Novas de l'heretge 266

$\begin{array}{ll}\text { 22.7. Proverbs } & 267\end{array}$

22.8. Quan tu a la taula seras 269

22.9. [El Romanz] de quatre vertutz principals 270

22.10. Le Savi (Libre de Senequa; Mettra Ceneche) 270

$\begin{array}{ll}\text { 22.11. Sidrac } & 271\end{array}$

$\begin{array}{ll}\text { 22.12. Thezaur } & 271\end{array}$

23. Religious Literature

23.1. General

23.2. Religious Lyric $\quad 273$

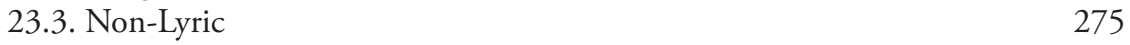

$\begin{array}{ll}\text { 23.4. Sermons } & 277\end{array}$

23.5. The Bible and Apocrypha 278

24. Hagiography

[For Sainte Foy (Canso de Sancta Fides), see 17.8; for Brendan, see 18.5.]

24.1. General Studies

24.2. Barlaam et Josaphat 281

24.3. Vida de la Benaurada Sancta Doucelina 282

24.4. Vida de Santa Enimia 283

24.5. Vida del Glorios Sant Frances 284

24.6. Vida de Sant Honorat 284

24.7. Viatge al Purgatori de Sant Patrici 285

$\begin{array}{ll}\text { 24.8. Other Saints } & 285\end{array}$

25.1. General

25. Nonliterary Texts

25.2. Flora and Fauna $\quad 287$

25.2.1. Romans dels auzels cassadors $\quad 288$

25.3. Legal $\quad 289$ 
25.4. Scientific

V. Related Fields (Diffusion, Influences)

[See also 3.3. History of Occitan Scholarship, Reception Studies, Medievalism]

26. Modern Occitan

27. Medieval Latin

28. Catalan

29. Spanish

30. Northern French (Trouvères, etc.)

31. Galician

32. Sicilian

33. Italian

34. German Minnesänger

35. Cathar Heresy

36. Arabic/Hispano-Arabic

37. Jewish

\section{The Troubadours, Trobairitz}

- 1820-3037: listings for 217 troubadours and trobairitz arranged by PC (BdT) number from PC 2 Ademar Jordan to PC 458 Uguet:

Ademar Jordan (PC 2)

Ademar lo Negre (PC 3)

Ademar de Rocaficha (PC 5)

Aicart del Fossat (PC 7)

Aimeric de Belenoi (PC 9)

Aimeric de Peguilhan (PC 10)

Aimeric de Sarlat (PC 11)

Alaisina Yselda (PC 12)

Alamanda (PC 12a)

Alberjat and Albert (PC 12b and 13)

Albric (PC 16a)

Aldric del Vilar (PC 16b) 
xii

Contents

Amanieu de Sescas (PC 21a)

Anfos [King Alfons II of Aragon] (PC 23)

Arnaut de Brancalo (PC 26)

Arnaut Catalan (PC 27)

Arnaut de Comminges (PC 28)

Arnaut Daniel (PC 29)

Arnaut de Maruelh (PC 30)

Arnaut Peire d'Agange (PC 31)

Arnaut de Tintinhac (PC 34)

Azalais d'Altier (PC 42a)

Azalais de Porcairagues (PC 43)

Azar (PC 44)

Baussan (PC 45)

Comtessa de Dia [Beatritz de Die] (PC 46)

Berenguier de Palazol (PC 47)

Bernart Arnaut d'Armagnac (PC 54)

Bernart Arnaut de Moncuc (PC 55)

Bernart d'Auriac (PC 57)

Bernart de la Barta (PC 58)

Bernart de Durfort (PC 60)

Bernart Marti (PC 63)

Bernart Sicart de Marvejols (PC 67)

Bernart de Tolmon [Tot-lo-Mon] (PC 69)

Bernart de Ventadorn (PC 70)

Bernart de Venzac (PC 71)

Bertolome Zorzi (PC 74)

Bertran d'Alamano (PC 76)

Bertran de Born (PC 80)

Bertran Carbonel (PC 82)

Bertran Folcon d'Avignon (PC 83)

Bertran de Paris de Roergue (PC 85)

Bertran del Pojet (PC 87)

Bertran de Preissac (PC 88)

Bietris de Roman (PC 93)

Lo Vesques de Bazas (PC 94)

Lo Vesques de Clarmon (PC 95)

Blacasset (PC 96)

Blacatz (PC 97)

Bofils (PC 100)

Bonifaci Calvo (PC 101) 
Cadenet (PC 106) 381

Calega Panzan (PC 107) 382

Carenza (PC 108) 383

Castelloza (PC 109) 383

$\begin{array}{ll}\text { Cercamon (PC 112) } & 385\end{array}$

$\begin{array}{ll}\text { Clara d'Anduza (PC 115) } & 387\end{array}$

Cossezen (PC118) 388

Dalfin d'Alvernhe (PC 119) 388

Dalfinet (PC 120) 389

Dante da Maiano (PC 121) 389

Daude de Pradas (PC 124) 390

Eble de Ventadorn (PC 130) 391

Elias de Barjols (PC 132) 391

Elias Cairel (PC 133) 392

Elias Fonsalada (PC 134) $\quad 392$

Elias d'Ussel (PC 136) 393

En Genim d'Urre de Valentines (PC 137) 394

Enric II Comte de Rodez (PC 140) 394

Folquet de Lunel (PC154) 394

Folquet de Marselha (PC 155) 395

Falquet de Romans (PC 156) 396

Garin d'Apchier (PC 162) 397

Garin lo Brun (PC 163) 398

Gaucelm Faidit (PC 167) 398

$\begin{array}{lr}\text { Caudairenga (PC 169) } & 402\end{array}$

Gaudi (PC 170) $\quad 402$

Gausbert Amiel (PC 172) $\quad 403$

Gausbert de Puycibot (PC 173) 403

Gavaudan (PC 174) 404

Geneys lo Joglar (PC 175) $\quad 404$

Gormonda (PC 177) $\quad 405$

Guilhem de Peitieus (PC 183) 406

Coms de Proensa [Raimon Berenguier IV d'Aragon] (PC 184) 415

Garsenda de Forcalquier (PC 187) 415

Granet (PC 189) 416

Grimoart Gausmar (PC 190) $\quad 416$

$\begin{array}{ll}\text { Gui de Cavaillon (PC 192) } & 417\end{array}$

Gui d'Ussel (PC 194) 419

Guilhelma de Rosiers (PC 200) $\quad 420$

Guilhem Ademar (PC 202) $\quad 421$

Guillem d'Anduza (PC 203) $\quad 421$

Guillem Anelier de Tolosa (PC 204) 422

Guilhem Augier Novella (PC 205) 422 
xiv

Contents

Guilhem d'Autpol (PC 206)

Guillem de Berguedan (PC 210)

Guilhem de Cabestanh (PC 213)

Guillem de Durfort (PC 214)

Guillem Figueira (PC 217)

Guillem Godi (PC 219)

Guilhem Magret (PC 223)

Guilhem de Montanhagol (PC 225)

Guilhem de Mur (PC 226)

Guilhem Peire de Cazals (PC 227)

Guilhem Raimon de Gironela (PC 230)

Guilhem Rainol d'At (PC 231)

Guilhem de Saint Gregori (PC 233)

Guillem de Saint-Didier (PC 234)

Guillem de la Tor (PC 236)

Guiraudo lo Ros (PC 240)

Giraut de Bornelh (PC 242)

Guiraut de Cabreira (PC 242a)

Guiraut de Calanso (PC 243)

Guiraut d'Espanha (PC 244)

Guiraut Riquier (PC 248)

Domna H (PC 249a)

Isabella (PC 252)

Iseut de Capion (PC 253)

Jaufre Rudel (PC 262)

Lanfranc Cigala (PC 282)

Lantelm (PC 283)

Lanza Marques (PC 285)

Linhaura (PC 287)

Lombarda (PC 288)

Peire de Lunel (PC 289)

Marcabru (PC 293)

Marcoat (PC 294)

Maria de Ventadorn (PC 295)

Jofre de Foixà (PC 304) 
N'At de Mons (PC 309)

Olivier lo Templier (PC 312)

Ozil de Cadartz (PC 314)

Palais (PC 315)

Paolo Lanfranchi da Pistoia (PC 317)

Paulet de Marselha (PC 319)

Peire d'Alvernhe (PC 323)

Peire II King of Aragon (PC 324)

Peire de Barjac (PC 326)

Peire Basc (PC 327)

Peire de Blai (PC 328)

Peire Bremon Ricas Novas (PC 330)

Peire Bremon lo Tort (PC 331)

Peire de Boussignac (PC 332)

Peire Catalan (PC 333a)

Peire de la Cavarana (PC 334)

Peire Cardenal (PC 335)

Peire de Corbian (PC 338)

Peire Duran (PC 339)

Peire Guilhem (PC 344 and 345)

Peire de Maensac (PC 348)

Peire Milo (PC 349)

Peire de la Mula (PC 352)

Peire Raimon de Tolosa (PC 355)

Peire Rogier (PC 356)

Peire de Valeira (PC 362)

Peire Vidal (PC 364)

Peirol (PC 366)

Perceval Doria (PC 371)

Pistoleta (PC 372)

Pons Barba (PC 374)

Pons de Capduelh (PC 375)

Pons Fabre d'Uzes (PC 376)

Pons d'Ortaffa (PC 379)

Raimbaut d'Aurenga (PC 389)

Raimbaut de Beljoc (PC 390)

Raimbaut d'Eira (PC 391)

Raimbaut de Vaqueiras (PC 392) 
xvi Contents

Raimon Jordan (PC 404)

Raimon Menudet (PC 405)

Raimon de Miraval (PC 406)

Raimon de las Salas (PC 409)

Raimon Vidal de Besalù (PC 411)

Raimon Bistortz d'Arles (PC 416)

Reculaire (PC 417)

Richard I of England (PC 420)

Rigaut de Berbezilh (PC 421)

Ricau de Tarascon (PC 422)

Ricaut Bonomel (PC 423)

Cerveri de Girona (PC 434 and 434a)

Sordel (PC 437)

$\mathrm{Na}$ Tibors (PC 440)

Tomier e Palaizi (PC 442)

Torcafol (PC 443)

Tostemps [Raimon de Miraval?] (PC 444)

Turc Malec (PC 447)

Uc Brunenc (PC 450)

Uc de l'Escura (PC 452)

Uc de Mataplana (PC 454)

Uc de Pena (PC 456)

Uc de Saint Circ (PC 457)

13038-99: anonymous lyrics designated under the listing PC 461, consisting of four groups:

3038-55: general studies of anonymous works;

3056-75: listings for nine anonymous poems (out of ca. 250) that have attracted scholarly interest;

13076-79: twelve poems by the "anonyme religieux" of the Wolfenbüttel manuscript, listed under PC 461a;

3080-99: poems of the Toulouse School, numbered as PC 463-573 by François Zufferey

general studies 3080-85

listings for three representative poets of the fourteenth and fifteenth centuries

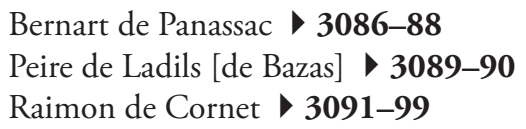

Note that PC $461 \mathrm{~b}$ is used as a reference to nine quotations of lyric poems from the fourteenth-century play Jeu de Sainte Agnes (see 1328-35). 
Note that PC 462,1 is used as a reference to a bilingual tenso in Occitan and GallegoPortuguese between Alfonso X of Castile and Arnaut, probably Arnaut Catalan (see 1919-21).

Index 



\section{Preface}

\section{A Selective Critical Guide}

This manual provides orientation and detailed reference for students and researchers over the whole field of medieval Occitan studies. It offers a listing of over two thousand recent books and articles that treat all categories of Occitan literature from the earliest enigmatic texts to the works of Jordi de Sant Jordi, an Occitano-Catalan poet who died young in 1424; it is selective in the sense that the works chosen for inclusion are intended to provide a rational introduction to the many thousands of studies that have appeared over the last thirty-five years in many languages and from many countries around the world; the listings are critical in the sense that descriptive comments have been added to elucidate the nature and the interest of each contribution, with occasional remarks on striking or controversial content and numerous cross-references to identify complementary studies or differing opinions.

\section{Occitan Scholarship in the Twenty-first Century}

Although it seemed in the mid-1970s that study of the troubadours and of Occitan literature had reached a sort of zenith, it has since become apparent that this moment was merely a plateau from which an intensive renewal was being launched. Thanks to the advent of electronic research tools and new critical methodologies, research has not only continued but has multiplied in quantity and intensity to the point where it has become difficult for any single scholar to keep up with developments over the whole field. Recent investigations have demonstrated the value of a renewed searching study of the manuscripts themselves, of new ways to combine musicological research with literary and metrical analysis of the lyrics, of psychocritical explorations of subconscious poetic motivations, of intertextual bonds that link lyric and non-lyric genres as well as linking the poets one to another-to name a few of the most fruitful of new orientations. Some scholars have begun to urge the necessity of undertaking a complete renewal of the basic philological editions and linguistic studies so that our knowledge of the language itself and the preserved texts may be placed on a surer footing. The field of medieval Occitan scholarship is clearly a vigorous and continuing one.

\section{Scope}

Listings have been limited in general to the last thirty-six years, 1975-2011, except for editions and classic studies that have not yet been replaced; a number of books and articles from 2012 have been included whenever they were accessible to me, but these recent references are far from complete. 
An attempt has been made to maintain a certain equilibrium among the various genres, periods, and methodologies over the whole of Occitan literature from the beginnings to the end of the fifteenth century. But since it has also been desirable to follow the actual directions of recent research, there may seem to be an apparent imbalance, for example, between the intensive studies of the troubadour lyrics and the less-frequent publications in the area of non-lyric works, or between the numerous studies devoted to a few of the most popular troubadours (such as Arnaut Daniel, Bernart de Ventadorn, or Guilhem de Peitieus), contrasted with the relative neglect of other less-studied poets, or between the exhaustive analysis of detail in Flamenca that has not yet been undertaken for the other narrative works; a compromise has been necessary between an attempt at equilibrium and the actualities of recent publication.

Studies of language have been included only insofar as they may be of practical help in the understanding of the literary texts; however, since the connections between literature and the language in which it is preserved have become ever more apparent, reference should be made to the linguistic bibliographies presented by Kathryn Klingebiel 14, which cover everything from "pure" linguistics to the edition of Occitan texts.

Similarly, the musicological references have been limited to those that touch on the actual analysis of troubadour songs, although it has become more and more difficult to draw a line between "pure" and "applied" musicology in this context. Other specialized areas such as sociohistory, religious heresy, critical methodology, or psychoanalytical analysis have been listed only insofar as they touch directly on the study of Occitan literary works. Some of these outside areas that touch upon Occitan literature have been mentioned briefly under the separate rubric "Related Fields" 1606-1789.

\section{Presentation}

Under most of the rubrics, one or more essential works are listed first, followed by recent publications in the same field, in alphabetical order. In the listings for individual troubadours, and those for non-lyric works, the most useful edition is given first, along with other studies that deal with editorial questions, followed, in alphabetical order, by studies of various aspects of the poet's output or analysis of specific literary questions.

\section{Practical Suggestions}

This manual is meant to provide a dependable guide to essential publications in the various areas of research in the field. In most cases, it will be easy for readers to establish a more complete retrospective bibliography in specific areas by following backward the references and footnotes in the recent listings provided here, and by completing these by searching forward through perusal of annual bibliographical listings 4-8 and current periodicals $\$ 84$ to update the present material. Useful information may often be found on some of the Internet sites mentioned in $\mathbf{1 5}$, $\mathbf{4 7 - 5 3 , 8 1 , 6 9 0 - 9 1 . ~ I n ~ a d d i t i o n , ~ i t ~ i s ~ m y ~ i n t e n t i o n ~ t o ~ p r o v i d e ~ f u t u r e ~ s u p p l e m e n t s ~}$ 
to this manual on the Internet (search for Taylor Occitan Bibliography). Suggestions and queries: roberttayloruoft@gmail.com.

Editions and studies of individual troubadours may be found by direct consultation of the listings ( 1820-3037) which are arranged numerically according to the standard number adopted from Bartsch by Pillet and Carstens (see 1 ), with cross-reference to the appropriate PC number whenever the names are out of alphabetical order; reference to specific non-lyric texts and areas of scholarship will require consultation of the contents pages as well as the index; major subdivisions and texts are listed in the former, and less obvious references in the index.

Thanks to those who have contributed to the making of this volume: - to Peter Ricketts, who first introduced me to the troubadours;

- to my wife Johanna, who supported and encouraged me through many years of preparation;

- to Wendy Pfeffer, who furnished facts and enthusiasm whenever required;

- to Kathryn Klingebiel, who shares my passion for bibliography;

- to Patricia Hollahan, who believed in the project and lit the requisite fires to urge its completion;

- to Ronald Akehurst, Elizabeth Aubrey, Vincent Pollina, and William Paden, who provided expert guidance in specialized areas;

- to Judith Knelman, who helped me polish the style and avoid imprecisions;

- to Juleen Eichinger, who rationalized, corrected, and clarified the presentation;

- to colleagues around the world who inspired me through their devotion to Occitan studies. 



\section{Sigla/Abbreviations/Symbols}

: symbol for cross-reference

AIEO: Association internationale d'études occitanes

AIUO: Annali Istituto Universitario Oriental Napoli, sezione romanza

AM: Annales du Midi

AMod: AnticoModerno

GRLMA: Grundriss der romanischen Literaturen des Mittelalters

BdT: Bibliographie der troubadours (= PC)

BRABLB: Boletín de la Real Academia de Buenas Letras (Barcelona)

CCM: Cahiers de civilisation médiévale

CDT: Critica del testo

$C N$ : Cultura neolatina

DOM: Dictionnaire de l'occitan médiéval

FL: La France latine

JEGP: Journal of English and Germanic Philology

ICLS: International Courtly Literature Society

$M A$ : Le Moyen âge

MAev: Medium aevum

MS, MSS: Manuscript(s)

$M R$ : Medioevo romanzo

Neo: Neophilologus

NM: Neuphilologische Mitteilungen

PC: Pillet-Carstens. Bibliographie der Troubadours (=BdT)

RF: Romanische Forschungen

RLaR: Revue des langues romanes

RLiR: Revue de linguistique romane

$R N$ : Romance Notes

Rom: Romania

RPh: Romance Philology

RR: Romanic Review

RST: Rivista di studi testuali

RZL: Romanistische Zeitschrift für Literaturgeschichte

SM: Studi medievali

$S M V$ : Studi mediolatini e volgari

$V R$ : Vox romanica

ZrP: Zeitschrift für romanische Philologie 



\section{Bibliographical Guide to the Study of the Troubadours and Old Occitan Literature}





\section{Reference Works}

\section{Bibliographies}

\subsection{General Bibliographies}

1.

Pillet, Alfred, and Henry Carstens. Bibliographie der Troubadours. Halle: Niemeyer, 1933. Reprint, New York: Franklin, 1968. [An essential reference for listings of individual poems by all troubadours and trobairitz; the standard reference to poems is: $\mathrm{PC}$ (or $\mathrm{BdT}$ )/space/number of poet/comma/number of poem (e.g., PC 262,43 for Bernart de Ventadorn's lark poem Can vei la lauzeta mover); includes an index of rhymes, pp. 441-518; does not always include references to non-lyric literature, though a few works are mentioned if their authors also composed lyrics; lacks a table of contents, list of abbreviations, subject index, author index.]

Suggested Improvements:

- to the classification system: $>$ 57, Frank, Répertoire métrique, 1953-57, pp. xv-xxix; - important corrections and additions in reviews by Alfredo Cavaliere, Archivum romanicum 19 (1935): 451-87, and by William P. Shepard, Modern Language Notes 49 (1934): 408-10.

Updatings:

- to the description of manuscripts, pp. vii-xliv: 10, Brunel-Lobrichon, Colloque de Wégimont, 1991, pp. 1-12; and 29, Ricketts, COM2, 2005;

- to the listing of individual poets: 13, Zufferey adds numbers 463 to 573 , to 1500 ; -4, Distilo, Per le concordanze, 2000; and 49, Asperti, BEdT, from 2002 on;

- to the listing of textual editions: 57, Frank, Répertoire métrique, 1953-57, pp. 84-192, up to 1956; 56, Chambers, Proper Names, 1971, pp. 15-33, up to 1971; - 281, Handbook, 1995, pp. 475-82, up to 1994; 29, COM2, 2005, up to 2000; - to the listing of manuscripts: Sergio Vatteroni. "Fragments of Provençal Lyrical Manuscripts: A Bibliography.” Tenso 12 (1996): 14-30, with listings from 1889 to 1994 , along with an index by poet of poems mentioned, an index of unica, of poems not listed in PC and of fragments by repository.

2.

Taylor, Robert A. La Littérature occitane du moyen âge: bibliographie sélective et critique. Toronto: University of Toronto Press, 1977. [Includes 740 selected and annotated listings (up to 1976): reference works, fields of literary criticism, related scholarly areas; listings for sixty-eight poets by name, and for fifty-one non-lyric works by title; index.]

3.

Pfeffer, Wendy, and Robert Taylor. Bibliographie de la littérature occitane: trente années 
d'études (1977-2007). Turnhout: Brepols, 2011. [A cumulative listing of publications over thirty years on all Occitan literature from the Middle Ages to the present; works are divided by historical period, by subject and by author, with an extensive index; all published works are listed, without descriptive or critical comments.]

4.

Distilo, Rocco. Per le concordanze della lirica trobadorica: incipitlexplicit. Rome: Bagatto Libri, vol. 1, 2000, vol. 2, 2003. For CD-ROM, see 28. [Contains essential checklists for identification of troubadour poems by PC number, including anonymous (vol. 1 is for poets of the classical period, while vol. 2 includes later poets and the Toulouse School, along with comprehensive indices of incipits, explicits, genres, extant melodies, names of poets, manuscripts, and a bibliography of text editions); also available on CD-ROM: information at http://www.textus.org (access by password); minor weaknesses: does not mention controversial attributions, e.g., 3039 , Bond, "Last Unpublished," 1985; 480, Marshall, "Dialogues of the Dead," 1987 (listed in the bibliography, but not utilized); $\mathbf{8 0 8}$, Paden, "Dramatic Formalism," 1982; for the Jeu de Ste Agnes, lists only nine of the ca. eighteen lyric interludes; gives Bietris de Roman's poem PC 16a to Albric and does not mention Bietris at all, nor Baussan (PC 45), nor Richard Coeur-de-lion (PC 420); some lack of coordination with Zufferey's numbering.]

5.

\subsection{Annual or Periodic Bibliographies}

Tenso. Athens, GA, from 1985-86. [Covers literature and linguistics, medieval and modern; literary and linguistic bibliographies separately from 1989.]

6.

Year's Work in Modern Language Studies [YWMLS]. Cambridge: Modern Humanities Research Association, from 1930. [Treats literature and language separately; Occitan literature is done currently by Miriam Cabré and Sadurní Martí.]

7.

MLA International Bibliography. Menasha, WI: Modern Language Association of America, 1964-. [Online, in CD-ROM format, or hard copy.]

8.

Romanische Bibliographie. Tübingen: Niemeyer. [From 1875 to 1961, appeared as supplement to $\operatorname{ZrP}$.]

9.

International Medieval Bibliography. Institute for Medieval Studies, University of Leeds. Turnhout: Brepols, 1967-. [Also available online at http://www.brepolis.net by subscription or university access.]

10.

\subsection{Specialized Bibliographies}

Brunel-Lobrichon, Geneviève. "Réflexions sur les manuscrits occitans médiévaux." In Colloque de Wégimont: les outils de la recherche occitane. 2 vols. Bulletins de l'AIEO 7, 
8. London: Royal Holloway and Bedford New College, University of London, 199091, 2:1-12. [Describes efforts to update Brunel's catalogue of Occitan manuscripts, including revised locations, several additions to the corpus, texts newly discovered or recognized as Occitan.]

11.

Switten, Margaret. Music and Poetry in the Middle Ages: A Guide to Research on French and Occitan Song. With Howell Chickering. New York: Garland, 1995.

12.

Thiolier-Méjean, Suzanne. "Petite bibliographie des troubadours à l'usage des étudiants et des doctorants." FL 146 (2008): 208-46. [A basic guide for nonspecialists; many gaps, especially among recent studies.]

13.

Zufferey, François. Bibliographie des poètes provençaux des XIVe et XVe siècles. Publications romanes et françaises, 159. Geneva: Droz, 1981. [Adds numbers 463 to 573 to $\mathrm{PC}$, listing poets from the end of the thirteenth century to the beginning of the sixteenth: École de Toulouse (Consistoire des Jeux Floraux), registre de Cornet, registre de Galhac, second part of MS Sg, the Leys d'Amors.]

14.

\subsection{Linguistic Bibliographies}

Klingebiel, Kathryn. Bibliographie linguistique (1960-82) de l'ancien occitan. Romanistik in Geschichte und Gegenwart, 19. Hamburg: Buske, 1986. Continuations: Bibliographie linguistique (1983-97) de l'ancien occitan. AIEO, 8. Birmingham: University of Birmingham, 1999, and Bibliographie linguistique de l'occitan médiéval et moderne (1987-2007). Turnhout: Brepols, 2012; see also her annual bibliography of Occitan linguistics and text editions in $\mathbf{5}$, Tenso, since 1989, and in $\mathbf{6}$, Year's Work, since 1998.

\section{5.}

\subsection{Bibliographical Theory}

Klingebiel, Kathryn. "L’occitan médiéval: un bilan, en lisant une bibliographie." In 107, Ab nou cor, 2004, pp. 89-100. [Outlines the difficulties and frustrations of the bibliographer; includes listings of recent publications, projects, desiderata; also lists Internet resources.]

16.

Klingebiel, Kathryn. "Guilhem IX: Banned at the BN?" Tenso 24 (2009): 63-81. [Includes helpful hints for consulting bibliographic records in online library catalogues, which often have disparate forms of identification for troubadour names, faulty dates, etc.]

17.

See 89, Paden, "Etat-présent," 2001, pp. 13-35. [Within his discussion of recent developments in research, Paden gives copious bibliographical notes.] 
18.

Pic, François. "La bibliographie et la documentation, pierres d'angle de la recherche en domaine occitan.” Plenary paper in $\mathbf{1 0 0}$, AIEO 7, 2003, pp. 1385-1406. [Pleads for more rationalized and systematic bibliographic scholarship as the essential base for further research.]

19.

Taylor, Robert A. "Bibliography." In 281, Handbook, 1995, pp. 467-74. [Outlines the political and scholarly complications of bibliographical research in Occitan; includes a guide to the best introductory and reference tools, hints for keeping up to date, and comments on a few landmark works.]

\section{Alphabetized Reference}

\subsection{Dictionaries}

20.

Levy, Emil. Provenzalisches Supplementwörterbuch. 8 vols. Leipzig, 1894-1924. Reprint, Hildesheim: Olms, 1973. Online at http://archive.org/details/provenzalischess01levyuoft. [Definitions are in German. Must be used along with $\$ 24, Raynouard, Lexique, since it adds only supplementary and corrected material to that work.]

21.

Baldinger, Kurt, and Doris Diekmann-Sammet. Complément bibliographique au Provenzalisches Supplementwörterbuch de Emil Levy: Sources-datations. Geneva: Slatkine, 1983.

22.

Levy, Emil. Petit dictionnaire provençal-français. 1909. Frequent reprintings. [Recent editions contain some revised material for the first letters of the alphabet; definitions are in French.]

23.

Harris, Marvyn Roy. Index inverse du Petit dictionnaire provençal-français. Heidelberg: Winter, 1981. [Useful for the study of rhyme-words.]

24.

Raynouard, François. Lexique roman, ou dictionnaire de la langue des troubadours. Paris: Silvestre, 1836-44. Reprinted 2006 by Adamant Media Corporation, Boston.

25.

DOM: Dictionnaire de l'occitan médiéval. Tübingen: Niemeyer, 1996-. [Initiated by Ernst Gamillscheg in 1958, carried forward by Helmut Stimm until his death in 1987, directed now by Wolf-Dieter Stempel. A semiological, etymological dictionary; wide documentation will include all medieval Occitan texts up to 1550; will supersede the standard dictionaries of Raynouard and Levy. There are to be ten volumes of six fascicles each, published at the rate of one or two fascicles per year. Fascicules 1-6 have appeared (1996-2009); also Supplement 1 (1997). Rich information is to be found on the website http://www.dom.badw-muenchen.de (listings of fascicles 
published, extensive bibliographies, complete list of chansonniers, standard abbreviations, reviews, etc.; all may be downloaded; see the presentation of $D O M$ by J.-P. Chambon in RLaR 105 (2000): 439-58. (Stimm's intended two-volume Dictionnaire étymologique de l'ancien provençal has apparently been absorbed into the much larger $D O M$ project; see a tribute article to Stimm by H. Christmann, with four groups of sample entries for the projected $D E A P$, in $Z r P 104$ [1988]: 592-609).]

\section{6.}

Baldinger, Kurt. Dictionnaire onomasiologique de l'ancien occitan (DAO) and Dictionnaire onomasiologique de l'ancien gascon (DAG). Tübingen: Niemeyer, 1975-. [Begun in 1955 by Kurt Baldinger, directed since 2007 by Jean-Pierre Chambon; onomasiological regrouping (listing by standardized concept) of all Occitan words in the semasiological dictionaries of Levy, Raynouard, and Wartburg; information on context and sources will not be repeated from these works; the most recent publications for $D A O$ are fascicle 10, 2008, and Supplément 10, 2007; there is also a Supplément bibliographique, edited by Max Pfister, 1999, which coordinates abbreviations, text datings, etc. with the DOM. The most recent for $D A G$ are fascicule 12 (2009) and Index (2000). Website for $D A G$ http://www.rzuser.uni-heidelberg.de; as of 2008, financial constraints have forced the indefinite suspension of work on the $D A O$ in favor of the $D A G$.]

27.

Olivier, Philippe. Dictionnaire d'ancien occitan auvergnat. Mauriacois et Sanflorain (1340-1540). Beihefte zur ZrP, 349. Tübingen: Niemeyer, 2009. [Very rich information, based on original manuscript research; includes more than seven thousand entries, twelve thousand definitions, mainly juridical, commercial, artisanal, and military terms; gives references to all major dictionaries (FEW, DOM, etc.); presents all the vocabulary, making it useful for all areas of Old Occitan, not just a specialized supplement.]

\subsection{Concordances}

28.

Distilo, Rocco. Trobadors. Concordanze della lirica trobadorica in CD-ROM. Florence: SISMEL/Galluzzo, 2001. [Complete Occitan lyric texts, based on - 57, Frank, Répertoire métrique, 1953-57; searchable by text, incipit, explicit, rhyme, etc.]

29.

Ricketts, Peter T. COM: The Concordance of Medieval Occitan. Concordance de l'occitan médiéval. COM1: Textes lyriques. Turnhout: Brepols, 2001. COM2: Les textes narratifs en vers, Turnhout: Brepols, 2005. Technical direction by A. Reed; with the collaboration of F. R. P. Akehurst, J. Hathaway, and C. van der Horst. [A vast database whose aim is to document all medieval Occitan texts and to make them available in electronic format; comes with a short guidebook for usage; COM1 contains all 2,500 lyric poems; COM2 all non-lyric verse; COM3 will cover prose texts to complete the database, except for administrative texts, many unedited, which will be added as they are edited over the next few years; COM4 will present all the troubadour 
chansonniers. See the extensive review by K. Klingebiel, Tenso 21 (2006): 63-68, which gives detailed instructions and hints for utilizing $C O M$, along with a list of things it will not do; another by Dominique Billy, RLiR 71 (2007): 596-611, offers a number of corrections and suggestions.]

\section{0.}

Ricketts, Peter T. "La Concordance de l'occitan médiéval et les chansonniers des troubadours." In 99, AIEO 6, 2001, pp. 119-22. [Part of a roundtable at the congress, along with two other participants (Perugi and De Conca) who spoke about specific research using COM; Ricketts gives the history of the project.]

31.

Pellen, René. "Concordance de l'occitan médiéval (COM1)." Le Médiéviste et l'ordinateur. Dossier 45, mai 2006 (Varia). Online at http://lemo.irht.cnrs.fr/varia/ com.htm. [An introductory guide to use of COM; tests the principal functions of the search engine one by one, to determine its rich possibilities and limits, leading to a number of suggested improvements to the User's Guide.]

32.

Klingebiel, Kathryn. "La dérivation dans la Concordance de l'occitan médiéval: morphologie et ambiguïté chez les troubadours." Lexique 17 (2006): 21-27. [Uses COM to investigate the ambiguous effects that can be obtained by affixation, compounding, hybrids, conversion, or by explicit manipulation of Old Occitan morphology.]

33.

Betti, Maria Pia. "Un progetto di concordanze: il corpus di Guiraut Riquier." In - 107, Ab nou cor, 2004, pp. 331-35. [Work in progress: a report on the state of research; part of a larger project to reedit all 101 of Guiraut Riquier's works.]

34.

Corradini Bozzi, Maria Sofia. Concordanze delle Biografie trovadoriche. Biblioteca degli Studi Mediolatini e Volgari, Nuova Serie, 9 and 11. 2 vols. Pisa: Pacini, 1982 and 1987. [Includes listings for the vidas and razos; see review by Max Pfister, $Z r P$ 107 (1991): 246-48: notes a few minor difficulties and omissions; adds material from three newly discovered razos of Bertran de Born.]

35.

Hishikawa, Eiichi. A Concordance to Arnaut Daniel's Poems. Kobe: Kobe University, 1989. Distributed by the author, 13-36-203 Toyotsu-cho, Suita-shi, Osaka 564, Japan. [Searchable database available online at http://www.lib.kobe- u.ac.jp/infolib/ meta_pub/G0000003daniel_e.]

36.

\subsection{Encyclopedias}

Diccionario de la música española e hispanoamericana. Edited by Emilio Casares Rodicio. 10 vols. Madrid: Sociedad General de Autores y Editores, 1999-2002. [Includes many articles by Antoni Rossell on Catalan troubadours and music: Guillem de Berguedan, Guillem de Cabestany, Guillem de Cervera, Guillem de Murs, Guillem de Ribes, Guillem Ramon de Gironella, Peire d'Alvernhe, Peire de 
la Roca, Peire de Monso, Peire Raimon de Tolosa, Peire Vidal, Peironet, Raimbaut de Vaqueiras, Raimon de Miraval; see also vol. 10, pp. 485-88: “Trovador"; note that most of the bibliographical listings are limited to ca. 1979, i.e., twenty years out of date at printing.]

37.

Dictionary of the Middle Ages. 13 vols. plus Supplement. New York: Scribner, 1981-89. [Contains brief introductory articles, now somewhat dated, covering chansonniers, major genres, themes, metrical structures, some of the major poets and non-lyric works; "Troubadours and Trouvères" by Ron Akehurst; "Provençal Literature" by Karl Uitti; only a few listings for individual troubadours, none for trobairitz; "Supplement" adds material, i.e., on satire by Jan Zielkowski.]

38.

Dictionnaire des lettres françaises: le Moyen Âge (DLF). Paris: Fayard, 1964. New edition edited by Geneviève Hasenohr and Michel Zink, 1993. [Most articles are new or revised, though some are barely changed from the 1964 edition; many Occitan poets and works are analyzed fully, with copious bibliography. See pp. lix-lxi for an index by name to page references for 149 poets treated in $\$ 312, G R L M A$, vol. 2, book 1 , fascicle 7,1990 .]

39.

Fabre, Paul. Petit dictionnaire de la littérature occitane du moyen âge: auteurs, oeuvres, lexique. Lo gat ros, 10. Montpellier: Publications de l'université Paul-Valéry Montpellier 3, 2006. [For nonspecialists; brief general introductory information; chronological tables from A.D. 987 to 1498; brief articles on the major troubadours, genres, non-lyric titles, key vocabulary; mentions only a few of the trobairitz.]

40.

Lexicon der Weltliteratur. Düsseldorf: Harenberg, 1989. 5 vols. [Contains articles by Angelica Rieger on: Aimeric de Peguilhan, Altokzitanische Literatur, Arnaut Daniel, Bernart de Ventadorn, Bertran de Born, Comtessa de Dia, Guilhem de Peitieus, Guiraut de Bornelh, Guiraut Riquier, Jaufré Rudel, Marcabru, Peire Cardenal, Peire Vidal, Raimbaut d'Aurenga, Raimbaut de Vaqueiras, Raimon de Miraval, Rigaut de Berbezilh, and Trobador.]

41.

The Literary Encyclopedia. Online at http://www.litencyc.com. [Includes "Jaufre Rudel" (2006) and "Troubadours" (2005) by Judith M. Davis: succinct introductions with brief bibliography.]

42.

Medieval France. An Encyclopedia. Edited by William H. Kibler. New York: Garland, 1995. [Contains articles by W. Paden on: Boeci, Guilhem de Montanhagol, Guiraut Riquier, Monk of Montaudon, pastourellelpastorela, Peire Cardenal, planh, sirventes, trobairitz, and troubadours.]

43.

The New Princeton Encyclopedia of Poetry and Poetics. Edited by Alex Preminger and T. V. F. Brogan. Princeton, NJ: Princeton University Press, 1993. [Includes articles 
on: Félibrige, feminist poetics, jongleur, mal mariée, minstrel, Occitan poetry, pastourelle, sestina, troubadour, trouvère; no articles on individual poets.]

44.

The Oxford Dictionary of the Middles Ages. Edited by Robert E. Bjork. Oxford: Oxford University Press, 2010. [Includes brief but dense articles by: Simon Gaunt on many troubadours, genres; his article "Troubadour" touches on major scholarly problems; John Haines on several poets and "Song Sources: Southern France"; and Miriam Cabré on Medieval Catalan Literature, Cerverí de Girona, Ramon Llull, Francesc Eiximenis, Ausiàs March, and Tirant lo Blanc.]

45.

Schaus, Margaret. Women and Gender in Medieval Europe: An Encyclopedia. New York: Routledge, 2006. [Contains variable presentations by individual scholars on many specialized areas; brief bibliographies; Occitania, Occitan Literature, Dawn Song (alba), Pastourelle, trobairitz, Roman de Flamenca, Ermengard, Douceline of Digne, and Cathars.]

46.

Women in the Middle Ages: An Encyclopedia. Edited by Katharina M. Wilson and Nadia Margolis. 2 vols. Westport, CT: Greenwood, 2004. [Includes informative entries for all the known trobairitz by McCash, Braet, Bruckner, Blakeslee, and Rosenstein; other articles on, for example, "Alba Lady" by Gale Sigal, pp. 16-20; succinct and clear, with good bibliographies.]

\section{Aids to Research}

\subsection{Electronic Resources}

47.

See 29, Ricketts, Concordance of Medieval Occitan, 2001, 2005. [Updates are posted at: http://www.textworld.com/occitan/ and at Arnaut http://www.arnaut.it/ article.php?sid=1.]

48.

Di Girolamo, Costanzo. RIALTO (Repertorio informatizzato dell'antica letteratura trobadorica e occitana). Online at www.rialto.unina.it. [Web-based database of Old Occitan texts; see also Oriana Scarpati, "Lecturae tropatorum. Une nouvelle revue en ligne dédiée aux troubadours," in 102, AIEO 9, 2011, pp. 1035-37; www.lt.unina.it.]

49.

Asperti, Stefano. Bibliografia elettronica dei trovatori (BEdT). (CD-ROM, versione di prova 0.6), 2002. [An eventual planned revision of $>1$, Pillet-Carstens, and - 57, Frank, and the core of a database of all European medieval lyrics, along with indexes of the troubadour chansonniers; see the explanatory article by Asperti and Fabio Zinelli: "Bibliografia elettronica dei trovatori (in French)," Le Médiéviste et l'Ordinateur 39 (2001), online at http://www.bedt.it; has a number of text editions, some with introductory study, Italian translation, notes; bibliographical information is not always complete or up to date; new texts are added sporadically.] 
50.

See 1654, Els Trobadors. [Website created by Miquel Alonso; listings for twenty Catalan poets writing in Occitan, giving information on sociohistorical background and genres, at http://www.xtec.es/ - malons22/trobadors/trobadors.htm.]

51.

LEXICOLOGOS: http://www.lexilogos.com/occitan_ancien.htm. [A basic practical online lexicon of more than four thousand Occitan words compiled from various sources; provides links to many classic texts (out of copyright and available online) on language and literature, such as Raynouard's Lexique roman, Levy's Supplementwörterbuch and Petit dictionnaire, Mistral's Lou Tresor dóu Felibrige, many older anthologies, studies, and editions; links to many modern critical works that are only partially available online, or by subscription.]

\section{2.}

De Conca, Massimiliano. Lessico dei trovatori del periodo classico (LTC). Vol. 1: Arnaut Daniel (progetto pilota). [Doctoral thesis, University of Geneva, 2008, directed by Maurizio Perugi; the first partial realization of a wider lexical project meant to include all the classical troubadours; presentation of the complete lexical resources of Arnaut, in all seven editions of his poetry, plus a new one in COM2, and also all the variant forms from the chansonniers, critically examined; for preliminary justification of the overall project, see Perugi, Maurizio: "Modelli critico-testuali applicabili a un lessico dei trovatori del periodo classico (LTC)," SM, 3a serie, 31 (1990): 481-544.]

53.

Klingebiel, Kathryn. Trobar. Online at http://www.tempestsolutions.com/trobar/. [Basic information on identification of poets, places, names, dating, works; the database may be searched in many ways.]

\section{4.}

\subsection{Indexes, Databases, Checklists}

Beltrami, Pietro G., with the collaboration of Sergio Vatteroni. Rimario trobadorico provenzale. Vol. 1: Indici del Répertoire di I. Frank. Vol. 2: Dalle origini alla morte di Raimbaut d'Aurenga (1173). Biblioteca degli Studi mediolatini e volgari, n.s., 12 and 14. Pisa: Pacini, 1988 and 1994. [Vol. 1 provides keys to facilitate the consultation of 57, Frank, Répertoire métrique, consisting of one index by rhyme, the second by poet; vol. 2 gives detailed listings of rhymes for all poets datable to 1173; further volumes were projected but have not appeared.]

55.

Santini, Giovanna. Rimario dei trovatori. Rome: Nuova Cultura, 2010. [A complete index of rhymes for all Medieval Occitan lyrics up to PC/Zufferey 573,2; introduction, bibliography; see also Santini's "Questione linguistiche e testuali a margine del Rimario dei trovatori," in 118, La lirica romanza, 2009, pp. 139-53, where she discusses the preparatory work on materials that was undertaken for this Rimario: lemmatization, justifying apparent irregularities of rhyme within open and closed vowels and diphthongs, through scribal or editorial interference.] 
56.

Chambers, Frank M. Proper Names in the Lyrics of the Troubadours. Chapel Hill: University of North Carolina Press, 1971. [Pages 17-33 update PC listings of textual editions by name of troubadour.]

57.

Frank, István. Répertoire métrique de la poésie des troubadours. 2 vols. Bibliothèque de l'École des hautes études, 302 and 308. Paris, 1953 and 1957. [Complete catalogue of lyric poems according to their metrical structure; also useful for its bibliography of text editions (vol. 2, pp. 84-214): lyric poems under the name of the poet (pp. 84-192), non-lyric under the title (pp. 193-214); for further updating of lyric editions, see (up to 1971): 56, Chambers, Proper Names, 1971; (up to 1994): Akehurst/Taylor "Editions," in 281, Handbook, 1995, pp. 471-82; and the present bibliography; see also Sergio Vatteroni, "Rima interna e formula sillabica: alcune annotazioni al Répertoire di I. Frank," SMV 29 (1982-83): 175-82, and 54, Beltrami, Rimario, 1988.]

58.

Billy, Dominique. "Répertoires métriques de la poésie lyrique médiévale." In Sö wold ich in fröiden Singen: Festgabe für Anthonius H. Touber zum 65. Geburtstag. Edited by C. Dauven-van Knippenberg and H. Birkhan. Amsterdam: Rodopi, 1995, pp. 49-78. [Summary of recent scholarship; discussion of organizational problems in the creation of a repertory: classification of material, choice of corpus, information to be included, presentation of information, means of exploitation; all of these considerations impose limitations in the printed work which make consultation and comparisons difficult; see 922, Billy, "Métrique et informatique," 1999, pp. 305-15: Billy envisages a vast collective database, in collaboration with Thierry Glon, which will revise and merge all the existing repertories, add more information, and allow maximum electronic utilization of material.]

59.

Ziltener, Werner. Repertorium der Gleichnisse und bildhaften Vergleiche der okzitanischen und der französischen Versliteratur des Mittelalters, part 1: Unbelebte Natur. Berne: Francke, 1972; parts 2: Natur; 2, 2: Belebte Natur, 1983; and 3: Mensch, Mensch und Aussenwelt, Register, 1989. [Detailed index of figures of comparison and metaphor.] See also the author's study based on part 1: Unbelebte Natur: Studien zur bildungsgeschichtlichen Eigenart der höfischen Dichtung: Antike und Christentum in okzitanischen und altfranzösischen Vergleichen aus der unbelebten Natur. Bern: Francke, 1972. [Many examples from troubadour poetry of comparisons and proverbial sayings, fully indexed by name of poet.] 
3.3. History of Occitan Scholarship, Reception Studies, Medievalism [See also listings under V. Related Fields]

\subsection{1. État-présent Studies}

60.

Vatteroni, Sergio. "Littérature médiévale lyrique." In 102, AIEO 9, 2011, pp. 13-20. [Asserts that new basic reference tools-DOM, COM, BEdT, RIALTO, and INTAVULARE - promise a renewal of research; careful detailed study of the individual chansonniers will lead to better editions and to richer analysis of the poetic texts themselves, which must remain the central focus of study.]

61.

Henrard, Nadine. "Épopée, roman, théâtre . . . : les études dans le domaine des genres non lyriques occitans depuis 1981.” In 102, AIEO 9, 2011, pp. 21-30. [Notes that new editions of most narrative texts have appeared recently, except for Aigar and Morin and Ferabratz; datation and localization remain controversial for several works; generic distinctions and mixtures have been investigated, especially intertextual links between lyric poetry and the other genres; the area of dramatic literature has been largely neglected; ends with a call for widespread global studies that go beyond single texts.]

62.

Kullmann, Dorothea. "Les recherches sur l'épopée médiévale en langue d'oc." In - 102, AIEO 9, 2011, pp. 431-48. [Detailed historical review of scholarship on all eleven Occitan epic texts, stressing the controversial opinions about the origins in northern or southern France, datation and localization of individual texts and the identification of mixed language features.]

63.

See 704, Paden, "Some Recent Studies of Women," 1992, pp. 94-124. [Survey of scholarship, mostly late 1980s, early 1990s, on the trobairitz and on the status of medieval women in southern France; more detailed discussion of $\$$ 363, Bloch, Medieval Misogyny, and $\mathbf{7 3 5}$, Rieger, Trobairitz, with analysis of recent work by Paterson, Kay, Saouma, Gaunt, Städtler, Poe, and many others.]

64.

Pfister, Max. "Bilan de la linguistique de l'ancien occitan, 1998-2008." In $\mathbf{1 0 2}$, AIEO 9, 2011, pp. 73-100. [Very rich guide, with commentaries, to ten years of scholarship in the area, with references to previous ten-year summaries; covers global linguistic studies that include Occitan, major lexicological projects and databases, twenty-one troubadour editions, and twenty non-lyric editions.]

65.

Ibarz, Alexandre. "État présent des recherches sur les troubadours catalans: essai d'un bilan et perspectives." In 102, AIEO 9, 2011, pp. 421-30. [Stresses the close connection between Catalan and Occitan poetry; discusses current questions of attribution and datation for seven poets and non-lyric works; points out the need for more collaborative research as investigations become more complex.] 


\subsubsection{Sociopolitical Forces and Scholarship}

66.

Graham, John M. "National Identity and the Politics of Publishing the Troubadours." In Medievalism and the Modernist Temper. Edited by R. Howard Bloch and Stephen G. Nichols. Baltimore: Johns Hopkins University Press, 1996, pp. 57-94. [Discussion of the forces at work in the early scholarship, calling for publication of all extant texts in order to guarantee a complete understanding of the language and the poetry; this was disrupted by cultural and nationalist politics and by hasty work resulting in badly edited texts and imperfect knowledge of the language; many recent scholars are calling for a whole new study of the grammar, based on all texts and close analysis of the chansonniers; the future seems to lie in a combination of theoretical and positivistic research methods.]

67.

Haines, John. Eight Centuries of Troubadours and Trouveres: The Changing Identity of Medieval Music. Cambridge: Cambridge University Press, 2004. [History of the ways troubadour and trouvère music has been interpreted over eight hundred years: antiquarianism in the sixteenth century, synthesis of scholarly and popular traditions in the eighteenth, archaeology and philology in the nineteenth, more recent theories about rhythm and musicological research.]

68.

Kendrick, Laura. "The Science of Imposture and the Professionalization of Medieval Occitan Literary Studies." In Medievalism and the Modernist Temper. Edited by R. Howard Bloch and Stephen G. Nichols. Baltimore: Johns Hopkins University Press, 1996, pp. 95-126. [A semicynical look at the science of medieval scholarship as practiced from Nostradamus to our day; asserts that the real poets have been hidden behind various creations of imaginative scholarship; there has been much speculative study of the troubadours' lives, dubious or contested attributions of work to one or another; textual scholars cannot hope to produce anything but pseudomedieval texts, and therefore our field is a discipline of imposture; we find it difficult to admit that we as scholars may be inventing a fictive object that fulfills our own needs.]

69.

Leterrier, Sophie-Anne. "Troubadours and Trouvères — a North-South Dialogue?" Revue du Nord 87 (2005): 443-57. [Discusses the politicization of opinions on the troubadours and trouvères: nationalistic drive and social oppositions in France in the nineteenth century reversed the previous assumption that the trouvères represented a pale copy of the troubadours' richness; detailed history of the rivalry of the two for title of "true French."]

70.

See 338, Menocal, "Close Encounters," 1981. [Discussion of anti-Arab and antiSemitic bias in nineteenth-century scholarship.]

71.

Paden, William D. "Alfred Jeanroy et la découverte française des troubadours." In En un vergier: Mélanges offerts à Marie-Françoise Notz. Edited by Joëlle Ducos and Guy 
Latry. Bordeaux: Presses Universitaires de Bordeaux, 2009, 197-210. [Detailed biography of Jeanroy and his family; paradox of his lifelong devotion to establishing the textual history of the troubadours, combined with his insensitivity to their aesthetic; he provided researchers with the essential texts and documentation, but the modern flourishing of troubadour scholarship is based more on the rejection of his harsh aesthetic and moral judgments than on his nonexistent love for the poetry.]

72.

Touber, Anton. "L'importance des troubadours pour les lyriques médiévales nationales en Europe." In 101, AIEO 8, 2009, 1:141-56. [Sketches the spread of troubadour poetry into Catalonia, Italy, Aragon, northern France, Germany, GaliciaPortugal, and Sicily, characterized by the reduction in semantic complexity, genres, themes, and strophic forms; pp. 144-56: very detailed comparison of strophic forms in Occitan and six neighboring cultures, using the electronic program Anastrof.]

\subsubsection{Medievalism: Legends and Popularizing Studies}

\section{3.}

Dauzier, Martine. Le Mythe de Bertran de Born du Moyen Âge à nos jours. Paris: Presses de l'Université Paris-Sorbonne, 1986. [A reception study intended to explain the dual mythification of Bertran as Dantean horror and passionate chevalier, and perhaps an attempt to integrate Bertran's image into the bicentenary of the French Revolution; see also Dauzier's follow-up article in Cahiers de recherches médiévales 2 (1996): 179-86.]

74.

Dillange, Michel. Guillaume IX d'Aquitaine: le duc troubadour. Mougon/La Crèche: Geste, 2002. [A charming, if misleading, biography of the first troubadour; almost nothing is known about Guilhem's private life, but the lack of detail is filled in with imagination, including a tender dialogue in regional Occitan between father and mother at the moment of William's birth, details concerning his childhood, his education, and his daily activities, imagined by the author.]

75.

Ippolito, Marguerite-Marie. Bernard de Ventadour: troubadour limousin du XIIe siècle: prince de l'amour et de la poésie romane. Paris: L'Harmattan, 2001. [Romanticized reconstitution of the life of Bernart; poems by Guilhem de Peitieus, Eble II (the courtly poems of Guilhem) and Bernart are interspersed with details of Bernart's life and times that are largely imaginary.]

76.

Morgner, Irmtraud. Leben und Abenteuer der Trobadora Beatriz nach Zeugnissen ibrer Spielfrau Laura. Berlin: Aufbau-Verlag, 1974. Vie et aventures de la trobairitz Béatrice d'après les témoignages de sa ménestrelle Laure. Paris: Éditions des Femmes, 1983. The Life and Adventures of Trobadora Beatrice as Chronicled by Her Minstrel Laura. Lincoln: University of Nebraska Press, 2000. [Morgner uses the legendary figure of the Comtessa de Dia to address issues of feminism, ecology, and socialist realism in the particular context of East Germany.] 
77.

Nelli, René. Le Roman du troubadour Raimon de Miraval, suivi de ses chants d'amour. Paris: Albin Michel, 1986. Reprint, 2000. [A poetical vie romancée of Raimon, found after Nelli's death, supposedly inspired by a dream; the twenty-two poems are given in a Romanticized translation only, dating from 1979, without the original Occitan.] 78.

Rieger, Angelica. "La Poétesse de Carcassonne de Paul Heyse, ou: comment 'moraliser' la fin'amor?" In 151, Mélanges Bec, 1991, 485-96. [A fictionalized biography of Caudairenga, the sometime wife of Raimon de Miraval; Heyse's work is a nineteenthcentury misreading of finamor as a representation of bourgeois morality, similar to the reinterpretations undertaken by Mistral and Pound.]

79.

Rieger, Angelica. “Trobador-Mythen: Guilhem de Cabestanh und Jaufre Rudel.” In Mittelaltermythen. Edited by Ulrich Müller and Werner Wunderlich. Vol. 4: Künstler, Dichter, Gelehrte. Konstanz: UVK Verlagsgesellschaft, 2005, pp. 487-528. [The "heart-rending" story of Guilhem, and the romantic story of Jaufre dying for the love of an unknown lady, are retold as examples of how two real-life poets were transformed into enduring legends by the creators of the Occitan vidas; modern examples of further retellings in literature, opera, and film.]

80.

Rosenstein, Roy. "A Medieval Troubadour Mobilized in the French Resistance." Journal of the History of Ideas 59 (1998): 499-520. [Study of the role of the arts (film, drama, and particularly poetry) during the German occupation of France 1940-44; detailed look at the legend and lyrics of Jaufre Rudel and his themes of crusading and of distant love, used to inspire unity among French people at home, in prison camps, or in exile abroad as they sought to recover their beloved homeland.]

\subsection{Research in Progress, Goals for the Future}

81.

Beltrami, Pietro G. "Lirons-nous encore les troubadours, et comment?" In $\mathbf{1 0 2}$, AIEO 9, 2011, pp. 101-20. [Wide-ranging discussion of trends in troubadour research, especially the importance of electronic resources that are changing the way we conduct our investigations (COM, Trobadors, BEdT, RIALTO) and will inevitably alter our relationship to the texts, as did the passage from oral to written transmission in the thirteenth century; asserts that we are beginning to better understand the manner and purposes of the collection of poems into chansonniers and to appreciate the necessity of studying in depth the poetic value of each poem and each poet; text editions remain the chief task.]

82.

Fassó, Andrea. "La letteratura cavalleresca: nuove proposte." In La civiltà cavalleresca e l'Europa. Ripensare la storia della cavalleria. Atti dei I Convegno internazionale di studi (San Gimignano, Sala Tamagni, 3-4 giugno 2006). Edited by Franco Cardini and Isabella Gagliardi. Pisa: Pacini, 2007, pp. 107-37. [Sketches a few directions for new 
research: in the epic, traditional datings and chronology established by Bédier need to be redone; Celtic themes in the early troubadours need to be reexamined: dream worlds, sickness caused by a nighttime spirit; interrelationships between the epic and lyric should be further explored.]

\section{3.}

Gouiran, Gérard, et al. "Table ronde: le retour à la littérature." In $\mathbf{1 0 0 ,}$ AIEO 7, 2003, pp. 1273-1310. [Presentations by Gouiran, P. Beltrami, F. Kirsch, E. SchulzeBusacker, and M. Spampinato Beretta on possible new directions for Occitan literary research; most cautioned against the sweeping overall explanations that have been tried ("köhlerian," formalistic, feminist, psychoanalytic), in favor of deeper direct study of the individual texts one by one, aided by new editions, better understanding of the manuscripts, advanced electronic aids; more work is required on individual poets within their socio-historico-cultural background, on intertextuality not only within Occitan literature but also with Latin and neighboring literatures; several stressed the sheer pleasure to be found in contact with such rich works of art.]

84.

Klingebiel, Kathryn. "The State of Occitan Linguistic Studies: A Retrospective from the Bibliographer's Viewpoint, with a Look Forward.” Tenso 8, no. 2 (1993): 105-15. [Overview of tasks, strengths, and weaknesses of Old Occitan (mostly linguistic) research and publication; lists of journals, conferences, etc.; see also pp. 116-31: "Editions Extant and Desiderata," by Michael Routledge, and addenda by Mark Taylor, Tenso 12 (1996-67): 81-88.]

\section{5.}

Lachin, Giosuè. "Introduzione: Il primo canzoniere." In 164 , I trovatori nel Veneto, 2008, pp. xiii-cv. [A call for renewal of studies of the troubadour tradition in Italy, a period representing the turning point from oral to written transmission, the impetus toward the development of Sicilian and Italian poetry; argues that new, more precise philological methods to study the manuscripts in depth are essential to restarting the scholarship on a more solid base.]

\section{6.}

Lug, Robert. "Images sonores des troubadours: théories d'hier, postmodernisme naïf et la chance du XXIe siècle." In $>$ 102, AIEO 9, 2011, pp. 121-56. [Historical outline of the transcription and interpretation of troubadour melodies, through to modern theories involving arborescence; calls for further cooperation between philologists and musicologists to find ways to link metrical structures of the text with melodic structures; notes that continuing research may profit from the experience of oral practices that are still maintained on the periphery of Europe, for example in Irish oral traditions.]

\section{7.}

Meneghetti, Maria Luisa. "Permanence et renouveau des études médiévales (innovations théoriques et méthodologiques).” In $\$ 99, AIEO 6, 2001, pp. 3-12. [Identifies the uniqueness of Occitan scholarship as its openness to insights from many disciplines, along with its relative protection from the waves of new critical fads; identifies 
recent advances in the fields of intertextuality, feminist criticism, psychoanalytic approaches, and gender criticism; foresees advances in the areas of genre studies, chansonniers, Lacanian psychoanalysis, and sociocultural study of the courts.]

88.

Paden, William D. "The State of Medieval Studies in Occitan and French Literature." JEGP 105 (2006): 137-55. [Isolates three pressing themes that require urgent scholarly attention: the role of the trobairitz, within the new developments in gender studies; the Arab influence on Occitan literature; and better understanding of medieval textuality through the study of the chansonniers in their own right, perhaps by means of electronic variorum editions of the manuscripts.]

89.

Paden, William D. "Etat-présent des études sur les troubadours à la fin d'une décennie et à l'aube d'un siècle." In $>$ 99, AIEO 6, 2001, pp. 13-35. [Discussion of recent acceleration of research, diversification of methodologies, identification of new problems, new areas of interest in manuscripts, art, and music, and renewal of interest in areas once thought to be fully explored; discusses the meaning and importance of New Philology.]

90.

Rieger, Angelica. "Zukunftsaussichten und Perspektiven der deutschsprachigen Okzitanistik. Mit Diskussionsbeiträgen von Trudel Meisenburg, Jan Rüdiger, Tilbert D. Stegmann, Barbara Wehr und Ralf Bauer." In 125, Okzitanistik, Altokzitanistik, 2000, pp. 15-33. [An assessment of the history and present threatened state of teaching Occitan language and literature in Germany, Switzerland, and Austria; to assure the continuity of contributions to Occitan studies, a German-speaking branch of the AIEO has been formed; see http://www.occitania.de.]

91.

Rieger, Dietmar. "Audition et lecture dans le domaine de la poésie troubadouresque. Quelques réflexions sur la philologie provençale de demain.” RLaR 87 (1983): 69-85. In German: $\operatorname{ZrP} 100$ (1984): 78-91. Reprinted in Chanter et dire, Paris: Champion, 1997, pp. 31-44. [A call for more "positivist" research, especially into performance practices and the role of the jongleurs; discussion of reception theory: there may have been a specific public for the written presentation of the lyrics, alongside the predominantly oral audience; offers examples of written reception and suggestions for further research, using material from the vidas, razos, and salutz.]

\section{Collective Research Publications}

\subsection{Periodicals}

Twenty-six journals active in Medieval Occitan literature, in order of approximate frequency of articles over thirty years (N.B.: ZrP, CN, Tenso, Spec, RLiR, and RP publish many reviews):

CN (Cultura neolatina) Modena

RLaR (Revue des langues romanes) Montpellier 
Tenso Louisville

Rom (Romania) Paris

$M R$ (Medioevo romanzo) Naples

FL (La France latine) Paris

CCM (Cahiers de civilisation médiévale) Poitiers

RPh (Romance Philology) Berkeley

CDT (Critica del Testo) Rome

RST (Rivista di studi testuali) Alessandria

SMV (Studi mediolatini e volgari) Bologna

$\operatorname{ZrP}$ (Zeitschrift für romanische Philologie) Tübingen

SM (Studi Medievali) Spoleto

AMod (AnticoModerno) Rome

Neo (Neophilologus) Groningen

RZL (Romanistische Zeitschrift für Literaturgeschichte) Heidelberg

MAev (Medium Aevum) Oxford

NM (Neuphilologische Mitteilungen) Helsinki

$R N$ (Romance Notes) Chapel Hill, NC

Spec (Speculum) Cambridge, MA

$R R$ (Romanic Review) New York

$V R$ (Vox romanica) Berne

$R F$ (Romanische Forschungen) Frankfurt

AM (Annales du Midi) Toulouse

MA (Le Moyen Âge) Brussels

RLiR (Revue de linguistique romane) Strasbourg

\section{2.}

\subsection{Conference Proceedings (Professional Organizations)}

Actes du XXe Congrès international de linguistique et philologie romanes, Université de Zürich (6-11 avril 1992). Edited by Gerold Hilty. Tübingen: A. Francke, 1993.

93.

Atti del XXI Congresso internazionale di linguistica e filologia romanza (Palermo, 18-24 settembre 1995). Edited by Giovanni Ruffino. 6 vols. Tübingen: Niemeyer, 1998.

94.

AIEO 1 - Actes du premier congrès international de l'AIEO, Southampton, England, 1984. Edited by Peter Ricketts. London: Westfield College and AIEO, 1987.

95.

AIEO 2 - Atti del Secondo Congresso Internazionale della AIEO (Turin, 31 Aug.-5 Sept., 1987). Edited by Giuliano Gasca Queirazza. 2 vols. Turin: Dipartimento di Scienze Letterarie e Filologiche, 1993.

96.

AIEO 3 - Contacts de langues, de civilisations et intertextualité: IIIe Congrès International de l'AIEO-Montpellier 20-26 septembre [sic August] 1990. Edited by Gérard Gouiran.3 vols. Montpellier: Université de Montpellier CEO and Section française AIEO, 1992. 
97.

AIEO 4 - Actes du 4e Congrès international de l'AIEO, Vitoria-Gasteiz [Spain], 22-28 août 1993. Edited by Ricardo Cierbide-Martinena and Emiliana Ramos. 2 vols. Vitoria: Evagraf, 1994.

98.

AIEO 5 - Toulouse à la croisée des cultures. Actes du Ve Congrès international d'études occitanes, Toulouse, 19-24 aồt, 1996. Edited by Jacques Gourc and François Pic. 2 vols. Pau: AIEO, 1998.

99.

AIEO 6-Le Rayonnement de la civilisation occitane à l'aube d'un nouveau millénaire. Sixth Congress AIEO (Vienna, 12-19 September, 1999). Edited by Georg Kremnitz, Barbara Czernnilofsky, Peter Cichon, and Robert Tanzmeister. Vienna: Edition Praesens, 2001.

100.

AIEO 7 - Scène, évolution, sort de la langue et de la littérature d'oc. Actes du Septième Congrès International de l'AIEO, Reggio Calabria-Messina, 7-13 juillet 2002. Edited by Rossana Castano, Saverio Guida, and Fortunata Latella. 2 vols. Rome: Viella, 2003.

101.

AIEO 8 - La voix occitane: Actes du VIIIe Congrès de l'AIEO (Bordeaux, 12-17 octobre 2005). Edited by Guy Latry. 2 vols. Bordeaux: Presses Universitaires de Bordeaux, 2009.

102.

AIEO 9 - L'Occitanie invitée de l'Euregio. Liège 1981-Aix-la-Chapelle 2008: Bilan et perspectives Actes du Neuvième Congrès International de l'AIEO, Aix-la-Chapelle, 24-31 aout 2008. Edited by Angelica Rieger, with the collaboration of Domergue Sumien. Aachener Romanistische Arbeiten, 3. Aachen: Shaker, 2011.

AIEO 10 - Béziers, 12-19 June 2011. [not yet published]

103.

ICLS 3 - Court and Poet: Selected Proceedings of the Third Congress of the ICLS (Liverpool, 1980). Edited by Glyn S. Burgess et al. ARCA Classical and Medieval Texts, Papers and Monographs, 5. Liverpool: F. Cairns, 1981.

104.

ICLS 4 - The Spirit of the Court: Selected Proceedings of the Fourth Triennial Congress of the ICLS, Toronto, 1983. Edited by Glyn S. Burgess and Robert A. Taylor. Woodbridge: Boydell and Brewer, 1985.

105.

ICLS 6 - L'Imaginaire courtois et son double. Actes du VIème Congrès triennal de la Société internationale de littérature courtoise (ICLS), Fisciano (Salerno), 24-28 juillet 1989. Edited by Giovanna Angeli and Luciano Formisano. Naples: Edizioni scientifiche italiane, 1991.

106.

ICLS 9- The Court Reconvenes: Courtly Literature across the Disciplines (Selected Papers 
from the 9th ICLS Congress, Vancouver, July 1998). Edited by Barbara K. Altmann and Carleton W. Carroll. Cambridge: D. S. Brewer, 2003.

107.

\subsection{Congress and Colloquium Proceedings}

Ab nou cor et ab nou talen: Nouvelles tendances de la recherche médiévale occitane. Actes du Colloque AIEO (L'Aquila, 5-7 juillet 2001). Edited by Anna Ferrari and Stefania Romualdi. Modena: Mucchi, 2004.

108.

Atti del Convegno Internazionale di Studi su Sordello da Goito (Goito-Mantova 13-15 nov. 1997). Edited by Stefano Asperti and Maria Careri, in CN 60 (2000). [Includes fifteen articles on various aspects of Sordello, his poetry, his life, his background, and his influence.]

109.

Comunicazione e propaganda nei secoli XII e XIII. Atti del convegno internazionale, Messina, 24-26 maggio 2007. Edited by Rossana Castano, Fortunata Latella, and Tania Sorrenti. Rome: Viella Libreria Editrice, 2007.

110.

The Cultural Milieu of the Troubadours and Trouvères. Edited by Nancy van Deusen. Ottawa: Institute of Mediaeval Music, 1994.

111.

L'Espace lyrique méditerranéen au Moyen Âge. Nouvelles approches. Edited by Dominque Billy, François Clément, and Annie Combes. Toulouse: Presses Universitaires du Mirail, 2006.

112.

Filologia classica e filologia romanza: esperienze ecdotiche a confronto. Atti del convegno di Roma 25-27 maggio 1995. Spoleto: CISAM, 1998.

113.

Il genere "tenzone" nelle letterature romanze delle origini. Atti del convegno Losanna 13-15 novembre 1997. Edited by Matteo Pedroni, Antonio Stäuble, and Gianni A. Papini. Ravenna: Longo, 1999.

114.

Les genres au Moyen Âge: la question de l'hétérogénéité. Actes du colloque, Pau, 12-13 novembre 2009. Edited by Hélène Charpentier and Valérie Fasseur. Bandol: Éditions Vallongues, 2010.

115.

Interpretazioni dei trovatori. Atti del Convegno, Bologna, 1999. Quaderni di filologia romanza, 14. Edited by Andrea Fassò and Luciano Formisano. Bologna: Pàtron, 2001.

116.

Languedoc et langue d'oc. Actes du colloque, Toulouse, janvier 1996. Perspectives médiévales special number, supplement to 22 (1996). 
117.

Le letterature romanze del medioevo: testi, storia, intersezioni. Atti del V Convegno nazionale della Società italiana di filologia romanza, Roma, 1997. Edited by A. Pioletti. Rome: Rubbettino, 2000.

\section{8.}

La lirica romanza del Medioevo: Storia, tradizioni, interpretazioni. Atti del VI convegno triennale della Società italiana di fllologia romanza. Edited by Furio Brugnolo and Francesca Gambino. Società Italiana di Filologia Romanza (SIFR). 2 vols. Padua: Unipress, 2009.

\section{9.}

Lyrique romane médiévale: la tradition des chansonniers. Actes du colloque de Liège, 1989. Edited by Madeleine Tyssens. Bibliothèque de la Faculté de Philosophie et Lettres de l'Université de Liège, 258. Geneva: Droz, 1991.

120.

Medieval Lyric: Genres in Historical Context. Edited by William D. Paden. Urbana: University of Illinois Press, 2000.

121.

Medieval Woman's Song: Cross-Cultural Approaches. Edited by Anne L. Klinck and A. M. Rasmussen. Philadelphia: University of Pennsylvania Press, 2002.

122.

Métriques du Moyen Âge et de la Renaissance. Actes du Colloque international du Centre d'études métriques (1996). Edited by Dominique Billy. Paris: L'Harmattan, 1999.

123.

La narrativa in Provenza e Catalogna nel XIII e XIV secolo. Atti del colloquio svoltosi a Roma dal 12 al 14 maggio 1993. Pisa: ETS, 1995.

124.

L'Occitan. Une langue du travail \& de la vie quotidienne du XIIe au XXIe siècle. Les traductions et les termes techniques en langue d'oc. Actes du colloque organisé à Limoges les 23 et 24 mai 2008. Edited by Jean-Loup Lemaître and Françoise Vielliard. Ussel: Musée du Pays d'Ussel_Centre Trobar, 2009.

125.

Okzitanistik, Altokzitanistik und Provenzalistik. Geschichte und Auftrag einer europäischen Philologie. Edited by Angelica Rieger. [From section 15 of the 26th Deutscher Romanistentag, Osnabrück, 1999.] Frankfurt: Lang, 2000.

126.

Poeti e poesia a Genova (e dintorni) nell'età médiévale. Atti del convegno per Genova capital della cultura europea 2004. Edited by Margherita Lecco. Alessandria: Orso, 2006. 127.

Poetics of Love in the Middle Ages: Texts and Contexts. Edited by Moshé Lazar and Norris J. Lacy. Fairfax: George Mason University Press, 1989.

128.

Le Rayonnement des troubadours. Actes du colloque de l'AIEO, Amsterdam, 16-18 oct., 1995. Edited by Anton [Anthonius Hendrikus] Touber. Amsterdam: Rodopi, 1998. 
129.

Lo spazio letterario del medioevo. 1. Il medioevo latino; 2. Il Medioevo volgare; 3. Le culture circonstanti. Edited by Piero Boitani, Mario Mancini, and Alberto Varvaro. Rome: Salerno Editrice, 1999-2006. [This is a vast encyclopedic work in fifteen large volumes; only 2. Il medioevo volgare, is applicable directly to Occitan: it contains many individual articles by a variety of scholars, distributed throughout its six volumes, touching on many aspects of Occitan literature as well as the other six Romance vernaculars and medieval Germanic, Celtic, and English; see critical remarks regarding use of the work in $\mathbf{2 0 9 7}$, Guida, "Rechercher," pp. 71-82.]

130.

Troubadours et cathares en Occitanie médiévale. Actes du colloque de Chancelade, 24 et 25 août 2002. Edited by Richard Bordes. Cahors: L'Hydre, 2004.

131.

Les Troubadours et l'état toulousain avant la croisade (1209). Colloque du CELO, Toulouse, Dec. 9-10, 1988. Edited by A. Krispin. Bordes: CELO and William Blake, 1994.

132.

The Voice of the Trobairitz: Perspectives on the Women Troubadours. Edited by William D. Paden. Philadelphia: University of Pennsylvania Press, 1989. [Introduction, pp. 1-28, has useful observations on trobairitz composition; bibliography in "Checklist of Poems by the Trobairitz" (pp. 227-37).]

133.

The World of Eleanor of Aquitaine: Literature and Society in Southern France between the Eleventh and Thirteenth Centuries. Edited by Marcus Bull and Catherine Léglu. Woodbridge: Boydell, 2005.

\section{4.}

\subsection{Collective Publications: Mélanges/Festschrift Volumes}

Cantarem d'aquestz trobadors: studi occitanici in onore di Giuseppe Tavani. Edited by Luciano Rossi. Alessandria: Dell'Orso, 1995.

135.

Carmina semper et citharae cordi: études de philologie et métrique offertes à Aldo Menichetti. Edited by M.-C. Zai, P. Gresti, S. Perrin, Ph. Vernay, and M. Zennari. Geneva: Slatkine, 2000.

136.

Chrétien de Troyes and the Troubadours: Essays in Memory of the Late Leslie Topsfield. Edited by Peter S. Noble and Linda M. Paterson. Cambridge: St. Catherine's College, 1984.

137.

Contez me tout: Mélanges de langue et de littérature médiévales offerts à Herman Braet. Edited by Catherine Bel, Pascale Dumont, and Frank Willaert. Louvain: Peeters, 2006.

138.

Convergences médiévales: épopée, lyrique, roman. Mélanges offerts à Madeleine Tyssens. Brussels: De Boeck, 2001. 
139.

Ensi firent li ancessor. Mélanges de philologie médiévale offerts à Marc-René Jung. Edited by Luciano Rossi et al. 2 vols. Alessandria: Edizioni dell'Orso, 1996.

\section{0.}

Études de langue et de littérature médiévales offertes à Peter T. Ricketts à l'occasion de son 70ème anniversaire. Edited by Ann Buckley and Dominique Billy. Turnhout: Brepols, 2005.

141.

Études de philologie romane et d'histoire littéraire offertes à Jules Horrent à l'occasion de son soixantième anniversaire. Edited by J.-M. D'Heur and N. Cherubini. Liège: Gedit, 1980.

142.

Filologia romanza e cultura médiévale. Studi in onore di Elio Melli. Edited by Luciano Formisano, Mario Mancini, and Andrea Fassò. 2 vols. Turin: Edizioni dell'Orso, 1998.

143.

Homenaje a Álvaro Galmés de Fuentes. 3 vols. Oviedo: Editorial Gredos, 1985 and 1987.

144.

The Legacy of Muslim Spain. Edited by Salma Khadra Jayyusi. 2 vols. Leiden: Brill, 1992.

\section{5.}

"Liber," "Fragmenta," "Libellus" prima e dopo Petrarca. In ricordo di D'Arco Silvio Avalle. Seminario internazionale di studi, Bergamo, 23-25 ottobre 2003. Edited by F. Lo Monaco, L. C. Rossi, and N. Scaffai. Florence: SISMEL-Galluzzo, 2006.

146.

Literatur: Geschichte und Verstehen. Festschrift für Ulrich Mölk zum 60. Geburtstag. Edited by H. Hudde and U. Schöning. Heidelberg: Winter, 1997.

147.

Mélanges d'histoire littéraire, de linguistique et de philologie romanes offerts à Charles

Rostaing par ses collègues, ses élèves et ses amis. Edited by Jacques de Caluwé. 2 vols. Liège: Association des romanistes de l'Université de Liège, 1974.

148.

Mélanges de langues et de littératures romanes offerts à Carl Theodor Gossen. Edited by G. Colón and Robert Kemp. 2 vols. Berne: Francke, and Liège: Marche romane, 1976.

\section{9.}

Mélanges de philolologie et de littérature médiévales offerts à Michel Burger. Edited by Jacqueline Cerquiglini-Toulet and Olivier Collet. Geneva: Droz, 1994.

150.

Mélanges de philologie romane offerts à Charles Camproux. Montpellier: CEO, 1978.

151. Il miglior fabbro: Mélanges de langue et de littérature occitanes en hommage à Pierre Bec. Poitiers: Université de Poitiers, CESCM, 1991. 
152.

Miscellanea di studi in onore di Aurelio Roncaglia a cinquant'anni dalla sua laurea. 4 vols. Modena: Mucchi, 1989.

153.

Miscellanea di studi romanzi offerta a Giuliano Gasca Queirazza. Edited by Anna Cornagliotti et al. Alessandria: Edizioni dell'Orso, 1988.

154.

Plaist vos oür bone cançon vallant? Mélanges de langue et de littérature médiévales offerts à F. Suard. Edited by Dominique Boutet, Marie-Madeleine Castellani, Françoise Ferrand, and Aimé Petit. Lille: Université Charles de Gaulle Lille 3, SRED, 1999.

155.

Romania cantat: Lieder in alten und neuen Chorsätzen Gerhard Rohlfs zum 85. Geburtstag gewidmet. Edited by Francisco Javier Oroz Arizcuren. 2 vols. Tübingen: Gunter Narr, 1980.

156.

Das Schöne im Wirklichen—Das Wirkliche im Schönen. Festschrift für Dietmar Rieger zum 60. Geburtstag. Edited by Anne Amend-Söchting et al. Heidelberg: C. Winter, 2002.

157.

De Sens Rassis: Essays in Honor of Rupert T. Pickens. Edited by Keith Busby, Bernard Guidot, and Logan E. Whalen. Amsterdam: Rodopi, 2005.

158.

Studi di filologia romanza offerti a Valeria Bertolucci Pizzorusso. Edited by Pietro G. Beltrami, Maria Grazia Capusso, Sergio Vatteroni, and Fabrizio Cigni. 2 vols. Pisa: Pacini, 2006.

159.

Studia occitanica in memoriam Paul Remy. Edited by Hans-Erich Keller, in collaboration with Jean-Marie D'Heur, Guy R. Mermier, and Marc Vuijlsteke. 2 vols. Kalamazoo, MI: Medieval Institute Publications, 1986.

160.

Studia in honorem prof. M. de Riquer. Edited by Carlos Alvar. 4 vols. Barcelona: Quaderns Crema, 1986-91.

161.

Studies in Honor of Hans-Erich Keller: Medieval French and Occitan Literature and Romance Linguistics. Edited by Rupert Pickens. Kalamazoo, MI: Medieval Institute Publications, 1993.

\section{2.}

Trobadors a la Península Ibèrica. Homenatge al Dr. Martí de Riquer. Edited by Vicenç Beltrán, Meritxell Simó, and Elena Roig. Barcelona: Publicacions de l'Abadia de Montserrat, 2006.

163.

The Troubadours and the Epic: Essays in Memory of W. Mary Hackett. Edited by L. M. Paterson and S. B. Gaunt. Warwick: Dept. of French, University of Warwick, 1987. 
164.

I trovatori nel Veneto e a Venezia. Atti del Convegno Internazionale Venezia, 28-31 ottobre 2004. Edited by Giosuè Lachin. Rome: Antenore, 2008.

\section{Occitan Language}

\subsection{Practical Guides}

165.

Lafont, Robert. Eléments de phonétique de l'occitan. Valderiès: Vent Terral, 1983. [A basic presentation of essential evolutions from Vulgar Latin to modern Occitan.]

166.

Jensen, Frede. The Old Provençal Noun and Adjective Declension. Odense: Odense University Press, 1976.

167.

Jensen, Frede. Syntaxe de l'ancien occitan. Beihefte zur $\operatorname{ZrP}$, 257. Tübingen: Niemeyer, 1994. [Revision of his Syntax of Medieval Occitan, 1986.]

168.

Paden, William D. An Introduction to Old Occitan. New York: Modern Language Association, 1998. [Language instruction, readings, CD-ROM with poetry spoken by Paden, sung by Elizabeth Aubrey; musical notation for nine songs, pp. 560-77, with complete text; five of these are sung by Elizabeth Aubrey on the accompanying CD-ROM; introductory material "The Music of the Troubadours" by Aubrey, pp. 578-81.]

169.

Romieu, Maurice, and André Bianchi. La Lenga del trobar: precís de gramatica d'occitan ancian. La langue du trobar: précis de grammaire d'ancien occitan. Bordeaux: Presses Universitaires de Bordeaux, 1999. 2nd edition, revised and corrected, 2002; 3rd edition, 2006. [Helpful presentation of morphology and syntax-in Occitan and French.]

170.

Rourret, Robert. La lenga dels trobadors = La langue des troubadours. Grasse: Oiseau bleu, 2006. [Practical guide (in French) to grammar, pronunciation, and vocabulary; pp. 244-339: useful lexicon of key vocabulary of finamors, with quotations from the poetry.]

171.

Smith, Nathaniel B., and T. Bergin. An Old Provençal Primer. New York: Garland, 1984. [Presentation of history, pronunciation, phonetics, morphology; includes exercises with answers; eleven readings with glossary; extensive bibliography of linguistic items, pp. 351-61.]

172.

\subsection{Philological Research}

Borghi Cedrini, Luciana. "La lingua dei trovatori tra grammatiche e edizioni." In 
- 107, Ab nou cor, 2004, pp. 191-206. [Argues that we cannot judge what is "normal" in poetic language until we break free from the vicious circle by which grammars have been formulated by reference to the early editions of the poetry, and judgments as to the correctness of language forms made by reference to these same early grammars; concludes in this and other articles that Old Occitan grammars need to be redone, based on a new analysis of the manuscript tradition.]

173.

Field, Thomas T. "Troubadour Performance and the Origins of the Occitan Koiné." Tenso 21 (2006): 36-54. [Argues that the popular notion of Occitan as a miraculous, unified literary language, and an oral one at that, is a myth; the proper linguistic definition of a koiné does not apply; the troubadours used a semiartificial form of language, associated with the musical performance of poetry. The performance pattern was established by the pronunciation and lexicon of the most prestigious of the early poet/performers and was used for aesthetic reasons by many others, even from other linguistic origins — not obligatory, not always consistent, and not to be identified with any of the local regional forms.]

174.

Lee, Charmaine. "Considérations sur la langue des romans occitans." In $\mathbf{1 0 2}$, AIEO 9, 2011, pp. 207-15. [Argues that the formation of the Occitan scripta may be studied more satisfactorily through lexical investigation than through phonetics and morphology; the vocabulary of Jaufre and other non-lyric texts reveals shared characteristics: "mixed regionalisms," more frequent rare forms, etc., which are unlike usage in the troubadour lyrics; this points to the formation of the basic Occitan scripta in an area from the Rhone valley to Poitou, an area under the influence of Cluny; the troubadour koiné is more restricted, "purified," and may have been fixed mainly in northern Italy in connection with its use in the chansonniers.]

175.

Paden, William D. "Declension in Twelfth-Century Occitan: On Editing Early Troubadours, with Particular Reference to Marcabru." Tenso 18 (2003): 67-115. [Critical of Gaunt et al. editors of Marcabru for not trying to solve the "non-normative case-inflexions" found in many manuscripts; detailed analysis of early non-lyric texts reveals anomalies in declension that must be taken into consideration by editors. Was there a use of declension governed by register? The complex investigation may help editors to make better editions.]

\section{6.}

Stasyk, Maria. Sprache und Werke von vier Trobadors im Licht der Forschung, unter besonderer Berücksichtigung fremdsprachlicher und dialektaler Einflüsse. Doctoral diss., University of Siegen, 2006. Online at http://dokumentix.ub.uni-siegen.de/opus/ volltexte/2007/283/pdf/stasyk.pdf. [Investigation of the content and language of poems by Guilhem de Peitieus, Peire Cardenal, Peire Vidal, and Marcabru, looking for linguistic influence from foreign (German, French, Italian, Spanish) and regional forms, whether these were used consciously for reasons of style (i.e., the use of forms in -ei by later poets, imitating Guilhem's usage) or accidentally (by poet or scribe). 
Points out the need for new work into the nonstandard linguistic forms of most troubadours, in order to better grasp the total variety of the poetic language.]

\section{The Texts}

\section{Manuscript Sources}

\subsection{The Chansonniers: General Studies}

[There are about 425 extant manuscripts containing Occitan texts; ninety-five contain troubadour poetry, forty-one of which are true chansonniers, complete or fragmentary; the thirty-one major chansonniers are listed in $\mathbf{2 8 2}$, Gaunt and Kay, Troubadours, 1999, pp. 303-5. A full list is online at http://www.bedt.it.] 177.

León Gómez, Magdalena. "Les chansonniers provençaux.” Europe 86 (2008): 31-45. [Useful summary of the status of research on the Occitan manuscripts; information on dating, contents, history of compilations, location of copy-centers, and principles of organization.]

\section{8.}

Avalle, d'Arco Silvio. I manoscritti della letteratura in lingua d'oc. New edition by Lino Leonardi. Turin: Einaudi, 1993. Original edition, 1961: La letteratura médiévale in lingua d'oc nella sua tradizione manoscritta: problemi di critica testuale. Abbreviated German version of the original in Geschichte der Textüberlieferung, Zürich: Atlantis, 1964, pp. 261-318. [Landmark study, advocating the neo-Lachmannian approach to text editing, which entails an attempted reestablishment of an archetype for the extant manuscript copies; Bédier's principle of editing the "best manuscript" has caused the variant readings of other manuscripts to be neglected; the study postulates that there was a written form at the origins of troubadour poems, and that transmission was primarily written; the 1993 update retains Avalle's principles, but its new title emphasizes more clearly the major focus on manuscript analysis, as a first step toward better literary understanding. Three valuable appendices from 1961 have been omitted from the new edition. See detailed review by Naohiko Seto, FL 130 (2002): 159-71; for more recent developments of Avalle's principles, see Lino Leonardi, "Creazione e fortuna di un genere: la filologia dei canzonieri dopo Avalle," in 145, "Liber,"2006, pp. 3-21, calling for the study of the chansonniers as independent entities, rather than as anthologies.]

179.

Asperti, Stefano. "La tradizione occitanica." In 129, Lo spazio letterario, 2, Il Medioevo volgare, vol. 2, 2002, pp. 521-54. [Pp. 545-53: bibliography for study of the chansonniers; a useful summary of what the manuscripts are like, where from, new types of research required to clarify their nature; pp. 553-54: list of the fortynine major troubadour manuscripts.]

180.

Barbieri, Luca. "Tertium non datur? Alcune riflessioni sulla 'terza tradizione' manoscritta della lirica trobadorica.” SM 47 (2006): 497-548. [Supportive of Avalle 
178 I manoscitti, 1993; applauds a return to Lachmann's basic principles in Italian scholarship, giving latitude for the editor's experience and careful intuition = "neoLachmannian."]

181.

Borghi Cedrini, Luciana. "I libri della poesia trobadorica." In 145, "Liber," 2006, pp. 69-80. [Comparative groupings of the chansonniers by date, by place, by inner organizing principle or lack thereof, and collections made by amateurs.]

\section{2.}

Brunel-Lobrichon, Geneviève. "Réflexions sur les manuscrits occitans médiévaux." Colloque de Wégimont: les outils de la recherche occitane. 2 vols. Bulletins de l'AIEO 7, 8. London: Royal Holloway and Bedford New College, University of London, 1990-91, 2:1-12. [Description of efforts to update Brunel's catalogue of Occitan manuscripts, including revised locations for some manuscripts; several additions to the corpus, texts just discovered or recognized as Occitan; a detailed list of all medieval Occitan manuscripts in Paris; methodology of new advanced study of manuscripts; copies of original manuscripts (now disappeared) may still be found-they are difficult to locate. Pp. 9-10: history of the manuscripts that preserved the Chanson de la croisade albigeoise; pp. 11-12: history of the preservation of the Chanson de Sainte Foy.]

183.

See 25, DOM. [Lists eighty-three chansonniers with identification, location, date, etc.: at http://www.dom.badw-muenchen.de/fr/biblio/SigelCh.htm.]

\section{4.}

Ferrari, Anna. "Le chansonnier et son double." In 119, Lyrique romane, 1991, pp. 303-27. [Stresses the importance of copies of manuscripts we still have, or those now lost, and isolated tables of manuscripts, all relatively neglected by researchers and none listed in PC.]

185.

Greene, Virginie. "Suite provençale for Ocarina, Triangle, and Powerpoint.” Glossator 4 (2011): 139-70. [A provocative, experimental, tongue-in-cheek look at the troubadour manuscript tradition and the meaning of illuminated initials introducing poems of Jaufre Rudel.]

186.

Guida, Saverio. "La 'Biografia' di Aimeric de Peguilhan.” RST 3 (2001): 221-34. [Stresses the likelihood that Uc de Saint Circ wrote the continuation of the vida of Aimeric in MS $R$; enriches the appreciation of how close the two troubadours were as participants in the rich cultural life of the courts of the Marca and how influential they and other troubadours were in forming the base of poetic life that was about to be transformed into the new Italian poetic movement.]

187.

Kendrick, Laura. "L'image du troubadour comme auteur dans les chansonniers." In Auctor et auctoritas. Invention et conformisme dans l'écriture médiévale: Actes du colloque tenu à l'Université de Versailles-Saint-Quentin-en-Yvelines (14-16 juin 1999). Edited 
by Michel Zimmermann. Paris: École des Chartes, 2001, pp. 507-19. [The intent of the compilers of the chansonniers, particularly in northern Italy, was to "authorize" the poetry, modeled on biblical and classical compilations, in order to dignify the troubadours as authors rather than just as entertainers, and to limit the possible interpretations of their texts.]

188.

Meliga, Walter. "La tradizione manoscritta dei trovatori genovesi." In $>126$, Poeti e poesia, 2006, pp. 151-62. [Very detailed information on the group of nine "Genovese” troubadours: Bonifaci Calvo, Calega Panzan, Jacme Grill, Lanfranc Cigala, Luquet Catelus, Perceval Doria, Rubaut, Scot, and Simon Doria; close analysis of manuscript tradition, which separates them from the group of troubadours centered on the Veneto and aligns them more closely with Provence.]

189.

Meneghetti, Maria Luisa. "La forma-canzoniere fra tradizione mediolatina e tradizioni volgari." CDT 2, no. 1 (1999): 119-40. [Collections of poetry with varied interior structures or "messages" was typical of the chansonniers of the mid-thirteenth century, but the full tradition of authordirected choices of works is more typical of Sicilian and Italian poets.]

190.

Nichols, Stephen G. "Reading \& Seeing: Troubadours in a Manuscript Context." Poetica 38 (2006): 297-328. [Theories of communication from Hugh of St. Victor are applied to a complex reading of troubadour songs and accompanying marginal decorations, principally works by Jausbert de Puycibot; dialectical interactions between text and paintings are interpreted in three imagined scenarios.]

191.

Paden, William D. "Manuscripts." In 281, Handbook, 1995, pp. 307-33. [History of Occitan texts from about A.D. 1000 on: charters, earliest texts, chansonniers; discussion of the controversial theories of transmission (oral vs. written) preceding the notation of the extant chansonniers, and of the methods of textual edition (Bédier vs. Lachmann); practical guidance for modern text editors; in appendix, sigla of thirty-one troubadour manuscripts.]

192.

Pulsoni, Carlo. "Appunti per una descrizione storico-geografica della tradizione manoscritta trobadorica." CDT 7 (2004): 357-89. [A study of chronology and location of the production of the troubadour chansonniers and their influence on some fourteenth-century Italian authors.]

193.

Zimei, Enrico. Paraula escricha: Ricerche sulla segmentazione della catena grafica nei canzonieri trobadorici. Rome: Nuova Cultura, 2009. [Fifteen troubadour manuscripts are analyzed for word division, agglutination, abbreviations, etc.; scribes have varying but stable practices, thus enabling closer study of manuscript history.]

194.

Zufferey, François. Recherches linguistiques sur les chansonniers provençaux. Geneva: 
Droz, 1987. [A remarkably complete and scientific analysis of forty manuscripts in five groups; chansonnier $C$, pp. 134-52; detailed bibliography; see extensive commentary by Lino Leonardi, "Problemi di stratigrafia occitanica: a proposito delle 'Recherches' di François Zufferey,” Rom 108 (1987): 354-86.]

\section{5.}

Zufferey, François. "Philologie matérielle et codicologie: l'enseignement des chansonniers provençaux." In Filologia classica e filologia romanza: Esperienze ecdotiche a confronto. Atti del convegno di Roma 25-27 maggio 1995. Spoleto: CISAM, 1998, pp. 429-43. [The importance of a close, informed analysis of the material codex as a prerequisite to textual edition; three examples from Occitan chansonniers of valuable information that can be deduced and used to better understand the fabrication of the codices or to explain apparent anomalies in their presentation.]

\section{6.}

Lemaître, Jean-Loup, Françoise Vielliard et al. Portraits de troubadours: initiales des chansonniers provençaux I et $K$ (Paris BNF fr. 854 et 12473). Ussel: Musée du pays d'Ussel et Pennautier: CREMM-Trobar and Paris: Diffusion de Brocard, 2006. [A (Rome), $I$, and $K$ (Paris) are the three most interesting of the five manuscripts containing historiated initial letters, all three coming probably from the same workshop in northern Italy; contains high-quality color reproductions of 170 miniatures; introduction on the chansonniers (Vielliard), workshops (Gousset), manuscript descriptions (Lafitte), and heraldry (Palasi).]

197.

Camps, Jean-Baptiste. "Vocabulaire du texte, vocabulaire de l'image: la représentation des troubadours dans les chansonniers occitans." In Actes du colloque Nouvelle recherche en domaine occitan: approches interdisciplinaires (Albi, 11-12 juin 2009). Turnhout: Brepols, 2012, in press. [In some of the chansonniers, works of individual poets are introduced by a vida together with a representative miniature portrait; computer analysis is used to establish the vocabulary of the image and its link to the text of the vida.]

198.

Jullian, Martine. "Images de trobairitz." CLIO: Histoire, femmes et sociétés 25 (2007): 165-83. [This is a close study of the portraits of trobairitz found in four chansonniers: there is no representation of individual personality, only standardized poses; equality of treatment with the masculine portraits; descriptions of portraits of seven named trobairitz.]

199.

Riquer, Martin de. Vidas y retratos de trovadores: textos y miniaturas del siglo XIII. Barcelona: Circulo de Lectores y Galaxia Gutenbeg, 1995. [Contains reproductions in rich color from four manuscripts: $A$ and $H$ from the Vatican, $I$ and $K$ from the Bibliothèque nationale de France in Paris, juxtaposed with the vidas and razos from the same manuscripts; Riquer says it is for nonspecialists, but the introduction has rich information for specialists as well; 173 vidas and razos with Spanish translation; 223 miniatures of 116 poets, some depicted more than once.] 


\subsection{Individual Chansonniers}

200.

Intavulare: Tavole di canzonieri romanzi. Vol. 1: Canzonieri provenzali. General editor Anna Ferrari. Modena: Mucchi, 1990-2009, except for vol. 1, part 1: published by Biblioteca Apostolica Vaticana. [A project to tabulate the contents of all Romance songbooks; plans call for the study of twenty-three Occitan manuscripts out of ca. fifty, of which sixteen have appeared as of 2009; each study is to contain new editions of the tables of contents, or the creation of tables for those manuscripts that have none, various indices, detailed description of the codex, facsimiles; see the review article by William D. Paden, RPh 61 (2007): 79-92: history of the project to 2007; lists of works published, in press, in preparation; comments, queries, and suggestions; as Paden points out, much of the information is now available online: see $\$$ 49, BEdT; see also the review article by Fabio Zinelli, Rom 112 (2004): 46-110, providing a detailed critique up to vol. 6; published so far: vol. 1, part 1: A, F, $L, O$ (A. Lombardi, 1998) [see "Istruzioni per l'uso" vol. 1, pp. 1-14.]; vol. 1, part 2: $H$ (M. Careri, 1998) [see preliminary technical study by Careri, 1990, and complementary literary study by Poe in Compilatio, 2000]; vol. 2: $I$ and $K$ (W. Meliga, 2001); vol. 3: $V$ (I. Zamuner, 2002) [see complementary information by Anna Alberni, "El cançoner occità $V:$ un estat de la qüesti," CN 65 (2005): 155-80]; vol. 4: P (G. Noto, 2003); vol. 5: S (L. Borghi Cedrini, 2004); vol. 6: $G$ (F. Carapezza, 2004); vol. 7: $C$ (A. Radaelli, 2005); vol. 8: J (E. Zimei, 2006); vol. 9: $B$ (S. Romualdi, 2006); vol. 10: Sg (S. Ventura, 2009); vol. 11: $V e A g$ (A. Alberni, 2006 [2008]); seven are in preparation: $a$ (L. Borghi Cedrini, and W. Meliga); $D$ (G. Lachin); $a 1$ (L. Borghi Cedrini and W. Meliga); $N$ (C. Gillioz); $E$ (C. Pulsoni); $M$ (A. Ferrari); $T$ (G. Brunetti).]

\section{1.}

Asperti, Stefano. "Sul canzoniere provenzale $M$ : ordinamento interno e problemi di attribuzione.” Romanica Vulgaria. Quaderni 10-11 (1989): 137-69. [Analysis of the principles of organization of the manuscript; individual fascicles start with a major poet, then are filled in with minor poets (prestigious place is given to Giraut de Bornelh); arranged by genres; detailed study of the sirventes section, suggesting that attributions in it need to be reexamined.]

202.

Bertolucci Pizzorusso, Valeria. "Osservazioni e proposte per la ricerca sui canzonieri individuali." In 119, Lyrique romane, 1991, pp. 273-302. [Studies the relative order of Bertran de Born's poems in several manuscripts.]

203.

Cabré, Miriam, and Sadurní Martí. "Le chansonnier Sg au carrefour occitano-catalan." Rom 128 (2010): 92-134. [History and codicological study of the manuscript, prepared probably for Count Pere II in the late fourteenth century; see note 85 regarding Ventura's edition of $\mathrm{Sg}$ for Intavulare, 200, 2009, which Cabré was not able to consult.]

\section{4.}

Canova Mariani, Giordana. "Il poeta e la sua immagine: il contributo della miniatura alla localizzazione e alla datazione dei canzonieri provenzali $A, I, K$ e $N$." In $>164, I$ 
trovatori nel Veneto, 2008, pp. 47-76. [Links the figures in $I, K$, and $A$ with those in other Venetian manuscripts; $A$ is earlier, and $K$ probably precedes $I$, both being in the 1290 s; $N$ is less likely to be Venetian but is from the Veneto region.]

205.

Keller, Hans-Erich. "Le chansonnier occitan N2 et son rapport avec les chansonniers I et K." In Philologies Old and New: Essays in Honor of Peter Florian Dembowski. Edited by Joan Tasker Grimbert and Carol J. Chase. Princeton, NJ: Edward G. Armstrong Monographs, 2001, pp. 85-92. [Completed before Keller's death in May 1999; published with a critical study by Elizabeth Poe.]

\section{6.}

Meliga, Walter. "I canzonieri $I, K$ : la tradizione veneta allargata." In $>\mathbf{1 6 4}$, I trovatori nel Veneto, 2008, pp. 305-24. [Study of the twin chansonniers as models of rationally organized songbooks, created in the Veneto; precise information on ordering of elements, minor inadvertent slips, slight editorial changes from $K$ to $I$; confirmation of the lost two-branched transmission that precedes the two codices.]

207.

Poe, Elizabeth W. Compilatio: Lyric Texts and Prose Commentaries in Troubadour Manuscript H (Vatican Latin 3207). Lexington, KY: French Forum, 2000. [A complement to Maria Careri. Il canzoniere provenzale H (Vat. lat. 3207). Struttura, contenuto e fonti. Modena: Mucchi, 1990; Careri gives a meticulous exposition of the more technical aspects of the compilation of MS $H$; Poe provides the complementary literary analysis of the codex, as invited by Careri in her book.]

208.

Poe, Elizabeth W. “A Re-evaluation of Troubadour Manuscript N2.” Revue belge de philologie et d'histoire 83 (2005): 819-28. [MS N2 is not a faithful, trustworthy copy of a lost original manuscript, as is MS $a$, but was drawn from several sources; compiled by Giulio Camillo, it seems to have been conceived as a personal study-guide to Petrarch's Canzoniere, a collection of poems, vidas, and razos concerning the troubadours held in high esteem by Petrarch; it testifies to the circulation of Occitan manuscripts in sixteenth-century Italy and to interest in Petrarch's debt to the troubadours, but it should not be taken as the equivalent of a medieval manuscript.]

209.

Romualdi, Stefania. Edizioni Diplomatiche a confronto: I Canzonieri Provenzali B (BnF, fr. 1592) e A (BAV, Vat. lat. 5232). Modena: Mucchi, 2008. [This is a diplomatic edition of the two manuscripts side by side, giving variations in spelling and content; see also her preliminary study, "Il canzoniere provenzale $B$, gemello trascurato," in 101, AIEO 8, 2009, 1:327-37, calling for a closer study and evaluation of $B$, unjustly neglected in favor of $A$, but which shows a more careful scribe who used a secondary collation source and made more judicious corrections to the texts.] 210.

Signorini, Maddalena. "Aspetti codicologici e paleografici della produzione di manoscritti in lingua provenzale (secc. XIII-XIV).” In $>\mathbf{1 6 4}$, I trovatori nel Veneto, 2008, 
pp. 279-303. [Stresses the complexity of the troubadour chansonniers, both in concept and in their material production, as their varied producers experimented widely; investigates the reasons for the lack of written texts before the late thirteenth century: lack of clients for expensive materials in the vernacular; written texts limited to functional use by the troubadours and joglars; evolution in writing and in the material fabrication of the codex, different from the scholastic manuscripts; interest in preserving and collecting and in the new forms of narrative biography.]

211.

Zinelli, Fabio. "Il canzoniere estense e la tradizione veneta della poesia trobadorica: prospettive vecchie e nuove." MR 34.1 (2010): 82-130. [A review of recent research on the manuscript; dating to ca. 1254; possible collaboration of Uc de Saint Circ in the confection of the chansonnier; detailed study of subdivisions, tables, decorations, and corrections; consideration of the hypothesis of multiple archetypes and provenance from Auvergne.]

\subsection{Editing Theory and Practice}

[A number of scholars have suggested that basic studies of language, text editions, and analysis of the chansonniers must now be redone in light of recent new understanding of the complexities of Occitan philology, text transmission, and critical theory, and in the light of new technologies.]

212.

See 88, Paden, "State of Medieval Studies," 2006, esp. pp. 153-55. [One of the pressing needs for future research is that of editing theory: discussion of recent scholarship, including 216, Busby, 2002 and 226, M. Taylor, 2003; Paden concludes that there is no straightforward solution but that "We live in interesting times."]

213.

Asperti, Stefano. "A ritroso: Bertran Carbonel, Sordello, Guglielmo di Poitiers." Rom 128 (2010): 273-98. [A demonstration of the careful use of lectio difficilior in textual criticism; through a detailed study of the form entrenan in Bertran Carbonel's PC 82,12 and working backwards by way of Sordello and twenty others to Guilhem de Peitieus PC 183,1 line 15, Asperti is able to reestablish the legitimacy of the variant reading qu'esta sobre l'arbr'entreman instead of sobre l'arbr'en creman ("upright, steadily" instead of "fearfully"), removing the one negative element from the stanza which is otherwise devoted entirely to joyful gratification.]

214.

Benozzo, Francesco. Cartografie occitaniche. Approssimazione alla poesia dei trovatori. Naples: Liguori, 2008. [Asserts that an archeological approach treats the preserved manuscripts as mere vestiges of a larger reality that is lost to us: the performance aspect, the diffusion, the oral reception, and the displacement between the poetry and its recording in the manuscripts - all this makes the complex dynamic living presence of the poetry difficult for us to grasp; attribution of the poems to real composers is futile: all songs circulated as part of a common fund of poetry going back to ancient Celtic sources; new methodology must be developed to discover traces of this evolution.] 
215.

Bozzi, Andrea, and Maria Sofia Corradini. "New Trends in Philology: A Computational Application for Editing Old Provençal Texts." In L'Epopée romane, I-II: Actes $d u$ XVe Congrès international Rencesvals, Poitiers, 21-27 aô̂t 2000. Edited by Gabriel Bianciotto, Claudio Galderisi, and Bernard Guidot. Poitiers: CESCM, 2002, pp. 1031-43. [Outline of the experimental program Better Access to Manuscripts and Browsing of Images (BAMBI) for computing relationships among multiple copies of a medieval text and establishing a provisional stemma.]

216.

Busby, Keith. Codex and Context. Reading Old French Verse Narrative in Manuscript. 2 vols. Amsterdam: Rodopi, 2002. [On editing theory, Busby is ambivalent: he believes in the validity of critical editions, but at the same time he claims that only direct recourse to the manuscripts will allow us to fully comprehend medieval textuality; see also 226, M. Taylor, "Challenge of Editing Marcabru," 2003, esp. pp. 25-27, who foresees an electronic variorum edition of manuscripts, for which Pickens's edition of Jaufre Rudel 2392 is a precursor.]

217.

See 66, Graham, "National Identity," 1996, pp. 57-94. [Calls for a whole new study of Occitan grammar and poetry, based on a close analysis of the chansonniers in their own right and the publication of all Occitan texts; see similar views in 172, Borghi Cedrini, "La lingua dei trovatori," 2004, 175, Paden, "Declension," 2003, and 176, Stasyk, Sprache und Werke, 2007.]

218.

Lazzerini, Lucia. "Mouvement langagier, hapax, mostri e chimere." In Filologia classica e filologia romanza: esperienze ecdotiche a confronto (atti del convegno di Roma 25-27 maggio 1995), Spoleto: CISAM, 1998, pp. 241-58. [Close Lachmannian analysis of several cruces of textual criticism, including synoptic editions of poems by Jaufre Rudel and Marcabru, pp. 242-45, Giraut de Bornelh's tenso with Raimbaut d'Aurenga, pp. 247-50, and difficult vocabulary in Arnaut Daniel's Lancan son passat li giure, pp. 251-57.]

219.

Meliga, Walter. "Philologie et linguistique de l'occitan médiéval." In 101, AIEO 8, 2009, 1:23-51. [Stresses the importance of careful linguistic study for philological research; analysis of the vicious circle caused by early assumptions about a lyric koiné resulting in "corrected" texts which "proved" the existence of the koiné; in fact, recent scholarship has discovered much more diversity in alternative forms and dialectal variants in administrative documents (pp. 25-28), monuments (pp. 28-33), troubadour lyric (pp. 33-41); outlines recent scholarship that is renewing Occitan philology (editions, dictionaries, concordances); calls for renewed work on textual criticism, stressing localization, spelling, and morphosyntax.]

220.

Perugi, Maurizio. "Arnaut Daniel L'Aura amara (PC 29,13): esercizi di stratigrafia lessicale e testuale." In 149, Mélanges Michel Burger, 1994, pp. 289-99. [Meticulous 
study of codicology, phonetics, syntax, and dialectology to clarify the meaning of lines 64-65 of the poem, incorrectly understood by most editors of Arnaut Daniel.] 221.

Perugi, Maurizio. Saggi di linguistica trovadorica: saggi su Girart de Rousillon, Marcabruno, Bernart de Ventadorn, Raimbaut d'Aurenga, Arnaut Daniel e sull'uso letterario di oc e oil nel Trecento italiano. Tübingen: Stauffenburg, 1995. [Perugi calls for a renewal of the techniques of textual edition, with the goal of recovering the full richness and subtlety of troubadour vocabulary, which has been dulled by centuries of scribal levelling and by modern editors; ten detailed studies of editorial problems in Marcabru, Raimbaut d'Aurenga, Arnaut Daniel, Bernart de Ventadorn; six new critical editions; detailed study of Raimbaut d'Aurenga's Cars douz e feinz, PC 389,22; see similar linguistic analysis of Peire Cardenal by Chambon RLiR 60 (1996): 73-109.]

222.

Ricketts, Peter T., and Sergio Vatteroni. "Ce qui reste d'inédit de l'ancienne prose occitane." In 102, AIEO 9, 2011, pp. 471-86. [Work to be undertaken for COM3; example of MS Assisi, Chiesa Nuova 9.]

223.

Roncaglia, Aurelio. "Conservare o congetturare: un falso dilemma." In Filologia classica e filologia romanza: esperienze ecdotiche a confronto (atti del convegno di Roma 25-27 maggio 1995). Spoleto: CISAM, 1998, pp. 291-306. [The problems of either being conservative (Bédier) or conjectural (Lachmann); both are problematic, but useful.]

224.

Santini, Giovanna. "La tradizione indiretta della lirica trobadorica. Le tradizioni siciliane: alcune lezioni da inserire nell'apparato delle edizione critiche." CDT 6 (2003): 1051-88. [Demonstrates the usefulness of using Sicilian lyric witnesses (translations of Occitan poems) as input for critical editions of Occitan texts and listed among variant readings in the critical apparatus.]

225.

See 2892, Saviotti, "Nella tradizione di Raimbaut de Vaqueiras," 2009, pp. $217-$ 39. [In the context of a longer project leading to a new critical edition of Raimbaut's works, a detailed paleographic study of the fourteen manuscripts and two fragments of PC 392,2 leads to division into three families, and the strong hypothesis of authorial intervention in the history of the text, though it is not possible to clarify the chronological ordering of the textual variants.]

226.

Taylor, Mark N. "The Challenge of Editing Marcabru: A Discursive Review." Tenso 18 (2003): 3-38, esp. pp. 25-27. [Review article on Gaunt's edition of Marcabru 2622; a very detailed analysis of editing techniques and practical difficulties, suggestions for improvement; speculates that the next step should be an electronic variorum edition.] 


\title{
7. Anthologies
}

[For musical anthologies, see 13.2; for anthologies of trobairitz poetry, see 14.3.]

227.

\author{
7.1. Troubadour Lyric Anthologies \\ [Broadly based, representative selections]
}

Riquer, Martin de. Los Trovadores: historia literaria y textos. 3 vols. Barcelona: Ariel, 1975. [The most complete anthology, with 371 poems and many vidas and razos; rich introduction pp. 9-102, bibliography and discography; poets are presented chronologically, with individual introductions and selected poems with Spanish translation; a French edition is projected by Cahiers de Carrefour Ventadour; up to 2009, only a trial edition of Ebles and Bernart de Ventadorn, Gui D'Ussel, and Maria de Ventadorn has appeared, along with a new article on Maria de Ventadorn; the introduction to Riquer's text is available in an Italian translation by Katia Boccanera: Leggere $i$ trovatori, edited by Massimo Bonafin. Macerata: EUM, 2010.]

228.

Baumgartner, Emmanuèle, and François Ferrand. Poèmes d'amour des XIIe et XIIIe siècles. Paris: Union Générale d'Éditions, 1983. [A selection of forty-nine cansos and seven other genres, with French translation; some with music.]

229.

Bec, Pierre, with the collaboration of Gérard Gonfroy and Gérard Le Vot. Anthologie des troubadours. Textes choisis, présentés et traduits. Paris: Union Générale d'Éditions, 1979. [Succeeds his Petite anthologie from 1961 and his Nouvelle anthologie from 1970, enlarged to sixty-seven texts, plus vidas and eighteen melodies.]

230.

Di Girolamo, Costanzo. I trovatori. Turin: Bollati Boringhieri, 1989. Translated into Catalan: Els trobadors, Valencia: Edicions Alfons el Magnànim, 1994, with an additional section on Catalan troubadours. [Includes a historical introduction; covers the manuscript tradition, the troubadours, language, pronunciation, melodies, versification, rhymes, and genres; chapters are arranged around an anthology of poems, chronologically ordered, interspersed with short discourses on topics of style, background, and critical topics, giving a rich survey of cultural and critical depth.]

231.

Di Girolamo, Costanzo, and Charmaine Lee. Avviamento alla fllologia provenzale. Rome: Nuova Italia Scientifica, 1995. Reprint, 1996, 2002 by Carocci. [Includes a grammar, a ninety-page anthology, and a glossary.]

232.

Fabre, Paul. Anthologie des troubadours: XIIe-XIVe siècle. Orléans: Paradigme, 2010. [A broad selection of poems for a general audience, the fruit of an impassioned desire to make the troubadours better known and remembered as the originators of vernacular poetry in Europe and a new conception of love; introduction to the historicocultural context, finamor, poetic genres and structures; texts of 143 poems in modern 
Occitan spelling, with facing-page French translation; brief information on ninetyfour poets, pp. 641-83.]

233.

Felbeck, Christine, and Johannes Kramer. Troubadourdichtung: eine dreisprachige Anthologie mit Einführung, Kommentar und Kurzgrammatik. Tübingen: Narr, 2008. [A teaching text for nonspecialists; thirty-five standard songs, texts from $\mathbf{2 2 7}$, Riquer, 1975, with German translation; the bibliography is out of date; the sociohistorical background sketch dates from the 1960s.]

234.

Jensen, Frede. Troubadour Lyrics: A Bilingual Anthology. New York: Peter Lang, 1998. [Includes ninety poems by thirty poets; an introduction on sociocultural context, genres, versification, themes, origins, and the manuscript tradition.]

235.

Paden, William D., and Frances Freeman Paden. Troubadour Poems from the South of France. Cambridge: Brewer, 2007. [Contains 126 poems in English verse translation only: 117 Occitan, four Hebrew, four Italian, one Old Norse; succinct introduction to sociohistory, court culture, origins, manuscripts, music, poetic structures, and ongoing influence.]

236.

Riquer, Martin de, and Isabel de Riquer. La poesía de los trovadores (Antología). Madrid: Espasa Calpe, 2002. [Includes seventy-five poems by forty poets, chosen to illustrate the great variety of poetic voices, to counter the widespread but erroneous notion that all the poets were similar; four poems by trobairitz; eleven vidas, one razo; five anonymous poems; texts with Spanish translation; no melodies; rich bibliography up to 2001; discography of nineteen items up to 2000.]

237.

Romieu, Maurice, and André Bianchi. Iniciacion a l'occitan ancian: dètz e nòu tèxtes de l'Edat Mejana comentats. Initiation à l'ancien occitan: dix-neuf textes du moyenâge commentés. Pessac: Bordeaux University Press, 2002; 2nd edition, 2006. [A solid autodidactic introduction to Old Occitan language and poetry.]

238.

Roubaud, Jacques. Les Troubadours: Anthologie bilingue. Introduction, choix et version française. Paris: Seghers, 1971. Reprint, 1981. [Contains an introduction, 119 poems by forty-seven poets; texts with facing French translation, sparse notes, bibliography, discography of eleven items].

239.

Sansone, Giuseppe E. La Poesia dell'antica Provenza: testi e storia dei trovatori. Biblioteca della Fenice, 50. Parma: Guanda, 1984, 1986. 2nd edition, 1993. [Includes 119 poems by fifty-seven poets, plus seven anonymous; introduction, bibliography, texts with Italian translation, notes.]

240.

Zuchetto, Gérard, and Jörn Gruber. Le livre d'or des troubadours: XIIe-XIVe siècle, anthologie. Paris: Éditions de Paris, 1998. [For nonspecialists; includes ca. three 
hundred songs by ninety-one poets; the Occitan text is given for the first piece by each poet, with facing translation; others are in French translation only; in appendix, pp. 295-99: known troubadours and jongleurs, listed by place of origin, with number of poems; pp. 300-301: list of the forty-four principal chansonniers with date, provenance, and an occasional indication of contents.]

\subsection{Comprehensive Anthologies (Lyric, Non-Lyric, and Prose) 241.}

Liborio, Mariantonia, and Andrea Giannetti. Letteratura provenzale médiévale. Antologia di testi. Rome: Carocci, 2004. [Covers literature from the tenth to the fourteenth centuries; introduction on orthography, pronunciation; early texts; seventeen troubadours; nine non-lyric texts: vidas, razos, epic, romance, and didactic; bibliography.]

242.

Bec, Pierre. Anthologie de la prose occitane du moyen âge (XIIe-XVe siècle). Vol. 1: Vidas et razons, chroniques et lettres, prose narrative. Avignon: Aubanel, 1977. Vol. 2: Grammaires et arts poétiques, littérature religieuse et morale, prose juridique, didactique et scientifique, petit corpus épigraphique. Valariès: Vent Terral, 1987. [Introduction; broad selection of passages from grammar treatises, religious, didactic, scientific, and epigraphic works; texts in Occitan, with following French translation, notes, and restricted glossary; see suggestions regarding translation by G. Gouiran, RLaR 92 (1988): 410-17.]

243.

Lafont, Robert. Histoire et anthologie de la littérature occitane. 2 vols. Montpellier: Les Presses du Languedoc, 1997. [A popular history and highlights of literature, for nonscholarly readers; vol. 1 covers the "Age classique: 1000-1520"; vol. 2, edited by Philippe Gardy, covers the "Age du baroque: 1520-1798.”]

\section{4.}

\subsection{Contre-texte Anthologies}

Bec, Pierre. Burlesque et obscénité chez les troubadours: pour une approche du contre-texte médiéval. Paris: Stock, 1984. [Discusses fifty poems with French translation; various types of reaction against the very narrowly structured paradigm of fin'amor: category 1 is for dissenting voices against the courtly idealization of women; 2 is for the humorous and burlesque tours de force and parodies; 3 is for the obscene and scatological shockers including the "Cornilh affair," pp. 138-53; category 4 is Bec's unusual and controversial classification: "Le contre-texte féminin" (trobairitz); category 5 is for linguistic or rhetorical playing with sounds and forms "l'hypertrophie du trobar."]

245.

Nelli, René. Ecrivains anticonformistes du Moyen Âge occitan. Vol. 1: La femme et l'amour. Vol. 2: Hérétiques et politiques. Paris: Phébus, 1977. [Includes fifty-one poems by thirty-five poets and one anonymous; vol. 2 has Cathar texts and an assortment of religious, moral, and anticlerical texts, excerpts from the Canso de la Crozada and from the Life of Saint Douceline; a few texts on superstition and magic.] 
246.

Sansone, Giuseppe. I trovatori licenziosi. Milan: ES, 1992. [Divided into five categories: anticourtly, erotic, sexual hyperbole, variations, and parodic contrafacts.]

247.

\subsection{Specialized Anthologies}

Rialto website http://www.rialto.unina.it. [May be consulted under names of Trovatori: listings for many poems by about one hundred troubadours, plus ca. forty-five anonymous poems; some of these are newly edited, some with translation, some with introduction; additional listings are ongoing.]

248.

Bec, Pierre. Pour un autre soleil. Le sonnet occitan des origines à nos jours. Une anthologie. Orléans: Paradigme, 1994. [Contains a brief introduction; 275 sonnets by about one hundred poets, with French translation, from the thirteenth century to the modern day: one poem is a sonnet-sirventes, by Paolo Lanfranchi da Pistoia, ca. 1282-95, an Italian writing in Occitan; text also in 227, Riquer, 1975, 3:1662-65; two poems are by Dante da Maiano, in highly Italianized Occitan.]

249.

Bec, Pierre. Florilège en mineur. Jongleurs et troubadours mal connus. Orléans: Paradigme, 2004. [Anthology of sixty forgotten or neglected works by fifty-eight poets, from the twelfth century to the fifteenth (1471), edited with French translation; very spare presentation: brief introductions, few notes.]

250.

Bonnarel, Bernard. Les 194 chansons dialoguées des troubadours. Paris: Bonnard, published by the author, 1981. Available through the Service de diffusion de l'Institut d'Études Occitanes at Laurens. [Popular anthology of 194 dialogue songs, with texts in modern Occitan spelling, adapted to his own dialecte, i.e., modern Languedocian; songs are arranged by content on a continuum from purely "love" to "social criticism" to "sirventes."]

251.

Gadea i Gambús, Ferran. En so vell i antic. Antologia de trobadors catalans. Barcelona: La Magrana, 1990. [An anthology concerned with the spread of Occitan troubadour poetry into Catalonia; very brief introductory material, texts reproduced from previous editions with translation into Catalan; poems by eighteen Catalan poets who composed in Occitan: Berenguer d'Anoia (de Noya); Berenguer de Palou; Alfons I de Catalunya, II d'Aragó, el Cast; Ponç de la Guàrdia; Guillem de Cabestany; Guillem de Berguedà; Uc de Mataplana; Pons d'Ortafa; Cerverí de Girona; Amanieu de Sescas; Formit de Perpignan; Guillem Ramon de Gironella; Peire Salvatge; Raimon Vidal de Besalú; Peire II de Catalunya-Aragó, el Gran; Jofre de Foixà; Jaume II de Catalunya-Aragó, el Just; Guerau de Cabrera.]

252.

Gambino, Francesca. Canzoni anonime di trovatori e trobairitz: edizione critica con commento e glossario. Alessandria: Edizioni dell'Orso, 2003. [Edition of all twenty-one 
anonymous cansos, with diplomatic transcription, critical text, and Italian translation, and copious philological notes; plus one further controversial poem in appendix, which may belong to the Catalan fourteenth-century tradition rather than to the Occitan troubadours.]

\section{3.}

Gouiran, Gérard. "Et ades sera l'alba." Angoisse de l'aube. Recueil des chansons de l'aube des troubadours. Collection Lo gat ros. Montpellier: Publications de l'université Paul-Valéry Montpellier 3, 2005. [Contains an introduction by Franck Bauer and G. Gouiran: definition of the genre in relation to the canso; edition of twenty-two albas with French translation: two early examples, thirteen profane, six religious, and one serena.]

254.

Guida, Saverio. Canzoni di crociata francesi e provenzali. Parma: Pratiche, 1992. [Contains a historical introduction, plus eighteen crusade songs by sixteen troubadours, with Italian translation, notes.]

255.

Guida, Saverio. Trovatori minori. Modena: Mucchi, 2002. [Contains a detailed sociohistorical introduction; critical edition of eight poems by six poets: Ozil de Cadars, il vescovo-trovatore di Bazas (Eveque de Bazas), Pons Barba, Ademar Jordan, Arnaut de Brantalon, Guilhem d'Anduza.]

\section{6.}

Harvey, Ruth, and Linda Paterson. The Troubadour "Tensos" and "Partimens": A Critical Edition. 3 vols. Cambridge: Boydell \& Brewer, 2010. [A critical edition of the corpus of 155 tensos and partimens, with introduction, facing-page English translation, notes, and glossary; a rich resource for the study of courtly life, contemporary politics, and social attitudes to gender, class, and sexuality; the few extant melodies are not given; see detailed remarks and suggestions by D. Billy, RLaR 115.1 (2011): 227-44; poems excluded from the edition (exchanges of coblas, fictive debates, and those involving an anonymous participant) are being published periodically by Rialto: see "Foreword to the Online Edition of Dialogues Not Included in Boydell Volume," 2011: so far, six tensos are available at http://www.rialto.unina.it.]

257.

Liborio, Mariantonia. Storie di dame e trovatori di Provenza. Milan: Bompiani, 1982. [Anthology of eighty-one vidas and razos with Italian translation; the placement of texts within their social context brings out mechanisms that transform poems into narrative, while church values are reinterpreted in lay terms; texts from Boutière/ Schutz, arranged thematically, with a few corrections of detail.]

\section{8.}

Mantovani, Dario. Ans am ieu lo chant e.l ris: Episodî di parodia e satira presso i trovatori. Milan: CUEM, 2008. [Anthology of poems dealing with satire and parody; critical texts of ten poems by six troubadours, with detailed introduction, commentary, notes, and Italian translation; thirteen other texts printed in appendix.]

259.

See 1517, Oroz Arizcuren, La lírica religiosa, 1972. [Anthology of fifty-five lyrics 
chosen for their religious orientation; critical texts with Spanish translation, textual notes, and glossary.]

260.

Vatteroni, Sergio. Falsa clercia. La poesia anticlericale dei trovatori. Alessandria: Edizioni dell'Orso, 1999. [A study of anticlerical themes and traditions and what constitutes heresy; anthology of ten poems: four by Peire Cardenal, two by Guihem Figuera, one each by Bernart Sicart de Marvejols, Guilhem de Montanhagol, Bertran Carbonel, and Calega Panzan, all with Italian translation, no notes.]

261.

Viel, Riccardo. Troubadours mineurs gascons du XIIè siècle. Alegret, Marcoat, Amanieu de la Broqueira, Peire de Valeria, Gausbert Amiel. Classiques français du moyen âge, 167. Paris: Champion, 2011. [Introduction gives historico-cultural context for each poet, manuscript tradition, attribution problems, language, and metrics; critical edition of nine poems, with French translation, textual notes, rich glossary; three other poets traditionally grouped with these five are left out because of the limitation to the twelfth century: Bernart Arnaut d'Armagnac, Giraut de Calanson, and Arnaut de Comminges.]

262.

Zambon, Francesco. I Trovatori e la crociata contro gli albigesi. Milan: Luni, 1999. [Anthology of fourteen poems by Peire Vidal, Raimon de Miraval, many by Peire Cardenal, Tomai/Palaizi, Guilhem Figueira, Bernart Sicat de Maruejols, and Guilhem de Montanhagol, and extracts from the Canso de la crozada, with Italian translation, notes; introduction analyzes the nowdiscredited scholarly myth of the Cathar heresy; claims that the troubadours and heretics shared a common spirit and cause on a deeper level of morality.]

\section{Attribution Studies}

Much remains to be done in the area of attribution studies, especially with the recent renewal of philological interest in the chansonniers; see $>$ 4, Distilo, Per le concordanze, 2000, note 16, p. xvi, about the problem of attributions and of deciding at what point repertories should change attributions to reflect current scholarship; see also 1825, Borghi Cedrini, "Una recente acquisizione," 1996, who claims that much scholarly work in the area of attribution has been called into question by the discovery of one small unica.

\subsection{General}

263.

Asperti, Stefano. "Répertoires et attributions: une réflection sur le système de classification des textes dans le domaine de la poésie des troubadours." In $\ \mathbf{9 5}$, AIEO 2, 1993, 2:585-94. [Outlines the confused history of attributions in the philological history of troubadour studies; maintains that there is need for active study instead of the largely passive attitudes prevalent until now; calls for more study into the mode of composition of the chansonniers, each of which is embedded in its own cultural and social context.] 
264.

Gambino, Francesca. “Osservazioni sulle attribuzioni 'inverosimili' nella tradizione manoscritta provenzale (I).” In \99, AIEO 6, 2001, pp. 372-90. [A report on her project to study questionable attributions; close study of poems by Guilhem de Peitieus and Jaufre Rudel, illustrating the vicious circle of attribution decisions made on the basis of style, vocabulary, structure, themes, or especially on the basis of a poet's typical tone, decisions that are then used as evidence for further attributions; analysis of poems attributed to Marcabru, Cercamon, Bernart de Ventadorn, Peire Rogier, Raimbaut d'Aurenga, and Giraut de Bornelh; see also "Caso, imitazione, parodia. Osservazioni sulle attribuzioni 'inverosimili' nella tradizione manoscritta provenzale (II)," SMV 46 (2000): 35-84, a study of wrongly ascribed poems, with a list of thirty-three texts divided into those whose author has now been identified and those which remain anonymous, with a consideration of possible causes for the confusion.]

265.

Pulsoni, Carlo. Repertorio delle attribuzioni discordanti nella lirica trobadorica. Modena: Mucchi, 2001. See preparatory article in $\mathbf{1 1 7}$, Le letterature romanze, 2000, pp. 113-22; in French in Bulletins de l'AIEO 14 (1998): 65-71. [Many cases of multiple attribution, about 360 poems out of the 2,600 extant, were provisionally resolved long ago by a consideration of themes or formalistic qualities, and these solutions have tended to become accepted as solid fact; Pulsoni argues that they must now be reconsidered individually by a very careful study of each manuscript witness for dating, localization, and interior structure, seeking the possible reasons behind dubious attributions in the manuscripts; as a guide to future research, two listings are presented, one based on the manuscripts, the other on the poets and by incipit.] 266.

Meneghetti, Maria-Luisa. "Problemi attributivi in ambito trobadorico." In L'attribuzione: teoria e pratica. Storia dell'arte, musicologia, letteratura. Atti del Seminario di Ascona 30 sett.-5 ott. 1992. Edited by Ottavio Besomi and Carlo Caruso. Basel: Birkhäuser, 1994, pp. 161-82. [Points out the basic principles of verifying attributions of lyric poems; the necessity of understanding the methods and attitudes of those responsible for creating the chansonniers; several examples of difficult cases in Raimbaut d'Aurenga, Marcabru, Peire Vidal, Folquet de Marselha, Cercamon, and Peire Bremon Ricas Novas; shows that often the solution will depend on the flair of the scholar, based on wide experience.]

267.

Rossi, Luciano. "Anonymat poétique et hétéronymie. Le cas des premiers troubadours et trouvères." CDT 12.1 (2009): 239-59. [Early troubadours may have played with double or multiple poetic identities through the conscious use of pseudonyms: Guilhem de Peitieus, Cercamon (= Eble II?), Jaufre Rudel; the meaningfulness of the names was doubtless more evident to contemporary audiences than to us, but Rossi postulates bold interpretations through names: religiosity in Guilhem de Peitieus, more direct eroticism in Jaufre Rudel, and an identification of Cercamon with Eble II.] 
268.

\subsection{Specialized}

Beech, George. "L'attribution des poèmes du Comte de Poitiers à Guillaume IX d'Aquitaine." CCM 21 (1988): 3-16. [Outline of scholarship concerning the identity of the "first troubadour"; since no clear historical proof has yet been found to link the poetry of the Coms de Peitieus with William IX Duke of Aquitaine, only the vida can give a semitrustworthy identification; see subsequent investigations and/or hypotheses: 2363, Lafont, "Lecture du Comte de Peitieus," 1991; 2355, Fassò, "Fate," 1999; 2378, R. Taylor, "Assessment," 2006, pp. 883-84; and 2364, Manetti, "Osservazioni," 2009.]

269.

Guida, Saverio. "Una canzone provenzale in cerca d'autore." SMV 44 (2008): 49-76. [PC 70,11 Belh Monruelh, attributed variously to Bernart de Ventadorn, Perdigo, Peire Rogier, Raimon de las Salas, Raimbaut de Vaqueiras, Peire Raimon de Tolosa, Alegret, and Peire Bremon lo Tort; Guida considers external and internal matters (history, sociocultural characteristics, vocabulary, themes, style), and finally attributes it to Raimbaut de Vaqueiras, attaching Monruelh and $\mathrm{Na}$ Helis to the Malaspina family, and hence to Raimbaut.]

270.

Guida, Saverio. "Sospette paternità di due dispute e d'un sirventese in lingua d'oc $($ BdT 201,5 = 25,2; 150a,1 = 25,3 = 201,5a; 345,2).” CN 70 (2010): 277-321. [A wide-ranging historical investigation of poetic and political activity around the court of Toulouse in the early thirteenth century; many details about the names and activities of little-known or poorly identified poets are brought to light, particularly Arnaut de Comenge, Guilhem Peire de Cazals, and Bertran Folc d'Avignon; includes many valuable insights into the complex workings of the court and the politico-cultural functions of the poets and entertainers, who played a major role in setting the moral tone and social pride of class among the ruling figures and administrators.]

271.

Morlino, Luca. "Omonimi equivoci e riconoscimenti trobadorici: il caso di Peire Guillem.” In 118, La lirica romanza, 2009, pp. 241-61. [Close study of identities to sort out several poets with similar names; Peire Guillem de Luserna is an invented name, playing on the value of Luserna as symbolic of courtly perfection; the same troubadour is known as Peire Guillem, Peire Guilhem de Tolosa, and Peire Guilhem de Luserna.]

272.

See 1936, Paden, "Un plazer," 1983. [Edition of a poem that combines the theme of occupations of the months with a tradition of plazers, poems listing the poet's favorite things; reaffirms its attribution to Arnaut, against Zufferey $>$ 1939, who would classify it as PC 461,170d anonymous.]

273.

Zinelli, Fabio. "Un cas d'attribution douteuse? Bernart de Ventadorn, Amors, enquera. us preyara (BdT 70, 3).” In 102, AIEO 9, 2011, pp. 577-92. [Several structural 
and metrical characteristics seem to place the poem outside the normal practices of Bernart; Zinelli undertakes a meticulous study of all variant readings and the place of the poem in the various chansonniers, comparing lexical usage, rhymes, and forms showing French influence, concluding that there is no compelling reason to deny attribution to Bernart, and none at all to support authorship by Peire Vidal.]

\section{4.}

\subsection{Lost or Neglected Poets and Works}

Asperti, Stefano. "Testi e frammenti recuperati per il corpus della lirica trobadorica." MR 33 (2009): 264-94. [A series of eight detailed investigations of orphan texts and fragments that have been rejected or ignored by scholars: supposedly apocryphal stanzas or tornadas, unidentified fragments, manuscript witnesses that were not utilized in critical editions, and late copies of lost manuscripts; many precise examples of texts that need further investigation.]

275.

Careri, Maria. "Alla ricerca del libro perduto: un doppio e il suo modello ritrovato." In 119, Lyrique romane, 1991, pp. 329-78. [Presentation of a manuscript in Madrid's Real Academia de la Historia, which had been thought to be lost: eightyfour folios transcribed in the eighteenth century containing sixty-four poems, thirty by Peire Vidal, and the only known copies of two sirventes by Guilhem de Durfort.] 276.

Klingebiel, Kathryn. "Lost Literature of the Troubadours: A Proposed Catalogue." Tenso 13, no. 1 (1997): 1-23. [Sets out the principles for establishing a comprehensive catalogue, drawn in part from the work of Deyermond (1995); a relational database has been designed; see also Klingebiel, "La littérature perdue," in \$ 99, AIEO 6, 2001, pp. 212-21, and "A la recherche des troubadours perdus: Languedoc, Comté de Foix, Quercy, Rouergue," in $1 \mathbf{1 0 0}$, AIEO 7, 2003, pp. 471-78.]

277.

Klingebiel, Kathryn. "A la recherche des troubadours: la Gascogne." In $>\mathbf{1 0 1}$, AIEO $8,2009,1: 131-40$. [Outline of a project to name, date, and localize not only lost troubadours but all of the poets up to the end of the fourteenth century; a special look at supposed Gascon poets, but more interesting for the general methodology.]

278.

Melani, Silvio. "Il cammino della croce e gli artigli della lussuria: ipotesi sulle 'perdute' cantilenae composte da Guglielmo IX in occasione della sua crociata." In - 117, Le letterature romanze, 2000, pp. 281-94. [Postulates that a little research might restore the supposedly "lost" works that Guilhem performed "before kings and magnates and Christians" after his escape from massacre in 1101 and that PC 183,10 may be a crusade song dating from just before his departure in 1101; PC 183,12 may be a parody of a pilgrimage that Guilhem made after his deliverance from the disaster of the crusade.]

279.

Rieger, Angelica. "Les troubadours-fantômes en Italie." In $>$ 95, AIEO 2, 1993, 
1:327-47. [Study of poets known only by name, many of whom may have composed in non-lyric genres; of the seventy-eight phantoms among the 460 names in PC (17 percent), forty remain unidentified, and five more must be added to PC, giving forty-five phantoms in all, including Eble II de Ventadorn, Caudairenga, and the two Ermengaut brothers.]

280.

See 754, Rosenstein, “Ubi sunt?" 2005. [New information about Alis, mentioned in poems by Guiraudo lo Ros, Sarrazina, the wife of Hugh VII of Lusignan, and Gaudairenca, wife of Raimon de Miraval and trobairitz with no extant poems.]

\section{Literary Criticism (Lyric)}

\section{Orientation}

\subsection{Guides to the Field}

281.

Akehurst, F. R. P., and Judith M. Davis. A Handbook of the Troubadours. Berkeley: University of California Press, 1995. [A basic introduction to the discipline; twentyone chapters give an overview of the whole field, with an emphasis on informative coverage of a practical nature; provides guidance on a number of topics missing from

- 282, Troubadours, 1999, such as origins, language, vocabulary, imagery, non-lyric texts, and Minnesingers.]

282.

Gaunt, Simon, and Sarah Kay. The Troubadours: An Introduction. Cambridge: Cambridge University Press, 1999. [A guide to research in the field; sixteen chapters represent distinct research areas and recent developments in critical methodology, some of which are not covered specifically in 281, Handbook, 1995, such as satire, parody, intertextuality, subjectivity, and orality.]

283.

Bolduc, Michelle. "Occitan Studies." In Handbook of Medieval Studies: Terms, Methods, Trends. Edited by Albrecht Classen. 3 vols. Berlin: de Gruyter, 2010, pp. 102338. [Succinct introduction to the history of Occitan scholarship, with indications of recent trends and future possibilities; covers language, lyric literature as well as narrative, epic, hagiographical and didactic works, and a discussion of the various critical methodologies that have been used to explore them; specific attention is given to the study of lyric genres, themes, metrics, and musicological analysis; a final section is devoted to key works and recent trends in Occitan scholarship.]

284.

Europe. Revue littéraire mensuelle 86, nos. 950-51 (2008): 3-149. Special number: Les Troubadours. [Nonspecialist guide to the field; rudimentary anthology of twelve poems, two in Occitan with French translation, ten in translation only; nine articles: introductory guides to chansonniers, versification, music, genres (canso, sirventes, tenso), and influence (Galicia, Catalonia, Italy), each by an authority in the field.] 
285.

Pintarič, Miha. Trubadurji. Ljubljana: Znanstveni institut Filozofske fakultete, 2001. [In Slovenian; half-page summary in English, p. 244; good widespread introduction to the field for beginners; social background; origins; nature of finamor; troubadour poetics; interpretations of the ethical, philosophical, aesthetic, psychological, erotic, and humorous qualities of the poetry; brief survey of a dozen of the major troubadours; no texts, no language study; good bibliography.]

286.

Occitan Poetry. Special issue of Glossator 4 (2011). Online at http://www.doaj.org. [A collection of ten articles chosen to show the vitality and variety of ongoing modern scholarship in troubadour studies; from a meticulously detailed philological investigation to a provocative tongue-in-cheek study by PowerPoint presentation of illuminated initials, by way of original studies of individual texts and poets, by established and beginning scholars, the volume demonstrates that the field of Occitan studies is alive and well and is an exciting place to be.]

\subsection{Sociohistory [General cultural history, courts and patronage, politics and poetry]}

287.

\subsubsection{General Studies}

Akehurst, F. R. P. The "Costuma d'Agen": A Thirteenth-Century Customary Compilation in Old Occitan Transcribed from the "Livre Juratoire." Turnhout: Brepols, 2010. [A collection of customary laws from the Agenais region; edition with facing-page English translation; the introduction gives information on thirteenth-century society: economic concerns, social relations among classes and within families, and law enforcement; legal vocabulary used by the troubadours; index, several appendices, including a detailed description of the Livre juratoire by Alison Stones.]

288.

Dupuy, André. Historique de l'Occitanie. Montpellier: Alain Nouvel, 1976. [General survey of Occitan history from prehistory to the present.]

289.

Hancke, Gwendoline. Femmes en Languedoc: la vie quotidienne des femmes de la noblesse occitane au XIIIe siècle, entre catholicisme et catharisme. Cahors: La Louve, 2006. [Detailed analysis of the life of noble women in the convent or at home, touching on everything that affected their daily concerns, their conception of love, or their attitudes to death or maternity; see also Hancke's L'Hérésie en héritage, Cahors: La Louve, 2006, in which she retraces the destinies of several noble families to clarify the role of women in the success of the heresy, as protectors of the heretics and even as members of the Cathar clergy.]

290.

Harvey, Ruth. "Courtly Culture in Medieval Occitania." In $\mathbf{2 8 2}$, Troubadours, 1999, pp. 8-27. [Detailed exploration of court life and social structures at the time 
of the troubadours, giving lively insight into the lives of the poets and jongleurs who circulated about the lord and sought their own competitive advantage through song, flattery, and administrative skills.]

291.

Lafont, Robert. Petita istòria europèa d'Occitania. Perpignan: Trabucaire, 2003. [A comprehensive patriotic outline of the history, geography, and sociolinguistic character of Occitania; indicates the importance of the Visigoths in the formation of a Romanized culture distinct from that of northern France which was influenced more by the Franks; outlines the seven regional standards of the modern Occitan language.]

292.

Marks, C. Pilgrims, Heretics and Lovers: A Medieval Journey. New York: Macmillan, 1975. [A lively presentation of Occitan culture from the sixth century to the end of the sixteenth; poems of eight major troubadours are set into their sociohistoric context to bring out the strongly humanistic values of the civilization; solid documentation of history and literature.]

293.

Meliga, Walter. "L'Aquitaine des premiers troubadours. Géographie et histoire des origins troubadouresques." In L’Aquitaine des littératures médiévales (XIe-XIIIe siècle). Edited by Jean-Yves Casanova and Valérie Fasseur. Paris: Presses de l'Université ParisSorbonne, 2011. [Historical exploration of the cultural and political interconnections among the Aquitanian courts of the first half of the twelfth century; Poitou was at the center, with influence that spread to the north and south, supporting a group of the earliest troubadours, who knew each other and exchanged songs: Guilhem de Peitieus, Jaufre Rudel, Cercamon, Marcabru, and others, forming the "Poitevin School" at the origins of Occitan lyric.]

\section{4.}

Paterson, Linda M. The World of the Troubadours: Medieval Occitan Society, c. 1100-c. 1300. Cambridge: Cambridge University Press, 1993. Reprint, 1998. Spanish translation by José Manuel Alvarez Flores, Barcelona: Peninsula, 1997. French translation by Gérard Gouiran et al., Montpellier: Presses du Languedoc, 1999. [Overview of various aspects of medieval Occitan society as background to the troubadours; the poetry itself is examined mainly for its corroborative insights into social structures and practices; specialized information about the functions of different social groups, types of soldiers, hierarchic groups in court, etc.; the section on trobairitz, pp. 25665 is wide-ranging and sums up much current research; analysis of the Cathar heresy, pp. 332-40.]

\section{5.}

Pons, Alain. Ventadour et les troubadours. Ventadorn fontana de fin'amor. Egletons: Société historique des amis de Ventadour, 2003. [An introductory survey of the history of the Ventadour dynasty, and the importance of the court of Ventadour in the fostering of literary Occitan culture over several centuries.] 
296.

Verlato, Zeno. "Il pretesto trobadorico della raccolta di poesie religiose del manoscritto di Wolfenbüttel.” In 118, La lirica romanza, 2009, pp. 263-91. [Explores the possibility of another stream of poetic development, a religious moralizing stream that may have coexisted alongside the courtly stream in Italy but was not collected into chansonniers; documents the manner in which the anonymous poets use the prestigious troubadour language and forms, along with occasional intertextual references, but exclude amorous and political themes in favor of religious.]

297.

\subsubsection{Courts and Patronage}

Bianchini, Simonetta. "L'alta marquesana qe fo de Monferato." CN 46 (1986): 9-16. Also in 152, Miscellanea Roncaglia, 1989, 1:157-64. [Identifies the cultivated author of the Proverbia quae dicuntur super natura foeminarum (parody in Italian of the Old French Chastiemusart, Veneto region, ca. 1216) as Beatrice of Monferato, daughter of Bonifacio II; describes her place in the intellectual circles of many Occitan troubadours: Raimbaut de Vaqueiras, Peire Vidal, Bertolome Zorzi, Guilhem Augier, and others; she was highly influenced by Occitan poetic traditions and undoubtedly influenced their use of proverbs.]

298.

Cheyette, Fredric L. Ermengard of Narbonne and the World of the Troubadours: Conjunctions of Religion and Power in the Medieval Past. Ithaca, NY: Cornell University Press, 2001. [A close analysis of the reciprocal cross-influence between historical and literary forces; chapter 13 concerns the troubadours and trobairitz who were to be found at her court; supplies provocative ideas about the political involvement of the troubadours and their poetry, the use of the vocabulary of love in feudal agreements, the role of poetry in promoting the position of the sovereign, and the function of poets as spokespersons for their leader.]

299.

Gourc, Jacques. "Les troubadours, négociateurs et entremetteurs." In 131, Les troubadours et l'état toulousain, 1994, pp. 39-43. [The precarious marginality of the troubadour's social position makes him seek help from God, from birds, from patrons, from his social circle, in the tornada; examples from Marcabru of the poet seeking to strengthen his social role as model or teacher.]

300.

Loeb, Ariane. "Les relations entre les troubadours et les comtes de Toulouse (11121229).” AM95 (1983): 225-59. [Reexamination of the supposedly long and generous patronage of the troubadours by the court of Toulouse; finds that, in spite of claims in the vidas and razos, there is little historical evidence until Raymond V, 1148, when a number of well-known poets are found there, and especially under Raymond VI and VII, at the time of the Albigensian Crusade; argues that many poets were politically engaged, anti-French, and anti-crusade; Peire Vidal had an influential position for a time, and Raimon de Miraval was prominent, though mostly as entertainer.] 
301.

Lomenec'h, Gérard. Aliénor d'Aquitaine et les troubadours. Luçon, France (Bordeaux): Sudouest, 1997. [Popular introduction to Eleanor and her family and their connections, real or legendary, to poetic culture.]

302.

Lushchenko, Marina. "Raymond VII (1194-1249), comte de Toulouse, dans la poésie épique et lyrique de son temps." FL 146 (2008): 173-98. [The importance of Raymond VII in his society, as seen in the second half of the Canso de la Crozada and in poems by eight other troubadours, mainly Guy de Cavaillon and Peire Cardenal; the count is depicted as immensely popular among the people of Toulouse, a model of the courtly sovereign, an incarnation of pretz and valor.]

303.

Meliga,Walter. "L'Aquitania trobadorica." In $\mathbf{1 2 9}$, Lo spazio letterario, 2. Medioevo volgare, vol. 1, part 2: La produzione del testo, pp. 201-51. [Discussion of the courts of Poitiers and elsewhere as the social sources of troubadour poetry: the identity of Guilhem de Peitieus and his importance as originator; the "Poitevin School"; the "Escola n'Eblo"; the attachment of Marcabru, Cercamon, and perhaps Jaufre Rudel to the court under Guilhem X and probably earlier; see also by Meliga, in the same publication, "Il pubblico dei testi cortesi," vol. 3: La ricezione del testo, pp. 79-123.] 304.

Rieger, Angelica. "La cour de Champagne, centre d'un réseau interculturel entre troubadours et trouvères." Europe 86 (2008): 150-63. [Describes the court of Champagne, Eleanor of Aquitaine, and her family as the central force in an intertwined complex of poets and patrons that facilitated contacts between three generations of troubadours, trouvères, and Minnesänger; contains rich information on intertextuality.]

305.

Routledge, Michael J. "Troubadours, trouvères et la cour du Puy." In $\mathbf{9 6}$, AIEO 3 , 1992, pp. 1133-44. [A careful assessment of the historical traces of the supposed literary competition of Puy-en-Velay; however, there is no proof beyond literary references.] 306.

Salvatori, Enrica. "Les Malaspina: bandits de grands chemins ou champions du raffinement courtois? Quelques considérations sur une cour qui a ouvert ses portes aux troubadours (XIIe-XIIIe siècles)." In Les élites lettrées au Moyen Agge: modèles et circulation des savoirs en Méditerranée occidentale, XIIe-XVe siècles: Actes des séminaires du CHREMMO. Edited by Patrick Gilli. Montpellier: Presses Universitaires de la Méditerranée, 2008, pp. 11-27. [A historian's perspective on the poems published in 1738, Caïti-Russo, Les Troubadours et la cour des Malaspina, 2005; documentation for the ongoing project of reevaluating the cultural, economic, and political role of the Malaspina; information is analyzed from the perspective of the patrons rather than from that of the patronized.]

307.

Sánchez Jiménez, Antonio. "Catalan and Occitan Troubadours at the Court of Alfonso VIII." La Corónica 32.2 (2004): 101-20. [Identifies the troubadours who 
visited Alfonso's Castilian court; Peire d'Alvernhe's satiric gallery poem was perhaps composed for the procession to Bordeaux in 1170 to fetch Eleanor as Alfonso's wife and queen; Peire and seven other important troubadours played a key role in strengthening ties between Aragon and Castille in their fight against the French kings; suggests that they were a key to persuading Alfonso to use the Castilian vernacular; shows that Alfonso recognized the importance of their effective propaganda.]

\subsubsection{Politics and Poetry}

308.

Asperti, Stefano. “Testi poetici volgari di propaganda politica (secoli XII e XIII)." In La propaganda politica nel basso medioevo. Atti del XXXVIII Convegno storico internazionale (Todi, 14-17 ottobre 2001). Spoleto: CISAM, 2002, pp. 533-59. [A consideration of songs by Marcabru, Bertran de Born, and others, analyzed in their relationship to political propaganda and concrete political action; shows that the poems are not meant so much to convince the listeners as to create a symbolic display that will generate the desired reputation of the court and its leader; this type of text was eventually replaced by a new, more direct rhetoric coming from the university tradition.]

309.

Aurell, Martin. "Les troubadours: naissance et diffusion de la chanson engagée." In Sociabilité, Culture et Patrimoine. Cahiers du Groupe de Recherche d'Histoire (GRHIS) 6 (1997): 25-36. Edited by Loïc Vadelorge and Ludovic Tournés. [Courtly themes are relatively neglected after 1200 in favor of engagement in political and social actuality; the sirventes is the preferred form, often based on the metrical and musical structure of an existing canso; three poems are reproduced with French translation and commentary as examples; PC 76,16 is called anonymous by Aurell, but see $\mathbf{2 1 0 1}$, Asperti, "Sul sirventes," 1995, who confirms its attribution to Bertran d'Alamanon; see more detail in 2104, Aurell, La Vielle et l'épée, 1989.]

310.

Paterson, Linda M. "Occitan Literature and the Holy Land." In $>$ 133, World of Eleanor, 2005, pp. 83-99. [Poetic responses among the second generation of troubadours (Marcabru, Cercamon, Jaufre Rudel) to the Second Crusade, in which Eleanor of Aquitaine and Louis VII visited Antioch; details on website http://www2.warwick. ac.uk/fac/arts/french/about/staff.]

311.

Paterson, Linda. "Une perspective aquitaine des croisades? Le témoignage des troubadours." In L'Aquitaine des littératures médiévales (XIe-XIIIe siècle). Edited by Jean-Yves Casanova and Valérie Fasseur. Paris: Presses de l'Université Paris-Sorbonne, 2011. [An initial investigation involving Aquitaine, in view of a new research project into the involvement of French and Occitan lyric with the Crusades and the Reconquista; Aquitaine was the starting point for this involvement, but after the Second Crusade, poetic response was stronger in the eastern regions; in appendix, pp. 190-99: rich thematic and chronological data.] 


\subsection{Literary History (Overview: Lyric, Non-Lyric, Prose)}

312.

GRLMA. Heidelberg: Winter. [An ongoing multivolume reference which began publishing in 1968 (vol. 6, book 1); now overtaken in part by new critical theories and new documentary techniques, but still provides valuable literary and bibliographical guidance; of particular interest for Occitan are vol. 2, book 1, A (Avant les troubadours), 1979, and B (La lyrique occitane); B is divided by genre and has been published in fascicles from 1979 to 1990; fascicles 2 to 5 give a historical presentation of all major genres, fascicle 7 (1990) gives documentary information and bibliography. Vol. 4 (1978 and 1984) gives information about Occitan romances, vol. 6 about the novas.]

313.

Brunel-Lobrichon, Geneviève, and Claudie Duhamel-Amado. Au Temps des troubadours: XIIème et XIIIème siècles. Collection La Vie Quotidienne. Paris: Hachette, 1997. [Broadly based introduction to the medieval society of southern France, covering travels and patronage in France, Spain, and Italy, the position of troubadours, trobairitz, and joglars, music and lyric performance, real life in the cities and chateaus, the effects of the Albigensian Crusade and the Inquisition; in appendix, a list of 106 principal poets with brief biographical information; poetic texts are quoted in French translation. See objections by Lafont 762, "Voix des dames," 1997, to the so-called enthusiastic feminism that exaggerates, in his view, the independence of women poets.]

314.

Mölk, Ulrich. "Occitan Poetry.” In Neues Handbuch der Literaturwissenschaft. Vol. 7: Europäisches Hochmittelalter. Edited by Henning Kraus. Wiesbaden: Athenaion, 1981, pp. 19-36. [Occitan poetry: music, forms, social milieu, genres, diffusion. Part of a twenty-five-volume manual covering all world literature. Vol. 7 covers 10501250, especially oriented toward France and Germany; organized by genre.]

\section{5.}

Lafont, Robert. Histoire et anthologie de la littérature occitane. Montpellier: Les Presses du Languedoc, 1997. [A popular history and selected highlights of the literature, for nonscholarly readers; vol. 1 covers L'âge classique (1000-1520); vol. 2, edited by Philippe Gardy, covers L’âge du baroque (1520-1789).]

316.

Storia delle letterature romanze medievali. Directed by M. L. Meneghetti. Bari: Laterza, 1999. Four volumes were projected: (1) Le origini, (2) Ibero-romanze, (3) Galloromanze (provenzale a cura di L. Lazzerini), and (4) Italiana. The first appeared in 1997: see 934, Le origini. [Contains information on seven Old Occitan "monuments": "Esordi provenzali," pp. 162-93, with bibliography pp. 259-61 and p. 266.] The second appeared in 1999: see $\$$ 1676, Le letterature d'area iberica. [Chapter 3 under "La letteratura catalana médiévale" by Stefano Asperti, pp. 340-61, discusses the role of Catalan poets who composed in Occitan from about 1160 (Berenguer de Palazol) to the mid-fourteenth century.] Vols. 3 and 4 have not appeared. The Occitan part of vol. 3 has been replaced by 320, Letteratura médiévale in lingua 
d'oc, 2001, in which L. Lazzerini thanks M. Meneghetti for giving her the idea for the volume.

317.

Varvaro, Alberto. Letterature romanze del medioevo. Bologna: Mulino, 1985. [Broadly based traditional introduction to medieval literature in the whole Romance area; Occitan lyric in chap. 3: "Lesperienza lirica," pp. 139-214; analysis of various aspects of the lyric tradition through close study of poems by Guilhem de Peitieus, Bertran de Born, Peire Cardenal, Peire Vidal, and Bernart de Ventadorn.]

\subsection{Introduction to Occitan Lyric Poetry \\ [For introduction to areas of research, see especially $\mathbf{2 8 1}$, Handbook, 1995, and 282, Troubadours, 1999.]}

\section{8.}

Burgwinkle, William E. “The Troubadours: The Occitan Model.” In The Cambridge History of French Literature. Cambridge: Cambridge University Press, 2011, pp. 20-27. [Notes the hesitancy of French scholars to include Occitan literature in their cultural heritage, as Catalan and Italian scholars have done; the collective literary identity of the troubadours was original in several ways; it was secular, vernacular, devoted to the praise of beauty, power, wealth, youth, and erotic desire, celebrating a love that elevated the individual; it was intricate in form, sometimes contradictory in meaning, and often playful in tone; Arnaut Daniel is evoked as the highest development of the art.]

319.

Di Girolamo, Costanzo. I trovatori. Turin: Bollati Boringhieri, 1989. In Catalan: Els trobadors. Valencia: Edicions Alfons el Magnànim, 1994. [Introduction to background history, the manuscript tradition, language, melodies, versification, and genres; chapters are arranged around an anthology of poems, chronologically ordered, intermixed with short discourses on style, background, and critical areas, giving a rich survey of cultural and critical depth.]

\section{0.}

Lazzerini, Lucia. Letteratura médiévale in lingua d'oc. Modena: Mucchi, 2001. [Succinct chronological overview, including a new interpretation of the bilingual alba; information on the evolution of linguistic and literary norms; bibliography is copious but omits many important works from North America, Great Britain, and Germany.] 321.

Mölk, Ulrich. Trobadorlyrik: Eine Einführung. Munich: Artemis, 1982. In Italian: La lirica dei trovatori. Bologna: Il Mulino, 1986. [Sketches the history of Occitan studies; detailed information on Guilhem de Peitieus, ideology, formal structures, stylistics, and genres.]

\section{2.}

Bermejo, José María. La vida amorosa en la epoca de los trovadores. Madrid: Temas de Hoy, 1996. [A popular introduction to troubadour poetry for nonspecialists; brief sketches of a dozen major poets, legends of Peire Vidal, Guilhem de Cabestanh, and Peire Cardenal.] 


\section{Origins}

\subsection{General Studies}

323.

Bec, Pierre. "Les influences." In 2334, Le Comte de Poitiers, pp. 29-56 [Considers all the theories of origins, with many judicious clarifications; argues that, since there is no absolute answer to the search, we should only consider certain parallelisms in form, motifs, and themes, without trying to prove a filiation.]

324.

Boase, Roger. The Origin and Meaning of Courtly Love: A Critical Study of European Scholarship. Manchester: Manchester University Press, 1977. [Detailed, objective, and well-documented survey of the various competing theories concerning the sources of troubadour lyric. See also the detailed review article 338, Menocal, "Close Encounters," 1981.]

325.

Bond, Gerald A. “Origins." In 281, Handbook, 1995, pp. 237-54. [Stresses the crucial importance of the theories of origins, since they determine wider critical attitudes; a review of the major theories leads to the conclusion that we must accommodate multiple sources reflecting the hybrid court culture of the time.]

326.

Brunel-Lobrichon, Geneviève. "La formation des troubadours, hommes de savoir." Cahiers de Fanjeaux 35 (2000): 137-48. [Explores the sources in classical and religious literature available to the troubadours.]

327.

Fleischer, Ezra. "Contributions hébraïques à une meilleure compréhension de quelques aspects de la poésie européenne du haut Moyen-Age." In Gli Ebrei nell'Alto Medioevo. 2 vols. Spoleto: Sede del Centro italiano di studi sull'alto medioevo, 1980, 2:815-66. [Explores the possibility that Hebrew poetry may have helped in the transmission of new rhythmic forms from Hebrew or Andalusion sources to Guilhem de Peitieus, pp. 854-59; includes a discussion on this possibility with Vitale-Brovarone, pp. 863-66.]

328.

Kay, Sarah. "The Contradictions of Courtly Love and the Origins of Courtly Poetry: The Evidence of the lauzengiers." Journal of Medieval and Early Modern Studies 26 (1996): 209-53. [An exploration of the social and psychological tensions out of which the troubadour love ethic arose; rather than the rivalry between young nobility and established aristocracy (Köhler), Kay sees the tensions between clerical and lay members of the court as the key to the central contradictions of fin'amor, with the figure of the lauzengier acting as a scapegoat; appendices show contradictions in poems from Guilhem de Peitieus through Bernart de Ventadorn on a variety of topics, as well as excerpts from their works dealing with the key themes: lauzengiers, the Crusades, adultery, and religion.] 
329.

Lafont, Robert. Le Chevalier et son désir. Essai sur les origines de l'Europe littéraire, 1064-1154. Paris: Kimé, 1992. [Emphasizes the importance of Occitan culture in the formation of a European cultural identity, beginning with saints' lives and epics, oriented toward Spain; chivalric love for male companions and the lord is turned toward the domna in troubadour lyric; opens up new vistas for Occitan studies, though much of the analysis is based on a simplified notion of Freudian psychology.] 330.

See 377, Ribémont, Sexe et amour, 2007. [Examines possible Latin and Arabic sources, pp. 49-53, concluding that neither theory is exclusively convincing.]

331.

Schippers, Arié. "Les troubadours et la tradition poétique hébraïque en Italie et en Provence: les cas d'Abraham ha-Bedarshi et Immanuel ha-Romi." In $\ \mathbf{1 2 8}$, Le Rayonnement, 1998, pp. 133-42. [Outline of studies on the origins of troubadour poetry, especially Hebrew poetry in Arabic Spain and its connection with that of Provence and Italy through the works of two multilingual poets, one from Occitania, the other from Italy; see also his "Forme, style et thématique dans les poésies strophiques occi-

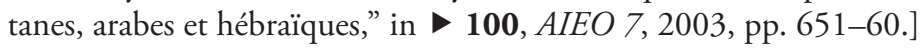

\subsection{Arabic Theory}

\section{2.}

Abu-Haidar, Jareer A. Hispano-Arabic Literature and the Early Provençal Lyrics. Richmond: Curzon Press, 2001. [Only part 3 (chapters 10-12) concerns Occitan lyric; the rest is about Arabic popular literature (part 1) and the zajal and Muwashshah (part 2); in part 3, Abu-Haidar systematically denies any Arabic parallels with troubadour poetry, claiming that the most frequent and characteristic tropes and images of the Occitan poets, the moral idealization of the beloved, and the Occitan concepts of fin'amors, pretz, valors, proeza, jois, mezura, and jovens are absent from Andalusian traditions, but he does not acknowledge significant recent contradictory scholarship.] 333.

Aurell, Martin. "Fin'amor, wadd et féodalité dans la lyrique des troubadours." In 111, L'Espace lyrique, 2006, pp. 77-88. [Analysis of the concept of elevated love in the two traditions; similarities despite the frequent homosexual nature of the Arabic ideal; differences in the underlying social structure explain the preponderance of the feudal submission of the poet to his lady as the key distinctiveness of the troubadour ethic.]

334.

Boase, Roger. "Arab Influences on European Love-Poetry." In $\mathbf{1 4 4}$, Jayyusi, Legacy of Muslim Spain, 1994, pp. 457-82. [Agrees with Menocal that the most characteristic features of troubadour lyric, except for feudal analogies, may be found in Arabic poetic tradition going back to the seventh century; proposes a new comparative study of European and Arabic love poetry to explore the cultural links and possible avenues of transmission, along with detailed comparative study of music, formal elements, 
major motifs and philosophical theories; outlines in detail many thematic parallels such as submission of the lover, the need for secrecy, the concept of joi, and the ennobling nature of self-restraint.]

335.

Chahal Timery, Joumana. "Points de rencontre du muwassah arabo-andalou et de la poésie lyrique des troubadours: le sentiment de l'amour et son expression poétique." In Echi letterari della cultura araba nella lirica provenzale e nella Commedia di Dante. Edited by Claudio Gabrio Antoni. Udine: Campanotto, 2006, pp. 76-95. [Asserts that both Arabic and troubadour poetry celebrate a new freedom from social and religious constraint, expressed in different languages and reflecting different values, but with many similarities in vocabulary, themes, metrics, and music that make the thesis of Arabic origins highly probable; includes a very rich bibliography.]

336.

See 1793, Corriente, "Kharjas," 2009. [A report on research on the Arabic verseforms and the controversies surrounding their relation to Hispanic and Occitan poetry; revised edition of all Romance Kharjas as a basis for further unbiased research.] 337.

Giffen, Lois Anita. "Ibn Hazm and the Tawq al-ham ma." In 144, Jayyusi, Legacy of Muslim Spain, 1994, pp. 420-42. [Analysis of The Dove's Neck Ring, Ibn Hazm's literary masterpiece, examining its origins, structure, content, themes, reception, and its depiction of women and Arab society; pp. 435-37: lists eight clear parallels between themes in this book and the themes of courtly love in the troubadours; in the absence of specific historical "proof" of actual contact, argues that we may only claim the strong possibility that parts of the Arab poetic tradition influenced the rise of the troubadour conception of finiamors and trobar.]

338.

Menocal, Maria Rosa. "Close Encounters in Medieval Provence: Spain's Role in the Birth of Troubadour Poetry." Hispanic Review 49 (1981): 43-64. [Pp. 44-50: detailed evaluation of 324, Boase, Origin and Meaning, 1977; discusses anti-Arab bias in nineteenth-century scholarship, and proposes the etymology of trobar and trobador from the Arabic taraba.]

339.

Menocal, Maria Rosa. The Arabic Role in Medieval Literary History: A Forgotten Heritage. Philadelphia: University of Pennsylvania Press, 1987. Reprint, 2004. [Arabic cultural presence in the court of Guilhem de Peitieus, Frederick II, etc., and its importance for Dante and Boccaccio; renews the Arabic thesis, arguing that it seemed entirely plausible until the heyday of European colonialism, when suddenly it was found to be unthinkable, for obvious reasons of cultural prejudice; see especially pp. 27-70.]

340.

Monroe, James T. "Zajal and Muwashshaha: Hispano-Arabic Poetry and the Romance Tradition.” In 144, Jayyusi, Legacy of Muslim Spain, 1994, 1:398-419. [Suggests that perhaps the zajal preceded the muwashshah; formulates the possibility 
of reciprocal influences: Christian music and love themes may have influenced the Andalusian notion of elevated love.]

341.

Robinson, Cynthia. In Praise of Song: The Making of Courtly Culture in Al-Andalus and Provence, 1005-1134 A.D. Leiden: Brill, 2002. [Reviews the theories of origins; thorough study of Hispano-Arabic poetry in the eleventh century; notes the clear use of several key topoi of troubadour lyrics in earlier Andalusian poetry; suggests that Zaragoza is the probable site of contact between Andalusian court culture and the early Occitan courts, perhaps involving Guilhem de Peitieus himself. Chapter 4 of part 2 (pp. 323-52) points out many very close parallels in poetic usage between Andalusian and Occitan cultures, specifically in several poems of Guilhem de Peitieus; also the derivation of trobar from Arabic is persuasively explored, pp. 342-47, along with the important concepts of joi and joven, pp. 347-52. In chapter 5, Robinson notes several documented instances of cultural exchange in Arabic between Christians and Andalusians.]

342.

Uhl, Patrice. "Guillaume IX d'Aquitaine et la sorcellerie de Babel-à propos des vers arabes de la chanson V (MS C)." Arabica 38 (1991): 19-39. [Reinterprets the "Arabic" lines of $C$ as authentic, suggesting that they make erudite reference to the Jewish/ Islamic legend of the fallen angels Harut and Marut, who condemned themselves by succumbing to the wiles of a woman; Guilhem may have heard the legend in a story or song performed by an Andalusian slave and referred to it obliquely/ironically to provide a key to his own poem.]

\section{3.}

\subsection{Latin Theory}

See 2341, Banniard, "Les deux voies," 2011. [Asserts that Guilhem de Peitieus had a broadly based education, was aware of sociocultural innovations in Latin poetry and religious music, and participated in them through his own idiosyncratic poetry, influenced by sociocultural movements such as those of Robert d'Arbrissel and perhaps by the subconscious trauma of illegitimacy that they shared; Guilhem's originality is firmly rooted in the innovative fabric of his time.]

\section{4.}

Bologna, Corrado. "Orazio e l'ars poetica dei primi trovatori." CDT 10.3 (2007): 173-99. [Some of Horace's major themes in the Ars poetica seem to have influenced directly the poetry of Jaufre Rudel, Marcabru, Peire d'Alvernhe, and Bernart Marti; see also the article of Marco Bernardi in the same issue, pp. 201-34, proving that a manuscript of the Ars poetica circulated in the Occitan area and could have been known to the troubadours.]

345.

See 2349, Bond, Loving Subject, 1995. [Makes a strong case for medieval Latin influences in chapter 4, pp. 99-128, by investigating the dense cultural context surrounding the first troubadour, Guilhem de Peitieus.] 
346.

Switten, Margaret. "Modèle et variations: Saint-Martial de Limoges et les troubadours." In \$9, AIEO 3, 1992, 2:679-96. [A richly provocative study of the possible influences of the St. Martial versus on the forms and meaning of troubadour songs; the hymn Ave maris stella, the versus O Maria Deu maire, Giraut de Bornelh's alba Reis glorios, and an alba by Cadenet are analyzed to show how intertextual and intermelodic associations may enrich the experience of lyric performance. Both melody and text provide a complex set of interwoven associations that make both the Virgin Mary and Eve present at the beginning of the alba, both earthly and heavenly paradise presented as desirable goals, and both pure and sensual love as powerful forces in human life.]

347.

\subsection{Popular Theory (Indigenous Sources)}

Mölk, Ulrich. "Chansons de femme, trobairitz et la théorie romantique de l'origine de la poésie lyrique européenne." In $\ \mathbf{9 5}$, AIEO 2, 1993, 1:243-54. Also in Lingua e stile 35 (1990): 135-46. [Postulates an earlier tradition of popular love poetry before the troubadours by women or composed from the female perspective; calls for more precise distinctions between popular and elevated registers, between varying perspectives of male or female protagonists, and varying presentations (monologue, dialogue, or third-person narration), in order to better understand the development of the chanson de femme in the various European literatures.]

348.

See 363, Bloch, Medieval Misogyny, 1991. [Revives the theory, put forward in 1940 by Bezzola, that Guilhem de Peitieus may have promulgated or even invented courtly love as a competitive secular response to the spiritual seductions of Robert d'Arbrissel.]

349.

See 369, Duby, "Le modèle courtois,"1991. [Claims that the love code was developed as a means of controlling the pent-up energies of young unmarried males of the court, based on the ethical model of vassalage transferred to the male-female relationship.]

350.

\subsection{Celtic Theory}

Benozzo, Francesco. "Guglielmo IX e le fate: il Vers de dreit nien e gli archetipi celtici della poesia dei trovatori." MR 21 (1997): 69-87. [Invokes Celtic archetypes for many themes found in the troubadours: the belief in fairies or supernatural women, dreams, composing on horseback or while sleeping, the unresolved tension between reality and unreality.]

351.

Benozzo, Francesco. La tradizione smarrita. Le origini non scritte delle letterature romanze. Rome: Viella, 2007. [Proposes a continuous oral evolution of popular literary culture through the Celtic shaman or druid from prehistoric times; claims that 
the etymology of trobar is not from church Latin or Greek but from a Celtic verb; stresses the need for scholars to work with archeology, linguistics, history, and anthropology to renew research into Romance literary history; downplays the importance of traditionally identified sources of European culture. See further development of these theories in his "Residui del canto sciamanico arcaico nella poesia dei trovatori," in 118, La lirica romanza, 2009, pp. 59-92, and in "Trouver, trovare, trobar: l'ipotesi celtica," $\operatorname{ZrP} 127.1$ (2011): 155-61.]

352.

Bottani, Giorgia. "Archeologia ferica. Tristano e le tre Isotte." In $>115$, Interpretazioni, 2001, pp. 45-76. [In connection with a search for Celtic sources of the Tristan legend, analyzes the similarities to Celtic belief in fairies or otherworldly women in the early troubadours, pp. 51-53 (Guilhem de Peitieus, Jaufre Rudel), and worship of the domna to the point of ecstatic transport (Bernart de Ventadorn).]

353.

Fassò, Andrea. "Le troubadour, la dame et la fée." In $>$ 99, AIEO 6, 2001, pp. 355-66. [An exploration of traditional superstitions concerning goddesses, demons, and fairies, suggesting that perhaps the domna was originally related to Irish fairies and the senhal may correspond to the necessity of keeping secret the love between a mortal and a fairy spirit; pp. 22-28 provides a new reading (lectio difficilior) of Guilhem de Peitieus's Ben vueill, based on the notion of a gift offered at birth by a supernatural goddess figure.]

\section{The Love Ethic: Definition of Fin'amors}

\subsection{General Studies of the Love Ethic}

354.

Lazar, Moshé. “Fin'amor." In 281, Handbook, 1995, pp. 61-100. [Sketches the transformation from the masculine-oriented epic society of the eleventh century to the courtly service of the god of love in the twelfth, especially in the south of France; defines the complex nature of courtliness and fin'amors and their varying realizations in the songs of the troubadours and trobairitz, with many examples quoted from the poetry itself; the notion of joy; the metaphorical sublimation of the erotic drive, seen in its key concepts: the places, the games, the rewards, and the dangers of love; the evolution of the love ethos and its transformations in time and location, specifically in its transformation into religious poetry.]

355.

Paterson, Linda. "Fin'amor and the Development of the Courtly Canso." In 282, Troubadours, 1999, pp 28-46. [Text and translation of Guilhem de Peitieus's poem Pos vezem, PC 183,11, as an introduction to the basic concepts of fin'amor, stressing that the concept was flexible from one poet to another and evolved over time; defines the main concepts of joi, joven, cortesia, largueza, pretz, valor, and mezura; the richness, complexity, and ambiguous sensuality of the mature period is illustrated through analysis of Arnaut Daniel's song Si.m fos amors, PC 29,17.] 
356.

Paden, William D. and Don A. Monson. “The Troubadour's Lady: An Exchange between Don A. Monson, College of William and Mary, and William D. Paden, Northwestern University." Exemplaria 14 (2002): 485-517. [Culmination of a longstanding scholarly debate about the social and marital position of the domna; despite some tendency to provocative overstatement of the other's position, the debate ends in substantial agreement that the poetry must be analyzed on its own terms, not according to any unsubstantiated presuppositions about the sociocultural reality of the time, or any inadvertent assumptions that we may supply from our own time.]

\section{7.}

Paden, William D. "La poésie des troubadours et le mariage: deux pratiques sociales sans élément commun?” In 124, L'Occitan, 2009, pp. 17-41. [A call for reconsideration of two traditional views: that troubadour love was adulterous and therefore alien to the moral principles of the church, and that marriage was a political/commercial arrangement inimical to finamor; based on the poetry and materials in the Histoire générale de Languedoc, Paden finds that the notion of love-marriage is more widespread than thought and that love songs of the troubadours do not necessarily rule out the possibility of marriage; a few poems make it clear that the loved one is married, and many seem directed toward marriage; but the greatest number express desire, without specifying whether or not the goal is marriage.]

\section{8.}

Paterson, Linda. "Les troubadours et l'amour." Mot so razo 1 (1999): 62-68. [Argues that finamor is based on the emotional tension between desire and fulfilment, elevated to become the source of social and moral value; often ambiguous, both sensual and spiritual, serious and playful, made up of adoration for the domna and barely disguised misogyny, above all it expresses a love for the creation of poetry.]

359.

Wind, Bartina, and Michel Zink. "Courtoisie." In 38, DLF, pp. 334-42. [A consideration of the nature of fin'amor, its possible origins, and its history in southern and northern France.]

360.

Rüdiger, Jan. Aristokraten und Poeten. Die Grammatik einer Mentalität im Tolosanischen Hochmittelalter. Europa im Mittelalter, 4. Berlin: Akademie Verlag, 2001. [A study of eighteen patrician families from Toulouse, linking historical research with literary analysis; cortesia is seen as a program of cultural empowerment through which the aristocracy tried to strengthen its position; more than just a ritualized representation of love, the poetry of the troubadours was a discourse, based on fin'amors, that stood for everything worthwhile in the society, including notions of family, inheritance, piety, property, weapons, and wordplay; the domna was not a metaphor but a symbolic morpheme capable of taking on diverse meanings such as erotic love, politics, arms, and conflicts.]

361.

Akehurst, F. R. P. “Courtly Love as Zero-Sum and Non-Zero-Sum Game.” Romance 
Languages Annual 6 (1994): 1-5. [Questions whether fin'amor may be illuminated by Foster's theory of limited good (zero-sum): if the Lady's love is finite, then all others (rivals, lauzengiers, husband) will be deprived if she grants some to the poet/lover, and they will seek to punish or destroy him; his only recourse is to maintain secrecy and hope for fate to intervene in his favor, while continuing his almost hopeless quest; the non-zero-sum model applies less well, except in the partimen.]

\section{2.}

Baladier, Charles. Érôs au Moyen Âge: amour, désir et "delectatio morosa." Paris: Éditions du Cerf, 1999. See also debate on the book by Baladier and three others, in Médiévales 40 (2001): 133-57. [Outlines the Christian theological creation of the notion of delectatio morosa, or long-drawn-out desire, coming between desire and fulfillment; see esp. pp. 141-44, "La delectation morosa des troubadours": as in the concept of fin'amors, emphasis is placed on the sentiment and desire for love, rather than on sexual fulfillment, which destroys its essential nature.]

363.

Bloch, R. Howard. Medieval Misogyny and the Invention of Western Romantic Love. Chicago: University of Chicago Press, 1991. [Analysis of the contradictions inherent in troubadour poetry: the Lady as wicked and worshipped; love as a paradox of knowledge and ignorance; the pride in the poetic voice coupled with a fear of speaking; use of a song to renounce singing (Bernart de Ventadorn); a desire not for the Lady but for her absence, not for a real lady but for an abstraction of the lady (Jaufre Rudel). Courtly poetry is masochistic and fatalistic, love is linked intimately to death. Guilhem de Peitieus shows the inherent paradox of love and misogyny in his "two-faced" poetry, as does Andreas Capellanus in his contradictory treatises: 1 and 2 praise love, 3 denounces it.]

364.

Burns, E. Jane. "The Man behind the Lady in Troubadour Lyric." RN 25 (1985): 254-70. [Uses Bernart de Ventadorn's poetry to illustrate the figure of the dompna as seen through the male poetry; parallel and contemporary to the development of the cult of the Virgin, Mary being the personification of abstract moral virtues, the dompna being this as well as erotic, real, and sensual. Argues that the ambivalent status of the lover is reflected in her sensual attractiveness and her refusal to satisfy his desire; the lack of fulfillment turns him, paradoxically, into a poet.]

365.

Calin, William. "Contre la fin'amor? Contre la femme? Une relecture de textes du Moyen Âge." In Courtly Literature: Culture and Context. ICLS 5, Dalfsen 1986. Edited by Keith Busby and Erik Kooper. Amsterdam: Benjamins, 1990, pp. 61-82. [Discusses the complementary role of misogyny and contre-textes, but not in the troubadours: analyzes directly only Old French texts: Ipomedon, pastourelles, Roman de la Rose, Guillaume de Machaut. Fin'amor and anti-fin'amor have always coexisted, as have the idealization and derision of women, as a reflection of the realities of our life and letters.] 366.

See 2262, Camproux, "On the Subject of an Argument," 1980. [Camproux claims 
that the tenso between Gui d'Ussel and his cousin Elias shows the falsehood of the common myth of finamor as a necessarily adulterous relationship; Gui defends the standard courtly game of idealized love, while Elias prefers the secure, private bond of perfect love in marriage.]

367.

Cherchi, Paolo. Andreas and the Ambiguity of Courtly Love. Toronto: University of Toronto Press, 1994. [Andreas's model of courtly love is seen as inherently ambiguous, as opposed to the notion that Andreas was mocking it; eros and moral perfection can be both symbiotic and mutually essential, not mutually exclusive; Jean de Meung reduces finiamor to pure eros, Dante to pure spirituality, whereas the troubadours tried to balance both.]

368.

Cropp, Glynnis M. “Courtly Lyric Style: Some Preliminary Thoughts.” Parergon 16 (1976): 19-37. [Questions the credibility of the courtly love situation; is it just a pastime, a jeu? To what extent is courtly love a matter of style? Considers the convention of secrecy, the poet's attitude to his work, aspects of poetic style, and the tensions on which it depends. Analysis of Raimbaut d'Aurenga Un vers farai de tal mena (PC $389,41), 30-34$, to illustrate the unity achieved by the interweaving of words and themes by repetition, parallelism, and antithesis. See also $\mathbf{2 8 5 5}$, Milone, "Raimbaut d'Aurenga, Un vers farai," 2007.]

369.

Duby, Georges. "Le modèle courtois." In Le Moyen Âge. Edited by Christiane Klapisch-Zuber. Vol. 2 of Histoire des femmes en Occident. Edited by Georges Duby and Michelle Perrot. Paris: Plon, 1991. In English: "The Courtly Model." In A History of Women in the West. 5 vols. Cambridge, MA: Harvard University Press, 1992-94, 2:250-66. [A sociological interpretation of fin'amors, emphasizing the carnal appetite of the young man, his deceptiveness in pretending to abase himself before his Lady, in the spheres of fantasy and play; Duby claims that the love code was developed as a means of controlling the pent-up energies of the young unmarried males of the court, based on the ethical model of vassalage being transferred to the male-female relationship; Cheyette 698, "Women, Poets and Politics," 1999, modifies Duby's theory, interpreting fin'amor as an eroticization of the overall power relations within the court society of the time, serving to implant the proper ethos and code of behavior that supported it; see also 2635, Gaunt, "Marginal Men," 1990: not only does fin'amor act as a safety valve in helping control the young men but also it can be directly subversive, since it refers to both lay and ecclesiastic norms of marriage and sets up a third (courtly) model of its own.]

370.

Ferrante, Joan. "Male Fantasy and Female Reality in Courtly Literature." Women's Studies 11 (1984): 67-97. [Women serve as projections of the male poet's ideal or fantasy, embodying his ideal of perfection so that he can attempt to achieve the ideal himself. In pastorelas and debate poems, the woman's function is to point out the contradictions between what he says and what he does, or attempts to do; a series 
of six pastorelas by Guiraut Riquier, pp. 72-75, explore the tension between courtly pretense (male) and reality (female).]

371.

Hagman, Roy. "The Personified Love of the Troubadours: A Quantitative Historical Semantics." In LACUS Forum 34: Speech and Beyond. Edited by Patricia Sutcliffe et al. Houston: LACUS, 2009, pp. 83-92. [An investigation of the evolving metaphor and personification of Amor; the abstract entity was given the attributes of a person, at first powerless, then becoming more controlling, even menacing, in the second and third generations, playing a central role in human existence.]

372.

Karnein, Alfred. "Amor est passio_Aa Definition of Courtly Love?" In 103, ICLS 3 Court and Poet, 1981, pp. 215-21. [Argues that Andreas Capellanus's De amore is not a celebration of courtly love but a mockery of it; not at the court of Champagne but at Paris; not within the vernacular tradition but scholarly.]

373.

See 836, Lacan, L'éthique de la psychanalyse, 1986. [Pp. 174-90; in English pp. 139-60: the code of fin'amors is a unique example of art playing an essential role in its society: argues that for a century and a half it governed rules of behavior, loyalty, service, and conduct in Occitan society, linked closely to a highly developed poetic craft. It was an idealization, without connection to the social realities of the time, dependent on a Lady who is inaccessible, an abstract figure that can easily turn into philosophy or allegory.]

374.

Meylakh, Michael. "The Structure of the Courtly Universe of the Troubadours." Semiotica 14.1 (1975): 61-80. [A report on research toward constructing a typological model of the system of values at the base of Occitan lyric culture (fin'amors and its negative correlate fals'amors); for the troubadours, amors means "poetry about amors" or even "the language of poetry about amors"; the key characteristics are set out as a series of binary oppositions centered around cortes and vilans.]

\section{5.}

Monson, Don A. "Why Is la Belle Dame sans Merci? Evolutionary Psychology and the Troubadours." Neo 95.4 (2011): 523-41. [A basic anthropological interpretation of fin'amors, reflecting recent research into evolutionary psychology; universal rituals of mate selection are based on the biologically determined asymmetry of sexual desire between men and women: the amorous desire of the lover is opposed by the resistance of the lady, as each strives toward a different goal; the canso is a rhetorical discourse of courtship stressing the sincerity of the man's commitment to the relationship.]

376.

Paden, William D. "Utrum copularentur: of cors." L'Esprit Créateur 19 (1979): 70-83. [Did the troubadours have sex? We don't know and shouldn't ask; ambiguous language is typical, and should turn our focus away from the literal and toward the poem itself; analysis of Bernart de Ventadorn's Non es meravilha, PC 70,31, shows ambiguity to be intentionally at the very heart and in the very body of the poem; 
Jaufre Rudel's Lanquan li jorn, PC 262,2, is similarly structured around the ambiguous distinction between secular and spiritual love; shows that erotic ambiguity is a central and necessary part of troubadour poetry.]

377.

Ribémont, Bernard. Sexe et amour au Moyen Âge. 50 Questions. Paris: Klincksieck, 2007. [Succinct nonspecialist introduction to the nature and practice of sexuality in the Middle Ages; pp. 30-53: good basic introduction to the concept of finamor.] 378.

Rieger, Angelica. "La dialectique du réel et du poétique chez les troubadours. Les quatre 'protagonistes' de la fin'amors.” RLaR 87 (1983): 241-57. [The poetry posits four potential protagonists: two real people, the lady and the poet, and two poetic creations, the lover and his domna; their roles may coincide, but only outside the poem; one couple is subject to the complex realities of the court, the other only to the rules of fin'amor, but listeners may bring both couples together by sharing in their secret and identifying with them against the common enemy, the lauzengiers.]

379.

Schnell, Rüdiger. "L'amour courtois en tant que discours courtois sur l'amour (I and II).” Rom 110 (1989): 72-126 and 331-63. Translated into French by Eva Podlaha from the original German: "Die 'höfische' Liebe als 'höfischer' Diskurs über die Liebe." In Curialitas. Studien zu Grundfragen der höfisch-ritterlichen Kultur. Edited by Josef Fleckenstein. Göttingen: Vandenhoeck \& Ruprecht, 1991, pp. 231-301. [An exploration of eight essential aspects of "courtly love" in Medieval French, Occitan, and German poetry: exclusivity, constancy, sincerity, impartiality, reciprocity, spontaneity, moderation, and patience; courtly love is not so much a code of behavior toward love as it is a continuing ludic discourse; part II: the antagonisms found within the lover, between lover and lady, between the lovers and society; courtly love cannot be defined, since it evolved over time and over genres.]

380.

Städtler, Katharina. "En cort, en cambra o dinz vergier: Überlegungen zu einer historischen Anthropologie der fin' amor." In 125, Okzitanistik, Altokzitanistik, 2000, pp. 217-30. [Believes that philological and historical studies have not so far brought us very close to grasping the alterity of the Middle Ages; methodology from the sociological and anthropological disciplines will advance our understanding of finamor by investigating it anthropologically through a study of the places where it is found (in cort, cambra, vergier), rather than treating the poetry as if it were about a living experience.]

381.

Thiolier-Méjean, Suzanne. L'archet et le lutrin. Enseignement et foi dans la poésie medieval d'Oc. Paris: L'Harmattan, 2008. [Analysis of the worldview of the troubadours through their own reality: their vidas and their lyrics; finamor is seen as a total passion akin to divine love, remaining close to Christian virtues of faith and spirituality, even when these are adapted to the more profane interests of the courts, or when they express hostility to the temporal administration of the church; the goal of the poets is to attain 
virtue through love; the troubadour song is neither purely mystical nor totally profane, but in constant tension between the two; their songs spring from this tension.]

382.

\subsection{Themes of Troubadour Poetry (Motifs, Images, Topoi)}

Schulze-Busacker, Elisabeth. “Topoi.” In 281, Handbook, 1995, pp. 421-40 [Definition of the term and outline of recent scholarship in the area; analysis of a planh by Bonifaci Calvo (PC 101,12) by way of example.]

383.

Schweickard, Cristine. Sobre.l vieill trobar e.l novel: Zwei Jahrhunderte Troubadourlyrik: Thematische Schwerpunkte und Schlüsselbegriffe: Ein interpretatorischer und inhalts-analytischer Versuch. Frankfurt: Haag und Herchen, 1984. [Computerized statistical study of the evolution over two centuries of themes, keywords, the love ethic, poetic theory, and technique; analysis is divided into five historical periods, limited to sixty-one poets; gives a chronological list of troubadours, pp. 314-28.]

384.

Atturo, Valentina. "Cor ai fol: la folia dei trovatori." In Variabili della follia. Materiali di studio. Edited by Simonetta Bianchini. Rome: Edizioni Nuova Cultura, 2007, pp. 13-66. [Detailed study of the notion of madness in troubadour poetry, through a systematic investigation of the whole semantic field of foudatz; 1155 occurrences of lemmata of the root FOL- were examined through numerous quotes to reveal the positive and negative meanings fol and folia have in different contexts and in different genres, basically stemming from the opposition with mesura and sen; pp. 47-62: a specialized investigation of usage of the terms in Marcabru, contrasted with that of Bernart de Ventadorn.]

\section{5.}

Benozzo, Francesco. "Preistoria rituale del dono cortese: dalle iscrizioni galliche alla poesia dei trovatori." In Vincolare, ricambiare, dominare: Il dono come pratica sociale e tema letterario. Atti del X Convegno internazionale (Rocca Grimalda, 23-25 settembre 2005). Edited by Nicolò Pasero and Sonia Maura Barillari. Alessandria: Orso, 2007, pp. 153-63. [The troubadour theme of an offering to his domna may be traced back to Celtic rituals of sacrificial offerings to the goddess Epona; the poet offers his songs of fidelity and suffering but waits in vain for the expected reciprocal gift; in both cases, the submission and humiliation leads paradoxically to further exaltation and continued adoration.]

386.

Bianchini, Simonetta. "Letteratura e natura nel secolo XII." RST 4 (2002): 41-76. [Examines the use of descriptions of nature in lyric, epic, and courtly romance, in French and Occitan; special attention to troubadour lyrics, pp. 55-70: analyzes the variations and evolution of poetic uses of the topos, from its positive development in the early poets to its reversal and eventual renunciation.]

387.

Blakeslee, Merritt R. "Lo dous jocx sotils: la partie d'échecs amoureuse dans la poésie 
des troubadours." CCM 28 (1985): 213-22. [Discusses the metaphor of chess as an expression of the ritualized formalism of finamor, as opposed to that of dice, which is associated with the disorders of desire.]

388.

Borriero, Giovanni. "Il topos dell'ineffabile nella retorica médiévale e nella lirica trobadorica." MR 23 (1999): 21-65. [Analysis of the motif of midons, especially in Cerveri de Girona and Guilhem de Cabestanh, in relation to the theoretical formulations in the rhetorical Artes; she is the silent, the inexpressible, named only by a senhal; she belongs to another dimension, going beyond the power of the poet's words to describe her; a metapoetic reflection on the communicative powers of language, involving as well the lover's powerlessness to express his joy or his despair.]

\section{9.}

Braet, Herman. "Visio amoris: genèse et signification d'un thème de la poésie provençale." In 147. Mélanges Rostaing, 1974, 1:89-99. [Traces the theme of the erotic dream from antiquity and through the troubadours (except for Guilhem de Peitieus); popular theme among the troubadours, sometimes as a trick to make contact with the lady, but more often to heighten the delicious torment, or as a sort of exaltation of the unreal love-quest; the idealized poetic image is stronger than reality, and preferred to it.]

390.

Brea, Mercedes. "Les animaux dans les poésies amoureuses des troubadours occitans." RLaR 98 (1994): 403-43. [Studies the use made of animals in the lyrics: as comparison, allegory, symbol, in conjunction with their traditional characteristics in the bestiaries; systematic catalog of the use of birds, mammals, insects, reptiles, fish, and fantastic animals, calling for further detailed and comparative study; many references in twelve pages of notes, but no bibliography.]

391.

Brea, Mercedes. "L'hortus conclusus dans la poésie lyrique des troubadours." In - 111, L'Espace lyrique, 2006, pp. 101-19. [The spring opening is linked to Christian evocations of earthly paradise and to the protective refuge for lovers, a compromise between the natural instincts of nature and the controlled life of the castle.]

392.

Cabré, Miriam. "Mors et vita in manibus linguae: la metafora della lingua nei trovatori.” In 100, AIEO 7, 2003, pp. 179-99. [A novel approach to analysis of troubadour poetic techniques through a study of the metaphorical use of the speech act; language is identified with poetry, and the troubadours called themselves craftsmen with words; the professional use of language by preachers, courtiers, and troubadours; historical development of the metaphor in the earliest troubadours, Marcabru and Arnaut Daniel shows how in the thirteenth century the metaphor took on moral and pedagogical values, with emphasis on good speech as a courtly virtue; and bad as a sin in its use for deception; special analysis of Cerveri de Girona and his pedagogical use of proverbs.] 
393.

See 534, Canettieri, La sestina e il dado, 1993. [Reviews the theme of gaming in a number of troubadours; proposes that the metrical structure of Arnaut Daniel's sestina was inspired by the arrangement of numbers on the dice; argues that the notion of gambling suggested by this structure may be intended to represent the capricious influence of fate on human love and the poet's belief that love of the domna and love of poetry are analogous.]

394.

Elizalde, Ignacio. "El tema de Navarra en la lirica trovadoresca." In La Juglaresca: Actas del I Congresso internacional sobre la juglaresca. Edited by Manuel Criado de Val. Madrid: EDI-6, 1986, pp. 359-76. [The theme is traced through the works of nineteen troubadours, including Arnaut Daniel, Bertran de Born, Cerveri de Girona, Giraut de Bornelh, Marcabru, Peire Cardenal, and Sordello.]

395.

Fabre, Daniel. "Lenguaje de los pájaros e idea de la poesia." Revista de antropología social 17 (2008): 165-90. [Addresses the metaphorical use of bird imagery in oral folklore, troubadour poetry and modern folk society; anthropological analysis of the origins of artistic response and the social production of virile erotic identity.]

396.

Gaunt, Simon. Love and Death in Medieval French and Occitan Courtly Literature: Martyrs to Love. New York: Oxford University Press, 2006. [An interpretation of the psychosexual dynamics of the linked themes in a number of Occitan and French texts, based on the theoretical approaches of Lacan, Derrida, Bataille, and Foucault; argues that courtly literature has instituted a new secular ethics of desire, because of its connection with sacrificial death; a study of the interplay between lyric and romance shows how this "poetic" predilection has imposed a "real" repressive sex/ gender system, not only gay but also especially narcissistic, in that it is about men examining their own position in society.]

397.

Ghil, Eliza Miruna. "The Seasonal Topos in the Old Provençal canso: A Reassessment." In 159, Studia occitanica, 1986, 1:87-100. [Detailed study of the topos in twelve troubadours (367 poems), with statistical analysis of the constituents of seasonal openings and the way they are utilized in the development of the poems, revealing "remarkable poetic craftsmanship, and infinite variety of detail"; see also the related article by H.-C. Haupt, "Autour du début printanier: naissance d'une nouvelle structure syntaxique," FL 115 (1992): 155-87, and "Errata," 116 (1993): 169-70.]

398.

Gross, Charlotte. "Loc Aizi/Anima Mundi: Being, Time, and Desire in the Troubadour Love Lyric." In Desiring Discourse: The Literature of Love, Ovid through Chaucer. Edited by James J. Paxson and Cynthia A. Gravlee. Selinsgrove, PA: Susquehanna University Press, 1998, pp. 111-22. [In line with Plato's concept of the world soul, the troubadours use the figure of loc aizi as the expression of a fragile transcendent 
ideal of fulfilled desire, accessible only in dream, vision, or memory; analysis of works by Jaufre Rudel, Bernart de Ventadorn, and Raimbaut d'Aurenga to illuminate their search for a compromise between imperfection and perfection: Jaufre's distant love, Bernart's struggle with loss of identity, and Raimbaut's spiritual union with his domna through the contradictions of poetry all speak to the impossible joy of uniting two separate beings.]

399.

Gubbini, Gaia. "La ponha d'amor e la cadena: ferita e catene trobadoriche tra Jaufre Rudel, Raimbaut d'Aurenga et Bertran de Born.” CDT 8 (2005): 781-801. [Study of an intertextual debate by a group of poets linked by the motifs of the suffering and chains of love: Raimbaut takes the themes from Jaufre Rudel and Bernart de Ventadorn; Bertran de Born then comments on all previous uses, agreeing with Raimbaut on the immutability of love.]

400.

Gubbini, Gaia. Tactus, osculum, factum. Il senso del tatto e il desiderio nella lirica trobadorica. Rome: Nuova Cultura, 2009. [Detailed study of the importance of the sense of touch in troubadour lyric and study of the vocabulary used to evoke the various stages of desire and its sensory evocation by the poet/lover; individual analysis of the work of Guilhem de Peitieus, Raimbaut d'Aurenga, and Arnaut Daniel; suggests that in contrast to the classical and patristic attitudes to love discourse, the troubadours developed the characteristic notion of "spiritualized corporality."]

401.

Mancini, Mario. "Cortigiani e cavalieri-predoni: intorno a un motivo trobadorico." RZL 4 (1980): 125-60. Slightly revised in his Metafora feudale: per una storia dei trovatori. Bologna: Il Mulino, 1993, pp. 13-62. [The theme of arms and pillage, emphasizing the social contrast between the North (structure, law, and order) and the South (disorder and pillage outside the courts, isolation and refined courtliness within) may explain the preferences in literary genre (epics and political writing in the North, lyrics and novas in the South); suggests that the contrast in forces and themes found in the South (armas/amor, exterior/interior, raubar/finamor) explains how the troubadour cultural model can have become so compact and creative compared to that of the North.]

402.

Mancini, Mario. "Marcabru, i sambuchi e il castello assediato." In $\mathbf{1 5 2}$, Miscellanea Roncaglia, 1989, 3:773-87. Also in 401, Mancini, Metafora feudale, 1993, pp. 107-31. [Argues that the elder-tree is sterile and useless, used by Marcabru in his invective against those who do not follow his moral guidance; the besieged castle is more complex: in Bel m'es quan la rana, PC 293,11, the peaceful garden of the locus amoenus is turned into a fortress, a place of violence, typical of the paranoia of the obsessively neurotic; the castle of Proeza is under siege, society is collapsing under evil; the only hope is a return to original purity and love.]

403.

Mölk, Ulrich. "La réflexion sur la notion de propriété artistique chez les troubadours." 
In 118, La lirica romanza, 2009, pp. 5-16. [Originality is stressed by many troubadours; they pride themselves on choosing "new" words and forms and stress their personal individuality; the joglars are secondary to the poems they perform, though some are more professional and more highly valued; the public was called upon to participate actively in the performance by recognizing the subtleties and intertextual references, and by identifying the distinctiveness of the individual poets.]

404.

Riquer, Isabel de. "Lo donars sobre totz senhoria (PC 278,75, v. 68).” In 162, Trobadors a la Peninsula Ibèrica, 2006, pp. 311-33. [Analysis of the theme of liberality, especially among the later troubadours after the Albigensian Crusade: Guiraut Riquier and other poets in Spain and at the court of Rodez, who are anxious to be treated as professionals; list of the nine tensos between Guiraut Riquier and various poets.]

405.

Ron Fernández, Xosé Xabier. "Les degrés du service amoureux existent-ils dans la lyrique occitane? Visions et révisions sur un lieu commun de la lyrique des troubadours." RLaR 108 (2004): 189-242. [A fresh look at the figure of the steps of love, which have become a commonplace in scholarship but were not used as such by most poets; they are not obligatory progressive steps for the lover but complex and varied representations of the nature of love service of the poet/lover, based on the central notion of discretion at all stages of love.]

406.

Saouma, Brigitte. "La notion de beauté dans la fin'amor à travers l'esthétique médiévale." In 101, AIEO 8, 2009, 1:287-95. [Physical and spiritual beauty are important in medieval theology, and both are essential to the troubadours' notion of beauty, based on idealized harmony, a reflection of the moral qualities of the lady, in which love and beauty are one.]

407.

Saouma, Brigitte. "Lidée de 'guerre juste' dans la poésie des troubadours." In $\mathbf{1 0 2}$, AIEO 9, 2011, pp. 505-12. [Analysis of the contradictions between the church's doctrinal position against secular war, in favor of diplomacy, and the troubadours' enthusiasm for combat, complicated by the church's actual tolerance of war and the troubadours' stated acceptance of the church's teachings.]

408.

Sanguineti, Francesca, and Oriana Scarpati. "Comensamen comensarai: uno studio tipologico sugli incipit trobadorici." In Actes du colloque Nouvelle recherche en domaine occitan: approches interdisciplinaires (Albi, 11-12 juin 2009). Turnhout: Brepols, 2012, in press. [Analysis of the constituent elements of the opening lines over the entire troubadour lyric corpus, with an aim to identify constants and variables in each author's production; shows that, because the opening lines of medieval lyrics often operate as titles, the first line may provide a key for further interpretation. The incipit lines of more than two thousand Occitan poems may be grouped into a small number of typological categories, among which the following stand out: declaration of the genre, invocation, self-pity, comparison, and denial.] 
409.

Spence, Sarah. "The Topos of Discretion in Troubadour Poetry." RF 112 (2000): 181-91. [Suggests that the topos is not connected as much to the supposed necessity of concealing an adulterous love as to the poetic necessity of muting the characteristics of uncultivated vernacular language in order to create a new elevated diction worthy of supplanting the old. "Discretion remains a literary constant necessary to love, but it is revised in the hands of the troubadours to speak to their artistic needs."] 410.

Thiolier-Méjean, Suzanne. "Des roses dans la glace, ou le monde à l'envers chez les troubadours." In 137, Contez me tout, 2006, pp. 839-57. [The motif of the world upside-down, natural laws reversed (adynaton), found from classical times on, is linked by the troubadours to both moral and esthetic values; Marcabru, Peire Cardenal, and others use it to censure decadence, while others, such as Bernart de Ventadorn, stress its positive connection to the transfiguring effects of love; Raimbaut d'Aurenga uses it enigmatically to indicate that the inner poetic dream is the only true reality; his masterful use of enigma is difficult to comprehend without reference to the long history of classical and medieval rhetoric, with its insistence on highly disciplined poetic technique.]

411.

\subsection{Vocabulary, Terminology of Fin'amors}

Ghil, Eliza Miruna. "Imagery and Vocabulary." In 281, Handbook, 1995, pp. 441-66. [Analysis, with examples, of the important figurative vocabulary coming from feudal, legal, and commercial practice, from religion, and from medicine; the figurative usage adds depth and resonance which is not always easy to appreciate from our modern perspective; suggests several areas in which further study is required.]

412.

Akehurst, F. R. P. "Words and Acts in the Troubadours." In $>127,1989$, Poetics of Love, 1989, pp. 17-28. [Treats the vocabulary of the gradus amoris in troubadour lyric; words and expressions attached to each of the five classic steps of love.]

413.

Akehurst, F. R. P. “The Bottom Line of Love: A Semiotic Analysis of the Lover's Position." In 365, Courtly Literature, ICLS 5, 1990, pp. 1-10. [An attempt to place the troubadour love ethic on a Greimasian square to clarify the psychological forces and emotional movements involved in the game of finamor; the prime moving force is identified as merce.]

414.

Babin, Malte-Ludolf. Orgolh-umil: Untersuchungen zur lexicalischen Ausprägung des Altokzitanischen im Sinnbereich des Selbstgefühls. Beihefte zur ZrP 251. Tübingen: Niemeyer, 1993. [Exhaustive collection of lexical data based on onomasiological principles; more than nine hundred lyric and non-lyric occurrences are analyzed, with a consideration of semantic evolution of the terms in Occitan literature; attaches a sample dictionary entry (in French) for orgolh and its derivatives.] 
415.

Callewaert, Augustijn. “Entreb(r)escar los motz: à propos d'un terme poétologique chez les troubadours.” In $>\mathbf{9 8}$, AIEO 5, 1998, pp. 115-22. [Reviews the scholarship devoted to the expression; detailed study based on etymology: attached to the production of honey by fermentation, used by classical authors as a symbol for poetic creation (eloquence), then by Christian authors as a symbol for the process of explicating the deeper allegorical meanings of the Bible behind the literal sense (fermenting or refining the words). Used to express the fusion into a new richer unity of diverse words and materials gathered from many sources, a symbol of poetic creation, especially apt to suggest the semantic density and formal complexity of trobar clus and trobar ric.]

416.

Ciprés Palacín, María Ángeles. "La douz'amor de la lírica trovadoresca." Revista de filología románica, extra 5, 2007, pp. 69-84, online at http://www.revistas.ucm.es. [Argues that the sensuality of the troubadours is particularly oriented toward the vocabulary of touch, taste, and hearing; provides documentation of the troubadours' usage of vocabulary of the senses.]

417.

Cocco, Marcello M. Lauzengier: semantica e storia di un termini basilare nella lirica dei trovatori. Cagliari: Istituto di lingue e letterature straniere, 1980. [A study of all thematic and lexical groups that evoke the lauzengiers; stresses intertextual links concerning the figure in early poets.]

418.

Cropp, Glynnis M. Le Vocabulaire courtois des troubadours de l'époque classique. Geneva: Droz, 1975. [Systematic study of the troubadour lexicon dealing with finamor, including physical terms for the lover and lady as well as the sophisticated abstract vocabulary pertaining to its sociological and psychological nature.]

419.

Cropp, Glynnis M. "L’expression de la générosité chez les troubadours." In 159 , Studia occitanica, 1986, 2:255-68. [Detailed study of largueza (liberality, generosity) as a dynamic factor of life in the court and in love; shows that the poets were discreet in asking for generosity from their patron but more direct in requesting a reward from the domna.]

420.

Cropp, Glynnis M. "Les expressions mans jonchas et a (de) genolhos dans la poésie des troubadours." In 151, Mélanges Bec, 1991, pp. 103-12. [Analysis of the use of this and other feudal vocabulary to indicate submission to authority, to God, or to the domna; the three registers may overlap or become ambiguously mixed, or the poet/ lover may use the ritual as a way to come closer to his lady.]

421.

Cura Curà, Giulio. "Annotazioni sull'uso degli antonimi fals e leyal in contesti metapoetici della lirica trobadorica." La parola del testo 10 (2006): 7-20. [Stresses the utility of consulting the grammatical treatises to better understand the vocabulary 
concerning rhetorical and formalistic matters; for example, the term fals is used to indicate a word used inappropriately according to the rhetorical rules, or grammatically incorrectly, sometimes meaning "discordant, improper"; the opposing terms are covinen, verai, leyal: "well-chosen, proper, correct."]

422.

Fassò, Andrea. "Chi cerca trova. Cherchez et vous trouverez. Chiens couards, chasseurs et troubadours." In 154, Mélanges Suard, 1999, 1:231-39. Italian version: "Sulle tracce del trovatore." RST 1 (1999): 109-18. [On the example of abstract words evolving from down-to-earth etymological origins in the animal world, proposes the Greek verb $\tau \rho \circ \pi \mathrm{o \omega}$ "to put to flight" as etymon for trobar in both senses of "find" and "compose"; from its use in hunting, along with the related origin of cercar

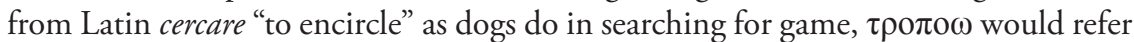
to the end of the hunt, when the game turned to run, leading to the more abstract, figurative meanings of trobar "discover, find, invent, compose," perhaps with the added reinforcement of Arabic tarab "song."]

423.

Guida, Saverio. "Mots-témoins." In his Religione e letterature romanze. Messina: Rubbettino, 1995, chapter 1. [In-depth study of four lexical concepts dealing with religious values in troubadour poetry: amistatlamistanza; ermita; quet; rire/ris.]

424.

Guida, Saverio. "Eufemismi erotici metageografici nella lirica dei trovatori." $Z r P$ 127.4 (2011): 595-611. [Inquiry into the use of geographical terms as indirect references to sexuality (terra, mar, Fransa, val de Josafalla, lo Far); study of multiple layering of meaning in the lyrics, and the constant tendency to play with language as a part of poetic competitiveness; the obscure meaning of several poems is clarified.]

425.

Gutiérrez-Garcia, Santiago, and Mónica Souto-Espasandín. "Contextualización histórica e ideológica de la lírica cortés: el léxico del sufrimiento amoroso y el pensamiento cristiano." Estudis romànics, 27 (2005): 147-60. [A comparison of the vocabulary of suffering in the troubadours and in contemporary Christian concepts, especially the similarities between the poetic steps of love and the penitential steps of purgatory, both leading toward perfection.]

426.

Kendrick, Laura. The Game of Love: Troubadour Wordplay. Berkeley: University of California Press, 1988. [Review of classical traditions of wordplay; proposes a controversial new way of approaching the poems, attuned to their ludic qualities of punning, mockery, contradictions, and innuendo; the game of love is seen as "deep play," with the audience as an essential part of the process; at stake for the poet is not only material gain but also esteem, honor, respect, and social status; for a cautionary note on the methodology, see Duggan, in 110, Cultural Milieu, 1994, pp. 9-15.]

427.

Meylakh, Michael. "Du miel à la poésie: entreb(r)escar los motz, la formule métapoétique des troubadours." In Hommage à Jacques Allières. 2 vols. Edited by Michel 
Aurnague and Michel Roché. Anglet: Atlantica, 2002, pp. 477-93. [Analysis of a key expression for the understanding of troubadour poetry; the universal figure of honey-making as a metaphor for the creation of poetry has evolved to take in new meanings of "interweaving" and even "fermenting"; just as fermented honey can lead to ecstasy, poetic transfiguration can lead to otherworldly insights; Meylakh adds the notion of distorting and fracturing as a further semantic evolution, helping to justify the deliberate distortion of meaning in trobar clus.]

428.

Mocan, Mira. I pensieri del cuore. Per la semantica del provenzale cossirar. Rome: Bagatto, 2004. [Using the whole Occitan corpus, undertakes a detailed semantic analysis of the lexical family of considerare, one of the most important concepts of troubadour ideology and lyric expression; provides insight into the rich, ambiguous metaphorical systems of the poetry and into the process of the inward-looking experience of love and lyric.]

429.

Mussons, Anna-María. "Fols et fols naturaus chez les troubadours." In 96, AIEO 3, 1992, pp. 1053-69. [Different types of folia, the opposite of sen and mezura-not specifically mental illness as we define it; love was often considered a sickness in Ovid, in Arabic literature, and in the troubadours, an emotion that separates the lover from reality, troubles his equilibrium, and transports him beyond the normal world through joi.]

430.

Rüdiger, Jan. "Das Morphem Frau: Überlegungen zu einer 'Grammatik der Mentalität' im okzitanischen Mittelalter." In $>$ 125, Okzitanistik, Altokzitanistik, 2000, pp. 231-47. [Asserts that fin'amor is seen as a pure sign-system, a symbolic idiom; following up on Georges Duby's work on "mentalités," he describes the vocabulary of love as a linguistic system that gives expression to "mentalités" such as that of cortesia.]

431.

Shapiro, Marianne. "Entrebescar los motz: Word-Weaving and Divine Rhetoric in Medieval Romance Lyric.” ZrP 100 (1984): 355-83. [Entrebescar refers to a systematic exploitation of language to create a new order of discourse that is unique to poetry, in contrast to the rational unfolding of an argument; the use of enigmatic language by Raimbaut d'Aurenga leads to its full exploitation by Arnaut Daniel and Dante.]

432.

Spaggiari, Barbara. "Artimalec e archimalec." Rom 111 (1990): 331-45. [The two terms are not connected in time or meaning, and neither of them is biblical; Marcabru created the first from the name of a Celtic hero, and it was connected in other poets with blame cast on joglars; the second, of Arabic or pseudo-Arabic origin, was used in the Vida de Sant Honorat and later by Peire Cardenal to add exotic flavor reminiscent of the epic.]

433.

Tavera, Antoine. "Ancien provençal $\operatorname{cor}(s)$ et $\operatorname{cor}(p) s$ : une quasi-homonymie riche de 
conséquences." In Le "Cuer" au moyen-âge. Sénéfiance, 30. Aix-en-Provence: Université de Provence/CUER MA, 1991, pp. 411-37. [The art of playing with the ambiguity of the two words was perfected by Bernart de Ventadorn, then spread widely; includes a tabulation of occurrences of cor and cors in five troubadours; in Arnaut Daniel, even the scribes were very confused by the ambiguities.]

434.

Winter-Hosman, Mièke de. "Les mots et les choses: ambiguïté dans le vocabulaire des premiers troubadours." In La "fin'amor" dans la culture féodale. Actes du Colloque du Centre d'Études Médiévales de l'Université de Picardie Jules Verne, Amiens, mars 1991. Greifswald: Reineke, 1994, pp. 195-206. [The key terms of fin'amor identified by Lazar and Cropp are examined succinctly with a view to showing how they are suspended ambiguously between the concrete and the abstract; their typical polysemy accounts for much of the richness of the poetry; focuses on terms such as servir, domnejar, deport, honor, joi, with special attention to pretz and valor.]

\subsection{Obscenity, Contre-text}

[See also 1982-92: the Cornilh affair, an "obscene" debate involving Arnaut Daniel, Raimon de Durfort, and Truc Malec.]

435.

See 244, Bec, Burlesque, 1984. [Different types of reaction against the very narrowly structured paradigm of finamor: \#1 is for dissenting voices against the courtly idealization of women; \#2 is humorous and burlesque "tours de force" and parodies; \#3 the obscene and scatological shockers, including the "Cornilh affair," pp. 138-53, and L'altrier cuidai aver druda, pp. 178-83; \#4 is Bec's surprising classification: "Le contre-texte féminin" (trobairitz); and \#5 is linguistic or rhetorical, playing with sounds and forms ('l'hypertrophie du trobar').]

\section{6.}

Gaunt, Simon. "Obscene Hermeneutics in Troubadour Lyric.” In Medieval Obscenities. Edited by Nicola McDonald. Woodbridge: York Medieval, 2006, pp. 85-104. Papers presented at a seminar series at University of York 2001. [Three parts: (1) general idea of obscenity in the troubadour tradition; 2) relationship between erotics and poetics in the troubadour lyric (Guilhem de Peitieus Ben vueill); 3) analysis of Arnaut Daniel's sestina: many ambiguities are dissected using Lacan's insights into sexual language; Gaunt's 1993 article $>$ 95, AIEO 2, 1993, 1:101-17 concentrated on aesthetics (obscenity used to generate humor and satire); this article examines methods of psychocritical interpretation of obscenity.]

437.

See 836, Lacan, L'éthique de la psychanalyse, 1986. [See pp. 191-94 (English, pp. 161-64): Arnaut Daniel's obscene poem PC 29,15 and the Cornilh affair; Lacan calls it a paradox of sublimation, arguing that sublimation does not have to work only in the direction of the sublime, even the crudest of sexual gaming can be the ambiguous object of poetry; this is a problem of courtly moral casuistry concerning the limits 
of the lover's service to the wishes of the Lady, a sublimation of desire revealing the profound ambiguity of the sublimating imagination.]

438.

Levron, Pierre. "Mélancolie et scatologie: de l'humeur noire aux vents et aux excréments." Questes, Bulletin no. 21 (2010): 72-88. [Scatological passages in two troubadour lyrics are seen to be linked to the love service: in one, a knight is asked to fart in order that a becalmed ship may continue its voyage, taking noble ladies to the Holy Land; in the other, a knight is asked to blow into his lady's anus as a proof of his devotion; these are parodies of the traditional elevated love, but may also be thought of as cures for the sickness (melancholia) of love. Online at http://questes.free.fr/pdf/ bulletins/0021/6_article_pierre.pdf.]

439.

Malm, Ulf. Dolssor Conina: Lust, the Bawdy, and Obscenity in Medieval Occitan and Galician-Portuguese Troubadour Poetry and Latin Secular Love Song. Uppsala: Uppsala University Library, 2001. [Pp. 137-210: analysis of the "noncourtly" side of troubadour, Galician and Latin poetry; detailed study of a number of poems by Guilhem de Peitieus, Marcabru and others; texts are from 244, Bec, Burlesque, 1984, with English translation in the notes.]

440.

See 245, Nelli, Ecrivains anticonformistes, 1977, vol. 1. [Anthology of fifty-one poems by thirty-five poets, consisting of various departures from the courtly ideal, including the frankly obscene, such as the Cornilh affair, pp. 79-96, the tenso PC 306,2 between Montan and a lady, pp. 200-204, and the porquiera, pp. 339-48.]

\section{1.}

Poe, Elizabeth W. "Na Veilla Carcais. The Text and Contexts of Montan's Vostralens es tant putnais." In 146, Literatur Mölk, 1997, pp. 155-74. [New edition of PC 306,4 and full examination of its place in relation to other similar poems and to the idealizing cansos. The "old whore poems" are "a momentary escape from the civilizing constraint of the canso"; see Krispin's edition of the tenso PC 306,2 Eu veing vas vos in 2701, 1981.]

442.

Rieger, Angelica. "Gran dezir hai de ben jazer. Die Bettgeschichten der Trobadors." In Abkehr von Schönheit und Ideal in der Liebeslyrik, für Peter Brockmeier zum 65. Geburtstag. Edited by Carolin Fischer and Carola Veit. Stuttgart: J. B. Metzler, 2000, pp. 48-65. [A protest against the recent double tendency to interpret troubadour poetry either as Platonic or homosexual; demonstrates with many examples from the most popular poets that the troubadours sang of a sexuality that was both active and fulfilled.]

443.

Uhl, Patrice. "La tenso entre Montan et une dame (PC 306.2): petit dialogue obscène entre amics fins." Expressions 31 (2008): 67-86. [Detailed analysis to show that the poem belongs to the same level of structural and lexical intricacy as the traditional courtly lyrics; complex intertextual links with several poems by Cerveri de Girona, 
Peire Duran, and the anonymous balada Coindeta sui (PC 461,69); argues that the anonymous female participant is no less a real trobairitz than any other; if a woman could participate in the performance of the poem, she could surely have participated as composer, even in the obscene contre-text mode, as in the Hispano-Arabic tradition.]

\section{Genres of Troubadour Lyric}

\subsection{General}

[Overviews of the field, genre definitions and problems, followed by a number of more specialized areas: genres and music, genre treatment in the medieval grammatical treatises. The Leys d'amors recognize eleven major genres (dictatz principals) and an indeterminate number of minor genres (dictatz no principals); it is noteworthy that the notion of genre was imprecise, and that many works tend to mix or ignore theoretical characteristics; many so-called generic rules have been imposed retrospectively, from the time of the Leys d'amors into modern times.]

\section{4.}

Bec, Pierre. La Lyrique française au moyen âge (XIIe-XIIIe siècles). Contribution à une typologie des genres poétiques médiévaux. Vol. 1: Etudes; vol. 2: Textes. Paris: Picard, 1977-78. [The basic study of typology of Occitan and Old French lyric forms; the important notion of "poésie popularisante" as defined in earlier works.]

445.

Canettieri, Paolo. "I generi trobadorici e la trattatistica. Variazioni sul tema e sul sistema." In 92, Actes du XXe Congrès, 1993, 5, pp. 73-88. [Asserts that genre definitions were systematized not by the poets but only after the fact by the poetical treatises, subject to much debate among modern scholars; identifies a tripartite division according to content (cansolvers, sirventes, planh, alba, pastorela), dialogic mode (tenso, partimen, cobla), and metrical form (dansa, balada, descort, estampida, retroencha, etc.); includes a fuller discussion of the third category.]

446.

Canettieri, Paolo. "L'empozitio del nom e i dictatz no principals. Appunti sui generi 'possibili' della lirica trobadorica." In $>97$, AIEO 4, 1994, pp. 47-60. [Investigation into the origin of new genres and the reasons for their success or failure: vers, escondig, retroencha, plazer, enueg, and other rare, hybrid, or nonexistent genres; p. 57: provisional list of more than sixty minor genres.]

\section{7.}

See 850, Chambers, Introduction, 1985. [Pp. 191-279: the panoply of genres seen in historical perspective; the presentation is diachronic, progressing through the key figures, texts, schools, and generations of poets; the book is appropriate for the specialist scholar; not entirely up to date (bibliography only to 1983): recent scholarship is sometimes not mentioned; for a more approachable introduction to versification, see 227, Riquer, Los Trovadores, 1975, 1:34-49.]

448.

Gaunt, Simon. Gender and Genre in Medieval French Literature. Cambridge: 
Cambridge University Press, 1995. [A new investigation of the feminist and sociopolitical implications of medieval genre structure, as this is determined by distinct constructions of the masculine as well as the feminine; chapter 2 treats the canso, discussing recent works by Cholakian, Huchet, and Kay, raising many provocative questions.]

449.

Gonfroy, Gérard. "Les genres lyriques occitans et les traités de poétique: de la classification médiévale à la typologie moderne." In Actes du XVIIIe Congrès international de linguistique et de philologie romanes, Université de Trèves (Trier), 1986.7 vols. Edited by Dieter Kremer. Tübingen: Niemeyer, 1988-92, 6:121-35. [Examines closely the information about genres in all twelve poetic treatises that mention them; demonstrates the complex and sometimes contradictory nature of the information; stresses the dynamic nature of genre evolution: not a calm, continuous process but a dynamic struggle to make something new of traditional forms.]

450.

Gourc, Jacques. “D’un exemple de permeabilitat e de mobilitat actancial a cap a un assag de redefinicion de la lyrica trobadorenca." In $\ \mathbf{9 6}$, AIEO 3, 1992, pp. 919-26. [Explores the formal and thematic links that connect three songs-Peire Rogier PC 356,4, Bernart de Ventadorn PC 70,17, and Giraut de Bornelh PC 242,3-to the dialogic passage in Flamenca, culminating in the fulfillment of the poetic desires in the expanded social narrative; claims that our definition of lyric needs to be widened to allow connections with narrative genres.]

451.

Gourc, Jacques. "Le trobar entre contrainte et transgression." In 114, Les genres, 2010, pp. 17-23. [Analysis of the processes behind the creation and evolution of genres from Guilhem de Peitieus on; Gourc sees the poetry's function as establishing a social and psychological bond among members of the courtly audience; genre rules evolved to provide a framework to orient the audience quickly and encourage participation in the performance; the polymorphic state of the earliest poems quickly developed into a set of relatively fixed genres, which nonetheless remained flexible and open to mixing.]

452.

Paden, William D. "The System of Genres in Troubadour Lyric.” In $>\mathbf{1 2 0}$, Medieval Lyric, 2000, pp. 21-67. [The early poets did not make clear genre distinctions; these only appeared with the poetic treatises, systematically from the second half of the thirteenth century, after most of the "classical" works had been composed; we must recognize the constantly evolving, dynamic sense of genre throughout the troubadour tradition; the canso dominated until ca. 1220, when it was largely supplanted by the cobla and sirventes; the cobla has about the same number of texts as the sirventes but has been relatively neglected; pp. 44-57: analysis of a poem by Azalais de Porcairagues in the light of her use or awareness of genre "definitions"; edition of all three versions of the poem, with detailed notes.] 
453.

Pickens, Rupert T. “The Old Occitan Arts of Poetry and the Early Troubadour Lyric.” In 120, Medieval Lyric, 2000, pp. 209-41. [Exploration of the confused use of genre designations among the early troubadours and the many contradictions and exaggerated distinctions in the later poetic treatises; modern scholars must beware of applying modern concepts back onto the early period.]

454.

Rieger, Dietmar. "Norm und Störung. Zum Verhältnis lyrischer und narrativer Verfahren in der mittelalterlichen Lieddichtung Frankreichs." In Lyrische Narrationen, narrative Lyrik: Gattungsinterferenzen in der mittelalterlichen Literatur. Edited by Hartmut Bleumer and Caroline Emmelius. Berlin: De Gruyter, 2011, pp. 103-20. [The change in generic usage around the turn of the thirteenth century was caused by a new emphasis on present reality as opposed to past nostalgia or future idealization; dramatic and narrative features, including dialogue, realism, and frank sexuality were featured in the alba and pastorela and in themes such as the mala domna poems and obscene parodies.]

455.

See 2910, Vatteroni, "La fortuna," 2004. [Comparison of two songs by Marcabru and Raimon Escrivan shows that the genres of pastorela, tenso, and fictive tenso are variable and open; and cross-genre interference can touch on structure, vocabulary, and content.]

456.

Wunderli, Peter. "Réflexions sur le système des genres lyriques en ancien occitan." In 151, Mélanges Bec, 1991, pp. 599-615. [Reinterpretation of the notion of genre from the perspective of structural semantics based on content and register, and fixed synchronically at the end of the twelfth century; relational charts are constructed for the various genres by means of binary oppositions.]

\subsection{Canso}

[The quintessence of the troubadour lyric form, based on the notion of finamor, stressing originality of form and content; the ideal sought is not so much passion

but the exaltation of the soul (joi), to be achieved through striving for love, as well as for moral and literary perfection; see also 471-77: the mala canso (and the mala domnalmala femna, comjat, camjar, escondig), for variations on the classic form of the genre.

457.

Bec, Pierre. "La canson." Europe. Revue littéraire mensuelle 86 (2008): 76-87. [A rich and nuanced analysis of troubadour poetry; basic metric structures and their terminology; analysis of medieval lyricism and its dynamics, as contrasted with modern poetic assumptions; explains how poems may be linked intertextually by a series of dialectic resonances in words, in melody, in content: motz, so, razo; analysis of content: the notion of finamor and its paradoxes, ambiguity, and subtle variations.] 
458.

Blakeslee, Merritt R. "Apostrophe, Dialogue, and the Generic Conventions of the Troubadour Canso." In 104, Spirit of the Court, 1985, pp. 41-51. [Generic identity depends on a stable "deep structure" combined with a small number of variables that allow for innovation; one basic principle of the canso is the absence of the domna: the poem is not a dialogue between lover and lady but an apostrophe directed to her by the poet; the domna remains absent and, thus, ineffable.]

459.

Gambino, Francesca. "Segon lo vers del novel chan: piccola ricognizione su alcune accezioni romanze dei derivati di versus." Rom 128 (2010): 501-12. [Covers the history of Latin versus and its evolution in the Romance languages; its use in the Abbey of St. Martial de Limoges gives a precedent for the meaning "melody"; the development of a new melodic form here at the turn of the eleventh century, featuring rhymes, syllabic count, and stanzaic structure, is referred to by Guilhem as a "new style" that he is anxious to use.]

460.

Ghil, Eliza Miruna. "Topic and Tropeic: Two Types of Syntagmic Development in the Old Provençal Canso." L'Esprit Créateur 19 (1979): 54-69. [Instead of plan/clus, distinguishes two categories of canso based on the use or avoidance of poetic clichés oriented toward listener/reader response; "topic development" is illustrated by analysis of Bernart de Ventadorn's Non es meravelha and "tropeic development" by a study of Raimbaut d'Aurenga's Ar resplan la flors enversa; the two poles of poetic practice govern the infinite variability of individual cansos.]

461.

Köhler, Erich. "Zum Verhältnis von vers und canso bei den Trobadors." In 141, Études Jules Horrent, 1980, pp. 205-11. [Though indistinguishable from the canso among the early troubadours, the vers evolved after 1250 into a moralizing didactic genre.]

\subsection{Sirventes}

[About five hundred are extant; the metrical form was often borrowed from that of well-known cansos (melodic contrafacture), so that they could be sung to the same melody; may be classified as personal, moral, or historical, depending on their subject matter; "personal" sirventes are satirical, caustic, mocking, insolent, even crude or obscene and include the malas cansos 471-77; "moral" sirventes denounce the errors of society and destiny; "historical" sirventes attack political figures, urge the

participation of lords in crusades or wars; the Albigensian Crusade called forth many sirventes of protest against the French.]

\section{2.}

Léglu, Catherine. "Moral and Satirical Poetry." In 282, Troubadours, 1999, pp. 47-65. [Overview of the complex interplay of genres, mostly sirventes, that deal with moral and social issues, political comment, satire, and personal invective; special attention is given to the works of Marcabru, Bertran de Born, Guillem de Berguedan, and Peire Cardenal.] 
463.

See 309, Aurell, "Les troubadours," 1997, pp. 25-36. [Analysis of political engagement by the troubadours in the thirteenth century; the theatricality of the sirventes made it responsive to the audience and suitable for use by political leaders to influence public opinion and stir up enthusiasm for their campaigns; three typical sirventes are studied in detail as examples of the art.]

464.

Di Luca, Paolo. "Sirventesca: le sirventés parodié.” RLaR 112 (2008): 405-34. [Wideranging study of a group of innovative poems from the later thirteenth century, characterized by innovation in metrics, register, and genre; explores various rare types of burlesque parody of the canso tradition: peguesca "song of the fool," gelosesca "song of the jealous one," saumesca "song of the donkey"; study of two quite dissimilar sirventescas, by Bernart de Rovenac PC 66,4, and Peire Basc PC 327,1; concludes that the mixing of folk traditions and unpolished metrics with the classical themes and forms seems to have been an attempt to break out of the confining limitations of the standard poetic rules.]

465.

Gouiran, Gérard. "Un genre à la jonction de l'histoire et de la littérature: les sirventès (à partir de textes de Bertran de Born).” In Histoire et littérature au moyen âge: Actes du colloque du centre d'études médiévales de l'Universite de Picardie, Amiens, 20-24 mars 1985. Göppingen: Kümmerle, 1991, pp. 129-41. [Examines the role played by the sirventes in public life, especially those of Bertran de Born; poems circulated widely to furnish news of local wars, often referred to by other poets; they may illuminate obscure historical events or broaden our knowledge of social history and ideologies.] 466.

Léglu, Catherine. "Defamation in the Troubadour sirventes: Legislation and Lyric Poetry." MAev 66 (1997): 28-41. [Investigation of the legal status of slander in medieval society; serious attacks on honor and reputation are examined in poems of Guilhem de Berguedan and Peire Cardenal, who accuse public figures of treachery, homosexuality, deformity, and impotence in legalistic terms that would fit the definition of slander.

467.

Léglu, Catherine. Between Sequence and Sirventes: Aspects of Parody in the Troubadour Lyric. Oxford: Legenda/European Humanities Research Centre of the University of Oxford, 2000. [Parody and self-parody are characteristic of troubadour poetry from the beginning; finds a parodic relation between Latin sequences and certain Occitan sirventes; parody often leads to obscenity and sexual innuendo; many examples and commentaries on poems by Peire Cardenal.]

468.

Rieger, Dietmar. Gattungen und Gattungsbezeichnungen der Trobadorlyrik. Untersuchungen zum altprovenzalischen Sirventes. Tübingen: Niemeyer, 1976. [Deals with the alba, the planh, and the mala canso, in addition to its main focus on the sirventes, whose etymology he postulates from the Old French serventois, indicating the servant 
function of the poet to his lord; traces the history of the genre as it evolves in relation to surrounding genres; proposes that the generic name mala canso be applied to the comjat and camjar as well as to any poems involving a mala domna.]

469.

See 227, Riquer, 1975, 1:53-59; 3:1590-1600. [A cycle of sirventes from 1285 that seems to have made a direct political impact.]

470.

Thiolier-Méjean, Suzanne. La poétique des troubadours: trois études sur le sirventès. Paris: Presses de l'Université Paris-Sorbonne, 1994. [Three loosely organized explorations of the use of language and themes in the sirventes; one is centered on vocabulary and figures of speech, featuring the analysis of word-creation by Marcoat, Raimbaut d'Aurenga, and others; the second is a study of the enueg and plazer as examples of liberation from the constraints of poetic rules, using a poem by Peire Cardenal, PC $335,14 \mathrm{a}$, as example; the third seeks to understand the value that the troubadours placed on their own work, based on a study of the words pretz, valor, and lauzor.]

\subsubsection{Mala Canso}

[A variation of the sirventes, in which the lady is accused of betraying the code of finamor; related to the comjat, camjar, and escondig; also the theme of the mala domnalfemna.]

471.

Archer, Robert, and Isabel de Riquer. Contra las mujeres: poemas médiévales de rechazo y vituperio. Barcelona: Quaderns Crema, 1998. [Anthology of thirteen Occitan malas cansos and twenty-nine Catalan maldits, with translation into modern Catalan; introduction, pp. 13-103, covers the short-lived outburst of the negative genre among the troubadours at the turn of the twelfth and thirteenth centuries, and its continuation among Catalan poets into the fifteenth, with an analysis of the social and literary aspects of the phenomenon.]

472.

Leube-Fey, Christiane. Bild und Funktion der Dompna in der Lyrik des Trobadors. Heidelberg: Winter, 1971. [Study of the presentation of the female figure from classical to modern times; pp. 27-38: the image of the lady in several major Occitan poets; pp. 50-59: a study of the adjectives, figures, and topoi that are used to describe her; pp. 74-106: study of the figure of the mala domna, followed by a short outline of the escondig genre, in which the poet excuses and justifies himself for rumored disloyalty; pp. 107-23: the female figure in the salut d'amors and the pastorela.]

473.

See 468, D. Rieger, Gattungen, 1976, pp. 303-18. [Chapter D: "Bona canso-mala canso: zum Abschiedslied der altprovenzalischen Lyrik."]

474.

See 3030, Poe, "Unravelling," 1990. [This is a very unflattering depiction of a mala domna.] 
475.

See 890, A. Rieger, "La mala canso de Gui d'Ussel," 1992. [Study of a network of poems critical of ladies, centered on Gui d'Ussel's Si be.m partetz, mala domna, de vos PC 194,19, involving Maria de Ventadorn, Raimbaut de Vaqueiras, and others.]

\section{6.}

Riquer, Isabel de. "Amor (motivo da mala cansó)." Parola del testo 8, no. 2 (2004): 333-48. (Studi in onore di Giuseppe E. Sansone). [Comparative study of the mala canso in Galician and Occitan poetry; pp. 336-40: listing, with examples, of eight thematic characteristics of the subgenre from eleven Occitan poems.]

477.

Winter-Hosman, Mièke de. "Un texte peut en cacher un autre: intertextualité chez quelques troubadours autour de 1200.” In \$9, AIEO 6, 2001, pp. 348-54. [Folquet de Marselha's S'al cor plagues PC 155,18 is used as an intertextual model by Gaucelm Faidit PC 167,39 and by Peire de Barjac; these and another by Gaucelm make a closely knit series of malas cansos that turn against fin'amors and denigrate the mala domna; Gui d'Ussel PC 194,19, Raimbaut de Vaqueiras, and a partimen between Maria de Ventadorn and Gui d'Ussel are also involved; see also $\$$ 890, A. Rieger, "La mala canso de Gui d'Ussel," 1992.]

\subsection{Tenso, Partimen}

[A debate poem whose participants alternate from stanza to stanza. Some are real, representing an actual exchange between two poets, some are fictive, written by one poet (one has God as interlocutor, another a horse; another is a dialogue between two war machines). The partimen or joc-partit is similar, but the terms are more rigid: one poet sets the topic to be debated, the opponent chooses one side and the rival must support the other; an exchange of coblas or even of sirventes may use the same dialogic structure.]

478.

See 256, Harvey and Paterson, Troubadour "Tensos," 2010. [Critical edition of the corpus of 155 tensos and partimens, out of the total corpus of 173, with introduction, facing-page English translation, notes, and glossary; poems excluded from the edition (exchanges of coblas, fictive debates and those involving an anonymous participant) will be published on Rialto at http://www.rialto.unina.it.]

479.

See 250, Bonnarel, Les 194 chansons, 1981. [Popular anthology of 194 dialogue songs, with texts in modern Occitan spelling, no translation; the texts are adapted to the editor's modern Languedocian dialect; songs are arranged by content, on a continuum from those purely about love, to social criticism, to sirventes.]

480.

Marshall, John H. "Dialogues of the Dead: Two tensos of Pseudo-Bernart de Ventadorn." In 163, Troubadours and the Epic, 1987, pp. 37-58. [Believes that some tensos and partimens may be fictitious, pretending to be debates between well-known troubadours; new critical edition of a tenso between Peirol and fictional Bernart de 
Ventadorn PC 70,32 = 366,23, and another between Bernart and Gaucelm, PC 52,3 $=165,2$, with critical notes and English translation.]

481.

Paterson, Linda. "Les tensons et partimens." Europe. Revue littéraire mensuelle 86 (950951) (2008): 102-14. [Nonspecialist introduction with definitions and numerous examples; stresses the genre's dependence on oral performance and its wealth of social, erotic, or capricious subject matter; poses unresolved questions: were they improvised or performed as set pieces? why is music not preserved? how dramatic were the performances?]

482.

Fèvre, Mavis. "A 'Game of Words': Why Were 'Insult Tensos' Performed in Occitan Courts?" Neo 94 (2010): 209-24. [Four works are examined in order to clarify the nature and purpose of these aggressive exchanges between nobles and joglars: two tensos between Bona-Fe and Blacatz, another between Gui de Cavaillon and Falco, a fourth between Bertran de Gordon and Peire Raimon de Toulouse; insults may have been part of the performance tradition, mere entertainment not meant to be taken seriously, but may also have been part of a ceremonial competition, channeling inherent violence, or instigated by enemies of the noble participant; see also $\mathbf{5 8 9}$, Léglu, "Reading," 1996, who hints that some exchanges may be elaborate gameplaying; also

- 2879, Paterson, "Insultes," 2009, who calls PC 15,1 "a performance piece, not a serious fight."]

483.

Harvey, Ruth. "La voix dans les pièces dialoguées: à propos du partimen PC 185,2 = 457,24." In 101, AIEO 8, 2009, 1:237-49. [Explains the difficulty of identifying the speakers in many of the dialogue poems; close analysis of this partimen leads to a probable attribution to Savaric de Mauleon, with either Uc de Saint Circ or Uc de la Bacalaria as respondent, and a likely second performance of the poem from the court of Aragon, in which an unknown Certan takes the place of Savaric; edition of the text, with English translation; full critical edition in 256, Harvey and Paterson, Troubadour "Tensos," 2010, 2:427-35, with the same text and translation, but the respondent now seen as probably Uc de Saint Circ.]

484.

Paterson, Linda M. "Jeux poétiques et communication de valeurs: les tensos et partimens des troubadours." In 109, Comunicazione e propaganda, 2007, pp. 515-28. [Argues that a few tensos were used to propagate political messages, but their interest lies more in the insight they provide into the everyday social preoccupations of the poets and their courtly audiences; a list of 172 questions posed at the opening of the poems illustrates the nature of these preoccupations: courtship, sex, marriage, reputation, money, chivalry, religion, politics, philosophy; see a similar list in $\mathbf{2 5 6}$, Harvey and Paterson, Troubadour "Tensos," 2010, 1:xxxii-xxxix.]

485.

Bec, Pierre. La joute poétique: de la tenson médiévale aux débats chantés traditionnels. Paris: Les Belles Lettres, 2000. [History of scholarship on the tenso/partimen; shows 
that the nature of the tenso is based on the dynamic of opposition, rivalry, antagonism; the generic boundaries between tenso and joc-partit, partimen, torneiamen are indistinct (even the pastorela can take the form of a tenso); the tenso is flexible in content, the partimen is not; exchanges of coblas or sirventes partake of the tenso format as well.]

\section{6.}

Billy, Dominique. "Pour une réhabilitation de la terminologie des troubadours: tenson, partimen et expressions synonymes." In 113, Il genere tenzone, 1999, pp. 237-313. [Tenso is the overall term used for a dialogue poem; joc partit, partimen, and a number of other terms are used, sometimes for more specific poetic forms, often interchangeably with tenso; full exploration and analysis of terms used in the chansonniers and within the poems; partimen is sometimes applied to the alternative side of the argument; neither tenso nor partimen were clearly names of genres until after the Leys d'amors; an appendix describes the tenso sections of the chansonniers.]

487.

Cropp, Glynnis M. “The partimen between Folquet de Marseille and Tostemps." In The Interpretation of Medieval Lyric Poetry. Edited by W. T. H. Jackson. New York: Columbia University Press, 1980, pp. 91-112. [Detailed study of manuscripts, poets, genre, and versification; analysis of PC 155,24 = 444,1 as a polished courtly game; uses Stronski's text, with a few corrections; Tostemps is a senhal, perhaps to be identified as Raimon de Miraval.]

488.

Rieger, Dietmar. "La tenson." In 312, GRLMA, vol. 2, book 1, fascicle 7. Heidelberg: Winter, 1990, pp. 433-52. [This is the "partie documentaire," which complements the "partie historique" presented by Erich Köhler in 1979, pp. 1-15; listing by PC number of all tensos (as opposed to partimens /jeu-partis, which are listed separately under "jeu-parti," pp. 453-84) corresponding to the historical outline by Erich Köhler 1979, pp. 16-32; a useful catalogue raisonné of tensos attesting the continued vitality of the term tenso fictive.]

489.

Rosenstein, Roy. "Fictitious tenso: Authentic Genre?” In L'Offrande du Coeur: Medieval and Early Modern Studies in Honour of Glynnis Cropp. Edited by Margaret Burrell and Judith Grant. Christchurch: Canterbury University Press, 2004, pp. 96-107. [A plea to study all tensos as "genuine poetry" worthy of a place in the lengthy tenso tradition and not to dismiss or shortchange them as frivolous entertainment.]

490.

Zufferey, François. "Tensons réelles et tensons fictives au sein de la littérature provençale." In 113, Il genere tenzone, 1999, pp. 315-28. [Some tensos are obviously fictive, but often it is difficult to tell; listings for twenty-one that are clearly so (there are no fictive partimens); close study of PC 32,1 by Arnaut Plages, which is unusual in form, a canso but with inner dialogic structure between the heart and the mind; there is no feminine interlocutor, and the poem must be removed from the trobairitz corpus; Zufferey doubts the reality of Alamanda and laments the polarized scholarship 
concerning the reality of some trobairitz, pitting misogynist denial against feminist all-inclusion.]

\subsection{Pastorela}

[A "popularizing" genre practiced in courtly circles (about thirty are extant in Occitan).]

491.

Bertolucci Pizzorusso, Valeria. "Guiraut Riquier e il genere della pastorella." In - 162, Trobadors a la Península Ibèrica, 2006, pp. 121-33. [Reviews recent scholarly activity in the study of Guiraut; identifies a series of six dated pastorelas forming a cycle over a period of twenty-two years; argues that the evolution of Guiraut's poem cycle shows moral progression, leading to his conclusion that the only true motivation for poetry is the praise of God and Virgin.]

\section{2.}

Cepraga, Dan Octavian. "Sistema dei generi lirici e dinamiche compilative: la posizione della pastorella nei canzonieri occitanici." CDT 3, no. 3 (2000): 827-70. [Study of the place of pastorelas in the chansonniers leads to a revised history of the pastorela and its distinction from the canso.]

\section{3.}

Franchi, Claudio. Trobei pastora. Studio sulle pastorelle occitane. Alessandria: Edizioni dell'Orso, 2006. [The pastorela's status as a minor genre allows for the study of subjective relationships difficult to conduct in the major genres; history of studies in the area; considers the main characteristics of the genre, the arrangement of pastorelas in the manuscripts, metrical form and the role of masculine and feminine protagonists, as well as the importance of the narrator; this volume of analysis is accompanied by a separate anthology of all thirty-eight poems: Pastorelle occitane. Alessandria: Edizioni dell'Orso, 2006.]

\section{4.}

Paden, William D. The Medieval Pastourelle. 2 vols. New York: Garland, 1987. [Texts of twenty-five Occitan pastorelas by fifteen poets, including the six by Guiraut Riquier, with English translation, succinct textual notes.]

495.

Paden, William D. "New Thoughts on an Old Genre: The pastorela," Romance Languages Annual 10 (1999): 111-16. [Iconographic and literary study of the shepherdess figure in the pastorela shows that Marcabru may have taken the concept from biblical/religious traditions rather than from a nonexistent real social type.]

\subsection{Alba}

[A lyric song lamenting the separation of lovers at dawn; the definition of the genre is controversial; about eighteen are extant, thirteen of which are attributed to named poets; two have an extant melody.]

496.

Bauer, Franck. "L'aube et la nuit." RLaR 110 (2006): 291-327. [Explores the 
traditional distinctions between religious and profane albas, between positive and negative attitudes toward the night, between differing perspectives toward time; the genre is largely indeterminate, unstable, and filled with paradoxes; a detailed look at three albas shows that the interference between sacred and profane is most evident in Giraut de Bornelh's Reis glorios, suggesting that the poem may have been of religious inspiration; the mixed register of the alba is a characteristic: it is a plastic genre, impossible to define closely.]

497.

Bauer, Franck. "Ironie de l'aube?" RLaR 112.2 (2008): 321-71. [Exploration of the presence of irony in the albas, which are very different from cansos in that they take place in urgently present time, the poet and the lover are not usually the same voice, and the lover is satisfied rather than perpetually seeking an impossible love; analysis of PC 461,3 Ab la gensor que sia, linked by intertextual irony with earlier albas by Giraut de Bornelh, Cadenet, and Bertran d'Alamanon; echoes from one to the other suggest that irony and parody were present in all of them; see also $>$ 511, Poe, "Lighter Side," 1985, who first pointed out the parodic nature of the anonymous poem.]

498.

Bernard, Katy. "La voix de la dame dans la chanson d'aube occitane profane: de la lyrique à la narration." In En un vergier: Mélanges offerts à Marie-Françoise Notz. Edited by Joëlle Ducos and Guy Latry. Bordeaux: Presses universitaires de Bordeaux, 2009, pp. 135-59. [Demonstrates that the feminine voice is present in four albas, in contrast to its absence in the masculineoriented cansos; her voice expresses the perfect, sensual moments of love, as though it might be prolonged; she is conscious of her body and her power, and her voice leads into the active feminine voice and presence in Occitan narratives.]

499.

Billy, Dominique. "Le traitement théorique de l'alba dans la Doctrina de compondre dictats et la question de l'alborada." RLaR 113 (2009): 195-214. [Discussion of Chaguinian's claim that in the Doctrina the traditional alba de séparation is called a gayta and what is called an alba refers to the Spanish genre alborada (aubade); questions Chaguinian's explanation of why the anonymous writer would have chosen gayta instead of the firmly traditional designation of the genre.]

500.

Billy, Dominique. "Les mutations de l'alba dans la poésie des troubadours." CRMH: Cahiers de recherches médiévales et humanistes 18 (2009), mis en ligne le 15 décembre 2012. URL http://crm.revues.org //11699. [The corpus of the albas supplies data that allow Billy to propose a historical outline of the genre through the question of "designation" as well as the specific contributions of Guiraut Riquier and the structure of the poems that have survived.]

501.

Billy, Dominique. "Nouvelles perspectives sur l'alba." CCM 53.4 (2010): 355-77. [Suggests the need for a new typology for the alba, which was developed as an original 
genre by the Occitan poets as part of courtly poetic expression; argues that it may have taken some of its formal aspects from popular poetry, such as the refrain, but in subject matter it is entirely courtly.]

502.

Chaguinian, Christophe. Les albas occitanes. Transcription musicale et étude des mélodies par John Haines. Paris: Champion, 2008. [Edition and study of nineteen albas, with French translation, notes; the same corpus as that of Riquer 1944; see suggestions by Castano, CN 69 (2009): 233-39.]

503.

Chaguinian, Christophe. "Alba et gayta: deux définitions à problème de la Doctrina de compondre dictats et leur possible solution." Rom 123 (2007): 46-68. [Claims that in the Doctrina the traditional alba ("de séparation") is called a gayta and what is called an alba refers to the Spanish genre alborada ("aubade"); see detailed commentary by Dominique Billy, RLaR 113 (2009): 195-214, who questions Chaguinian's explanation; the problem of why the anonymous writer would have chosen gayta instead of alba is taken up again in 502, Chaguinian, Les albas, 2008, pp. 25-34.] 504.

Cherchi, Paolo. "Filologia d'autorità." CDT 8 (2005): 861-88. [Compares metrical and syntactical structures of Giraut de Bornelh's Reis glorios and Cadenet's S'anc fui belha ni prezada, along with their melodies, to show that such lyrics may be reelaborations of older structural models; comparison with a number of liturgical chants indicates that our notions of the popular origins of the alba may need to be reconsidered.] 505.

De Conca, Massimiliano. "Le albas ses titol del ms. C (BNF f. fr. 856)." Available only in a shortened version, 2003. Online at http://www.arnaut.org; see "Premessa alle albas anonime di C (461.3, 113 e 203)" [Report on preparatory research for a revision and publication of the corpus of the albas: definition of the genre, literary and material tradition, and ecdotic revision of all texts; see study of corpus by Rossell, - 514, "So d'alba."]

506.

Fuente Cornejo, Toribio. "Canción de alba provenzal.” In Actas del XXIII Congreso internacional de lingü.stica y filología románica. Edited by Fernando Sánchez Miret. Vol. 4, 2003, pp. 317-31. [Study of the complex mixing of registers and genres in the evolution of the alba as a popular and refined lyric form; distinguishes three types of alba: regular, inverse, and religious, with analysis of overlap and interference.]

507.

See 253, Gouiran, "Et ades sera l'alba," 2005. [Definition of the alba as different from the canso; anthology of twenty-two albas, showing the variety of poems in religious, profane, mocking, tragic, or parodic mode.]

508.

Gouiran, Gérard. "Solitude de l'alba." In 158, Studi Bertolucci Pizzorusso, 2006, 2:1105-37. [Analysis of the anonymous poem En un vergier sotz fuelha d'albespi (PC 461,113), along with reminiscences and echoes from a number of other albas; 
captures the feeling of unreality of the poem, which may be the song of the lady or the narrator re-creating a dream or a vague memory.]

509.

Malm, Ulf. "Ades sera l'alba: Structure and Composition in the alba, aube and Tageliet." Studia neophilologica 67 (1995): 75-97. [Exploration of the qualities of dawn songs with a view to clarifying the structural properties and the functions of the lady, the lover, the watchman, and the lauzengiers; analysis of a number of Occitan albas, German Tagelieder, and French aubes.]

510.

Poe, Elizabeth Wilson. "The Three Modalities of the Old Provençal Dawn Song." RPh 37 (1983-4): 259-72. [Building on previous work by Bec, Poe extends the structural analysis of the alba to all eighteen poems, adding two subgenres (counteralbas and religious albas) to the category of true albas, finding similarities and contrasts that link them closely.]

511.

Poe, Elizabeth W. "The Lighter Side of the alba: Ab la genser que sia." Romanistisches Jahrbuch 36 (1985): 87-103. [PC 461,3 is a parody of the alba genre, a comic response to Giraut de Bornelh's Reis glorios, perhaps composed by the scribe of MS C; see also 516, Sigal, "Reis glorios," 1989.]

\section{2.}

Poe, Elizabeth Wilson. "La transmission de l'alba en ancien provençal." CCM 31 (1988): 323-45. [Studies the presence of the albas in the chansonniers, particularly in $C$ and $R$, and their absence from Italian manuscripts; postulates the existence of an alba collection, now lost, from which $C$ and $R$ drew their material; the genre was briefly very popular in Provence and Languedoc but not among poets of the Toulouse School.]

\section{3.}

Riquer, Isabel de. "Alba trobadoresca inedita." In 160, Studia Riquer, 1986-91, pp. 595-601. [Edition of a newly discovered alba to add to the corpus, with Spanish translation; the author was an anonymous Catalan poet, and the poem has structural similarities to the anonymous PC 461,25a, Eras dirai ço que.us dei dire, edited in - 253, Gouiran, "Et ades sera l'alba," 2005, pp. 74-79.]

\section{4.}

Rossell, Antoni. "So d'alba." In 160, Studia Riquer, 1986-91, pp. 705-21. [Comparison of melodies of Ave maris stella, albas by Giraut de Bornelh, Cadenet, and Alfonso X indicate a close relationship of the "alba music" (so d'alba) with religious traditions; list of nineteen albas, with their metrical structure.]

\section{5.}

Sigal, Gale. "The Poetics of Dismemberment: Eros and Identity in the alba." Tenso 5 (1989-90): 133-52. [Freudian interpretation of the antisocial nature of love in the $a l b a$, in which the lovers isolate themselves in union against hostile forces and learn about their own individuality by defying social norms; their parting at dawn is seen as a tearing apart not only of the couple but also of the individual selves.] 
516.

Sigal, Gale. "Reis glorios: An Inverted alba?” Medieval Perspectives 4-5 (1989-90): 185-95. [Giraut's poem speaks more explicitly to the bond between the two male companions than to that of the two lovers; the companion implores God's aid in spite of his friend's sin; Sigal makes the point that there is no standard alba: each one is exceptional.]

517.

Sigal, Gale. "The Alba Lady, Sex Roles and Social Roles: Who Peyntede the Leon, Tel me Who?" In The Rhetorical Poetics of the Middle Ages: Reconstructive Polyphony: Essays in Honor of Robert O. Payne. Edited by John M. Hill and Deborah SinnreichLevi. Madison, NJ: Fairleigh Dickinson University Press, 2000, pp. 221-40. [Some scholars have depicted women in the alba as powerless and passive, as in the canso, but Sigal sees women as active participants in a fulfilling mutual love; she argues that alba-love is not gender-specific; see also Sigal's "Alba Lady," in 46, Women in the Middle Ages, 2004, pp. 16-20.]

518.

Zufferey, François. "L'aube de Cadenet à la lumière de Giraut de Borneil." CN 70 (2010): 221-76. [A searching reevaluation of the typical structures of the alba, applied first to a critical appraisal of all six existing editions of Cadenet's poem PC 106,14 , all found to be seriously wanting, followed by a new edition and interpretation, with French translation and copious notes; a similar study of structure and interpretation in Giraut de Bornelh's Reis glorios confirms the authenticity of the final stanza, essential to the poem's meaning; further penetrating remarks about the other seven albas may lead to a fuller appreciation of the fine subtleties of the whole corpus.]

\subsection{Salut d'amor}

[A love letter in rhyming couplets; up to twenty-seven are extant (as few as nineteen according to more prudent scholars); not listed by Pillet/Carstens, Frank, Distilo, etc., because they do not have strophic structure and are not considered to be "lyric," even though they are similar to cansos in themes, vocabulary, etc.; Monson thinks they are "foncièrement lyrique," not didactic; Poe thinks they are lyric in genre, narrative in topos.]

519.

Solla, Beatrice. "I salutz del canzoniere provenzale L." In Actes du colloque Nouvelle recherché en domaine occitan: approches interdisciplinaires (Albi, 11-12 juin 2009). Turnhout: Brepols, 2012, in press. [Description of the small pocket-sized manuscript containing a variety of genres, characterized by the mixing of courtly and didactic, lyric and narrative texts; more detailed presentation of three salutz: Cel cui uos etz al cor plus pres (PC 30,I by Arnaut de Maruelh), Domna genser q'eu no sai dir (PC 30,III by Arnaut de Maruelh), and Bella domna gaja e ualentz (PC 457, I perhaps by Uc de Saint Circ).] 
520.

Gambino, Francesca, et al. "Salutz d'amor." Edizione critica del corpus occitanico. Rome: Salerno, 2009. [Detailed introduction, report of recent research and paleographical study by Speranza Cerullo, pp. 795-822; all twenty-seven poems proposed by recent criticism are included here, even dubious ones, in order to avoid omitting any; individual poems are edited by Gambino, Ilaria Zamuner, and eleven other editors, all with commentary, notes, and Italian translation. Seven are listed by PC as lyric poems, others are listed following the lyrics of individual poets, with special numbering by Roman numeral instead of Arabic; fifteen are by named poets, twelve anonymous; the salutz are narrative in form, in octosyllabic couplets, but occasionally in strophic form.]

521.

See 2845, Carapezza, "Raimbaut travestito," 2001. [New edition and study confirms attribution to Raimbaut d'Aurenga; the poem shows direct intertextual influence of Ovid on the creation of the Old Occitan salut; includes a rich bibliography on the history and nature of the salut.]

522.

Cerullo, Speranza. "Lirica e non-lirica nella poesia dei trovatori: intersezioni generiche e metrico-formali tra salut e canso." In 118, La lirica romanza, 2009, pp. 155-74. [Argues that the genres are distinct in most cases: the canso is inherently musical, depending on stanza-form; the salut has a nonstanza "narrative" form and typical favorite topoi; but there are mixed forms and experimentations; some poets seem to play with the creation of a hybrid form (Falquet de Romans, Rambertino Buvalleli), but they do not seem to have succeeded; lyric or non-lyric?- there is no consensus yet.]

523.

Di Girolamo, Costanzo. "Madonna mia: Una riflessione sui salutz e una nota per Giacomo da Lentini." CN 66 (2006): 411-23. [Tries to loosen the definition of the genre; brief review of recent scholarship on the salut: wonders whether its origin is as an insertion within a narrative text; the question of genre is still open (lyric or didactic?); urges flexibility in fixing the generic norms for themes as well as metrics.] 524.

Gambino, Francesca. "Forme e generi in contatto: A Deu coman vos el vostre ric preç." In 100, AIEO 7, 2003, pp. 343-62. [Study and critical edition of PC 461,7, whose genre is difficult to define; she doubts whether it is a salut, but she has included it in her edition of the saluts: see 520, Salutz, 2009: "Presentazione," p. 14.]

525.

Giannini, Gabriele. "Une ébauche méconnue de salut occitan et le noeud ovidien Eneas-Cligés en Italie." In 102, AIEO 9, 2011, pp. 383-94. [Analysis of the fragment of a probable salut at the end of MS Pluteus 41.44 (Florence, Laurenziana) containing the Roman d'Eneas; shows that it is a carelessly transcribed text from the mid-thirteenth century, with several motifs that are typical of the salut; further study will be required to clarify the complex interconnections that link this Occitan text, 
Latin love epistles, the Novas del papagai, and the French romances Eneas and Cliges.] 526.

Leube (-Fey), Christiane. "Salut d'amor." In 312, GRLMA, vol. 2, book 1, fascicle 5, 1979, pp. 77-87. [Discusses the corpus of nineteen poems and their characteristic themes and structures, but admits that the genre is difficult to define; in many cases it is close to the canso.]

527.

Poe, Elizabeth Wilson. "Another salut d'amor? Another trobairitz? In Defense of Tanz salutz et tantas amors." ZrP 106 (1990): 314-37. [Argues for the status of PC 42a as a salut d'amor; examines the probability that it was composed by the trobairitz Azalais d'Altier or alternatively by Uc de Saint Circ; text in appendix, with notes, no translation; see also Poe, "Un poème marginal," in \$ 95, AIEO 2, 1993, 1:283-88.]

528.

Poe, Elizabeth W. "Marie de France et le salut d'amour." Rom 124 (2006): 301-23. [The saluts d'amor were known earlier than thought; Bernart de Ventadorn refers to them, though none of his is preserved; the genre goes back to Ovid's Heroïdes; it is at once a lyric genre and a narrative topos; see response by Di Girolamo in CN 67 (2007): 161-65.]

529.

Uulders, Hedzer. "Le salut occitan: du genre dialogué à un dialogue de genres." Modern Language Notes 122 (2007): 848-74. [The hybrid combination of genres complicates the study of the salut and makes it impossible to agree upon a definitive corpus; in Uulders's view, one of the principal characteristics is its dialogic structure; the lover and his domna are in communication, though she does not speak; the lover has a destination, whereas in the canso he does not; the salut is halfway between the canso and the narrative, in effect instituting a dialogue between literary genres; Uulders is undertaking further study of the salut in Old French: see Estudis Romànics 31 (2009), 77.]

530.

Uulders, Hedzer. Salutz e amors: la lettre d'amour dans la poésie des troubadours. Leuven: Peeters, 2011. [Outline of scholarship on the salut; defining the corpus; study of poetic technique; detailed analysis of Arnaut de Maruelh's Dona, genser qe no sai dir, pp. 49-94.]

\subsection{Sestina}

[A lyric form initiated by Arnaut Daniel, utilized by other troubadours, then by poets in Italy, Spain, and Portugal; characterized by lexical repetition instead of rhyme, in a fixed pattern; see 1965-81 for a listing of specialized studies of Arnaut Daniel's sestina.]

531.

Bec, Pierre. "La sextine de Pons Fabre d'Uzès: essai d'interprétation.” In Miscellanea mediaevalia. Mélanges offerts A Philippe Ménard. Edited by Alain Labbé, Danielle Quéruel, and Jean-Claude Faucon. Paris: Champion, 1998, pp. 91-100. [History of the precursors of the sestina and those who followed Arnaut Daniel, its creator: three 
other Occitan poets: Guilhem de Sant Gregori, Pons Fabre d'Uzès, and Bertolome Zorzi.]

532.

Billy, Dominique. "La sextine à la lumière de sa préhistoire: genèse d'une forme, genèse d'un genre." MR 18 (1993): 207-39 and 371-402. [Traces the precursors of Arnaut's "invention" in a very detailed geometrical study, in particular the experimentations with rhyme, refrain-words, permutation of rhymes, retrogradation, numerology, etc., in poets of his generation and earlier, then as further refined by Petrarch and Dante.]

533.

Billy, Dominique. "La sextine réinventée suivi d'un essai de métrique génétique." Stilistica e metrica italiana 4 (2004): 3-32. [Response to Canettieri's hypothesis that the metric form of the sestina may be based on the game of dice; there is no reference to dice in any of the poets concerned, nor in poetic treatises of the time; a review of scholarship on the functioning of the retrogradatio cruciata form and his own close analysis of sestinas by a number of poets leads Billy to conclude that Arnaut's point of departure was the technique of the coblas dissolutas reversed; new analysis of Arnaut's choice of rhyme-words.]

534.

Canettieri, Paolo. La sestina e il dado: sull'arte ludica del trobar. Rome: Colet, 1993. [Reviews the presence of gaming imagery in a number of troubadours; proposes that the metrical structure of Arnaut Daniel's sestina was inspired by the arrangement of numbers on the dice; the figure of gambling suggested by this structure represents the capricious influence of fate on human love and the poet's belief that love of the domna and love of poetry are analogous.]

535.

Lartigue, Pierre. L'Hélice d'écrire. La sextine. Architecture du verbe. Paris: Les BellesLettres, 1994. [History of the sestina in sweeping terms, from Ribérac through Italy, Europe, and America, with many examples; the metrical form is seen as "a Nautilusshaped helix that propels poets through the sea of language."]

536.

Pulsoni, Carlo. "Petrarca e la codificazione del genere sestina." In "La Sestina." AMod 2 (1996): 55-65. [Traces the steps of codification of the genre in the areas of form and metrics, as well as those of concepts and images, making the sestina into an autonomous genre in the hands of Petrarch; studies Arnaut's poem and those of five followers, who still considered the form to be a canso.]

537.

Roncaglia, Aurelio. "L'invenzione della sestina." Metrica 2 (1981): 3-41. [A very close study of the cultural background of Arnaut's time, the artistic forces that nourished the "invention" of the sestina: rhyme-words, retrograde structure, semantic density in Raimbaut d'Aurenga; Roncaglia finds resonances of Chrétien de Troyes (Perceval's oncle) and Béroul's Tristan (oncle, cambra, intra), suggesting that the "miracle" of Arnaut's sestina may have been inspired by a combination of the structural techniques of Raimbaut and the themes of Béroul.] 
538.

Dujardin, Lucien. The most recent permutation of the sestina is its graphic equivalent ("6-pictine”) invented by Dujardin: http://l.d.v.dujardin.pagesperso-orange.fr expo/ sextine/index.html.

\subsection{Planh}

[A type of sirventes to celebrate the memory of a famous person, friend, or lover; see a chronological table of forty-two planhs: http://www.en.wikipedia.org/wiki/Planh.] 539.

Yearley, Janthia. "A Bibliography of planctus in Latin, Provençal, French, German, English, Italian, Catalan, and Galician-Portuguese from the Time of Bede to the Early Fifteenth Century." Journal of the Plainsong and Mediaeval Music Society 4 (1981): 12-52. [Pp. 28-32: listing of fifty-two Occitan planhs, alphabetically by incipit, forty-seven lay and five religious; lists manuscripts, editions, and studies; extensive bibliography pp. 49-52.]

540.

Neumeister, Sebastian. "Car tant com dec no só passionat oder wie man den Tod der Geliebten wider Erwarten überlebt." In Abkehr von Schönheit und Ideal in der Liebeslyrik, für Peter Brockmeier zum 65. Geburtstag. Edited by Carolin Fischer and Carola Veit. Stuttgart: J. B. Metzler, 2000, pp. 66-78. [Sketches the reaction to the death of the beloved in six planhs by Ausiàs March and in two by Occitan poets: one by an anonymous trobairitz lamenting the death of her lover, and one by Bonifaci Calvo, who contemplates suicide but decides that living would be an even greater sacrifice to his beloved.]

541.

Pelosini, Raffaella. "Contraffazione e imitazione metrica nel genere del compianto funebre romanzo." In 122, Métriques du Moyen Âge, 1999, pp. 207-32. [Examines the flexible treatment of the planh in the Occitan treatises Doctrina de compondre dictats and Leys d'amors, which advise on themes, metrical form, and melody; contrafacts were relatively uncommon but grew more frequent with time, especially in Catalan, Old French, and Italian; points to the conscious use of a light and pleasing melody, to contrast with the tragic content and to assure acceptance of the song in performance.]

542.

See 2302, Pollina, "Word/Music," 1989, 3:1075-90. [Looks specifically at the planh for Richard Coeur-de-lion; musical features are used to draw attention to the text, particularly the word Richartz in line 6.]

543.

Riquer, Isabel de. "Los planhs por la (falsa) muerte de Jaufré." In $>139$, Ensi firent, 1996, 1:151-62. [The five planhs for the mistaken death of the romance hero follow the established traditions of the lyric genre, as documented here by analysis of formulaic elements and intertextual comparisons with regular planhs in Occitan, French, and Catalan literature.] 


\section{4.}

See 2223, Rossi, "Du nouveau sur Cercamon," 2000. [Critical edition of the planh by Cercamon, with French translation, copious notes, Latin planctus in appendix; this is the oldest planh, dated just after 9 April 1137; it is both planh and sirventes, because it is being manipulative politically as well as expressing genuine grief at Guilhem's death; comparison with the slightly later Latin planctus by Richard de Cluny: the Latin poem is stereotyped; the planh has more originality, containing social and moral criticisms of contemporary importance and revealing strategic aims of the poet, trying to arrange political alliances as well as encouraging the French king to fight the Saracens.]

\section{5.}

Scarpati, Oriana. "Mort es lo reis, morta es midonz. Une étude sur les planhs en langue d'oc des XIIe et XIIIe siècles." RLaR 114 (2010): 65-93. [Study of the typology of the genre: structure, themes; identification and listing of all forty-five Occitan planhs.]

\section{6.}

Schulze-Busacker, Elisabeth. "La complainte des morts dans la littérature occitane." In Le sentiment de la mort au moyen âge. Montréal: L'Aurore, 1979, pp. 228-48. [Outline of scholarly studies of the planh; typology of the genre; close analysis of two stylistic features: the declaration of death, and the expression of grief.]

\section{7.}

Shapiro, Marianne. "The Decline of Joi in the Provençal Planh." Kentucky Romance Quarterly 28 (1981): 351-69. [The evolution of the planh, studied principally through the texts of Bertran de Born, Gaucelm Faidit, Aimeric de Peguilhan, and Joan Esteve de Beziers.]

\section{8.}

Stäblein, Patricia Harris. "New Views on an Old Problem: The Dynamics of Death in the planh." RPh 35 (1982): 223-34. [An attempt to redefine the genre of the planh on the basis of semantic patterns.]

\subsection{Descort}

[A sort of "anti-canso" in which everything is topsy-turvy: each stanza has its own metric form and its own melody; expresses the poet's sadness or anger over a love not shared; about twenty are extant, including the most famous by Raimbaut de Vaqueiras in five languages.]

549.

Aubrey, Elizabeth. "Issues in the Musical Analysis of the Troubadour Descorts and Lays." In 110, Cultural Milieu, 1994, pp. 67-98. [Discussion of problems of definition and genre designation for the forty or so Occitan descorts/lays; detailed analysis of the six extant melodies and a consideration of performance problems, including improvisation, rhythmic interpretation and the possibility of instrumental accompaniment.] 
550.

Billy, Dominique. "Lai et descort: la théorie des genres comme volonté et comme représentation,” 94, AIEO 1, 1987, pp. 95-117. [As a further refinement to his 1983 study in RLaR 87 (1983): 1-28, Billy reexamines the criteria for defining and distinguishing the two polymorphous genres; the lai is low style, seems to belong only to northern France, except for one anomalous one by Bonifaci Calvo (Bonifaci only thought he was composing a lai); the descort is high style, often difficult to distinguish from the canso except as a reaction to the canso's contradictions and by the structural presence of the versicle.]

\section{1.}

Canettieri, Paolo. Descortz es dictatz mot divers: ricerche su un genere lirico romanzo del XIII secolo. Rome: Bagatto Libri, 1995. Partially available as a "knol": "La discordia d'amore nella poesia médiévale.” Online at http://www.knol.google.com. [History and definition of the descort as a genre in Occitan, Italian, Old French, and GalicianPortuguese; stresses the need to recognize the clearly ludic character of the form, which is not really a genre; offers a repertoire métrique of the whole corpus; Canettieri is proposing a complete edition of the descortz.]

\section{2.}

Cyrus, Cynthia J. "Musical Distinctions between descorts and lais: Non-Strophic Genres in the Troubadour and Trouvère Repertory." Ars musica Denver 4 (1992): 3-19. [The two genres are difficult to distinguish in the thirteenth century, except for differences in their musical nature; descorts have a freer melodic line, while the lais have a more repetitive structure, but both merged in the later fourteenth century in the North as lais.]

\section{3.}

Maillard, Jean. "Descort, que me veux-tu?" CCM 25 (1982): 219-23. [The descort seems to have defied generic description so far; Maillard looks at a typical poem, PC 10,45 by Aimeric de Peguilhan, one of four out of the total of twenty-eight descorts preserved with its melody, in two versions; one melody is quite atypical within the troubadour tradition, filled with distortions perhaps meant to reinforce the expression of the poet's distress, while the other is more subtly discordant.]

\section{4.}

Marshall, J. H. "The Isostrophic descort in the Poetry of the Troubadours." RPh 35 (1982): 130-57. [Provides the characteristics and a list of the twenty-four "normal" heterostrophic descorts, using PC 205,5 by Guilhem Augier Novella as an example of a poem difficult to categorize: unlike the canso, its melodic structure is varied in each set of double versicles, but the descort as a whole obeys a series of principles rather than a set of rules; as a genre it was open to continuous and flexible development; PC 10,45 by Aimeric de Peguilhan is used as an example of the five isostrophic descorts, which are distinguished from the heterostrophic and from the canso.] 


\title{
12.11. Minor Genres (Balada, Cobla, Comjat, Dansa, Devinalh, Enueg/plazer, Estampida, Estribot, Gap, Porquiera, Other Minor or Fictious Genres, Escondig)
}

\begin{abstract}
Balada
555.

Bec, Pierre. "Pour une typologie de la balada occitane: à propos de la pièce Qant lo gilos er fora." In Hommage à Jean-Charles Payen: "Farai chansoneta novele": Essais sur la liberté créatrice au Moyen Âge. Caen: Université de Caen, 1989, pp. 53-65. Also in Ecrits sur les troubadours, 1992, pp. 105-117. [Analysis of the six to ten extant baladas, giving the identifying characteristics and an overall typology of the genre; zadjalesque structure is noted in a majority of poems; about half have a feminine voice, half masculine; edition and detailed analysis of Quant lo gilos er fora as the most typical balada.]
\end{abstract}

556.

Bohnet, Arthur. "Ballads, ballada, ballade and A l'entrade del tens clar." In Ballads and Ballad Research: Selected Papers of the International Conference on Nordic and AngloAmerican Ballad Research, University of Washington, Seattle, May 2-6, 1977. Edited by Patricia Conroy. Seattle: University of Washington, 1978, pp. 17-25. [Urges the broadening of definitions to include all poems that share thematic and formal characteristics under the same generic heading; circularity of form seems to be more characteristic than an etymological connection with "dance" linking the ballada with the canso; close analysis of $A$ l'entrada del tens clar shows that the circular structure and the joyful content create a protected locus amoenus similar to that found in several courtly genres.]

\section{Cobla}

557.

Leube, Christiane. "Cobla." In 312, GRLMA, vol. 2, book 1, fascicle 4, 1980, pp. 67-72. [Identified as a minor, popular form, the cobla makes up 19 percent of all Occitan lyric compositions, typically polemic and satirical in content, occasionally scurrilous; exchanges of coblas are often comic, sometimes violent and insulting; they may take up moral questions or complain about decadence in society.]

558.

Petrossi, Antonio. "Le coblas esparsas occitane anonime: studio ed edizione dei testi." Doctoral thesis, Università degli Studi di Napoli Federico II, 2009. Online at http:// www.fedoa.unina.it/3772/1/petrossi.pdf. [Study of the genre in its nature and evolution; at the height of its development, it is indicative of a poetic and social mutation after the Albigensian Crusade; critical edition of 136 "classic" coblas (from a total of 481 texts), with Italian translation, notes; the introductory material is available in French: "Coblas esparsas se fan esparsament: analyse d'un genre poétique mineur," RlaR 114.1 (2010): 95-119.]

559.

Poe, Elizabeth W. “'Cobleiarai, car mi platz': The Role of the Cobla in the Occitan 
Lyric Tradition." In 120, Medieval Lyric, 2000, pp. 68-94. [Nineteen percent of troubadour poems are classified as the "minor" genre cobla; definitions of inserted coblas, extracted coblas, coblas esparsas, and exchanges of coblas represent a modern attempt to impose order on an unruly body of texts; history of the genre from the 1190 s through the thirteenth century and well into the fourteenth: often insulting in tone, satirical, parodying standard poems.]

560.

Rieger, Angelica. "La cobla esparsa anonyme: phénoménologie d'un genre troubadouresque." In 449, Actes du XVIIIe, 1988, 6:202-18. [Preliminary exploration of the corpus of 136 anonymous coblas out of the 472 items called cobla by PC; an ongoing project will define the genre, establish the corpus and its manuscript history, examine the contents and the place of the poems in the repertory, and furnish a complete edition; in a brief survey of the corpus, Rieger has established five categories by content, with illustrative quotations from twenty-five poems, and a plea for closer study of this rich but neglected source of information about the troubadours' world.]

561.

\section{Comjat/camjar (Chanson d'adieu/Chanson de change)}

See 2596, Heintze, "Die Rezeption," 2002. [Pp. 102-7: attempts to define the comjat (separating from the domna, renouncing love) and to differentiate it from the camjar (leaving one domna for another.]

\section{2.}

Newcombe, Terence H. "Remarks on the Themes and Structure of the Medieval Provençal comjat." Nottingham Medieval Studies 34 (1990): 33-63. [Observes that in the comjat the poet announces his leave-taking from the lady; discusses the tripartite organization of the content.]

\section{3.}

Zinelli, Fabio. "Quando l'amore finisce: comjat et chanson de change nella poesia dei trovatori." In Liebe und Logos. Edited by Andreas Gelz. Bonn: Romanistischer Verlag, 1996, pp. 113-25. [The comjat and the camjar introduce a narrative element into lyrics, especially when the chansonniers arrange poems into series dealing first with the rejected domna, then with the new one; the social dynamics and emotions involved can lead to moralizing in a sirventes or dramatization in a tenso; if invective is involved, the comjat may become a mala canso; as a genre, the comjat is defined only by content.]

\section{Dansa}

[The earliest are by Guiraut d'Espanha, who composed eight at the end of the thirteenth century; also Joan Esteve, Paulet de Marselha, Cerveri de Girona; half a dozen anonymous, including $A$ l'entrada del temps clar.]

\section{4.}

Leube, C. "Tanzlied." In 312, GRLMA, vol. 2, book 5, fascicle 5, 1979, pp. 60-64. [There are about forty dansas (also called ballada and retroencha; Cerveri de 
Girona has also: espingadura, viadeyra, and the humorous peguesca); simple in structure, courtly in content.]

565.

Avenoza, Gemma. "La dansa. Corpus d'un genre lyrique roman." RLaR 107 (2003): 89-129. [Establishment of a corpus of 151 poems, mostly Catalan, but including forty-two Occitan, in order to prepare a study of the development of the dansa form; the list is in approximate chronological order, giving information on identification, edition, and metrical structure.]

\section{6.}

Radaelli, Anna. Dansas provenzali del XIII secolo. Appunti di genere ed edizione critica. Alinea: Florència, 2004. [Critical edition of twenty dansas, with introduction, Italian translation, notes; all are anonymous except for six by Guiraut d' Espanha; pp. 76-81: comprehensive list of forty-one Occitan dansas and baladas from the late thirteenth century.]

\section{7.}

\section{Devinalh}

Uhl, Patrice. “So es devinalh (PC 461,226)?” Tenso 15 (2000): 97-117. [Discussion of the generic nature of the devinalh in six poems so labeled, starting with the only one actually called a devinalh (the anonymous Sui e no suy, PC 461,226); also "enigmas" treated by Guilhem Molinier in Leys d'Amors and elsewhere; the anonymous poem is the only one that could be called a devinalh in the generic sense, therefore it does not exist as a genre.]

\section{Enueg/plazer}

[A type of sirventes listing things that the poet dislikes or likes.]

\section{8.}

Allegretti, Paola. "Parva componere magnis. Una strofa inedita di Bernart de Ventadorn (BdT 70,33) e due schede per BdT 461,127." RST 1 (1999): 9-28. [A new edition of an anonymous two-stanza plazer-enueg, PC 461,127; denies attribution to Raimon de Miraval, suggests Jofre de Foixà.]

\section{9.}

Borghi Cedrini, Luciana. "Anonimo (Peire Milo?)." Online, 2003, at http://www. rialto.unina.it/PMilo/349.3/349.3prem.htm. [Edition of a cobla (plazer), PC 461,170 b; several similarities attach it to works by Peire; perhaps a contrafact of a poem by Guilhem de Capestanh or Bertran de Born lo Filhs.]

570.

Gresti, Paolo. "La canzone S'ieu trobes plazer a vendre di Bertolome Zorzi (PC 74,15)." In Italica-Raetica-Gallica. Studia linguarum literarum artiumque in honorem Ricarda Liver. Edited by P. Wunderli, I. Werlen, and M. Grünert. Tübingen: G. Narr, 2001, pp. 521-37. [Analysis of the poem's relationship to three other poems with the same metric structure (printed in appendix), and a problematic tenso: concludes that it is impossible to decide which of the five might be the original, or whether there was 
a common source now lost; edition of Bertolome's song, with Italian translation, notes.]

571.

Gsell, Otto. "Les genres médiévaux de l'enueg et du plazer." In Actes du Ve congrès international de langue et littérature d'Oc et d'études franco-provençales, Nice, 6-12 septembre 1967. Edited by G. Moignet and R. Lassalle. Nice: Publications de la Faculté des lettres et des sciences humaines, 1974, pp. 420-27. [These are types of sirventes, found in lo Monge de Montaudon and elsewhere, not really genres; their adherance to a group is based more on stylistic traits such as repetition of phrases: m'enoia, no.m azaut, or be magrada, be.m platz; the plazer is more common; the enueg is its negative extension.]

572.

See 1936, Paden, "Un plazer, 1983. [Edition of PC 29,14a that combines the theme of occupations of the months with a tradition of plazer poems listing the poet's "favorite things": a humorous satire directed against overused themes such as the seasons of love and the unsatisfied passions of the courtly lover; reaffirms its attribution to Arnaut Daniel.]

573.

See 1939, Zufferey, "Un plazer attribué à Arnaut Daniel." In $>152$, Miscellanea Roncaglia, 1989, 4:1503-13. Also in CN 49 (1989): 1503-14. [Edition of PC 29,14a, Mout m'es bel el tems d'estiou, which Zufferey would renumber 461,170d, denying attribution to Arnaut.]

\section{Estampida}

[Only six are extant in Occitan, but they are earlier than the nineteen estampies in Old French; for analysis of origins and form, see 249, Bec, Florilège en mineur, 2004, p. 95.]

574.

Cummins, Patricia W. "Le problème de la musique et de la poésie dans l'estampie." Rom 103 (1982): 259-77. [Analyzes the structure of estampidas and estampies; seven are extant in Occitan, nineteen in French; it is difficult to define the text/music relationship, since some have text without music, some have music without text, one has both (Kalenda maya); establishes five categories as a starting point for further study.] 575.

Leube, C. "Estampida." In 312, GRLMA, vol. 2, book 5, fascicle 5, 1979, pp. 65-66. [Related to the dansa in rythmic structure, but to the canso in metric form and thematic content; six poems are extant, only one with music, Kalenda maya; the mixture of long and short lines and interior rhymes makes for a strong rhythmic quality.]

576.

Schima, Christiane. Die Estampie. Amsterdam: Thesis Publishers, 1995. [A very thorough investigation of the genre in Occitania, France, and throughout Europe, with music and documentary texts in appendix; the genre is difficult to define; pp. 31-49 
deal with Occitan materials: the difficulty of distinguishing the estampida from other overlapping genres; in Occitan tradition, the estampida is like the canso in content, tone, and register, but with "popular" features; pp. 31-36: Kalenda maya and Souvent sospire; music and text in Appendix; pp. 36-41: four estempidas by Cerveri de Girona.

\section{Estribot}

[Genre characteristics are uncertain; lyric poems based on the parody of liturgical songs, satire against monks; the only two extant Occitan examples are Peire Cardenal PC 335,64 and Palais PC 315,5, though the genre is mentioned in various

577. poems and works, including Leys d'amors.]

Ricketts, Peter T. "L'estribot: forme et fond." In 151, Mélanges Bec, 1991, pp. 47583. [History of the use of the term estribot by Occitan poets and the Leys d'amors; edition and detailed analysis of the two extant Occitan examples, by Peire Cardenal and Palais, offering biting satirical criticisms of monks and clerics.]

578.

Vatteroni, Sergio."Peire Cardenal e l'estribot nella poesia provenzale." MR 15 (1990): 61-91. [Prehistory of the estribot is difficult to establish; Palais's poem is much like a cobla esparsa, but Peire Cardenal's is more complex; he may have been responsible for renewing the genre and assuring its prestige; pp. 78-81: new critical edition of Peire Cardenal's estribot PC 335,64, with Italian translation, notes; in appendix, text by Palais and a cobla by Folquet de Marselha, which is similar in structure to the estribot, though not designated as such.]

579.

See 468, D. Rieger, Gattungen, 1976, pp. 128-32. [Only two estribots are extant; the lack of music shows that they were probably performed like the epics; their lack of success was likely due to competition from the sirventes, and their reputation as a low-style popular genre.]

580.

Gap

Bonafin, Massimo. "Un riesame del gap ocitanico (con una lettura di Peire d'Alvernhe, BdT 323,11)." In 139, Ensi firent, 1996, pp. 85-99. [The distinctiveness of the gap should be respected and reexamined; detailed study of Peire d'Alvernhe's Cantarai d'aquests trobadors, attempting to show that it is a gap and that it provides an example of total formalization in morphological and functional terms.]

581.

Ceron, Sandra. "Un tentativo di classificazione del gap." $M R 14$ (1989): 51-76. [Analysis of the varied components of the genre, concluding with six elements of classification; she calls it a "criptogenere letterario," stressing that it was dynamic, subject to constant modification and evolution in order to maintain its vitality.]

582.

Fraser, Veronica. "The gap or Boasting Song in the Works of Guilhem de Peitieus, 
Raimbaut d'Aurenga, Peire d'Alvernhe and Peire Vidal." Tenso 24 (2009): 47-62. [An attempt to categorize the gap as a motif or theme, rather than a genre designation; Fraser is preparing an anthology of all the Occitan boasting songs.]

583.

Grigsby, John. The Gab as a Latent Genre in Medieval French Literature: Drinking and Boasting in the Middle Ages. Cambridge, MA: Medieval Academy of America, 2000. [Pp. 81-98: exploration of the gap in six troubadours; the Occitan lyric gap never became a full-fledged genre as the epic gab did in Old French epics.]

584.

Köhler, Erich. "Gabar e rire: Bemerkungen zum gap in der Dichtung der Trobadors." In Marche romane: Mélanges de Philologie et de littérature romanes offerts à Jeanne Wathelet-Willem. Edited by Jacques De Caluwé. Liège: Marche romane, 1978, pp. 315-26. [Sees the gap as part of the courtly life of fin'amors, the essence of fun and liveliness (joke, blame, or boasting), that were characteristic of the joven group that Köhler places at the sociocultural origin of trobar; thinks that the gap did not quite become a genre: it is a variation of the sirventes or perhaps of the later vers.]

\section{Porquiera}

[An obscene parodied form of the pastorela, quoted by the Leys d'Amors, ostensibly for its metric structure but perhaps also as a contre-texte to establish a balance with the traditional attitude to love.]

\section{5.}

See 244, Bec, Burlesque, 1984, pp. 184-90. [Used in the Leys as an illustration of its specific rhyme scheme, coblas retrogradadas per acordansa, in spite of its obscene content, which seems contrary to the normal tone of morality in the treatise; text of Audiau, with French translation, notes.]

586.

See 245, Nelli, Ecrivains anticonformistes, 1977, pp. 339-47. [Text from GatienArnoult, with introduction, French translation, notes; Nelli believes that the intent of the song may be more ambiguous than thought, since the tornada seems to be addressed to the Virgin.]

587.

Adam, Cécile and Jean-Marie D’Heur. "La porquiera: simple parodie ou leçon de morale?" In Contemporary Readings of Medieval Literature. Edited by Guy Mermier. Ann Arbor: Department of Romance Languages, University of Michigan, 1989, pp. 145-67. [The poem seems to be a distortion of the regular rules for the pastorela and has been considered obscene, even pornographic, but the authors place it back into its context (a quotation in the Leys d'amors) and claim that it returns to a moral message in the tornada, difficult as this may be for modern readers to appreciate.]

588.

\section{Other Minor or Fictitious Genres}

Dijkstra, Cathrynke. “Troubadours, Trouvères and Crusade Lyrics.” In 128 , Le 
Rayonnement, 1998, pp. 173-84. [Comparative study of crusade lyrics in Occitan and Old French; dissimilarities reveal a divergence in the way crusades were viewed in the two societies; the trouvères see the duties of the crusader as absolute, similar to a pilgrimage, while the troubadours treat the Crusades as just another war, not mutually exclusive with love; the troubadours do not sing only about the tormenting conflicts and tensions but include the continuing celebration of love.]

589.

Léglu, Catherine. "A Reading of Troubadour Insult Songs: The Comunals Cycle." Reading Medieval Studies 22 (1996): 63-84. [Analysis of the process and rhetoric of insult in the sirventes joglaresc; description of several cycles by Bertran de Born, Guillem de Berguedan, and Peire Cardenal, leading to a detailed look at the cycle of ten poems exchanged between Garin d'Apchier and Torcafol, addressed to a certain Communal, perhaps a reciprocal senhal designating both poets, and hinting that the whole cycle is elaborate game-playing.]

590.

Uhl, Patrice. "Contribution à la typologie d'un genre provençal du XIVe siècle: le reversari." Studia neophilologica 70 (1998): 89-100. [Study of parallels between the anonymous reversari PC 461,26 and five poems (by Guilhem de Peitieus PC 183,7, Giraut de Bornelh PC 242,80, Raimbaut de Vaqueiras PC 392,21 and 28, and Raimbaut d'Aurenga PC 389,28); all fit the enigmatic definition of devinalh or reversari.]

\section{Escondig}

["Excuse/denial/explanation/protestation of innocence"; the only extant example in Occitan is by Bertran de Born, PC 80,15, but there must have been others, now lost.] 591.

Martos, Josep Lluís. "L'escondit de Joan Roís de Corella." Revista de poética medieval 22 (2009): 115-132. [Study of a Catalan poem, which he shows to be an escondig; pp. 122-24: outline of the history and nature of the genre in Occitan and general Romance.]

\section{Music}

[About forty-five major chansonniers have transmitted ca. 2,600 poems, 264 with musical notation, preserved in four of the chansonniers; 255 poems with extant melody are listed in $\$ \mathbf{6 0 7}$, van der Werf.]

\subsection{General Studies}

592.

\section{Bibliography}

Switten, Margaret. Music and Poetry in the Middle Ages: A Guide to Research on French and Occitan Song. (with Howell Chickering). New York: Garland, 1995. [A guide to research and methodologies for the investigation of connections between text and melody, mainly 1980 to the early 1990s, concentrating largely on North American 
scholarship; the introduction surveys critical approaches and editorial practices from the Middle Ages to the present; advantages and drawbacks of major recent critical trends are identified, along with suggestions for moving forward; an annotated discography of 138 recordings, many of which contain troubadour songs.]

593.

Comprehensive Guides

Aubrey, Elizabeth. The Music of the Troubadours. Bloomington: Indiana University Press, 1996; reissued in paperback, 2000. [An invaluable critical account of troubadour music for musicologists and literary scholars; places constant emphasis on the link between text and music; detailed information on each of the forty-two poets whose music has been preserved, and on all four manuscripts that have transmitted the melodies; successive chapters on poetic and musical treatises, approaches to the study of musical form and style, and problems of performance practice.]

594.

Aubrey, Elizabeth. Poets and Singers: On Latin and Vernacular Monophonic Song. Aldershot, Hampshire: Ashgate, 2009. ["Introduction” by Aubrey, pp. xi-xxxvi, gives a wide-ranging and up-to-date survey, to 2006, of the main currents of scholarship and its problems in six medieval European repertoires over the past fifty years: Occitan, French, Portuguese, Italian, German, and Latin; useful summaries of the state of scholarship in such areas as presence of women, relationship between text and music, problems of transmission, notation, and performance, with an ample twelve-page bibliography; the volume itself is a collection of previously published articles by various scholars, eight concerning troubadours, from 1986 to 2002, designed to furnish an overview of the main scholarly trends and problems that have recently engaged scholars in the area.]

\section{5.}

Rossell, Antoni. El cant dels trobadors. Girona: Ajuntament de Castelló d'Ampúries, 1992. [General introduction to the musicology of the troubadours: detail on social background, musical forms, intermelodicity, genres, metrics, versification, and bibliography: especially strong on Catalan; ten pages of discography, pp. 277-87.]

\section{6.}

Ziino, Agostino. "Caratteri e significato della tradizione musicale trobadorica." In - 119, Lyrique romane, 1991, pp. 85-218. [Extensive, detailed repertoire of all musical notation in troubadour manuscripts; includes valuable charts comparing extant manuscripts for all extant melodies; copious notes; useful remarks on musicological interpretation and performance; seven photographic reproductions of musical notation in the Ambrosiana and the Vatican chansonniers.]

597.

Introductory Guides

Acciai, Giovanni. "Il testo musicale e le sue esecuzioni," chapter 2: "I trovatori." In

- 129, Lo spazio letterario del medioevo, 2. Medioevo volgare, vol. 2: La circolazione del 
testo, pp. 348-56. [General introduction to musical production; six major composers of preserved melodies: Raimon de Miraval, twenty-two; Bernart de Ventadorn, twenty; Peirol, seventeen; Gaucelm Faidit, fourteen; Folquet de Marselha, thirteen; Peire Vidal, twelve; stresses the importance of Latin traditions, along with possible Arabic influences; lyrics are theatrical in form, depending on a live vocal production.] 598.

Switten, Margaret. "Music and Versification." In 282, Gaunt and Kay, Troubadours, 1999, pp. 141-63. [Clear introduction to manuscript sources, text structures, musical structures, linking of text to music, and performance; brief musicological analysis of four melodies by Bernart de Ventadorn, Comtessa de Dia, Raimon de Miraval, and Guiraut Riquier; more detailed study of Peire Vidal's Be.m pac, PC 364,11; musical transcriptions in appendix.]

\section{9.}

van der Werf, Hendrik. "Music." In 281, Handbook, 1995, pp. 121-64. [History of research dealing with the relationship between texts and melodies; problems of rhythmic notation; stages in oral and written transmission; a scholarly presentation, challenging for nonmusicologists; in appendix, transcription of six complete melodies, with variant copies, brief notes.]

\section{0.}

\section{Specialized Studies}

Aubrey, Elizabeth. "La razo trouvée, chantée, écrite et enseignée chez les troubadours." In 98, AIEO 5, 1998, pp. 297-305. [The four meanings of razo are interwoven to illustrate the complexity of a song by Gaucelm Faidit, Tant ai sufert, PC 167,59; the theme, both that of the poem and that of the melody, the prose text which serves to introduce it at a performance, and the poetic treatise that explains the rules for creating songs, all of these interact to deepen and enrich its layered meanings, which modern audiences may find difficult to experience fully.]

601.

Aubrey, Elizabeth. "The Dialectic between Occitania and France in the Thirteenth Century." Early Music History 16 (1997): 1-53. [Although Occitania was being taken over politically by France during the thirteenth century, the troubadours maintained their cultural creativity and their influence on the North, while being very little influenced by northern musical and poetic traditions; close analysis of several examples of this one-way dialectic: Li jalous, PC 461,148a, and Tuit cil, PC 240a; the melody and language of L'altrier cuidai aber druda, PC 461,146; a motet invoking a song by Folquet de Marselha; the northern lai and the southern descort; history and comparison of the separate genres estampida and estampie.]

602.

Aubrey, Elizabeth. "Genre as a Determinant of Melody in the Songs of the Troubadours and Trouvères." In 120, Medieval Lyric, 2000, pp. 273-96. Also in - 594, Aubrey, Poets and Singers, 2009, pp. 183-206. [Analysis of medieval treatises to explore the ways in which text and melody were seen to relate to one another 
according to the art of rhetoric; Grocheio claims that form and material make up the substance of a song-it is a complex of text and melody; melody without text has no meaning; text without music has no form; Occitan treatises stress that the melody must be suitable to the genre; the sirventes, tenso, alba, retroncha, pastorela, dansa, planh, and estampida all have prescriptive rules governing their melodic structure; only in performance do all the elements of the song come together to serve the essential rhetorical purpose of moving the audience.]

\section{3.}

See 1743, Gallo, Musica nel castello, 1992. [Studies the importance of the sung poems in Italian courts, hitherto examined only from textual, historical, and social perspectives.]

\section{4.}

Haines, John. Eight Centuries of Troubadours and Trouveres: The Changing Identity of Medieval Music. Cambridge: Cambridge University Press, 2004. [History of the evolving interpretations of troubadour and trouvère music: creation of the chansonniers in the thirteenth century, antiquarianism in the sixteenth, synthesis of scholarly and popular traditions in the eighteenth, archaeology and philology in the nineteenth, more recent attitudes and interpretations, including sound recording, modern folk song, and Occitan pop as part of the living tradition of trobar.]

\section{5.}

Le Vot, Gérard. "Réalités et figures: la plainte, la joie et la colère dans le chant aux XIIe-XIIIe siècles." CCM 46 (2003): 353-80. [Suggestions as to how the troubadours may have tried to portray strong emotions through their melodies.]

\section{6.}

Paden, William D. "What Singing Does to Words: Reflections on the Art of the Troubadours." Exemplaria 17 (2005): 481-506. [A wide-ranging exploration of the nature, history, and art of singing troubadour lyrics, and the implications of repetition and memory for transmission of the songs.]

\section{7.}

\subsection{Musical Anthologies}

van der Werf, Hendrik. The Extant Troubadour Melodies: Transcriptions and Essays for Performers and Scholars. Edition of texts by Gerald A. Bond. Rochester: Published by the author, 1984. [The standard scholarly edition of the entire troubadour musical corpus; 236 different troubadour melodies in all extant versions, including contrafacts; total of more than three hundred readings; first stanza of text, with references to scholarly text editions; observations on editing and performing; introductory information on transmission, manuscripts, medieval notation, essentials of melodic analysis, meter, form, and content.]

608.

Rosenberg, Samuel N., Margaret Switten, and Gérard Le Vot. Songs of the Troubadours and Trouveres: An Anthology of Poems and Melodies. New York: Garland, 1998. Includes CD-ROM. [A broadly based pedagogical text; sociohistoric overview of the 
poetry, themes, genres, and styles by Rosenberg, pp. 1-6; "Music" by Le Vot treats the musical structures, types of rhythm, and the medieval voice, pp. 7-13; "Music and Words" by Switten discusses meter, rhetoric, and versification, pp. 14-28, giving helpful instruction on the methodology of melodic analysis, with detailed study of one song by Marcabru and one by the Chastelain de Coucy; sixty-three Occitan songs by twenty-three troubadours/trobairitz, thirty-six with melodies, five of which are sung on the CD; discography; Occitan texts are reprinted from existing editions, with new English translation; no glossary.]

609.

Fernandez de la Cuesta, Ismael. Las cançons dels trobadors. Opera omnia. Melodies by F. de la Cuesta, texts by Robert Lafont. Toulouse: Institut d'Estudis occitans, 1979. [Complete edition of melodies in nonmensural notation; all versions are presented; medieval ligatures are given, as well as modern transcriptions on a five-line staff; first stanza only of texts, with translation into French, German, Spanish, and English by Lafont, Kremnitz, Fernandez, and Kremnitz; some inaccuracies in transcription; texts and translation are sometimes idiosyncratic.]

610.

Haines, John. Medieval Song in Romance Languages. Cambridge: Cambridge University Press, 2010. [Survey of songs from Vulgar Latin to early Romance vernaculars (ca. 500 to 1200), predominantly female-voiced; texts with musical notation and commentary; five pre-troubadour Occitan songs.]

611.

See 168, Paden, Introduction, 1998, pp. 560-77. [Musical notation for nine songs, with complete text; five of these are sung by Elizabeth Aubrey on the accompanying CD-ROM; introduction "The Music of the Troubadours" by Aubrey, pp. 578-81.]

612.

Collins, Fletcher, Jr., with Robert F. Cook and Roger Harmon. A Medieval Songbook: Troubadour and Trouvère. Charlottesville: University of Virginia Press, 1982. [For nonspecialists; twenty-two Occitan songs; transcriptions are idiosyncratic, texts and translations are sometimes inaccurate.]

613.

Rossell i Mayo, Antoni. Monodia cortesana trobadoresca. Seixanta-quatre transcripcions inèdites de Mn. Higini Anglès. Catàlegs i altres publicacions de la Secció de Música, 32. Barcelona: Disputació de Barcelona, Biblioteca de Catalunya, 1986. [Edition of sixty-four musical transcriptions in nonmensural notation done in 1958 by Higini Anglès.]

614.

Gennrich, Friedrich. Der musikalische Nachlass der Troubadours. Summa musicae medii aevi, 3, 4, and 15. Darmstadt: Published by the author, 1958, 1960, 1965. [Contains much important information that has not been supplanted; multiple versions of melodies are "regularized" according to unknown principles; transcriptions are made in modal rhythm.] 


\subsection{Manuscript Sources, Transmission}

[Four manuscripts contain music: $X$ (Metz 1231); W(Artois? ca. 1254-80);

$G$ (Lombardy or Veneto, late thirteenth century); $R$ (Languedoc:

Toulouse? 1292-1326); plus a few fragments.]

615.

Aubrey, Elizabeth. "Literacy, Orality and the Preservation of French and Occitan Medieval Courtly Songs." Revista de Musicología 16 (1993): 2355-66. Actas del XVo Congreso de la Sociedad International de musicología, Madrid, 1992: "Culturas musicales mediterráneo y sus ramificaciones." [Postulates differences between French and Occitan musical traditions: trouvère melodies are tighter in structure and pitch, more ritualized and predictable; troubadour music is less predictable, more individualistic, less repetitive in structure, often connected rhetorically to the poems, attempting to express the same emotion in mot and son; Occitan melodies seem to have come to us more through oral transmission, French by earlier use of written transmission; the chansonniers became a new kind of performance, intended for a reading audience, as early as the 1220s in the North, not before the end of the century in the South.]

616.

Beldon, Valeria. "Osservazioni sulla tradizione manoscritta della lirica d'oc e d'oïl in area lorenese." CDT 7 (2004): 425-46. [Paleographic study of three manuscripts from the area of Lorraine $(C, I, U)$; internal structures, sources, criteria of organization; study of musical notations in $U$ (= Occitan MS X).]

617.

Haines, John. "The First Musical Edition of the Troubadours: on Applying the Critical Method to Medieval Monophony." Music and Letters 83 (2002): 351-70. [Analysis of early work from 1905 by Jean Beck on the edition of troubadour melodies; careful new historical research on the development of the modal theory.]

618.

Krülls-Hepermann, Claudia. "Contextes de transmission médiévaux: manuscrits et notations musicales." In 96, AEIO 3, 1992, pp. 627-36. [Studies the particular problems of mouvance in musical transmission, which seems to function separately, or differently, from textual transmission.]

619.

Lug, Robert. "Katharer und Waldenser in Metz: Zur Herkunft der ältesten Sammlung von Trobadorliedern [1231]." In 125, Okzitanistik, Altokzitanistik, 2000, pp. 249-74. [MS X was created between August and November 1231 at Metz, as the wedding gift of a patrician for his noble bride: twenty-four Occitan lyrics, twentythree with melody; Lug attaches the manuscript to the presence in Metz of a considerable group of Waldensians and Cathar refugees from the Albigensian Crusade; links to the Roman de la Violete and the Roman de la Rose, both of which have Occitan lyric inserts; further details in Lug's article in Lettres, Musique et Société en Lorraine Médiévale, Geneva: Droz, 2012, pp. 475-77.]

620.

Mayer-Martin, Donna, and Dorothy Keyser. The Thematic Catalogue of Troubadour 
and Trouvere Melodies, with a Study of the Manuscripts. Stuyvesant: Pendragon, 2011. [Inventory of all manuscripts containing music of the troubadours and trouvères, with introductory descriptions of each manuscript, its contents, and its relationship to the other chansonniers; melodic incipits are presented in intervallic order, with cross-references to standard handbooks; extensive bibliography.]

621.

\subsection{Structural Analysis}

Aubrey, Elizabeth. "Forme et formule dans les mélodies des troubadours." In $>\mathbf{9 4}$, AIEO 1, 1987, pp. 69-83. [Review of research into troubadour melodic structures (by, e.g., Gennrich 1932, van der Werf 1972). Now we know that each performance creates a "specific" song alongside the "general" one; but how to analyze a melody? Rhythm and meter are generally inaccessible, but we can study the repetition of musical phrases, groups of notes used as motifs or themes to unify a song; range, central tones, intonations, cadences, melodic contours, scales, and relationship of one phrase to another; variant melodies came about because the melody was re-created with each free performance; analysis of the four preserved melodies of Jaufre Rudel to identify characteristic elements of his style.]

622.

Centili, Sara, and Oreste Floquet. "Macrostructures mélodiques chez les troubadours: pour une grammaire des notes finales." In 102, AIEO 9, 2011, pp. 311-26. [Experimental analysis of the formalistic qualities of troubadour melodies, attempting to clarify the relationship of the musical structures to the metrical structures of the text; the stanzaic melodic structures may be broken down into sub-stanzaic groups, and these into musical modules, allowing detailed comparison of these units with similar units in the metrical structure; more complex studies promise to refine the definitions and reveal more detailed parallels.]

623.

Chaillou, Christelle. "Le 'marqueur sonore': un exemple de conjugaison subtile des mots et des sons dans l'art de trobar." Tenso 25 (2010): 36-62. [Mirror structures within Peire Raimon de Tolosa's Atressi cum la candela (PC 372,3) emphasize the fourth line of each stanza, in both text and melody; this line contains the series of end-words that carry the meaning of the poem; five musical techniques make the melody stand out in this line; in Pistoleta's Ar' agues eu (PC 372,3), line five, the center of the stanza is made to stand out musically by other means: three repeated notes, ornamentations, intervals; the melody is designed to bring out the textual structures.] 624.

Cullin, Olivier, and Christelle Chaillou. "La mémoire et la musique au Moyen Âge." CCM 49 (2006): 143-62. [Pp. 152-58: close analysis of Guilhem Ademar's Lanquan vei flurir (PC 202,8) and Cadenet's S'anc fui belha (PC 106,14) to demonstrate the ways in which memorization is utilized to produce a harmonious interlacing of text and melodic structures; the melody may adopt the poem's architecture, emphasizing the two final lines of each stanza and facilitating memorization; in Cadenet's alba, the 
textual and melodic structures are based on rhetorical principles; a detailed analysis of the melody; musical techniques of amplification and abbreviation; texts and transcriptions in appendix.]

\section{5.}

Haines, John. "Vers une distinction leu/clus dans l'art musico-poétique des troubadours." Neo 81 (1997): 341-47. [Trobar leu poets prefer melodies with repetition (pedes/cauda); clus poets prefer the through-composed oda continua, and when they use melodic repetition, the structure is invariably rare and original.]

626.

Haines, John. "Irregular Rhythm in the Music of Marcabru." Tenso 18 (2003): 50-66. [Only five troubadour melodies out of the ca. 260 extant attest (imperfectly) to medieval rhythmic interpretation; two of Marcabru's songs are so notated, two are not; brief exposition on the history of mensural ambiguities and controversies from the thirteenth century; irregularities in MS R.]

627.

Lug, Robert. "Chevaliers chantant à cheval. Nouvelles observations sur la rythmique des troubadours." In 98, AIEO 5, 1998, pp. 337-49. [Review of the theories of rhythm in troubadour melodies; new experimental rhythmic model of Can vei (PC $70,43)$, following the bodily rhythms of riding on horseback.]

628.

Mahrt, William Peter. "Grammatical and Rhetorical Aspects of Troubadour Melodies." In 110, Cultural Milieu, 1994, pp. 116-24. [Very accessible methodology for the analysis of melody, with three divergent examples: Bernart de Ventadorn's Can vei (PC 70,43), Arnaut Daniel's Chansson do.ill mot (PC 29,6), and Peire Vidal's Baros, de mon dan (PC 364,7), illustrating the ways in which syntax and rhetorical structure can be echoed and strengthened by the structures of the music.]

629.

Switten, Margaret. "La musique des troubadours." Europe. Revue littéraire mensuelle 86 (2008): 46-58. [Brief outline of methodology for analyzing the musical structures of poems, with examples from Arnaut Daniel and Jaufre Rudel; notions of variation during performance.]

\subsection{Performance}

630.

Aubrey, Elizabeth. "Non-Liturgical Monophony: Introduction" (1) and "Occitan Monophony" (2), in A Performer's Guide to Medieval Music. Edited by Ross W. Duffin. New York: Schirmer, 2002, pp. 105-15 and pp. 122-33. [1: transmission has left us with poor evidence for performance practices; imperfect transmission of melodies obliges modern performers to make difficult choices regarding rhythm, use of instruments, pronunciation, and improvisation; historical sketch of scholarly attempts to deal with problems. 2: Occitan sociohistorical background, language; poetic structures, including the progression of the same melody to reflect the progression of the poem's structure and content; the notion of mouvance and oral transmission; 
choosing a theory of rhythm; integration of text and melody; many hints for successful performance techniques.]

631.

Aubrey, Elizabeth. "Finding Music to Fit the Words." [Review article of the CDROM Lo Gai Saber: Troubadours et Jongleurs 1100-1300. Camerata Mediterranea, Erato Disques, directed by Joel Cohen]. Historical Performance: The Journal of Early Music America [new title: Early Music America] 4 (1991): 105-6. Joel Cohen's response: Historical Performance 5 (1992): 29. Aubrey's counter-response: Historical Performance 5 (1992): 30-32. [A lively debate that seeks a balance between the scholarly demands for performance practices that are historically verifiable and the need for modern singers to engage their listeners in a living performance; both seem to agree that much borrowing of structures, melodies, themes, and words took place among the medieval poets, and that the only way to fully appreciate an Occitan song is to hear, see, and feel it in a live performance-even better than to experience it on such a fine CD-ROM!]

632.

Aubrey, Elizabeth. "References to Music in the Old Occitan Literature." Acta musicologica 61 (1989): 110-49. Reprinted in 594, Aubrey, Poets and Singers, 2009, pp. 415-54. [Exploration of lyrics and other genres to clarify the evidence for performance practice; poets insist on the convergence of mot and son; satirical comments on other poets' skills; vidas and razos; epic, narrative, and didactic texts; instruments are mentioned, but their precise use is not clear; massive evidence of the importance of music in the society, but little that can be used to define closely the actual performance practices of the time.]

633.

Boynton, Susan. "Women's Performance of the Lyric before 1500." In $\mathbf{1 2 1}$, Medieval Woman's Song, 2002, pp. 47-65 and notes, pp. 219-23. Reprinted in 594, Aubrey, Poets and Singers, 2009, pp. 111-34. [Detailed study of performance practices by women in Occitan, French, Hispano-Arabic, German, Italian, and English; shows persuasively how the roles of creator and performer were intertwined, since performance meant re-creation; the trobairitz are linked to Arab traditions, in which women had a literary role and a voice in their society; poetic dialogues between men and women were important in both societies; male/female collaborative performances of tensos seem to have occurred; discography of eighteen items, half of which contain Occitan songs.]

634.

Boynton, Susan. "La cançó trobadoresca en escena" [Troubadour song as performance]. Mot So Razo, 6 (2007): 75-90. [Very down-to-earth study of the connection between text and melody and its sensitive interpretation during performance; discusses the various forms that performance can take, including the solitary reading of the text itself on a manuscript page, even without musical notation; there is virtual performance going on in the mind of the reader; detailed analysis of Guiraut Riquier's Pus sabers no'm val ni sens (PC 248,66), called a canso redonda et encadenada 
de motz e de son; edition and English translation, with full musical notation stanza by stanza.]

635.

Cohen, Joel. "Peirol's Vielle: Instrumental Participation in the Troubadour Repertory." Historical Performance: The Journal of Early Music America 3 (1990): 73-77. [Finds evidence of instruction by Albertet de Sisteron in PC 16,8, Ben chantar far to the joglar Peirol, urging him to play his vielle and sing his poem delicately; this is seen as proof that troubadour songs were at least sometimes accompanied by a musical instrument.]

636.

See 3014, Guida, "Giullari a Tolosa," 2007. [New light on joglar performance activities, gleaned from archival documents; the gab-sirventes of Uc de l'Escura names eight joglars and gives information on the dramatic activities of the group in Toulouse responsible for theatrical activities similar to the commedia dell'arte; each had a particular talent: Peire Vidal was an accomplished troubadour, Albertet a good singer, Perdigon an instrumental musician, Aimeric de Peguilhan a composer of cansos, Arnaut Romieu a braggart, Elias Fonsalada a singer, Pelardit a mime, and Gualaubet a violist.]

637.

Le Vot, Gérard. "Sur l'interprétation musicale de la chanson des troubadours: pour une musicologie appliquée." In Musique, littérature et société au moyen âge. Actes du colloque du Centre d'études médiévales de l'Université de Picardie. Edited by Danielle Buschinger and André Crépin. Paris: Champion, 1980, pp. 99-122. [Exploration of the musical heritage preserved in the troubadour manuscripts and the problems inherent in preparing an authentic modern-day performance: text contamination, lack of rhythmic notation, uncertainty regarding instrumental accompaniment, and fluidity of transmission of the melody; in appendix: four songs prepared for a suggested modern performance.]

638.

Le Vot, Gérard. "Notation, mesure et rythme dans la canso troubadouresque." CCM 25 (1982): 205-17. [État-présent of knowledge of musical rhythm in medieval texts; suggests possible interpretations of troubadour music.]

639.

Le Vot, Gérard. "Quelques indices du silence dans la canso des troubadours." In - 151, Mélanges Bec, 1991, pp. 295-306. [Discussion of intervals of more than four or five causing extraordinary emphasis on the word affected, and interruptions in the melodic line such as punctuation in the text, bar lines; analysis of comments in Leys d'amors; emphasizes the free use in performance of improvisation; all are matters to be studied further.]

\section{0.}

Page, Christopher. "The Twelfth Century in the South." In his Voices and Instruments of the Middle Ages: Instrumental Practice and Songs in France 1100-1300. London: J. M. Dent, 1987, chapter 1, pp. 12-28, and notes, pp. 245-58. Reprinted in $\mathbf{5 9 4 ,}$ 
Aubrey, Poets and Singers, 2009, pp. 343-62. [An exploration of the nature of the troubadour lyric and the conditions of performance; the opening stanza of Arnaut de Maruelh's La grans beutatz, PC 30,16, illustrates the delicate rhapsodic flow of the "high style" melody; the question of instrumental accompaniment is pursued through various narrative texts, with no conclusive proof for or against, but a suggestion that accompaniment was more common in "lower style" dansas and descorts.] 641.

Schembri, Marcello. "Interpretare i trovatori. Una quaestio da aprire." In $\mathbf{1 0 0}$, AIEO 7, 2003, pp. 639-50. [Condemnation of attempts to reinvent troubadour music without proper regard to the information contained in the chansonniers (e.g., by Binkley and Clemencic); wants to clear the decks of all the false medievalism rampant in interpretations and instrumental accompaniment of the songs, in favor of the prudent "declamatory rhythm" proposed by van der Werf. The original paper was accompanied by examples of bad and good practices, sung by soprano Maria Caterina Conti.]

642.

Taylor, Robert A. "Occitan.” In Singing Early Music. Edited by Timothy McGee, with A. G. Rigg and David N. Klausner. Bloomington: Indiana University Press, 1996, chapter 7, pp. 103-18. [A practical guide to pronunciation for performers, with historical and linguistic introduction, sample texts in IPA transcription and complete readings by Klausner on the accompanying CD-ROM.]

643.

van der Werf, Hendrik. "The 'Not-so Precisely Measured' Music of the Middle Ages." Performance Practice Review 1 (1988): 42-60. Reprinted in 594, Aubrey, Poets and Singers, 2009, pp. 489-507. [The rhythm of troubadour songs may be flexible, allowing for pitches, syllables or words to vary in length or emphasis, depending on the sense, varying from one stanza to another, a sort of free rhythm in which both text and melody can receive proper attention, with neither subservient to the other; this would be preferable to a "declamatory" reading, which seems to imply the primary importance of the text; van der Werf now advises singing the poem through, giving fairly equal value to all pitches, but concentrating on the meaningfulness of the text, allowing small differences in the duration of individual pitches and some subtle variations in tempo.]

644.

Warning, Rainer. "Lyrisches Ich und Öffentlichkeit bei den Trobadors." In Deutsche Literatur im Mittelalter: Kontakte und Perspektiven: Hugo Kuhn zum Gedenken. Edited by Christoph Cormeau. Stuttgart: Metzler, 1980, pp. 120-59. Also as "Moi lyrique et société chez les troubadours." In Archéologie du signe. Edited by Lucie Brin d'Amour and Eugene Vance. Toronto: Pontifical Institute of Mediaeval Studies, 1983, pp. 63-100). [The lyric as fictional theatre: the "I" of the poem is a fiction, not to be confused with the poet; the song must be interpreted as part of the public courtly performance in order to grasp the identity of the connoisseur group forming the audience for troubadour poetry.] 


\subsection{Contrafacture}

645.

Gennrich, Friedrich. Die Kontrafaktur im Liedschaffen des Mittelalters. Summa musicae Medii Aevi, 12. Darmstadt: Published by the author, 1965. [Comprehensive study of medieval contrafacta.]

646.

Bonse, Billee A. "Singing to Another Tune": Contrafacture and Attribution in Troubadour Song. PhD diss., Ohio State University, 2003. Available online at http://etd. ohiolink.edu. [Structural imitation was most closely associated with several specific genres, including the sirventes, tenso, coblas, and planh; but very few melodies have been preserved with melodies borrowed from preexistent cansos; several suspected cases of melodic contrafacture are examined minutely, allowing the possibility of reattributing borrowed melodies to their original composers.]

647.

Chambers, Frank M. "Imitation of Form in the Old Provençal Lyric." RPh 6 (195253): 104-20. [Classic study of contrafacture within Occitan poetry; metrical analysis covers the entire lyric corpus, goes further than $\$$ 57, Frank's Répertoire métrique, by introducing diachronic analysis into the metrical results; demonstrates for the first time the vital process of growth and change in the formal practice of the troubadours; see also 850, Chambers, Introduction, 1985: Index, s.v. "Imitation of Form"].

648.

Marshall, John H. "Pour l'étude des contrafacta dans la poésie des troubadours." Rom 101 (1980): 289-335. [Careful methodology for identifying contrafacta; to judge the possibility of a borrowed melody, an identical rhyme scheme alone is insufficient, unless allied with the metrical structure; confirmation depends on further resemblances: rare metrical form or choice of rhymes; twelve meticulous studies are used to test and illustrate the principles; eight or nine melodies are reinstated into the troubadour musical corpus.]

649.

Di Luca, Paolo. "Epopée et poésie lyrique: de quelques contrafacta occitans sur le son de chansons de geste." RLaR 112 (2008): 33-60. [Analysis of contrafact lyrics by Guiraut del Luc and Raimbaut de Vaqueiras, in which the poets stated that the melody was borrowed from epics; two others by Peire Bremon Ricas Novas and Uc de Saint Circ were said to be set to a melody by En Gui, but neither Gui de Cavaillon nor Gui d'Ussel have poems with Alexandrine lines; Di Luca suggests the hero of the epic Gui de Nanteuil; the discovery gives witness to the willingness of the troubadours to experiment with poetic forms and promises to be helpful in the study of melodic structures in a dozen similar poems; see the continuation of this investigation in Di Luca's "Salutz d'amour et de geste," RLaR 114.1 (2010): 47-63.]

650.

Lannutti, Maria Sofia. "Intertestualità, imitazione metrica e melodia nella lirica romanza delle Origini." MR 32 (2008): 3-28. [A consideration of musical contrafacture and the way it has been studied historically: intertextual structures in the poems 
suggest the possibility of musical likeness based on metrical similarity; the metrical structure of the Kalenda maya text is compared with an Old French estampie, and found to be almost identical, but the two melodies are rather different; conclusion: the melody is the most important element of a contrafact structure, leading to a duplication of the metrical structure.]

651.

Monari, Giorgio. "Osservazioni su un caso di imitazione nel repertorio trobadorico." In 118, La lirica romanza, 2009, pp. 117-37. [Analysis of a tenso between Bernart de Ventadorn and Peire (d'Alvernhe?), Amics Bernartz de Ventadorn; Peire is mocking Bernart's typical style, and Bernart is being untypical, perhaps for humorous purposes; the melody is similar in structure to others by Bernart, but this aspect too is ambiguous: perhaps it is part of the parody of Bernart, or perhaps it is Bernart being humorous himself.]

652.

Mouchet, Florence. "Entre canso et sirventes: contrafacture et composition poéticomusicale." In 114, Les genres, 2010, pp. 39-57. [When the melody from a canso is used for a sirventes, it acts as a kind of auctoritas, calling for a renewal in the sense that it requires a new association of words to music; the music is the guiding principle, not the text, and its use demands active memorial participation by the audience in order to cope with the adaptation of a new text and context to the familiar melody.] 653.

Phan, Chantal. "Les trobairitz et la technique du contrafactum." In $>$ 93, Atti del XXI Congresso, 1998, 6:693-701. [Only one trobairitz poem is preserved with melody, but others may be restored through the notion of intertextuality; analysis of three trobairitz cansos in light of melodies taken from other poems with similar metrical structure; Comtessa de Dia's Estat ai en greu cossirier, with melody from Raimon de Miraval; Alais, Iselda and Carenza's $\mathrm{Na}$ Carenza, with melody from Arnaut de Maruelh; Garsenda's Vos que.m semblatz, with melody from Gaucelm Faidit; see also Phan's study of the comtessa's $A$ chantar mer and its preserved melody in $\mathbf{6 6 6}$, Women Composers, 1996, 1:61-68.]

\section{4.}

Phan, Chantal. "Imitation and Innovation in an Anonymous French Contrafactum of Bernart de Ventadorn's Ara no vei luzir solelh." Tenso 16 (2001): 66-75. [ Comparison of melody and text of two poems, seeking dynamic elements that link and differentiate them beyond their shared metrical-melodic structure; changes in the French song reveal a deep understanding of the rich phonetic and thematic features of Bernart's poem and an effort to preserve them; the rare use of accidentals in the French contrafact seem to be linked to key words in the text, indicating that the poet has appreciated the text-music architecture of Bernart's song and has tried to replicate it sensitively in his own way.]

655.

Phan, Chantal. "From Sacred to Secular and from Secular to Sacred: The Role of Text-Music Relations in Two Lyric Contrafacta." In The Church and Vernacular 
Literature in Medieval France. Edited by Dorothea Kullmann. Toronto: Pontifical Institute of Mediaeval Studies, 2009, pp. 214-23. [Pp. 215-19: the melody of Giraut de Bornelh's Reis glorios is based on the Latin hymn Ave maris stella; pp. 219-21: the Latin-French song by Philip the Chancellor uses Bernart de Ventadorn's melody from Can vei la lauzeta.]

656.

Rossell, Antoni. "L'intermelodicità come giustificazione delle imitazini metriche nella lirica trobadorica." In Vettori e percorsi tematici nel mediterraneo romanzo. L'Apollonio di Tiro nelle letterature euroasiatiche dal Tardo-antico al medioevo, Roma, Villa Celimontana, 11-14 ottobre 2000: Atti. Edited by Fabrizio Beggiato and Sabina Marinetti. Soveria Manelli: Rubbettino, 2002, pp. 33-42. [Three graded levels of contrafact borrowing: (1) melody and syllabic structure; (2) verse, rhymes, and stanza structure; and (3) lexical content, themes. Melodies were chosen carefully to awaken musical and thematic echoes among the listeners, in order to create a subtle dialogue between the new song and its model. Examples of contrafacts by Raimon de Miraval, Peire Cardenal, Jaufre Rudel, Arnaut Catalan, and a "double-contrafact" by Alfonso X demonstrate the purposeful choice of models for the resonances of melody, theme, and tone that they could add to the new song on a metapoetic and metamelodic level.]

\section{7.}

\subsection{Text/Melody Relationship}

Butterfield, Ardis. "Vernacular Poetry and Music." In The Cambridge Companion to Medieval Music. Edited by Mark Everist. Cambridge: Cambridge University Press, 2011, pp. 205-24. [See esp. pp. 205-14: a detailed overview of the poetry and music of the troubadours and the scholarly problems involved in relating text and melody; do the words drive the melody, or does the music follow rules of its own, apart from the poetry? Succinct presentation of scholarship on the origins and socioliterary functions of troubadour songs; discussion of genres, melodic structures, and the "vocabulary" of music, illustrated by the analysis of Bernart de Ventadorn's Can vei la lauzeta.]

658.

Carapezza, Francesco. "Cantus divisio e partizioni sintattiche nella canzone decasillabica dei trovatori." SMV 56 (2010): 55-73. [Working on a corpus of sixty poems with ten-syllable metrics and extant melody, Carapezza studies the syntactic articulations of the texts and their relationship to the melodic divisions, concluding that this relationship forms the structural base of the song and may help to judge the authenticity of the melody and its appropriateness to contrafacta, as well as help to restore original texts.]

659.

Chaillou, Christelle. "L'étude des liens entre musique et poésie dans l'art de trobar: bilan et perspectives." In 102, AIEO 9, 2011, pp. 327-38. [A report on the present state of research on the relationship of text and melody in troubadour song, and prospects for future research; the study of smaller structural repetitions in twenty-four 
songs, according to the traditional categories of rhetorical analysis, reveals a strong melodic logic which accompanies the architectural logic of the text, without being subordinated to it; the convergence of the two modalities would achieve its full effect in oral performance.]

\section{0.}

See 678, Chaillou, "Le chant du texte," 2009. [Analysis of poems by three troubadours in which the melody is designed to bring out the thematic structures.]

\section{1.}

See 2026, Cheyette/Switten, "Women," 1998. [Detailed analysis of words and music of Comtessa de Dia's poem A chanter mer (PC 46,2), and Marcabru's L'autrier jost'una sebissa (PC 293,30).]

\section{2.}

Grange, Huw. "A Musico-Literary Commentary on Bernart de Ventadorn's Qan vei la laudeta mover." Glossator 4 (2011): 81-99. [A meticulous analysis stanza-by-stanza of the interrelationship of music and text in Bernart's song; the music is a powerful, traditional force, which seems to guide and reinforce the text; recurring patterns in the melody, along with melodic leaps, pitch goals, and melismas, may have helped the joglars to memorize the poem and facilitated oral transmission.]

663.

Krülls-Hepermann, Claudia. Trobador-Liedkunst. Literaturwissenschaft und Musikgeschichte im Kontext. Bern: Lang, 2000. [Stresses the importance of studying the reciprocal links between literary and melodic aspects of the poetry, taking into account the textual content (mot), as well as the musical message (son); detailed analysis of five cansos by Bernart de Ventadorn, Folquet de Marselha, Berenguier de Palazol, Arnaut Daniel, and Peirol, demonstrating the ways in which performance adapts the effect of the melody to the message of succeeding stanzas.]

\section{4.}

Moscatelli, Roberta. "La musica dei trovatori: indagini su aspetti melodico ritmici ed esecutivi." Quaderni di fllologia e lingue romanze 12 (1997): 141-62. [Introduction to questions of musicality and performance practice in the troubadours; comparison of several transcriptions of Bernart de Ventadorn's Can vei la lauzeta, in order to see whether music is the primary force, or secondary to the text: the melody seems to be secondary and has to be adapted to the metrics of the poem.]

\section{5.}

Mouchet-Chamard, Florence. "La pratique du contrafactum dans le corpus des troubadours: vers une redéfinition du rapport entre texte et musique au sein du sirventés." In Les langues du Sud: entre érosion et émergence. Actes du 126e Congrès national des sociétés historiques et scientifiques, 9-14 avril, 2001. Edited by Geneviève Hasenohr. Paris: Comité des Travaux Historiques et Scientifiques, 2004, pp. 91-104. [Close association of text and melody is generally seen as a prized feature of the canso, but some poets followed the opposite compositional practice by borrowing the melody from a preexistent canso, dansa, or estampida; analysis of works by Peire Cardenal allows the restoration of melodies to poems which lack them, but calls for a 
reevaluation of our basic understanding of the lyrics, for which at least two fundamentally different approaches to composition are present.]

666.

Phan, Chantal. "The Comtessa de Dia and the Trobairitz." In Women Composers: Music through the Ages. Vol. 1: Composers Born before 1599. Edited by Martha Furman Schleifer and Sylvia Glickman. New York: G. K. Hall, 1996, pp. 61-68. [Brief introduction on troubadour style, performance problems, the trobairitz and their perspective on finamor, the relationship of text to music, melodic borrowings, and contrafacts; transcriptions of melody are provided for three poems, with English translation of the first stanza.]

\section{7.}

Steel, Matthew C. "A Case for the Predominance of Melody over Text in Troubadour Lyric: Bernart de Ventadorn's Can vei la lauzeta mover." Michigan Academician 14 (1982): 259-71. [The poem appears in twenty-eight different manuscripts, its melody in three, and in seven further contrafacts outside Occitan; the melody seems more stable than the text, perhaps because of its strong connection with the trope style of chant repertory; detailed analysis of the version in MS $R$, in which text and melody are very closely linked, controlled by the central mirror-image of the text, which is like the mirrored structure of the melody; the music reflects the poem and the poem reflects the music in a finely tuned complementary relationship.]

\section{8.}

Rossell, Antoni. “Oralité et lyrique troubadouresques: texte et musique." In $\mathbf{1 0 2}$, AIEO 9, 2011, pp. 487-504. [An exploratory methodology, through comparative interdisciplinary analysis, to better understand the textual and musical elements utilized in oral composition; a common architectonic system valid for both text and melody will elucidate the principles of mnemotechnic processes essential to oral transmission; the architectonic analysis of several troubadour melodies and texts brings out similarities in the syntactic and melodic structures that reveal the interdependence of music and text.]

\section{9.}

Treitler, Leo. "The Troubadours Singing Their Poems.” In The Union of Words and Music in Medieval Poetry. Edited by Rebecca Anne Baltzer et al. Austin: University of Texas Press, 1991, pp. 15-48. With accompanying cassette. [Rejects the notion that music was unrelated to the text in medieval traditions; the basic principles of correspondence between melodic and poetic syntax are illustrated by analysis of Jaufre Rudel's melody for Lanquand li jorn, its syntax being exactly suited to the conceit of "love from afar"; in Bernart de Ventadorn's Can vei, there is some mimetic correspondence to the motions of the bird, but basically, the connection is a syntactic one, suitable only for the first stanza; this natural interaction of music and language stopped around 1400.]

670.

Treitler, Leo. "The Marriage of Poetry and Music." In With Voice and Pen: Coming to Know Medieval Song and How It Was Made. Oxford: Oxford University Press, 2003, 
chapter 17, pp. 473-78. [Detailed analysis of the text-music relationship in Jaufre Rudel's Lanquand li jorn, revised from an earlier article 1995.]

671.

See 2886, Vallín, "Sobre el contenido," 1999, pp. 131-39. [Sees the basic textual message of Kalenda maya as negative toward the courtly ideal, contrasted with the joyfulness of the melody.]

672.

Vanin, Claudio. "Musical Form and Tonal Structure in Troubadour Song: A Study of the Music and Poetry of the Twelfth-Century Troubadours." PhD diss., University of Western Ontario, 1994. Available online at http://www.troubadours.vaninpiano. com. [Analysis of the troubadours' fascination with structure, both in versification and in the musical forms, reveals an intimate and dynamic interaction between the two, which can serve as a paradigm for the understanding of music/text relationships in the canso; selected examples are analyzed to show how the troubadours created subtle and finely articulated formal designs in their music; a new catalogue of all attributed songs is provided.]

673.

Wingell, Richard J. "Motz e chan: Textual and Musical Rhythm in Medieval Latin Poetry and Troubadour Songs." In 110, Cultural Milieu, 1994, pp. 99-115. [Analysis of the complex interrelationships of natural language rhythms, metrical rhythms, and melodic rhythms, establishing a methodology first in Latin hymns, then applying it to the troubadour songs. Similar patterns of endlessly variable interactions among the multiple levels of rhythm promise to lead to a more subtle understanding of troubadour poetry and music.]

\section{4.}

\subsection{Single Poets and Works}

Aubrey, Elizabeth. "La langue musicale de dévotion: les cantigas de loor et les chansons de Guiraut Riquier." In 111, L'Espace lyrique, 2006, pp. 219-29. [Guiraut's three songs to the Virgin are analyzed poetically and musically to isolate some characteristics that contrast with those of Alfonso X; poetically, Guiraut is attached to the beauties of life on Earth, whereas Alfonso looks toward heaven; musically, too, Guiraut's songs are typical of his troubadour traditions, having little in common with those of Alfonso.]

675.

Boynton, Susan. "Emblems of Lament in Latin and Vernacular Song." In The Church and Vernacular Literature in Medieval France. Edited by Dorothea Kullmann. Toronto: Pontifical Institute of Mediaeval Studies, 2009, pp. 224-50. [Examines the text-melody relationship in Gaucelm Faidit's planh for the death of Richard Coeurde-lion; text with melody and English translation in appendix.]

676.

Carapezza, Francesco. "La voix de Marcabru: écarts tonaux et clausules mélodiques dans le Vers del lavador (BdT 293.35)." In 101, AIEO 8, 2009, 1:157-69. [The 
mockery of Marcabru's harsh voice may be based on a humorous contrast with the sound of the lark; the reality may be different: in his songs, Marcabru admires his own dramatic performances, and takes pride in the moral strength of his poetic message; analysis of the melody of his Vers del lavador demonstrates that the melodic structures reflect those of the syntax, both of which are suitable for the oratory of a preacher.]

677.

Carapezza, Francesco. "Implicazioni musicali in Peire d'Alvernhe: sul vers autunnale 323,15," in 118, La lirica romanza, 2009, pp. 93-116. [Study of De josta is breus jorns, the only one of Peire's poems with a preserved melody, in the light of an examination of all references to singing in his poetry and in comparison with Jaufre Rudel's Lancan li jorn, to which it may be a replique; Peire's melody is more ornamented and has greater range and structural leaps but has similarities of structure which echo the similarities of theme in the two poems; Peire's reputation as a composer is shown to be fully deserved; his musical style is complex and elaborate and served as a model for later troubadours: Raimbaut d'Aurenga, Peire Cardenal, and Arnaut Daniel.]

\section{8.}

Chaillou, Christelle. "Le chant du texte dans la poésie lyrique des troubadours." In 101, AIEO 8, 2009, 1:545-57. [Detailed analysis of musical, phonetic, and textual structures in Monge de Montaudon's PC 305,6: Era pot ma domna saber; an attempt to define the ways in which all elements interact in the subtle performance of a song; the delicate nuances of words and sounds could be fully appreciated only by a refined audience in an oral presentation; see also Chaillou's article "Le marqueur sonore," in Tenso 25 (2010): 36-62, in which the melody is shown to enhance the textual structures in poems by Peire Raimon de Tolosa and Pistoleta.]

679.

Falvy, Zoltán. Mediterranean Culture and Troubadour Music. Budapest: Akadémiai Kiadó, 1986. [Detailed analysis of the musical style of Peire Vidal (pp. 83-126: nineteen melodies) and Gaucelm Faidit (pp. 127-208: thirty melodies); text and melody are interdependent, both are essential to the song; transcriptions use notation with neutral time values.]

\section{0.}

Green, Edward. "Marcabru and the Foundations of Modern Song." Ars lyrica 15 (2007): 79-101. [Very detailed analysis of melody and words of Marcabru's Bel m'es quan son li fruich madur (PC 293,13), first stanza only, indicating how intricately the two elements are aligned and interdependent; analysis of syllabic structure, rhyme structure, melodic structure, "dovetailing," and other subtle qualities; Green believes that Marcabru was a compositional genius and acted as a model for later troubadours, being responsible for much of the lasting greatness of troubadour songs; the emphasis of his composing is on the organic creation of a stanza as a "tightly organized unity of verbal and melodic elements." Marcabru's ethical strength (belief in absolute integrity) is allied with his aesthetic striving for absolute unity of words and music; stanza 1 of PC 293,13 is given in appendix.] 
681.

Haines, John. "La musique des albas de Guiraut de Bornelh et de Cadenet." In - 502, Chaguinian, Les albas, 2008, pp. 91-101. [The melodies are unusual: similarities between them indicate that Cadenet's melody is an elaborated version of Giraut's; it is clear and forceful, in the tradition of Gregorian chant, lending it a sacred, memorable tone.]

682.

Pitombeira, Liduino. "A Rhythmic Realization for Raimbaut de Vaqueiras' Kalenda Maya." Per Musi-Revista Acadêmica de Música da UFMG [Universidade Federal de Minas Gerais] 12 (2006): 95-104. [A brief survey of rhythmic theories for troubadour melodies, a number of renditions of Kalenda Maya derived from these theories, as well as his own hybrid performance rendition (both mensural and declamatory).] Online at http://www.musica.ufmg.br/permusi.

683.

See 2302, Pollina, "Word/Music," 1989, 3:1075-90. [Looks specifically at the planh for Richard Coeur-de-lion; musical features are used to draw attention to the text, particularly the word Richartz in line 6.]

684.

Pollina, Vincent. "Les mélodies du troubadour Marcabru: questions de style et de genre." In $\$ 95, AIEO 2, 1993, 1:289-302. [The four extant melodies by Marcabru are varied in style, as are the accompanying texts: is this due to differences in genre or register? Each melody is briefly studied and characterized, indicating the desirability of a more complete analysis; all four melodies are edited.]

685.

Pollina, Vincent. "Canso mélodique et canso métrique: Era.m cosselhatz, senhor de Bernart de Ventadorn.” In 94, AIEO 1, 1987, pp. 409-22. [Very detailed analysis of PC 70,6 in terms of metric structure alongside the two melodic versions; the melody of $R$ supports closely the rhyme patterns of the text, while that of $G$ adds subtle touches to smooth the transition points; but in both cases there is a clear conscious awareness of the song's metrical structure on the part of the composer.]

686.

Rossell, Antoni. "Reconstrucción musical de la Epistola de Raimbaut de Vaqueiras: una hipótesis." In Dalla Provenza al Monferrato. Percorsi medievali di testi e musiche. Edited by Sonia Maura Barillari. Alessandria: Orso, 2007, pp. 29-43. [A hypothetical melodic structure is proposed for the poem, based on psalmody, Gregorian chant, and the hagiographical and epic traditions: an experimental trial.]

687.

Shinnick, Julia Wingo. "Singing Desire: Musical Innuendo in Troubadour and Trouvère Song." In Sexuality in the Middle Ages and Early Modern Times. Edited by Albrecht Classen. Berlin: de Gruyter, 2008, pp. 293-324. [A close study of Arnaut Daniel's Lo ferm voler; musical structures show a conscious design to add within the music additional layers of meaning to those already present in the text and metrics; six recurring pitches reinforce the sixfold use of recurring rhymewords; assertive repetition of the 
three pairs of end-pitches emphasize the central metaphor of determination to reach a goal; repetitive "neighbor gestures" (occurring twelve times) could be utilized in performance as innuendo to emphasize the poem's progressive metaphors of physical contact; the overall melodic contour of the poem is consciously designed to support the thematic advancement through fear and increasing desire to apparent fulfillment; the musical narrative toward conjunction is as strong as the textual one.]

\section{8.}

Stevens, John E. Words and Music in the Middle Ages: Song, Narrative, Dance, and Drama 1050-1350. Cambridge: Cambridge University Press, 1986. [Melodic analysis of Bernart de Ventadorn's Can l'erba fresca on pp. 26-33, especially with regard to the "number principle": stanza, line, and syllable count, patterns of rhyme, and metrical virtuosity.]

689.

Switten, Margaret. "De la sextine: amour et musique chez Arnaut Daniel.” In $\mathbf{1 5 1}$, Mélanges Bec, 1991, pp. 549-65. [Text of Lo ferm voler from Toja, with French translation from Bec, 1979, music transcribed by Switten; detailed analysis of the circular structure, with parallels in Plato's Timaeus; the rhyme-words evoke different forms of love; parallels between melodic structure and rhyme structure; as the demiurge of Plato seeks to reestablish the musical harmony of the universe by reconciling its contraries, Arnaut seeks to create, as an artisan of language, a poetic view of harmony through love.]

\section{0.}

\subsection{Electronic Resources for Musicology}

The journal Le Médiéviste et l'Ordinateur, published by the Institut de recherche et d'histoire des textes, has dedicated number 39, Winter 2000, to "La musicologie médiévale et l'ordinateur," which offers a list of links to sites of interest for all aspects of medieval music: Online at http://www.lemo.irht.cnrs.fr.

\section{1.}

Website: The Medieval Lyric http://www.mtholyoke.edu/acad/medst/medieval_lyric/ index.html. [Contains teaching materials and links regarding medieval Occitan music.]

\section{2.}

\subsection{Discography}

Early Music: http://www.medieval.org/emfaq/. [Very wide reference for recordings of European medieval and Renaissance music; listing of troubadours, giving number of songs, dates, and location, from $\ \mathbf{2 4 0}$, Zuchetto/Gruber, Le Livre d'or, 1998; individual discographies by Pierre-F. Roberge; see http://www.medieval.org/emfaq/composers/trobador/faidit.html (seventeen songs by Gaucelm Faidit); http://www.medieval.org/emfaq/ composers/trobador/vidal.html (twenty-two songs by Peire Vidal); http://www.medieval. org/emfaq/composers/trobador/ventadorn.html (twenty-four songs by Bernart de Ventadorn, including fifty-seven different performances of Quan vei la lauzeta mover).] 
693.

See 236, Riquer, La poesía, 2002, 1:1xiii-lxiv. [Discography of nineteen items up to 2000; no indication of contents.]

694.

See 608, Rosenberg et al., Songs, 1998, pp. 369-70. [Thirty-eight CD-ROM listings, of which at least twenty contain Occitan; individual songs on each CD are not listed; thirty-seven Occitan songs from the anthology are on the accompanying CD.] 695.

See 592, Switten, Music and Poetry, 1995, pp. 323-61 [Seventy-two listings, many containing Occitan songs, giving detailed contents and descriptive commentary, indicating performance style, provision of original text and translation.]

\section{The Trobairitz}

[Women may be present in the tradition in a number of ways: as domna, as dedicatee of a poem (more than three hundred), as patron of poets (five are known), or as trobairitz composer of poems (as many as forty-six, as few as none; about twenty names are known).]

\subsection{Medieval Women}

696.

See 633, Boynton, "Women's Performance," pp. 47-65. [Music historians have neglected to take full account of gender in the composition and performance of secular song, whereas literary and historical accounts suggest that women played an important role in the creation, performance, and transmission of lyric poetry; pp. 51-53: trobairitz are linked to Arab traditions, in which women have a literary role and a voice in their society; poetic dialogues between men and women are important in both societies.]

697.

Brunel-Lobrichon, Geneviève. "Images of Women and Imagined Trobairitz in the Béziers Chansonnier." In 132, Paden, Voice,1989, pp. 211-25. [Portraits of three trobairitz drawn in the late seventeenth and early eighteenth centuries, portraying Castelloza as religious, Azalais de Porcairagues as a prostitute, and Comtessa de Dia as a dramatic figure; the three images are reproduced; Brunel-Lobrichon claims that in the short "golden days" of the trobairitz, ca. 1180-1230, women had a privileged social position and could become "active" in love as in writing; but the patriarchal system was soon reestablished, as indicated by the varied representations of our trobairitz as pious, promiscuous, or rhetorical in place of the idealized portraits of the thirteenth century; appendix contains PC 109,3, PC 43,1, and PC 46,4 from the Béziers manuscript with facing texts from MS $I$.]

\section{8.}

Cheyette, Fredric L. "Women, Poets and Politics in Occitania." In Aristocratic Women in Medieval France. Edited by Theodore Evergates. Philadelphia: University of Pennsylvania Press, 1999, chapter 5, pp. 138-77 and notes pp. 225-33. [The courts of 
Ermengarde de Narbonne and Marie de Montpellier; description of an evening's entertainment in the castle; general introduction, from the historical point of view, to Occitan poetry, attempting to fix the audience and the social role of the songs; rejects the theory (Duby, Köhler) that the poetry was an expression of the struggle of the young, powerless knights against their feudal lords; instead, it was an eroticization of power relations within the court society of the time, serving to implant the proper ethos and to elaborate the code of behavior that supported it; analysis of text and music of Comtessa de Dia's $A$ chantar m'er to illustrate the close parallel between the traditional feudal loyalty between men and the concept of fin'amor.]

699.

Cheyette, Fredric. Ermengard of Narbonne and the World of the Troubadours: Conjunctions of Religion and Power in the Medieval Past. Ithaca, NY: Cornell University Press, 2001. [A stimulating demonstration of the cross-influence of historical and literary analysis. Chapter 13: troubadours and trobairitz at Ermengarde's court; provocative ideas about political involvement of the poets and their poetry in court activities, use of the vocabulary of love in feudal agreements, role of poetry in promoting the political agenda of the sovereign, and poets as spokespersons for their leader.]

700.

Dronke, Peter. Women Writers of the Middle Ages: A Critical Study of Texts from Perpetua (†203) to Marguerite Porete (†1310). Cambridge: Cambridge University Press, 1984. [Chapter 4: "Personal Poetry by Women: The Eleventh and Twelfth Centuries," pp. 84-106, esp. pp. 97-106: a brief presentation of Tibors, Iseut and Almuse de Castelnau, Alais, Lady Carenza, Yselda, and Comtessa de Dia.]

701.

Earnshaw, Doris. The Female Voice in Medieval Romance Lyric. New York: Peter Lang, 1988. [A broadly based, daring study of European lyric; pp. 81-93: the persona of the female Occitan voice: more self-confident than in other cultures, rational, equal to the male; analysis of thirty-six poems in five thematic categories: joyful love, lament, dance song, light parody, and burlesque; the first two and the last two impart balance as reverse images; many comparisons with male and female poets in other cultures; chapter 5, pp. 145-63, is devoted to the trobairitz: Tibors, Comtessa de Dia, Castelloza, the preponderant role of tensos, and the characteristics of women's songs; see complementary discussion in $\mathbf{3 8}$, Mölk, 1989, pp. 13-47.]

702.

Edwards, J. Michele. "Women in Music to ca. 1450." In Women and Music: A History. Edited by Karin Pendle. Bloomington: Indiana University Press. 2nd edition, 2001, pp. 26-53. [See "Medieval Lyric," pp. 29-32: a brief overview touching on trobairitz, female minstrels, etc. throughout Europe and elsewhere; the problems in establishing a trobairitz corpus; themes, poetic and musical style, and challenging the masculine discourse.]

703.

Martinengo, Marirì. "Il messaggio delle Trovatore." In $\mathbf{1 0 0}$, AIEO 7, 2003, pp. 521-32. [Generalized overview of women patrons, about twenty trobairitz, a number 
of anonymous women poets, and some who have names but no poems; discusses the trobairitz as part of a continuous tradition from the Hispano-Arabic through the early Italian tradition; finds women poets particularly adept at intersocial relations and didacticism.]

704.

Paden, William D. "Some Recent Studies of Women in the Middle Ages, Especially in Southern France." Tenso 7 (1992): 94-124. [Survey of scholarship, mostly late 1980 s and early 1990s, on the trobairitz and on the status of medieval women in southern France; pp. 95-99: more detailed discussion of Bloch's Medieval Misogyny, -363, pp. 104-5: A. Rieger's Trobairitz, 735, with analysis of recent work by Paterson, Kay, Saouma, Gaunt, Städtler, Poe, and many others.]

705.

Rieger, Angelica. "Ins e.l cor port, dona, vostra faisso: image et imaginaire de la femme à travers l'enluminure dans les chansonniers de troubadours." CCM 28 (1985): 385415. [Analysis of all pictorial images representing women and trobairitz in illuminated manuscripts, especially the "comic-strip" marginalia in $N$ (New York, Pierpont Morgan Library, MS M. 819); complete documentation for $N$ on pp. 406-15.]

706.

Rieger, Angelica. "Beruf: joglaressa: die Spielfrau im okzitanischen Mittelalter." In Feste und feiern im Mittelalter: Paderborner Symposium des Mediävistenverbandes. Edited by Detlef Altenburg et al. Sigmaringen: Jan Thorbecke, 1991, pp. 229-42. [Distinguishes the social position of the humble joglaressa and that of the noble trobairitz, while denying the association of the joglaressa with the putas; considers the soldadeira the female equivalent of the joglar.]

\subsection{General Studies of Trobairitz}

\subsubsection{Annotated Bibliography}

707.

Pendle, Karin. Women in Music: A Research and Information Guide. New York: Routledge, 2005. [Pp. 168-79: "Middle Ages": annotated bibliography up to 2002; fiftyfive entries, mostly from the 1980s and 1990s, twenty-three of direct interest for Occitan studies; helpful critical evaluations.]

708.

Schaus, Margaret. Feminae: Medieval Women and Gender Index. [Very broad collection of bibliographical information, including trobairitz.] Online at http://inpress. lib.uiowa.edu/feminae/Default.aspx.

\subsubsection{Encyclopedias}

709.

See 38, DLF, 1993. [Pp. 1450-51: “Trobairitz," succinct article by Geneviève Brunel-Lobrichon stresses women's independence in the South, active participation in poetry; outline of problems: are they historical people, poets, or poetical senhals, 
part of the masculine literary game? Many took part in tensos or exchanges of coblas or acted as arbiters in quarrels; the corpus is still controversial, interpretations still open; rich bibliography; listings for some named trobairitz (Comtessa de Dia, Gormonda, Castelloza, etc.).]

710.

Margolis, Nadia. "Trobairitz," article in $>$ 46, Women, 2004, 2:902-4. [Brief introduction to the trobairitz; also succinct articles with basic bibliography for all twentyone known trobairitz by June Hall McCash, Herman Braet, Matilda Tomaryn Bruckner, Merritt R. Blakeslee, and Roy Rosenstein.]

711.

Paden, William D. "Trobairitz," article in \$4, Medieval France, 1995, pp. 927-28. [Brief introduction to history, statistics, corpus (ca. twenty known trobairitz, thirtytwo songs), style, and relationship to the realities of society.]

\subsubsection{Introductory Studies}

712.

Sankovitch, Tilde. "The Trobairitz." In $>$ 282, Troubadours, 1999, pp. 113-26. [History of recent scholarship on the trobairitz, their corpus, their historical reality, their particular style, the definition of a female voice; pp. 118-25: detailed study of cansos by Azalais de Porcairagues, Comtessa de Dia, Castelloza, Bietris de Romans, and two tensos.]

713.

Bruckner, Matilda Tomaryn. "The Trobairitz." In 281, Handbook, 1995, pp. 20133. [Introduction to scholarship on the trobairitz, problems of historical reality, corpus, characteristic style, social reality, the part they played in establishing the poetic message of finamors; detailed consideration of the trobairitz corpus, adding two poems by named composers to Bogin's twentythree, and nine anonymous poems that may be by women, leaving the number open to amendment as scholarship advances; discussion of recent work in the literary analysis of trobairitz songs and directions for further research.]

714.

Callahan, Anne. "The Trobairitz." In French Women Writers: A Bio-Bibliographical Source Book. Edited by Eva Martin Sartori. New York: Greenwood, 1991, pp. 495502. [Broad introduction to sociohistorical presence of women poets in southern France; major themes: female desire, feminine perspective on fin'amors, anguish and confusion in dealing with the love ethic, less emphasis on the poetic role; list of twenty-one trobairitz with identification and characterization of each; survey of trobairitz scholarship up to 1989.$]$

715.

Huchet, Jean-Charles. "Trobairitz: les femmes troubadours." In Voix de femmes au Moyen Âge: savoir, mystique, poésie, amour, sorcellerie XIIe-XVe siècle. Edited by Danielle Régnier-Bohler. Paris: Robert Laffont, 2006. [Pp. 3-14: "Introduction": brief history of scholarship; problems of corpus, identity, and distinguishing between 
textual feminism and biological gender; importance of dialogue forms (tenso, partimen, exchange of coblas); bibliography to 1991; pp. 15-73: anthology of thirty-three poems in French translation only, based on texts by A. Rieger, $>735$.]

\section{6.}

Riquer, Isabel de. "Las trobairitz." In Breve historia feminista de la literatura espanola. Edited by Iris M. Zavala. 6 vols. Barcelona: Anthropos, 1993-2000, 6:27-39. 2nd edition, 2000, updated, at least in bibliography. [Treats the forty-six poems and twenty trobairitz as "real," active ca. 1135-1240; history of scholarship: not appreciated since their poetry was considered simple and emotional; now recognized as richer and more ambiguous than formerly thought; two Catalan women poets are presented at the end.]

717.

\subsubsection{Specialized Studies}

See 88, Paden, "State of Medieval Studies," 2006, pp. 137-55. [Identifies the trobairitz as one of the pressing themes for ongoing research: an adequate understanding of their role remains a matter of urgency, complicated by current developments in gender studies; discussion of $\mathbf{1 3 2}$, Paden, Voice, 1989, $\mathbf{7 3 1}$, Bec, Chants d'amour, 1995, 735, A. Rieger, Trobairitz, 1991, 733, Bruckner et al., Songs, 1995; see also Paden, "Azalais de Porcairagues," in 120, Medieval Lyric, 2000, and Cheyette in 699, Ermengarde, 2001.]

718.

Amtower, Laurel. "Private Desire and Public Identity in trobairitz Poetry." Dalhousie French Studies 73 (2005): 3-18. [The paradox of asserting a feminine voice within the masculine conventions of fin'amor. Agrees with Bloch 363 that the poetry is essentially misogynistic; the inaccessible and mysterious domna figure is replaced in trobairitz lyric by a very concrete and vocal feminine figure who appropriates the prestige of being in love, and through a public expression of her love, takes on an identity that is consecrated by the society of the court.]

719.

Bec, Pierre. "Trobairitz et chansons de femme: contribution à la connaissance du lyrisme feminine au moyen âge.” CCM 22 (1979): 235-62. [An influential and controversial article, in which distinction is made between "féminité génétique" (a real woman) and "féminité textuelle" (a feminine voice in a poem whose author may be male or female); detailed study of the place of the trobairitz in the sociopoetical system of the troubadours; their characteristic style; calls for much more detailed and sensitive analysis; feels that the trobairitz were more comfortable with the "style popularisant" (more emotional, more realistic, more sensual) and that their poetry struck an uneasy compromise between this and the elevated style of the troubadours; see objections by Grimbert 759, "Diminishing the trobairitz."]

720.

Bonnet, Marie-Rose. "Les trobairitz et la maladie d'amour." In $>\mathbf{1 0 1}$, AIEO 8, 2009,1:207-26. [Renewed interest in preventive medicine in the twelfth century 
is reflected in the poetry; the body becomes as important as the heart or the soul; mezura becomes a medical as well as a moral ideal; love is defined as melancholia, a form of insanity (cured by sexual intercourse, or discussion with friends, or listening to music); the trobairitz seem more aware of the realistic medical side of the love passion, and more concerned with avoiding its dangers for themselves and their lovers.] 721.

Hancke, Gwendoline. "La poésie des trobairitz: le sirventès de Gormonda de Monpeslier." In 130, Troubadours et cathares, 2004, pp. 101-18. [Succinct definitions and study of how the trobairitz managed to integrate themselves into the masculine world of trobar and how they were judged by their contemporaries; fixes the corpus of trobairitz poems at a maximum of forty-six (A. Rieger) and a minimum of twenty-three; sees the trobairitz role as halfway between an independent person and her poetic role as domna; detailed commentary of the sirventes of Gormonda de Monpeslier, the first woman in France to write a political poem, almost fanatically hostile to Catharism and to her "confrère" Guilhem Figueira.]

722.

Jullian, Martine. "Images de trobairitz." CLIO: Histoire, fermmes et sociétés [Musiciennes] 25 (2007): 165-83. [The stereotyped images of trobairitz are part of the fiction revealing the moral and social nobility of the domna figure, the ideal vision of the perfect lady sung by the troubadours; information on eight trobairitz.]

723.

Léglu, Catherine. "Did Women Perform Satirical Poetry? Trobairitz and soldadeiras in Medieval Occitan." Forum for Modern Language Studies 37 (2001): 15-25. [Argues that women performed some satirical and political poems before audiences; scholars have been slow to recognize the performance of women, especially in these poems that are not concerned with love, the topic deemed (by scholars) to be most suitable for women.]

724.

Nicholson, Francesca. "La mise en page des trobairitz: ordre fractal et espace performatif dans les chansonniers $N$ et $H$." In 100, AIEO 7, 2003, pp. 565-78. [Influenced by theories of fractal structuring in the universe and in everyday nature, Nicholson suggests that there are dynamic forces at work within the chansonniers that depend as much on the participation of each reader as upon the intentions of the compilers; the chansonnier $N$, for example, is not a single unit but is made up of various "spaces" (texts, illuminations, blanks), each of which may be reduced to smaller and smaller units by fractal ordering; the texts themselves and their parts have an inner dynamic which may react with that of other widely separated texts, making the chansonnier into a living performative space; close attention is given to the tenso between Alamanda and Giraut de Bornelh (PC 242,69 = 12a,1), which seems to function as an introduction to the trobairitz presence in most of the manuscripts that contain their songs.]

725.

See 294, Paterson, World, 1993, pp. 256-65. [The presence of women in Occitan 
literature; their social status; establishing the trobairitz corpus; difficulties of adapting the canso for a female voice; trobairitz especially active in dialogue poems; and Gormonda's assertiveness.]

726.

See 377, Ribémont, Sexe et amour, 2007. [Pp. 45-49: the trobairitz are real; they sing a love which is more open and frank, more modern; they play with the code of finamors and maintain a leading role for women.]

727.

Riquer, Isabel de. "Tota dona val mays can letr'apren: las trobairitz." In Mujeres y literatura. Barcelona: Promociones y Publicaciones Universitarias, 1994, pp. 19-38. [Rich introduction to the social background and relationship of women poets to men; notes differences in their interpretation of fin'amor, women turning the typical troubadour balance between joi and dolor more toward dolor; and ambiguous mixture of idealization of women and misogyny in much of troubadour poetry.]

728.

Rosenn, Eva. "The Discourse of Power: The Lyrics of the Trobairitz." Comitatus 21 (1990): 1-20. [Examines discursive strategies of the trobairitz, as they manage briefly to "speak through the cracks" in their own language, to protest against the contradictions inherent in the masculine discourse of the troubadours.]

729.

Sakari, Aimo. "La forme des poésies des trobairitz." In Miscellanea di studi romanzi offerta a Giuliano Gasca Queirazza. Edited by Anna Cornagliotti et al. 2 vols. Alessandria: Edizioni dell'Orso, 1988, 2:931-47. [Analysis limited to the structural outlines of the poems; listing of twenty-four poems by seventeen named poets and two anonymous; Sakari's remarks on content are colored by an unfortunate attitude of condescension toward the trobairitz as a group.]

730 .

Spampinato Beretta, Margherita. "Les trobairitz: la voix féminine au moyen âge." RLaR 100 (1996): 17-48. [A thoughtful analysis of the whole field of trobairitz poetry, attempting to express its complexity and ambiguity while distinguishing it in several ways from the dominant ideological system of the troubadour tradition.]

\subsection{Anthologies of Trobairitz Poetry}

731.

14.3.1. Complete Anthologies

Bec, Pierre. Chants d'amour des femmes-troubadours: Trobairitz et chansons de ferme. Paris: Stock, 1995. [Includes twenty-five poems, most with text from A. Rieger: fourteen cansos by six named trobairitz and two anonymous; participation in ten tensos by eight other trobairitz, one by Domna $\mathrm{H}$ and one anonymous; salut d'amor by Azalaïs d'Altier; nine feminine-voice popular poems, most anonymous, but one each by Raimbaut de Vaqueiras, Cadenet and Cerveri; rich bibliography.] 
732.

Bogin, Meg. The Women Troubadours. New York: Paddington Press, 1976. Also New York: Norton, 1980; and in Catalan, with "poetic" translation by Alfred Badia, Barcelona: LaSal, 1983. [Provides twenty-three poems with English translation and commentary; a pioneering popular presentation, giving historical and philological information; largely superseded, but useful for availability of texts.]

\section{3.}

Bruckner, Matilda Tomaryn, Laurie Shepard, and Sarah White. Songs of the Women Troubadours. New York: Garland, 1995; revised (paper) 2000. [Detailed introduction by Bruckner sketches the place of women poets within the masculine poetic system, the slight biographical and social evidence, an overview by genre, and a discussion of the problem of identifying a "female voice"; thirty-six texts, edited anew by Shepard, each from a single base manuscript; English translations by White are on facing pages; replaces older anthologies by Schultz-Gora and Bogin.]

\section{4.}

Martinengo, Marirì. Le trovatore. Vol. 1: Poetesse dell'amor cortese. Testi provenzali con traduzione a fronte. Introduction by Michel Pereira. Milan: Libreria delle donne di Milano, 1996.Vol. 2: Poetesse e poeti in conflitto. Preface by Angelica Rieger. Milan: Libreria delle donne di Milano, 2001. Spanish edition: Madrid: Horas y Horas, 1997. [Introductory presentation on sociohistory of the trobairitz, their biographies, their songs; vol. 1 has thirty-three songs, some fragmentary, with Italian translation; vol. 2 has twelve tensos between a woman and a man, and four "suffering" songs by trobairitz, plus extensive excerpts in Italian translation only. See also Martinengo's 2003 online presentation "Oggi parleremo d'amore," a broad introduction to trobairitz poetry, with musical interpretation of songs of Comtessa de Dia and Castelloza: http://www.url.it/donnestoria/testi/trovatore/trovrelmar.htm.]

\section{5.}

Rieger, Angelica. Trobairitz: Der Beitrag der Frau in der altokzitanischen höfischen Lyrik. Edition des Gesamtkorpus. Beihefte zur ZrP 233. Tübingen: Niemeyer, 1991. [The standard edition and study of the trobairitz poems; nineteen women are known by name (plus Domna $\mathrm{H}$ ); the corpus is expanded to forty-six by the inclusion of all texts that appear to express a feminine voice; includes cansos, debate poems, pastorelas, single coblas, sirventes, a salut, and a planh; twenty-three poems by named trobairitz and twenty-three anonymous, newly edited from the manuscripts, full variant listings, rich bibliography. Glynnis M.Cropp, NZJFS 18 (1997): 39, suggests that English readers may wish to use this alongside Poe's review, $R P h 49$ (1996): 335-43, and Matilda Bruckner's chapter in 281, Handbook, 1995, pp. 201-33.]

736.

Städtler, Katharina. Altprovenzalische Frauendichtung (1150-1250): historisch-soziologische Untersuchun und Interpretationen. Heidelberg: Winter, 1990. Germanischromanische Monatsschrift, Beiheft 9. [Skeptical of feminist approach that links the trobairitz to the history of "écriture féminine"; reduces corpus to twenty songs, four of which are anonymous, the rest by twelve named trobairitz; the twenty poems are 
reprinted from standard editions; following Erich Köhler, Literatursoziologische Perspektiven, Heidelberg: Winter, 1982, she links their actions to social conditions of the later twelfth century; they had no discourse of their own but adapted their songs to the masculine troubadour tradition.]

\subsubsection{Specialized Anthologies}

737.

Mölk, Ulrich. Romanische Frauenlieder. Munich: Fink, 1989. [Anthology of sixty lyric poems from the Romance tradition: nine in Occitan (pp. 52-77), one by Azalais de Porcairagues, one by Clara d'Anduza, seven anonymous; other songs in French, Italian, Catalan, and Galician; the introduction concerns the scholarly history of defining "women's poems" as a distinct entity, especially in the Galician tradition; complex problems of genre typology and attempts to distinguish "popular" and "elevated" style do not seem to apply helpfully to the trobairitz poems; new critical editions, with German translation, commentary, and copious notes; see complementary discussion in 701, Earnshaw, Female Voice, 1988.]

738.

Nappholz, Carol Jane. Unsung Women: The Anonymous Female Voice in Troubadour Poetry. New York: Peter Lang, 1994. [Anthology of twenty-six songs attributed to anonymous women poets, with English translation; it is left uncertain whether some of the poems may be by women, or by men writing in a woman's voice; see also her article "(Re)locating Lost Trobairitz: The Anonymous Female Voice in Provençal Debate Poems," Tenso 7 (1991-92): 125-41, a review of scholarship on the trobairitz, arguing for the reality of many of the anonymous domnas in tensos; Bogin, -732, 1976, listed twenty-three poems as the corpus, three of which were anonymous participants in tensos; Paden's checklist in 132, Voice, 1989, listed forty-six, half anonymous; 735, A. Rieger, 1991, listed forty-three; $>$ 733, Bruckner, 1993, listed thirty-six; we still lack clear criteria to assess their identity as women.]

739.

Paterson, Linda M. "Five trobairitz tensos and partimens: A New Critical Edition." RST 6-7 (2004-5): 191-245. [New critical editions, with full philological study for each poem, English translation, commentary, and copious notes; extensive bibliography, pp. 239-45.]

740.

Thiébaux, Marcelle. The Writings of Medieval Women. New York: Garland, 1987. 2nd edition, 1994. [Chapter 11, pp. 241-76: "The Women Troubadours," gives introduction, anthology of nine songs, in English translation only, by Tibors, Lombarda, Comtessa de Dia, Almuc de Castelnou and Iseut de Capio, Bietris de Romans, Alaisina/Iselda/Carenza, Gormonda, Azalais de Porcairagues, and anonymous.]

741.

\subsection{Feminist, Gender Criticism}

Gaunt, Simon. "Poetry of Exclusion: A Feminist Reading of Some Troubadour 
Lyrics." MLR 85 (1990): 310-29. [Questions the assumption that courtly love literature is about women, and attempts to expose the patriarchal structures within the texts written by men (works of the trobairitz are excluded); homosocial desire is more important than the fictional poet/lady relationship; many lyrics are directed to a male rather than a female listener; discussion involves five major troubadours: Arnaut Daniel, Bernart de Ventadorn, Guilhem de Peitieus, Marcabru, and Raimbaut de Vaqueiras.]

742.

Gravdal, Kathryn. "Metaphor, Metonymy and the Medieval Women trobairitz." $R R$ 83 (1992): 411-26. [A vigorous account of the feminist reinterpretation of trobairitz poetry, with much stress on phallocentrism and misogyny; claims that troubadours used metaphor to portray the lover as being like a helpless woman, while women poets used metonymy to suggest that their position in the poetry reflects their actual social position; in her tenso, Garsenda begs the man to court her; likewise, Castelloza undermines the courtly fiction of the powerful domna by mimicking the role of the masculine lover as rejected, submissive, and patient; the Comtessa de Dia laments that she has lost her lover by playing the role of the powerful domna instead of her real role of subjection; she debunks most of the male posturing in the cansos; she (and Gravdal) claim that female self-expression is prevented by male narcissism and misogyny.]

743.

Jewers, Caroline. "Reading and Righting: Issues of Value and Gender in Early Women Poets.” Exemplaria 10 (1998): 97-121. [Calls for the reevaluation of the trobairitz on their own terms, through their own poetic language, rather than from without; consideration of the unfair critical appraisal of women poets that is skewed by judgments based on their gender rather than their quality as poets; specific consideration of the Comtessa de Dia in relation to her own notions of value expressed in her poetry; feminist criticism may sometimes overstate the "reality" and "sincerity" of women poets, even though so little is known about the actual poets and their sociohistoric context; close analysis of poems by Azalais de Porcairagues, pp. 107-10, and Comtessa de Dia, pp. 111-21.]

744.

Nichols, Stephen G. "L’orgueil du manuscrit: sur un chansonnier des troubadours." In L'Orgueil de la littérature: autour de Roger Dragonetti. Translated by Jean-Marc Meylan. Edited by Jacques Berchtold and Christopher Lucken. Geneva: Droz, 1999, pp. 73-88. [Analysis of the ordering of poems in $N$; there are five poems by Guilhem de Peitieus, then six by trobairitz, then William's are repeated, suggesting a kind of debate; this may have been done on purpose, provocatively, by the scribe; William's two groups of poems begin and end with the cat poem, the others are in semiinverted form $(12345>34521)$, as though inviting readers to consider the macho poems, contrasting them with the very different tone of the trobairitz songs, then looking at them again in light of the feminine responses; Nichols challenges convention by painting the trobairitz as worthy of the classical Greek writers but has found convincing evidence of a conscious "layout" of the material in N.] 
745.

Nicholson, Francesca. "Seeing Women Troubadours without the -itz and -isms." In Troubled Vision: Gender, Sexuality and Sight in Medieval Text and Image. Edited by Emma Campbell and Robert Mills. Basingstoke: Palgrave Macmillan, 2004, pp. 63-76. [The notion of gender interplay is more useful than the tendency to overfeminize the trobairitz and force them into a limiting female identity; analysis of two poems: Bietris de Roman's Na Maria, pretz e fin valors (PC 16a,2) and Azalais d'Altier's Tanz salutz e tantas amors (PC 42a,1); in both, the "I" is saying that the position and identification of that "I" is changeable: the two trobairitz sometimes speak in the identity of a male lover and sometimes speak as women; in this Lacanian reading, "no single identification is claimed, and none is rejected (72)."]

746.

Oliver, Sophie. "Subversive Acts: Female Voice and Performance in the Songs of the trobairitz." French Studies Bulletin 95 (2005): 2-7. [The trobairitz lyric is a means of using irony to undermine and deconstruct masculine discourses of gender to establish a space where the female voice may find expression. The Comtessa de Dia and Maria de Ventadorn perform the role of the domna to point out the gap between the promises made by the troubadours and reality; Castelloza mimics the male role of martyr to reconstruct her own feminine identity as subject rather than object; the dialogues of the trobairitz are not only with male poets but also with lauzengiers and with other women.]

747.

See 792, Sankovitch, "Lombarda's Reluctant Mirror," 1989, pp. 183-93. [Lombarda's exchange with Bernart Arnaut is analyzed in light of feminist psychoanalysis à la Luce Irigaray, in which Lombarda frees herself from being the man's mirror and goes through the looking-glass to female self-discovery; see a similar analysis in - 783, Labbie, "Vacant Mirror," 1995.]

748.

Peters, Ursula. "Frauenliteratur im Mittelalter? Überlegungen zur Trobairitzpoesie, zur Frauenmystik und zur feministischen Literaturbetrachtung." Germanischromanische Monatsschrift 69, n.F. 38 (1988): 35-56. [Claims that the search for an authentic female voice in the trobairitz poetry has not been successful; Bogin was naive; Bec thought that they were caught between the two registers of "aristocratisant" and "popularisant" and confused by the contradictions; in spite of wishful thinking on the part of feminist scholarship, neither the trobairitz nor the German women writers were able to establish a genuine female literary voice; both remained bound in the preestablished conventions of style, themes, and genre established by men.]

749.

\subsection{Establishing the Trobairitz Corpus}

Bruckner, Matilda Tomaryn. "Debatable Fictions: The Tensos of the Women Troubadours." In Literary Aspects of Courtly Culture. Selected Papers from the Seventh Triennial 
Congress of the ICLS. Edited by Donald Maddox and Sara Sturm-Maddox. Woodbridge: Brewer, 1994, pp. 19-28. [The main issue of debate in tensos between male and female speakers is the sexual balance of power; whether the participants are real or fictional is not certain and cannot be proved easily; Bruckner bases her work on a corpus of sixteen tensos (out of A. Rieger's twentysix) that she believes could involve real women, with a detailed look at the debate between Alamanda and Giraut de Bornelh (PC 242,69 = 12a,1).]

750.

Krispin, Arno. "La tradition manuscrite des trobairitz: le chansonnier $H$." In $\square \mathbf{9 5}$ AIEO 2, 1993, 1:231-42. [Close study of the place of the trobairitz poems in the manuscript; identifies three more female voices in an anonymous planh and two tensos under the name of Guilhem Rainol; enriches the "registre féminin," maintaining that the female voice should be recognized not through biography but through language.]

751.

See 132, Paden, Voice, 1989. [The introduction, pp. 1-28, outlines sociohistorical background and has useful observations on defining trobairitz style; pp. 227-37: detailed information on twenty trobairitz in "Checklist of Poems by the Trobairitz"; pp. 227-37: discussion of the difficulty of establishing the corpus, a problem examined also in 755 , Zufferey, and $\mathbf{7 5 8}$, Chambers.]

752.

See 527, Poe, "Another salut, 1990. [Argues for the status of PC 42a as a salut d'amor; examines the probability that it was composed by the trobairitz Azalais d'Altier or, alternatively, by Uc de Saint Circ; text in appendix, with notes, no translation; see also Poe, "Un poème marginal," in \$ 95, AIEO 2, 1993, 1:283-88.]

\section{3.}

See 735, A. Rieger, Trobairitz, 1991. [Expands the trobairitz corpus to forty-six by adding texts, or parts of texts, that express a feminine voice, including debate poems, pastorelas, single strophes, sirventes, and other genres.]

\section{4.}

Rosenstein, Roy. "Ubi sunt? Three Lost (and Found) Ladies in the Troubadour Lyric." In Medieval Constructions in Gender and Identity: Essays in Honor of Joan M. Ferrante. Edited by Teodolinda Barolini. Tempe: Arizona Center for Medieval and Renaissance Studies, 2005, pp. 87-102. [Focuses on: (1) Alis/Elis, the real name hidden under the senhal Alixandres or Belhs Alixandres in two poems by Guiraudo lo Ros, as an acrostic in a third poem, and as a (corrected) equivocal rhyme in a fourth, confirming the attribution of four out of Giraudo's seven songs; (2) Sarrazina, wife of Hugh VII of Lusignan, on whose grave he swore to go on the fatal Second Crusade, is mentioned at the end of Jaufre Rudel's song Quan lo rius; (3) Caudairenca, sometime wife of Raimon de Miraval, was apparently a historically real trobairitz, mentioned in a sirventes by Uc de Mataplana and a reply by Raimon: see 227, Riquer, Los Trovadores, 1975, 2:985, though none of her songs is extant.] 
755.

Zufferey, François. "Toward a Delimitation of the trobairitz Corpus." In 132, Paden, Voice, 1989, pp. 31-43. [Careful examination of the whole corpus, genre by genre and poem by poem, results in a "final" tally, before A. Rieger, of eleven cansos, two or three baladas, one alba, one salut, three sirventes, three partimens, seven exhanges of coblas, and as many as sixteen tensos; forty-five in all, omitting Bietris de Romans.]

756.

\subsection{Real Women or Fictitious?}

Anderson, Patricia. "Na Carenza al bel cors avinen: A Test Case for Recovering the Fictive Element in the Poetry of the Women Troubadours.” Tenso 2 (1987): 55-64. [Close study of the tenso between $\mathrm{Na}$ Carenza and N'Alaisina Iselda, proposing that the two ladies are types, created by the anonymous poet as a dramatization of his message: this is a fictive imaginative poem meant to be entertaining, albeit unflattering to women; the satirical purpose seems clear, aimed at the figure of the domna and at the whole social convention of finamor; if it were to be read as a subjective courtly lyric, improvised by two real ladies, it would become, of course, a different poem.] 757.

See 797, Bruckner, "Mathematical Bodies," 1999. [Discussion of the tenso, or, rather, the exchange of coblas, between $\mathrm{Na}$ Carenza and Alaisina Iselda, PC 12,1 and 108,1 ; suggests that we cannot prove or disprove the reality of a body in a poem, nor its fictional construct, so that in "fuzzy logic" it is both at the same time.]

758.

Chambers, Frank M. "Las trobairitz soiseubudas." In 132, Paden, Voice, 1989, pp. 45-60. [Claims that all tensos in which the female speaker is unnamed were composed by male poets and doubts the existence of Alamanda and Domna $\mathrm{H}$; insists that only eight of the twenty-three debate poems have real feminine participants and that the other fifteen are the work of male poets using the feminine voice for rhetorical effect.]

759.

Grimbert, Joan Tasker. "Diminishing the Trobairitz, Excluding the Women Trouvères." Tenso 14 (1999): 23-38. [Critical of Bec's 1979 "Trobairitz et chansons de femme," which contains a bias that has skewed the scholarly contribution of women to medieval poetry; Bec claims that all chansons de fermme were male authored and that, since the trobairitz based their uniqueness on taking up the themes of the chansons de femme, their contribution is undermined; Grimbert insists that Bec for some reason is intent on deprecating the trobairitz; discussion of work by Gravdal, Gaunt, Städtler, and Tyssens.]

760.

See 1863, Guida, "Trobairitz fantomatiche?" 2001, pp. 411-33. [Reality demands a more careful assessment of the "anonymous" poets; some were probably women; the idea proposed by Frank Chambers, Pierre Bec, and others that the female-voice 
participants in some tensos may be fictitious trobairitz, in reality male poets, has no more or less validity than to say that the anonymous male-voice participants may be women in disguise; discusses the possible identities of Alamanda d'Estanc and Escaronha Jordan, whom he sees as two very real women; the song No puesc mudar no digua mon vejaire, PC 404,5, attributed to Raimon Jordan, is in a woman's voice, as shown by 2914, Asperti, Il trovatore Raimon Jordan, 1990, pp. 118-19, and - 448, Gaunt, Gender and Genre, 1995, pp. 160-65; this provokes several intriguing questions: could a copyist have misread R. Jordan for E. Jordan? Could E. Jordan be the Escaronha de l'Isla Jordan known to Arnaut Guilhem de Marsan, or the domna addressed by Giraut de Bornelh? Could the "anonymous" ladies of PC 461,56 be Alamanda (donzela) and Escaronha (bona domna)?]

761.

Huchet, Jean-Charles. "Les femmes troubadours ou la voix critique." Littérature 51 (1983): 59-90. [A provocative claim that all trobairitz are fictional characters on principle: "The feminine voice lends itself to the deconstruction of the themes of trobar through sly linguistic games," echoed by Georges Duby and to some extent by Pierre Bec, who included the trobairitz songs in the category of "contre-texte"; Huchet believes that trobairitz criticism has been marred by misogyny and by the simplistic naivety of early feminist criticism; now we must distinguish between poetic creation and social or sexual reality, by admitting that the trobairitz poems might represent a literary fiction; the textual markings of femininity in a poem are not to be confused with the actual sex of the author; the poetic language of the trobairitz depends on the masculine model, which it copies and parodies; sexual definition comes only through the grammar or vocabulary within the poem.]

762.

Lafont, Robert. "Varia: La voix des dames.” RLaR 101 (1997): 185-205. [Reaction to

- 313, Brunel-Lobrichon, Au Temps, 1997, to 735, A. Rieger, Trobairitz, 1991, and to 731, Bec, Chants d'amour, 1995; modern positivist criticism is anxious to see the trobairitz texts as authentic, created by historical poets with their individual reality, but Lafont cannot ignore the fact that the medieval poetry itself is already an affabulation; the trobairitz have an identity as participants in a social game, not as historical women; only the passion is real; for psychocritical analysis, fin'amor is based on the transfer of man-to-man homage, vassal to lord, to that of knight to lady, a relationship that Lafont sees as one of more or less sublimated homosexuality; the socio-sexual-poetic game seems to have been orchestrated at the court of Raimbaut d'Aurenga, who made it as ambiguous as possible; the real meaning of trobairitz poetry is that of an involution into masculine anguish and fantasy, in which the trobairitz symbolize masculine impotence when faced with the "other."]

763.

MacDonald, Aileen Ann. “The Female Tenso: Alamanda's Response to Guiraut de Bornelh." In The World and Its Rival: Essays on Literary Imagination in Honor of Per Nykrog. Amsterdam: Rodopi, 1999, pp. 79-92. [Sixteen tensos have a female voice, four of which are defined as the so-called "donzella tensos"; the identity of the female 
voice in shared tensos: was Alamanda a real person or a fictional creation by Giraut de Bornelh? MacDonald remains divided 50/50, or, based on internal evidence, a little in favor of her "reality"; on this problem, see 370, Ferrante, "Male Fantasy," 1984, pp. 67-97. The Alamanda figure is very down-to-earth, in contrast to the exaggerated suffering of the poet; in performance, this exchange could be dramatic, even comic.] 764.

Poe, Elizabeth Wilson. "A Dispassionate Look at the Trobairitz." Tenso 7, no. 2 (1992): 142-64. [Casts doubt on the historical reality of five of the seven anonymous trobairitz, maintaining only Garsenda and Guilhelma de Rosiers; Bietris de Roman may be in fact Alberico da Romano, as Schultz-Gora thought in 1891; intricate arguments for Uc de Saint Circ as author of Azalais d'Altier's canso, as well as the response to it by Clara d'Anduza, and of the exchange of coblas between Iseut de Capio and Almuc de Castelnou; but resemblance to Uc's work may reflect only his influence, not his authorship.]

765.

Rieger, Angelica. "En conselh no deu hom voler femna: les dialogues mixtes dans la lyrique troubadouresque.” Perspectives médiévales 16 (1990): 47-57. [Denies the fictionality of the mixed tensos, in response to Huchet and Duby, who consider the trobairitz themselves to be fictional; a systematic inventory and classification of tensos with a feminine voice: twenty-six poems (three between women, eight mixed with named women participants, thirteen mixed with anonymous women participants, two with feminine voice and role-playing; geographically and chronologically they fit into the general history of troubadour lyrics; subject matter (four thematic groups) and themes are traditional.]

766.

See 490, Zufferey, "Tensons réelles," 1999. [Close study of PC 32,1 by Arnaut Plages, which is unusual in form: a canso but with inner dialogic structure between the heart and the mind; there is no feminine interlocutor, and the poem must be removed from the trobairitz corpus; doubts the reality of Alamanda; laments the polarized scholarship concerning the reality of some trobairitz, pitting misogynistic denial against feminist all-inclusion.]

\section{7.}

\subsection{Distinguishing Features of Trobairitz Poetry}

Blakeslee, Merritt R. "La chanson de femme, les Héroïdes et la canso occitane à voix de femme: considérations sur l'originalité des trobairitz." In Farai chansoneta novele. Hommage à Jean-Charles Payen: Essais sur la liberté créatrice au Moyen Âge. Caen: Université de Caen, 1989, pp. 67-75. [Examines the narrative structures of twelve feminine cansos: oriented toward the past, fixed in the concrete, even anecdotic, as opposed to the masculine cansos; except for two by Comtessa de Dia, they are adaptations of the formal conventions of masculine lyric to the themes of abandonment, perhaps under the influence of the Heroides of Ovid: see also $\$ 777$, Shapiro, "Provençal Trobairitz," 1979.] 
768.

Bruckner, Matilda Tomaryn. "Fictions of the Female Voice: The Women Troubadours." In 121, Medieval Woman's Song, 2002, pp. 127-51. [Slight revision of her article in Speculum 67 (1992): 865-91; analysis of the work of twenty trobairitz, who experimented with literary and cultural definitions of sex and gender, manipulating the conventional format in which a male speaker addresses a distant, silent lady, inventing his own distinctive literary version of the female voice; pp. 877-80: close analysis of songs by the Comtessa de Dia and Castelloza to show how their narrative voice meshes different strands of lyric femininity.]

769.

Ferrante, Joan M. "Notes toward the Study of a Female Rhetoric in the trobairitz." In

- 132, Paden, Voice, 1989, pp. 63-72. [Tentative study of the cansos of the trobairitz compared with those of Bernart de Ventadorn, Peire d'Alvernhe, Arnaut Daniel, Peire Cardenal, and Sordello; finds "somewhat different" rhetoric among women poets: much more frequent use of the second person to address the lover, more frequent use of the negative and of the past tense, play on the pairing of masculine and feminine forms, making fun of exaggerated male rhetoric, especially in the tensos; see further considerations in 776, Marnette, "L'expression féminine," 1997.]

770.

Fraser, Veronica. "Two Contrasting Views of Love in the Songs of the Troubadours and the Trobairitz." Tenso 13 (1997): 24-47. [The male boasting of the gab (Guilhem de Peitieus, Peire Vidal) is not found in trobairitz poems, which stress the loss and frustration of love, even anger and resentment at their cold and boastful lovers or at patriarchal social constraints.]

771.

Grimbert, Joan Tasker. "Songs by Women and Women's Songs: How Useful Is the Concept of Register?” In 106, ICLS 9, 2003, pp. 117-24. [Suggests that Bec's registral distinctions are not useful, since they do not reflect distinctions used in medieval times; "popularisant" seems to imply inferiority; in fact there is much borrowing and intermixing of registers and genres.]

772.

Heidenreich Findley, Brooke. "Reading Sincerity at the Intersection of Troubadour/ Trobairitz Poetry: Two Poetic Debates.” Romance Quarterly 53 (2006): 287-303. [It is particularly the female figures who voice concerns about sincerity in men's poems; as outsiders to the masculinevoiced tradition, they speak from a more credible perspective; two debates, one in a tenso between Ysabella and Elias Cairel, PC 252,1 = 133,7, the other an exchange of coblas between Bernart Arnaut, PC 54,1, and Lombarda, PC 288,1.]

773.

Hurley, E. Anthony. "Justifying the Male: The Function of the Poem in Bernart de Ventadorn and Na Castelloza." Tenso 8 (1992-93): 26-41. [The voices of poet and lover in Bernart are closely interwoven: a close look at PC 70,31, 12, 39, 6 by Bernart and all four of Castelloza's songs: PC 109,1, 2, 3, and 461,191; both exalt the 
male persona, Bernart by vaunting his own qualities as poet and lover, Castelloza by singing her lover's praises while complaining of him; Bernart's poet derives power from writing his poem, while Castelloza is claiming the right to self-expression on a personal rather than professional level; hers is a polemic of protest which serves to validate the male-dominated sociopoetic system.]

774.

Kasten, Ingrid. "The Conception of Female Roles in the Woman's Song of Reinmar and the Comtessa de Dia." In 121, Medieval Woman's Song, 2002, pp. 152-67. Also in German in Germanisch-Romanische Monatsschrift 37 (1987): 131-46. [The comtessa's assertiveness is contrasted with the timidity of the women in Reinmar's Frauenlieder.]

775.

Kay, Sarah. "Derivation, Derived Rhyme, and the trobairitz." In 132, Paden, Voice, 1989, pp. 157-82. [Studies rhyme in its function "as a metaphor for the experience of poetic creation, and as a metonym for the meaning of the poetic text"; derived rhyme is analyzed in several troubadours and in the two trobairitz, Comtessa de Dia and Lombarda, who make elaborate use of it, perhaps because it is well suited to the themes of gender differences, male-female boundaries, and reciprocation.]

776.

Marnette, Sophie. "L'expression féminine dans la poésie lyrique occitane." $R P h 51$ (1997): 170-93. [Continuation of the search for a feminine rhetoric undertaken by 769, Ferrante, "Notes Toward the Study," 1989; two linguistic and stylistic analyses, one comparing ten cansos by four trobairitz (Comtessa de Dia, Castelloza, Azalaïs de Porcairagues, and Clara d'Anduza) with nine by four troubadours (Peire Vidal, Raimon de Miraval, Guilhem de Cabestanh, and Bertran de Born), the second examining twenty-two tensos containing dialogues between male and female characters; Marnette finds several linguistic and structural qualities that indicate a clearly original feminine discourse: the masculine discourse is "stronger" in that it remains stable, whereas the feminine is "weaker" in that it tends to adapt and avoid confrontation; but these differences, though clear in themselves, are difficult to interpret.]

777.

Shapiro, Marianne. "The Provençal Trobairitz and the Limits of Courtly Love." Signs: Journal of Women in Culture and Society 3 (1978): 560-71. [The structural principles of trobairitz poetry are similar to those of Ovid's Herö̈des: agonistic, esthetics of antithesis and internal contradiction, male agressivity and deceit, essentially negative; the female response is not just passivity and tragedy but is an understanding of the love relationship that needs to be learned by men poets, a contemplation that allows them to rise above their subjected state, to learn how to govern themselves and control their own destiny.]

\subsection{Individual Trobairitz}

778.

Bec, Pierre. "Avoir des enfants ou rester vierge? Une tenson occitane du XIIIe siècle 
entre femmes." In Mittelalterstudien: Erich Köhler zum Gedenken. Edited by Hemming Kraus and Dietmar Rieger. Heidelberg: Winter, 1984, pp. 21-30. [Provisional edition, with French translation, of PC 12,1 = 108,1, a unique tenso between $\mathrm{Na}$ Carenza and N'Alaisina Yselda on the topic of motherhood; philological analysis of the difficult text, establishing a down-to-earth meaning, probably parodic, in opposition to several mystical interpretations.]

\section{9.}

Bruckner, Matilda Tomaryn. "Na Castelloza, trobairitz, and Troubadour Lyric." $R N$ 25 (1985): 239-53. [Discusses the uniqueness of Castelloza's songs, each of which shows "a position that is simultaneously offensive and defensive"; presents some criteria for identifying the feminine voice in trobairitz poetry, claiming that Castelloza cleverly channeled other feminine lyric roles through the reconfigured stance of the courtly speaker to produce an "energetic fusion."]

780.

Dronke, Peter. “The Provençal trobairitz: Castelloza.” In Medieval Women Writers. Edited by Katharina M. Wilson. Athens: University of Georgia Press, 1984, pp. 131-52. [Castelloza is unique for her frank declarations of love, actively seeking, not waiting to be chosen; four of her songs are given in English translation only, no Occitan texts.]

781.

See 721, Hancke, "La poésie des trobairitz, 2004. [Pp. 111-18: detailed commentary of the sirventes of Gormonda de Monpeslier, the first woman in France to write a political poem, almost fanatically hostile to Catharism and to her "confrère" Guilhem Figueira, whom she thinks should be burned.]

782.

See 743, Jewers, "Reading and Righting," 1998. [Seeking to define a distinct feminized/feminist rhetoric, Jewers analyzes poems by Azalais de Porcairagues, pp. 107-10, and Comtessa de Dia, pp. 111-21; she finds no truly authentic female voice but a deep sense of reevaluation and the need to deconstruct and reconstruct them through their own poetic language.]

783.

Labbie, Erin F. “The Vacant Mirror in Lombarda's tenson.” RN 36 (1995): 13-26. [Curiously unaware of 792, Sankovitch, “Lombarda's Reluctant Mirror," 1989, which covers much of the same ground; postulates Lombarda as the sole composer of the tenso, creating the figure of Bernart Arnaut d'Armagnac as a fictive masculine voice to which she can respond freely, claiming back her liberty and maintaining her sense of self; she satirizes the male gaze, undermining its narcissism; the mirror must be destroyed before either can know the other.]

784.

Langdon, Alison. "Pois dompna s'aveld'amar: Na Castelloza's cansos and Medieval Feminist Scholarship.” Medieval Feminist Forum 32 (2001): 32-42. [Feudal metaphors in Castelloza; her speakers must be historicized; in many cases they have taken up the supplicant position of the male troubadours.] 
785.

Millay, S. Lea. "The Voice of the Court Woman Poet." In Crossing the Bridge: Comparative Essays on Medieval European and Heian Japanese Women Writers. Edited by Barbara Stevenson and Cynthia Ho. New York: Palgrave, 2000, pp. 91-116. [Poetry of Izumi Shikibu compared with that of Comtessa de Dia, both having the voice of the passionate woman.]

786.

See 745, Nicholson, "Seeing Women, 2004, pp. 63-76. [Two poems are analyzed: Bietris de Roman's Na Maria, pretz e fin valors, PC 16a,2, and Azalais d'Altier's Tanz salutz e tantas amors, PC 42a, 1 ; in both, the "I" is saying that the position and identification of that "I" is changeable; Nicholson argues that the two trobairitz sometimes identify with a male lover and sometimes speak as women.]

787.

See 2208, Paden et al., "Poems," 1981, pp. 158-82. [Critical edition of the four cansos of $\mathrm{Na}$ Castelloza, with English translation and extensive notes; intense searching for traces of her historical identity gives scant information, but enough to indicate that she was a real woman; attribution of the fourth song to her (PC 461,191) is "not unreasonable"; the tone of her songs is one of constant submission, suffering, and melancholy, from which she derives an almost masochistic satisfaction.]

788.

Rieger, Angelica. “Un sirventes féminin-la trobairitz Gormonda de Monpeslier." In - 94, AIEO 1, 1987, pp. 423-55. [PC 177,1 is a unique feminine sirventes, presenting a vigorous defense of the papacy in reply to the attack by Guilhem Figueira in PC 217,2; Guilhem's song itself is related to two other poems, whose chronology within the series is studied here in detail; new critical edition with French translation, notes; detailed contrastive analysis with Guilhem's poem.]

789.

Rieger, Angelica. "Was Bieiris de Romans Lesbian? Women's Relations with Each Other in the World of the Troubadours." In 132, Paden, Voice, 1989, pp. 73-94. [The prevailing ambiguity of gender identification in troubadour poetry sometimes makes it difficult to determine the intended orientation; detailed examination of the widely varied expression of friendship between women leads Rieger to deny lesbianism in Bietris de Romans as a product of modern misreadings of friendly affection; edition of PC 93,1 = 16a,2 with English translation.]

790.

Rieger, Angelica. "Alamanda de Castelnau, une trobairitz dans l'entourage des comtes de Toulouse?” In 131, Les Troubadours et l'état, 1995, pp. 183-92. [Revised version of an article in $\operatorname{ZrP} 107$ (1991): 47-57; argues that Alamanda is attached to the important Alaman family of Toulouse, possibly even to a historical lady, Alamanda de Castelnau, through evidence of her influence, intertextual connections, and some hypothesis based on a razo.] 
791.

Sakari, Aimo. “Azalais de Porcairagues, interlocutrice de Raimbaut d'Orange?” In - 95, AIEO 2, 1993, 1:369-74. Also in Neophilologica fennica 45 (1987): 430-40. [Explores the possibility that the link with Raimbaut, prior to their use of the reciprocal senhal "Joglar," was fixed as early as 1169; Sakari deduces a reference to Azalais in a poem by Giraut de Bornelh and in a tenso with Raimbaut, PC 39,6, in which the anonymous dona is probably Azalais, supposing that her active participation in the tenso would justify her later qualification as Joglar.]

792.

Sankovitch, Tilde. "Lombarda's Reluctant Mirror: Speculum of Another Poet." In - 132, Paden, Voice, 1989, pp. 183-93. [Sankovitch's “jewel-like” essay reads Lombarda's exchange with Bernart Arnaut in the light of feminist psychoanalysis à la Luce Irigaray, turning Bernart's male narcissistic mirror into a subversive reworking in which the trobairitz frees herself from being the man's mirror and goes through the looking-glass to female self-discovery; compare the similar analysis in $\mathbf{7 8 3}$, Labbie, "Vacant Mirror," 1995.]

793.

Siskin, H. Jay, and Julie A. Storme. "Suffering Love: The Reversed Order in the Poetry of Na Castelloza." In 132, Paden, Voice, 1989, pp. 113-27. [Examines the negative, suffering love that is characteristic of Castelloza and finds that her masochism leads paradoxically to an extraordinary sense of self-esteem; an attempt to explain why she is so compulsively masochistic: her poetic universe is entirely negative, as exemplified in her poetry by the mechanism of reversal - positive emotions or wishes are immediately deconstructed. Her suffering permits the exaltation of her virtue and righteousness, leading to a positive self-image.]

\section{4.}

Städtler, Katharina. "The sirventes by Gormonda de Monpeslier." In 132 , Paden, Voice, 1989, pp. 129-55. [A penetrating study (independent of 721, A. Rieger, 1987) of Gormonda's sirventes as a response to a poem by Guilhem Figueira (PC 217,1 ), imitating the metric structure and rhyme scheme cobla by cobla; transcription of both poems side by side, with a detailed and penetrating study of the intertextuality that links them; she mocks him by using the same structure and much of the rhyme scheme and vocabulary, while turning Guilhem's message on its head: he rants against Rome and the papacy, she supports Rome and the Albigensian Crusade.]

795.

Van Vleck, Amelia E. "Tost me trobaretz fenida: Reciprocating Composition in the Songs of Castelloza.” In 132, Paden, Voice, 1989, pp. 95-111. [In Amics, s’iéus trobes avinen, Castelloza makes the argument that women should compose their share of the world's love poetry; Van Vleck finds that Castelloza's poems are concerned with verbal power, as are those of the troubadours, as she tries to provoke from her lover a "reciprocal" text.] 


\section{Critical Approaches to Literary Analysis}

796.

\subsection{General Studies of Critical Methodology}

Benozzo, Francesco. Cartografie occitaniche. Approssimazione alla poesia dei trovatori. Naples: Liguori, 2008. [The preserved manuscripts offer only vestiges of a larger reality that is lost to us. For example, the performance aspect, the diffusion, the oral reception, and the displacement between the poetry and its recording in the manuscripts; all this makes the complex poetic presence of the compositions difficult for us to grasp; new methodology must be developed.]

797.

Bruckner, Matilda Tomaryn. "Mathematical Bodies and Fuzzy Logic in the Coupling of the Troubadour Lyric.” Tenso 14 (1999): 1-22. [Discussion of how to distinguish real from fictional bodies in the troubadour lyric; three poems are studied: Bernart de Ventadorn's Era.m cosselhatz, senhor (PC 70,6), Guilhem de Peitieus's Farai un vers de dreit nien (PC 183,7), and the exchange of coblas between $\mathrm{Na}$ Carenza and Alaisina Iselda (PC 12,1 and 108,1); suggests that we cannot prove or disprove the reality of a body in a poem, nor its fictional construct, so that in "fuzzy logic" it is both at the same time.]

798.

Burle, Elodie. "Le sujet lyrique médiéval en question." In L'expérience lyrique au Moyen Âge. (Assemblée des Médiévistes du 26 au 28 septembre 2002). Special issue of Perspectives médiévales 28 (2002): 21-31. [Trobar implies rediscovering something that exists already, using forms and themes and language that are part of a tradition; the poet is enriching the tradition rather than changing it; Bernart de Ventadorn remains apart from the " $\mathrm{je}$ " of the poem, treating it as a learning experience about the nature of love rather than as a personal cry of suffering; Arnaut Daniel is focused on the poem itself as a structure, rather than on themes or images; he is aiming for poetic perfection in a song that is a work of art.]

799.

Calin, William. "Singer's Voice and Audience Response: On the Originality of the Courtly Lyric, or How 'Other' Was the Middle Ages and What Should We Do about It?” Esprit Créateur 23 (1983): 75-90. [Medieval courtly lyric may and must be studied with the same critical approaches now applied to modern texts; examples from Old French lyric.]

800.

Canettieri, Paolo. "Forma e gioco nella lirica dei trovatori," posted online 5 December 2007: http://paolocanettieri.wordpress.com. [Ludic tendencies are hidden under the formalistic surface; the troubadour is playing a game with his Lady, with himself, with the subject matter of his poem, with his listeners, and especially with other troubadours.]

801.

Canettieri, Paolo. "Il trobar e l'esprit de géometrie." In Scienze matematiche e 
insegnamento in epoca médiévale. Atti del convegno internazionale di studi, Chieti, 2-4 maggio 1996. Naples: Edizioni scientifiche italiane, 2000, pp. 287-97. [Claims that some troubadours did understand mathematical principles and used them in the structure of their poems; examples from Peire de Corbian's Thezaur, Arnaut Daniel's sestina (connected closely with gaming imagery and astrology), At de Mons, and Guiraut Riquier's canso redonda (the circle being the geometrical and aesthetic form of perfection).]

802.

Fuksas, Anatole Pierre. Etimologia e geografia nella lirica dei trovatori. Rome: Bagatto, 2002. [Wide-ranging analysis of the use of place-names and personal names for their allusive value; several poets are treated more fully: Aimeric de Peguilhan, Peire Vidal, Na Lombarda, and Guilhem de Montanhagol; index by toponym; index by troubadour.]

803.

Gaunt, Simon. Troubadours and Irony. Cambridge: Cambridge University Press, 1989. [Shows that troubadour poems are permeated with playful irony, laced with humorous sexual innuendo; a key part of the "dialectic" of intertextuality (both lending and borrowing), which Gruber has shown to be an essential part of troubadour poetics; the introduction provides definitions and historical overview of irony; examples from Guilhem de Peitieus and Bernart de Ventadorn; individual chapters to Marcabru, Bernart Marti, Peire d'Alvernhe, Raimbaut d'Aurenga, and Giraut de Bornelh; new critical editions of several poems.]

\section{4.}

Kay, Sarah. Subjectivity in Troubadour Poetry. Cambridge: Cambridge University Press, 1990. [Against the depersonalization of troubadour lyric in modern criticism, Kay opposes a new Lacanian postmodern understanding; the domna is not really elevated by the troubadours, whose humility is in fact a rhetorical device to mask their misogyny and advance their own status through courtship; domna and midons are seen as androgynous terms referring to a figure that is neither masculine nor feminine but akin to the grammatical neuter or universal gender; the true subject of the poetry is the poet himself seeking to improve his moral, social, and cultural position.] 805.

See 835, Kay, Courtly Contradictions, 2001. [Difficult and wide-ranging study; introductory comments on different modern critical approaches to the antitheses and contradictions found in Bernart de Ventadorn, with examples from Bec (formalism), Carlson (Greimasian structural semiotics), Köhler (Marxist social realism), Huchet (Lacanian psychoanalysis), and Bloch (deconstruction), before revealing her own Lacan-inspired interpretations of "contradictoriness" in medieval lyrics, romance, and hagiography in Occitan and (mostly) French.]

\section{6.}

Khemir, Nawar. "La notion de personnage à travers le texte lyrique troubadouresque (Bernard de Ventadour).” Actes du 31e colloque du CUER MA, 9, 10 et 11 mars 2006. Sénéfiance, 53. Aix-en-Provence: Publications de l'Université de Provence, 
2007, pp. 157-69. [An exploration of the nature of lyric, questioning whether it is a true genre; in narrative we can distinguish the author from the narrator and from the literary persona, but in lyric this is difficult; Bernart's poetry is used as an example to explore the borders between the autobiographical identity of the poet and that of the fictionalized lover/persona; a variety of narrative elements in the form of proverbs, myths, assumed background narrative, portrayal of the lover as prisoner, servant, vassal, or martyr, intrude upon the universal lyric tone; further exploration will be required, involving the other poetic entities such as the lady and the lauzengiers.]

807.

Landoni, Elena. La teoria letteraria dei provenzali. Florence: Olschki, 1989. [An introductory résumé of research into the expression of poetic theory by the early troubadours; pp. 29-46: the debate about trobar clus and trobar leu, involving principally Marcabru, Giraut de Bornelh, Raimbaut d'Aurenga, and Lanfranc Cigala; pp. 77-86: the cycle of devinalh poems responding to Guilhem de Peitieus's dreit nien; pp. 113-36: the retrospective views of the theoretical treatises, providing only basic practical guidance for beginner poets and listeners.]

808.

Paden, William D. "Dramatic Formalism in the Alba Attributed to Gaucelm Faidit." NM 83 (1982): 68-77. [Paden uses the poem as a model for the analysis of any troubadour poem in terms of its verbal, fictional, and musical aspects, all three occurring in inextricable simultaneity; reproduces Mouzat's text of PC 76,23, with English translation; analysis of the genres alba and pastorela, as well as the lyric in general, which Paden believes is characterized by its formal dramatic structures; Paden discusses the unique phonetic/metrical structure of this poem, including internal echoes and isolating rhymes, that make the poem so striking as a unified formal structure.]

\subsection{Formalistic Analysis}

809.

Castano, Rossana. "Sulla struttura della canzone trobadorica." RST 3 (2001): 11326. [Formalistic analysis of wordplay and derivatives at the rhyme by Aimeric de Peguilhan — a major element of his poetic style; also the "system of interstrophic and intrastrophic concatenations," seeking the "deep structures" in his songs.]

810.

Perugi, Maurizio. "Come lavorava un autore: strumenti e tradizioni formali," $\mathbf{1 2 9}$, Lo spazio letterario del medioevo. Vol. 2: Il Medioevo volgare, vol. 1, part 2: La produzione del testo. Edited by Piero Boitani, Mario Mancini, and Alberto Varvaro. Rome: Salerno Editrice, 1999, pp. 459-91. [Pp. 473-91: "L'aggiornamento del testo lirico": three successive manuscripts versions of PC 29,8 by Arnaut Daniel reveal the processes of composition and revision; one stanza is totally rewritten twice, and other notable revisions can be followed in detail.]

811.

See 1946, De Conca, "Approximations métriques," 2000, pp. 25-79. [Intensive analysis of the technical aspects of Arnaut Daniel's poetry; internal and external 
intertextuality is traced, based on metric and thematic structures: links with Marcabru, Raimbaut d'Aurenga, pseudo-Guilhem de Peitieus, and Bertran de Born; see also 804, Kay, Subjectivity, pp. 13-16, who notes internal intertextuality between Arnaut's songs 10 and 14.]

\section{2.}

Gross, Charlotte. "Studies in Lyric Time-Structure: Dream, Visions, and Reveries." Tenso 2, no. 1 (1986): 21-36. [Analysis of the structural function of time in the poems of Jaufre Rudel and Bernart de Ventadorn; the effect of unusual modes of time found in dreams, visions, and reveries; narrative uses a chronological continuum, but lyric time is purely structural and "timeless," regulated only by love and the domna; perfect love can only be attained in the unreal time of dream or vision, in the idealized loc aizi which transcends both time and space.]

\section{3.}

Hansen, M. "Poetic Architecture as a Clue to the Structural Character of a Submerged Language: Patterns of Phonic Accord and the Underlying Morphological Structure as Components of Bernart de Ventadorn's Troubadouresque Style." RPh 30 (1976-77): 574-88. [Meticulous linguistic analysis of Bernart de Ventadorn's 42 cansos, revealing the intricate but flexible patterns of phonemic, morphological, and semantic structure that characterize the language silhouette of Bernart's poetic usage of Occitan, and in particular of the rhyme structures of his poetry; essential knowledge for the renewal of text editions based on a detailed knowledge of the range of language structures available to the troubadours.]

\section{4.}

Hardy, Ineke, and Elizabeth Brodovitch. "Tracking the Anagram: Preparing a Phonetic Blueprint of Troubadour Poetry." In 106, ICLS 9, 2003, pp. 199-213. [An experimental method for electronic calculation of possible hypophonic structures (subliminal meaning hidden below the surface of the linear text-paragram, hypogram, etc.); two poems out of the forty-five analyzed seem to use consciously repetitive phonetic structures: Jaufre Rudel's No sap chantar (PC 262,3) and Raimon Jordan's Amors, no.m posc partir (PC 404,3).]

\section{5.}

Locher, Caroline. "Folquet de Marseille and the Structure of the Canso." Neo 64 (1980): 192-207. [A study of logic and patterned repetitions in five of Folquet's cansos, especially in PC 155,8, En chantan maven, which is not constructed of independent stanzas but carefully structured throughout in sustained formal and thematic unity and continuity.]

816.

Medina Granda, Rosa María. "La repetición sinonímica en la chansó cortés occitana: una primera aproximación desde el 'motivo registral', el 'coupling poético' y las “imágenes mentales." In 102, AIEO 9, 2011, pp. 219-24. [A study of the categories of ornamentation in medieval rhetoric, specifically the use of synonymical repetition as a cognitive process for fixing a mental figure by means of words, both for the performer and the listeners; this mental map would serve as a guide for the 
development of the song, an amplification using repetitions and inferences familiar to the listeners.]

817.

Monson, Don Alfred. "Bernart de Ventadorn et Tristan." In $>$ 151, Mélanges Bec, 1991, pp. 385-400. [A new interpretation of the senhal "Tristan" in light of new critical techniques—structuralist and post-structuralist—which are now being applied fully to medieval literature; recognition that the poetry is not positivist, to be studied against a background of historical reality, but is a formulation of linguistic structures utilizing modalities of language and sociocultural codes to create a desired effect on a targeted audience; this new recognition leads us back to a renewed evaluation of the historical base within which the poetry was created.]

\section{8.}

See 808, Paden, "Dramatic Formalism," 1982. [Analysis of the dramatic structures of Gaucelm's alba PC 76,23: three speakers—narrator, lover, watchman-represent three poetic worlds engaged in Aristotle's classic pattern of "exposition, complication, dénouement"; the unique phonetic and metrical features of the song, including internal echoes and isolating rhymes, make it striking as a unified formal structure; the explication of this poem may serve as a model for the analysis of any troubadour song in terms of its interlocking verbal, fictional, and musical aspects.]

\section{9.}

Roubaud, Jacques. La fleur inverse: Essai sur l'art formel des troubadours. Paris: Éditions Ramsay, 1986. [An idiosyncratic reading of a number of troubadour poems, offered as an emotional homage to the spirit of poetry; Marcabru is characterized as leading a polemic against trobar and profane love; the poetry as a whole is seen as obsessed with death and nothingness, behind a seeming joyful exuberance; the meaning of the poems is shown to be inextricably intertwined with their formal structures.]

820.

Switten, Margaret. "De la sextine: amour et musique chez Arnaut Daniel." In - 151, Mélanges Bec, 1991, pp. 549-65. [Detailed analysis of the circular structure of Arnaut's poem, with parallels in Plato's Timaeus; the rhyme-words evoke different forms of love; parallels are demonstrated between melodic structure and rhyme structure; Arnaut, the artisan of language, is seeking to create a poetic view of harmony through love, just as the demiurge of Plato sought to reestablish the musical harmony of the universe by reconciling its contraries.]

\section{1.}

\subsection{The Debate: Orality versus Literacy}

Aubrey, Elizabeth. "Literacy, Orality and the Preservation of French and Occitan Medieval Courtly Songs." Revista de Musicología 16 (1993): 2355-66. "Culturas musicales mediterráneo y sus ramificaciones," Actas del XVo Congreso de la Sociedad International de musicología, Madrid, 1992. [Establishes basic differences between the nature of Occitan and French musical traditions and transmission practices: the music is simpler and more stable in the North, freer, more varied, and idiosyncratic 
in the South; there was a closer relationship between music and text in the South; written forms were used earlier in the North, whereas the South retained longer the tradition of oral composition and transmission.]

\section{2.}

Fausel, Andrea. Verschriftlichung und Sprechen über Sprache. Das Beispiel der Trobadorlyrik. Frankfurt: Peter Lang, 2006 (Europäische Hochschulschriften, Reihe XIII, Französische Sprache und Literatur 282). [Detailed investigation of orality and scripturality in the troubadours; close study of the vocabulary attached to creation, transmission, performance, and reception of the lyric; analysis of genres and style designations; emphasis on the transition from oral to written and its impact on the language and the culture.]

823.

Galano, Sabrina. "Indizi di oralità nel Blandin de Cornoalha." Romanica Vulgaria. Quaderni 16-17 (1999): 199-239. [There are many indications that Blandin was composed orally and was meant to be performed by recitation, not read; its real-time setting, spare language, and repetitions show that it was directed to a popular audience, using the standard Occitan koiné with some French and Catalan influences.]

824.

Gaunt, Simon. "Orality and Writing: The Text of the Troubadour Poem." In $\mathbf{2 8 2}$, Gaunt and Kay, Troubadours, 1999, pp. 228-45. [An invitation to reflect on the real status of troubadour poems that we find in modern editions, after they have passed through several modes of textuality, and how this knowledge should inform our reading; from original composition (oral or written?), through unclear transmission (oral or written?), to notation in the chansonniers, and to subsequent edition by modern scholars (Lachmannian or Bédiériste?), the poems have traveled far and have undergone many changes; the mobility and plurality of the text is a recent concept, not universally accepted by modern editors; sources of textual instability, e.g., authorial revisions, scribal corrections, apocryphal additions, and reordering of stanzas.]

825.

Gaunt, Simon. "Fictions of Orality in Troubadour Poetry." In Orality and Literacy in the Middle Ages: Essays on a Conjunction and Its Consequences in Honour of D. H. Green. Edited by Mark Chinca and Christopher Young. Turnhout: Brepols, 2005, pp. 119-38. [Traditional criticism stresses the need to imagine oral performance of a poem in order to understand fully the humor, social references, and its power to move; but the supposed "orality" may be a façade. Written transmission was important, even preeminent; Marcabru's poetry illustrates this notion of écriture as the basic conceptual form; his poems are implicitly written songs; Marcabru has an idea of the word as a concrete object existing in a spatial medium, not of an oral concept in which "words" are represented temporally.]

\section{6.}

Gruber, Jörn. "Singen und Schreiben, Hören und Lesen als Parameter der (Re-) Produktion und Rezeption des occitanischen Minnesangs des 12. Jahrhunderts." Zeitschrift für Literaturwissenschaft und Linguistik 15 (1985): 35-51. [Persuasive 
claim that oral composition and transmission was primordial among the early troubadours and was only replaced gradually in the thirteenth century by a new emphasis on writing; imprecise understanding of remarks by the troubadours led to a widespread misunderstanding that must be replaced by a close study of the manuscript sources.]

827.

Holmes, Olivia. "The Representation of Time in the libre of Guiraut Riquier." Tenso 9 (1993-94): 126-48. [The so-called "conversion"' of Guiraut's poet/lover from carnal to divine love in the course of his libre can be read as a figure for the historical movement from orality to writing; it also coincides with the replacement of the domna by the Virgin Mary, and perhaps with the end of troubadour poetry.]

\section{8.}

Paden, William D. "Europe from Latin to Vernacular in Epic, Lyric, Romance." In Performance of Literature in Historical Perspectives. Edited by David W. Thompson. Lanham, Maryland: University Press of America, 1983, pp. 67-105. [Analysis of the nature of the composition, performance, and diffusion of troubadour poems; we must assume a period of oral transmission preceding the written transmission that begins in the thirteenth century; the poetico-musical mode characteristic of the early Occitan lyric was swept along in the change from orality to literacy; this evolution, and not the Albigensian Crusade, was the ultimate cause of the decline and transformation of troubadour lyric.]

829.

Pfeffer, Wendy. "A Sign of the Times: The Question of Literacy in Medieval Occitania," see 721, ICLS 7, 1994, pp. 283-89. [Postulates the concept of fin'amor as the "text" for the medieval Occitan society, never spelled out, but taken for granted as an organizing principle for the literate inner core, who spread the concept to the wider community through oral poetic performance; see also her "The World of Books in Occitan Literature." In 110, Cultural Milieu, 1994, pp. 46-55, in which the notion of authority is seen to be based on written sources.]

830.

Rieger, Dietmar. "Audition et lecture dans le domaine de la poésie troubadouresque: quelques réflexions sur la philologie provençale de demain.” RLaR 87 (1983): 69-85. Reprinted in Chanter et dire, Paris: Champion, 1997, pp. 31-44. In German: $Z r P$ 100 (1984): 78-91. [Reception theory: there may have been a public specifically for the written lyric, alongside that for the oral recitation.]

\section{1.}

\subsection{Psychocritical Approach}

Allegretto, Manuela. Lacan e l'amore cortese. Rome: Carocci, 2008. [Detailed analysis of Lacan's thinking over twenty-three years on the sublimation of desire and its importance for the creative process, especially in the formulation of courtly lyric; the works of five troubadours and the Roman de Flamenca are used as a corpus to attempt a clarification of Lacan's sometimes obscure theories concerning the poetic 
expression of the subconscious; the full application of these theories to individual poems remains problematic.]

832.

Cholakian, Rouben Charles. The Troubadour Lyric: A Psychocritical Reading. New York: St. Martin's Press, 1990. [Feminist, Freudian, and Lacanian insights are applied to explain the psychosexual subtext of love in Guilhem de Peitieus, Marcabru, Jaufre Rudel, Arnaut Daniel, and Guiraut Riquier; reflecting the mindset of a troubled age, troubadour poetry is pervaded with issues of guilt, sexuality, and control, the poet often portrayed as weak, abandoned, and narcissistically craving attention.]

833.

Gaunt, Simon. "The Look of Love: The Gender of the Gaze in Troubadour Lyric.” In -745, Troubled Vision, 2004, pp. 79-95. [Lacanian analysis of the dynamics of seeing and being seen in troubadour lyric: the poet's life depends on being looked at by the lady; in Bernart de Ventadorn and Arnaut de Maruelh, the gaze itself becomes the object of desire, thus affecting the categories of gender; the masculine senhal creates ambivalence, calling into question the fixity of the symbolic order; troubadour lyric is seen as a homosocial discourse that marginalizes women.]

\section{4.}

Huchet, Jean-Charles. L'Amour discourtois: la Fin' Amors chez les premiers troubadours. Toulouse: Privat, 1987. [A narrowly Lacanian interpretation of the love ethic, suggesting that it is basically homoerotic; the discussion of sexuality, taboos, castration complex, etc. offers provocative psychoanalytic insights into the first-generation poets, without much direct analysis of the poems themselves.]

\section{5.}

Kay, Sarah. Courtly Contradictions: The Emergence of the Literary Object in the Twelfth Century. Stanford: Stanford University Press, 2001. [Traces the history of "operations of contradiction" in the interrelated genres of lyric, romance, and hagiography, from the perspectives of medieval thought and Lacanian psychoanalysis; provocative comments on five modern critical approaches to the analysis of paradox in Bernart de Ventadorn: Bec (formalism), Carlson (Greimasian structural semiotics), Köhler (Marxist social realism), Huchet (Lacanian psychoanalysis), and Bloch (deconstruction).]

836.

Lacan, Jacques. L'éthique de la psychanalyse. Séminaire livre VII [1959-60]. Paris: Seuil, 1986, pp. 167-94. English translation by Dennis Porter: The Seminar of Jacques Lacan. Book 7: The Ethics of Psychoanalysis 1959-1960. New York: Norton, 1992, pp. 139-60. [Troubadour poetry is a unique example of art playing an essential role in society; fin'amors governed the strong social code of a refined society for a century and a half, setting rules of behavior, loyalty, service, and conduct in society, linked closely to a highly developed poetic craft. It was an idealization, without connection to the social realities of the time, dependent on a Lady who is inaccessible - an abstraction that can easily turn into philosophy or allegory. Man has a central need to be deprived of something, to find a hollow space, "la vacuole," called love; the sublimation of courtly morality, essentially narcissistic, calls forth the ideal social type.] 
837.

Leupin, Alexandre. "L'expérience mentale des troubadours." In L'Expérience lyrique au Moyen Âge. Assemblée des Médiévistes du 26 au 28 septembre 2002. Supplement to: Perspectives médiévales 28 (2002): 69-78. [The incarnation of Jesus has changed our way of thinking and knowing. Sex was sacralized in the Ancients, as a hermaphroditic totality, but when Jesus was incarnated as a male, we lost the possibility of imaging our desire except in our own body as the sole source of pleasure (desire); the life-force was everywhere for the Ancients, but for us has been reduced to the sexual organs; Guilhem de Peitieus illustrates this new way of thinking and knowing and poetizing; he can be masterful with pen or with penis, but only by recognizing that the victory is a false one, gained only by trickery, portrayed only by irony.]

\section{8.}

Mancini, Mario. La gaia scienza dei trovatori. Parma: Pratiche, 1984. [Exploration of the theatricality of fin'amor, its playfulness as it skirts the social subjects of ethics and politics; based on theories of Barthes, Lacan, and Irigaray; opposed to those, like Paden, who would "rationalize" the love ethic by denying its idealization and worship of the unattainable (married, superior Lady); fin'amor is an absolute, reachable through psychoanalytical and rhetorical analysis.]

839.

Rey-Flaud, Henri. La névrose courtoise. Paris: Navarin (Seuil), 1983. See also "La sublimation de Freud à Lacan: le fil rouge de l'amour courtois," Figures de la psychanalyse 7, no. 2 (2002): 137-48. [Freudian analysis of troubadour fin'amor: the fiction of unrequited love and patient submission to the domna is a subtle or subconscious ploy used to avoid consummation, out of fear of castration, or fear of damaging the perfection of the ideal figure; if the female body stands for a new sheet of parchment, then the symbolic fear is that of not being able to create a poetic text.]

\section{0.}

\section{Specific Applications}

See 792, Sankovitch, "Lombarda's Reluctant Mirror," 1989. [A reading of Lombarda's exchange with Bernart Arnaut in light of feminist psychoanalysis à la Luce Irigaray; Lombarda turns Bernart de Ventadorn's male narcissistic mirror into a subversive reworking in which she frees herself from being the man's mirror and goes through the looking glass to female self-discovery.]

\section{1.}

Burgwinkle, William E. "Raimbaut de Vaqueiras et les rites de l'identité." In $>\mathbf{1 0 0}$, AIEO 7, 2003, pp. 157-66. [Psychoanalytic interpretation of an enigmatic vision inserted into the vida of Raimbaut; seen as a fantasm symbolizing the basic dynamics of finamor, the mysterious scene evokes the secret desires of the poet/lover to identify with the powerful domna, who herself takes on the identity of their master; the homosocial nature of the fin'amor ethic is neatly encapsulated into a vision which seems close to the reality of Raimbaut's actual career.] 
842.

Cautionary Views of the Psychocritical Method

Bec, Pierre. "Du son poétique médiéval à la lettre du pseudo-exégète." CCM 29 (1986): 243-55. [Sharp criticism of recent psychoanalytical interpretations that do not consider the specificity of the texts concerned, nor the sociocultural context, nor the author.]

843.

Uhl, Patrice. "Un chat peut en cacher un autre: autour d'une interprétation 'sans difficulté de Henri Rey-Flaud et de Jean-Charles Huchet.” Neo 75 (1991): 17884. [Criticizes $\ \mathbf{8 3 9}$, Rey-Flaud, La Névrose courtoise, 1983, and $>\mathbf{8 3 4}$, Huchet, L'Amour discourtois, 1987, for not taking into account the difference in time and attitudes between our period and that of Guilhem de Peitieus; they interpret the cat of PC 183,12 too glibly as a metaphor for a vulva, linking it to the poet's fear of castration and other neuroses, all of which may be present but may also be anachronistic; more cogently, enoios is linked to Arabic traditions and to figures like the gilos/ gardador/lausengier, and a shady sinister presence of the envious/odious one; the poem fits into a very old archetypal theme, found in zajals, in fabliaux, and elsewhere; the psychoanalytical interpretation is too much a product of our time.]

\section{4.}

\subsection{Rhetorical Analysis, Metrics, Versification}

Antonelli, Roberto. "Rimique et poésie." In 122, Métriques du Moyen Âge, 1999, pp. 1-14. [Stresses the key importance of rhyme, which is the starting point for poetic creation among the troubadours; after the choice of rhymes or rhyme scheme, the poets work backward to form verses and stanzas, especially in contrafacta, sestinas, and tensos, with their strictly ordered rhymes; rhymes are of central importance in the working-out of the principles of memoria; examples from a few troubadours and many Italian poets up to Petrarch and beyond.]

\section{5.}

Barberis, Valerio. "Illustration et défense du mot-refrain.” In Actes du colloque: Jeunes chercheurs en domaine occitan. Special issue of Bulletins de l'AIEO 14 (1998): 7-23. [Catalogues a rich variety of uses of the technique of lexical repetition in rhyme, with illustrations of its use in over seven percent of troubadour lyrics (166 songs).]

846.

Billy, Dominique. "Lanalyse distributionnelle des vers césurés dans la poésie lyrique medieval occitane et française.” In \ 96, AIEO 3, 1992, pp. 805-28. [Distributional regularities in verses longer than eight syllables are examined to indicate the interest of metrical flexibility, lost in modern times because of the modern preference for symmetrical and static rhythms; demonstrates the inaccuracies in several recent metrical studies.]

847.

Billy, Dominique. L’Architecture lyrique médiévale: Analyse métrique et modélisation des structures interstrophiques dans la poésie lyrique des troubadours et trouvères. 
Montpellier: Section française de l'AIEO, 1989. Also: "Corrections et compléments." Cahiers du Centre d'études métriques 1 (1992): 65-70. Also: "Une introduction à l'Architecture lyrique médiévale," AMod [Convergenze testuali] 1 (1995): 221-40. [An original investigation that bridges the boundary between linguistic and literary analysis; describes the basic metrical rules and systems that govern the organization and linking of stanzas, creating the song's total architecture; rhymes and rhyme patterns are the principal element.]

\section{8.}

Billy, Dominique. "La versification des troubadours: un art du langage." Europe 86 (2008): 59-75. [Detailed, accessible introduction to the richness of troubadour versification: verse and stanza structures, rhymes, and sounds.]

\section{9.}

See 1969, Canettieri, Il gioco," 1996. Also: "Forma e gioco nella lirica dei trovatori," online at http://paolocanettieri.wordpress.com. [Detailed analysis of the formal features of the sestina and the chronology of its sources and influences.]

\section{0.}

Chambers, Frank M. An Introduction to Old Provençal Versification. Memoirs of the American Philosophical Society, 167. Philadelphia: American Philosophical Society, 1985. [Meticulous historical presentation of the formal aspects of Occitan lyric, progressing through the key figures, texts, schools, and generations of poets; chapters on monuments (Boeci, Sainte Foy), Guilhem de Peitieus, Marcabru, Cercamon, Jaufre Rudel, Bernart Marti, Alegret, Marcoat, trobar clus/leu, Bertran de Born, Aimeric de Peguilhan, Dalfi d'Alvernhe, and genres; up to date only to ca. 1978.]

\section{1.}

Chambers, Frank M. "Versification.” In 281, Handbook, 1995, pp. 101-20. [A technical outline of the main structural features of Occitan lyric, narrative, and epic literature; clear exposé of the evolution from Latin quantitative metrics to the vernacular syllable-based rhyming lines; concise treatment of rhyme schemes, stanzaic structures, formal variety and originality, contrafacts, and the notion of craftsmanship.]

852.

Fraser, Veronica." Diminutio and superlatio in the Lyric of the Troubadours and the trobairitz." In 105, L'Imaginaire courtois, 1991, pp. 109-18. [An attempt to find a difference in poetic style between Peire Vidal and two trobairitz, Beatriz de Dia and Castelloza, specifically in the presence or absence of hyperbolic or exaggerated discourse; in fact, the gab is absent from the feminine poems, very much present in the masculine; the ostentation and exhibition in Peire's work is replaced in the trobairitz by concealment and restraint.]

\section{3.}

Fraser, Veronica. "Figures and Tropes of Erotic Implication in the Occitan Lyric." Tenso 7 (1991-92): 1-11. [Devices of euphemism, understatement, and interruption of discourse are used to disguise the poet/lover's direct desires; examples from Peire Vidal, Comtessa de Dia, and Castelloza; humility and restraint are the dominant registers in both troubadour and trobairitz songs.] 
854.

Ghil, Eliza Miruna. “'Here' and 'Now' in the Old Provençal Canso.” RPh 35 (1982): 203-12. [Examines the use of adverbs of place and time, topo $i$ of spatial description, and verb tenses to create a verbal universe.]

\section{5.}

Gruber, Jörn. "La dialectique du trobar. Essai de poétique troubadouresque.” Marche romane 33 (1983): 123-35. [Analysis of a number of openings, endings, and tornadas in order to grasp the essence of trobar as "le principe de la sublimation intertextuelle."]

856.

Haahr, Joan G. "Justifying Love: The Classical Recusatio in Medieval Love Literature." In Desiring Discourse: The Literature of Love, Ovid through Chaucer. Edited by James J. Paxson and Cynthia A. Gravlee. Selinsgrove: Susquehanna University Press, 1998, pp. 39-61. [For the troubadours, recusatio implies the use of dialectic, irony, challenges to convention, or a subversive use of non-sense, or semiobscene innuendo; Guilhem de Peitieus undermines his listeners' expectations by claiming to compose a poem about nothing, while sleeping on his horse; Raimbaut d'Aurenga, Arnaut Daniel, and Peire Vidal use the same rhetorical principle to claim the primordial importance of love and desire over other subjects of poetry.]

857.

Kay, Sarah. "Rhetoric and Subjectivity in the Troubadour Lyric." In 163, Troubadours and the Epic, 1987, pp. 102-42. [Rhetorical language avoids literal statement as well as abstract expression of emotions; decoding lends variation to a poem, since it happens differently for each reader or listener; this is illustrated by analysis of Bernart de Ventadorn's Ja mos chantars (PC 70,22); trouvère songs are "open," their lyric persona ready to be taken over by any performer, but the troubadour poems generally have some precise reference to the outside world and guard jealously their identity with their creator; discussion of allegory in poems by Marcabru and Folquet de Marselha, two levels of discourse in Arnaut Daniel, irony, perhaps even parody, in the tenso between Giraut de Bornelh and Raimbaut d'Aurenga about trobar clus; see also 804, Kay, Subjectivity, 1990.]

\section{8.}

Kay, Sarah. "Derivation, Derived Rhyme, and the trobairitz." In 132 , Paden, Voice, 1989, pp. 157-82. [Analysis of the use of derived rhymes by the trobairitz to make ironical comment on real as well as grammatical gender interplay, and perhaps to mock the artificial conventions of male poetry; in appendix: a table of derived rhymes in troubadour poetry, Comtessa de Dia's Ab joi e ab joven, PC 46,1, and an exchange of coblas between Lombarda and Bernart Arnaut d'Armagnac.]

859.

Lorenzo Gradín, Pilar. "Exordio y dialéctica en los provenzales." In Paisaje, Juego y Multilingüismo. Actas del X Simposio de la Sociedad Española de Literatura General y Comparada. Edited by Darío Villanueva and Fernando Cabo Aseguinolaza. Santiago: Universidade de Santiago de Compostela, 1996, pp. 367-82. [The nature opening 
had a long history since its first use by Guilhem de Peitieus as a signal for springtime and love, with many variations and cycling from spring to winter, giving rise to a continuing dialectic in which Marcabru debates with Guilhem, then with Jaufre Rudel, Bernart de Ventadorn, and Eble II in a series of subtle references and rejoinders.]

\section{0.}

See 647, Marshall, "Imitation of Form," 1978. [Very detailed study of contrafacta and other levels of metrical imitation in sixty-six works by Cardenal, including four pieces modeled on Old French poems.]

861.

Nichols, Stephen. "Voice and Writing in Augustine and in the Troubadour Lyric." In Vox intexta: Orality and Textuality in the Middle Ages. Edited by A. N. Doane and Carol Braun Pasternack. Madison: University of Wisconsin Press, 1991, pp. 137-61. [Stresses the importance of live performance as an integral part of the poetic experience, along with the written aspect, supported by close analysis of Guilhem de Peitieus Ben vueill, PC 183.2; the importance given to the body differs from Augustine, who sought eventual abandonment of the body in favor of silence as the ultimate goal; Nichols does not refer to $\mathbf{8 6 8}$, Spence, Rhetorics, 1989, on a similar topic.]

\section{2.}

Paterson, Linda M. Troubadours and Eloquence. Oxford: Clarendon, 1975. [Study of the literary terminology used by five major troubadours to formulate theories of style and eloquence, and understand how they each adapted classical traditions flexibly to their own sense of rhetoric; varying "definitions" of trobar naturau/braus/clus/leu/ric/ prim; individual analysis of Marcabru, Peire d'Alvernhe, Giraut de Bornelh, Raimbaut d'Aurenga, and Arnaut Daniel.]

\section{3.}

Phan, Chantal. "La tornada et l'envoi: fonctions structurelles et poiëtiques." CCM médiévale 34 (1991): 57-61. [The tornada has been insufficiently analyzed for its stylistic importance; it is at the same time a "return" to the internal matter of the poem and a "reaching out" to the outside world: on the one hand the poetic "I" of the lover, the senhal of the lady, the song itself; on the other hand the poet as a real person, the joglar, the addressee, and the named places; both perspectives must be seen in their relation to the structural and musical qualities of the poem, open to adaptation in performance.]

\section{4.}

Scarpati, Oriana. Retorica del trobar: le comparazioni nella lirica occitana. Rome: Viella, 2008. [Thorough exploration of the comparative mode in troubadour poetry, beginning with Aristotle, the Classics, and artes poetriae of the twelfth and thirteenth centuries; structural, figurative, and historical analysis of usage, with a complete repertorium of thirteen thousand images (pp. 177-255), and comparisons (pp. 257446) listed by author; extensive bibliography.]

\section{5.}

Scarpati, Oriana. "La priamel abbreviata nella lirica médiévale." MR 32 (2008): 289_ 302. [A priamel is a rhetorical device used widely by the troubadours, similar to the 
accumulation of elements in the plazer but with a final preference for the last one; in the reduced priamel there are only two elements, the first of which is generally preferred ; the most frequent use is for the expression of negative hyperbole, choosing the lesser of two evils (Bernart de Ventadorn would rather lose both eyes than displease his lady).]

\section{6.}

Smith, Nathaniel B. "Rhetoric." In 281, Handbook, 1995, pp. 400-420. [For the most part, troubadours used eloquence and the rich array of rhetorical figures to persuade their patrons (and themselves) that their society was solid, rational, admirable, and perfectible; their poetry is characterized by the strong interaction of form and content, predetermined to a point by a rich but fixed inventory of traditional and recent usage, but endlessly varied in the original uses made of it.]

867.

Solimena, Adriana. “. . pausatz et ordenatz ...” Romanica Vulgaria. Quaderni 16-17 (1999): 41-105. [A statistical survey of the stanza structures found in the 2,523 extant troubadour lyrics, with materials for a comparative study of metric and melodic formulas in the 232 poems with preserved melody; musical innovation seems to have been the determining factor that drew metric structure after it.]

\section{8.}

Spence, Sarah. Rhetorics of Reason and Desire: Vergil, Augustine, and the Troubadours. Ithaca, NY: Cornell University Press, 1988. [Exploration of three rhetorical modes: Virgil celebrates reason and denigrates desire, Augustine believes that persuasion depends on balancing reason and desire, whereas the troubadours emphasize desire; classical reason suppresses desire through an authoritarian rhetoric, transforming chaos into order; for Augustine, speaker and audience attempt to achieve a balance; the troubadours claim authority and control as poets, but as lovers they are fearful and must resort to persuasion; the female role is suppressed or rejected by Virgil, accepted in Christian tradition, feared and displaced in troubadour poetry.]

\section{9.}

Spence, Sarah. "Rhetoric and Hermeneutics." In 282, Gaunt and Kay, Troubadours, 1999, pp. 164-80. [Rhetoric is a means of granting authority to the vernacular language of the body (desire); the troubadours are more interested in the processes of creating poetry than in the use of rhetoric to persuade; Spence attempts a definition of trobar clus and trobar leu, and of the lyric genres, all of which involve the tensions caused by desire; rhetoric was a way to legitimize the tangible and visual as vehicles for the expression of desire in vernacular language.]

870.

Vallet, Edoardo. A Narbona. Studio sulle tornadas trobadoriche. Alessandria: Edizioni dell'Orso, 2010. [Detailed study of the structural, metrical, and musical qualities of the tornada; analysis of themes, style, and functions.] 


\subsection{Intertextuality}

871.

Gruber, Jörn. Die Dialektik des Trobar: Untersuchungen zur Struktur und Entwicklung des occitanischen und französischen Minnesangs des 12. Jahrhunderts. Beihefte zur ZrP, 194. Tübingen: M. Niemeyer, 1983. [A groundbreaking methodological investigation of intertextual links among troubadour songs; the introduction sets the conceptual base in poetological theory; the definition of intertextuality is based on the three fundamental notions of troubadour creativity: motz, son, and razo; five illustrative examples show how Guilhem de Peitieus is used as a model by Marcabru, Cercamon, Jaufre Rudel, and Bernart de Ventadorn; in part 3, five model studies illustrate the principle of intertextual synthesis through the analysis of poems by Jaufre Rudel, Raimbaut d'Aurenga, Peire Vidal, Arnaut Daniel, and a group of trouvères.]

872.

See 647, Chambers, "Imitation of Form," 1952, pp. 104-20. [Explores contrafacture within troubadour poetry; his metrical analysis covers the entire lyric corpus, goes further than Frank's Répertoire métrique by introducing diachronic analysis into the metrical results; demonstrates for the first time the vital process of growth and change in the formal practice of the troubadours.]

873.

Bardin, Gay. "The Poetics of Nullity: 'Nonsense' Verses of William of Aquitaine, Jaufre Rudel and Raimbaut d'Orange.” Comitatus 34 (2003): 1-23. [Intertextuality is used to construct a canon, to define the new art form of the troubadours; a metapoetic debate on the nature of poetry.]

874.

Fassò, Andrea, and C. Bologna. Da Poitiers a Blaia: prima giornata del pellegrinaggio d'amore. Messina: Sicania, 1991. [Comparative analysis of poems by Guilhem de Peitieus, Jaufre Rudel, and Marcabru show intertextual links in vocabulary and metrics that point to a "dialogue": Jaufre shows not just a reaction against Guilhem but a real exchange; similar links are found by Pasero for Guilhem and Marcabru, by Gizzi for Guilhem and Peire d'Alvernhe; Aimeric de Peguilhan's N'Albertz (PC 10,3) is a systematically antithetical poem to Jaufre Rudel's Belhs m'es l'estius; the theme of the pilgrim is analyzed in Guilhem, Jaufre, Thomas's Tristan, Bernart de Ventadorn, and Alexis; much is hypothetical, but it indicates the interest of reexamining the dating and chronology of the poets and works involved.]

875.

Canettieri, Paolo. "Strutture modulari e intertestualità nella lirica dei trovatori." In - 122, Métriques du Moyen Âge, 1999, pp. 53-70. [Intertextuality: a procedure is outlined for recognizing the dependence of a poet on the model and the individuality of his re-creation; in appendix, twelve examples of borrowed structures.]

876.

Chambers, Frank M. “D’aisso lau Dieu and Aldric del Vilar.” RPh 35 (1982): 489500. [A study of intertextual links between Aldric's sirventes Tot a estru, PC 16b,1, composed in reaction to Marcabru's D'aisso, PC 293,16, and Marcabru's answer in 
Seigner n'Andric, PC 293,43; very subtle interpretations by Chambers indicate that many of Marcabru's injurious remarks are meant to be sarcastic.]

877.

Cirlot, Victoria. "Discussion troubadouresque sur l'amor de lonh." In $\ \mathbf{9 6}, A I E O 3$, 1992, pp. 855-64. [Analysis of Jaufre Rudel's amor de lonh, from a starting point in Guilhem de Peitieus, with responses by Marcabru, Bernart Marti, Cercamon, Peire d'Alvernhe, Giraut de Bornelh, and Raimbaut d'Aurenga: a creative intertextual debate or polemic, followed by another phase in the thirteenth century, more indirectly concerned with defining the notion of amor de lonh.]

878.

Corcoran, Mary Cynthia. "Intertextualité dans le devinalh (Guilhem IX, PC 18, 7; Raimbaut d'Aurenga, PC 389, 28; et Giraut de Bornelh, PC 242, 80)." In $>96$, AIEO 3, 1992, pp. 865-77. [The poems by Raimbaut and Giraut are used as backreferences to illuminate the interpretation of Guilhem's dreit nien song; all three use contradictions that seem to pose a riddle to their listeners; the sexual innuendoes that the two later poets make indicate that they are interpreting Guilhem's poem along the same lines, thus confirming the phallic significance of Guilhem's contraclau.]

879.

Fassò, Andrea. "Due note sui primi trovatori." Studi orientali e linguistici 6 (1995-96): 179-91. Miscellanea in memoria di Luigi Rosiello. [Analysis of Cercamon's planh PC 112,2a for Guilhem X, compared to Guilhem IX's farewell poem PC 183,10 Pos de chantar; adds several thematic, formalistic, and lexical analogies to those noted already by Pasero; the possibility that Guilhem X might be the first troubadour instead of his father is broached but finally seen as unlikely; a similar comparison of Guilhem's PC 183,3 (the two horses) with Bernart de Ventadorn's PC 70,6 Era me cosselhatz, senhor, shows that Bernart has turned Guilhem's poem upside down: in place of a powerful lord faced with a "difficult" choice between two ladies, Bernart depicts a lover whose dominant lady puts him rather in the position of one of the horses; in both of these comparisons, very close linkage of the poems, and the poets, is demonstrated.]

880.

See 1823, Gourc, "D’Outre-Pyrénées," 1993. [Exploration of the nature of trobar as a constantly renewed dialogue, through the poems of Ademar lo Negre, whose tenso PC 1,1 cleverly contradicts Raimon de Miraval's mala canso PC 406,21; since Bertran de Born had already responded to the same poem in his PC 80,5, Ademar is responding in fact to both of these; further links are explored between Ademar's poems and those of Raimon de Miraval, Peire Vidal, Ramberti de Buvalel, and Peire d'Alvernhe.]

881.

Huchet, Jean-Charles. "De Dilexi quoniam à Ailas! Que plans?: de la citation à l'intertexte dans Flamenca." In \$9, AIEO 3, 1992, pp. 957-66. [The author of Flamenca quotes from the Latin Psalms as a necessary prelude to the bisyllabic vernacular "love poem," converting religious context into profane, divine love into fin'amor; the rich and constant interplay of language, themes, and genres make Flamenca a unique literary creation.] 
882.

Lazzerini, Lucia. "La trasmutazione insensibile: intertestualità e metamorfismi nella lirica trobadorica dalle origini alla codificazione cortese.” MR 18 (1993): 153-205 and 313-69. [Jaufre Rudel's amor de lonh is interpreted as an evolving metaphorical expression of a fragile Christian's struggle with the forces of evil, longing for a spiritual, mystic love (laus Sapientiae), in opposition to the earthy eroticism found in Guilhem de Peitieus; this metaphorical language was to be fully developed later in the tradition, taking Jaufre Rudel's poetry as a starting point.]

883.

Mantovani, Dario. "Prove di dialogo fra i trovatori: Bertran de Born, Monge de Montaudon, Folquet de Marselha, Palais." In 118, La lirica romanza, 2009, pp. 197-216. [Close investigation of identical rhyme-words in four poems (PC 80,8; PC 305,12; PC 155,12; PC 315,2) leads to a strong hypothesis that the first three were contemporaneous, perhaps composed as part of a "Puy" meeting, and that the fourth, by Palais, may have been inspired by a collection of the three others that circulated as a unit; it is also likely that Monge's satirical gallery of poets PC 305 originated from a "Puy" meeting; for the importance of these meetings, see $\$ 305$, Routledge, "Troubadours du Puy," 1992.]

\section{4.}

Meneghetti, Maria Luisa. Il pubblico dei trovatori: la ricezione della poesia cortese fino al XIV secolo. Modena: Mucchi, 1984. Subsidia al Corpus des Troubadours, 9. Reprint, Turin: Einaudi, 1992. [In the light of reception theory, a sweeping investigation of the "troubadour adventure" is told in the history of its evolution and reinterpretations and renewals for the benefit of changing audiences in different times and places: genres, topics, vidas/razos, iconography; intertextuality.]

\section{5.}

Meneghetti, Maria Luisa. "I confini del grand chant courtois." In $\mathbf{1 1 8}$, La lirica romanza, 2009, 295-312. [Considers the usefulness of the concepts of "grand chant courtois" or "poésie formelle"; stresses the unique characteristics of intertextuality, which is occasionally present in trouvère poetry but makes up the very essence of troubadour poetry.]

\section{6.}

Meneghetti, Maria Luisa, "Intertextuality and Dialogism in the Troubadours." In 282, Gaunt and Kay, Troubadours, 1999, pp. 181-96. [Dialogism is the key structure, often using intertextuality as a means, but present in other forms as well; three examples: (1) interaction between Guilhem de Peitieus and Jaufre Rudel: Guilhem's cat poem calls forth a riposte in Jaufre's Lancan li jorn, followed by Guilhem's dreit nien, answered by Jaufre's Non sap, a discursive duet, more sophisticated than had been thought previously; (2) five linked poems involving three troubadours and two trouvères which form an "anaphoric knot"; and (3) a number of texts from several cultures using the theme of the lover taking the form of a bird.]

887.

See 651, Monari, “Osservazioni su un caso di imitazione," 2009. [The tenso PC 
323,4 = 70,2, Amics Bernartz de Ventadorn, is preserved with melody, unusual for the genre, but no model has been found from which it might have been copied; since the metric structure of the text is unique; several resemblances with another melody of Bernart's indicate a possibility that the melody may have been part of an elaborate humorous parody on the part of Peire (d'Alvernhe?) of poetic and musical structures typical of Bernart; see the new edition in $\mathbf{2 5 6}$. Harvey and Paterson, Troubadour "Tensos," 2010, 3:964-71.]

\section{8.}

Pasero, Nicolò. "Cattivi consiglieri. Ancora sui rapporti intertestuali fra Guglielmo IX e Jaufré Rudel.” In 146, Literatur Mölk, 1997, pp. 133-42. [Study of several instances of intertextuality: between Guilhem and Bernart de Ventadorn; between Guilhem and Jaufre Rudel, following upon Fassò/Bologna's demonstration ( $>\mathbf{8 7 4}$, 1991) that Jaufre's Lancan was a reaction to Guilhem's cat poem; Pasero adds to these instances another possible intertextual link between Guilhem's Ben vueill and Jaufre's Pro ai, in which Jaufre seems to criticize Guilhem's boasting and bad advice.]

889.

Peron, Gianfelice. "Il conselh di Guilhem Figueira a Federico II (BdT 217,4)." AMod 4 (1999): 217-239. [New edition of Ja de far un sirventes, previously fragmentary, made possible by a manuscript copy now available; suggestions for textual improvements; discovery of further intertextual relationships with Guilhem de Peitieus's Ben vueill (PC 183,2) and other poems, as well as with Marcabru as Guilhem's opponent.] 890.

Rieger, Angelica. "La mala canso de Gui d'Ussel, un exemple d'intertextualité de pointe." In 96, AIEO 3, 1992, pp. 1071-88. [Study of an intertextual "network" involving Raimbaut de Vaqueiras, Gui d'Ussel, Maria de Ventadorn, Gaucelm Faidit, and Peire d'Ussel; analysis of Gui d'Ussel's Si be.m partetz, mala domna, de vos, PC 194,19; for a study of the mala canso as genre, see $>$ 468, D. Rieger, Gattungen, 1976, pp. 303-18; the mala domna in troubadour poetry is analyzed by $\mathbf{4 7 2}$, Leube-Fey Bild und Funktion, 1971.]

891.

Rieger, Angelica. "Relations interculturelles entre troubadours, trouvères et Minnesänger au temps des croisades." In 128, Le Rayonnement, 1998, pp. 201-25. [A case study of a poetic network, involving Raimbaut de Vaqueiras, Elias Cairel, Conon de Béthune, and Albrecht von Johansdorf, illustrating the complexity of connections and intertextuality encouraged in large part by intercultural mixing during the Crusades; the phenomenon is posed in terms of give and take rather than of origin and influence, the idea of cultural exchange as multiple, many-sided, and manydirectional; a shortened German version in Internationalität nationaler Literaturen. Göttingen: Wallstein, 2000, pp. 485-500.]

\section{2.}

Rieger, Angelica. "La cour de Champagne, centre d'un réseau interculturel entre troubadours et trouvères." Europe 86 (2008): 150-63. [Presents the court of Champagne (Eleanor of Aquitaine and her family) as the central force in an intertwined 
complex of poets and patrons that facilitated contacts among three generations of troubadours, trouvères, and Minnesänger; rich and detailed information on intertextuality among the poets who moved in the aura of the court.]

\section{3.}

See 656, Rossell, "L'intermelodicità," 2002. [Melodies were chosen carefully to awaken musical and thematic echoes among the listeners, in order to create a subtle dialogue between the new song and its model. Examples of contrafacts by Raimon de Miraval, Peire Cardenal, Jaufre Rudel, and a "double-contrafact" by Alfonso X demonstrate the purposeful choice of models for the resonances of melody, theme, and tone that they could add to the new song on a metapoetic and metamelodic level.]

894.

Rossell, Antoni. "Lintermélodicité comme mémoire dans le répertoire de la lyrique médiévale." In Mémoire et culture: actes du colloque international de Limoges, 10-12 décembre 2003. Edited by C. Filteau and M. Beniamino. Limoges: Presses Universitaires de Limoges, 2006, pp. 349-60. [Listeners must have been receptive to metapoetic and metamelodic discourse during the performance of the songs, in order to recognize the repetition of melodic and poetic themes from past works and performances by oral transmission; music is a kind of lingua franca.]

\section{5.}

Rossi, Luciano. "La 'chemise' d'Iseut et l'amour tristanien chez les troubadours et les trouvères." In 96, AIEO 3, 1992, pp. 1119-32. [Intertextuality: Marcabru's poem PC 293,11, Bel m'es quan la rana chanta, is used by Bernart de Ventadorn and Raimbaut d'Aurenga; complex interplay with Chrétien de Troyes and le Chastelain de Couci, references to Eneas, and various versions of Tristan and Chrétien de Troyes's romances.]

\section{6.}

See 2412, Seláf, "Frère mineur ou frère cadet," 2008. [Analysis of possible intertextual connections of poem PC 159,1 with an Occitanized Old French alba and poems by Gui and Eble d'Ussel, Bertran d'Alamanon, and several others; if the unknown poet could be called the "younger brother" rather than "Franciscan Friar," then he might be identified as Peire d'Ussel; other possible interconnections are explored without a definitive conclusion.]

897.

Spence, Sarah. "Et ades sera l'alba: 'Revelations' as intertext for the Provençal alba." $R P h 35$ (1981-2): 212-17. [The term alba, in addition to denoting the dawn, also evokes the Last Judgment; the refrain of Reis glorios echoes a line from Prudentius's dawn-hymn, and through it the passage in Revelation describing the second coming; see similar interpretation of the bilingual alba by Lazzerini, $\mathbf{3 2 0}$, pp. 19-23.]

898.

See 794, Städtler, "Sirventes," 1989. [A penetrating study of the intertextual links between Gormonda's sirventes and Guilhem Figueira’s PC 217,1; she mocks him by using the same structure and much of the rhyme scheme and vocabulary, while turning Guilhem's message on its head: he rants against Rome and the papacy, she 
supports Rome and the Albigensian Crusade.]

899.

Washer, Nancy. "Paraphrased and Parodied, Extracted and Inserted: The Changing Meaning of Folquet de Marseille's Amors, Merce?' Neo 91 (2007): 565-81. [Analysis of the changes in meaning undergone by excerpts from Folquet de Marseille's Amors, merce! after their extraction and insertion into ten new works; sometimes new meanings are produced that are in contradiction with the original sense.]

900.

See 477, Winter-Hosman, "Un texte peut en cacher" 2001. [Intertextual links centering on Folquet de Marselha's S'al cor plagues (PC 155,18), used as a model by Gaucelm Faidit, Peire de Barjac, and several others, making a series of malas cansos that turn against fin'amors and denigrate the mala domna; Gui d'Ussel (PC 194,19), Raimbaut de Vaqueiras, and a partimen between Maria de Ventadorn and Gui d'Ussel are also involved.

\subsection{Trobar Clus}

901.

Gaunt, Simon, and John Marshall. "Trobar clus," 1350, Cambridge History, 2005. [Pp. 479-81: mention of modern discussions of the terms clus and plan and the debate between Giraut de Bornelh and Raimbaut d'Aurenga in their tenso PC $389,10 \mathrm{a}=242,14$, which Gaunt thinks may be a "literary joke," a parody directed at uninitiated listeners, rather than a real controversy.]

902.

See 38, DLF, 1993, pp. 1451-52. [Article by Charles Camproux: "Trobar clus, trobar ric"; definition of clus in Marcabru, Peire d'Alvernhe, Raimbaut d'Aurenga, and Bernart Marti; ric in Giraut de Bornelh and Arnaut Daniel; in reality, most troubadours wrote in various styles, including plan; the clus and ric styles were used to speak to an elite, using many of the devices of classical rhetoric.]

903.

Bossy, Michel-André. "The trobar clus of Raimbaut d'Aurenga, Giraut de Bornelh and Arnaut Daniel.” Mediaevalia 19 (1996): 203-19. [Review of the terminology used to describe difficult poetry: clus/leu and clus/ric; the abrasive morality of Marcabru and Peire d'Alvernhe is toned down by Giraut, Raimbaut, and Arnaut, who stress artistic virtuosity and experiment with poetical obscurity for its own sake; trobar clus in Raimbaut aims for a projection of radiant light, not darkness, for a specific select audience of initiated listeners, but Raimbaut, Giraut and Arnaut play with the concept, even teasing their audience while aiming for the expression of emotions beyond the grasp of words; obscurity is part of a satisfying game, creating a complicity of discovery.]

904.

Bottani, Giorgia. "Paraul'escura: sull'ermetismo scaldico e trobadorico." SMV 47 (2001): 169-89. [For Marcabru as for the skaldic poets, the function of poetry is to represent the world as it is, disordered and incomprehensible, not to gloss it over with false beauty and order.] 
905.

See 803, Gaunt, Troubadours and Irony, 1989. [Pp. 122-26: claims that in the debate on style with Giraut de Bornelh, Raimbaut d'Aurenga's supposed support for trobar clus is ironical; pp. 167-78: Giraut's supposed change in support from trobar clus to trobar leu is in fact not to be found in his poems, and his attitude toward the "debate" was probably teasing and ambiguous.]

\section{6.}

See 460, Ghil, "Topic and Tropeic," 1979. [Instead of plan/clus, distinguishes two categories of canso based on the use or avoidance of poetic clichés, oriented toward listener/reader response.]

907.

Haines, John. "Vers une distinction leu/clus dans l'art musico-poétique des troubadours.” Neo 81.3 (1997): 341-47. [Analysis of melodic style in eight troubadours, compared with their poetic style; the trobar leu poets preferred simple, straightforward repetitive musical structures, the trobar clus poets preferred oda continua style without repetitions, in each case by conscious choice.]

908.

See 862, Paterson, Troubadours and Eloquence, 1975. [Detailed analysis of the theory and practice of trobar clus, leu, etc. in five major troubadours.]

909.

Pollina, Vincent. "Obscure Styles: The Early Troubadours." Mediaevalia 19 (1996): 171-202. [Obscurity in the early phases of troubadour poetry was part of the effort by the initiated to shelter their code of behavior, finamor, and their belief in the power and mystery of the word from profanation by the unworthy; discusses deliberate obscurity in poems by Guilhem de Peitieus, Jaufre Rudel, Marcabru, Cercamon, Alegret, Marcoat, Bernart Marti, Peire d'Alvernhe, and its abandonment in favor of trobar ric prior to the decline of Occitan literary culture.]

910.

Vuijlsteke, Marc. "Eléments de définition d'un mode de l'énoncé poétique: Raimbaut d'Orange et le trobar clus." In 151, Mélanges Bec, 1991, pp. 587-98. [Detailed analysis of the tenso PC 389,10a $=242,14$ shows that the debate between Giraut de Bornelh and Raimbaut d'Aurenga is more nuanced than generally believed; Raimbaut is calling not for a poetic form accessible only to the elite but, rather, one that is true to poetic principles and the exaltation of finamor; at the end of the poem, both are in agreement about the worth of their poetic calling and the necessity of remaining true to its ethic; see his related article: "Raimbaut d'Orange et le trobar ric ou prim," RLaR 96 (1992): 69-87, which shows that none of the descriptive adjectives may be taken to imply that the poetry was either hermetic or "easy."]

911.

Zambon, Francesco. "Trobar clus e oscurità delle scritture." In Obscuritas: Retorica e poetica dell'oscuro. Atti del XXVIII Convegno interuniversitario di Bressanone (12-15 Iuglio 2001). Edited by Giosuè Lachin and Francesco Zambon. Trento: Dipartimento di Scienze filologiche e storiche, Università degli studi di Trento, 2004, pp. 
91-102. [A study of how the troubadours may have been influenced by exegetical interpretations of "deliberately" obscure passages of the Bible; the first two stanzas of Marcabru's Per savi teing (PC 293, 37) show that the poet intended to incorporate the richness of biblical symbolic and layered meanings into his poetry.]

\subsection{Plurilinguistic, Hybrid-Language Texts}

[See also further listings dealing with multilinguism in individual poems:

Bonifacio Calvo 2179-87; Raimbaut de Vaqueiras 2887-2902;

Cerveri de Girona 2980-83; Gaucelm Faidit 2296, 2300; the

Bilingual Alba 947-57; L'altrier cuidai aber druda $\$$ 3069-72;

Lai Markiol and Lai Nompar 3067; and flatulence 1919.]

\section{2.}

Battelli, Maria Carla. "La ricezione della lirica provenzale nei codici $M$ (BNfr 884) e $U$ (BNfr 20050): alcune considerazioni.” In 96, AIEO 3, 1992, 2:595-606. [M is the Occitan chansonnier $W ; U$ is the Occitan $X$; together they have eighty-five Frenchified Occitan texts, of which eight are in both manuscripts; they are linguistically diverse and cannot be traced to a dialectal region, neither Occitan nor French; they are recognizably Occitan texts: "Mischsprache" is not an appropriate designation; the diffusion of troubadour lyrics in the North is dependent on interest in the melodies, rather than in the texts.]

913.

Blasco, Eduardo. "Il mistilinguismo poetico médiévale: una fata morgana? (Analisi della lingua del sirventes plurilingue di Bonifacio Calvo)." Beiträge zur romanischen Philologie 26 (1987): 57-89. [Theoretical linguistic analysis of the phenomenon of multilinguism: definitions of different types and their use by Raimbaut de Vaqueiras, Cerveri de Girona, and Bonifacio Calvo; detailed linguistic analysis of Bonifacio's poem, which uses "languages" for rhetorical effect (the second stanza is more or less Navarro-Aragonese) to persuade the Castilian king to take back control of Navarre; this is not proof of multilinguism but of use of language features as an element of ars poetica.]

\section{4.}

Cazal, Yvonne. Les voix du peuple/Verbum Dei: le bilinguisme latin/langue vernaculaire au Moyen Âge. Geneva: Droz, 1998. [Analysis of Latin and vernacular usage in early texts; in the bilingual alba (pp. 45-48), each language has its function: Latin is learned and authoritative, Occitan is popular, tied to oral traditions; in Sainte Foy (pp. 49-55), the poem is in the vernacular, but as part of the liturgy it remains subordinated to Latin; in the Sponsus (pp. 59-64, 227-40, and passim), the dialogue alternates from one language to the other, Latin advancing the dramatic content, Occitan stressing the lyric emotions, in a compromise which would lead eventually to a fully vernacular liturgical drama and later to an independent theater free of the church.]

915.

Formisano, Luciano. “Un nou sirventes ses tardar: l'emploi du français entre pertinence linguistique et pertinence culturelle.” In O Cantar dos trobadores: Actas do congreso 
celebrado en Santiago de Compostela entre os dias 26 e 29 de abril de 1993. Santiago de Compostela: Xunta de Galicia, 1993, pp. 137-54. [In his sirventes, Bonifaci Calvo was inciting Alfonso the Wise to war against Navarre and Aragon, in order to replace the young Thibaut II; in addition to his learned poetic language Occitan, he used Galician-Portuguese, the literary language of Alfonso's court, and Old French, the language of Thibaut II, successor to Thibaut I of Champagne; the languages were not only culturally and politically appropriate to the military controversy but also served to show off the poet's versatility.]

\section{6.}

Grutman, Rainier. "Le système triplement bilingue de la lyrique occitane (11501250)." RLaR 98 (1994): 465-75. [Redefines bilingualism as "literary," "poetic," or "referential"; reformulates the theory of influence in sociolinguistic terms, arguing that the troubadours temporarily "filled an empty slot" in the "defective systems" of French, Italian, and Galician poetry.]

917.

Léglu, Catherine E. Multilingualism and Mother Tongue in Medieval French, Occitan, and Catalan Narratives. University Park: Pennsylvania State University Press, 2010. [A broadly based study that challenges the centrality of French and Catalan "canonical" medieval narratives by exploring the literary, linguistic, and psychoanalytical significance of a number of "marginal" hybrid-language texts; demonstrates that the notion of mother tongue was a fantasy in the multilingual culture of the later Middle Ages and reestablishes the important place of Occitan as a dynamic agent of intercultural exchange. Occitan texts: Girart de Rossilhon, pp. 17-34; Guilhem de la Barra, pp. 35-53; early language acquisition and the Leys d'amors, pp. 55-74; two novas: Frayre-de-Joy e Sor-de-Plaser and Blandin de Cornualha, pp. 99-118.]

\section{8.}

See 176, Stasyk, Sprache und Werke, 2007, p. 9 [Lists the only six poets who were truly multilingual: (1) Richard Coeur-de-lion (French, Occitan?), (2) Gaucelm Faidit (French, Occitan), (3) Raimbaut de Vaqueiras (French, Occitan, Genovese, Gascon, Galician), (4) Bonifacio Calvo (Italian, French, Occitan, Galician), (5) Cerverí de Girona (Occitan, Catalan), and (6) Conon de Béthune (French, Occitan).]

\section{9.}

Tavani, Giuseppe. "Il plurilinguismo nella lirica dei trovatori." In Documenti letterari del plurilinguismo. Edited by Vincenzo Orioles. Rome: Editrice Il Calamo, 2000, pp. 123-42. [The use of multilinguism by Raimbaut de Vaqueira, Bonifaci Calvo, and Cerveri de Girona does not necessarily imply the mastery of languages by the poets, nor the capability to understand them on the part of the listeners; the languages are part of the style; perhaps the five languages chosen by Raimbaut represent a call for ideological unity among the five "nations" who pledged their commitment to the crusade in 1199; Bonifaci chose his three languages as the ones used most for composing courtly lyric; Cerveri seems to have been motivated only to create an amusing, playful show-off piece; see also Tavani, CDT 13, no.1 (2010): 17-40, in reply to

913, Blasco, 1987.] 
920.

Taylor, Robert A. "Barbarolexis Revisited: The Poetic Use of Hybrid Language in Old Occitan/Old French Lyric." In The Centre and Its Compass: Studies in Medieval Literature in Honor of Professor John Leyerle. Edited by Robert A. Taylor et al. Kalamazoo, MI: Medieval Institute Publications, 1993, pp. 457-74. [Discussion of the dynamic tensions created by the juxtaposition or mixture of two or more linguistic systems; outline of 120 poems extant in hybrid French/Occitan form: seventeen in Old French but Occitanized by scribes; ninety-six in Occitan but Frenchified; seven are consciously hybrid for poetic reasons, composed by French poets with the admixture of Occitan traits to enhance the poems' cultural status (five poems), or as parodies of this same Occitan prestige (two poems).]

921.

Trottier, Marc. "Vers breu and Vers estrayn: A Re-examination of Two Neglected Poems by Cerveri de Girona (PC 434a, 66 and 68).” FL 136 (2003): 193-206. [Points to playfully creative use of a jargon-type artificial language in Vers estrayn, "decoded" in Vers breu. For a more complete study of plurilinguism, see Trottier's doctoral thesis from University of Toronto, 2003: Collusions linguistiques: la littérature plurilingue en Occitanie au moyen âge.]

\subsection{Electronic Analysis (Methodology, Practical Applications) \\ [For reference works in electronic form, see 3.1. Electronic \\ Resources and 13.8 Electronic Resources for Musicology]}

922.

Billy, Dominique. "Métrique et informatique," roundtable discussion in $\mathbf{1 2 2}$, Métriques du Moyen Âge, 1999, pp. 305-46. [Papers and discussion of projects and methodology for the use of computer technology in the study of medieval metrics; further details: 58, Billy and Glon, 1995; 1761, Touber, 1999.]

923.

Grilli, Attilio. "Applicazioni informatiche allo studio della narrativa provenzale." In

- 123, La narrativa, 1995, pp. 47-66. [Computerized procedures for analyzing structures and techniques of versification in Jaufre and Flamenca.]

924.

See 814, Hardy and Brodovitch, "Tracking the Anagram," 2003. [An experimental method for electronic calculation of possible hypophonic structures (subliminal meanings hidden below the surface of the linear text: paragram, hypogram, etc.); two poems out of the forty-five analyzed seem to use consciously repetitive phonetic structures: Jaufre Rudel's No sap chantar, PC 262,3, and Raimon Jordan's Amors, no.m posc partir, PC 404,3.]

925.

Paden, William D. "Troubadours and History." In 133, World of Eleanor, 2005, pp. 157-82. [A statistical investigation of troubadour vocabulary and its evolution, with the help of COM; five historical periods were reduced to two in order to establish reliable figures for comparison; preliminary results show a decline in the use 
of canso and vers, along with the notions of court, love, and singing, offset by an increase in the use of sirventes and the minor genres, but not by a significant increase in religious, moral or satirical vocabulary; shows that the troubadours were not all the same, that the whole of the troubadour poetic phenomenon was subject to change and evolution, that it "has a history."]

926.

See 383, Schweickard, Sobre.l vieill trobar, 1984. [Computer-based information is used to undertake a statistical study of themes, key notions of love, and poetics in 239 songs by sixty-one troubadours; demonstrates that fin'amors evolved as a notion, not only over time but also from poet to poet, and that poetic technique was not as important for the poets as modern critics may suppose.]

927.

Touber, Antonius H. "Minnesänger, Troubadours und Trouvères im Computer." In Palaeogermanica et onomastica: Festschrift für J. A. Huisman zum 70. Geburtstag. Edited by Arend Quak and Florus van der Rhee. Amsterdamer Beiträge zur älteren Germanistik 29. Amsterdam: Rodopi, 1989, pp. 243-49. Online at http://www. books.google.ca. [A computerized study of contrafacta of troubadour works: Bertran de Born, Peire Raimon de Tolosa; study of the relationship of Romance and Germanic medieval lyric through a comparison of stanza forms: all Old Occitan, Old French, and MHGerman verse forms were computerized, with the French and Occitan forms restructured to correspond to the Germanic stress patterns instead of syllable count; intertextuality was demonstrated between several troubadours and MHG poets.]

\section{Literary Criticism \\ (Non-Lyric) (approx. 80 texts)}

\section{General Studies of Non-Lyric Literature}

[About 330 of the extant Occitan manuscripts are non-lyric; most non-lyric texts exist in unique copies, some added to lyric chansonniers; many are incomplete; many seem to have been preserved by chance.]

928.

See 57, Frank, 1953, pp. 193-214. [Bibliographical list of editions of all non-lyric texts: alphabetically by title, with many cross-references by name of author; up to date to ca. 1950.]

929.

Fleischman, Suzanne. "The Non-Lyric Texts." In 281, Handbook, 1995, pp. 16784. [A rapid survey of the most significant genres and the texts most likely to be of interest to nonspecialists: Flamenca and other romance narratives, the Castia-gilos and further novas, nine epics including Girart de Rossilhon and the Canso de la crozada, hagiographic texts including the Canso de Sancta Fides, dramatic literature mostly from the fourteenth century and later, didactic works including the ensenhamens, 
several allegorical texts, and treatises on grammar and poetics, chiefly the Breviari d'amors and the Leys d'amors; detailed bibliographic listings.]

930.

See 29, Ricketts, Concordance of Medieval Occitan, 2001, 2005. [COM2 covers all nonlyric verse literature from the mid-eleventh century to the end of the fifteenth; COM3 will cover prose, COM4 the chansonniers. See review by Kathryn Klingebiel, Tenso 21 (2006): 63-68, providing detailed instructions and hints for utilizing COM.]

931.

Harris, M. Roy. "Le texte médiéval non-lyrique: textes en prose." Bulletin de l'AIEO, vol. 1: Les tâches de la recherche occitane. London: Westfield College, University of London, 1985, pp. 11-16. [See companion article by Don A. Monson, "Textes en vers," pp. 17-20.]

932.

Vatteroni, Sergio, and Peter T. Ricketts. "Ce qui reste à éditer de l'ancienne prose occitane." In 102, AIEO 9, 2011, pp. 471-86. [In connection with work on $C O M 3$, a listing of texts still to be edited and the problems involved; special consideration of a mid-fourteenth-century collection of translations of Franciscan texts (MS Assisi, Chiesa Nuova 9).]

933.

Vielliard, Françoise, "Auteur et autorité dans la littérature occitane médiévale non lyrique." In Auctor et auctoritas. Invention et conformisme dans l'écriture médiévale: Actes du colloque de Saint-Quentin-en-Yvelines (14-16 juin 1999). Edited by Michel Zimmermann. Paris: École des Chartes, 2001, pp. 375-89. [Classification of nonlyric works in Occitan, twelfth and thirteenth centuries: (1) by line length, (2) by the "authority" invoked (God or a book), (3) under the authority of fin'amor (didactic-narrative works), and (4) under the authority of named troubadours (insertions, galéries littéraires); rich documentation of non-lyric texts, some relatively unknown.]

\section{Monuments}

[Archaic texts: pre-twelfth-century; there are thirteen items, some not unanimously accepted as Occitan, in approximate chronological order: vernacular insertions in Latin texts; two medical charms; the Passion of Augsburg; the bilingual alba; the poem In hoc anni; the Sponsus; two (really three!) Harley lyrics "versus limousins"; the Boeci; the Chanson de Sainte Foy; the Passion of Clermont-Ferrand (Occitan?), the Vie de Saint Leger (Occitan?), and the fragmentary Alexander romance.]

\subsection{General Studies}

934.

Meneghetti, Maria-Luisa. Le origini delle letterature medievali romanze. Rome: Laterza, 1997. [Good overview of the earliest Occitan texts, with facsimiles, pp. 162-93; historical presentation and analysis of seven items: two medical charms, pp. 164-67; Passion of Augsburg, pp. 167-69; bilingual alba, pp. 169-77; vernacular insertions 
in Latin texts, pp. 177-80; In hoc anni, pp. 180-85; Sponsus, pp. 185-89; and two Harley lyrics, pp. 189-93.]

935.

Frank, Barbara, and Jörg Hartmann. Inventaire systématique des premiers documents des langues romanes. Avec la collaboration de Heike Kürschner. Tübingen: G. Narr, 1997. 5 vols. [Codicological information on nine "monuments": Passion of Augsburg, pp. 215-16; Passion of Clermont-Ferrand, pp. 217-18; Saint Leger, pp. 217-18; bilingual alba, pp. 219-20; Sainte Foy, pp. 221-22; Be deu hoi mais, pp. 222-23; Mei amis e mei fiel, pp. 222-23; O Maria Deu maire, pp. 222-23; Sponsus, pp. 222-23.] 936.

Hilty, Gerold. "Les plus anciens monuments de la langue occitane." In 134, Cantarem, 1995, pp. 25-45. [Close philological analysis of three of the oldest Occitan texts: the two medical charms, the Passion of Augsburg, and the bilingual alba; concludes that all three are Occitan; believes that the refrain of the bilingual alba is a love poem in the woman's voice, similar to Galician cantigas de amigo.]

937.

Hilty, Gerold. "I primi testi romanzi." In 129, Lo spazio letterario del medioevo, 2. Il medioevo volgare, vol. 1, part 2, 1999, pp. 57-89. [Basic information on five items: Saint Leger (maybe not Occitan); Passion of Clermont-Ferrand (maybe not Occitan); Passion of Augsburg; two medical charms; bilingual alba.]

\section{8.}

Paden, William D. "Before the Troubadours: The Archaic Occitan Texts and the Shape of Literary History." In 157, Essays Pickens, 2005, pp. 509-27. [Information on five items that prepared the way for the troubadour lyrics: vernacular insertions in Latin texts, pp. 511-13; two charms, pp. 513-15; the Passion of Augsburg, pp. 516-17; the bilingual alba, pp. 517-21; and two Harley love poems, pp. 522-6; very brief mention, pp. 510-11, of the Boeci, the Chanson de Sainte Foy, the Sponsus, the three "versus limousins": the Passion of Clermont-Ferrand, the Vie de Saint Leger, and the fragmentary Alexander romance.]

939.

Teulat, Roger. "L’occitanité des textes originaux antérieur à 1125." In $\ \mathbf{9 7 ,}$ AIEO 4, 1994, pp. 921-33. [Close linguistic analysis of early texts confirms that Occitan was strong and independent of influence from Catalan or French until at least 1125; Latin still exerted influence, of course.]

\subsection{Two Medical Charms}

[The oldest known literary texts in Occitan, from the middle or second half of the tenth century, found in the margin of a manuscript from Clermont-Ferrand; the first, in prose, has sixteen words, of which seven are indistinguishable from Latin; the second, in verse, has fifty-five Occitan words; the first is a ritual exorcism to cure a dislocated hand, the second to remove pain from a swelling or from childbirth.] 
940.

Bischoff, Bernhard. "Altprovenzalische Segen (zehntes Jahrhundert)." In Anecdota novissima: Texte des vierten bis sechszehnten Jahrhunderts. Stuttgart: Hiersemann, 1984, pp. 261-3. [Facsimile, plate 4; facsimile also in \$934, Meneghetti Le Origini 1997, plate 8.]

941.

Chambon, Jean-Pierre, and Philippe Olivier. "L'histoire linguistique de l'Auvergne et du Velay: notes pour une synthèse provisoire." Travaux de linguistique et de philologie 38 (2000): 81-153. [P. 114: localization of the two charms: the form colbe (<Vulgar Latin colaphum, colpum) suggests northern Occitan from Poitou to Basse Auvergne to the Viennois; see also RLaR 104 (2000): 245.]

942.

See 935, Frank and Hartmann, Inventaire, 1997, Number 3076, p. 107. [Codicological description, diplomatic edition of both texts; dated to the middle or end of the tenth century.]

943.

See 320, Lazzerini, Letteratura médiévale, 2001, pp. 11-14. [Prints both texts with Italian translation; localization is difficult, but seems to indicate the general area of Poitiers and the Abbey of St. Martial de Limoges; discussion of folkloric magic healing from Roman times to the present; points to rhythmic qualities in the second text: parallel structures, isocola, rudimentary rhymes, and divides the text into lines to show its poetic structure.]

944.

See 934, Meneghetti, Le origini, 1997, pp. 164-67. [Historical background of popular ritual charms and their absorption into Christian prayers; difficulty of localizing the texts linguistically, in spite of some similarities with the Passion of Clermont-Ferrand; transcription and Italian translation of both texts.]

945.

Paden, William D. "The Language of the Tenth-Century Occitan Charms from Clermont-Ferrand." In L'Art de la philologie: Mélanges en l'honneur de Leena Löfstedt. Edited by Juhani Härmä et al. Mémoires de la Société néophilologique de Helsinki, 70. Helsinki: Société néophilologique, 2007, pp. 185-98. [Diplomatic and critical editions of both texts, with English translation; detailed analysis of phonetic and morphological characteristics, confirming general localization to the Auvergne/Limousin and the status of the language as a true archaic form of Occitan.]

946.

Paden, William D., and Frances Freeman Paden. "Swollen Woman, Shifting Canon: A Midwife's Charm and the Birth of Secular Romance Lyric.” PMLA 125 (2010): 306-21. [The Tomida femina, a tenth-century birthing charm in ancient Occitan, discovered in 1984; critical text with English translation; detailed analysis of the poem alongside earlier attempts to understand it; discussion of its place in the European sociohistorical context.] 


\subsection{Bilingual Alba}

[Eleventh-century manuscript from Fleury-sur-Loire; three Latin stanzas, nine lines in all, with a repeated two-line refrain in a form of vernacular; musical neumes indicate that it was sung; interpretation is controversial: either it is a "normal" erotic alba about the parting of lovers at dawn or, more likely, a Christian religious allegory; references below are given in chronological order because of the lively, and sometimes bitter, controversy.]

947.

Chiarini, Giorgio. "Il bilinguismo dell'Alba di Fleury e le kharagiat mozarabiche." L'Albero 59 (1974): 3-21. [Notes structural resemblances with the Mozarabic and Hebrew muwashshahas and their vernacular kharjas and attempts to find a rational meaning in the complete poem.]

948.

Lazzerini, Lucia. "Per una nuova interpretazione dell'Alba bilingüe (cod, Vat, Reg. 1462)." SM 20 (1979): 139-84. [A new interpretation stressing the identity of the entire poem as a morning hymn, part of the Easter liturgy, singing of Christ's reemergence from hell, in the form of an allegory of the sun rising out of the sea at daybreak; the melody is transcribed in five experimental versions by Clementi Terni.]

949.

Hilty, Gerold. "Die zweisprachige Alba.” In Europäische Mehrsprachigkeit: Festschrift zum 70. Geburtstag von Mario Wandruszka. Edited by W. Pockl. Tübingen: Niemeyer, 1981, pp. 43-51. [Interpretation of the refrain as an early Occitan erotic alba; draws parallels with several of the Spanish hargas.]

950.

Picchio Simonelli, Maria. "A proposito dell'Alba bilingue." AIUO 26 (1984): 297330. [Comments on articles by Chiarini and Lazzerini; close study of the vernacular refrain and the Latin verses, which reveal a rather learned author; the vernacular refrain is to be taken as is, not "corrected" but treated as though it was written by the same learned author, with the same attitudes and intricacies; corrects Lazzerini's "overly erudite" reconstruction of the refrain and restores it to its natural simplicity.] 951.

Zumthor, Paul. "Un trompe-l'oeil linguistique? Le refrain de l'aube bilingue de Fleury." Rom 105 (1984): 171-92. [After reviewing nineteen proposed translations of the refrain, proposes the provocative hypothesis that the composer was not trying to make a rational statement but, as a poet, to portray new aesthetic values in a linguistic register opposed to that of the traditional Latin monastic texts; the mysterious refrain echoes key suggestive images from the Latin stanzas, in the vernacular. See a simplified restatement in La linguistique fantastique, Paris: J. Clims, 1985, pp. 285-99.]

952.

Lazzerini, Lucia. "Nuove osservazioni sull'Alba bilingue.” MR 10 (1985): 19-35. [The alba is a crucial text for the history of Romance lyric, linked closely to Middle Latin hymnology as well as to later troubadour lyric, and to the love of allegory to depict the fight between good and evil; the poem evokes Jesus's descent into and 
reemergence from hell; vocabulary places the origin of the poem in the Franco-Provençal area, while the contents reflect the spirituality of Cluny; the seeming simplicity of the refrain hides a doctrinal depth showing the Latin and vernacular verses to be of one piece.]

\section{3.}

Hilty, Gerold. "Text und Melodie der altokzitanischen zweisprachigen Alba." In Expedition nach der Wahrheit. Edited by Stefan Horlacher and Marion Islinger. Heidelberg: Carl Winter, 1996, pp. 295-306. [The Latin text speaks of nighttime as sin, sleep as death, dreams as evil temptations, all transformed by the coming of Christ as the sun; the refrain is entirely different: a love lament by a girl at dawn, similar in themes to the Mozarabic muwashshaha and the Galician cantigas de amigo, the contrast carried through by the play of languages and the great melodic differences between the Latin and vernacular texts.]

\section{4.}

Meneghetti, Maria Luisa. "L’Alba di Fleury, un Osterlied.” In Miscellanea Mediaevalia. Mélanges offerts à Philippe Ménard. Edited byJ.-C. Faucon, A. Labbé, and D. Quéruel. 2 vols. Paris, 1998, 2:969-83. [Careful review of previous research, and (optimistic?) clarification of the last remaining uncertainties about the categorization and origins of the alba, as well as the meaning of the refrain and its function as a gloss on the Latin text; see also 934, Meneghetti, Le origini, 1997, pp. 169-77.]

\section{5.}

Hilty, Gerold. "L'énigme de l'aube de Fleury est-elle déchiffrée?" RLiR 62 (1998): 321-30. [Disagrees with the interpretations of Lazzerini and Meneghetti, pointing to several problematic interpretations, and a discrepancy between the melody and the transcription of the refrain; insists that the purpose of the refrain is precisely to portray a rupture-in syntax, style, vocabulary, prosody, melody, and register.]

\section{6.}

See 938, Paden "Before the Troubadours," 2005, pp. 517-21. [Leans toward Lazzerini's interpretation of the poem as a religious allegory, rather than Hilty's claim that it is an early example of the Occitan erotic alba; does not pursue the intriguing structural resemblances with the Arabic and Hebrew jarchas.]

\section{7.}

Lazzerini, Lucia, with the collaboration of Giulio Braccini for bibliographical research. "Alba bilingue di Fleury: bibliografia ragionata." Online, 2008, at http:// www.rialto.unina.it. [Detailed analysis of scholarship on the alba from Johannes Schmidt, 1881, to Stefano Asperti, 2006, evaluated vigorously according to her own standards of research and understanding of the poem.]

\subsection{Latin Farci}

[Occitan insertions in charters and archival texts from 970 on.]

958.

Belmon, Jérôme, and Françoise Vielliard. "Latin farci et occitan dans les actes du XIe siècle." Bibliothèque de l'École des chartes 155 (1997): 149-83. [History of the 
beginnings of Occitan archival scripta from the second half of the tenth century; this was not "bad Latin," since the scribes were capable of writing in either language; in appendix, thirty-two documents containing Occitan elements, mostly eleventh and twelfth centuries.]

959.

See 938, Paden, "Before the Troubadours," 2005, pp. 511-13. [The use of Latin or vernacular was determined by an effort to choose between a more personal or a more abstract medium; from the mid-tenth century, sworn ritual oaths were given in the actual words of the swearer; in the late twelfth century, the practice changed to the use of one language or the other throughout.]

\subsection{Passion of Augsburg}

[Six-verse dramatic poem from the late tenth century, written on one line, with melody; discovered in 1976; the text is difficult to interpret, the language may be 960.

Occitan or Old French; facsimiles in Berschin and Meneghetti.]

Berschin, Helmut, Walter Berschin, and Rolf Schmidt. "Augsburger Passionslied: ein neuer romanischer Text des X. Jahrhunderts." In Lateinische Dichtungen des X. und XI. Jahrhunderts: Festgabe für Walther Bulst zum 80. Geburtstag. Edited by Walter Berschin and Reinhard Düchting. Heidelberg: Lambert Schneider, 1981, pp. 251-79. [Team study of the text by three scholars and many colleagues: (1) diplomatic study and edition, (2) codicological-paleographic study, (3) linguistic analysis, and (4) literary-historical study and localization; may have been performed during informal church festivities for Easter Sunday; facsimile, plates VII and VIII; the language is probably northern French but could be Occitan; see updated thoughts by Berschin and Berschin, $\operatorname{ZrP} 127.2$ (2011): 209-19: denial of any proof that the text is Occitan.]

961.

Bischoff, Bernhard. Anecdota novissima: Texte des vierten bis sechzehnten Jahrhunderts. Stuttgart: Hiersemann, 1984. [Thinks that the Passion of Augsburg poem was influenced by the pseudo-Sybilline prophecies, predicting the passion of Christ in the future.]

962.

Hilty, Gerold. "La Passion d'Augsbourg, reflet d'un poème occitan du Xe siècle." In - 149, Mélanges Michel Burger, 1994, pp. 231-43. [An edition of the text, assumed to be an Occitan original transmitted by French speakers to Strasbourg where it was transcribed; probably of Limousin origin, maybe from St. Martial de Limoges.]

963.

See 936, Hilty, "Les plus anciens monuments," 1995, pp. 31-35. [Justifies his reestablishment of the "original" Occitan text, contaminated by northern French transmission and perhaps by a German scribe; interprets it as a sibylline prophecy predicting Christ's Passion, in accord with Bischoff, rather than as part of the liturgy for Good Friday, as Kuen believed.] 
964.

See 934, Meneghetti, Le origini, 1997, pp. 167-69 [Critical of Hilty's modifications to the difficult text, removing a "French patina" and scribal errors, but accepts it "faute de mieux"; agrees that the text is Occitan; believes it to be complete as it stands, representing an early form of the Galician and French rondeau or a quem quaeritis trope; facsimile, plate 7.]

\section{5.}

Henrard, Nadine. "La Passion d'Augsbourg: un texte dramatique occitan?” In Convergences médiévales, épopée, lyrique, roman: Mélanges offerts à Madeleine Tyssens. Edited by Nadine Henrard, Paola Moreno, and Martine Thiry-Stassin. Brussels: De Boeck université, 2001, pp. 243-55. [Comments on the language of the poem in its various editions; the nature of the text itself and its place in literary history have not been entirely clarified; influenced by the Sibylline Oracles found widely and in various forms, mainly from southwest France or Spain; origins are therefore in Limousin, maybe St. Martial; agrees with Meneghetti that it is lyric, a sort of primitive rondeau, rather than a dramatized form, though still leaving open the possibility of its dramatic use in performance to enliven the liturgy.]

\section{6.}

See 320, Lazzerini, Letteratura, 2001, pp. 14-17. [Provides an amended critical text; says that Hilty's reconstruction is ingenious but should be seen as a point of departure for further study; suggests removing some of the emendations; the text remains mysterious but seems to point to future developments in musical and dramatic forms.]

\subsection{Passion of Clermont-Ferrand}

[End tenth century; religious narrative, based on the Bible and other religious texts; lyric in style; 516 lines in 129 four-line stanzas, the first stanza with musical notation.] 967.

Avalle, d'Arco Silvio. Cultura e lingua francese delle origini nella Passion di ClermontFerrand. Milan: Ricciardi, 1962. [Critical edition with Italian translation, copious notes; suggests the importance of an early literary center (Poitou, St. Martial de Limoges) in the transition between Medieval Latin and vernacular culture.]

968.

See 935, Frank and Hartmann, Inventaire, 1997, Number 2057, pp. 217-18. [Codicological and paleographical information on the Passion as well as Saint Leger, both with mixed French and Occitan language, dated to the end of the tenth century.]

969.

See 937, Hilty, "I primi testi," 2001. [Identifies the language as hybrid, perhaps a French text reworked in Poitou (St. Martial de Limoges?) by an Occitan revisor; out of 253 assonances, sixty-three are clearly French or Poitevin, nineteen Occitan, eleven mixed French and Occitan, the rest indeterminate.]

970.

Rychner, Jean. "Observations sur le style des deux poèmes de Clermont: la Passion $d u$ 
Christ et la Vie de Saint Léger." In Orbis mediaevalis, Mélanges $R$. R. Bezzola. Berne: Francke, 1978, pp. 353-71. [The Passion is more lyric than the Saint Leger, supported by its hymnlike music and the addition of many affective and expressive adjectives not found in the source, whereas the Saint Leger remains basic and factual, as in the Bible, and its music is more like a recitative.]

\subsection{Boeci}

[Incomplete text of 258 rhymed lines in thirty-five laisses; dating is controversial, from early eleventh century to early twelfth; perhaps by a monk of the Abbey of St. Martial in Limoges; a sort of sermon or commentary inspired by Boethius's De consolatione philosophiae; the anonymous author speaks in his own voice, rather than that of Boethius.]

971.

Schwarze, Christoph. Der altprovenzalische "Boeci." Forschungen zur romanischen Philologie 12. Münster: Aschendorff, 1963. [Critical text with German translation; extensive study of sources, vocabulary, and style.]

972.

Mermier, Guy. "Boeci: An English Translation of the Old Provençal Fragment with a Preface and Notes." In Contemporary Readings of Medieval Literature. Edited by Guy Mermier. Michigan Romance Studies 8. Ann Arbor: Department of Romance Languages, University of Michigan, 1989, pp. 21-35. [English translation only, based on Schwarze's text, with introduction and textual notes.]

\section{3.}

See 850, Chambers, Introduction, 1985. [Pp. 1-9: the metric form of Boeci resembles that of the Old French epics, but since it is older than any of them, it cannot be claimed that it used the epics as a model; nor is it likely that the epics copied its form; probably both traditions were based on one of the rhythmic patterns of medieval Latin verse.]

974.

Cropp, Glynnis. "The Occitan Boecis, the Medieval French Tradition of the Consolatio philosophiae and Philosophy's Gown." In 140, Etudes Ricketts, 2005, pp. 255-66. [The Boeci is a didactic work, combining classical philosophical thought, as in the original Consolatio, with essential notions of Christian doctrine; instructs young people to "live a Christian life and thus avoid evil"; Cropp finds no parallels with hagiographical or epic textual traditions.]

975.

Fraser, Veronica. "Le Boeci: sa place dans la littérature hagiographique en langue romane." In 99, AIEO 6, 2001, pp. 367-71. [Analysis of three early Occitan texts, La Vie de Saint Leger, Boeci, and Chanson de Sainte Foy at the origins of vernacular hagiography exemplified by the Old French Vie de Saint Alexis: the Boeci has typical elements of the passion of a martyr who dies for his Christian beliefs and deserves to be recognized as one of the first vernacular saints' lives, with the title: Vida e passio de Sant Severin Boeci.] 


\subsection{Sainte Foy (Canso de Sancta Fides)}

[Feast-day 6 October; martyred in 303; anonymous narrative of her life, composed ca. 1060-80 in the southern Occitan or northern Catalan area;

593 lines in forty-nine rhyming laisses.]

976.

Hoepffner, Ernest, and Prosper Alfaric. La Chanson de Sainte Foy. Paris: Les BellesLettres, 1926. [Facsimile of manuscript; critical edition with introduction and philological study by Hoepffner; historical introduction, study of Latin sources by Alfaric; French translation based on text by Thomas; a new edition is announced by Marco Piccat: see 140, Etudes Ricketts, 2005, p. 60, n. 11.]

977.

Lafont, Robert. La Chanson de Sainte Foi: texte occitan du XIe siècle. Textes littéraires français, 490. Geneva: Droz, 1998. [Critical text with French translation; does not replace the Hoepffner/Alfaric edition; some misreadings and inaccuracies; several important recent studies were not utilized; demonstrates interesting generic links between hagiography and epic poems and discusses many contentious passages in the text.]

978.

Burger, Michel. "Remarques sur les deux premières laisses de la Chanson de Sainte-Foy et le sens de razon espanesca (v. 15).” VR 48 (1989): 41-57. [Proposes that the subject was "Spanish" because Saint Foy was an inspiration for Christians to fight the infidel in the Reconquista (good vs. evil) and that the hidden message was a call to crusade "in the manner of the French" since they were identified with the militant church as defenders of the faith.]

979.

Espòsito, Anthony P. "The Language of the Chanson de Sainte Foy: Why the Hispanic Manner Matters.” Romance Quarterly 56, no. 1 (2009): 21-32. Studies in Romance linguistics in honor of Roger Wright, part 1. [Dialectal evidence shows more Catalan linguistic presence in the poem than generally thought; possible composition was in the eastern Pyrenees area.]

980.

Fassò, Andrea. "Dai poemetti agiografici alle chansons de geste o vice-versa?" In Critica testuale e esegesi del testo. Studi in onore di Marco Boni. Bologna: Patròn, 1985, pp. 45-95 [Study of the origins of epic texts; stresses the close link between hagiographic and epic works, in techniques of composition and in narrative structures. Reprinted in Gioie cavalleresche, Rome: Carocci, 2005, pp. 19-69.]

981.

Hilty, Gerold. "Encore une fois le prologue de la Chanson de Sainte Foy." In 139 ,

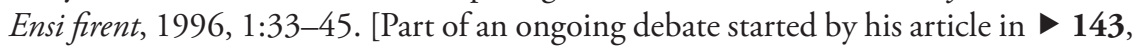
Homenaje Fuentes, 1985-87, pp. 361-74; lengthy review of interpretations by Burger 1989 and several by Lafont, most of which are accepted; continues to believe that the canczon of line 14 refers to a Latin poem, not to the extant vernacular song, and that the granz pros of line 21 will come to the song itself rather than to its performer.] 
982.

Lafont, Robert. "De la Chanson de Sainte Foy à la Chanson de Roland: le secret de la formule de composition épique.” RLaR 91 (1987): 1-23. Reprinted in La Source sur le chemin, Paris: Harmattan, 2002, pp. 147-71. [Calls for a renewal of studies of epic and hagiographic texts; finds links in structural architecture between the Sainte-Foy and the early versions of Roland, based on sequences of eleven laisses, found also in Guilhem de Tudela's Canso de la Crozada; the rhythm is that of a precisely measured processional dance within the basilica of Conques.]

983.

Lafont, Robert. "Sens et littérature à l'origine de l'Europe moderne." Littérature 76 (1989): 6-23. [Hypothesis that the Chanson, based on the Latin life made into an inspirational vernacular "dance," was the model for an original Navarro-Occitan Roland epic, similar to the later Ronsasvals, reformulated in the Norman dialect for the Franks in Spain; the early history of the epic must be reconsidered.]

984.

Lafont, Robert. La Geste de Roland. 2 vols. Paris: Harmattan, 1991. [Analyzes the beginning of the Chanson de Sainte Foy: 1:193-94: postulates a reference to a lost text, an early version of the Roland, perhaps similar to the later Occitan Ronsasvals, which served as a structural model for Sainte Foy.]

985.

Piccat, Marco. "La Chanson de Sainte Foy: quelques notes pour l'interprétation." In

- 140, Etudes Ricketts, 2005, pp. 59-70. [Localization and language of the Chanson are controversial; Piccat is preparing a new edition; in the meantime, two examples of textual exegesis are offered: the geography of the Holy Land is explored to correct the Bible and suggest the real meaning of "St. Nicolas" in the context (lines 40-41); the reference to Saint Felix (lines 169-71) is not to Felix of Girona but to a Roman martyr whose passion has several parallels to that of Foy. Several other passages require detailed clarification of social background before further investigation of the language, provenance, and even authorship of the text may be undertaken.]

986.

Rossi, Luciano. "Cantar, canczun et flabla de cuczun: sur le sens du dernier vers de la Sainte Foy." In 149, Mélanges Michel Burger, 1994, pp. 245-54. [Stresses the admirable structural coherence of the poem, while distinguishing between the first part, canczun, the glorification of Foy, to the end of laisse 41, which was probably sung and perhaps danced in procession, and the second part, cantar, the punishment of her tormentors, probably recited.]

987.

Sheingorn, Pamela. The Book of Sainte Foy. Philadelphia: University of Pennsylvania Press, 1995. [Sociohistorical introduction; English prose translation of the Latin texts: The Passion of Sainte Foy; The Book of Sainte Foy's Miracles; the Translation of Sainte Foy Virgin and Martyr to the Conques Monastery; the Occitan poem is presented in English prose by Robert L. A. Clark, based on Hoepffner's text; notes; see also Sheingorn's article with Kathleen Ashley, "The Translations of Foy: Bodies, 
Texts and Places," in The Medieval Translator 5, Traduire au Moyen Âge: Proceedings of the International Conference of Conques (26-29 July 1993), edited by Roger Ellis and René Tixier, Turnhout: Brepols, 1995, pp. 29-49; the figure of Sainte Foy is explored in terms of her physical translation from one place of veneration to another, the literal translation of texts concerning her life and works, and her role as intercessor/translator between the human and divine worlds.]

988.

Uitti, Karl D. "The Old Provençal Song of Saint Fides and the Occitanian Concept of Poetic Space." L'Esprit Créateur 19 (1979): 17-35. [The poem reflects the same social and artistic base, the "poetic space," as that of the later troubadour lyrics; it expresses already the characteristic value system within which the troubadour poetry was to function; Uitti distinguishes between the roles played in the poem by the narrator and the performer (joglar), making the work into a more sophisticated piece than had been thought.]

989.

Work, Elisabeth P. "The Eleventh-Century Song of Saint Fides: An Experiment in Vernacular Eloquence." RPh 36 (1983): 366-85. [The song is divided into two distinct parts; the first forty-one laisses, the story of Foy and her martyrdom, are rich and vibrant, while the final eight are unattractive, telling with disgust of the revenge exacted on the wicked felons; the poet speaks through a narrator of his own creation, creating a complex narrative dynamic; while the poet remains invisible, he stands behind the simple, colorful joglar narrator, manipulating multiple levels of diction and imagery.]

\subsection{Two Harley Lyrics}

[Two short Romance love poems from the late eleventh century, both with music; the oldest examples of Occitan vernacular lyric; one has been mostly deciphered, the other remains more mysterious.]

990.

Bec, Pierre. "Prétroubadouresque ou paratroubadouresque? Un antécédent médiéval d'un motif de chanson folklorique Si jeétais une hirondelle." CCM 47 (2004): 15362. [Folklore sources may have inspired the theme used by Bernart de Ventadorn and others: "If I were a swallow or bird, I would fly to my beloved"; the continuity and form of the theme suggests a popular usage independent of the courtly register; language is indeterminate, not necessarily Occitan, perhaps Franco-Provençal; not a prelude to troubadour lyric but a coexistent form still alive in many areas.]

991.

Bischoff, Bernhard. "Altfranzösische Liebesstrophen (Spätes elftes Jahrhundert?)." In Anecdota novissima: Texte des vierten bis sechszehnten Jahrhunderts. Stuttgart: Hiersemann, 1984, pp. 266-69. [Thinks that the language is French, with some Occitan and perhaps Latin forms; dates them to the last third of the eleventh century; speculates that they may have been transcribed by a German speaker from memory or by oral transmission; facsimile, plate 5.] 
992.

See 320, Lazzerini, Letteratura, 2001, pp. 28-34. [The widespread courtly motif of the lover as sparrow-hawk (or other bird) is found in the first song, which seems to predate Guilhem de Peitieus, confirming the existence of vernacular lyric traditions before the troubadours; language traits suggest an origin in the Poitou region, with unusual forms due to northern French oral transmission and a German scribe; the second poem is defective, but Lazzerini suggests that it may be an early form of sirventes, a moral condemnation of nuns who break their vows by entertaining knights.] 993.

See 934, Meneghetti, Le origini, 1997, pp. 189-93. [Confirms the Poitevin origin of the texts, obscured by northern French and Germanic contaminations; the clarification of the themes by Lazzerini, reinforced by historical references and Arabic parallels, proves the existence of a love ethic similar to that of the troubadours a full generation before Guilhem; facsimile, plate 12.]

994.

See 886, Meneghetti, "Intertextuality and Dialogism," 1999. [Discusses the place of the first poem in a series of variations on the theme of the lover/bird.]

995.

Mölk, Ulrich. "Zwei Fragmente galloromanischer weltlicher Lyrik des 11. Jahrhunderts." In 139, Ensi firent, 1996, 1:47-51. [Very detailed examination of the two fragments, following on Lazzerini's 1993 study; shows convincingly that the texts are Occitan, transmitted by a French speaker.]

996.

See 938, Paden, "Before the Troubadours," 2005, pp. 522-26. [The texts provide proof of the early emergence of Occitan as a vehicle of literary culture, providing both praise and blame for fin'amor; showing that "Guilhem and his contemporaries did not venture into a void."]

\subsection{Alexandre}

[Fragment of a romance by Alberic de Besançon; end of the eleventh century; Franco-Provençal; 105 lines in fifteen assonanced laisses of varying length.] 997.

Mölk, Ulrich, and Günter Holtus. "Alberics Alexanderfragment. Neuausgabe und Kommentar." ZRP 115 (1999): 582-625. [Paleographical description, half-diplomatic edition, critical text with German translation, pp. 618-19; the language is an original literary composite, basically Franco-Provençal with Occitan and French elements; the author's name is indeed Alberic de Besançon, since Besançon was within the dialectal zone of Franco-Provençal until the thirteenth century; many detailed notes.]

998.

Mölk, Ulrich. "Alberics Alexanderlied." In Alexanderdichtungen im Mittelalter. Kulturelle Selbstbestimmung im Kontext literarischer Beziehungen. Edited by Jan Cölln, Susanne Friede, and Hartmut Wulfram with the collaboration of Ruth Finckh. Göttingen: Wallstein, 2000, pp. 21-36. Also in CN 61 (2001): 7-24. [A convincing 
reconstruction of the lost elements of Alberic's text through careful comparisons with sources and later versions of the work; shows that Alberic was a very cultivated cleric who had access to a rich collection of Latin and vernacular works and a coherent, positive plan to glorify Alexander as the idealized hero who freed Greece from the Persian tyrant Darius.]

999.

Lafont, Robert. "Nouveau regard sur le Fragment d'Alexandre." RLiR 66 (2002): 159-207. [Diplomatic edition, study, and "critical" edition, with a stanza-by-stanza French translation and commentary; the critical edition is an idiosyncratic attempt to reconstruct the original "pure" text, by eliminating the Franco-Provençalisms and bringing back the "original" six-line stanzas.]

1000 .

Zufferey, François. "Perspectives nouvelles sur l'Alexandre d'Auberi de Besançon." $\operatorname{ZrP} 123$ (2007): 385-418. [Discusses the identity and origin of the author and the different linguistic components within the text; confirms the language as basically Franco-Provençal and the origin of Alberic (Auberi) as indeed Besançon; detailed study of the various components of the language: Latin, Franco-Provençal, Occitan, French; new critical edition with French translation and several elucidations to the meaning of the text.]

\subsection{Life of St. Leger}

[End of the tenth or early eleventh century; a sung hagiographical narrative modeled on Ambrosian hymns; 240 lines in forty six-line stanzas, the first line with musical notation; language is controversial: perhaps French in origin (Picard-Walloon?), copied in Poitou, with many Poitevin and Occitan forms; in the same manuscript as the Passion de Clermont-Ferrand.]

1001.

Linskill, Joseph. Saint Léger: étude de la langue du manuscrit de Clermont-Ferrand suivie d'une édition critique du texte. Paris: Droz, 1937. [Detailed phonetic and morphological analysis of the text, postulates a provenance from northeast France; study of the manuscript and versification; critical edition and glossary; no translation.]

1002.

See 935, Frank and Hartmann, Inventaire, 1997, Number 2057, pp. 217-18. [Codicological and paleographical information on Saint Leger, postulates mixed French and Occitan language, dated to the end of the tenth century.]

1003.

See 970, Rychner, "Observations sur le style," 1978. [The Saint Leger has a factual, "rustic" presentation, avoiding personal emotions or background commentary, reinforced by its non-lyrical, recitative music, whereas the Passion is more lyrical and expressive, with hymnlike music, intercalated adjectives of emotion, and background commentary.] 


\subsection{Sponsus}

[Anonymous liturgical drama from the end of the eleventh century; also called Drame de l'époux or Mystère des vierges sages et des vierges folles; bilingual text of eighty-seven lines, forty-seven in Latin, forty in Occitan, with music, based on

Matthew 25:1-13; the interplay of Latin and Occitan may be intended to underline the dramatic interplay of the wise and foolish virgins.]

1004.

Avalle, D'Arco Silvio, and Raffaello Monterosso. "Sponsus," dramma delle vergini prudenti e delle vergini stolte. Milan: Ricciardi, 1965. [Historical and linguistic study, critical text with Italian translation, notes; transcription and study of the melody by Monterosso; phototypographic reproduction of the manuscript; Avalle argues against the traditional view that the Sponsus and the Passion de Clermont-Ferrand were translated from French into Occitan; believes that they were written in Poitevin, regarded as one of the four linguistic zones of Gallo-Romance (i.e., Occitan, French, FrancoProvençal, and Poitevin).]

1005.

Beck, Alfons. “Le jeu des vierges du ms Paris BN lat 1139.” Revue romane 19 (1984): 245-83. [Edition of Sponsus with French translation; original analysis of the drama in part 3: the first ten lines form an independent poem, while 11-87 are a play, different from the poem in theological conception, dramatic structure, versification and melody.]

\section{6.}

Dronke, Peter. Nine Medieval Latin Plays. Cambridge: Cambridge University Press, 1994, pp. 3-24. [Introductory study of the sociohistorical setting and dramatic dialogues of the Sponsus, pp. xx-xxii: believes that the Occitan verses have greater poetic power than the Latin; pp. 3-23: analysis of structure, versification and manuscript; edition with English translation, notes.]

\section{7.}

See 1322, Henrard, Le Théatre religieux, 1998, pp. 15-28 and 441-60. [Pp. 15-28: study of the manuscript and the language indicates that the bilingual text was put together in the region of Poitou, with Occitan text intercalated as a gloss of the Latin, but many mysteries about the origin and the use of the play remain; pp. 441-60: study of versification (metrics, stanza structure, refrains) and the poetic use of bilingualism proves that the Latin and vernacular sections are independent.]

1008.

Hunt, Tony. "Le sensus moralis du Sponsus." CCM 26 (1983): 327-34. [Negligence, or lack of good works, or sleeping too long, do not explain the basic blame directed to the Foolish Virgins; good works must be accomplished with the right spirit of complete charity in order to be acceptable to God, following the ideals of St. Augustine and St. Gregory.]

1009.

See 934, Meneghetti, Le origini, 1997, pp. 185-89. [Dramatic structures, even stage directions, are used to enhance the performance, indicating the need for more 
and different space, which eventually takes drama outside the church; counterpoint is set up between the two linguistic registers, the lyric-narrative tone of the Latin verses contrasting with the elegiac coloring of the vernacular.]

\section{0.}

Ziino, Agostino. "Alcune osservazioni sul testo musicale dello Sponsus." CN 27 (1967): 109-19. [Problems of establishing a "correct" transcription of the melody that is as close as possible to the original composition; repetitive structures can be a guide; extemporaneous embellishment may be made by the composer, the performer, or the copyist; in the Sponsus, the musical structure is based on symmetry, with some flexibility; structural logic and statistics can guide us in evaluating variant notations, but critical procedures still need to be developed.]

\subsection{Two Poems to the Virgin ("Versus Limousins")}

[Texts from the end of the eleventh century, composed in the Abbey of St. Martial de Limoges, now bound into a thirteenth-century manuscript from the Abbey, all with music, preceded by: (1) A six-line prayer to God entitled Tu autem, incipit Be deu hoi mais, which is separate from the others, of uncertain dating, perhaps later; (2) a Nativity hymn of nineteen three-line stanzas plus refrain, the stanzas alternately in Latin and Occitan, the last four all in Occitan; incipit: In hoc anni circulo, second stanza: Mei amic e mei fiel, Laisat estar lo gazel; and (3) a prayer of devotion to the Virgin, Versus sancte Marie, with twelve four-line stanzas,

\section{1.} entirely in Occitan, beginning O Maria, Deu maire.]

Arlt, Wulf. "Zur Interpretation zweier Lieder: A Madre de Deus und Reis glorios." Basler Jahrbuch für historische Musikpraxis 1 (1977): 117-30. [Transcription of the melody of $O$ Maria Deu maire, which is the oldest preserved (ca. 1100) of a group of related melodies that includes the hymn Ave maris stella, the Spanish cantiga $A$ madre de Deus by Alfonso the Wise, and Giraut de Bornelh's alba Reis glorios; comparative analysis of musical structures and the relationship of text to music; datings and relative chronology in the group are difficult to establish.]

\section{2.}

Brunel-Lobrichon, Geneviève. "Le manuscrit du Sponsus et ses poésies bilingues. Edition et traduction de deux poèmes à la Vierge (XIe siècle)." In La Tradition vive: Mélanges d'histoire des textes en l'honneur de Louis Holtz. Edited by P. Lardet. Paris: Turnhout, 2003, pp. 401-15. [The last two poems were copied about 1100, at about the start of Guilhem de Peitieus's poetic activity; analysis of form and content: the first is a dialogue between Mary and the angel of the Annunciation; the second is an early representative of redemption theology, which became popular in the twelfth century, with contrasts and parallels between Eve and Mary, Adam and Jesus; edition of the two poems with French translation, textual notes.] 


\section{Epic Literature}

1013.

\subsection{General Epic}

Bertolucci Pizzorusso, Valeria. "Generi in contatto: le maschere epiche del trovatore." In Les chansons de geste: Actes du XVIe congrès int. de la soc. Rencesvals, pour l'étude des épopées romanes, Granada, 21-25 juillet 2003. Edited by Carlos Alvar and Juan Paredes. Granada: Universidad de Granada, 2005, pp. 111-22. [Third-generation lyrics make more reference to epic titles and heroes as part of a new emphasis on realism and the North-South dialectic and an effort to renew thematic content; special analysis of Bertran de Born, Guillem de Berguedan, and Raimbaut de Vaqueiras; Raimbaut manages to fuse epic and lyric themes entirely; for a similar investigation of the merging of genres, 1578, Busby, "Hagiography at the Confluence," 1997.]

\section{4.}

Brunel-Lobrichon, Geneviève. "Histoire et fiction: Guillaume et l'épique occitan." In Entre histoire et épopée. Les Guillaume d'Orange (IXe-XIIIe siècles). Edited by Laurent Macé. Toulouse: FRAMESPA, 2006, pp. 279-91. [Proposes as a strong hypothesis, following on that of Jean-Claude Dinguirard, that the epic Cycle of William of Orange was composed originally in Occitan as early as the tenth century, before being translated and transposed into French; see also Alice Colby-Hall, "Epic Traditions in the Land of the Troubadours," Perspectives médiévales 3 (1988): 1-26.]

\section{5.}

Colby-Hall, Alice M. "In Search of the Lost Epics of the Lower Rhône Valley." Olifant 8, no. 4 (1981): 339-51. Also in Romance Epic: Essays on a Medieval Literary Genre. Edited by Hans-Erich Keller. Kalamazoo, MI: Medieval Institute Publications, 1987, pp. 115-27. [Assembles several pieces of historical and literary evidence that point to the existence of an older lost version of the Prise d'Orange that she calls the Presa d'Aurenga, composed in Occitan or in the literary koiné Franco-Occitan; likewise, supposed "French" forms in the Roman d'Arles point to a local creation in hybrid language, rather than to a French source.]

\section{6.}

Gaunt, Simon. "Desnaturat son li Frances: Language and Identity in the TwelfthCentury Occitan Epic.” Tenso 17, no. 1 (2002): 10-31. [Vernacular language was a marker of cultural and political difference developed in the late twelfth and early thirteenth centuries, as opposed to Latin as the international language of high culture; analysis of Girart de Rossilhon and Daurel e Beton, both of which feature conflicts between France and Occitania, both of which are in Occitan mixed with hybrid forms; postcolonial translation theory is used to define national identities.]

1017.

Ivens, Angelika, and Annette Klein. "Karl im Land der Trobadors: das Karlsbild der altokzitanischen Epik." In Karl der Grosse in den europaïschen Literaturen des Mittelalters: Konstruktion eines Mythos. Edited by Bernd Bastert. Tübingen: Niemeyer, 2004, pp. 39-52. [The idiosyncratic treatment of the figure of Charlemagne and his 
epic heroes in the Occitan epics; in Roland a Saragosse, Olivier and Roland have a more complex relationship of devotion and rivalry; Charlemagne plays a passive role in relation to the younger generation; in Ronsasvals he is a broken leader, deprived of his best knights, admitting his incestuous sin in fathering Roland with his sister; this may be interpreted allegorically as signaling the end of Occitanian society and culture after the Albigensian Crusade (see 1119, Schulze-Busacker, "La datation," 1989), but dating and chronolgy remain uncertain.]

\section{8.}

Kay, Sarah. The Chansons de Geste in the Age of Romance. Political Fictions. Oxford: Clarendon, 1995. [Two Occitan epics are discussed in relation to the French tradition, which is represented by thirty-five texts: Daurel e Beton, Girart de Rossilhon; the first is used as an example of male companionship which is strengthened by exchanging gifts, including women; the second features also the destructiveness of male bonding but, in the two additions at beginning and end, stresses the importance of women, who bring about a degree of social redemption.]

1019.

Lafont, Robert. "Pour rendre à l'oc et aux Normands leur dû: genèse et premier développement de l'art épique gallo-roman." CCM 42 (1999): 139-78. Reprinted in La Source sur le chemin, Paris: Harmattan, 2002, pp. 449-523. [A strong claim for the origins of the Gallo-Roman epic in the late eleventh and early twelfth century as a dialectic between Occitan and Norman creativity; an important role was played by the Chanson de Sainte Foy and the original Occitan Roland.]

\section{0.}

Lafont, Robert. "Les trois espaces de l'épique occitane médiévale: essai de synthèse." In 99, AIEO 6, 2001, pp. 448-57. [Three centers of creation: Roland in the Aquitaine-Navarre area, the elaboration of a myth based structurally and thematically on the Chanson de Sainte Foy among Frankish colonists in Navarre; the area of Narbonne: Ronsasvals, perhaps the first part of the Canso de la Crozada; Arles and the Rhone valley: Roman d'Arles and an early version of Girart de Rossilhon; the origins of the epic are contemporaneous with the appearance of the troubadour lyrics, in the same places, using the same language.]

1021.

Lafont, Robert. "Epopée d'oïl et épopée d'oc: la place de la Cançon d'Antioca." In 140, Etudes Ricketts, 2005, pp. 37-46. [The Occitan Ferabratz precedes the Old French version; the Paris manuscript of Girart de Rossilhon (Occitan) is the original, of which the $O$ manuscript used as a base by modern scholars, is an unsuccessful adaptation into French, falsely called "langue mixte"; the Roman d'Alexandre was originally Occitan - the corrupted form, of which only a fragment remains, has been altered by various additions in different dialects; Bechada's fragmentary text of the Antioca is the original, forming the missing link that proves the originality of the "Tudèle-Aquitaine" school, the Occitan originators of Romance narrative and heroic poetry.] 
1022.

Routledge, Michael J. "Songs." In The Oxford Illustrated History of the Crusades. Edited by Jonathan S. C. Riley-Smith. Oxford: Oxford University Press, 1995, chapter 5. [A dozen specialist historians analyze religious, economic, and military aspects and motivations of the Crusades; Routledge, pp. 91-111, examines works that the people listened to and saw performed as entertainment, with an admixture of instruction and propaganda: i.e., the Canso d'Antiocha and Canso de la Crozada.]

\subsection{Aigar e Maurin}

[Anonymous epic, second half of the twelfth century; two fragments totaling 1,437 lines in forty-four laisses; recounts the war between the English king Aigar and his vassal Maurin (Henry II Plantagenet and the Capetians).] 1023.

Brossmer, Alfred. "Aigar et Maurin, Bruchstücke einer chanson de geste nach der einzigen Handschrift in Gent neu herausgegeben.” RF 14 (1903): 1-102. [Introduction: the manuscript, text history, résumé, linguistic analysis; critical text with notes, no translation; see corrections by Bertoni, Rom 41 (1912): 401-5, and Archivum romanicum 1 (1917): 224-26, and by Jeanroy, $A M 17$ (1905): 583-84.]

1024.

Galley, Claude. "Aigar et Maurin, témoins de la civilisation et de la littérature des marches occidentales du Nord-Ouest." Marche romane 33 (1983): 75-92. [Localization is unclear, but generally northwest, a mixture of Occitan and (Anglo-) Norman, perhaps from Poitou; the author shows familiarity with the military camps of his day.] 1025.

Keller, Hans-Erich. “Aigar et Maurin.” In $>$ 97, AIEO 4, 1994, pp. 159-63. [Text preserved only in two folios reused in a sixteenth-century Latin legal manuscript; unrelated to other epic cycles; concerns the revolt of Young Henry against his father Henry II and his brother Richard Coeur-de-lion; probably Anglo-Norman originally, but the extant folios are from a Poitevin reworking in a mixed language imitating that of Girart de Rosssilhon.]

1026.

Naudeau, Olivier. “Observations sur la langue de Aigar et Maurin.” Rom 115 (1997): 337-67. [Detailed analysis of forty-two linguistic items shows that the language is the composite literary language of the last third of the twelfth century, similar but not identical to the language of Girart de Rossilhon.]

1027.

Paterson, Linda M. "Knights and the Concept of Knighthood in the Twelfth-Century Occitan Epic.” FMLS 17 (1981): 115-30. Reprinted in W. H. Jackson, Knighthood in Medieval Literature. Woodbridge: D. S. Brewer, 1981, 23-38. [Detailed study of chevaler and its derivatives in Canso d'Antiocha, Girart de Rosssilhon, and Aigar e Maurin, Daurel e Beton.] 


\subsection{Canso d'Antiocha}

[1130-45? fragment of 714 lines; chronicle of the First Crusade by Gregori Bechada, perhaps freely adapted from the lost French Chanson d'Antioche by

Richard le Pèlerin, now known only in a later French adaptation by Graindor

de Douai; some scholars believe that Bechada's text was the original, while others claim that Bechada's original is lost and the extant fragment is a revised version of it, based on a later French version.]

\section{8.}

Sweetenham, Carol, and Linda M. Paterson. The "Canso d'Antiocha": An Occitan Epic Chronicle of the First Crusade. Aldershot: Ashgate, 2003. [Codicological and textual study, outlining unique features compared with the Old French version; analysis of the blending of historiography and epic qualities and allusions to the Roland tradition; critical text with facing-page English translation, notes, and glossary.]

\section{9.}

Gómez Moreno, Ángel. “Una nueva edición de la Canso d'Antiocha." Revista de Literatura Medieval 6 (1994): 9-42. [Analysis of previous scholarship, pp. 9-25; complete photographic reproduction of the manuscript; critical text of the first five laisses (he calls it an "edición semipaleográfica”) with Spanish translation, notes.]

\section{0.}

Gareyte, Jean-François. L'aube des troubadours: la Chanson d'Antioche du chevalier Béchade. Périgueux: La Lauze, 2005. [A readable, somewhat popularized reconstitution of the work, based on 86 fragments altogether, including the original fragment of 707 verses and others in Castilian, Occitan, and Latin; all are in French translation, no original texts given; detailed commentary, notes, sketchy bibliography.]

\section{1.}

Dewberry, Carol Elizabeth. "La Canso d'Antiocha, histoire et légende: perspectives sur la bataille d'Antioche." In La Croisade, réalités et fictions: Actes du colloque d'Amiens. Edited by D. Buschinger. Göppingen: Kümmerle, 1989, pp. 97-109. [More episodes of the fragmentary Canso may be recovered from the Spanish Gran Conquista de Ultramar, some of which was translated from Bechada's lost text; judging from a reconstituted version, Dewberry concludes that Bechada's work is remarkably detailed and realistic, even though influenced by popular legends and miracles, and epic traditions of style.]

1032.

See 1021, Lafont, "Epopée d'oïl," 2005, pp. 44-46. [Bechada's fragmentary text of the Antioca is the original, forming the missing link that proves the originality of the "Tudèle-Aquitaine" school, the Occitan originators of Romance narrative and heroic poetry.]

\section{3.}

Limentani, Alberto. "Pour le fragment de la Canso d'Antiocha." In Guillaume d'Orange and the Chanson de geste: Essays Presented to Duncan McMillan in Celebration of His Seventieth Birthday by His Friends and Colleagues of the Société Rencesvals. Edited by Philip E. Bennett and Wolfgang van Emden, with Alexander Kerr. 
Reading: University of Reading, 1984, pp. 75-83. [Study of the literary aspects of the fragment: line lengths, extension of laisses, use of laisses similaires, authorial interventions in the petits vers; all indicate a well-developed technique and a later rather than earlier dating for the work.]

\section{4.}

Paterson, Linda M. "La Canso d'Antioca occitane: gallicismes phonologiques et histoire textuelle." In 107, Ab nou cor, 2004, pp. 289-96. [History of manuscript and text; study of French and Occitan forms at the rhyme, which may represent corrupted forms, poor translation, or an intentional feature of style, even a subtle form of protest against the political and linguistic invasion of Occitania by the French.]

\section{5.}

Paterson, Linda. "Legal Agreements in the Occitan Canso d'Antioca." In Paterson, Culture and Society in Medieval Occitania. Farnham: Ashgate Variorum, 2011, \#19 (12 pp.). Originally presented 2001 as a paper and published in VIe Colloque international CRISIMA, Montpellier, 21-24 novembre 2001: Serment, promesse et engagement: Rituels et modalités au Moyen Âge. Edited by Françoise Laurent. Montpellier: Presses Universitaires de la Méditerranée, 2008, pp. 195-204. [Analysis of the negotiated covenant for a judicial duel between thirty Christians and thirty Saracens to decide the outcome of the battle for Antioch; discussion of the legal vocabulary and the complex rituals and traditions of warfare revealed by the text; edition with commentary of three excerpts from the Canso.]

\subsection{Roman d'Arles}

[Anonymous composite text of 1,289 lines, preserved in a copy made ca. 1374-75 by Bertran Boysset; an attempt to glorify Arles by furnishing it with a legendary history going back to paradise, then through Jerusalem and Rome to Arles.]

\section{6.}

Haupt, Hans-Christian. Le "Roman d'Arles" dans la copie de Bertran Boysset (manuscrit Aix-en-Provence, Musée Paul Arbaud, M.O. 63). Études et édition. Tübingen: Francke, 2003. [The preserved text is a composite, put together by a compiler by mid-fourteenth century, revised by a remanieur, then copied and perhaps further revised by Boysset before 1375; the three seemingly disparate sections of the text (legendary, religious, and epic) are held together (weakly) by the intention of glorifying Arles by furnishing it with a legendary history; detailed study of sources, language, and themes; critical text and facing-page French translation, with many notes and a glossary; see the review by Harris in FL 138 (2004): 291-304: detailed notes, suggestions, and corrections.]

1037.

Keller, Hans-Erich. "Charlemagne et ses pairs dans le Roman d'Arles." In 151, Mélanges Bec, 1991, pp. 235-48. [Olivier (de Verdun) is the same Olivier as Roland's compagnon, but from an older stratum of the legendary tradition; Olivier is essentially an Occitan hero.] 
1038.

Lafont, Robert. "Réflexions sur le Roman d'Arles." RLaR 108 (2004): 243-60. [Unravels the seemingly disorderly series of episodes and fragments that make up the Roman in its fullest state, in an attempt to explain Bertran's intentions and, even further back, to decipher the process of compilation; shows that the text is an amalgam of disparate pieces put together perhaps by Bertran himself, or more likely by an earlier compiler, in order to construct a legendary patriotic history to glorify Arles and probably to draw attention to the Abbey of Saint Honorat, along with Raymond Ferraud's mythological Vida de Sant Honorat (end of thirteenth century); see 1577 , Ricketts, La Vida de Sant Honorat.]

\section{9.}

Lafont, Robert. "Conflit de norme littéraire et d'oralité dialectale: le Roman d'Arles dans la copie de Bertrand Boysset." In Entgrenzungen. Für eine Soziologie der Kommunikation. Festschrift für Georg Kremnitz zum 60. Geburtstag. Edited by Peter Cichon, Barbara Czernilofski, Robert Tanzmeister, and Astrid Hönigsperger. Vienna: Praesens, 2005, pp. 401-6. [Analysis of the composite preserved text, made up of fragments from older written texts, with a few regional (patois) slips; other linguistic traits show traces of oral transmission, and notation by a young Bertran Boysset, whose natural language was local patois. The text is proof of older traces of a long-standing Occitan tradition in the epic, hidden by later smothering by French traditions.]

\subsection{Brendan}

[An anonymous mid-thirteenth-century Occitan translation, sometimes awkward, of the Legenda in Festa Sancti Brendani, itself a shortened and corrupted version of the source Navigatio Sancti Brendani.]

\section{0.}

Burrell, Margaret. "The Occitan Version." In The Voyage of St. Brendan. Representative Versions of the Legend in English Translation. Edited by W. R. J. Barron and Glyn S. Burgess. Exeter: University of Exeter Press, 2002, pp. 231-47 and notes pp. 351-55. [Critical text of the anonymous thirteenth-century version with English facing-page translation and summary of episodes.]

\section{1.}

Ricketts, Peter T. "La version occitane du Voyage de Saint Brandan: édition critique." FL 148 (2009): 209-31. [Basic edition, made for inclusion in COM, with the Latin following the Occitan text.]

\section{2.}

Bartoli, Renata Anna. "Lépopée irlandaise de Saint Brandan en terre d'oc." In - 96, AIEO 3, 1992, pp. 795-803. [Analysis of the Occitan text: it is highly simplified, sometimes in illogical ways that impair its meaning; miraculous elements are suppressed in favor of traditional Christian virtues; unlike the more cultivated Anglo-Norman version, the Occitan text was probably prepared by a simple cleric for a pious rustic audience; also printed with added analytical summary of episodes in 
Bartoli, La "Navigatio sancti Brendani" e la sua fortuna nella cultura romanza dell'età di mezzo. Fasano: Schena, 1993, chapter 5, pp. 339-50.]

1043.

Burrell, Margaret. "St. Brendan in Occitania: A Study in Confusion and Conflation." AUMLA: Journal of the Australasian Universities Languages and Literature Association 90 (1998): 21-38. [Comparing the one complete manuscript and two fragments of the Occitan Brendan text with two shortened Latin versions, Burrell concludes that there may well have been a lost intermediary but that it is impossible to tell how the extant texts are interrelated, at least until full critical editions of all of them (underway) have been completed; conflation is obvious, confusion remains.]

\subsection{Canso de la Crozada}

[Chronicle of the Albigensian Crusade 1209-13; part 1, 2,772 lines in 130 laisses, composed by Guilhem de Tudela in 1210-13, up to the battle of Muret, 1213; part 2 , written from about 1218 , relating events 1214-19, anonymous, but perhaps by Gui de Cavaillon (see 1057, Guida, "L'autore della seconda parte della Canso de la crotzada," 2003); 9,578 lines in total, up to the death of Simon of Montfort.]

\section{4.}

\subsubsection{Bibliography}

Meschini, Marco, with the collaboration of Martín Alvira Cabrer, Martin Aurell, Laurent Macé, Damian J. Smith, and Kay Wagner. "Bibliografia delle crociate albigesi." Reti Medievali-Rivista 7, no 1 (2006). Online at http://www.rivista.retimedievali.it. [Introduction showing the distinction between the first crusade (Simon de Monfort, 1209-15) and the second (Louis VIII of France, 1224-29); the bibliography has ten subdivisions listing: sources, studies on sources and their authors, general studies, protagonists in both crusades, political, religious, social, ideological, juridical and military/archeological aspects.]

1045.

Thiolier-Méjean, Suzanne. "Bibliographie sommaire de la Chanson de la Croisade." FL 131 (2000): 55-58.

\subsubsection{Editions}

\section{6.}

Martin-Chabot, Eugène. La Chanson de la Croisade albigeoise, éditée et traduite du provençal. Classiques de l'histoire de France au moyen âge, 13, 24, and 25. Paris: Champion, 1931-61; [Essential edition for scholarly use, with full textual apparatus and detailed philological notes; the facing-page French translation is straightforward and literal; vol. 1 has introduction and text for the first part by Guilhem de Tudela; vol. 2 for the first half of the anonymous continuation, laisses 132 to 186, with sparse information about the author; vol. 3 has laisses 187 to 214, list of additions and corrections, index for all three volumes.] 
1047.

Gougaud, Henri. Guillaume de Tudèle et l'anonyme: la Chanson de la croisade albigeoise: traduction nouvelle. Paris: Berg International, 1984. [Very brief introduction, facsimile print of the manuscript, with facing-page French translation, a more "literary" version that attempts to "reconstitute the fervour, the rhythm and the sonority of the original"; maps, chronology, index of place-names; does not replace the MartinChabot edition for scholarly use; also in paperback: La Chanson de la croisade albigeoise. Paris: Livre de poche, 1989: edited text of Martin-Chabot, with facing-page free translation; maps, chronology, expanded index of proper names.]

\section{8.}

Shirley, Janet. The Song of the Cathar Wars: A History of the Albigensian Crusade (by William of Tudela and an Anonymous Successor). Aldershot: Ashgate, 1996. [Brief introduction, text in English translation only, helpful maps, chronology of events.

1049.

See 38, DLF, 1993, pp. 243-47. [Succinct analysis of the poem by Joseph Salvat; bibliography.]

1050.

\subsubsection{General Studies}

Aurell, Martin. "Les sources de la croisade albigeoise: bilan et problématiques." In $\mathrm{La}$ croisade albigeoise (Colloque international du C. E. C., Carcassonne, 4-6 octobre 2002). Edited by M. Roquebert. Carcassonne: C.E.C., 2004, pp. 21-38. [Discusses the use of politically engaged troubadour songs as historical sources, pp. 32-35.]

1051.

Bottin-Fourchotte, Colette. "L'art de vivre dans la seconde partie de la 'Chanson de la Croisade." In Mélanges de langue et de littérature médiévales offerts à Alice Planche. Annales de la Faculté des lettres et sciences humaines de Nice, 48. Nice: Faculté des lettres, 1984, pp. 71-81. [Rich exploration of social attitudes revealed in the Canso during the periods of peace; appreciation of the beauties of nature, pleasures of the table and of good company, seen as gifts from God, expressed in the enthusiastic joi of the troubadours, combined with Christian belief and on the dynamic social principle of paratge, a song in praise of Occitan culture, contrasted with the brutish, unprincipled greed of the French.]

1052.

D’Heur, Jean-Marie. "Sur la date, la composition et la destination de la Chanson de la croisade albigeoise de Guillaume de Tudèle.” In 147, Mélanges Rostaing, 1974, pp. 231-66. [History of the scholarly debate over the (single or double) authorship of the Canso, tinged often with ideological prejudices; study of the division of the text: the first part, by Guilhem de Tudela ends at laisse 130; the composition was begun in early summer 1212 and ended in February 1213; it was written for Guilhem de Contres; in appendix, full bibliographic information about earlier editions of the Canso; see also his detailed codicological study in $A M 85$ (1973): 442-50.] 
1053.

Ghil, Eliza Miruna. "La Canso de la Crozada." In L’Age de parage: essai sur le poétique et le politique en Occitanie au XIIIe siècle. New York: Peter Lang, 1989, chapter 2, pp. 91-149, and chapter 3, pp. 151-218. [Shows that Guilhem de Tudela was favorable toward the crusade and Simon of Montfort; he supported the clerico-chivalric society; demonstrates intertextuality with lyrics; in the second part, notes negative attitudes toward the French invaders, support for the chivalric-urban society; negates the idea that poetry went into a decline in the thirteenth century because of religious and political upheaval; instead, there was a creative flowering in response to a culture in crisis.] 1054.

Gosman, Martin. "Les comptes rendus de la croisade d'Albi et les points de vue auctoriels. La fonction de la scène dialoguée.” In $>$ 95, AIEO 2, 1993, 1:119-30. [The first half of the Canso is presented as the chronicle of a legitimate offensive war of crusaders against heretics; the second part is more like an epic, portraying the legitimate defensive war of Occitans against invaders from the North; dialogues are much longer and more frequent in the second half and involve a wider spectrum of social classes, indicating a conscious effort to dramatize in epic style the outrageous destruction of Occitan culture.]

1055.

Gouiran, Gérard. "Français contre Montfort? Les conseils de guerre tenus par Simon de Montfort dans la seconde partie de La chanson de la croisade albigeoise." In "Furent les merveilles pruvees et les aventures truvees." Hommage à Francis Dubost. Edited by Francis Gingras et al. Paris: Champion, 2005, pp. 281-305. [Analysis of dialogues in the war councils when things were going badly for Simon; he seeks to blame anyone except himself; criticisms of his actions are frank and direct among his aristocratic allies, but he is supported by weak flatterers and churchmen; the anonymous author denounces the war as having nothing to do with the destruction of the heresy but everything to do with the destruction of Toulouse and of Paratge.]

1056.

Gouiran, Gérard. "Tolzan cridan: "Tolosa!" e "Cumenge!"·l Gascos . . . Le parallèle commingeois dans la Chanson de la croisade contre les Albigeois." In L'Aquitaine des littératures médiévales (XIe-XIIIe siècle). Edited by Jean-Yves Casanova and Valérie Fasseur. Paris: Presses de l'Université Paris-Sorbonne, 2011. [A clarification of the complex political links among the great Pyrenean families of the late twelfth and early thirteenth centuries, and their support or opposition to the crusade; both Raymond VII of Toulouse and Bernard V of Comminges are portrayed as youthful heroes in the second half of the Chanson, models of paratge.]

1057.

Guida, Saverio. "Lautore della seconda parte della Canso de la crotzada." CN 63 (2003): 255-82. [A strongly argued hypothesis for Gui de Cavaillon, who has all the necessary qualities to match him with the unknown author: he was very close to Count Raymond VII of Toulouse as advisor and propagandist, fervently loyal to the house of Saint-Gilles, intimately familiar with both Beaucaire and Toulouse, of 
considerable literary talent and general culture; many qualities of style in his poetry match those of the Canso (lexical and rhetorical usage); the same insistence on the rights of heredity, property, and lineage are found in Gui's partimen and the Canso; the sudden interruption at the end of the Canso coincides with the calling to Paris of the defeated Count Raymond, with Gui and other close advisers.]

\section{8.}

Hoekstra, Dirk. "Quelques aspects de quatre manuscrits en prose racontant la guerre des Albigeois." In 99, AIEO 6, 2001, pp. 203-8. [Only one complete manuscript of the verse chronicle exists; two contemporary Latin texts also tell the story of the war; four sixteenth-century manuscripts have prose versions of the history, three of which were edited in 1879 by Auguste Molinier; Hoekstra transcribed the fourth in 1998; the present study finds that all four late versions are closely related, from the Toulouse area, part of the traditionalist movement attempting to preserve Occitan social values and language in the face of French-oriented bourgeois "modernization."] 1059.

Huot, Sylvia. "The Political Implications of Poetic Discourse in The Song of the Albigensian Crusade." French Forum 9 (1984): 133-44. [Raimon Vidal, in his Razos de trobar, stressed the reciprocal dependency of poetic language and society: grammatical and poetic competence is a measure of the coherence and moral fibre of society; in the first part of the Canso, Guilhem expressed his positive view of the crusade in the elevated literary style of his culture; in the second part, these admirable social and esthetic values are depicted as subverted and destroyed, and with them the poetic forms in which they were expressed.]

\section{0.}

Lafont, Robert. "Guilhem de Tudela: ses origines, les origines de son art." In $>\mathbf{1 3 1}$, Les troubadours et l'état toulousain, 1994, pp. 219-28. Reprinted in La Source sur le chemin, Paris: Harmattan, 2002, pp. 299-311. [Lafont undertakes a sweeping renewal of the history of French epic: Guilhem de Tudela was unjustly eclipsed by the anonymous continuator of the Canso de la Crozada, in part due to false interpretations of the editor Martin-Chabot 1960; places the origins of the epic in Navarra, ca. 1080; these evolved into the Norman, not the later Anglo-Norman, Oxford Roland; further evolution of the chanson de geste into the chanson d'histoire, e.g., Antiocha, made Guilhem de Tudela the authoritative figure best suited to compose the Canso de la Crozada.]

1061.

Ménard, Philippe. "Rotiers, soldadiers, mainadiers, faidits, arlots, Réflexions sur les diverses sortes de combattants dans la Chanson de la croisade albigeoise." In Actes du colloque Languedoc et langue d'oc (Toulouse, janvier 1996): Special number of Perspectives médiévales, supplement to 22 (1996): 155-79. [Analysis of the role played by the lower classes in the conflict: differences in the composition of the two armies and in the way they are presented by the two authors; mercenaries, dispossessed knights, brigands, artisans, and valets who accompany the armies, most of whom are undisciplined, prone to violence, more interested in slaughter and booty than in mystic principles.] 
1062.

Paden, William D. "The Troubadours and the Albigensian Crusade: A Long View." RPh 49 (1995): 168-91. [Negates the common belief that the Albigensian Crusade caused the decline of troubadour poetry and Occitan culture; the society continued to prosper financially, there was an increase, not a decline, in numbers of poets after the crusade, and the quality of the poetry was in decline before the crusade began; sociolinguistic pressures favoring the prestige of French over Occitan seem to furnish the overall impetus, but the full explanation has yet to be found.]

\section{3.}

Leppig, Linda S., ed. Special issue of Tenso on the effect of the Albigensian Crusade on Occitan culture, Tenso 10.2 (1995): 87-89. [Leppig questions whether the traditional view of the "crusade" as a turning point in the fortunes of Occitan culture can be justified, or whether our view may have been colored by the emotional tone of the continuator, calling for reassessment; William D. Paden, in "Perspectives on the Albigensian Crusade," pp. 90-98, claims that Crozada is an anachronism, used in the sense of "expedition" in the Canso, rather than in the modern sense of "crusade"; Eliza Miruna Ghil, in "Crozada: Avatars of a Religious Term in Thirteenth-Century Occitan poetry," pp. 99-109, claims that as a whole the troubadours supported with enthusiasm the overseas crusades against the infidel but reacted fiercely, with strong antiFrench and anticlerical sentiment, against the Albigensian conflict; Sharon Bryant Neal, in "Las donas e las femnas, las tozas avinens: Women in La Canso de la Crozada," pp. 110-38, discusses the rare presence of women in the epic genre, passive and voiceless in the first part, vocal, innovative, and combative in the second, even given credit for killing Simon of Monfort; Elizabeth Wilson Poe, in "Suppressing the Memory of the Crusade: The Manuscript Tradition of the Poems of Gui de Cavaillon,” pp. 139_ 57, explores the placement of Gui's poems, wondering whether there was a conscious intent to suppress the horrific memories of the war by marginalizing them.]

\section{4.}

Pegg, Mark Gregory. A Most Holy War. The Albigensian Crusade and the Battle for Christendom. Oxford: Oxford University Press, 2008. [A dramatized re-creation of the crusade events; vicious genocide seems to have been approved by God as a holy cleansing; literary texts, eyewitness accounts, and testimonies from the Inquisition bring alive the horrors of the "Crusade."]

\section{5.}

Paterson, Linda. "La Chanson de la croisade albigeoise: mythes chevaleresques et réalités militaires." In La Croisade, réalités et fictions: Actes du colloque d'Amiens. Edited by D. Buschinger. Göppingen: Kümmerle, 1989, pp. 193-203. [The knight in Occitan epics is more a practical soldier driven by paratge, as opposed to the northern French tradition of the knight as part of a social elite imbued with idealistic principles and morality; if the king of Aragon had not been persuaded to lead the charge at Muret in the "northern" epic manner, instead of following the cautious but "unworthy" plan of the Count of Toulouse, the Occitan defeat might not have happened.] 
1066.

Pfeffer, Wendy. "Rotten Apples and Other Proverbs in The Song of the Albigensian Crusade." Proverbium: Yearbook of International Proverb Scholarship 8 (1991): 14758. [Explores the difference in the usage of proverbs and proverbial expressions in the two authors of the Canso de la Crozada and attaches this usage to different political and social views.]

\section{7.}

Raguin, Marjolaine. "Choix terminologiques et propagande dans la Chanson de la Croisade albigeoise." In Actes du colloque Nouvelle recherche en domaine occitan: approaches interdisciplinaires (Albi, 11-12 juin 2009), in press. [Study of the political and religious propaganda motivating the second half of the Canso; while the first part was in favor of the crusade, the continuation condemns it; close analysis of the terminology designating the major political and religious figures on both sides of the conflict; as interesting as what the text says is what it seeks to conceal from its audience, and its relationship to the first part of the Canso.]

1068.

See 262, Zambon, I Trovatori e la crociata, 1999. [Detailed historical introduction, pp. 7-34; edition of fourteen poems by Peire Vidal, Raimon de Miraval, many by Peire Cardenal, Tomai/Palaizi, Guilhem Figueira, Bernart Sicart de Maruejols, Guilhem de Montanhagol, and extracts from the Canso de la crozada; Italian translation, notes.]

\section{9.}

Le Royaume oublié-The Forgotten Kingdom/Savall, Hesperion 21, 2010. Label: Alia Vox, catalogue \#9873, 3 CD-ROMs on http://www.Arkivmusic.com; Conductor: Jordi Savall. Orchestra: La Capella Reial de Catalunya. [CD \#2 concerns the Albigensian Crusade, with narration from the Canso and songs of Giraut de Bornelh, Raimon de Miraval, and Guilhem Figueira; CD \#3 has reaction against the Inquisition by Peire Cardenal, Guilhem de Montanhagol, and Pons d'Ortafa.]

\subsection{Daurel e Beton}

[Anonymous text of 2,185 lines, incomplete at the end; end twelfth century, from an earlier lost text ca. 1150; unique feature is the central role played by the joglar Daurel.]

1070.

Lee, Charmaine. Daurel e Beton. Parma: Pratiche, 1991. [Renewed critical text based on Meyer 1880 and Kimmel 1971, with Italian translation, notes; introduction has information on manuscript, language, and metrics; limited glossary.]

1071.

Noto, Giuseppe. "La comunicazione come bisogno sociale e antropologico in Daurel e Beton." In 109, Comunicazione e propaganda, 2007, pp. 503-14. [Analysis of the role of the troubadour/joglar within the medieval social complex; mobility from court to court supports a function as carrier of news and promulgator of public opinion; in Daurel e Beton, Daurel incarnates a new social mobility and return to simple virtues that will allow a renewal of a run-down society.] 
1072.

De Caluwé, Jacques. "L’enfant dans Daurel et Beton.” L'enfant au Moyen âge: littérature et civilisation. Sénéfiance, 9. Aix-en-Provence: CUER MA, 1980, pp. 315-34. [Beton's development is followed in realistic detail in the text, from birth to precocious maturity at thirteen, giving insight into child development and education that is rare in medieval texts; physical and mental progress of the child are noted at length, year by year, with special emphasis on the ages of seven, when children were thought to achieve reason and discretion, and thirteen, the early attainment of independence; he is presented not only as a symbol of regeneration but also as a real living person; the anonymous author who seems to know him so closely could well be a woman.]

1073.

Kay, Sarah. "Compagnonnage, désordre social et hétérotextualité dans Daurel et Beton." In Actes du XIe Congrès international de la Société Rencesvals (Barcelone, 22-27 août 1988). 2 vols. Barcelona: Real Academia de Buenas Letres, 1990, 1:353-67. [Analysis of the text as a moment of passage from a stable society governed by and for men of the aristocratic class toward a more open one in which all might participate regardless of rank, sex, age, or race; structurally, the standardized evil story line is subverted by a countertext which succeeds, from a very weak start, in wresting narrative control to become the main text.]

1074.

Lafont, Robert. "Epopée et nòvas: le texte du joglar contador." RLaR 96 (1992): 25173. Reprinted in La Source sur le chemin, Paris: Harmattan, 2002, pp. 255-76. [A challenge to scholarly assumptions about the apparent predominance of epic and romance in the North, lyric in the South; our present knowledge of these genres stems from collections made during a crucial renewal of the traditions in the fourteenth and fifteenth centuries; only the Occitan lyrics found sponsors for this (largely in Italy); we cannot know what other texts were lost; Daurel e Beton seems to be part of a rich tradition, sharing generic qualities of saint's life, epic, romance, ensenhamen, and novas, and glorifying the social role of the joglar.]

\section{5.}

Legros, Huguette. L'Amitié dans les chansons de geste à l'époque roman. Aix-en-Provence: Publications de l'Université de Provence, 2001, pp. 155-56 and 343-50. [Analysis of the uniquely Occitan portrayals of friendship in Daurel e Beton: the obsessive purity of Beuve's devotion to Gui, compared with Gui's unremitting felony and its destabilizing effects on society; the strength and charitable wisdom of the joglar Daurel is required to thwart the perversity of Gui and reestablish social harmony.]

\section{6.}

Limentani, Alberto. "Per Daurel et Beton: il giullare pedagogo." In $\mathbf{1 1 2 9}$, Limentani, L'eccezione, 1977, pp. 102-10. [Daurel e Beton combines the qualities of several genres: the details of Beton's education by Daurel are similar to an ensenhamen, and the general tone is more "bourgeois" than epic, softening the harshness of French society with the more cultivated nature of the "Babylonian" and of Daurel's own civil principles.] 
1077.

See 1130, Menegaldo, Le jongleur, 2005, pp. 33-83. [Detailed analysis of the figure of the joglar in Daurel e Beton; Daurel is unique in the range of his qualities: he is a skilled entertainer, orator, politician, educator, and warrior; the anonymous author may himself be a remarkable joglar capable of improvising the plot of his own fictive text as a sort of mise en abyme.]

\subsection{Ferabratz}

[Thirteenth century, anonymous; 5,084 lines; adaptation of the French Fierabras, except for the first 610 lines added by the adapter; but Lafont $\boldsymbol{1 0 2 1}$, "Epopée d'oill," 2005, claims to have demonstrated that the Occitan version is the original.] 1078.

Bekker, Immanuel. Der Roman von "Fierabras" provenzalisch. Akademie der Wissenschaften zu Berlin, 10. Berlin: G. Reimer, 1829. [Suggestions and corrections by Hofmann and Baist, $R F 1$ (1883): 117-30, and Fischer, $R F 4$ (1886): 536-38; new editions have been announced by Formisano 1987, Babin 1994 (both abandoned), and Buridant 2003; two further editions have been completed as doctoral theses: M.-A. Pountney, Poitiers, 1980, and A. Kowalska, Limoges, 1997, but remain unpublished.]

1079.

Buridant, Claude. "Vers une édition du Fierabras occitan." In Le Rayonnement de Fierabras dans la littérature européenne. Actes du colloque international ( 6 et 7 décembre 2002). Edited by Marc Le Person. Lyons: Université Jean Moulin-C.E.D.I.C, 2003, pp. 65-84. [Detailed account of previous editions and proposed editions, outlining the difficulties presented by the text; the proposed new edition is to be carried through as a joint project with A. Kowalska and will be part of Ricketts's COM2; it will require a new and careful study of the language, whose localization has proved so far to be quite controversial; Buridant believes that the language is a "Mischsprache" and is rich in interest for morphology, syntax, and vocabulary.]

1080.

Lafont, Robert. "Les origines de la chanson de geste: le cas de F(i)erabras." CCM 41 (1998): 365-73. Reprinted in La Source sur le chemin, Paris: Harmattan, 2002, pp. 433-47. [Discovery of a very refined structure in eighteen groups of eleven laisses, and traits of language and rhyme which indicate that the Occitan original was poorly transmitted in the later French copies. See also $>$ 1021, Lafont, "Epopée d'oill," 2005, for a stronger claim that the Occitan Ferabratz precedes the Old French version.]

1081.

Babin, Malte-Ludolf. "La langue du Fierabras occitan." In $>$ 97, AIEO 4, 1994, 2:661-70. [Claims that the Occitan version is a poor translation of a French original; close study of phonetic, morphological syntactical, and lexical features that show the translator to have been a Toulousain from the early thirteenth century; more details are promised in his forthcoming edition of the text.] 
1082.

D’Heur, Jean-Marie. "Observations codicologiques sur le manuscrit du Ferabras d'Alichandre." In Mémoire en temps advenir: hommage à Theo Venckeleer. Orbis/ Supplementa 22. Edited by Alex Vanneste et al. Leuven: Peeters, 2003, pp. 241-57. [Detailed history of discovery, publication, and studies of the work; very careful codicological study; postulates that the Occitan version has been adapted from a lost French version; does not mention Formisano, 1987 ( $\ \mathbf{1 0 8 3})$.]

\section{3.}

Formisano, Luciano. "À propos du Fierabras occitan," from a roundtable discussion in Au carrefour des routes d'Europe: la chanson de geste. Xe congrès international de la Société Rencesvals pour l'étude des épopées romanes, Strasbourg, 1985. Sénéfiance, 20, 21. 2 vols. Aix-en-Provence: Publications de l'Université de Provence, 1987, 2:1239_ 45. [Detailed analysis of scholarship concerning the manuscripts and the editorial history of the various versions of Fierabras in French and Occitan; the Occitan text is a systematic abridgement of a (lost?) French original: French rhymes poorly adapted into Occitan, omission of otherworldly and intellectual references; much remains to be clarified.]

\section{4.}

Melli, Elio. "Rapports entre les versions française, provençale et italienne de Fierabras: ressemblances et différences structurales, stylistiques et registrales, intertextualité." In Actes du 10e Congrès international de la Société Rencesvals. Au carrefour des routes d'Europe: la chanson de geste. Sénéfiance, 21. Aix-en-Provence: CUER MA, 1987, pp. 879-96. [The Occitan version is an idiosyncratic abridgement of the French, creating a new epic work, omitting the traditional epic laisses similaires and concentrating on a more realistic presentation closer to that of the narrative genres; this quality is shared by other Occitan epics, some of which have descriptive passages that are lyric in nature.]

\subsection{Girart de Rossilhon}

[Anonymous; mid-twelfth century (1136-80); written in a mixed language, variously thought to be Franco-Provençal, a "Poitevin koinê" or a corrupted text; 10,002 lines; classed as an epic, but with elements of romance and saint's life; sensi-

tive insight into human motivations, moral outrage at the horrors of civil war.] 1085.

Hackett, Winifred Mary. Girart de Roussillon, Chanson de Geste. 3 vols. in 2. Paris: Picard, 1953-55. [Critical text in vols. 1 and 2; philological study, notes, and glossary in vol. 3; no translation; valuable for variant readings, rich glossary and index, which are absent from the edition by Combarieu du Grès and Gouiran.]

\section{6.}

Combarieu du Grès, Micheline de, and Gérard Gouiran. La Chanson de Girart de Roussillon. Traduction, présentation et notes. Paris: Librairie Générale Française, 1993. [The Occitan text is reproduced from Hackett, with a new French translation; ample introduction, many notes; concludes that the text is a unit, not the work of two authors.] 
1087.

Hackett, Winifred M. La Langue de Girart de Roussillon. Publications romanes et françaises 111. Geneva: Droz, 1970. [The linguistic polymorphism is characteristic of the original poem: a literary language (koiné) chosen by the author, who was probably from the region of Poitou; Lafont disagrees entirely (see $>1021$, "Lépopée d'oill," 2005), claiming that the original (MS $P$ ) was Occitan, of which the $O$ manuscript, used as a base by modern scholars, is an incompetent adaptation into French, falsely called "langue mixte."]

1088.

Pfister, Max. Lexicalische Untersuchungen zu "Girart de Roussillon." Beihefte zur ZrP 122. Tübingen: Niemeyer, 1970. [Lexicological study comes independently to virtually identical conclusions as Hackett regarding the polymorphism of the language ("künstlerische Mischsprache"), but postulates the region of Vienne (Dauphiné) for the author.]

1089.

Burgwinkle, William. "Ethical Acts and Annihilation: Feminine Heroics in Girart de Roussillon." In Women and Medieval Epic: Gender, Genre, and the Limits of Epic Masculinity. Edited by Sara S. Poor and Jana K. Schulman. New York: Palgrave Macmillan, 2007, pp. 159-82. [An original study of Girart's wife Berthe; the theories of Lacan and Žižek are used to characterize the heroic female "Act"; Berthe offers an alternative to the destructive heroic masculinity of the feudal system and to her own traditional maternal role within the kinship system; she abandons her position as wife and mother and disposes of her feudal privileges by founding monasteries, substituting only a will to act without any personal aim except to work through God in the world.]

1090.

Gaunt, Simon. "Le pouvoir d'achat des femmes dans Girart de Roussillon." CCM 33 (1990): 305-16. [Argues that Elissent and Berthe are not represented positively but are manipulated by Charles and Girart to further the relationship of the two men.]

1091.

Haugeard, Philippe. "Un baron révolté est-il un hors-la-loi? Droit et violence dans Girart de Roussillon." Cahiers de recherches médiévales et humanistes 18 (2009): 27991. [An examination of the relationship among law, right, and violence in the epics of revolt; Girart represents a world of warriors and lords in which "right" is not yet "law," and violence brought on by the struggle for power cannot be contained.]

\section{2.}

Kay, Sarah. "Singularity and Spectrality: Desire and Death in Girart de Roussillon." Olifant 22 (2003): 11-38. [The epic genre stresses the individuality of its main agents and the complex social difficulties that arise from their self-seeking acts; Girart and the king are both striving for personal power and position, making it impossible to achieve order and coherence in their shared world; each advantage gained by the one (in territory, sex, or pride) is mirrored by the disadvantage of the other; rage, killing, 
mourning, and revenge build increasingly to the only possible solution, which is renunciation of the secular world.]

1093.

Kullmann, Dorothea. "Kirchliche Lehren in Girart de Roussillon." In 142, Studi Melli, 1998, pp. 403-17. [The beginning and end of the poem contain many references to complex theological questions, indicating the specialized interests of the author and his possible status as an abbot or prior of a religious house; see further analysis of this position in "Réécritures expérimentales?" In Church and Vernacular Literature in Medieval France, Toronto, 2009, pp. 69-77.]

1094.

Kullmann, Dorothea. "Le contexte idéologique de Girart de Roussillon. Quelques remarques sur la partie finale du poème." In Epic Studies: Acts of the 17th International Congress of the Société Rencesvals for the study of Romance epic (2006). Olifant 25.1/2 (2008): 271-82. [A study of the ideological content of the text: for peace and against the warlike values of knightly society, especially in the final section, with a stress on doing good works while remaining in society; perhaps Girart was composed in part as a reaction against the heretical movement of Henri de Lausanne.]

1095.

Labbé, Alain. "Segles feniz. L'angoisse eschatologique dans la Chanson de Roland et dans Girart de Roussillon." In Fin des temps et temps de la fin dans l'univers médiéval. Sénéfiance, 33. Aix-en-Provence: CUER MA, 1993, pp. 287-306. [Divine intervention as a sign of the distress or anger of heaven, presaged by thunder, lightning, and darkness, is rare in the epic and emphasizes key moments in the two texts; in Girart, the message (from God and poet) is a condemnation of both disputants, impelling them away from the destructiveness of civil war toward a feudal society governed by humility and peace.]

\section{6.}

Lafont, Robert, "La Chanson de Girart de Roussillon: poème double, thème inverse, causes échangées." CCM 38 (1995): 239-65. Reprinted in La Source sur le chemin, Paris: Harmattan, 2002, pp. 335-84. [Points to the primacy of the Occitan MS $P$, neglected by scholars who have preferred to edit and study $O$. Lafont shows that $O$ derives from $P$ linguistically, historically, and philologically and that the text as we have it is a complex and contradictory mixture of two traditions, whose origins are to be found in southern France.]

1097.

Léglu, Catherine. "Babel in Girart de Roussillon." In $>917$, Léglu, Multilingualism and Mother Tongue, 2010, pp. 17-34. [The legend of Babel was a second Fall of Man, as it divided humankind by making it impossible to communicate freely, leading to war; Girart's wife Berthe masters languages and can overcome the confusion of misunderstandings and become a peacemaker; Berthe's building of Vézeley is meant to symbolize the reunion of mankind as one in a renewal of Pentecost. It is ironic that such a spiritually uplifting poem should be couched in a mixture of languages that has largely prevented its message being heard.] 
1098.

Thoss, Dagmar. Das Epos des Burgunderreiches: Girart de Roussillon. Graz: Akademische Druck- und Verlagsanstalt, 1989. [Twenty-eight full-page reproductions in color from the dedication copy of Philippe le Bon, Vienna MS 2549, many more in black and white; historical and literary introduction, codicological study, artistic analysis of style and iconography; no text.]

\subsection{La Guerra de Navarra}

[Chronicle by Guilhem Anelier de Tolosa, fourth quarter thirteenth century, recounting military events of 1276-77; 5,136 lines in 104 laisses, incomplete at beginning, interior, and end; modeled on the Canso de Crozada; written in an Occitan koiné; perhaps the same as the troubadour PC 204.]

1099.

See 312, GRLMA vol. 11, book 2, 1986, pp. 69-70 (\#13013) [Information on the unique manuscript, text in rhymed Alexandrines, concerning the conflict in 127677 that caused Philippe III to send troops to Navarra; Guilhem Anelier probably participated and certainly was present as an eyewitness; Guilhem also composed four sirventes: see PC 204.]

1100.

Santano, Julián, Ricardo Cierbide Martinena, Maurice Berthe, and Xabier Kintana. Guilhem Anelier de Tolosa, La Guerra de Navarra. Pamplona: Gobierno de Navarra, 1995. [Vol. 1: facsimile edition in color; vol. 2: study of author and paleography by Santano; manuscript history by Cierbide, historical background by Berthe; edition with Spanish translation by Santano, Basque translation by Xabier Kintana, onomastic index; a fuller glossary and study of linguistic and metrical qualities are still to be desired and are promised in a future publication; for a French translation, see the edition by F. Michel, 1856; discussion of several problematic passages by Francisco Javier Oroz Arizcuren in 98, AIEO 5, 1998, pp. 91-97, and BRABLB 45 (1995-96): 205-22.]

1101.

Cornagliotti, Anna. "Consonanze stilistiche della Guerra de Navarra." Romanistik in Geschichte und Gegenwart9 (2003): 17-31. [Proposes a number of corrections to the text of Santano 1100; detailed study of similarities in style, content, images, and phrasing to troubadour and trouvère songs and epic texts (Roland), showing that the author was familiar with a wide range of contemporary and older literature.]

1102.

Lafont, Robert. "La place de Guilhem Anelier dans l'histoire de l'art épique occitan." In 97, AIEO 4, 1994, pp. 165-72. Reprinted in La Source sur le chemin, Paris: Harmattan, 2002, pp. 385-95. [Traces the structural evolution of the epic in a steady evolution from the Boeci through Sainte Foy, Roland, Chanson d'Antioche, Canso de la Crozada and its continuation, to the Guerra de Navarra, demonstrating that the tradition is solidly fixed in the Occitano-Navarrese region, with influx from the Franks from Toulouse who settled in Navarre; Guilhem Anelier modeled 
his poem structurally on the continuation of the Canso de la Crozada, but altered it in tone and content to reflect his loyalty to the king of France.]

1103.

Straub, Richard E. F. "Les sirventes de Guilhem Anelier de Tolosa." In 134, Cantarem, 1995, pp. 127-68. [Close analysis of the four poems to clarify the sociohistorical background and their possible connection to the Guerra de Navarra and the Canso de la Crozada; critical edition with French translation, notes, study of metrics and rhymes; Straub was unaware of the 1995 edition of the Guerra.]

\subsection{Rollan a Saragossa}

[Anonymous heroi-comic epic, from a twelfth-century source text; dating of the extant text is controversial; 1,410 lines, incomplete at beginning; probably

by the same author as Ronsasvals; the author praises and makes fun of his heroes at the same time: a witty and ambiguous poem.]

\section{4.}

Gouiran, Gérard. "So dis la donna: Oy, bel sira Rollan, mos maritz es en malaür lo gran: Les Sarrasins et la Sarrasine dans Rollan a Saragossa." In De l'étranger à l'étrange ou la conjointure de la merveille (en hommage à Merguerite Rossi et Paul Bancourt). Treizième Colloque du C.U.E.R. M.A., Aix-en-Provence, mars 1988. Sénéfiance, 25. Aix-enProvence: CUER MA, 1988, pp. 223-44. [Complex portraits of Saracens, who can be heroic, sensitive, and admirable as well as cowardly and unworthy; Braslimonde is an independent woman, clear minded and forthright, a worthy counterpart to Roland; see the edition by Gouiran and Lafont 1113, in which Lafont postulates that the Roland is of Navarrese origin.]

1105.

Alvar, Carlos. "Acerca de los elementos novelescos en el Rollan a Saragossa y otras consideraciones." In L'Epopée romane: Actes du XVe Congrès international Rencesvals, Poitiers, 21-27 aồt 2000. Vol. 1. Edited by Gabriel Bianciotto, Claudio Galderisi, and Bernard Guidot. Poitiers: CESCM, 2002, pp. 413-21. [Detailed study of references from other works demonstrate a close relationship to a series of twelfth-century Italo-French epics and narratives; but the chronological succession is difficult to establish; suggests that an original Occitan source text from the late twelfth century was a straightforward epic and that the courtly narrative elements were added during transmission, prior to the copying of the extant text in the fourteenth century.]

\section{6.}

Belletti, Gian Carlo. "Rolando e i mercanti: comico e ideologia nel Roland à Saragosse." L'immagine riflessa 13 (1990): 3-54; also in Saggi di sociologia del testo médiévale. Alessandria: Dell'orso, 1993, pp. 155-95. [Beneath the carnival-like atmosphere of the epic is a more serious message: a new materialistic bourgeois worldview is competing with the traditional feudal order that has been taken for granted at the base of medieval literature; the aristocratic society is already threatened by the mercantile classes; perhaps the real hero of Saragossa is not Roland but Guizament.] 
1107.

See 1017, Ivens and Klein, "Karl im Land der Trobadors," 2004. [The figure of Charlemagne and his epic heroes is treated idiosyncratically in the Occitan epics compared with the wider French tradition; in Roland a Saragossa, Olivier and Roland have a more complex and ambiguous relationship of devotion and rivalry, while Charlemagne plays a passive role in relation to the younger generation.]

\section{8.}

Jewers, Caroline. "Becoming Saracen: Seduction, Conquest, and Exchange in Rollan a Saragossa." Romance Studies 27 (2009): 95-105. [Jewers examines the more open attitude toward foreign cultures in the poem, calling it "a cultural game of appearances and disguises"; many boundaries are crossed, including those between Saracen and Christian communities, the dominance of masculine authority (by Braslimonda), and the generic boundaries between epic and romance.]

\section{9.}

Horrent, Jules. "Nouvelle rêverie sur l'épopée en langue d'oc: à propos de Roland à Saragosse." In 159, Studia occitanica, 1986, 2:75-80. [The text features a witty exaggeration of epic themes, but with serious psychological insights into the principal actors; Horrent believes the poem to be of Catalan origin because of language traits and the author's detailed knowledge of Saragossa.]

\section{0.}

Keller, Hans-Erich. "Roland à Saragosse: rencontre de deux cultures." In Mélanges offerts à Rita Lejeune, professeur à l'Université de Liège. 2 vols. Gembloux: Duculot, 1969, 1:137-58. Reprinted in Autour de Roland, Paris/Geneva: Champion/Slatkine, 1989, pp. 311-31. [Analysis of the hybrid Occitan/French language leads to the conclusion that a French source text, now lost, was copied in the region of Grenoble; see also his "Roland à Saragosse: sa position dans la production rolandienne." In - 159, Studia occitanica, 1986, 2:93-106, reprinted in Autour de Roland, pp. 33346, in which he maintains the French origin of the poem, in opposition to Horrent, who thinks it is Catalan; also "Roland a Saragosse ou la vengeance d'Olivier." In - 95, AIEO 2, 1993, 1:221-29, reprinted in Autour de Roland, pp. 347-55, where he shows that some emphasis is on Roland's prowess, but even more is on the wisdom of Olivier, his mezura, his military superiority; the final glorification of Olivier is symbolic of Occitania standing up to France and claiming its superiority.]

\section{1.}

Marnette, Sophie. "Nord et sud: chansons de geste d'oc et d'oïl." In L'Epopée romane, I-II: Actes du XVe Congrès international Rencesvals, Poitiers, 21-27 août 2000. Edited by Gabriel Bianciotto and Claudio Galderisi. Poitiers: CESCM, 2002, pp. 927-35. [Attempts to date several epics by comparative study of the position of their narrator, and the narrator's relation to the text and to the listeners/readers; believes (provisionally) that parts of Rollan a Saragossa are earlier than Ronsasvals, that both share characteristics with epics from the twelfth century or earlier, and that both were partially rewritten in the fourteenth century.] 
1112.

Menegaldo, Silvère. "Ronsasvals et Roland à Saragosse: un passé épique en trompel'oeil?" In Le Passé à l'épreuve du présent. Appropriations et usages du passé du Moyen Âge à la Renaissance. Edited by Pierre Chasang. Paris: Presses universitaires de ParisSorbonne, 2008, pp. 345-58. [Exploration of a hypothesis that the two epic texts might be manipulating their listeners/readers by appearing to be older than they are; this would change our concept of the epic system in its development, and the relative chronologies that have been established.]

\subsection{Ronsasvals}

[Anonymous heroic epic, 1,802 lines in fifty-one laisses, incomplete at beginning and middle; early twelfth century; probably by the same author as Rollan a Saragossa.] 1113.

Gouiran, Gérard, and Robert Lafont. Le Roland occitan: Roland à Saragosse; Ronsasvals. Paris: Union générale d'éditions, 1991. [Critical texts with facing-page French translation, notes; introduction by Lafont claims Navarrese origin of the Roland epic.] 1114.

Burland, Margaret Jewett. "Ronsasvals: Distorted Discourse and Reliable Reception." In her Strange Words: Retelling and Reception in the Medieval Roland Textual Tradition. Notre Dame: University of Notre Dame Press, 2007, chapter 3, pp. 129-98. [Analysis of the way the Roncevaux material is reworked through transformed character discourse; going beyond the idea that the text may have been a subtle reaction to the annihilation of the Occitan political and cultural identity during the Albigensian war, Ronsasvals is seen as deepening and broadening the scope of the classical Roncevaux material, with its focus on crusading, the feudal system, French dynastic ancestry, and the collective struggle of good versus evil, by situating the struggle of good vs. evil within each human heart, stressing the bonds of individual loyalty and affection.]

\section{5.}

Gouiran, Gérard. "Per las lurs armas devon tostemps cantier. Effets d'intertextualité entre le Ronsasvals et certains planhz lyriques.” In 96, AIEO 3, 1992, pp. 907-18. [The lamentation for the dead (Roland, Turpin) takes a lot of space in Ronsasvals, indicating an Occitan taste for the planh; insertions from older lyrics make it very difficult to date the text; see also work on these insertions by Schulze-Busacker, Rom 110 (1989): 127-66 and 396-425, who dates the work to around the time of the Albigensian Crusade, certainly before 1250.]

\section{6.}

See 1017, Ivens and Klein, "Karl im Land der Trobadors," 2004. [In Ronsasvals Charlemagne is a broken leader, deprived of his best knights, admitting his incestuous sin in fathering Roland with his sister; this may be interpreted allegorically as signaling the end of Occitanian society and culture after the Albigensian Crusade (see 1119, Schulze-Busacker, "La datation de Ronsasvals,"1989), but dating and chronology remain uncertain.] 
1117.

Keller, Hans-Erich. "Propos sur la structure de Ronsasvals." In $\mathbf{1 6 0}$, Studia Riquer, 1986-91, pp. 567-77. Reprinted in Autour de Roland (1989), vol. 3, chap. 1, pp. 299-310. [Analysis of the composite structure of the text, which seems to be made up of parts taken from a larger construct, with several interruptions in the action that indicate serious omissions; Keller concludes that the text is a composite in a FrancoOccitan koiné transposed from several earlier French works now lost.]

\section{8.}

Palumbo, Giovanni. "Il Roland rimato et il Ronsasvals: problemi di interferenza." In Les chansons de geste: Actes du XVIe Congrès international de la Société Rencesvals, pour l'étude des épopées romanes, Granada, 21-25 juillet 2003. Edited by Carlos Alvar and Juan Paredes. Granada: Universidad de Granada, 2005, pp. 475-97. [Resemblances in style and narrative detail between Ronsasvals and the rhymed version of Roland indicate a complex set of reciprocal influences of several older textual versions which has still to be untangled.]

1119.

Schulze-Busacker, Elisabeth. "La datation de Ronsasvals." Rom 110 (1989): 127-66 and pp. 396-425. [Modern criticism has shown that Ronsasvals is a fourteenth-century restructuring of one or more older Occitan versions, probably from the twelfth century; further study of language details and themes leads to the conclusion that the text may date at the latest from the mid-thirteenth century, probably earlier, to the period of disillusionment following the Albigensian Crusade.]

\section{0.}

Traeschler, Richard. "Bon es lo sompni e Dieus que ho destin (Ronsasvals, v. 1723): à propos de ces rêves qui annoncent la mort." In La Fin des temps et temps de la fin dans l'univers médiéval. Sénéfiance, 33. Aix-en-Provence: CUER MA, 1993, pp. 519-34. [The Christian mystical dream of Aude (Belauda) is unique in the Occitan Ronsasvals, part of the religious discourse so characteristic of the text, as found also in the speeches and sermons of Turpin and the biblical aspects of Roland's death.]

\section{Narrative Literature}

[For Alexandre fragment by Alberic de Besançon, see under "Monuments" 17.10; seven known romances (Alberic de Pisançon's Alexandre fragment, Jaufre, Blandin,

fragment of translation of the prose Merlin, Flamenca, Arnaut Vidal de Castelnaudary's Guilhem de la Barra, and fragment of La Cour d'Amour.]

\subsection{General Studies}

\section{1.}

See 312, GRLMA vol. 4: Le roman. Heidelberg: Winter, 1978. [See Occitan narratives, pp. 627-44, by E. Baumgartner: a traditional factual presentation that does not deal with the newer critical methods.]

1122.

Bibliography: Annicchiarico, Annamaria. "Narracions en vers" catalane medievali. 
Appunti e materiali per una guida bibliografica. Rome: Edizioni di Storia e letteratura, 2003. [Has listings for Catalo-Occitan works: Blandin de Cornualha, La Faula by Guillem de Torroella, Frayre-de-joy e Sor-de-plaser, as well as two dozen Catalan works.] 1123.

Caluwé, Jean-Michel. Du Chant à l'enchantement: contribution à l'étude des rapports entre lyrique et narratif dans la littérature provençale du XIIIe siècle. Gent: Universiteit Gent, 1993. [Exploration of the two poles of Occitan literature, lyric and narrative, and their reciprocal influences; narrative works are analyzed with a view to understanding their dialogic interactions with the lyrics; beginning with the vidas and razos, through the novas (Castia-gilos, Novas del Papagai), to Flamenca, the narratives are more sensitive to economic, political, and sociocultural pressures; Flamenca consists of a number of fragments of amorous discourse that are ritually known as part of the lyric tradition and carry it on in a new form.]

1124.

Gaunt, Simon, and Ruth Harvey. "The Arthurian Tradition in Occitan." In Arthur of the French. Edited by Karen Pratt and Glyn Burgess. Cardiff: University of Wales Press, 2006, pp. 528-45. [No clear tradition of independent Arthurian material is to be found in Occitan lyric, only superficial knowledge. Only Jaufre of the three Occitan romances is Arthurian, and it is in comic mode, poking fun at the northern traditions and especially at Chretien de Troyes.]

\section{5.}

Hinton, Thomas. "Littérature narrative et identité culturelle en Occitanie au moyen âge." RLaR 113 (2009): 177-93. [In opposition to the notion that the lyric discourse in Occitan narratives was a form of cultural resistance to the influence of French literature (Huchet, Jewers), the use of French narrative models suggests rather a collaboration in a common literary culture. The canso exemplifies the ideology of finamor: the vidas/razos define and defend it, while Flamenca calls it into question, but all indicate the close connections that link French and Occitan literary traditions; hybrid texts like Jaufre and Flamenca are in dialogue with the dominant French narratives, questioning the nostalgic hegemony of Occitan lyric.]

\section{6.}

Huchet, Jean-Charles. Le roman occitan médiéval. Paris: Presses Universitaires de France, 1991. [Psychoanalytical approach to a mixed set of narrative texts, many not usually classified as "romans"; establishes undeniable links between $o c$ and ö̈l traditions, though the direction of influence remains ambiguous; unusual comparison of the domna of lyric poetry with the father figure in the romances; controversial notion that the Roman de Jaufre and Blandin de Cornualha are destructive reactions against the northern French Arthurian tradition.]

1127.

Jones, Lowanne. "Narrative Transformations of Twelfth-Century Troubadour Lyric." In The Expansion and Transformation of Courtly Literature. Edited by Nathaniel B. Smith and Joseph Snow. Athens: University of Georgia Press, 1980, pp. 117-27. [The new narrative forms of vidas, razos, novas, and allegories came into being in the 
first half of the thirteenth century; they shared the subject matter and the tone of the lyric poems and some of the earlier didactic ensenhamens; the Castia-gilos recounts the theme of the jealous lover which is to be further developed in the Papagai and in Flamenca; the allegorical works are squarely in the lyric tradition as well, all designed to enhance and preserve the threatened lyric tradition and its Golden Age.]

\section{8.}

Lazzerini, Lucia. "Romanzi arturiani e lirica d'oc: casi problematici d'intertestualità, tra animali misteriosi e perfide donzelle." In Materiali arturiani nelle letterature di Provenza, Spagna, Italia. Edited by Margherita Lecco. Alessandria: Edizioni dell'Orso, 2006, pp. 41-71. [Intense interpenetration of North and South in narrative traditions: Lazzerini wonders if perhaps the "Cornilh affair" may be a parody on the cor sounded by Erec to announce the "Joie de la cort"; edition of a poem by Peire de Cols d'Aorlac or Rigaut de Berbezilh, with Italian translation; many northern narratives were widely known in the South.]

1129.

Limentani, Alberto. L'eccezione narrativa. La Provenza médiévale e l'arte del raconto. Turin: Einaudi, 1977. [A series of detailed studies of narrative discourse in individual texts: see separate remarks for: (1) Marcabru's A la fontana, pp. 29-44 and pp. 12053; (2) Raimon Vidal's novas, pp. 45-60; (3) Arnaut de Carcassès's Novas del papagai, pp. 61-77; (4) Jaufre, pp. 78-101; (5) Daurel e Beton, pp. 102-10; (6) Arnaut Vidal de Castelnaudary's Guillem de la Barra, pp. 110-19; and (7) Flamenca, pp. 157-303.] 1130.

Menegaldo, Silvère. Le jongleur dans la littérature narrative des XIIe et XIIIe siècles: du personnage au masque. Paris: Champion, 2005. [Detailed study of the literary character of the jongleur in Occitan narratives, lyric and satirical poetry, vidas, razos, novas, pp. 129-209; the figure of the joglar in Daurel e Beton, pp. 33-127.]

\section{1.}

Thiolier-Méjean, Suzanne, and Marie-Françoise Notz-Grob. Nouvelles courtoises: occitanes et françaises. Paris: Librairie générale française, 1997. [Introduction on generic distinctions between novas and vidas/razos in Occitan and Italian; French nouvelles; study of novas in their evolution; texts of seven razos, six novas rimadas, and five Old French nouvelles.]

\subsection{Novas}

[A loosely defined term meaning "story"; listed here are general overviews of the genre and attempted definitions; see separate listings for individual works that are sometimes called novas: Castia-gilos 19.6; Esther 19.7; Flamenca 19.10; Frayre-de-joy

19.11; Judici d'amor (also known as So fo el temps or En aquel temps) 19.14;

Las novas del papagai 19.16; Chastel d'Amor 22.2.a; Cort d'Amor 22.2.b; Lai on cobra 22.2.c; Abrils issi'22.5.h; and Novas de l'heretge 22.6.]

\section{2.}

Salvat, Joseph, in 38, DLF, 1993, p. 1079. [Definition, list of novas.] 
1133.

Espadaler, Anton M. "Las novas. Un territorio sin fronteras." In De los origenes de la narrative corta en Occidente. Edited by Reinhard Huamán Mori and Helena Roig Torres. Lima/Barcelona: Tessel.la, 2007, pp. 103-17. [Etymology of the term, its relation to novel and leys; metrical characteristics of the novas, distinctive themes; believes that much of the tradition has been lost in transmission, since the few texts remaining are not usually earlier than the thirteenth century.]

\section{4.}

Huchet, Jean-Charles. Nouvelles occitanes du moyen âge. Paris: GF-Flammarion, 1992. [Detailed introduction, pp. 9-33, showing that the novas are closely related in form and content to the lyrics, but widened in scope, the form becoming more narrative, the themes more realistic, especially for the figure of the lady, who is individualized and humanized; texts of four novas are reproduced from previous editions, with notes and French translation: Abril issie mays entrava, En aquel temps com era jays, Castiagilos, Las novas del papagai; see also Huchet's article "Jaufre et Flamenca, 'nòvas' ou 'romans'?" RLaR 96 (1992): 275-300.]

1135.

Huchet, Jean-Charles. "Lapparition des novas au tournant des XIIe et XIIIe s." In - 131, Les troubadours et l'état toulousain, 1994, pp. 45-53. [Analysis of the Razos de trobar and the three novas of Raimon Vidal de Besalú, Abril issia, So fo, and Castiagilos, as indicators of a crisis in the evolution of troubadour poetry: the point at which narration is freed from the dependence on lyricism; the change signals a profound evolution of trobar even before the disruption caused by the Albigensian Crusade.]

\section{6.}

Luce-Dudemaine, Dominique. Flamenca et les novas à triangle amoureux: contestation et renouveau de la fin'amor. Montpellier: Presses universitaires de la Méditerranée, 2007. [Flamenca, Castia-gilos, Las Novas del Papagai: each text tells in its own way the triumph of love over jealousy, in various forms of opposition to the mythology of fin'amor, influenced by a number of narrative and didactic texts; together they create a new code of love and life.]

1137.

Majorossy, Imre Gábor. Unas novas vos vuelh contar: la spiritualité chrétienne dans quelques nouvelles occitanes. Frankfurt am Main: Peter Lang, 2007. [An attempt to recover the cultural, literary, and spiritual roots of European society through a preliminary study of the use of Judeo-Christian imagery and morality in seven novas; even in an increasingly lay medieval society, the traditional religious values are an essential part of the cultural context and literary expression.]

\subsection{Andrieu de Fransa (André de France)}

[A lost romance about the legendary hero who died of despair in love; perhaps

1138. partially preserved in a fragment of seventy-two lines in $N$.]

Di Luca, Paolo. "Il Roman du comte de Toulouse e altri frammenti narrativi della 
letteratura occitana médiévale." In Actes du colloque Nouvelle recherche en domaine occitan: approaches interdisciplinaires (Albi, 11-12 juin 2009). Turnhout: Brepols, 2012 , in press. [An investigation to establish the identity of the fragment and to trace references to Andrieu de Fransa in the troubadour poetry; information on other neglected didactic-narrative poems: Questa es cobla d'amic (PC 461.a), Mout aurai estat lonjamen (PC 461.e), Per auzir e per entendre (PC 461.f), and Totz hom fora cortes (PC 461.h).]

1139.

Zufferey, François. "Un fragment de roman provençal en décasyllabes monorimes." In 135, Carmina semper, 2000, pp. 105-16. [A 72-line fragment containing a dialogue between a count and a queen; critical edition with French translation and commentary; the text was called "Roman du Comte de Toulouse" by Suchier, who thought it had been the model of the Middle English romance Earl of Toulous; others disagree; Zufferey will not guess but mentions the lost romance of André de France.]

1140.

Field, William Hugh. "Le roman d'Andrieu de Fransa: état présent d'un problème avec une hypothèse basée sur un fragment dans le Chansonnier N." RLaR 81 (1976): 3-26, and 83 (1978): 1-14. [Draws together literary references to the legendary Andrieu, to reconstitute his story as much as possible; Andrieu died of love, but not by suicide, since the fault lay with the lady; Field proposes a date toward the end of the twelfth century or earlier; the second article is a critical edition of a 72-line fragment from a romance that might be the lost Andrieu de Fransa, with introduction, notes, and French translation; the fragment is a dialogue between an unnamed queen and a count; Field believes that the mastery of language, psychology, and structural technique make it a jewel, the equal of Jaufre or Flamenca.]

\section{1.}

Serper, Arié. “Giraut de Bornelh et Jaufre." In 151, Mélanges Bec, 1991, pp. 531-39. [The continuation of an earlier article in $R L a R 86$ (1982): 293-304; demonstrates that the reference by Giraut must be to a shorter, earlier version of the story, now lost, featuring the legendary exploits of Jaufre; other lost romances mentioned by the troubadours indicate a rich tradition of Occitan romance that has not been preserved.]

\subsection{Biographies (Vidas and Razos)}

[The vidas are from the thirteenth century, the razos from the fourteenth; 110 out of 450 known troubadours have vidas, at least twenty-five of which were composed by Uc de Saint Circ; razos elucidate the circumstances motivating a poem; there are 115 razos for poems by twenty-five poets, nineteen of them for Bertran de Born's poems alone.]

1142.

Boutière, Jean, and Alexander H. Schutz. Biographies des troubadours. Textes provençaux des XIIIe et XIVe siècles. Paris: Nizet, [1950]; second revised edition, 1964 (with I.-M. Cluzel); third edition, 1973, unchanged. See detailed notes by Meylakh, "Quelques observations à propos de l'édition Boutière-Schutz des Biographies des 
Troubadours," in 100, AIEO 7, 2003, pp. 543-53. This has become the standard edition of the entire corpus, in spite of a number of imperfections.]

1143.

Noto, Guiseppe. "Per una nuova edizione delle 'biografie' trobadoriche." In 101, AIEO 8, 2009, 1:315-26. [Proposes a new hypertext edition of the vidas and razos, which would contain both "reconstructive" (Favati, 1961) and "documentary" (Boutière/Schutz, 1964/73) editions, along with supplementary materials; proposes that all should be made available on RIALTO $>$ 48. Corrections and updating of the Boutière/Schutz edition may be made first, but a renewal of the whole project on modern (neo-lachmannian?) editorial principles will be necessary, in order to clarify the individual nature of the various groups of vidas and razos.]

1144.

Egan, Margarita. Vidas dels trobadors: The vidas of the troubadours. New York: Garland, 1984. [Literary introduction; analysis of style and purpose in their sociocultural context; all 101 extant vidas, including those of seven trobairitz; in English translation only, based on texts from Boutière/Schutz, 1973; chronological list of all troubadours with vidas, pp. 115-17.]

1145.

Liborio, Mariantonia. Storie di dame e trovatori di Provenza. Milan: Bompiani, 1982. [Anthology of vidas with Italian translation; many notes; a useful teaching collection; places the vidas in their social context; studies the mechanisms used to transpose lyric poems into narrative, as well as the ideological transfer of Latin church values into lay vernacular ones; the stories reflect the lives of the poets, not as they were but as they were imagined; eighty-one vidas for forty-eight troubadours (about one-third of the total); texts from Boutière/Schutz, arranged thematically, with a few corrections of detail.]

\section{6.}

Aslanov, Cyril. "The Imitation of Hagiographic Formulas in Occitanian vidas (Lives of the Troubadours)." In Sacred and Secular in Medieval and Early Modern Cultures: New Essays. Edited by Lawrence Besserman. New York: Palgrave Macmillan, 2006, pp. 19-27 and notes pp. 186-87. [Exploration of the affinities between these vernacular, profane texts and sacred literature in Latin, especially in the Legenda aurea; similarities are found in diction, particularly in the incipits, and in narrative patterns; the vidas seem to be a kind of secularized hagiography; see the complementary article by Guida 1151, Religione e letterature, 1995.]

\section{7.}

Bernsen, Michael. "Die Abkehr von der ritualisierten Aufführung altokzitanischer Trobadordichtungen und die Herausbildung eines modernen Autortyps in den razos des 13. Jahrhunderts." In Text und Handeln: Zum kommunikativen Ort von Minnesang und antiker Lyrik. Edited by Albrecht Hausmann et al. Heidelberg: Winter, 2004, pp. 225-42. [The circularity of the canso is turned into linearity in the razo; the timeless aesthetic message of the lyric voice becomes the real biographical story of a person located in time and space, and the unresolved tension of love and poetry is turned into 
a love adventure with development and conclusion; interpretation supported by close analysis of Rigaut de Berbezilh's Atressi con l'orifanz along with its razo.]

1148.

Burgwinkle, William E. Razos and Troubadour Songs. Garland Library of Medieval Literature, Series B, 71. New York and London: Garland, 1990. [The introduction furnishes new information on the attitude of Uc de Saint Circ, the principal biographer, and on some of the premises of fin'amor; the razos are given in English translation, accompanied by the poems which they purported to introduce.]

1149.

Burgwinkle, William E. Love for Sale: Materialist Readings of the Troubadour "razo" Corpus. New York: Garland, 1997. [A radical and provocative reappraisal of the razos (and many of the songs) and what they teach us about the socioeconomic background of Occitan poetry; the troubadours, and especially Uc de Saint Circ, take advantage of the more open market economy of the thirteenth century, in which love and poetry become transactions; the poets are aware of their role as publicists for their patrons or their ladies, and their lyrics are "imbued with issues of profit, marketing and self-promotion."]

1150.

Caluwé, Jean-Michel. "La Vida du MS Estense. Réflexions sur le statut littéraire des Vidas et des Razos." In \$95, AIEO 2, 1993, 1:83-90. [Vidas and razos came about with the transformation of the lyrics from oral songs to written poems, preserving them but changing their nature, making it essential to historicize them; immediacy was sacrificed to written mediation.]

\section{1.}

Guida, Saverio. "Vita monastica e vidas trobadoriche." Chapter 3 in his Religione e letterature romanze. Messina: Rubbettino, 1995, 103-49. [A follow-up to his article in 95, AIEO 2, 1993, 1:153-63; study of the didactic and paradigmatic function of the vidas, noting analogies between vidas and the hagiographic genre; the biographical texts are used to explore mental structures, psychological behavior, values, norms, expectations, and beliefs in medieval Occitan society.]

1152.

Guida, Saverio. "Le 'biografie' trobadoriche: prove di agnizione autoriale." Romanica Vulgaria. Quaderni 16-17 (1999): 141-98. [Convincing evidence that Uc de Saint Circ was responsible for at least twenty-five of the vidas; the format, contents, and vocabulary of Guilhem de Peitieus's vida are echoed back and forth in and between many others, providing a sort of collective trademark identifying Uc's authorship or influence; detailed investigation here of the vidas of Guilhem de Peitieus and six others, along with eighteen in previous articles; the format and contents were ritualized, simplified, and repetitive to suit the needs of the court of Alberico da Romano, where Uc's listeners had only limited knowledge of Occitan culture and language.]

1153.

Huchet, Jean-Charles. "Le réalisme biographique dans les vidas et les razos occitanes." In Roman, réalités, réalismes. Edited by Jean Bessière. Paris: Presses Universitaires de 
France, 1989, pp. 91-111. [The romance genre is little developed in Occitan and is regulated by traditional rhetoric and intertextuality, preventing the emergence of realism; even the biographical vidas and razos remain fictions, enclosed within a literary tradition, not realistic efforts to portray a life or actual circumstances behind a poem; but they are realistic in that they put the poet outside his poem, not enclosed within it; the vida recounts a particular life rather than a universal one, transforming the subjective ieu into the object $e l$.]

\section{4.}

Lachin, Giosuè. "Storiografia e critica letteraria nelle antiche biografie trobadoriche." In Literatur ohne Grenzen. Festschrift für Erika Kanduth. Frankfurt: Peter Lang, 1993, pp. 226-42. [Study of the historical and cultural background in which the chansonniers were put together, with increasing emphasis on the addition of biographical prose introductions; demonstrates the necessity of treating each text as part of the editorial project behind the creation of each chansonnier.]

\section{5.}

Meneghetti, Maria Luisa. "Uc e gli altri: sulla paternità delle biografie trobadoriche." In Il racconto nel medioevo romanzo: Atti del Convegno, Bologna, 23-4 ottobre 2000. Quaderni di filologia romanza 15 (2001-2), pp. 147-62. [A close investigation of several vidas and razos to temper the modern view that Uc may have been responsible for the creation of most of the early biographical texts; there is evidence that at least one other was involved, whom she calls "Uc's rival."]

\section{6.}

Meneghetti, Maria Luisa. "Vidas e razos: sondaggi di stratigrafia funzionale (con una riflessione su fonti e significato del 'Sirventes lombardesco')." In $\mathbf{1 6 4}$, I trovatori nel Veneto, 2008, pp. 227-51. [The vidas and razos seem to be based on two traditions preceding their systematizing by Uc de Saint Circ, one in which the texts serve to fix the poets in time and place as introduction to a selection of their poems, the other in which the biographical texts are grouped together for their own sake, without the poems, creating a new narrative genre; stresses the links between the two series of vidas and the "satirical gallery" poems of Peire d'Alvernhe and Monge de Montaudon; analysis of the sirventes lombardesco that may well be attributed to Sordello (see edition by Stussi 3055, "Note sul Sirventese lombardesco," 2000, in which he concluded that it was not by Sordello).]

\section{7.}

Noto, Giuseppe. Il giullare e il trovatore nelle liriche e nelle "biografie" provenzali. Alessandria: Edizioni dell'Orso, 1998. [A thorough study of the designations joglar and trobador; in the vidas there was hardly any distinction made: joglars were highly valued; in the lyrics, joglars were respected till the end of the twelfth century, the terms joglar and trobador being even interchangeable, but by the end of the twelfth century, the joglars were looked down on by some troubadours, even criticized by some later poets, who sought a more stable and respected position at court.]

\section{8.}

Poe, Elizabeth W. "The Vidas and Razos." In 281, Handbook, 1995, pp. 185-97. 
[Vidas normally introduce a selection of songs by one poet, razos a particular poem, though the two types are not always distinguished carefully; they are important sources of information about the troubadours, but also worthy of study in themselves as literary texts; most of them, up to the mid-thirteenth century, were composed, or rewritten, by Uc de Saint Circ; many vidas take their material from the poems themselves, turning "metaphor into anecdote" or lyric experience into prose, often with ironical or sarcastic tone; see also 2916, Poe, "At the Boundary," 1988.]

\section{9.}

Poe, Elizabeth. From Poetry to Prose in Old Provençal: The Emergence of the "Vidas," the "Razos" and the "Razos de trobar." Birmingham, AL: Summa Publications, 1984. [Traces the historical change from the dominance of the self-sufficient canso through the growing challenge of prose texts: the separation of music from words led through the vidas and razos to the non-lyrical poetic treatises, which attempted to recover the twelfth-century lyric flowering for a later audience; pp. 5-13: detailed analysis of Bernart de Ventadorn's Chantars no pot gaire valer, PC 70,15, as a model canso; pp. 83-88: comparison of the chansonniers I and P regarding their integration of songs, biographies and treatises, precursors to Dante's Vita Nuova.]

\section{0.}

Poe, Elizabeth Wilson. "L'autr'escrit of Uc de Saint Circ: The razos for Bertran de Born.” RPh 44 (1990): 123-36. [The expression l'autr'escrit refers to an early group of razos composed or compiled by Uc and circulated as a group; the collection is amorphous and incomplete, drawn from a variety of sources, but is quite separate from the other razos.]

\section{1.}

Pulsoni, Carlo. "Per un approccio bédieriano alle vidas. I codici $I K$ e le loro fonti." In - 145, "Liber,"2006, pp. 115-34. [An attempt to characterize the sequence of vidas in each manuscript according to the editorial project that motivated its creation; manuscripts $A B I K$ are examined and are found to have many discrepancies between the output claimed in the vidas and that which has in fact been copied.]

\section{2.}

Zufferey, François. "Paradigmes perdus et biographies des troubadours." RLiR 69 (2005): 369-403. [Close linguistic study of the vidas and razos has revealed several characteristic phonetic traits that will help to identify the texts that were composed by Uc de Saint Circ; no final conclusions are drawn as yet.]

\subsection{Blandin de Cornualha (et Guillot Ardit de Miramar)}

[Anonymous romance; 2,394 lines; composed after 1350 in southeast France.]

\section{3.}

Galano, Sabrina. Blandin di Cornovaglia. Alessandria: Ed. dell'Orso, 2004. [The detailed introduction is a revaluation of the text on aesthetic grounds, establishing its oral qualities and jongleuresque authorship; the language is a sort of koiné from southeastern France, between Occitan and Catalan, with some influence from French and corrupted by an Italian scribe; the critical edition with Italian translation 
attempts to restore the original by correcting the Italian copyist's mistakes; Blandin is characterized as an eclectic, ironic work of fantasy, like a subtle literary joke, more like a fable than a romance, an ambiguous, multifaceted work. See the earlier online edition of 2001 at http://www.rialc.unina.it.]

\section{4.}

Van der Horst, Cor H. M. Blandin de Cornouaille. Introduction, édition diplomatique, glossaire. The Hague: De Gruyter Mouton, 1974. [Diplomatic edition with extensive glossary, no translation; negates Meyer's claim that the author was a Catalan trying to write in Occitan; believes that linguistic study points to composition in the Rhone basin, probably copied by an Italian scribe.]

\section{5.}

Pacheco, Arseni. Blandin de Cornualla $i$ altres narracions en vers dels segles XIV à XV. Barcelona: Edicions 62, 1983. [Brief introduction; Pacheco is unaware that Van der Horst has clarified the provenance of the work, copied by an Italian scribe (not Catalan, as Pacheco claims); pp. 27-79: text of Blandin; nonscholarly edition with regularized spellings, no translation.]

1166.

Huchet, Jean-Charles. "Blandin de Cornouaille." In La légende arthurienne. Le Graal et la Table ronde. Edited by Danielle Régnier-Bohler. Paris: Laffont, 1989, pp. 92356. [Text in French translation only.]

\section{7.}

Annicchiarico, Annamaria. "Blandin de Cornualha." In 1122, Annicchiarico, Narracions en vers," 2003, pp. 17-20. [Outlines recent studies as to genre, place and date of origin, and the extent of corruption added by the Italian scribe; the rational structure seems designed to underline the interdependent relationship of the two friends, while reflecting sociocultural changes taking place in southern France and Catalonia during the thirteenth century; the ironic and comic tone transforms the heroes into chivalric automatons, indicating a popular uncultivated audience.]

\section{8.}

Busby, Keith. "Blandin de Cornoalha and Romance Tradition.” Tenso 8, no. 1 (1992): 1-25. [A report on Blandin studies: the standard edition is now that by Van der Horst, not replaced by Pacheco's; Van der Horst has clarified the provenance of the work as being the Rhone valley, copied by an Italian scribe, not Catalan, as Pacheco and others have claimed; opinions of the text have become more positive, reception-oriented views being more helpful than comparing the text with Chrétien de Troyes; examines the social context of Occitan reaction to French traditions after the Albigensian Crusade; Blandin is a kind of spoof of northern French traditions and attitudes, a very self-conscious "literary" attitude in which the heroes are constantly aware of themselves as characters in a courtly romance; all is placed within the earlier and surrounding romance tradition.] 
1169.

Cingolani, Stefano. "Il Blandin de Cornoalha e la letteratura 'populare' fra Provenza e Catalogna." In 123, La narrativa, 1995, pp. 145-59. [Analysis of codicological and linguistic data indicate origins in Provence rather than Catalonia, even though the content is closely linked to Catalan popular tradition; rhyme and vocabulary indicate a copyist from northern Italy.]

1170.

De Caluwé, Jacques. "Le Roman de Blandin de Cornouailles et de Guiot Ardit de Miramar: une parodie de roman arthurien?" CN 38 (1978): 55-66. [Despite negative judgments about its literary merit, analysis reveals that the structure of the work is logical, each episode preparing the eventual outcome; apparent defects of style may be attributed to the vagaries of transmission, requiring a very careful editorial study to restore the original state; its questionable status as an Arthurian text may be resolved by treating the action and characterization as a parody of courtly Arthurian traditions.]

1171.

Lacy, Norris. "Halfway to Quixote: Humor in Blandin de Cornoalha." In Risus mediaevalis: Laughter in Medieval Literature and Art. Edited by Herman Braet, Guido Latré, and Werner Verbeke. Louvain: Leuven University Press, 2003, pp.173-80. [A study of narrative development in Blandin; the story provides an entertaining look at two colorful heroes on a quest for adventure that will prove their chivalrous worth; in fact, they are playing a role as good knights according to a formulaic code, without really knowing how to go about it; the author seems to be aware of the absurdities found in romance themes, but knows how to use them entertainingly.]

1172.

Majorossy, Imre Gábor. "Aventures en deux directions: allusions chrétiennes dans Blandin de Cornualla." In 102, AIEO 9, 2011, pp. 453-62. [The Arthurian aspects of the story cannot be taken seriously; but the spiritual elements are more complex: many direct or indirect references to the Bible are made, and seem to be serious, though touched by an ironic tone; the Garden of Eden is suggested, but not as a place of peace; birds have supernatural power and suggest the Holy Spirit; there are hints of archaic myths and rites of initiation to love, but all of these are ambiguous and unsettling; further analysis may clarify more of the complexities of the work.]

1173.

Martínez, Vicent. "Una entesa ben interessada entre la realitat i la fantasia: Blandín de Cornualla." Caplletra. Revista de filologia 5 (1988): 39-49. [Analysis of the new development of narrative realism at the turn of the thirteenth/fourteenth centuries; allegory, fantasy, and the supernatural, as well as religious, moral, and ethical questions, and the courtly rules of love, are overshadowed by everyday realistic details; the only goal is to seek adventure in terms of a ritual code of honor, kill many enemies and monsters, find wives, and settle down; this seems to foreshadow later narrative developments.] 


\subsection{Castia-gilos}

[A novas of 450 lines, written after 1214 by Raimon Vidal de Besalú; an unjustly accused wife punishes her jealous husband by tricking him as he tries to test her virtue, then profits from the opportunity to spend the night with a lover.] 1174.

See 2934, Field, Ramon Vidal, 1991, 2:191-265. [Introductory study of biographical evidence, attribution; critical edition with Catalan translation, minimal glossary.]

\section{5.}

See 1131, Thiolier-Méjean and Notz-Grob, Nouvelles courtoises, 1997. [Analysis of generic distinctions and the history of the novas, with a consideration of the implications of non-lyric style and the position of the author and the narrator; text of Castiagilos, with facing-page French translation, pp. 158-85.]

\section{6.}

See 1134, Huchet, Nouvelles occitanes, 1992, pp. 224-49. [Edition with French translation, notes.]

1177.

See 1129, Limentani, L'eccezione, 1977, pp. 47-60. [Comparison with the French fabliau La Bourgeoise d'Orléans shows that Casti-gilos is more complex in narrative technique, makes closer contact with the listeners, presents richer character development, and belongs more to the courtly register than the popular.]

\section{8.}

See 1136, Luce-Dudemaine, "Flamenca" et les “novas,"2007, pp. 95-112. [Castiagilos is part of a literature of protest against the rigid social establishment and a victory for the repressed woman against the authoritative husband; but it is different from the two other similar novas in that the heroine truly dislikes her husband and tries to have him killed; the tone is closer to that of a fabliau; "love" is a subversive, pleasurable pursuit rather than the idealized quest of fin'amor.]

1179.

Majorossy, Imre Gábor. "Le triangle et l'émotion: stratagèmes et primauté de l'amour dans le Castia Gilos." Medioevo e Rinascimento 20 (2006): 30-48. Reprinted in - 1137, Unas novas, 2007, pp. 41-56. [The Castia gilos demonstrates a fine balance in form and theme: it is more delicate and refined than a fabliau, less idealized than the traditional fin'amors lyrics; the main thrust of the dramatic presentation is the condemnation of jealousy, rather than the seeking of love; the adulterous "love" is more accidental than planned, more entertaining than didactic.]

1180.

Monson, Don A. "L'intertextualité du Castía gilos." RLaR 96 (1992): 301-26. [The basic theme and structure are those of the erotic triangle common to fabliaux; but these are modified by subtleties inspired by several other genres, including the courtly lyric; the jealous husband is much more human and attracts a milder punishment, the lady is treated with more respect, and the ultimate fate of the lover is left unresolved, as in the lyric songs, leaving us with a refined and intricate work of charming complexity.] 
1181.

Noomen, Willem. "Le Castia-gilos: du thème au texte." Neo 71 (1987): 358-71. [Comparative structural analysis of Castia-gilos and the French fabliau La bourgeoise d'Orléans shows that the two texts are very different; in the first, the listeners are brought into direct identification with the story through its aristocratic setting; in contrast to the structural simplicity of the fabliau, three different codes of behavior (feudal, marital, and courtly) are in play in Castia-gilos, either at the same time or alternately, creating a complex interplay of motivations and misunderstandings; the Castia-gilos supports an ideology in which the destructive force of jealousy must be eliminated in order to maintain the stability of courtly society.]

\section{2.}

Tavani, Giuseppe. Raimon Vidal: Il Castia-gilos e i testi lirici. Biblioteca médiévale, 57. Milan: Luni, 1999. [Introduction on the author and his corpus; edition of Castiagilos and two lyrics, Entr'el taurs and Bel m'es, with Italian translation; analysis of the theme of jealousy in the lyric and narrative traditions of Occitania and Spain; see suggestions on the texts by Pfister, $\operatorname{ZrP} 117$ (2001): 550-55.]

\subsection{Esther (Roman de la Reine Esther)}

[Didactic novas, 449 lines, incomplete at beginning and end; Occitan text written in Hebrew characters by Crescas de Caylar (Caslari) ca. 1327.]

\section{3.}

See 1131, Thiolier-Méjean and Notz-Grob, Nouvelles courtoises, 1997. [Analysis of generic distinctions and the history of the novas, with a consideration of the implications of non-lyric style and the position of the author and the narrator; introduction to Esther, pp. 43-46, stressing the religious, didactic purpose and the realistic portrayal of women's position in society, in contrast to the idyllic picture given in the troubadour lyrics; text of Esther with facing-page French translation, pp. 124-57.]

\section{4.}

Silberstein, Susan Milner. "The Provençal Esther Poem Written in Hebrew Characters c. 1327 by Crescas de Caylar: Critical Edition.” PhD diss., University of Pennsylvania, 1973. [Reproduction of the manuscript, both diplomatic and critical editions, with English translation; meticulous establishment of the text, with copious notes and a detailed literary study; the description of Assuerus's sumptuous feast may be ironic, directed toward the Avignon popes, or a reminiscence of Flamenca.]

\section{5.}

Einbinder, Susan L. "A Proper Diet: Medicine and History in Crescas Caslari's Esther." Speculum 80 (2005): 437-63. Also reprinted with slight modification as chapter 4 of her No Place of Rest: Jewish Literature, Expulsion, and the Memory of Medieval France. Philadelphia: University of Pennsylvania Press, 2009, pp. 84-111. [Describes the two versions of Esther in verse, one in Occitan, one in Hebrew, from Avignon; the Occitan version shows richer resources for describing foods, fabrics, and table manners, as well as legal and courtly realia, probably designed to have a wider appeal to ordinary 
people; the descriptive passages in the vernacular version evoke the courts of Provence rather than the biblical East.]

1186.

See 1126, Huchet, Le roman occitan médiéval, 1991, pp. 173-84. [The beginnings of Occitan romance come from an effort to free literary expression by revolt against its current forms; in Esther, the Jews are being warned not to abandon their God in favor of the new idol called narrative romance, built around a quest for personal identity instead of subjection to God; King Aros has offended God, in the manner of the courtly rulers, by exaggerated luxury and by proposing for the admiration of the crowd his beautiful naked wife Vasti (the dream of all good troubadours); Esther represents a Jewish conception of femininity opposite to that of the courtly ideal, which seems to be entering into a phase of destabilization.]

1187.

Majorossy, Imre Gábor. "Problèmes moraux dans la novas de la Reine Esther." Les Genres en Transition. Acta romanica Szegediensis 23 (2004): 95-101. Reprinted in 1137, Unas novas, 2007, pp. 129-37. [A narrative moralistic work adapted from the biblical book of Esther shortly after 1322; the text is unfortunately incomplete, but its intention seems to be the preservation of the integrity of the Jewish community of the time, by stressing the importance of obediensa and the dangers posed by the immoral literary traditions of fin'amor in the Christian community, and by mixed marriages.]

1188.

Thiolier-Méjean, Suzanne. "Crescas et le Roman de la reine Esther." FL 134 (2002): 33-46. [Introductory information on the author, the social background and the moral value of the work; Crescas intended his work to be instructive to ordinary people of his community, as part of the feast of Purim; obedience to the husband is an essential feature of his morality, necessary for the maintenance of the integrity of the Jewish community, in direct opposition to the poetic ideal of fin'amor.]

\section{9.}

Viguier, Marie-Claire. "Les Juifs dans le texte occitan: autour de la reine Esther." In - 96, AIEO 3, 1992, pp. 569-82. [Introduction to the Roman d'Esther in the context of Jewish traditions; subsequent history of the story into the twentieth century.]

\subsection{La Faula}

[The only extant work of Guillem de Torroella, ca. 1374; novas in Occitano-

Catalan (some scholars claim it is entirely Catalan); 1,269 lines; an Arthurian legend recounting the author's voyage on the back of a whale to an Enchanted Island (Sicily?), where he meets King Arthur and Morgana and is given a mission back to the real world, where chivalry has fallen into decadence.]

1190.

Vicent Santamaria, Sara. Guillem de Torroella: La faula. Valencia: Tirant lo Blanch, 2011. [Critical edition, with a Catalan rhymed translation; detailed information on the Torroella family and its influence on the sociopolitical culture of Majorca; study 
of folkloric themes and motifs in La Faula, the Sicilian link to the Arthurian legend, the formulaic style, and the controversy over the possible political interpretation of the text.]

\section{1.}

Compagna, Anna Maria Perrone Capano. Guillem de Torroella: La Favola. Barcelona: Publicacions de l'Abadia de Montserrat, 2007. [Critical edition, with textual and literary notes, no translation; discussion of the controversial political interpretation: the text may be in support of the Majorcan cause, but direct references to this in the earlier versions of the text, now extant only in fragmentary form, may have been removed, leaving only ambiguous evidence of such involvement in the one complete copy; the language is a mixture of Catalano-Occitan typical of Catalan poetry of the time, with Franco-Catalan in the portions dealing with the French characters Morgana and Arthur; supersedes her edition of 2004 (Rome: Carocci); text also online since 2000 at http://www.rialc.unina.it/179.1.htm.]

\section{2.}

Bohigas, Pere, and Jaume Vidal i Alcover. Guillem de Torroella, La Faula. Tarragona: Edicions Tàrraco, 1984. [Introduction has information on the author, the poem, manuscripts and editions, language, and versification; the first critical edition of the text, with limited glossary, no translation; the principles of edition are imprecise: the "corrections" to the text seem like attempts to de-Occitanize the language.]

\section{3.}

Annicchiarico, Annamaria. "La Faula." In 1122, Annicchiarico, "Narracions en vers,"2003, pp. 21-25. [Review of recent scholarship: information about the author, the nature and influence of the text on subsequent works, such as Tirant lo Blanc, the self-imposed mission of the author to bring back moralistic guidance from the other world to restore a decadent society; perhaps the real motivation for the tale was to invest the author himself as literary savior of society, in a refined show-off piece glorifying the chivalrous golden age, and perhaps adding a hidden message of Mallorcan political activism.]

1194.

Compagna, Anna Maria [Perrone Capano]. "Una variante alessandrina all'isola di Avalon ne La faula del maiorchino Guillem de Torroella.” Parola del testo 13 (2009): 133-43. [The magical island of Avalon is identified with Sicily, the homeland of the author, who is both author and protagonist in the story, a mixture of reality and imagination.]

\section{5.}

Hauf i Valls, Albert. "Artus, aycell qui atendon Li breto"?: La Faula, seducció o reivindicació políticomoral?" Bolletí de la Societat Arqueológica Lul.liana 56 (2000): 7-24. [A reading of the text as a traditional voyage of initiation that conceals a complex political message, but more very careful historical research is required before the full message can be clearly understood.]

\section{6.}

Vicent Santamaria, Sara. “La faula de Guillem de Torroella: ¿Literatura o política?” 
Res publica 17 (2007): 341-56. [Detailed review of recent research; it is unclear whether the controversial Arthurian work has a hidden political message about the struggle over the restoration of the Kingdom of Majorca, but Santamaria believes that further research will clarify the interpretation in one direction or the other, or will sustain both interpretations.]

1197.

Riquer, Isabel de. "Lo maravilloso y lo cotidiano en La faula de Guillem de Torroella." Revista de Filologia románica 22 (2005): 175-82. [La Faula combines various aspects of the Breton romance tradition: it forms a sequel to the French Mort d'Artu and features a central adventure similar to that of Saint Brendan; fantastic and otherworldly elements gradually give way to details of everyday reality, in a model of confident use of the mother tongue by a Catalan writer.]

\section{8.}

Riquer, Isabel de. "La faula ou l'aventure littéraire de Guillem de Torroella." RlaR 115 (2011): 199-215. [Stresses the originality of Guillem's presentation in telling the fantastic adventure in his own name, with himself as protagonist and author; the tale remains attached to everyday reality while recounting fantastic experiences; several traditional themes from a wide choice of Arthurian and other literature, such as the suspension or speeding-up of time, are given a new twist; a unique mixture of themes, languages, and narrative perspective.]

\subsection{Filomena (Roman de Notre Dame de la Grasse)}

[Semihistorical work, mixed with memories of various epics, said to be written by Filomena, a scribe of Charlemagne; mid-thirteenth-century version in Occitan, based on the fictive Latin chronicle of the founding of the monastery of Lagrasse: Gesta Karoli Magni ad Carcassonam et Narbonam.]

1199.

Simonnet, Émile-Jean. Édition critique du roman de Notre Dame de Lagrasse. Doctoral thesis, Université de Paris IV Sorbonne, 1988. (C.E.C. microfiche). Published online in three parts at http://emile.simonnet.free.fr/sitfen/txlagras.htm: text in Occitan (MS b); http://emile.simonnet.free.fr/sitfen/traduc.htm: translation into French; http://emile.simonnet.free.fr/sitfen/etude.htm: analysis of the Occitan text. See also his article "Le Roman de Notre Dame de Lagrasse," FL 116 (1993) and available online at http://emile.simonnet.free.fr/sitfen/lagrasse.htm.

1200.

Keller, Hans-Erich. "Le Roman de Filomena et la chanson de geste." In $>$ 96, AIEO 3, 1992, pp. 1001-12. [Study of the Christian heroes of the poem as depicted by the narrator Filomena: a more courtly and civilized Roland treats his foes with respect and responds to the attentions of Orienda, Saracen queen of Narbonne; Ogier le Danois is depicted positively as an independent hero; at a second level of meaning, there seem to be allusions to the expedition of Simon of Montfort against Albi and Toulouse, 1213, and there is little doubt that the author-translator, probably from the Abbey of Grasse, was firmly supportive of the Occitan cause, hoping for support from the French king.] 
1201.

Lafont, Robert. "Réflexions sur le Roman d'Arles." RLaR 108 (2004): 243-60. [The Occitan text, translated later into Latin, was composed in the Abbey of Lagrasse before 1229; this is the second of three historical "prises de ville" from the Saracens (Chanson de Roland, Roman de Filomena, Roman d'Arles), in all of which actual history has been transformed into political myth. Filomena is about the capture of Narbonne by Charlemagne, but recast as a glorious victory over the Muslim enemy; for historical details, see Lafont, "Les trois espaces," in \$ 99, AIEO 6, 2001, pp. 450-53.]

\subsection{Flamenca}

[A text of 8,096 lines, incomplete at beginning and end (and elsewhere); also called Las Novas de Guilhem de Nevers; a romance or novas set in about 1234, written later, between the middle and the last third of the thirteenth century; a fragment of seven lines (2713-20) in a Catalan chansonnier from the end of the fourteenth or beginning of the fifteenth century, shows that the text circulated more widely than thought, and later.]

1202.

\section{Bibliography}

Gouiran, Gérard. "Encore une bibliographie pour Flamenca." RLaR 92 (1988): 105-23. [Listings up to 1988, consolidating listings from Limentani, 1977, and Gschwind, 1973-74; further consolidated to 2003 in 1136, Luce-Dudemaine, pp. 147-65.]

\section{3.}

\section{Editions}

Gschwind, Ulrich. Le "Roman de Flamenca," nouvelle occitane du XIIe siècle. 2 vols. Romanica helvetica, 86A, 86B. Bern: Francke, 1976. [Vol. 1 has the introduction and critical text; no translation; vol. 2 lists all rejected or problematic manuscripts readings, pp. 7-61, copious textual notes pp. 63-230, glossary and bibliography; see the detailed reviews by Suzanne Fleischman, RPh 34 (1981): 513-21, and Max Pfister, VR 38 (1979): 243-52.]

\section{4.}

Manetti, Roberta. Flamenca. Romanzo occitano del XIII secolo. Modena: Mucchi, 2008. [New critical edition with an Italian prose translation, notes, and glossary; the introduction stresses the rich originality: an entertaining story of jealousy and cuckoldry, enriched by a sophisticated combination of troubadour themes and symbols, mixed with subtle anti-Capetian political allusions; see suggestions for the translation by Monica Longobardi, MR 35 (2011): 141-49, aimed at preserving more of the lightness, humor, and erotic suggestiveness of the original.]

\section{5.}

Blodgett, E. D. The Romance of Flamenca. New York: Garland, 1995. [Occitan text from Gschwind, with facing-page English translation; introduction, study of dating, notes.] 
1206.

Huchet, Jean-Charles. Flamenca, roman occitan du XIIle siècle. Paris: Union générale d'éditions, 10/18, 1988. [Text based on a microfilm reading, with unspecified "corrections"; the facing-page French translation is very readable, but rather free; brief introduction, notes.]

1207.

Kirsch, Fritz Peter. Flamenca. Ein altokzitanischer Liebesroman, übersetzt, mit Einführung, Erläuterungen und Anmerkungen versehen. Essen: Phaidon, 1989. [Text in German, with introduction, notes.]

1208.

Mancini, Mario. Flamenca. Rome: Carocci, 2006. [Text reproduced from Gschwind, 1976, with introduction, notes, and facing-page Italian translation; analyses of plot, courtly ambiance, and characterization show that it is one of the most original and unusual creations of medieval literature, in that it attempts to reformulate the lyric traditions of troubadour poetry into narrative form.]

1209.

Rossell, Antoni. El román de Flamenca. Novela occitana del siglo XIII. Guadalajara (Mexico): Ediciones Arlequín, 2009. [New translation into Spanish, based on Gschwind's text of 1976; introduction by Mercedes Brea.]

1210.

Limacher-Riebold, Ute. Entre "novas" et "romans": Pour l'interprétation de "Flamenca." Alessandria: Edizioni dell'Orso, 1997. [Review of all former editions of Flamenca, with critical notes for a new edition; table of corrections to the manuscript proposed by Meyer, 1865 and 1901, Nelli/Lavaud, 1960, Gschwind, 1976, and Huchet, 1988; believes that the author is playing with his source-models, making it difficult to pin down the genre: it partakes of both lyric and narrative, with themes characteristic of novas and Arthurian romance.]

1211.

Murphy-Judy, Kathryn A. "Reading Flamenca Again, Why?" Tenso 6 (1990-91): 66-72. [In reaction to the various available editions of Flamenca, points out the need for a hypermedia version of the text on CD-ROM, containing the original manuscript text, a diplomatic reading, a complete concordance, several translations, Gschwind's commentaries, and anything that would lend itself to reading, hearing, and engaging the text in all of its possibilities.]

\section{2.}

Overall Studies

Grossweiner, Karen. "Flamenca." In \$ 45, Women and Gender, 2006, pp. 710-11. [Basic introduction to the romance, stressing the playful ironic tone, the movement between various rhetorical and literary discourses, the masterful combination of overlapping genres, and the independent voice given to the usually silent domna, which make for a rich and many-layered literary masterpiece.] 


\section{3.}

Asperti, Stefano. "Flamenca e dintorni. Considerazioni sui rapporti fra Occitania e Catalonia nel XIV secolo.” CN 45 (1985): 59-103. [Detailed investigation of contacts between Catalan and Occitan literatures, especially in the area of narrative genres; fragment of seven lines (2713-20) from Flamenca in a Catalan chansonnier from the end of the fourteenth or beginning of the fifteenth century shows that the text circulated more than thought, and later.]

\section{4.}

Bernard, Katy. "Les motifs de la 'science' divinatoire dans le déroulement narratif de Flamenca." In 101, AIEO 8, 2009, 1:457-90. [Detailed analysis of the erudite learning of Guilhem, especially of his "scientific" understanding, which reveals the depth of his (and the author's) psychological understanding.]

\section{5.}

Brea López, Maria Mercedes. "Los personajes de Flamenca, paradigma de la finamor." In Los caminos del personaje en la narrativa medieval, Actas del Coloquio Internacional, Santiago de Compostela, 1-4 diciembre 2004. Edited by Pilar Lorenzo Gradín. Florence: SISMEL-Edizioni del Galluzzo, 2006, pp. 77-98. [The three protagonists incarnate the essential figures of the lyric tradition: the lover, the domna, and the gilos; they bring to life the potential of the lyric code of fin'amors, making it into a complete narration.]

\section{6.}

Brea, Mercedes. "La arquitectura interna de Flamenca." MR 30 (2006): 92-110. [Structural analysis of the text, divided into four parts instead of the traditional three (different from the four parts of Graves, who divided the traditional first part into two); specific literary and social functions are assigned to each part, and specific psychological developments: the gilos, the knight, the couple, society restored; each part treats a stage in the classical development of fin'amors to its social apotheosis; analysis of the temporal organization and the spatial coordinates, especially the different types of imprisonment (psychological, physical, amorous, social.]

\section{7.}

Brunel, Geneviève. "Autour de Flamenca, quelques lectrices occitanes médiévales. De la lectrice à l'art d'aimer." In La Lecture au féminin/Lesende Frauen. Edited by Angelica Rieger and Jean-François Tonard. Darmstadt: Wissenschaftliche Buchgesellschaft, 1999, pp. 77-87. [Gathers together rare evidence of women who read: Flamenca and her two companions, Eleanor of Aquitaine, Héloise, and Saint Douceline; the act of reading represents for Flamenca the only way of surviving her years of imprisonment, as well as forming an introduction to love and life.]

\section{8.}

Caluwé, Jean-Michel. "Flamenca et l'enjeu lyrique. La médiation de Jaufre Rudel et de Peire Rogier.” In 96, AIEO 3, 1992, pp. 837-53. [Parallels and echoes from Jaufre Rudel's amor de lonh poems, his vida, and from a poem by Peire Rogier; the two-syllable exchange that forms the most original part of the romance can be read as a lyric octosyllabic stanza; Flamenca is seen to be a complex union of lyric and narrative, of Occitan and French traditions, of aesthetics and sensuality.] 
1219.

Chambon, Jean-Pierre, and Colette Vialle. "Pour le commentaire de Flamenca (III): nouvelles propositions concernant le cadre chronologique." RLaR 114 (2010): 15577. [Meticulous analysis of dates and chronology suggests that the framework of the story covers exactly seven years, 1217-24, and that the inner architecture is carefully structured, with the central part covering seven months, itself carefully subdivided; the framework years may have a political significance in tensions between Bourbon and Auvergne, which Chambon intends to investigate further.]

1220.

Dickey, Constance L. "Deceit, Desire, Distance and Polysemy in Flamenca." Tenso 11 (1995-96): 10-37. [Explores two threads of research on Flamenca: horizontal: the play between appearance and reality = "deceit, ambiguity, polysemy"; vertical: the centrality of the heroine herself, studied from many viewpoints; particular consideration of her personal identity as a woman, at odds with her public persona.]

1221.

Dragonetti, Roger. Le Gai savoir dans la rhétorique courtoise, "Flamenca" et "Joufroi de Poitiers." Paris: Seuil, 1982. [Close analysis of the overall structure of the romance, with detailed explorations of incidents and poetic developments that penetrate to the poetic heart of the work; many illuminating analyses of short episodes that prove the mastery of the author, who is mirrored in the personage of the lover-hero Guillem; suggests that the fragmentary state of the manuscript copy may be in fact a part of the structure, reflecting the incomplete state of our experience of love.]

1222.

Fasseur, Valérie. "Le point sur un i. Un exemple d'hybridation didactique dans Flamenca." In 114, Les genres, 2010, pp. 67-73. [A lengthy excursus on etymology by Guillem reveals unsuspected levels of complexity in the romance; references to encyclopedic texts as well as to troubadour lyrics show the immense breadth of knowledge and memory of Guillem (and of the author!); the union of poetic individuality and scientific universality is a remarkable feat for the author, but the audience must have been capable of recognizing these sources as well, and of understanding their tacit implications.]

1223.

Ghil, Eliza Miruna. "The Romance of Flamenca: A Study of the Implied Public." In Courtly Romance. Edited by Guy R. Mermier. Ann Arbor: Michigan Consortium for Medieval and Early Modern Studies, 1984, pp. 109-32. [An assessment of the degree of innovation of Flamenca with respect to accepted social conventions; the text is defiant in its advocacy of literature as a means of encouraging social change, thirdperson narrativity, and flesh-and-blood realism in the depiction of the love triangle, including frank reciprocal fulfillment in sex; Guilhem is portrayed as a role model for the use of educated ingeniosity rather than the traditional military virtues in the fight for survival through the instability of the post-Albigensian era.]

1224.

Ghil, Eliza Miruna. "La Nova de Flamenca ou quand lire c'est faire.” In $>1053$, 
Ghil, L'Age de parage, 1989, chapter 5, pp. 295-364. [Analysis of the complex ruses employed by Guillem and Flamenca to attain joi at a difficult moment in French social history; the reading of Latin auctores, the liturgy, troubadour lyrics, and French romances helps them to formulate ways to combat the political, military, and religious forces arrayed against personal happiness and plenitude.]

1225.

Gouiran, Gérard. "L’odeur de soufre des eaux thermales à propos de Flamenca et de textes médiévaux non littéraires." In L'Eau au Moyen Âge. Sénéfiance, 15. Aix-enProvence: CUER MA, 1985, pp. 171-84. [The records of the thermal baths of Digne furnish detailed information on the administration of the premises, which was quite similar to that of the fictive baths of Bourbon in Flamenca; the author had such precise knowledge of the layout and practices of the baths that they appear in complete realistic detail in the novel, including suggestions of illicit sensual pleasures.]

1226.

Graves, Rolande J. Flamenca: Variations sur les thèmes de l'amour courtois. Frankfurt: Peter Lang, 1983. [An investigation of the "originality" of Flamenca in its response to multiple changes in thirteenth-century society, specifically in the subversion of several courtly conventions such as the passivity of the lady or the ennobling nature of love; several important publications in the area are not discussed; other controversial ones are treated as authoritative.]

1227.

Grossweiner, Karen A. "Narrators and Narrating Characters: Voicing in Le Roman de Flamenca." Neo 92 (2008): 395-408. [The complex interwoven structures of Flamenca include those of multiple narrativity; the narrator does not merely represent the author but is himself a rhetorical construct who complicates his text by entering into multiple narratives with very different sets of values, using different voices and different ideologies in each; in the religious mode, he criticizes the lovers for blasphemy, while praising their resourcefulness in the courtly mode, sometimes being serious, sometimes ironic or humorous, at other times more bitterly sarcastic; other characters in the story may assume a narratorial role as well, resulting in a text that is a multilayered joyful game.]

1228.

Huchet, Jean-Charles. L'Etreinte des mots: "Flamenca" entre poésie et roman. Caen: Paradigme, 1993. [Stresses the interplay of lyric and romance, of religion and love, of French and Occitan; the author may have been trying consciously to renew the literary form.]

\section{9.}

See 804, Kay, Subjectivity, 1990, pp. 198-211. [Guilhem and Flamenca alternate between the roles of audience and performer, receiver and producer; their courtship is determined at first by constant literary reminiscences of troubadour lyric themes, their roles inscribed in the tradition of finiamors, until the words turn from text to acts and they take on real personalities - or do they? The romance is full of irony and playfulness, making it difficult to distinguish between reality and playacting.] 
1230.

Kirsch, Fritz Peter. "En traduisant Flamenca." In 151, Mélanges Bec, 1991, pp. 249-58. [Explains the supposed interruptions of the plot line in what seem to be dialogues involving Archambaut, Flamenca, and Guilhem, which are in fact interior monologues between two parts of the persons involved as they struggle inwardly to integrate the contradictions of society; disagrees with Fleischman, RF 92 (1980): 223-46, and Sankovitch, $R P h 35$ (1981): 217-23, who think that there is a certain amount of superficiality, hypocrisy, and amorality in the characters of Flamenca and Guillem; Kirsch will attach no blame to either.]

\section{1.}

See 1129, Limentani, L'eccezione, 1977, pp. 157-303. [A traditional exploration of cultural sources of Flamenca to better understand the sociocultural background out of which the work was composed; Latin traditions of rhetoric and moral philosophy, along with the narrative structures and descriptive techniques of Old French literature and the sensitive psychological analysis found in Occitan lyrics, all contribute to the richness of the author's creativity.]

1232.

See 1136, Luce-Dudemaine, "Flamenca" et les "novas," 2007. [The narrative mode is linked to different aims than those of the lyric; emphasis is placed on personal fulfillment and satisfaction of desire, not by adherence to the moral code of fin'amor but, rather, by the use of ruse and stratagem; idealism and merit are replaced by cleverness and manipulation, as well as by a generous use of money to pave the way to pleasure; complete bibliography of Flamenca, pp. 147-65, updating that of Gouiran in 1202 to 2003; see a similar but stronger interpretation by Luce-Dudemaine in -102, AIEO 9, 2011, pp. 349-58, in which Flamenca is shown to be closer to Ovid and the fabliaux than to the traditional courtly ethos.]

\section{3.}

Mancini, Mario. "Nella biblioteca di Flamenca: i trovatori." In $>\mathbf{1 0 0}$, AIEO 7, 2003, pp. 511-20. Also complementary article 158, Studi Bertolucci Pizzorusso, 2006, 2:921-39. [Considers the intertextual nature of Flamenca, especially themes and attitudes closely linked to the poetic traditions of Marcabru, Jaufre Rudel, Bernart de Ventadorn, Guilhem de Peitieus, and Chrétien de Troyes.]

1234.

Moreau, John. "The Perversion of Time: Jealousy and Lyric in the Romance of Flamenca." Modern Language Review 104.1 (2009): 41-54. [Archambaut's sociopathy is represented by a stasis or suspension of time that Guilhem must counteract by action; whereas the lyric lover exists in eternal anticipation outside of time, and in contrast to the gilos who operates in real time, here the roles are reversed, as the lover must turn the traditional lyric stasis into narrative action; the discord in Archambaut's personality comes from his insane desire to control time; he is out of step with society and with church time, while the lovers operate within both.]

1235.

Schlieben-Lange, Brigitte. "Ai las-que planhs? Ein Versuch zur historischen 
Gesprachsanalyse am Flamenca-Roman.” RZL 3 (1979): 1-30. [Stresses the importance of dialogue and conversation in the make-up of the romance; much more needs to be known about the dating, location, and the author before deeper analysis can be undertaken; models may be sought in the Latin conflictus, or in the troubadour dialogistic tensos and partimens, but in Flamenca the conversational goal is union rather than dispute; finding close parallels to this dynamic of conversation will help to pinpoint the source of Flamenca as well as to understand the cultural functioning of the conversational mode.]

1236.

Solterer, Helen. "Sermo and juglar: Language Games in Flamenca." In 104, Spirit of the Court, 1985, pp. 330-38. [Flamenca pokes fun at both religious and poetic language, the two key ritualized expressions of Occitan society; Archambaut suppresses joglar and mutilates sermo, while Guilhem is the master of both; within the story, language play not only serves to advance the action but it is an end in itself.]

1237.

Togni, Nadia. "Les lacunes du manuscrit de Flamenca." RLaR 105 (2000): 379-97. [Careful study of the lacunae: a single leaf at the beginning; two leaves after folio 2 (portrait of Flamenca); two leaves after folio 32 (voyage of Guilhem to Bourbon); one leaf after folio 116 (conclusion of Flamenca's oath to Archambaut); three leaves after folio 123 (the contents of the saluts brought from Guilhem to Flamenca by Archambaut); unknown number of leaves after folio 140, not likely more than two; some losses may be due to "collectors" who tore out miniatures at beginning and end, or the saluts, for their own enjoyment; all the lacunae are mechanical, contrary to the daring hypothesis of Dragonetti that the "silences" were intentional parts of the textual structure; see also R. Lejeune, "Le MS de Flamenca et ses lacunes," in Littérature et société occitane au moyen âge (Marche romane, hors série), Liège, 1979, pp. 332-39.] 1238.

Vitz, Evelyn Birge. "A Showcase for Talent: Performance in and of Flamenca." In - 157, De sens rassis, 2005, pp. 683-98. [Flamenca calls for at least three distinct types of drama: (1) the madman (Archambaut), (2) eroticized liturgical performance, and (3) intermittent amorous dialogue in twenty brief exchanges over several weeks, all composed and rehearsed ahead of time; the performance of Flamenca would have demanded a wide range of dramatic talents, preferably by a single highly talented performer.]

\section{9.}

Walkley, Maxwell. "Comic Elements in the Thirteenth-Century Provençal Romance Flamenca." Arts (The Journal of the Sydney University Arts Association) 18 (1996): $87-108$. [The anonymous poet is so much a master of courtly style and situation that he can play with conventions in a manner which amused him and probably his contemporaries — and certainly amuses us.]

1240.

Zak, Nancy C. "Modes of Love in Flamenca: Legitimate/Illegitimate, Vital/Sterile, Human/Inhuman." In 127, 1989, Poetics of Love, 1989, pp. 43-51. [Explores the 
dualist perspective of the poet toward love: there are two cultural models at work, one pagan/sexual, one Christian/feudal; individual, human values are superior to collective principles; Flamenca foreshadows the humanistic ethos of the Renaissance.]

\subsection{Frayre-de-joy et Sor-de-plaser}

[Anonymous, late thirteenth century; ca. 850 lines; both manuscripts are defective; a sort of narrative lai, a version of the Sleeping Beauty legend, placed in an Arthurian setting with intertextual references to troubadour lyric and the traditions of finamors.] 1241.

Thiolier-Méjean, Suzanne. Une Belle au Bois Dormant médiévale: "Frayre-de-Joy et Sorde-Plaser," nouvelle d'oc du XIVe siècle. Texte, traduction, notes et commentaires. Paris: Publications de l'Université de Paris-Sorbonne (Paris IV), 1996. [A rich introduction to the history of narrative poetry in Occitan and the meaning of the word novas; literary analysis of Frayre and its links to the Old French Perceforest, on which it may have been partly modeled; detailed linguistic analysis suggests an original lost Occitan text copied by two Catalan scribes, with a few Gallicisms; critical edition with French translation, notes and indexes; see a more succinct edition without the literary and linguistic studies in 1131, Thiolier-Méjean and Notz- Grob, Nouvelles courtoises, 1997, pp. 206-59.]

\section{2.}

Franci, Giovanna, and Esther Zago. La Bella Addormentata: Genesi e metamorfosi di una fiaba. Bari: Dedalo, 1984. [Popularized historical sketch of the "Sleeping Beauty" legend, from the Indian story of Surya Bai to the tales of Perrault and Grimm; introduction and Italian translation of Frayre-de-Joi, pp. 57-74.]

\section{3.}

Annicchiarico, Annamaria. "Frayre-de-joy e Sor-de-plazer." In 1122, Annicchiarico, Narracions en vers," 2003, pp. 25-28. [Review of recent research on Frayre: linguistic origin of the text; analysis of a new moral concept of joi, emphasizing love as physical union, to replace the sentimental idealization found in the troubadour lyrics; passion is central, but must remain discreet and lead to marriage (as in Blandin).] 1244.

Bibring, Tovi. "La Fausse morte ou la lutte entre le naturel, le merveilleux et le miraculeux: lecture de la novàs occitane Frayre-de-Joy et Sor-de-Plaser." In Actes du Colloque International: Ecriture et Rééciture du Merveilleux Féérique: Autour de Mélusine (Poitiers, 12-14 juin 2008). Edited by Jean-Jacques Vincensini and Claudio Galderisi. Paris: Garnier, 2010. [Analysis of variations on the motif of "la Fausse morte" and the subtle interplay of natural, magical, and miraculous forces in our understanding of life and death.]

\section{5.}

Léglu, Catherine E. "Languages and Borders in Three novas." In $>917$, Léglu, Multilingualism, 2010, chapter 5, pp. 99-118. [Exploration of the ambiguous exploitation of attitudes toward language, sexuality, and nationality in Frayre-de-Joi e Sor-dePlaser; the boundaries between truth and deception, reality and unreality, are bound 
up in the ambiguities of communication and the hybrid language of the text; similar concerns are found in Blandin de Cornualha.]

\section{6.}

Majorossy, Imre Gábor. "Langage biblique, enchantement et personnages redoublés dans Frayre de Joy et Sor de Plaser." Verbum (2006): 5-21. Reprinted in 1137, Unas novas, 2007, pp. 111-27. [The work has a curious mixture of Christian and pagan magical forces; many passages evoke Christian rituals and biblical imagery; there are suggestions of a virgin birth, and the magical bird is linked with the Holy Spirit, but the final interpretations remain morally ambiguous, except for the overriding fact that love is all-powerful and can conquer even death.]

1247.

Martin, Frédéric. "Les motifs arthuriens dans Frayre-de-joy et Sor-de-plaser." Online at http://littmedievale.chez.com/Lm033.htm. [Comparison of Frayre-de-joy with Blandin de Cornualha, Perceforest, and the works of Chrétien de Troyes; the magic bird plays a more important role in Frayre, becoming the central figure, similar to the parrot in Le Chevalier au papegau; the motifs are more flexible in Frayre, more open to interpretation by author or reader.]

\section{8.}

Thiolier-Méjean, Suzanne. "Virgile et Prêtre Jean dans la nouvelle Frayre-de-joy et Sorde-plaser." In 140, Etudes Ricketts, 2005, pp. 93-105. [The author of Frayre knew the legend of Virgil as virtual Christian, erudite, and magician, owner of a fabulous jay from the kingdom of the mythical Prester John, who was himself a legendary magician and perfect Christian; these links set the unique tone of the novas and indicate a date for the text in late thirteenth century, tied to political struggles between Arabs and Christians.]

\section{9.}

Zago, Esther. “Frayre-de-Joy e Sor-de-Plaser Re-examined." Fabula 24 (1983): 26974. [Study of narrative structures based on an integrated text of the two incomplete manuscripts: the structure is based on the interweaving of themes, issues, and motifs rather than conforming to our modern ideas of order and realism; an attempt to express a new ethic, keeping the trappings of fin'amors but leading to marriage; insistence on religious elements such as marriage and baptism, reflecting the changes in society in the thirteenth and fourteenth centuries; the lacunae may be intentional, to omit the defloration of Sor and the excessive banquet scene.]

\subsection{Guilhem de la Barra (Las aventuras de mosenher G. de la Barra)}

[5,344-line romance, composed in 1318 by Arnaut Vidal de Castelnaudary (first winner of the violette d'or at the Consistori de la Gaia Scienza, 1324).]

\section{0.}

See 38, DLF, 1993, pp. 91-92. [Biography of Arnaut Vidal and his patron Sicart de Montaut, a noble of Languedoc, loyal to the crusaders, participant in the siege of Toulouse in 1218; analysis of the religious canso to the Virgin that won Arnaut the first violette d'or awarded by the Consistori; presentation of the 
imaginary story of Guilhem de la Barra, a loyal knight falsely accused of seduction by his queen, then reinstated.]

1251.

Gouiran, Gérard. Arnaut Vidal de Castelnaudary: Le livre des aventures de Monseigneur Guilhem de la Barra. Paris: Champion, 1997. [Text with facing-page French translation; very brief notes; no glossary; introduction by J-P. Huchet, pp. 1-31, gives information on author, sociohistorical background, the manuscript, sources, and originality of the text.]

1252.

Chambon, Jean-Pierre, and Colette Vialle. "Sur la structure chronologique de Guillaume de la Barre." RLaR 102 (1998): 373-86. [A coherent interior chronology is based on the traditional "ages of man"; the young king and Guilhem had both reached the legal age of majority at the beginning of the text, not yet quite twentyone, the age of majority for a knight; the romance is articulated around the medieval theory of the stages of life, recounting the adventures of the mature Guilhem and giving unity and structure to the work.]

1253.

Galano, Sabrina. "La parodia dei generi nel romanzo di Guilhem de la Barra." In - 102, AIEO 9, 2011, pp. 371-82. Also in RLaR 114.1 (2010): 23-45. [The work reveals a typically Occitan generic mixture of hagiographic, epic, romance, and lyric elements, with reference to classical, courtly, religious, and popular sources, all with a characteristic parodic tone; Occitan narratives should not be studied in the light of genre definitions that may be applicable to French works, but should be seen as natural products of a different social, historical, and cultural background, with especially close ties to lyric expression.]

\section{4.}

See 1126, Huchet, Le roman occitan médiéval, 1991, pp. 161-72. [Discusses the heterogeneous nature of Occitan narratives, their dialogic interface with the lyrics, their overlapping genres, their ideological mixture of literary and didactic goals; Guilhem de la Barra is the foremost example of this hybridity: epic prowess in the service of Christianity in the first part gives way to a personal quest for identity in the second, indicating an author in complete control of his text; the dual structure is echoed in the importance of "Guilhem" in the first part and of "Barra" in the second, of Christian subjection in the first to a personal salvation, almost "pagan" in the second.]

1255.

Léglu, Catherine. "Tongues of Fire in Guilhem de la Barra." In 917, Léglu, Multilingualism, 2010, pp. 35-53. [The plot stresses misunderstandings, difficulties of communication, and false accusations that seem to echo the social instability of the post-Albigensian era in Occitania; the tongues of fire of Pentecost were meant to cancel the confusion of Babel, but the Albigensian Crusade and the Inquisition had turned them into the false but real tongues of fire that accused and burned supposed heretics; the message may well be that some compromise of principle was required 
in order that the conquered Occitans might make the most of a bad world and find some peace in exile within the new order.]

1256.

See 1129, Limentani, L'eccezione, 1977, pp. 110-19. [Guilhem de la Barra was written when the lyric tradition had turned already toward religious themes, replacing the domna with the Virgin; the hero Guilhem is totally loyal to his king, even through his unjust disgrace and exile, and toward the end leads a life of penitence as in a saint's life; however, the disparate adventures include fantasy, miracles, and direct humor alongside the overriding tone of Christian morality.]

\section{7.}

Notz, Marie-Françoise. "Un roman du romanesque: le Livre des aventures de Monseigneur Guillem de la Barra." In Le Goût du lecteur à la fin du Moyen Âge. Edited by Danielle Bohler. Paris: Léopard d'or, 2006, pp. 109-16. [Points out the incongruities of the exaggerated actions which turn almost to the comic (to us at least) but which are rooted in the absolute fidelity of Guilhem to feudal and religious laws, making him almost into a saint at the end, a figure who is perhaps only comprehensible to the disoriented audience of his time.]

\section{8.}

Poe, Elizabeth Wilson. "Segon que.m sove per semblan [Segon que.m par]: auctorial interventions in Arnaut Vidal's Guilhem de la Barra and their relation to his sources." In Conjunctures: Medieval Studies in Honor of Douglas Kelly. Edited by Keith Busby and Norris J. Lacy. Amsterdam: Rodopi, 1994, pp. 455-80. [A reevaluation of the work according to more objective criteria than the negative nineteenth-century judgments of Paul Meyer 1895, repeated by critics since; Arnaut calls it a roman, but it has many elements typical of the epic; Poe examines possible sources and the way they were put together by Arnaut.]

\subsection{Jaufre}

[Quest-romance; 10,956 lines; controversial dating to 1169-70 or 1205-28, or after 1270 , possibly reflecting several lost redactions; some parody of Arthurian traditions, along with an affirmation of the power of true piety against otherworldly evil.]

\section{9.}

\section{Editions}

Lee, Charmaine. Jaufre. Rome: Carocci, 2006. [Detailed introduction, philological study; text with facing-page Italian translation and full textual apparatus, notes, and abundant bibliography; elements of "Mediterranean" Arthurian traditions are juxtaposed, often comically, with northern French traditions, perhaps to propose a new model of chivalry in the southern mode, with the new Arthur modeled on the (unnamed) king of Aragon, who is asked to save southern culture after the Albigensian Crusade; also as electronic edition, 2002, at http://www.rialto.unina.it; see detailed discussion, suggestions, and corrections by Lazzerini, $\operatorname{ZrP} 125$ (2009): 341-57.] 
1260.

Arthur, Ross G. Jaufre, an Occitan Arthurian Romance. New York: Garland, 1992. [Introduction, English translation only, based on Brunel's text, 1943.]

\section{1.}

Gómez Redondo, Fernando. Jaufré. Madrid: Gredos, 1996. [Introduction; text in Portuguese translation only, based on Brunel's edition, 1943; many linguistic and textual notes.]

\section{2.}

Ely, Bernard. Jaufre, récit initiatique occitan du XIIIe. Avignon: IEO, 2001. [Popular edition, attempting to renew the interpretation of Jaufre; retelling of the story in résumé in French, based on the text by Nelli/Lavaud; interpretation of the story, following Gouiran, as an initiation text enhanced by parody: Jaufre seeks his higher mystical identity through a mixture of Christian, Jewish, and Muslim religious quest motifs, commits offenses, is punished and pardoned; brief study of the ca. 250 manuscript drawings in comic-strip form; Ely believes that the text was composed in Catalunya.] 1263.

Zink, Michel. "Le Roman de Jaufre." In La légende arthurienne. Le Graal et la Table ronde. Edited by Danielle Régnier-Bohler. Paris: Laffont, 1989, pp. 841-922. [About half of the text is given, in French translation only.]

\section{4.}

\section{Literary Studies}

See 38, DLF, 1993, pp. 739-41. [Article by Jacques Bousquet and Geneviève Brunel-Lobrichon: introduction, stressing the independence of Jaufre within the Arthurian tradition and its difference from Old French romances; ample bibliography to 1991.]

\section{5.}

Alibert, Laurent. "La terre gaste dans le Roman de Jaufre: Au-delà de l'influence de Chrétien de Troyes." RLaR 115 (2011): 163-82. This is a development of a paper from the 2009 colloquium Nouvelle recherche en domaine occitan: approaches interdisciplinaires, Turnhout: Brepols, in press. [The theme of the wasteland is present in several formulations in Jaufre, probably not borrowed directly from Chrétien de Troyes but representing an ancient pagan Indo-European theme; Jaufre makes reference to Chrétien's texts but remains more closely attached to the archaic aspects of Celtic myth, particularly through the Welsh story of Peredur.]

\section{6.}

Arthur, Ross G. "The Roman de Jaufre and the Illusions of Romance." In The Rusted Hauberk: Feudal Ideals of Order and Their Decline. Edited by Liam O. Purdon and Cincy L. Vitto. Gainesville: University Press of Florida, 1994, pp. 245-65. [The author of Jaufre seems to negate most of the traditions and principles of the Arthurian romance, demonstrating the contradictions between the fictional world and reality; this may reflect the particular historical situation in Aragon-Catalonia in the early thirteenth century, when the young king Jaume may have wanted the text 
to signal a departure from worn-out traditions and a fresh new start in sociopolitical ideals.]

1267.

Bartoli, Renata Anna. "Analisi rimica del Jaufre in rapporto al Conto du Graal di Chrétien de Troyes." In $>$ 95, AIEO 2, 1993, 1:3-29. [The Graal text is superior in thematic structure, psychology, and overall versification; but the anonymous author of Jaufre is independent and at times more elegant in choice of rhymes, and he manages to avoid some of the structural weaknesses of Chrétien.]

1268.

See 312, GRLMA vol. 4, book 1, 1978, pp. 627-34. [Traditional analysis by Emmanuèle Baumgartner of Jaufre as an Arthurian romance.]

1269.

Berthelot, Anne. "L'enchantement du récit: magie et illusion à la cour d'Arthur dans le Roman de Jaufré." In Materiali arturiani nelle letterature di Provenza, Spagna, Italia. Edited by Margherita Lecco. Alessandria: Edizioni dell'Orso, 2006, pp. 1-15. [Analysis of the "original" aspects of Jaufre: a romance in an area known mostly for lyric, Arthurian in a tradition that has no base in Breton traditions, but mostly because it is a parody of otherworldly and chivalrous romance literature.]

1270.

Calin, William. “Toward a New Reading of Jaufre: A Dialogue with Marc-René Jung." In 159, Studia occitanica, 1986, 2:13-21. [A Freudian interpretation of the romance as a sexual initiation ordeal in which Jaufre is called upon to make up for the failings of King Arthur and redeem the court and the Arthurian world; various enemies threaten his virility with phallic-type weapons, and he answers in kind with brutal violence, winning a bride and restoring fertility to a Waste Land; this is a systematic reworking of Chrétien's balanced ideal of private fin'amor and public chivalry, into a new ideal separating the two, and ridiculing the earlier Arthurian ethos; the "dialogue" is taken up by $\mathbf{1 2 7 8}$, Gouiran "Le roi et le chevalier-enchanteur," 2006, but not by Jung: see 1282, Jung, "Lecture de Jaufré," 1976, and "Jaufre: E aiso son novas rials," 1991.]

1271.

Eckhardt, Caroline D. "An Aragonese King, a Norman Count, an Arabic Enemy: The Curious Historical Context of Jaufre." In Courtly Romance. Ann Arbor: Michigan Consortium for Medieval and Early Modern Studies, 1984, pp. 89-107. [Explores the historical identity of three figures from Jaufre: the king of Aragon who has a model court, a Count Robert in Normandy, and the hero's biggest enemy Taulat; none can be identified with certainty, but Eckhardt ventures the possibility that Taulat may be an Arab; the references may have been intentionally obscure in order to suggest contacts with the real world without being specific.]

1272.

Eckhardt, Caroline D. "Reading Jaufré: Comedy and Interpretation in a Medieval Cliff-Hanger." Comparatist 33 (2009): 40-62. [Analysis of the story's actions using the lyric concepts of leu and clus: the apparently straightforward surface of 
the narration masks repeated mysteries; the narrator keeps the listeners puzzled and disoriented, but for what purpose? Whether parody of the Arthurian tradition is intended, or simply fun, or some more hidden message, is not clear; Eckhardt suggests that the author may intend to show that skillful agility is required in order to make appropriate choices in life; between clarity and obscurity lies a narrative space that is distinctively pleasurable.]

\section{3.}

Espadaler, Anton M. "Sobre la densitat cultural del Jaufre." In Literatura i cultura a la Corona d'Aragó, s. XIII-XV. Edited by L. Badia, M. Cabré, and S. Martí. Barcelona: Abadia de Montserrat, 2002, pp. 335-53. [A later dating of Jaufre, based on reference to works by Cerveri from 1272-76 and other borrowings from various genres from several periods (cures for leprosy using children's blood, the Arthurian romance Yder, the magic bird at the end), all point to composition in the 1270s.]

1274.

Espadaler, Anton M. "La cort del plus onrat rei: Jacques Ier d'Aragon et le roman de Jaufre." RlaR 115 (2011): 183-98. [Confirmation of James I of Aragon as the royal dedicatee of Jaufre; borrowings from Chrétien de Troyes, Raimon Vidal de Besalù, and Cerveri de Girona date Jaufre after 1272, at least for the portions of the romance concerned.]

\section{5.}

Fleischman, Suzanne. "Jaufre, or Chivalry Askew: Social Overtones of Parody in Arthurian Romance.” Viator 12 (1981): 101-29. [A close analysis of Jaufre indicates that humor functions structurally as part of an overall parodic design, similar to parody in Blandin discussed by Busby in Tenso 8, no. 1 (1992): 1-25.]

\section{6.}

Fraser, Veronica. "Humour and Satire in the Romance of Jaufre." Forum for Modern Language Studies 31 (1995): 223-33. [Interprets the adventures of Jaufre as burlesque, presenting the hero and King Arthur in an absurd and foolish light; the usefulness of the aristocratic class is called into question, contrasted with the emerging merchant class in the towns; the very absurdity of the hero's adventures satirizes the outmoded chivalric way of life, calling for peace and harmony that are conducive to economic activity.]

1277.

Gîrbea, Catalina. "De Girflet a Jaufré: destin et devenir d'un personage arthurien." RLaR 112 (2008): 7-32. Revised version of a paper given in Bucharest 2005 (available online at http://www.limbistraine.com). [Girflet/Jaufre is a close and faithful subject of King Arthur in several French Arthurian romances, but he remains unknown and mysterious, except when he is featured in Jaufre; Gîrbea suggests a date of about 1230 for the romance, but also the existence of earlier lost traditions featuring the hero, which may have been used as sources by others and by the author of Jaufre; Jaufre is able to renew the stature of the Arthurian court by combining feudal and magical powers to achieve a level of royalty superior to that of Arthur, while remaining loyal to him.] 
1278.

Gouiran, Gérard. "Le roi et le chevalier-enchanteur: les mésaventures du roi Arthur dans le Roman de Jaufré." In Materiali arturiani nelle letterature di Provenza, Spagna, Italia. Edited by Margherita Lecco. Alessandria: Edizioni dell'Orso, 2006, pp. 17-40. [The two episodes of strange adventure perpetrated on King Arthur at the beginning and end of the romance may signal an attempt to change and improve the world of chivalry in the first instance (change of clothes), or to renew and replace it in the second (new clothes); but even the new world must live with compromise, and the state of the new Arthurian court remains open-ended.]

1279.

Huchet, Jean-Charles. "Jaufre et le Graal.” VR 53 (1994): 156-74. [Suggests that Brunissen has the luminous features of the Holy Grail, and perhaps that her mother represents the Lance, in a semiserious, semiparodic answer to Chrétien's Perceval; Brunissen's marriage to Jaufre allows him to rise to a higher stage, superior even to that of Arthur.]

1280.

Hunt, Tony. "Texte and prétexte: Jaufre and Yvain." In The Legacy of Chrétien de Troyes. Edited by Norris J. Lacy et al. Amsterdam: Rodopi, 1988, pp. 125-41. [A study of points of contact between the two works which point to competitive rivalry between their authors; both are burlesques of the Arthurian tradition, but Jaufre seems to go further in exaggerating the deficiencies of Arthur's court; similarities in the succession of adventures are noted, with Jaufre clearly giving a new twist to elements borrowed from Chrétien de Troyes.]

\section{1.}

Jewers, Caroline. "The Name of the Ruse and the Round Table: Occitan Romance and the Case for Cultural Resistance." Neo 81 (1997): 187-200. [An interpretation of Jaufre as a parody of northern French romance traditions, developed as a negative reaction to the northern traditions, particularly during and after the Albigensian Crusade, but also as a straightforward reflection of the different social and cultural fabric of the South.]

\section{2.}

Jung, Marc-René. "Jaufre: E aiso son novas rials." In 151, Mélanges Bec, 1991, pp. 223-34. [A complement to his earlier article: "Lecture de Jaufré." In $>\mathbf{1 4 8}$, Mélanges Gossen, 1976, pp. 427-51. [A reevaluation of the romance by exploring the remarkably detailed structure and complex interweaving of themes; the author of Jaufre is criticizing, by irony and parody, the traditional ideology of the French Arthurian romance (Chrétien de Troyes), by injecting reality into the figures of Arthur and Jaufre; the ideals of chivalry need to be renewed, specifically by the king of Aragon, the dedicatee, whose court represents hope for the future, with some slight improvements; see the supporting article by Calin 1270.]

1283.

Kaltenbach, Nikki L. Le Roman de Jaufre: A Jungian Analysis. New York: Peter Lang, 1998. [Detailed analysis of the multilayered text, investigating the personal process 
of individuation of the hero, the universal level of rejuvenation of a stagnant society, and the historical level of the real concerns of Occitania and Aragon in the post-Albigensian era around 1230; Jaufre grows psychologically from his identification with the mother figure to a complete identification with the masculine, then to balance with the feminine; Arthurian society is offered renewal through adventure (reinforced by the trickster-magician who shows how to break, temporarily, out of confining social structures); for the real post-Albigensian era, the message is that new values and ideals are best found through compromise and integration rather than violent confrontation.]

\section{4.}

Kay, Sarah. "The Contrasting Use of Time in the Romances of Jaufre and Flamenca." MR 6 (1979): 37-62. [Narrative time (within the text) is examined relative to audience or reading time; the chronology of narrative time in Flamenca is based on the church calendar, giving a sense of aesthetic unity, always conscious of structure; in Jaufre the chronology is subjective and vague, even contradictory, creating an atmosphere of suspense and urgency; its pacing alternates periods of rapid adventure with slower, lyric passages; the pace of Flamenca is slower and controlled, creating an atmosphere of predictability.]

\section{5.}

Kelly, Douglas. "Exaggeration, Abrupt Conversion, and the Uses of Description in Jaufre and Flamenca." In 159, Studia occitanica, 1986, 2:107-19. [The descriptive techniques of exaggeration, contradiction, and abrupt changes in character are used consciously by medieval authors of romance, as recommended in works of poetics and rhetoric; augmentation of the principal character trait brings out the archetypal good or evil of a person; individuals become types, hyperbole emphasizes either good or bad qualities; cruel and evil knights are transformed by defeat and forgiveness into worthy members of court, and the hero overcomes impossible odds to lead his society to redemption and renewal.]

\section{6.}

Lecco, Margherita. Saggi sul romanzo del XIII secolo: Jaufré, Merveilles de Rigomer, Joufroi de Poitiers, Wistasse le Moine. Alessandria: Ediziono dell'Orso, 2003. [Three articles exploring different facets of Jaufre: pp. 3-30: "Artu e l'incantatore. Corrispondenze strutturali e semantiche nel Jaufre" (In the opening magical adventure, King Arthur is an idealized projection of the king of Aragon, who is also called upon to lead his people to higher status by his personal sacrifice; the ending adventure, culminating in Jaufre's gift of the all-powerful bird, is like a renewed investiture of King Arthur); pp. 31-40: "I giganti e la piucela. Un caso di intertestualità nel Jaufre" (many intertextual references to romances by Chrétien de Troyes and Renaut de Beaujeu, but more characteristic are the lyric forms, salutz d'amor and planhs, that are integrated into the story); pp. 41-45: "Nota sull'iconografia del ms. B. N. fr. $2164(A)$ " (many of the 269 extant miniatures in $A$ seem to depict the royal palace in Saragossa, and all are closely linked to the text of Jaufre); for a more detailed description of these, and links to the Roman d'Alixandre and to works of Chrétien de Troyes and Renaut de 
Beaujeu, see Lecco, in Materiali arturiani nelle letterature di Provenza, Spagna, Italia. Alessandria: Edizioni dell'Orso, 2006, pp. 73-95.]

1287.

Lee, Charmaine. "La tradizione testuale di Jaufre." MR 28 (2004): 321-65. [Complete codicological study of the two manuscripts and six fragments that have transmitted the romance: editions, stemma, variants, intertextuality, and miniatures; both manuscripts have imperfections because of their supposed oral transmission as performances; the determination of an "original" text seems impossible, just as a hybrid text is undesirable; $B$ should be used, with notes giving alternate readings from the other manuscripts.]

\section{8.}

Lee, Charmaine. "Guilhem de Montanhagol and the Romance of Jaufre." In 140 , Etudes Ricketts, 2005, pp. 405-17. [The identity of the king of Aragon dedicatee of the romance is crucial for dating the work; only James I now seems possible, due to influences noted from Chrétien and later romances; connections with troubadours may also help dating: Montanhagol's PC 225,10, Nulhs hom no val, stresses the need to uphold courtly values, and to seek God's help; themes of mezura, castitatz, and of the "golden age" are similarly important in both; since Montanhagol praises James I, the similarities of social tone suggest that Jaufre's author did the same; dating proposed is to that of Montanhagol's early poems (1233 or later).]

\section{9.}

Lee, Charmaine. "Le manuscrit comme forme de communication: Jaufre et les genres narratifs occitans en Italie." In 109, Comunicazione e propaganda, 2007, pp. 43142. [Demonstrates how the varying subdivisions of the text by different scribes can change its interpretation as it is adapted for a different patron or public; the Occitan scribe of $A$ was interested primarily in the series of adventures undertaken by Jaufre, while the Italian scribe of $B$ tried to focus interest on the speeches of Melian and Taulat in Arthur's court, and on the didactic dialogues of Brunissen and Jaufre when they are discussing love and the rules of courtliness.]

\section{0.}

Lee, Charmaine. "La tradition 'indirecte' dans l'édition d'un roman: l'exemple de Jaufre." In Actes du XXIVe Congrès International de Linguistique et de Philologie Romanes (Aberystwyth, 1er-6 aout 2004). Vol. 2. Tübingen: Niemeyer, 2007, pp. 199-210. [Analysis of the editorial use of "parallel" texts; study of the passages "borrowed" from Chrétien de Troyes and of the messages contained in the 269 extant miniatures in MS $A$ can help to reestablish an older version of the text closer to the lost original; in at least five passages, the miniature of $A$ confirms the lesson of $B$ against the incorrect lesson of $A$.]

1291.

See 1129, Limentani, L'eccezione, 1977, pp. 78-101. [Shows that Jaufre must have used Chrétien de Troyes as a source, rather than the other way around, and that the date of composition must be in the early thirteenth century, not in the twelfth; humorous scenes such as the sleepy Jaufre in Brunissen's garden are light parodies of similar scenes from Chrétien's Perceval.] 
1292.

Pinkernell, Gert. "Realismus und Märchenhaftigkeit in der Zeitstruktur des altprovenzalischen Jaufré-Romans: ein Beitrag zur Stutzung der Zwei-Verfasser-Theorie." In Interpretationen: Gesammelte Studien zum romanischen Mittelalter und zur französischen Literature des 18. Und 20. Jahrhunderts. Heidelberg: Winter, 1997, pp. 25-41. [Concludes that there were two authors: one up to line 6234, the other from 6235 on; in a companion article $\operatorname{ZrP} 88$ (1972): 105-10, Pinkernell concludes that Jaufre was begun in 1177 or one or two years later.]

1293.

Riquer, Isabel de. "Géneros trovadorescos en el Jaufre." In 123, La narrativa, 1995, pp. 11-26. [Jaufre makes intertextual reference to planhs, salutz, Chretien de Troyes, and King Arthur, in sublime to ridiculous modes; subtle humor is poked at the use of otherworldly, magic elements; analysis of the adaptation of Arthurian material and troubadour lyric to contemporary meridional tastes, against northern French traditions; see Riquer's more detailed article on the five planhs in 139, Ensi firent, 1996, $1: 151-62$.

1294.

Saly, Antoinette. "Jaufre, lo fil Dozon, et Girflet, fils de Do" in 159, Studia occitanica, 1986, 2:179-88. [Traces the genealogy of Jaufre back through Girflet to the Mabinogian hero Gilvaethwy, which would account for his attachment to the supernatural and would point to the existence of earlier lost stories in which the high status of Jaufre would have been established.]

\section{5.}

Szabics, Imre. "Interférences de motifs dans le Roman de Jaufre et les romans arthuriens de Chrétien de Troyes." In "Prismes irisé": textes recueillis sur les littératures classiques et modernes pour Olga Penke qui fête ses soixante années. Szeged: Klebelsberg Kuno Egyetemi Kiadó, 2006, pp. 73-83. [Compares several shared motifs that have not been analyzed previously: metamorphosis and the supernatural; the passivity of King Arthur; troubled sleep of the hero; the meeting of the knight and the fairy of the fountain.]

1296.

Szabics, Imre. "Interférences de motifs dans le Roman de Jaufré et les romans arthuriens de Chrétien de Troyes." RlaR 114 (2010): 489-503. [Analysis of intertextuality and the complex interplay of motifs in Jaufre and several romances of Chrétien; it is not always clear which author may have borrowed from the other, or whether both may be using the traditional folkloric stock of Breton material.]

1297.

Spence, Sarah. "Authority and Will in the Jaufre, Guillaume IX and Raimbaut d'Aurenga." Medieval Perspectives 2 (1987): 105-12. [In the absence of King Arthur's authority, Jaufre, or the author, takes over, suggesting that the artist is more powerful than the king because he is not trapped in the rituals of his time; Spence analyzes Guilhem de Peitieus's Dreyt nien poem and Raimbaut d'Aurenga's Escoutatz, mas no say, both concerned with the problems of knowing, creating, and singing; Guilhem 
states that he has absolute authority in the poetic sphere, as God does in His; Raimbaut realizes that he can control only the immediate reality of his poem but not the outcome of his love, which is controlled by the outside force of the domna; the struggle for control is a primordial concern of trobar.]

\subsection{Judici d'amor (So fo el temps c'om era jais, or En aquel temps, com era gais)}

[Novas of 1,698 lines, transposition into narrative form of a tenso theme, debating a problem of amorous casuistry; composed by Raimon Vidal de

Besalù in the early thirteenth century; Raimon Vidal may be the author of only the second part, Raimon de Miraval (?) of the first.]

1298.

See 2934, Field, Ramon Vidal, 1991, 2:6-173. [Detailed introduction, critical edition with Catalan translation, limited glossary.]

1299.

See 1134, Huchet, Nouvelles occitanes, 1992. [Text of Judici d'amor reproduced from an existing edition, with French translation, notes.]

1300 .

Majorossy, Imre Gábor. "Amours et refus: émotions et opinions dans En aquel temps." Medioevo e Rinascimento 20 (2006): 48-64. Reprinted in 1137, Unas novas, 2007, pp. 57-71. [A lively discussion of love by two ladies; the themes suggest a generic mixture of tenso and novas, with many quotes from troubadours; the direct realistic statement of erotic desire contrasts with a didactic, moralizing aspect introduced by the idealistic lyrics and the use of a semibiblical quote to characterize love; amor is dominant, though it must be kept in balance with saber.]

1301.

See 1131, Thiolier-Méjean and Notz-Grob, Nouvelles courtoises, 1997, pp. 260353. [Analysis of generic distinctions and the history of the novas, with a consideration of the implications of non-lyric style and the position of the author and the narrator; text of Judici, with facing-page French translation.]

\section{2.}

Brea, Mercedes. "E a vos aug son escondig/comtar (Judici d'amor, vv. 1387-8)." In - 99, AIEO 6, 2001, pp. 334-42. [Analysis of the multiple perspectives contained in the Judici; problematic in genre: the text is moralistic, not a true narrative; there is a narrative frame, but the text is an attempt to restore the past glory of troubadour culture by a return to strict observance of the code of fin'amors: the lady has transgressed, but the lover cannot leave her for another; the legalistic terminology may indicate an intertextual reference to Bertran de Born's Eu m'escondisc, dompna (PC $80,15)$, in which Bertran uses similar legal procedures to return to the good graces of his domna.]

1303.

Caluwé, Jean-Michel. "So fo e.l temps de Raimon Vidal de Besalù: d'une fiction de la tenso à une représentation de la canso." In $\mathbf{1 0 5}$, L'Imaginaire courtois, 1991, pp. 
83-96. [Explores the unusual structure of the work in order to understand why it was, and is, less popular than other Occitan texts; very little "action," narrative line is interrupted by lyric interludes; strong moralizing intent, similar to the ensenhamens, and with thematic similarities to the tenso or joc partit.]

1304.

Keller, Hans-Erich. "La Cort d'Amors de Raimon Vidal et ses citations." In 146, Literatur Mölk, 1997, pp. 185-92. [Thirty-six intercalated lyrics in So fo el tems (Judici d'amor) seem to have been chosen in order to evoke nostalgically the ideal period of troubadour poetry, at a time, early thirteenth century, when the tradition was already in decline; and yet the techniques employed by Raimon Vidal are original and point to new avenues of development for the poetry.]

\section{5.}

Poe, Elizabeth W. "No volc aver nom Raymbaut!: Names and Naming in So fo el tems." Tenso 22 (2007): 29-40. [Ingenious analysis of So fo, suggesting prudently but convincingly that it was originally composed as a debate between Raimon de Miraval and Raimon Vidal, similar to the exchange of sirventes between Peire Rogier, PC 356,7, and Raimbaut d'Aurenga, PC 389,34; it takes the form of a series of debates about the proper actions of a lover in a love triangle, with one answer in the first half, by Raimon de Miraval: "Stay with lady number two!" and another in the second half by Raimon Vidal, through his patron Uc de Mataplana: "Go back to lady number one!" the text having then been reworked by a scribe to seem like a single work.]

1306.

Wilhite, Valerie M. "Instructing the Court: Raimon Vidal's Pedagogy for the Courtly joglar." In Courtly Arts and the Art of Courtliness: Selected Papers from the Eleventh Triennial Congress of the ICLS, University of Wisconsin-Madison, 29 July-4 August 2004. Edited by Keith Busby and Christopher Kleinhenz. Woodbridge: D. S. Brewer, 2006, pp. 755-70. [Raimon's philosophy for teaching and learning is at the center of both Abril issia and So fo, based on protagonists who want to know and who want to teach; ethical education is at the heart of the donzela's advice to the cavayer: he will learn by reflecting on the memorized lines from troubadour poems; cortezia is a set structure (like grammar): once one learns the rules, one will succeed.]

\subsection{Merlin}

[Fragment of a thirteenth-century Occitan translation of the French prose Roman de Merlin by Robert de Boron; the two extant leaves represent parts of paragraphs $54-58$ and $80-83$ of the 1980 Micha edition, from

1307. the middle and the end of the French text.]

Cornagliotti, Anna. "Les fragments occitans du Merlin de Robert de Boron." In - 131, Etudes Ricketts, 2005, pp. 5-16. [New critical edition, identification within the French Merlin tradition; many lacunae and mistakes; linguistic analysis left for a further study; localization established as vaguely Gascon.] 


\subsection{Las Novas del papagai}

[Narrative of 309 lines, satire against jealous husbands composed by Arnaut de Carcassès at the beginning or first half of the thirteenth century.]

1308.

Fuksas, Anatole Pierre, has announced a new edition of Novas del papagai: in CDT 3 (2000): 1159.

\section{9.}

Bec, Pierre. Las Nòvas del papagai d'Arnaut de Carcassés. Mussidan: Fédérop, 1988. [Text of $R$, based on Lavaud/Nelli, 1966, which was in turn based on Savj-Lopez, 1901; French translation following the Occitan text; see the review article by $\mathrm{R}$. Lafont, "Des nouvelles du perroquet," RLaR 92 (1988): 383-97, reprinted in La Source sur le chemin, Paris: Harmattan, 2002, pp. 43-58, calling for a new study of the text, taking into account all the different manuscript versions.]

1310.

See 1136, Luce-Dudemaine, "Flamenca" et les "novas,"2007. [The Papagai is closer to the lyric tradition than the other novas studied; the gilos plays no specific role, the lady is not suffering in her marriage; the situation is a latent, ritualized one, as in most cansos.]

\section{1.}

See 1131, Thiolier-Méjean and Notz-Grob. Nouvelles courtoises, 1997, pp. 186205. [Analysis of generic distinctions and the history of the novas, with a consideration of the implications of non-lyric style and the position of the author and the narrator; text of Las novas del papagai, with facing-page French translation.]

\section{2.}

Barca, Daniele. Novella provenzale del pappagallo. Rome: Salerno, 1992. [Detailed introductory analysis; critical edition of both versions from manuscripts $R$ and $J$, with facing-page Italian translation.]

\section{3.}

See 1123, Caluwé, Du Chant à l'enchantement, 1993, pp. 173-81. [Papagai is basically narrative, but tends toward the lyric with its fairy-tale atmosphere and the ideal enclosed garden-space setting typical of fin'amor; comparison with Peire d'Alvernhe's Rossinhol, el seu repaire, a lyric that tends toward the narrative; the metaphorical bird becomes the main protagonist, song turns to speech, but with a layer of ambiguity in both cases.]

\section{4.}

Fuksas, Anatole Pierre. "La materia del racconto e le opzioni narrative: ricerche sulla tradizione delle Novas del papagai." In 1155, Il racconto, 2001, pp. 239-64. [Analysis of the manuscript tradition indicates that a critical text in Lachmannian terms is not possible: there are individual voices that must all be heard and evaluated for themselves; samples from five manuscripts are given in appendix, for comparative purposes.]

\section{5.}

Gouiran, Gérard. "Le Papagai de Flaubert: réflexions à propos de la dame de Las Novas del papagai." In 99, AIEO 6, 2001, pp. 391-404. [A rather sarcastic 
reappraisal of the novas, poking fun at scholars who have taken it seriously; despite the parrot's reputation as a very eloquent and persuasive speaker, Gouiran finds him full of clichés, and the lady full of irony; in fact, she is the one who leads the action in the story, for reasons of her own, perhaps in the vain hope of becoming one of the famous heroines of literature; is the novas a gigantic spoof?]

1316.

Kay, Sarah. "The Monolingualism of the Parrot and the Prosthesis of Origins in Las Novas del papagay," RR 101 (2011): 23-35. [Discussion of "parroting" (i.e., the use of the Occitan koiné by early Italian and Catalan writers, illuminated by an analysis of communication in Las novas del papagay; for Derrida, any language is an alien appendage, and seeking identity through it leads only to further alienation; a bird parroting amorous discourse is "hilarious" because it is the bird, not Antiphanor, who woos the lady, and in fact, both lover and lady seem to be parroting the bird; who is the ventriloquist and who is the dummy?]

1317.

Langlois, Gauthier. "Notes sur les origines du troubadour Arnaut de Carcassés." RLaR 113 (2008): 89-99. [A few historical fragments place Arnaut's family in the petty nobility, without fortune, in a fragile social position, perhaps motivating him to take up the alternative life of a troubadour and seeking a kind of comic revenge against his aristocratic superiors; it is curious and perhaps ironic that his supposed granddaughter Rixenda was accused of adultery and of having her husband killed in the name of love, a situation somewhat similar to that of Arnaut's hero Antiphanor in Papagai.]

\section{8.}

See 1129, Limentani, L'eccezione, 1977, pp. 61-77. [Analysis of the differences between the two manuscript versions of Papagai; $A$ is closer to the lyric tradition, $B$ more evolved in the direction of narrative structure; both are valid witnesses to the formulation of the story.]

\section{9.}

Gérard-Zai, Marie-Claire. "La forme dialogique dans Las novas del papagay occitanes." In 113, Il genere tenzone, 1999, pp. 329-39. [Reproduction of lines 7-126 (six coblas) from Bec 1988; these may be seen as a dialogue between the parrot and the lady, almost like a tenso inserted into the narrative text; analysis of the mixture of the two codes, their oppositions and the compromises that allow both to function; similar mixing of genres may be seen in Marcabru's L'autrier jost'una sebissa and Cadenet's L'autrier, lonc un bosc fullos, which could be called tensos as well as pastorelas.]

\section{0.}

Majorossy, Imre Gabor. "Papagay, trop es bels parliers." In Ecritures: Scritture, actes du colloque international de Veszprém. Edited by Gabrielle Tegyey, András DésfakviToth and Livia A. Mihályka. Veszprém: Pannon Egyetemi Kiadó, 2006, pp. 168-78. Reprinted in 1137, Unas novas, 2007, pp. 73-92. [Noting the direct hedonistic tone of the story, the presence of magic and supernatural, and several contradictions and improbabilities, Majorossy hypothesizes a tormented textual history in which 
the original figure of a chevalier/valet, courting in the name of his master, was transformed symbolically into a parrot, or in which the detachable soul of the lover was able to communicate magically with the lady until she accepted him in person; many mysteries remain in this enigmatic text, to be resolved by closer study of the literary culture in which it was created.]

1321.

Thiolier-Méjean, Suzanne. "Le motif du perroquet dans deux nouvelles d'oc." In Miscellanea Mediaevalia I-II. Mélanges Ph. Ménard. Edited by J. Claude Faucon et al. Paris: Champion, 1998, pp. 1355-75. [Survey of use of the parrot (or jay) in medieval literature; in Frayre, the magical qualities of the bird are tempered by constant biblical references; in Papagai, the hybridism is found in a combination of folklore and classical wisdom.]

So fo el Temps (See 19.14. Judici d'amor)

\title{
20. Dramatic Literature
}

\author{
20.1. General Studies \\ [For the Sponsus, see under Monuments 17.12.]
}

\section{2.}

Henrard, Nadine. Le Théâtre religieux médiéval en langue d'oc. Liège: Faculté de Philosophie et Lettres-Diffusion Droz, 1998. [Detailed outline of the complete repertory of twenty-nine texts based on analysis of manuscripts, sources, and contents, followed by a consideration of stage directions and the analysis of versification and metric structures for each text; Henrard calls for more individual studies, particularly of a sociohistoric nature, and a more complete look at profane drama; see discussion and suggestions by Paola Alegretti, VR 59 (2000): 353-61.]

\section{3.}

Henrard, Nadine. "Observations sur la tradition manuscrite du théâtre religieux médiéval en langue d'oc.” In 100, AIEO 7, 2003, pp. 419-31. [An exploration of the sociohistoric background to medieval Occitan religious theater through a study of the manuscript traditions; activity is found to be constant and widespread, though the preserved manuscripts are rare and in poor condition; they served essential practical purposes in the production of performances, but were not written with care on parchment and were not often preserved after the performances.]

1324.

Henrard, Nadine. "Le théâtre religieux médiéval en Aquitaine." In L'Aquitaine des littératures médiévales (XIe-XIIIe siècle). Edited by Jean-Yves Casanova and Valérie Fasseur. Paris: Presses de l'Université Paris-Sorbonne, 2011. [A general overview of resources and research in the area reveals a scarcity in both areas, making it difficult to judge the extent of development specific to Aquitaine; discussion of the Sponsus, pp. 138-39, and the Didot Passion, pp. 143-45, both of which are attached to Aquitaine 
but of uncertain provenance; sketch of religious dramatic activity up to the fifteenth century, calling for further research.]

1325.

Lazar, Moshé. "The Saint and the Devil: Christological and Diabological Typology in Fifteenth-Century Provençal Drama." In Essays in Early French Literature Presented to Barbara M. Craig. Edited by Norris J. Lacy and Jerry C. Nash. York, SC: French Literary Publications, 1982, pp. 81-92. [Three pieces are studied: Istoria Petri et Pauli, Mystère de Saint Eustache, and Mystère de Sant Anthoni de Viennès; the major theme is the struggle between good and evil, in the form of saints struggling against diabolized humans or allegorized sins; basic structures are common to all three plays, and all finish with beatings and tortures, either of captured and diabolized creatures or of devils, even Satan, by other devils.]

\section{6.}

Lewicka, Halina, "Le mélange des langues dans l'ancien théâtre du Midi de la France." In Mélanges de philologie romane dédiés à la mémoire de Jean Boutière. 2 vols. Liège: Soledi, 1971, 1:347-59. [Overview of Occitan dramatic literature from the fourteenth to the sixteenth century; studies the use of patois for comic effect and as an expression of the vitality of local language faced with the expansion of French.]

1327.

Vitale-Brovarone, Alessandro. Il quaderno di segreti d'un regista provenzale del medioevo: note per la mesa in scena d'una Passione. Alessandria: Edizione dell'Orso, 1984. [Edition of a newly discovered cahier from the end of the fifteenth or beginning of the sixteenth century, giving detailed instructions for the production of a Passion play; introductory historical study of the manuscript, the text, staging, and language; critical edition with Italian translation, notes, and complete glossary; this is a rare, fire-damaged document, meticulously restored by the editor, which enriches our knowledge of dramatic production, hitherto known only through scattered notations within the texts themselves; thirteen stage settings are described, along with effects such as bleeding; the unpolished script suggests that the writer was working on a tablet on his legs, or directly on his legs.]

\subsection{Jeu de Sainte Agnes}

[Anonymous play in 1,182 lines, missing three or four folios at the beginning; mid-fourteenth century (ca. 1340-50); contains eighteen lyric interludes with melodic notation, one using the melody of PC 183,10 by Guilhem de Peitieus (otherwise unknown) and another using that of Reis glorios by Giraut de Bornelh; nine other melodies have been linked with the anonymous poems PC 461b,1-9.]

1328.

Jeanroy, Alfred. Le "Jeu de Sainte Agnès," drame provençal du XIVe siècle, avec la transcription des mélodies par Théodore Gérold. Classiques français du moyen âge 68. Paris: Champion, 1931. [Contains a brief philological introduction, critical text, no translation; notes, analysis, transcription, glossary; study of melodies by Gérold, pp. 
58-77; see the detailed appraisal and suggestions for a new edition by Aurelio Roncaglia in Scritti in onore di Luigi Ronga, Milan: Ricciardi, 1973, pp. 573-91.]

1329.

See 614, Gennrich, Der musikalische Nachlass, 1958-65, 3:238-46. [The melodies of the Jeu de Sainte Agnès, regularized and transcribed in modal rhythm.]

1330.

Bonafin, Massimo. "Alcune considerazioni sul Miracolo di Sant'Agnese in occitano." In La scena assente: realtà e leggenda sul teatro nel medioevo (Siena, 2004). Edited by Francesco Mosetti Casaretto. Alessandria: Edizioni dell'Orso, 2006, pp. 269-79. [Stresses the dramaturgical richness and complexity of the work: multiple stage settings, thirtysix distinct roles, 154 stage directions, dynamic personal development, even among the negative characters, complex interplay of metrics in verse structure, frequent musical interludes; the scope of the drama would require performance outside the church while providing an inspiring model of progress toward sainthood; Bonafin announces a new edition in preparation, in collaboration with the musicologist Guido Milanese.]

1331.

See 1322, Henrard, Le Théatre religieux, 1998, pp. 62-82 and 474-510. [Stresses the richness and unique qualities of the play; analysis of the manuscript, its provenance, sources, and originality; pp. 474-510: study of metric structure, rhymes, lyric, and musical interludes.]

\section{2.}

Hoepffner, E. "Les intermèdes musicaux dans le jeu provençal de Sainte Agnès." In Mélanges d'histoire du théâtre du Moyen-Age et de la Renaissance offerts à Gustave Cohen. Paris: Nizet, 1950, pp. 97-104. [Literary description and metrical analysis of each of the interludes; all are called planctus, though many are prayers; most are simple in style, destined for a popular audience.]

\section{3.}

Jeanroy, Alfred. "Le théâtre méridional des origines à la fin du XIVe siècle." Histoire littéraire de la France 38 (1949): 431-61. [Detailed analysis of the Jeu, pp. 442-52: manuscript, author, date, localization, sources, versification, staging: the musical interludes were to be played by angels.]

1334.

Piemme, Jean-Marie. "L'espace scénique dans le jeu provençal de Sainte Agnès." In - 1110, Mélanges offerts à Rita Lejeune. 1:235-45. [Study of the 153 Latin stage directions suggests interesting hypotheses: they reveal eight different stage settings, probably in several compartments on different levels, along with a crucial central space that is neutral and adaptable; this staging, so different from classical French practice, allows for simultaneous actions instead of chronological, through which the author can accentuate the spectacular side of the legend; studying the works within their own social and cultural setting will allow fuller understanding of their intention and account more clearly for their success.]

1335.

Schulze-Busacker, Elisabeth. "Le théâtre occitan au XIVe siècle: le Jeu de Sainte 
Agnès." In The Theatre in the Middle Ages. Edited by Herman Braet, Johan Nowé, and Gilbert Tournoy. Louvain: Leuven University Press, 1985, pp. 130-93. [Sainte Agnès is more innovative than the Esposalizi and the Passion Didot in themes, verse structures, complexity of stage directions, and the insertion of lyric interludes with music; information is provided on the cult of Saint Agnes, with a tableau to show the dramatization of the Latin source material, and another to show innovations by the author; analysis of the polymetric structures, the staging, and the dramatic placing of the four types of interlude.]

\subsection{Esposalizi de Nostra Dona (Sancta Maria Verges e de Jozep)}

[Mystery play of 792 lines from the end of the thirteenth or beginning of the fourteenth century, dramatizing the marriage of Joseph and the Virgin, the visitation of

Elizabeth by the Virgin, the Nativity, and the Adoration by the shepherds.] 1336.

Kravtchenko-Dobelmann, Suzanne. "L'Esposalizi de Nostra Dona, drame provençal du XIIIe siècle.” Rom 68 (1944-5): 273-315. [A philological introduction: manuscripts, sources, analysis of text, language and versification; the text has no stage directions, very little historical truth or dramatic art; critical edition, no translation; the article is reproduced, with facing-page French translation by Gilles Lefebvre, in Cahiers de Joséphologie 5 (1957): 203-39 and 6 (1958): 77-107.]

1337.

See 1322, Henrard, Le Théâtre religieux, 1998, pp. 34-41 and pp. 463-64. [Analysis of manuscripts, sources, and versification, particularly the change in meter from line 776 to the end.]

1338.

Jeanroy, Alfred. "Le théâtre méridional des origines à la fin du XIVe siècle." Histoire littéraire de la France 38 (1949): 431-61. [Detailed analysis of Esposalizi de Nostra Dona, pp. 432-42: sources, versification, date, and localization.]

\subsection{Mystery Plays}

[For earlier texts, see under Monuments 17.5, Passion of Augsbourg, and 17.6, Passion of Clermont-Ferrand.]

\section{9.}

See 38, DLF, 1993, pp. 1051-54. [The article "Mystères en Occitanie," by Joseph Salvat: historical sketch providing information on the tenth-century Passion de Clermont, fragments of a mystery play from the thirteenth century found in a church wall, the Esposalizi from the end of the thirteenth century, the Passion Didot (or Passion provençale) from the mid-fourteenth century, the Jeu de Sainte Agnes from the second half of the fourteenth century, "Mystères alpins," fifteenth century, "Mystères rouergats," end of fifteenth century.]

1340 .

Cornagliotti, Anna. "Riflessioni sui Misteri occitani di area alpina." Parola del testo 7 
(2003): 321-39. [Survey of scholarship on eight "Mystères alpins," two of which are fragmentary, from the end of the fifteenth, beginning of the sixteenth century, from the region of Briançon (Gap); proves the need for new critical editions of the texts and for global studies of all eight in order to clarify their attribution; Cornagliotti is directing a collaborative research project at Turin to accomplish these goals.]

\section{1.}

See 1322, Henrard, Le Théâtre religieux, 1998. [Pp. 85-232 and 561-76: study of the "Mystères rouergats": detailed information on the manuscript and on sources and versification of the fifteen passion plays and their adaptation for the stage, including Lo jutgamen general and the related Mysteri des Rampans; pp. 233-95 and 511-60: similar presentation for the Mystères alpins.]

\section{2.}

Lazar, Moshé. Le Jugement dernier (Lo jutgamen general): drame provençal du XVe siècle. Paris: Klincksieck, 1971. [Includes an introduction, critical text with French translation, and glossary; see also 1322 , Henrard, Le Théâtre religieux, 1998, pp. 199-203.]

\section{3.}

Pfeffer, Wendy. "The Passion of Occitan." Glossator 4 (2011): 131-37. [A late fifteenth-century insertion into a Middle French mystery play, in which the low-class character Mallegeype speaks a regional form of Occitan, incarnating a criticism of the aristocracy in the name of the common people; the use of Occitan marks "foreignness" and is used for semicomic effect alongside French, the language of culture and refinement.]

\section{4.}

Runnalls, Graham. Les Fragments du Mystère auvergnat de Sainte Agathe, étude et texte. Montréal: CERES, 1994. [Edition of two fragments (123 lines and 104 lines) from a late fifteenth-century mystery play, with textual notes and glossary; no translation; the introduction gives a review of previous scholarship, study of dramaturgy, sources, language, and versification.]

\subsection{La Passion provençale (Didot Passion)}

[Anonymous mystery play from the mid-fourteenth century recounting the arrival of Jesus in Jerusalem, the Passion, the descent into hell, and the Resurrection; the preserved text is Occitan, but the original may have been Catalan.]

\section{5.}

MacDonald, Aileen Ann. Passion catalane-occitane. Textes littéraires français, 518. Geneva: Droz, 1999. [Critical edition with facing-page French translation; the text was composed in the Catalan area, probably Palma de Majorca, using the Occitan koiné; the detailed introduction, pp. 13-59, is available in English in a slightly earlier version in Rom 115 (1997): 495-518; MacDonald is undertaking further study on the staging of the play.]

\section{6.}

Massip, Fransesc. "La dramatisation de la Passion dans les pays de langue catalane 
et le dessein scénique de la cathédrale de Majorque.” Fifteenth Century Studies 20 (1993): 201-45. [Detailed background of Passion plays in Catalonia over the whole of the fourteenth century; believes that the Didot Passion was translated into Occitan from a Catalan original, of which two fragments remain.]

1347.

See 1322, Henrard, Le Théâtre religieux, 1998, pp. 42-61 and 465-73. [Description of manuscript and two fragments, provenance, sources, verse structure, and polymetrics.]

1348.

Jeanroy, Alfred. "Le théâtre méridional des origines à la fin du XIVe siècle." Histoire littéraire de la France 38 (1949): 431-61. [Detailed analysis of the Didot Passion, pp. 452-61: manuscripts, date, localization, sources, language, and versification.]

\section{Treatises of Grammar and Rhetoric}

\subsection{General Studies}

1349.

Brüning, Berit Irina. "Frühe romanische Grammatiken: Las Razos de trobar und Lo Donatz Proensals." Seminararbeit, 2008, FSU Jena, Institut für Romanistik, 21 pp. Table of contents and four pages available online, with provision to purchase the whole item: http://www.grin.com/profile/427873/berit-irina-bruening. [Information on authors, dating, contents, and textual analysis, with bibliography.]

1350.

Gaunt, Simon, and John Marshall. "Occitan Grammars and the Art of Troubadour Poetry." In The Cambridge History of Literary Criticism. Vol. 2: The Middle Ages. Edited by Alastair Minnis and Ian Johnson. Cambridge: Cambridge University Press, 2005, pp. 472-95. [Pp. 473-82 (Gaunt): discussion of the twelfth-century practices of intertextuality, parody, techniques of composition, melodic qualities, trobar clus, and trobar leu, from information within the poetry itself; pp. 482-95 (Marshall, edited by Gaunt): the importance of the thirteenth-century theoretical treatises from the Razos de trobar to the Doctrinal de trobar, which sought to teach novices and foreigners how to write poetry, stressing generic structures and rhymes; the history of the compilation of the chansonniers with their vidas and razos.]

1351.

Kelly, Douglas. The Arts of Poetry and Prose. Typologie des sources du Moyen Âge occidental 59. Turnhout: Brepols, 1991. [Documentary information on Occitan treatises: bibliography of all editions, pp. 15-16; work in progress and desiderata, pp. 120-23; list of treatises, extant or not, for Catalan and Occitan, pp. 176-77.]

1352.

Swiggers, Pierre. "Les plus anciennes grammaires occitanes: tradition, variation et insertion culturelle." In $\ \mathbf{9 6}$, AIEO 3, 1992, pp. 131-48. [The Razos de trobar were directed toward a Catalan erudite audience of poets and amateur litterati learning the 
art of poetry through the Occitan language; the Donatz proensals was for a scholarly Italian public, familiar with Latin and the classical artes, with no direct quotes from troubadour lyric; the Leys d'amors was intended for a wide circle of the Occitan public interested in learning the fine art of trobar, treating the Occitan language as the equal of Latin and accepting variations of form and usage.]

\section{3.}

Vidal i Alcover, Jaume. Mirall de trobar. Universitat de Palma: Abadia de Montserrat, 1984. [A treatise by Berenguer d'Anoià (de Noya?), preserved in a fourteenth-century manuscript along with many other treatises; introduction, text with facing-page Catalan translation; Berenguer ( $f$. c. 1300) was a Catalan troubadour from Majorca, of whom very little is known; the Mirall is in the tradition of the Razos de trobar of Raimon Vidal and the Regles de trobar of Jofre de Foixà, differing from these in giving more emphasis to poetics and rhetoric than to grammar, making it a sort of résumé of the Leys d'amors.]

\section{4.}

Wells, Courtney. "Ad dandam doctrinam vulgaris provincialis: Chansonnier P and the Medieval Latin Curriculum in Italy." Tenso 28 (2013). [One of the texts in MS P written for an Italian audience; instructions on reading Occitan and on composing poems in Occitan; pedagogical use: everything needed by students of Old Occitan poetry.]

\subsection{Donatz proensals}

[A treatise on metrics and grammar, composed in Italy about 1240 by Uc de Saint

Circ (also known as Uc Faidit), accompanied by a Latin translation; it is more methodical and complete than the Razos de trobar, but drier and more mechanical in style; instead of quoting from the troubadours, Uc made up his own examples;

\section{5.} contains a glossary of verbs and a dictionary of rhymes.]

Marshall, John H. The "Donatz Proensals" of Uc Faidit. London: Oxford University Press, 1969. [Detailed philological introduction; edition of Occitan and Latin texts side by side; notes, glossary; no translation.]

\section{6.}

Guida, Saverio. "L'epilogo del Donat Proensal." In 134, Cantarem, 1995, pp. 243-57. Reprinted in 2013, Guida, Primi approcci, 1996, pp. 145-70. [By convincing deduction, Guida reestablishes the original reading of the Latin epilogue in MS A (Cuius Ugo nominor) as Ugo Cir(i)cus nominor, assuring attribution of the Donat to Uc de Saint Circ; in any case, the pseudonym Uc Faidit, the hitherto supposed author, is likely a mere nickname for the itinerant Uc de Saint Circ, meaning "stranger, exile"; the epilogue also reveals details of the intention of the work and its sociohistorical background.]

1357.

Janzarik, Diether. "Uc de St. Circ_auteur du Donatz proensals?" ZrP 105 (1989): 264-75. [A reconsideration of all the evidence leads to the almost certain conclusion that Uc de Saint Circ and Uc Faidit were the same: time and place coincide, Uc de 
Saint Circ showed his interest and skill in philology through his collection of vidas and razos and his assembly of the chansonnier Libro d'Alberico for his patron Alberico da Romano; Faidit is probably a nickname meaning "stranger; exile," referring to his "exile" during the Albigensian Crusade; the Donatz was written to strengthen troubadour poetry at a time when it was in decline.]

1358.

Swiggers, Pierre. "La méthode grammaticale d'Uc Faidit dans le Donatz proensals." RLaR 95 (1991): 343-50. [Uc follows the traditional Latin method, divided into eight parts of speech; he does not treat articles or passé composé, and distorts some categories to fit Latin theory, but there is some flexibility to admit evolutionary changes in Occitan; it is a daring, pioneering work, flawed but admirable.]

\subsection{Leys d'Amors}

[Composed by Guilhem Molinier for the Consistori de la Subragaya Companhia del Gai Saber, Toulouse; exists in several versions: the first, in verse, from 1330-32, has disappeared; a prose résumé of it by Joan de Castelnou (PC 518) is known as the Compendi; three other versions are extant: A: prose, in five books, composed 1340 (two manuscripts); B: versified transposition of A, in six books; C: prose adaptation in three books, composed 1355; bibliography and clarifications in $\mathbf{1 4 7 3}$, Cigni, 2001, pp. 251-52, n. 3; a new edition of Flors del gay saber has been announced by Gonfroy, a publication of his thesis from 1981.] 1359.

Gonfroy, Gérard. La Rédaction catalane en prose des "Leys d'amor": édition et étude critique des trois premières parties. Thèse de 3e cycle, Poitiers, 2 vols. in typescript, 1981. [The $A$ version was first edited by Gatien-Arnoult in 1841-43 from the Toulouse manuscript; this edition is based on the second ("Catalan") manuscript; very up-to-date on poetology; available in the University Library, Poitiers: TL 28-1981-8-1 and 2.]

\section{0.}

Casas Homs, Josep M. Joan de Castellnou: Obres en Prosa. Barcelona: Fundació Salvador Vives Casajuana, 1969. [Introduction on Joan and on Raimon de Cornet, manuscript tradition, analysis of the two works, dating, language, and influence; edition of the Compendi, a prose résumé of the first version of the Leys (in verse, now lost), and the Glosari, with notes, no translation.]

\section{1.}

Fedi, Beatrice. "Per un'edizione critica della prima redazione in prosa delle Leys d'amors." SM 40 (1999): 43-118. [Confirms the proper title as Leys d'amors for the prose versions, Flors del Gay Saber for the verse; close analysis of manuscripts and editions; study of the historical process involved in the composition of the prose text by Guilhem Molinier; the new edition will show its genetic evolution through three stages; pp. 92-99: provides a sample text dealing with the definition of the cobla.]

\section{2.}

Fedi, Beatrice. "Il canone assente: l'esempio metrico nelle Leys d'Amors fra citazione e innovazione." In 115, Interpretazioni, 2001, pp. 159-86. [Definition of genres; 
history of the use of quotes or made-up quotes in the various redactions of the Leys.] 1363.

Fedi, Beatrice. "Les Leys d'Amors et l'école de Toulouse: théorie et pratique de l'écriture au XIVe siècle." In $\ \mathbf{1 0 2}$, AIEO 9, 2011, pp. 357-70. [Through a close examination of a number of winning poems in the competitions of the Consistori, Fedi concludes that there is little evidence that the Leys were widely known or read, except perhaps by the judges, and that the sense of "Toulouse School" may need to be revised.]

\section{4.}

Hagman, Roy. "Grammar of an Uncodified Language: The Old Occitan Grammar of Guilhem Molinier." Tenso 25 (2010): 23-35. [The third book of the Leys was composed in order to clarify what constituted correct grammatical usage of the language, the earliest to have been written for native speakers; it tried to deal with structures unknown to classical Latin as well as the principle of inherent variability; variant forms were distinguished as acceptable and unacceptable, with recent variants tending to be rejected.]

\section{5.}

Huchet, Jean-Charles. "L’amor de lonh du grammairien." Médiévales 9 (1985): 64-79. [Demonstrates how the rules proclaimed by the Leys d'Amors "substituent l'amour de la langue aux affres de désir et aux folies des corps"; language is seen as a transmutation of sensuality onto the higher plane of poetry.]

\section{6.}

Kelly, Douglas. "The Late Medieval Art of Poetry: The Evidence from At de Mons and Raimon de Cornet." 140, Etudes Ricketts, 2005: 681-92. [See pp. 685-88: At de Mons is quoted frequently in the Leys d'Amors to illustrate features of the art as promulgated by the Consistori: emphasis is placed on religious and moral themes, so that the poems could be applied equally well to an honorable domna or to the Virgin.]

\section{7.}

Landau, Justine. "Figures of Grammar and Rhetoric in Las Leys d'Amors." Tenso 20 (2005): 1-18. [Guilhem Molinier intended his text as an initiation to the secrets of poetic composition, but in retrospect it seems more like a death notice for trobar. The treatise is mainly concerned with grammar and figures of style, in an attempt to regulate the use of poetic language, but it also shows awareness of the contradictory nature of this language by analyzing first as mistakes, then as virtues, the mistakes and rebellious uses of the language of trobar, which has now lost its creative energy].

\section{8.}

See 917, Léglu, Multilingualism, 2010, pp. 65-74. [Presents information on the founding of the Consistori and the several versions of the Leys, parts of which act as a kind of teaching text to instruct boys in the use of formalized "poetic" Occitan, building on a knowledge of Latin; ambiguously, the Leys combine the notion of a "fertile multiplicity of languages" with "anxiety over the confusion of tongues"; Latin and the vernacular may "exist side by side and fertilize each other, producing new and rich flowers of rhetoric," but the process is a dangerous one, and, as it turned out, unsuccessful.] 
1369.

Majorossy, Imre. "La morale des Leys d'Amors: le grand jeu?" In 1516, Amors es bona volontatz, 2006, pp. 178-204. [The Leys were meant to create a literary guide for the poetic competitions of the Consistori, but in addition they reveal a curious mixture of theology, morality, and rhetoric aimed at the proper composing of religious poetry on love; whether the omnipresent moral severity came from Molinier himself or from the necessity to please the officers of the Inquisition is difficult to judge, but calls for further investigation.]

1370.

Maninchedda, Paolo. "Per una riedizione del Compendi de la conexença dels vicis que.s podon esdevenir en los dictats del Gai Saber di Joan de Castellnou." Chapter 1 in his Studi catalani e provenzali. Cagliari: CUEC, 1996, pp. 9-40. [Includes historical background of the Consistori in Barcelona and analysis of date and composition of Joan's Compendi; sketch of his other works: eleven lyrics and the prose Glosari; justification for the new edition of the Compendi that he is preparing: concludes that all three manuscripts are lacking in some way; Casas Homs used $B u$ but $B c$ is shown to be better; a more precise textual history is required.]

1371.

Pfeffer, Wendy. "Guilhem Molinier as Literary Critic." In $>159$, Studia occitanica, 1986, 1:205-12. [Discusses the problems inherent in the use of Guilhem Molinier's work as a basis for literary analysis of the troubadour poetry: the vocabulary is imprecise, the examples often inappropriate, the listing of genres incomplete.]

1372.

Salvat, Joseph. "Leys d'Amors." In $>$ 38, DLF, 1993, pp. 928-30. [Outline of the history and contents of the Leys.]

1373.

Swiggers, Pierre, and Nico Lioce. "Grammaire, culture et réalité dans les Leys d'Amors: la vision grammaticale du monde." In $\ \mathbf{1 0 0}$, AIEO 7, 2003, pp. 675-84. [Background history of the Consistori and its need for a set of rules to guide the judging of poems in the yearly competition; analysis of the grammatical section of the Leys, emphasizing its complexity and sophistication.]

\subsection{Las Razos de trobar}

[Prose treatise, composed between 1190 and 1213 by Raimon Vidal de Besalù; grammar is treated briefly and dogmatically, with quotations from troubadours of the classical period. An anonymous continuation, called Doctrina de compondre dictats, presents sixteen poetic genres; a versified adaptation, called Doctrina de cort, was composed about $1270-80$ by Terramagnino da Pisa; another adaptation, called Regles de trobar, was composed about 1290 by Jofre de Foixà, characterized by the author's modern attempt to free himself from Latin grammar.]

\section{4.}

Marshall, John H. The "Razos de Trobar" of Raimon Vidal and Associated Texts. London: Oxford University Press, 1972. [Contains critical texts of four treatises: the 
Razos, Terramagnino da Pisa's Doctrina d'Acort, Jofre de Foixa's Regles de trobar, the anonymous Doctrina de compondre dictats (perhaps by Jofre de Foixa), and two anonymous treatises; full literary and philological study, notes; no translations; for English translations of the Razos and the Doctrina see 1748, Shapiro, De vulgari, 1990; see corrections proposed by Tavani in 147, Mélanges Rostaing, 1974, pp. 1059-74.]

\section{5.}

Ruffinatto, Aldo. Terramagnino da Pisa, "Doctrina d'Acort": Edizione critica, introduzione e note. Rome: Ateneo, 1968. [Includes a historical introduction, edition, notes, and linguistic study; no translation.]

\section{6.}

Dagenais, John. "Genre and Demonstrative Rhetoric: Praise and Blame in the Razos de trobar and the Doctrina de compondre dictats." In 120, Paden, Medieval Lyric, 2000, pp. 242-54. [Genre distinctions may have been based more on moral didactic intent than on formal elements; the treatises stress the rhetorical methods of praising and blaming, which were essential parts of the medieval reading and writing processes, distinguishing just and unjust, good and evil, noble and base; genre definitions are examined in this light in the Razos de trobar and later in the Doctrina de compondre dictats.]

1377.

See 1159, Poe, From Poetry to Prose, 1984, pp. 67-82. [Analysis of the Razos de trobar as an attempt to capture the essence of Lemosi, the language of trobar; and to keep it alive in a less-sympathetic society; Raimon Vidal presents the rules for composing poetry in dogmatic terms because of his belief that trobar is a binding force within society, linking poets and audience in a common goal to develop a refined discrimination between worthy and unworthy.]

1378.

Swiggers, Pierre. "Norme et usage dans les Razos de trobar de Raimon Vidal." In - 137, Contez me tout, 2006, pp. 859-73. [Analysis of Raimon's technique of dialogic interaction with his readers, indicating his zeal to distinguish between good and bad usage and to correct frequent errors in language or logic; his intent was to instruct a wide audience of amateurs of troubadour verse in the techniques of composition, using as his model la parladura de Lemosin, the most suitable language for composing vers et cansons et serventes.]

\section{Didactic Literature}

\subsection{General Studies}

1379.

Bornstein, Diane. The Lady in the Tower: Medieval Courtesy Literature for Women. Hamden, CT.: Shoe String Press (Archon Books), 1983. [Brief reference to advice for aristocratic women on deportment and love, in the ensenhamens, Cour d'Amour, and Breviari.]

1380.

Kay, Sarah. Troubadour Quotation in the Occitan Tradition: Subjects and Objects of 
Knowledge. Leeds: Maney, 2009. [Study of quotes from troubadour lyrics that were used in various Occitan-language texts from the thirteenth and early fourteenth centuries; whereas in northern France the poems were quoted to help produce a tone of courtly color and sentiment, southern writers (in Spain, Occitania, and Italy) sought insight into the troubadours' wisdom, specifically their understanding of the mechanisms of love and the virtues and faults that it exposes, and their insight into the truths of philosphy and God's purpose in creation.]

\subsection{Allegories}

[Five or six pieces are defined as full allegorical works, though the troubadours used allegorical figures in many of their poems.]

\section{1.}

Jung, Marc R. "Les poèmes allégoriques occitans." In Études sur le poème allégorique en France au moyen âge. Berne: Francke, 1971, pp. 122-69. [A consideration of problems in defining medieval allegory; global study of Latin, Occitan, and French traditions; specific analysis of five works: poems by Guillem de Saint-Didier, Guiraut de Calanso (with Guiraut Riquier's explication), the Chastel d'Amors, the Cort d'Amor, and Peire Guillem's Lai on cobra (listed individually below).]

\section{2.}

Kay, Sarah. "Allégorie et subjectivité dans la poésie des troubadours." In $>$ 95, AIEO 2, 1993, 1:207-19. [The personifications of Amors, Jovens, and Merces served as a means to explore the psychology of the lover, and to allow the poets to explore their own identity; traditional rhetoric had to be adapted to this new preoccupation; see also 804, Kay, Subjectivity, 1990.]

\section{3.}

See 3086, Cura Curà, "Un commento," 2007. [Edition of Bernart de Panassac's allegorical vers to the Virgin En vos lauzar es (PC 482,2), along with Raimon de Cornet's Gloza, a verse interpretation of it, intercolated between the stanzas; see also a similar commentary, Als subtils aprimatz by Guiraut Riquier, of Guiraut de Calanso's allegorical poem Celeis cui am de cor e de saber, in 2543, Capusso, L'exposition, 1989.]

\section{4.}

Grimaldi, Marco. Allegoria in versi. Generi e forme nella tradizione manoscritta trobadorica, Doctoral thesis, University of Siena, 2010. Revised as Allegoria in versi. Un'idea della poesia dei trovatori. Bologna: Il Mulino, 2012. [Finds that allegory is important for a full understanding of troubadour poetry, especially in the pastorela and the tenso, which are narrative and objective in presentation; it is less important in the canso, which is based on subjectivity and on formal structures.]

\section{5.}

Jones, Lowanne E. "Lo Saber dans les quatre allégories occitanes du XIIIe siècle." In - 159, Studia occitanica, 1986, 2:81-92. [In Guiraut de Calanso's early poem Celeis cui am de cor e de saber, the ideal of finamor depends on a balance of passionate desire and rational wisdom; in the later allegories composed after the Albigensian Crusade, the Cort d'Amor, Lai on cobra, and the Chastel d'Amors, the importance of rational wisdom is paramount.] 
1386.

See 1439, Monson, Les ensenhamens, 1981, pp. 94-101. [Analysis of three allegories Chastel d'Amors, Cort d'Amor, and Lai on cobra, compared with the features of the ensenhamen, concluding that the allegories are a genre apart.]

1387.

Pfeffer, Wendy. The Change of Philomel: The Nightingale in Medieval Literature. New York: Peter Lang, 1985, pp. 73-114. [A broadly based study of the figure of the nightingale in about fifty troubadour poems, compared with usage in Latin, French, and German; the origins of the symbolic inspiration to love and poetry may be sought in folklore, but troubadour usage was influential on surrounding literatures.]

\section{8.}

Poe, Elizabeth W. "Aqest chastel es d'Amors: Troubadours' Resistance to Allegory." In - 156, Das Schöne, 2002, pp. 165-76. [Explores use of the castle as allegorical figure in Marcabru and other poets; Poe uses the image to trace the "uneasy alliance between lyric and allegory in troubadour verse"; takes a brief look at allegorical lyric poems by Guiraut de Calanso, Guilhem de Saint-Didier, and an anonymous Catalan poem Del primer nom d'Amor suy en demanda, as well as the three longer verse allegories Cort d'Amor, Chastel d'Amors, and Lai on cobra; Poe concludes that true allegory never took root in Occitan, compared with its full development in the North.]

\subsubsection{Chastel d'Amors}

[Anonymous fragment of 180 lines in six-line stanzas; mid-thirteenth century; description of a magic and imaginary castle, made of abstract notions, thoughts, attitudes, and qualities; the entry keys are prayers, the fire inside is love.] 1389.

See 1131, Thiolier-Méjean and Notz-Grob, Nouvelles courtoises, 1997. [Analysis of generic distinctions and the history of the novas, with a consideration of the implications of non-lyric style and the position of the author and the narrator; text of Chastel d'Amors, pp. 39-43.]

1390.

See 1385, Jones, "Lo Saber," 1986, pp. 89-91. [The Chastel d'Amors is a protected environment in which reason and knowledge shelter worthy lovers from outside dangers.] 1391.

See 1381, Jung, "Les poèmes allégoriques," 1971, pp. 146-48. [Points out resemblances between Chastel d'Amors and Guiraut de Calanso's allegorical poem; thinks it was written for a simple audience that needed explanations for the hidden allusions.]

\subsubsection{Cort d'Amor (Seinor vos que volez la flor)}

[Allegorical narrative text of 1,730 lines, incomplete at the end; late twelfth or early thirteenth century, just after Andreas Capellanus, to whose work it may be a response; predates and foreshadows the Roman de la Rose; the "court" in question is a court of law, where a variety of legal opinions regarding questions of love are debated at length.] 
1392.

Jones, Lowanne. The "Cort d'Amor": A Thirteenth-Century Allegorical Art of Love. Chapel Hill: University of North Carolina Press, 1977. [Detailed introduction covering the manuscript, date, author, sources, and a literary analysis; critical edition, with facing-page English translation, notes.]

1393.

Bardell, Matthew. La Cort d'Amor (Seignor, vos que voletz la flor): A Critical Edition. Oxford: European Humanities Research Centre (Legenda), 2002. [Solid introduction showing how the text predates and foreshadows better-known examples of the genre, particularly the Roman de la Rose; Bardell formulates the hypothesis that it may have been written at the court of Champagne as a reaction to Andreas Capellanus; critical edition with English translation on facing pages, extensive notes, glossary; see notes and suggestions by Ricketts, RLaR 107 (2003): 211-27.]

1394.

See 1385, Jones, “Lo Saber," 1986. [Pp. 83-87: the allegorical figure of Fin'Amor in Cort d'Amor represents wisdom, demanding from her adherents not a faithful heart but knowledge, a rational understanding of love and its rules.]

1395.

See 1381, Jung, "Les poèmes allégoriques," 1971, pp. 148-59. [The poem has almost no action, but much debating about the nature and the rules of love; the courtly tone of the first half gives way in the second to a more libertine attitude, where the goal is no longer attaining perfect courtliness but reaching sensual completion.]

\subsubsection{Lai on cobra sos dregs estatz (Lo Dieu Amor)}

[Allegorical novas by Peire Guilhem (wrongly known as de Tolosa or de Luserna); controversial dating: probably 1194-1214 (possibly 1252-53); incomplete text of 439 lines; colorful moral allegory of Love and his entourage, with political overtones.] 1396.

Bardell, Maria Grazia. "La novella allegorica di Peire Guilhem (MS R). I: Introduzione; 2: Testo, traduzione italiana e note." SMV 43 (1997): 35-130. [Detailed introduction covering previous scholarship, extensive analysis of MS $A$, the cultural and literary context, author (problematic), dating, structural qualities, and language; critical text with Italian translation, notes, and rich bibliography.]

1397.

See 1131, Thiolier-Méjean and Notz-Grob, Nouvelles courtoises, 1997. [Analysis of generic distinctions and the history of the novas, with a consideration of the implications of non-lyric style and the position of the author and the narrator; text of Lai on cobra, with facing-page French translation, pp. 354-85.]

1398.

Morlino, Luca. Online at http://www.rialto.unina.it. [A provisional edition of Lai on cobra, with brief introduction, no translation; supports the common attribution of works by Peire Guilhem to P. G. de Tolosa/de Luserna, as in his thesis "Il trovatore Peire Guillem. Identificazione ed edizione critica," University of Padua, 2005.] 
1399.

See 271, Morlino, "Omonimi equivoci, 2009. [Peire Guillem de Luserna is an invented name, playing on the value of Luserna as symbolic of courtly perfection; there is only one troubadour, called Peire Guillem, who is erroneously known also as P. G. de Tolosa and P. G. de Luserna.]

1400.

Capusso, Maria Grazia. "Contacts franco-ibériques dans la 'nouvelle' allégorique de Peire Guilhem (MS R).” RLaR 100 (1996): 223-45. [A series of intertextual relationships lead to the conclusion that the earlier dating for the poem is the most likely.]

\section{1.}

See 1381, Jung, "Les poèmes allégoriques," 1971, pp. 159-67. [Presents the historical context of the poem, its references to Jaufre, the moral criticisms directed at several aristocratic figures, the complete allegorization of the content within a living context.]

\section{2.}

Majorossy, Imre Gábor. "Amour de l'Amor: dialogues sur l'amour dans Lai on cobra par Peire Guillem de Tolosa." In 1137, Unas novas, 2007, pp. 93-110. [The four allegorical figures of Amor, Merces, Vergonia, and Leutatz outline the ideology of fin'amor; the specific references touch on the virtues and vices of Thibaut I of Navarre and Alfonso X of Castille, but the chief interest is in the presentation of the profound transformative power of love.]

\section{3.}

See 1439, Monson, Les ensenhamens, 1981, pp. 98-101. [Notes the close connection of Lai on cobra with the ensenhamens but identifies it as a true allegory in which the characters represent the courtly virtues in flight from an unfriendly environment.] 1404.

Taylor, Robert. "The Figure of Amor in the Old Provençal Narrative Allegories." In - 96, ICLS 3 Court and Poet, 1981, pp. 309-17. [Outlines the ambiguous and changing role of Amor from Greco-Latin to medieval traditions; analysis of the first full development of the god in physical and allegorical terms in Peire Guilhem's Lai on cobra; intertextual relationships with troubadour songs and Jaufre.]

\subsubsection{Allegorical Lyric by Guiraut de Calanso \\ (Celeis cui am de cor e de saber PC 243,2)}

[Poem of fifty-four lines, composed prior to 1202, whose allegorical meaning is analyzed by Guiraut Riquier in a 949-line Exposition: see

- 2543, Capusso, L'exposition, 1989.]

1405.

Jones, Lowanne. "Guiraut de Calanso's Lyric Allegory of Lady Love.” In 150, Mélanges Camproux, 1978, pp. 105-20. [Detailed analysis of the lyric; Jones notes the structural and thematic importance of three (three-stanza units, three arrows, three levels of love, three sets of doors, several syntactic triads, the word tres at the exact center of the poem) and adds a third level of interpretation to the literal and 
allegorical: the power of desire and the power of the domna are equaled by the power of poetry itself; in appendix, edition of the poem with English translation.]

1406.

Mitchell, James G. "A Troubadour Lyric: The Power of Love." Cornell Working Papers in Linguistics 17 (1999): 101-7. [An edition and English translation of Giraut de Calanson's Celeis cui am de cor e de saber, with linguistic notes and English translation; no introductory remarks, nor discussion of meaning.]

\section{7.}

See 2543, Capusso, L'exposition, 1989. [This introductory study outlines previous scholarship, analyzes Guiraut de Calanson's poem (text from Ernst edition, with Italian translation, notes, pp. 37-46), the Exposition, pp. 47-97, and the Testimoni, a sort of guarantee of authenticity, pp. 98-109; critical edition of the Exposition, with Italian translation, detailed notes.]

1408.

Capusso, Maria Grazia. "Le tre frecce d'amore nella canzone allegorica di Guiraut de Calanson, Celeis cui am de cor e de saber." In \$94, AIEO 1, 1987, pp. 157-70. [Detailed investigation of the ambiguous and evolving interpretations attached to each of the three arrows (steel, gold, lead) in several works after Guiraut's poem; Guiraut Riquier altered the original meaning in his exposition by his moralizing tendencies; the lead arrow is the most difficult to interpret, since it has been taken variously to cause the death of love or to bring its supreme development; further study of Latin and French traditions will be required.]

\section{9.}

See 1385, Jones, "Lo Saber," 1986, pp. 81-82. [Guiraut's poem is the earliest true Occitan allegory; love requires first an overwhelming irrational desire (cor), represented with traits of the Latin goddess Fortuna, then the learned qualities required by a contemporary lord presiding over an ideal courtly society (saber).]

\subsection{Breviari d'Amor}

[Composed ca. 1288-90 by Matfre Ermengaud; the subject matter is love in all its dimensions, an attempt to reconcile the love of God with the sexual love sung by the troubadours; 34,597 lines in rhyming couplets, incomplete, with quotes from 262 poems by sixty-six troubadours, including Matfre himself and his brothers Peire and Raimon, plus six anonymous and four trouvères; for Matfre's lyrics and a letter to his sister, see 2682-86.]

\section{0 .}

Ricketts, Peter. Le "Breviari d'Amor" de Matfre Ermengaut. Various publishers, 1976[The first complete edition of the encyclopedic work using all twelve full manuscripts and eleven fragments; replaces the edition by Azaïs, 1862-81, which used $A$ as base, with only $B, C$, and $D$ as control; Ricketts uses $M$ as base, along with all extant manuscripts. Vol. 5 was published first, in 1976, by Brill; a revised version of this is now in production by AIEO/Brepols for 2012; the intended French translation will appear later; vol. 2 appeared in 1989, 3 in 1998 (AIEO), 4 in 2004 (Brepols), completing 
the text; vol. 6 will be an exhaustive glossary, and finally vol. 1, the introduction, will follow shortly after.]

1411.

Bolduc, Michelle. "Transgressive Troubadours and Lawless Lovers? Matfre Ermengaud's Breviari d'Amor as a Courtly Apologia." In Discourses on Love, Marriage and Transgression in Medieval and Early Modern Literature. Edited by Albrecht Classen. Tempe: Arizona Center for Medieval and Renaissance Studies, 2004, pp. 65-83. [Matfre writes in defense of his fellow troubadours and lovers, who need instruction about the true doctrine of love from someone (himself!) who is a master in theology, a servant of love, and a troubadour in his own right.]

\section{2.}

Bolduc, Michelle. "The Paradox of Sacred and Profane Love: Matfre Ermengaud's Polyvalent Poetic Identity in the Breviari d'amor." In her Medieval Poetics of Contraries. Gainesville: University Press of Florida, 2006, chapter 3, pp. 89-128. [Matfre juxtaposes Catholic doctrinal theories of love and the fin'amors of troubadour lyric, united in the Breviari by the central motif of the Tree of Love; he establishes himself as authoritative in theology as well as in matters of love and as a poet, and he upholds the contraries as part of the human condition; love for God and love between humans can be maintained at the same time, juxtaposed yet separate; Bolduc gives the text and analysis of Matfre's poem Dregs de natura comanda, with English translation, pp. 122-27.]

\section{3.}

Bolduc, Michelle. "Naming Names: Matfre Ermengaud's Use of Troubadour Quotations." Tenso 22 (2007): 41-74. [Naming is closely related to authority in scholastic and canonical terms; as teacher, cleric, and master at law, Matfre considers himself an authority, subject to God; but auctoritas is an unstable element, subject to flexible interpretation, including the notion of troubadour poetry as authority; this is a rather startling status given to the secular vision of love in a religious summa text; two opposite worldviews are established: Catholic theology and courtly love—caritas and fin'amors.]

\section{4.}

Bolduc, Michelle. "Troubadours in Debate: The Breviari d'Amor." Romance Quarterly 57 (2010): 63-76. [Analysis of the multidirectional dialogue in the Perilhos tractat among lovers, ladies, poets, and the lauzengiers as they debate the nature of love and its rules, as well as the overall interpretation of the troubadours' poetic tradition, mediated by Matfre at the culminating point of his lengthy treatise on the nature of love.]

\section{5.}

Botana, Federico. "Virtuous and Sinful Uses of Temporal Wealth in the Breviari d'Amor of Matfre Ermengaud (MS BL Royal 19.C.I)." Journal of the Warburg and Courtauld Institutes 67 (2004): 49-80. [An investigation of three miniature cycles, the Works of Mercy, the Vainglory Cycle and the Ten Torments of Hell, showing how they illustrate the good and bad uses of money and the inexorable consequences of 
making a choice; the moral lessons reflect the efforts of mendicant teachings in Latin summas, made more accessible to the laity in the Breviari by the use of very specific miniature illustrations.]

\section{6.}

Bousquet, Jacques. "Breviari d'amor." In \$ 38, DLF, 1993, pp. 998-99. [A succinct résumé of the structure of the Breviari; brief mention of the intercalated poetry.]

\section{7.}

Cherchi, Paolo. "L'enciclopedia nel mondo dei trovatori: il Breviari d'amor di Matfre Ermengau." In Enciclopedismo médiévale. Edited by Michelangelo Picone. Ravenna: A. Longo, 1994, pp. 277-91. [Didactic interest is found in Marcabru, Peire d'Alvernhe, and the ensenhamens, but there were no truly encyclopedic works until the naive Tezaur by Peire de Corbian, and especially the Breviari d'amor, in which Matfre was seeking a new synthesis among the contradictory concepts of love, a sort of debate between the worthy and unworthy attitudes to love; the work seems to have had minimal influence in its time, since fin'amors had already declined and the era of more "realistic" encyclopedic works was to begin.]

1418.

Ducos, Joëlle. "La cosmologie dans le Breviari d'Amor de Matfre Ermengaud." In - 101, AIEO 8, 2009, 1:491-507. [Analysis of the encyclopedic nature of the Breviari and of the originality of its structure; it follows the traditions of southern compilers such as Ramon Llull rather than those of works from northern France; its most characteristic emphasis is on moral edification in a world which is governed by the forces of astrology and meteorology playing on human destiny.]

\section{9.}

Galent-Fasseur, Valérie. "Une expérience avec la lyrique: le Perilhos tractat d'amor de donas de Matfre Ermengaud." In L'expérience lyrique au Moyen Âge. (Assemblée des Médiévistes du 26 au 28 septembre 2002) Perspectives médiévales 28 (2002), pp.16992. [Analysis of the contradictory messages by Matfre: it is difficult to see whether he is for or against fin'amor; he seems to be teasing his readers; the message of the Tractat seems to be that human sexual love is dangerous, but that it is possible to go beyond this to the love of love itself, as some of the poets suggest; the pure act of desire, or loving, without an object, may lead us to union with God.]

1420.

Hershon, Cyril P. "Matfre Ermengaud: An Exercise in Biography." In $\mathbf{1 4 0}$, Etudes Ricketts, pp. 447-59. [A presentation of what little is known of Matfre's biography: his family, his education and wide erudition, especially in the areas of philosophy and religion, and his career in law and in literature; there is no indication that he married or that he became a Franciscan, and neither seems likely.]

1421.

Kay, Sarah. "Grafting the Knowledge Community: The Purposes of Verse in the Breviari d'amor of Matfre Ermengaud." Neo 91 (2007): 361-73. [Analysis of Matfre's image of the grafted tree to explain why he uses verse vernacular and quotations from troubadour poetry to reach his preferred audience, the lovers and poets of his 
community; the figure of the grafted branch expresses the way in which individuals may be bound through knowledge into a common unity with each other and with God, but in different ways, and at different times; verse form and vernacular language are particularly appropriate, given the social nature of the court and the spirit of community with men and God that Matfre wants to create.]

1422.

Kay, Sarah. "Book-Trees: Deleuze, Porphyry, and the Breviari d'Amor by Matfre Ermengaud." In her Place of Thought: The Complexity of One in Late Medieval French Didactic Poetry. Philadelphia: University of Pennsylvania Press, 2007, chapter 1, pp. 19-41. [A study of the concept of oneness (concern with the uniqueness of God, with the potential for community with God, and with the nature of the individual) in the Breviari; Matfre uses a variation on the Porphyrian tree as a model to explain the relationship between human love, the natural order, and divine love.]

1423.

Kay, Sarah. "How Long Is a Quotation? Quotations from the Troubadours in the Text and Manuscripts of the Breviari d'Amor." Rom 127 (2009): 1-29. [Analysis of the placement of quotations in the text, to show that the indistinct boundaries are a means for Matfre to proceed with his persuasive goal to lead his listeners through the comprehension of human sexual desire to moral enlightenment regarding God's purpose and eventual salvation.]

\section{4.}

Kay, Sarah. "Knowledge and Truth in Quotations from the Troubadours: Matfre Ermengaud, Compagnon, Lyotard, Lacan.” Australian Journal of French Studies, 46.3 (2009): 178-90. [Using Lacan and other postmodern theorists, Kay explores the goals of Matfre and his methodology; the quotations serve not so much as poetic expressions of love and sentiment, as in northern French usage, but more as a rational statement of the moral, religious, or reflective content of the poems; the quotes serve to establish an outside authority in the search for knowledge and/or truth; the troubadours were thought to have expert insight, even though Matfre often absorbed their words into his own discourse.]

\section{5.}

Kay, Sarah. "L'arbre et la greffe dans le Breviari d'amor de Matfre Ermengaud: temps du savoir et temps de l'amour." In L'Arbre au moyen âge. Paris: Presses de l'Université Paris-Sorbonne, 2010, pp. 169-81. [A further development of Kay's and Nicholson's 2007 analysis of the grafting image; the stock tree must precede the graft, but the graft may be older or younger than the stock, leaving an ambiguity of time reference that is exploited by Matfre in his linking of mankind's fate to the tree of the knowledge of good and evil and the possibility of returning beyond this sin to find redemption; a quote from Arnaut Daniel seems to have been altered by Matfre to suit his own message.]

\section{6.}

Majorossy, Imre. "Le Breviari d'Amor." In 1516, Majorossy, Amors es bona volontatz, 2006, pp. 144-78. [Claims that the guiding principle of the Breviari lies in 
Matfre's belief in the metaphysical unity of God and his creation, governed by love; stresses the flexibility of Matfre's moral position, in which he tries to reconcile the classical and biblical values of morality with the need to teach ordinary people how to live Christian lives in the real world of compromise.]

\section{7.}

Nicholson, Francesca M. "Branches of Knowledge: The Purposes of Citation in the Breviari d'Amor of Matfre Ermengaud." Neo 91 (2007): 375-85. [In the final section of the Breviari, the Perilhos Tractatz, the quotations are not outside the text, but integral parts of it, chosen to ramify Matfre's own voice and carry forth his purpose, to show how love of all sorts converges and leads through matrimony to the fulfillment of God's purpose; among the 266 citations, most have been chosen to point toward the singular truth of God's love, which is the goal of the entire work; the most frequently quoted is Aimeric de Peguilhan (twenty-four times), whose moralizing voice of reason is close to Matfre's own and who, along with Matfre himself, can seem to speak for the whole of the troubadour community.]

1428.

Richter, Reinhilt. Die Troubadourzitate im "Breviari d'Amor." Kritische Ausgabe der provenzalischen Überlieferung. Modena: STEM-Mucchi, 1976. [The detailed introduction includes the history of the Breviari, study of the manuscripts, and the relationship of the quoted texts to the chansonnier tradition; critical edition of all quoted texts, no translations; tables of concordance to other editions and reference works.]

1429.

Ricketts, Peter T. "L'éthique de Matfre Ermengaud." In $>$ 99, AIEO 6, 2001, pp. 464-68. [Matfre's purpose is to explain the nature of fin'amor to lovers and troubadours; the world was created by God's love, and love is the essential part of everything in the world; his intent is not encyclopedic in itself but an illustration of how God's love is part of everything; he is in favor of finamor but aware of its inherent dangers.] 1430.

Ricketts, Peter T. "Knowledge as Therapy: A Comparison between the Confessio amantis of Gower and the Breviari d'Amor of Matfre Ermengaud." In 106, ICLS 9, 2003, pp. 57-69. [Both works come out of a similar cultural framework; attempting to present the summa of love and knowledge in a compact form; the Breviari seeks to reconcile the troubadour ethic of finamor, outside marriage and procreation, with Christian morality emphasizing marriage and the continuation of the species, in order to heal the tattered society of the South; Gower seeks to heal his society too, by restoring the importance of reason, moderation, and self-control in place of willfulness and blind passion, the success of which (repose) seems to depend on getting old and giving up.]

1431.

Ricketts, Peter T. “Texte, transmission et traduction: le cas du Breviari d'amor de Matfre Ermengaud de Béziers." In Translatar i transferir: la transmissió dels textos $i$ el saber (1200-1500). Edited by Anna Alberni, Lola Badia, and Lluís Cabré. Santa Coloma de Queralt: Obrador Edèndum, U Rovira i Virgili, 2010, pp. 19-38. [Analysis of 
the manuscript traditions of the Breviari, different in Occitan, where the 7,500-line Perilhos tractat was the featured part, and in Catalan, where the tractat was omitted; other changes in the Catalan translation avoid links between God and carnal love, and they challenge the morality of courtly love; Ricketts mentions, with Tobella, the possibility of Eiximenis as translator.]

1432.

Ricketts, Peter T. Connaissance de la littérature occitane. Matfre Ermengaud (12461322) et le Breviari d'amor. Perpignan: Presses universitaires de Perpignan, 2012. [A reprint of three previous articles and one new one from 2011; a rich introduction to Matfre, his time and the nature of his work; the new article stresses Matfre's unique encyclopedic vision, combining theology, spirituality, and poetry.]

1433.

See 2667, Sunderland, "Marcabru in Motion," 2011, pp. 115-29. [Traces the vagaries of transmission of Marcabru's poem Dire vos vuoill through a number of chansonniers and its particular use by Matfre Ermengaud in the Breviari to show the poet as the ultimate misogynist and maligner of love and ladies; Marcabru cannot be taken even as a negative authority on love, because he has never known love himself.] 1434.

von Gohren, Abbey. "The Voice of Love, the Voice of Reason: Transitions of Textual Authority in Matfre Ermengaud's Breviari d'Amor." In In Search of the Medieval Voice: Expressions of Identity in the Middle Ages. Edited by Lorna Bleach, Katariina Närä, Sian Prosser, and Paola Scarpini. Newcastle: Cambridge Scholars Publishing, 2009, pp. 76-89. [Analysis of the debate staged by Matfre in his Perilhos tractat, moving from unrefined attack by the maldizen, countered by the author's use of reason; stronger debaters are troubadours who criticize Love, but they are reprimanded for knowing too little of what love is and how it can turn seeming folly into reason; the final attack is by actual lovers who have suffered grievously in love, supported by quotes from some of the best troubadours, representing perhaps Matfre's own experience of suffering; he shows that this suffering is caused by folly and pride; in combating these foes, Matfre discovers his own authorial identity, based on his personal convictions.]

\subsection{Lo Codi}

[Anonymous, from the second half of the twelfth century; a summa of the Justinian Code, extremely important in the Middle Ages for its influence on juridical development in France, Spain, Catalunya, Italy, and even Jerusalem; it is not certain whether it was originally composed in Occitan (probably) or translated from Latin; it was also translated into French, Spanish, Franco-Provençal, and Catalan; feudal law, referred to most often by the earlier troubadours, was gradually replaced by

\section{5.}

Roman law from the twelfth century on.]

Derrer, Félix. Lo codi: Eine Summa Codicis in provenzalischer Sprache aus dem XII. Jahrhundert. Die provenzalische Fassung der Hs A (Sorbonne 632). Vorarbeiten zu einer kritischen Textausgabe. Zürich: Juris, 1974. [A study of manuscripts and previous 
scholarly work; a provisional diplomatic edition, with textual notes, no translation; available online, with Latin and Spanish versions, thanks to J. Kabatek, at http:// www.uni-tuebingen.de/kabatek/codi.]

\section{6.}

Kabatek, Johannes. "Lo Codi und die okzitanischen Texttraditionen im 12. Und 13. Jahrhundert." In 125, Okzitanistik, Altokzitanistik, 2000, pp. 147-63. [Focuses on the linguistic place of the Codi and its wide influence in France, Spain, Catalunya, Italy, even Jerusalem; rich bibliography.]

\subsection{Ensenhamens: General Studies}

[Monson, following Bathe, 1904, lists nine texts as "real" ensenhamens: Garin lo Brun's El termini d'estiu; Arnaut-Guilhem de Marsan's Qui comte vol aprendre; Arnaut de Maruelh's Razos es e mezura; Sordello's Ensenhamen d'onor (Aissi co.l tesaurs es perdutz); Raimon Vidal de Besalù's Abril issi' e mays intrava; N'At de Mons's Sitot non es enquiestz; Amanieu de Sescas's Ensenhamen de la donzela (En aquel mes de mai) and Ensenhamen del escudier (El temps de nadalor); and Peire Lunel de Montech's Ensenhamen del guarso (L'autrier, mentre ques ieu m'estava).] 1437.

See 38, DLF, 1993, pp. 410-12. [See the article Ensenhamen by Joseph Salvat; outline of the rich Occitan tradition of moralistic literature, including epistles, coblas, vers, sermons, and proverbs, as well as a dozen or so loosely defined ensenhamens.]

\section{8.}

Lacroix, Daniel W. "Le brouillage des codes narratifs et didactiques dans les novas et ensenhamens occitans." In 114, Les genres, 2010, pp. 59-65. [Discussion of generic definition in two ensenhamens, by Arnaut-Guilhem de Marsan and by Garin le Brun, and in the three novas by Raimon Vidal; stresses the varying degrees of mixture of narrative and didactic qualities in the works and the necessity of widening the investigation to take in other ensenhamens, several allegorical works, the saluts d'amor, and other didactic texts.]

\section{9.}

Monson, Don Alfred. Les ensenhamens occitans. Essai de défnition et de délimitation du genre. Paris: Klincksieck, 1981. [Monson limits true ensenhamens to nine texts after comparison with novas, allegories of love, saluts, sirventes, and didactic and religious treatises in order to clarify the definition of the genre; his rigid classification is not shared by some scholars, who prefer to see the ensenhamen as fluid in generic terms; Monson intended to complement this genre study with a literary one, but it has not yet appeared.]

\section{0.}

Pirot, François. Recherches sur les connaissances littéraires des troubadours occitans et Catalans des XIIe et XIIIe siècles: les "sirventes-ensenhamens" de Guerau de Cabrera, Guiraut de Calanson, et Bertrand de Paris. Memorias de la Real Academia de Buenas Letras de Barcelona 14. Barcelona: Real Academia, 1972. [Detailed study of the genre ensenhamen, compared to similar genres: history, distinguishing features; specialized 
analysis of the sirventes-ensenhamen, with critical editions of those by Guerau de Cabrera, Guiraut de Calanson, and Bertran de Paris; see separate critical references under the names of the three poets.]

\section{1.}

Sansone, Giuseppe E. Testi didattico-cortesi di Provenza. Bari: Adriatica, 1977. [Global introductory study of five ensenhamens by Garin lo Brun (dama), Arnaut Guilhem de Marsan (cavaliere), Amanieu de Sescas (donzela and escudier), Peire Lunel de Monteg (guarso); critical edition of each, with Italian translation, notes; glossary; see discussion and corrections by R. Richter, $\operatorname{ZrP} 96$ (1980): 441-47.]

\subsubsection{Cabra joglar, Fadet joglar, Gordo}

[Three sirventes-ensenhamens addressed to the jongleurs Cabra, Fadet, and Gordo by Guiraut de Cabreira (mid-twelfth century), Guiraut de Calanso (beginning of thirteenth century), and Bertran de Paris de Rouergue (last quarter of thirteenth century); these are sirventes in form, ensenhamens in content; see separate listings under each poet's name in the troubadour listings.]

\section{2.}

See 1440, Pirot, Recherches, 1972. [Critical text of all three poems, with French translation, detailed analysis of historical background, codicology, philology, bibliography.]

\section{3.}

Cingolani, Stefano. "The sirventes-ensenhamen of Guerau de Cabrera: A Proposal for a New Interpretation.” Journal of Hispanic Research 1 (1992-93): 191-200. [Analysis of Cabra joglar suggests that it was not composed by Viscount Guerau III de Cabrera but, rather, by his grandson Guerau IV, not 1155-60 but rather 1196-98; comparison with Guiraut de Calanson's Fadet joglar indicates that they are much closer in time than had been thought; this calls for a reconsideration of the reception of northern epics and romances in the South.]

\section{4.}

De Conca, Massimiliano. "Pour une nouvelle édition de Fadet joglar: études structurales et pistes de recherches." 140, Etudes Ricketts, 2005, pp. 495-508. [Praises Pirot's edition, but claims that it needs to be done differently to present the text in a single study, with complete critical apparatus, as a base for more detailed linguistic, metrical, and literary studies; here he considers only textual problems, analyzing samples of textual cruces to establish a critical method for the eventual new edition; his study of structural and lexical items leads him to conclude that the two manuscripts may need to be edited separately; both provisional texts are printed in appendix.]

\section{5.}

Lafont, Robert. "Relecture de Cabra joglar." RLaR 104 (2000): 337-77. Reprinted in La Source sur le chemin, Paris: Harmattan, 2002, pp. 545-78. [A systematic survey of the ideal repertory set out by Guiraut de Cabrera for the imaginary joglar Cabra; Lafont concludes that the origins of the epic, already shown to be closely linked to 
the origins of the troubadour lyric, are linked as well to the origins of the roman antique and the Breton romances; the "two Normandies" are the cradle of all of these new literary forms; the poem is reproduced in appendix.]

\section{6.}

See 1439, Monson, Les ensenhamens, 1981, pp. 156-64. [These three texts are sirventes rather than ensenhamens; strophic in form, satirical invectives against the joglars in question, or boasts of their own skill relative to those of the joglars; Giraut de Calanson seems to be rivaling the poem of Giraut de Cabreira by not repeating any of the recommended works, and by lengthening his text.]

\subsubsection{Ensenhamen au cavayer (Qui comte vol apendre)}

[Composed by Arnaut Guilhem de Marsan, ca. 1170-80; 629 lines; the code of the perfect knight, advice to gain the love of a lady (agreeable appearance, generosity, professional equipment); this complements Garin lo Brun's poem, which expresses the code of the perfect lady.]

1447.

de Cauna, Jacques, and Gérard Gouiran. L'ensenhamen d'Arnaut-Guilhem de Marsan ou Code du parfait chevalier. Monein: PyréMonde, 2007. [Pp. 5-61: introductory study by de Cauna of the sociohistorical background, the biography of Arnaut Guilhem and the extended genealogical history of the Marsan dynasty and the lords of Cauna into the eighteenth century and beyond, with an attempt to identify several women mentioned in the ensenhamen; the text is given in a French translation by Gouiran.]

\section{8.}

See 1441, Sansone, Testi, 1977, pp. 111-45. [Introductory study, critical text with Italian translation, notes.]

\section{9.}

Gîrbea, Catalina. "Aimery Picaud et Arnaut de Marsan: clerc et chevalier en Aquitaine." In L'Aquitaine des littératures médiévales (XIe-XIIIe siècle). Edited by Jean-Yves Casanova and Valérie Fasseur. Paris: Presses de l'Université Paris-Sorbonne, 2011, pp. 155-69. [A study of the values held in common by representatives of two social classes, one who wrote in Latin a pilgrim's guide to St. Jacques of Compostela, the other a courtly guide in Occitan to chivalric perfection; both are didactic in intent and stress the importance of proper language, clothing, and table manners, as well as stressing the importance of military valor.]

\section{0.}

See 2470, Guida, "Cartulari e trovatori," 1999, pp. 77-86. [A strong case for the need to ally historical research with literary; much detail about the social status of ArnautGuilhem; dating of his ensenhamen may be clarified (between 1170 and post-1180).]

\subsubsection{Ensenhamen alla dama (El termini d'estiu)}

[The earliest endenhamen, composed by Garin lo Brun before 1156;

the code of the perfect lady, complemented by Arnaut Guilhem de Marsan's guide for the perfect knight.] 
1451.

Regina Bruno, Laura. Garin lo Brun: “L'Ensegnamen alla Dama.” Rome: Archivio G. Izzi, 1996. [Detailed introduction, covering the author, the originality of his poem, the manuscript tradition, and language; critical edition, followed by Italian prose translation, very detailed textual notes.]

1452.

Regina Bruno, Laura. "Ensenhamen e cortesia." In $\$ 95, AIEO 2, 1993, 1:307-25. [Close analysis of a unique forty-line passage from Garin's ensenhamen in which he attempts to define cortesia; many passages from troubadours are adduced by Regina Bruno to explore the qualities of the perfect domna; Garin does not manage to formulate an abstract definition of the concept, but the close link of cortesia to ensenhamen is established.]

1453.

See 1441, Sansone, Testi, 1977, pp. 41-107. [An introductory study, critical text with Italian translation, notes.]

\subsubsection{Ensenhamen del escudier (El temps de nadalor) and} Ensenhamen de la donzela (En aquel mes de mai)

[Texts from ca. 1278-95 by Amanieu de Sescas, Catalan, fl. 1274-95; Escudier: 472 lines; recommendations to a young knight on combat, dress, etiquette, general deportment, household service, speech, behavior, and courtly love; Donzela: 686 lines; similar advice, except for combat, to a lady-in-waiting in the service of a chatelaine, specifically on table manners and how to handle a would-be lover.]

\section{4.}

See 1441, Sansone, Testi, 1977. [Introductory study, critical text with Italian translation, notes.]

\section{5.}

Johnston, Mark. "Gender as Conduct in the Courtesy Guides for Aristocratic Boys and Girls of Amanieu de Sescas." Essays in Medieval Studies 20 (2003): 75-84. [Ensenhamen de l'escudier and Ensenhamen de la donzela; a narrative frame in which a young knight and a young marchioness approach Amanieu for advice; the advice is similar in both cases, except that only the boy receives recommendations on combat and only the girl on table manners.]

\section{6.}

Johnston, Mark D. "Ensenhamen de l'escudier and de la donzela by Amanieu de Sescas." In Medieval Conduct Literature: An Anthology of Vernacular Guides to Behavior for Youths. Edited by Mark D. Johnston. Toronto: University of Toronto Press, 2009. Chapter 2, pp. 23-60. [Critical texts, based on Sansone's edition with some emendations, English translation, notes.]

\section{7.}

See 1439, Monson, Les ensenhamens, 1981, pp. 106-8. [In the advice to the donzela concerning the appropriate handling of suitors, the poet presents actual supposed supplications, with the proper responses she should make.] 


\subsubsection{Ensenhamen del guarso (L'autrier mentre ques ieu m'estava)}

[By Peire Lunel de Montech; written 1326, the last example of the genre; written on the model of Amanieu de Sescas's Ensenhamen de l'escudier, for an aspiring poet looking for advice on how to compose.]

1458.

See 1441, Sansone, Testi, 1977. [An introductory study, critical text with Italian translation, notes.]

\subsubsection{Ensenhamen d'onor (Aissi co.l tesaurs es perdutz)}

[By Sordello; composed between 1246 and 1257; 1,327 lines; gives advice on deportment and love; rules of morality, concerned primarily with honor, fidelity, and reputation (i.e., Platonic love); for Sordello's lyric poems, see below, PC 437.]

1459.

Wilhelm, James J. The Poetry of Sordello. Garland Library of Medieval Literature, Series A, vol. 42. New York: Garland, 1987. [Edition of forty-two cansos, plus the Ensenhamen d'onor (1,327 lines), with English translation, textual notes.]

\section{0.}

Burgwinkle, William. "Rhetoric and Ethics in Sordello's Ensenhamen d'onor." Glossator 4 (2011): 33-51. [An exploration of the contradictory opinions and judgments concerning Sordello, in his own day and into modern times; the exuberant, hedonistic poet of early years is in opposition to the image of moderation and rectitude that he projects in his ensenhamen; this work is a propaganda piece meant to guide society, based on a system of ethics that is adaptable to particular circumstances and is essentially aimed at self-advancement; politics does well to hide behind rhetoric.]

\section{1.}

Caliaro, Ilvano. Sordello da Goito. Verona: Mazziana, 2000. [Twelve cansos, two tensos, four partimens, seven sirventes, one planh for Blacatz, four minor lyrics, three exchanges of coblas, one salutz, nine varied lyrics, Ensenhamen d'onor.]

\section{2.}

Schulze-Busacker, Elisabeth. "Sordello, Ensenhamen d'onor." RST 5 (2003): 99-109. [The ensenhamen participates in the flourishing period of didactic literature in Europe; as in the Disticha catonis, the advice proffered is based on common-sense popular wisdom but is directed mainly to a chosen group of courtly personages, who are encouraged to protect ladies, poor knights, and jongleurs.]

\subsubsection{Razos es e mesura}

[By Arnaut de Maruelh, end twelfth century, 365 lines; dedicated to Alfonso II of Aragon; gives the fundamental values of the courtly ethic, in particular proeza; advice on how to gain worldly esteem, directed at knights, ladies, bourgeois, and clerics.] 1463.

Eusebi, Mario. “L'ensenhamen di Arnaut de Maruelh.” Rom 90 (1969): 14-30. [Text with Italian translation.] 


\subsubsection{Abrils issi' e mays intrava}

[The earliest of the novas, composed by Raimon Vidal de Besalù prior to 1213;

1,773 lines; sometimes called a novas, but the last section is an ensenhamen, giving didactic advice to a joglar about proper courtly behavior to counteract the decline of chivalry and poetry; many quotations from classical troubadours.]

\section{4.}

See 38, DLF, 1992, p. 1228. [Outline by John H. Marshall of the contents and interest of the work.]

\section{5.}

See 2934, Field, Ramon Vidal, 1991, vol. 2. [Introduction to biography and literary activity of Raimon; detailed introduction to Abril issi; critical text with Catalan translation, notes, and brief glossary.]

\section{6.}

See 1134, Huchet, Nouvelles occitanes, 1992. [The introduction develops the idea that Raimon Vidal's novas represent a transitional genre between lyric and narrative; text based largely on previous editions, with French translation.]

\section{7.}

Francis, Scott M. "The joglar as Salesman in Raimon Vidal de Besalús Abrils issi' e mays intrava." Tenso 24 (2009): 1-19. [Consideration of the genre and audience of the work; analysis of the author's advice to the joglar on performative techniques and reception; the novas contains a kind of advertising directed at potential aristocratic clients, reflecting the new commercial developments in Occitan society, as merchants became more mobile and tried to increase their client base; troubadours were quoted in order to establish them as figures of authority, which then in turn established the authority of the narrator.]

\section{8.}

Caluwé, Jean-Michel. "Abril issia ou le jongleur aux portes de la cité.” Bien dire et bien aprandre 9 (1991): 51-72. [Caluwé sees an intertextual conjunction between the ensenhamen and Giraut de Bornelh's poem PC 242,55, Per solatz revelhar, as Giraut laments the end of the era of lyric trobar, and Raimon Vidal inaugurates the new era of narrative; the gap between the two will be bridged by the jongleur, who must understand how profoundly society has changed, and how it requires a mythical narrative base to preserve the image of what it once was.]

\section{9.}

Calzolari, Monica. "I favolosi anni Settanta: riflessioni sulla datazione di Abril issia di Raimon Vidal de Besalú." In $>$ 123, La narrativa, 1995, pp. 83-108. [Previous attempts at dating have varied from 1199 to 1213; a new datation of 1219-22 is proposed, based on anti-French and anticlerical attitudes, and on the decadence of the baros in the text, applied to the historical context; if accepted, then Raimon Vidal would be seen not as a precursor but as a participant in the generalized response to the social crisis of his time.]

1470.

Majorossy, Imre Gábor. "Entre deux époques: cours seigneuriales et le respect de 
la poésie dans Abril issia." Medioevo e Rinascimento 20 (2006): 7-30. Reprinted in - 1137, Unas novas, 2007, pp. 19-40. [The first of the Occitan novas is a philosophical dialogue concerned with the qualities required of a joglar in the difficult period when the stern values of antiquity and the courtly ideals of the troubadours have faded; Majorossy believes that Raimon Vidal's ensenhamen is advocating Christian qualities by subtle reference to biblical passages, suggesting that the poet, like Jesus, has a sacred calling to uphold the traditional virtues through the sacrifice of literary creation.]

\section{1.}

Pizzaleo, Luigino. "La tecnica della citazione nelle novas di Ramon Vidal." CDT 2.3 (1999): 861-81. [In Abril issi'e mays intrava and So fo el temps, Raimon quotes widely from the troubadour lyrics, treating them as a sort of authoritative canon of ethics and wisdom, rather than for their literary qualities; the ideological message is explicated through a series of lyrical sententiae.]

1472.

Poe, Elizabeth Wilson. "The Meaning of Saber in Raimon Vidal's Abril issia." In - 159, Studia occitanica, 1986, 2:169-78. [Saber is an ambiguous, composite quality obtained slowly and only with maturity; the joglar lacking in saber should be a little bolder and more ambitious without being presumptuous, positive and purposeful rather than negative and complaining, and must trust to common sense to guide him and temper his boldness when appropriate in a society in flux.]

\subsubsection{Ensenhamen au jongleur ( $S$ i tot non es enquistz)}

[By N'At de Mons; second half thirteenth century; 1,539 lines; advice to a young joglar who came to him for guidance; see also lyric poetry by At de Mons, 2706-10.]

\section{3.}

Cigni, Fabrizio. “Il trovatore N’At de Mons di Tolosa.” In Testi, generi e tradizioni nella Romània médiévale. Atti del VI Convegno della Società Italiana di Filologia Romanza, Pisa, 2000. Edited by Fabrizio Cigni and Maria Pia Betti. Studi mediovali e volgari 47 (2001): 251-73. [Analysis of the sparse background information concerning At and his texts; review of former scholarship and the manuscript tradition; Cigni is preparing a new edition of At's complete works.]

\section{4.}

Bernhardt, Wilhelm. Die Werke des Trobadors N'At de Mons. Altfranzösische Bibliothek, 11. Heilbronn: Henninger, 1887. Reprint, Wiesbaden 1968. Available online through Google Books under Die Werke des Trobadors N'At de Mons. [Detailed introduction on biography, poetic output, language, metrics; several valuable remarks by Wendelin Foerster on phonetics; critical text and analysis of five poems, with detailed notes; no translation.]

\subsection{Novas de l'heretge}

[End thirteenth or beginning of fourteenth century; debate of 682 lines between Izarn and a Cathar heretic Sicart de Figueiras, in which Sicart is finally 
brought back to orthodox faith; the identity of Izarn is difficult to establish, since there are three troubadours of that name.]

1475.

Ricketts, Peter T. Las novas del heretje. Online, 2002, at http://www.rialto.unina.it. [Very brief introduction, text, no notes, no translation; also in $\mathbf{2 0 0 1}$, Ricketts, Contributions, 2000, pp. 75-113, with French translation, brief notes.]

\section{6.}

Zambon, Francesco. "Sicart de Figueiras, il perfetto cataro de Las novas del heretge." In 100, AIEO 7, 2003, pp. 729-37. [Further archival documents clarify the identity and biography of Sicart, who is not to be identified with Sicart de Lunel; his portrait in the novas is somewhat caricaturized, but the historical details are accurate; he converted by 1244 at the latest and denounced several former colleagues to the Inquisition.]

1477.

Gouiran, Gérard. "Las novas del heretje, ou à qui profite la propagande?” In $\mathbf{1 0 9}$, Comunicazione e propaganda, 2007, pp. 331-48. [Explores the daring hypothesis that the difficult and contradictory text may be a complex propaganda piece, designed to show the Inquisition in a favorable light, able to protect the interests of the church by facing a highly placed member of the heresy and negotiating firmly and humanely his return to orthodoxy; the text may be an attempt to manipulate the general public into continuing support for the fading Inquisition; Gouiran calls for further study to resolve the remaining unexplained contradictions.]

\subsection{Proverbs}

[The analysis of proverbs and sentences in the poetry can give insight into the sociocultural context, the make-up of the audiences, the use of sources, and the literacy of the court culture; the use of proverbs is especially frequent in the salutz and tensos.]

\section{8.}

See 297, Bianchini, "L'alta marquesana, 1986. [Establishes a link between the anonymous author of the Proverbia quae dicuntur super natura foeminarum and Beatrice of Monferato, who moved in the cultural circle of troubadours such as Raimbaut de Vaqueiras, Peire Vidal, Bertholome Zorzi, Guilhem Augier, and others, and probably influenced their use of proverbs.]

1479.

See 2966, Cabré, "Wisdom for the Court," 2005. [Exploration of Cerveri's Verses proverbials as an early vernacular teaching handbook, meant for the education of Jaume II's two sons as well as for a general vernacular audience; Cerveri is shown to be very successful as a combined sage and troubadour, teaching sen and saber through down-to-earth proverbs to the unlearned members of the court; see $\mathbf{2 9 5 9}$, edition by Coromines, 1991.]

1480.

See 3033, Cabré, "La maneyra pus fina," 2005, pp. 543-58. [Detailed analysis of the Verses proverbials, indicating the richness of didactic and moralizing themes, the 
constant pedagogical tendencies, and close resemblances to Cerveri's other lyric and narrative works.]

1481.

See 520, Gambino, Salutz, 2009. [The introduction by Speranza Cerullo analyzes typical themes and structures of the salutz; one of the defining characteristics is the frequent use of proverbial expressions.]

\section{2.}

Goddard, Richard N. B. "Marcabru, Li proverbe au vilain, and the Tradition of Rustic Proverbs." NM 88 (1987): 55-70. [Outlines the material and methodological problems of dealing with proverbs; discusses fifteen proverbs found in Marcabru, of which nine occur in the Old French pedagogical collection Li proverbe au vilain; the reference to elementary school-learning through rustic proverbs would strengthen the contrast between aristocratic decadence and wholesome peasant wisdom.]

\section{3.}

See 2548, Longobardi, "Sondaggi retorici," 2003. [Rhetorical study of the fifteen epistles to establish their argumentative and expository structures; special emphasis is placed on the connective figures of speech that strengthen the inner thematic coherence and on the frequent use of proverbs and maxims to reinforce praise or blame or to emphasize the down-to earth advice that Guiraut offers so freely; see also Longobardi, "La citazione del proverbio nella disputa." In Atti del XXXI convegno interuniversitario di Bressanone. Padua: Esedra, 2009, pp. 105-28 (here pp. 123-27), for a study of the use of proverbs by Guiraut in his tensos.]

\section{4.}

See 2551, Pfeffer, "Guiraut Riquier and the Study of Proverbs," 1996. [Guiraut Riquier was sparing in the use of proverbs: only twenty are found in his eighty-eight lyric and debate poems, relatively more in those composed in Castile at court of Alfonso X.]

\section{5.}

Pfeffer, Wendy. Proverbs in Medieval Occitan Literature. Gainesville: University of Florida Press, 1997. [Detailed survey of paremiological usage in eleven poets and in the Canso de la Crozada, demonstrating that there is more evidence of learned culture in Occitan society than commonly thought; presents many fruitful ideas for future research; the bibliography lists several of her previous studies on the presence of proverbs in Occitan, and on their specific use by Aimeric de Peguilhan, Folquet de Marselha, and in the Canso de la Crozada.]

\section{6.}

Santini, Giovanna. "Omnia praeclara rara: la citazione tra fonte letteraria e proverbio." In La citazione: Atti del XXXI convegno interuniversitario di Bressanone (11-13 luglio 2003). Edited by Gianfelice Peron. Quaderni del circolo filologico-linguistico padovano, 19. Padua: Esedra, 2009, pp. 149-67. [The use of the same proverb, with similar vocabulary and rhymes, may indicate that the author of the Leys d'amor knew a poem by the Sicilian poet Jacopo da Lentini; the parallels are striking, but the direct intertextuality cannot be proved, since the proverb is so widely used from classical 
times; the investigation itself is interesting in the understanding it brings of the cultural tradition of proverbial expressions.]

1487.

Schulze-Busacker, Elisabeth. "Les proverbes dans la lyrique occitane." FL 128 (1998): 189-210. [Using as example an anonymous sirventes PC 335,51a, structured around proverbs in each stanza, sketches the overall presence of paremiological material in Occitan; more than mere rhetorical adjuncts, proverbs and maxims form a fundamental component of the teaching aspect of the poetry, especially in the learning of moral precepts; general survey of usage by about twenty poets in various periods.]

1488.

Schulze-Busacker, Elisabeth. "Sordello, poète didactique." In $\mathbf{1 0 8}$, Atti Sordello, 2000, pp. 161-205. [In his most productive period, 1233-46, Sordello uses proverbs in all major lyric genres, compared with most of his contemporaries, who used few or none; in the Ensenhamen d'onor he attains the richest and most mature use of paremiological material to express his subtle concept of onor; see the author's more detailed study of the ensenhamen in RST 5 (2003): 99-109, where she sees the Disticha catonis as the general framework of the text.]

1489.

Schulze-Busacker, Elisabeth. "L'héritage gnomique et parémiologique dans la poésie des troubadours." In 107, Ab nou cor, 2004, pp. 169-88. [The outline of a research project to collect and study all Occitan occurrences of proverbs and maxims from the earliest to the sixteenth century, placing each in chronology of transmission, in its cultural context, and in its literary use.]

\subsection{Quan tu a la taula seras}

[Anonymous "Contenance de table"; 118 lines; manuscript from the fourteenth century; a didactic poem, translated from the Latin, thought by some to be an ensenhamen.]

\section{0.}

Chichmarev, Vladimir Federovich. "Contenances de table en vers provençaux." RLaR 48 (1905): 289-95. [Edition with notes; no introduction, no translation; the text is a free translation of the Latin Quisquis es in mensa.]

1491.

Glixelli, Stefan. "Les contenances de la table." Rom, 47 (1921): 1-40. [A survey of poems giving advice on table manners in Latin, French, Occitan, Italian, and other European languages; historical development of the genre; pp. 11-13: draws parallels between the Occitan text and a Latin version of the text that must have been used as source, and mentions some unique rules that distinguish it from the French texts; p. 24: a number of parallels with the Ensenhamen de la donzela by Amanieu de Sescas.]

\section{2.}

See 312, GRLMA, vol. 6, book 1, 1968, pp. 86-87.

1493.

See 1440, Pirot, Recherches, 1972, p. 28, n. 21: (\#15), and p. 33, n. 24: [Pirot 
considers the text to belong to a subgenre of general didactic poems; it is not an ensenhamen.]

\section{9. [El Romanz] de quatre vertutz principals}

[Moral poem by Daude de Pradas; 1,812 lines; translated and adapted between 1220 and 1236 from De quattuor virtutibus (Formula honestae vitae) by Martin de Braga, with added glosses and exempla; dedicated to Etienne III de Chalançon, bishop of Puy-en-Velay 1220-31; Daude also composed seventeen poems (see PC 124) and Dels Auzels Cassadors (see 22.3).]

\section{4.}

Stickney, Austin. The Romance of Daude de Pradas on the Four Cardinal Virtues. Florence: Würtenberger, 1879. Available online through Google Books under Austin Stickney. [Introduction, critical edition with brief textual notes, no translation.]

\section{5.}

Ricketts, Peter T. "Le roman de Daude de Pradas sur les quatre vertus cardinales." FL 134 (2002): 131-83. [Basic edition of the text, with notes; no translation; the work is based on Martin de Braga's Formula honestae vitae, but with added glosses in the form of exempla.]

1496.

See 312, GRLMA, vol. 6, book 2, \#4024.

\subsection{Le Savi (Libre de Senequa; Mettra Ceneche)}

[Collection of proverbs in verse, 1,128 lines, from the second half of the thirteenth century; fifty-one lines, six unique, are quoted in the Leys d'Amors.]

1497.

See 312, GRLMA, vol. 6, book 1, p. 104; and book 2, p. 161, \#3120. [Short description and documentation by Cesare Segre.]

\section{8.}

D’Agostino, A. Le Savi: Testo paremiologico in antico provenzale. Rome: Bulzoni, 1984. [A provisional critical edition, more comprehensive than that of Orlando; based on $V$, with added verses from $P$ and $M$ and four from the Leys d'Amors, with a philological introduction, copious notes, no translation, no glossary; to be followed by a more complete edition, based likely on $P$, with literary, paleographical, and linguistic analyses and glossary.]

\section{9.}

Orlando, Sandro. Un'altra testimonianza del "Seneca" provenzale. Alessandria: Edizioni dell'Orso, 1984. 2nd edition, 1988. [Edition based only on $M$, a reworking of a previous edition by Pensado; lacks a thorough study of the paleographical and textual history.] 1500.

Borghi Cedrini, Luciana. Cultura "provenzale" e cultura "valdese" nei "Mettra Ceneche (Versi di Seneca)" del ms. Dd XV 33 (Bibl. Univ. de Cambridge). Turin: G. Giappichelli, 1981. [A nonstandard version of the text in Vaudois dialect, with Italian translation.] 


\subsection{Sidrac}

[Translation of the anonymous Old French encyclopedic Livre de Sidrac, a compendium of medieval popular culture and belief, from the end of the thirteenth century, in question and answer form, presented as a dialogue between King Boccus and the sage Sidrac; two manuscripts, one containing only the first thirty-seven

1501. questions, the other mutilated at the end.]

Bianchi de Vecchi, Paola. "Preliminari all'edizione critica del Sidrac provenzale." In - 95, AIEO 2, 1993, 1:65-81. [Introductory study of the vast work, also known as La fontaine de toutes sciences; this is one of the most widespread didactic works of the Middle Ages; Bianchi de Vecchi does not seem to have continued with the full edition.]

1502.

Steiner, Sylvie-Marie. “D'un texte à l'autre, d'une langue vernaculaire à l'autre: édition bilingue du 'bestiaire' du Livre de Sidrac (BnF fr. 1158 et BnF fr. 1160).” FL 148 (2009): 75-104. [Extracts in Oc and Oil of a short passage; Steiner is working on an edition of the two Occitan manuscripts of the text (there are seventy-two Old French manuscripts).]

\subsection{Thezaur}

[An encyclopedic work in two versions, one of 520 lines, the other, with interpolations, 840 lines, with one rhyme, -ens, used throughout; composed in the early thirteenth century by Peire de Corbian, the uncle of Aimeric de Belenoi; may have influenced the Spanish Libro de Alexandre and the Tesoro of Brunetto Latini; Peire also wrote one poem to the Virgin: see 2775-78.]

\section{3.}

Bertoni, Giulio, and Alfred Jeanroy. "Le Thezaur de Peire de Corbian." AM 23 (1911): 289-308 and 451-71. [Text of both versions, with critical notes; a new edition is in preparation at Rome by Maria-Laura Palermi: see her paper at the Eighth Congress of the AIEO, Bordeaux, 2005: "Peire de Corbian: per una nuova edizione del Thezaur."] 1504.

Canettieri, Paolo. "Il Tesoro, la misura della torre e la figura del niente." In Vettori e percorsi tematici nel mediterraneo romanzo. L'Apollonio di Tiro nelle letterature euroasiatiche dal Tardo-antico al medioevo, Roma, Villa Celimontana, 11-14 ottobre 2000: Atti. Edited by Fabrizio Beggiato and Sabina Marinetti. Soveria Manelli: Rubbettino, 2002, pp. 117-34. [The text indicates that the author was familiar with methods of measuring and counting that were beginning to change the cognitive mentality of western Europe at the turning of the twelfth century; the Indo-Arabic system of counting offered distinct practical advantages over the Roman system (abacus), though it did not prevail until the sixteenth century; Canettieri claims that the notion of zero may have influenced some troubadour poetry.]

1505.

Lefèvre, Yves. "Deux poètes médoquins du XIIIe siècle (Aimeric de Belenoi et Peire 
de Corbian)." Revue historique de Bordeaux 13 (1964): 123-31. [Historical study of Aimeric and his uncle Peire; identifies several further sources for the Thezaur; dates the work to the beginning of the thirteenth century; attempts to characterize Peire through his treatise.]

\section{6.}

Léglu, Catherine. "Memory, Teaching and Performance: The Two Versions of Peire de Corbian's Thezaur." In 140, Etudes Ricketts, 2005, pp. 281-92. [The longer text has interpolations, rather than being a copy which incorporates marginal glosses; the author's intent seems to have been to prove his worth as an entertainer, and perhaps also as a teacher of the new forms of music; emphasizes the importance of face-to-face charismatic teaching.]

\section{Religious Literature}

[Pious literature, biblical, religious, devotional themes]

\subsection{General}

1507.

Cingolani, Stefano. "La letteratura religiosa in Occitania e Catalogna fra XI e XIII secolo." BRABLB 43 (1993-94): 37-55. See also the preliminary formulation in - 95, $A I E O$ 2, 1993, 1:91-99. [A projected framework for research into the study of religious literature in the South from the eleventh to thirteenth centuries, in comparison with earlier developments in Anglo-Norman and Old French.]

\section{8.}

Hasenohr, Geneviève. "Le christianisme méridional au miroir de sa littérature (douzième siècle).” Heresis 11 (1988): 29-40. [Broadly based survey of religious literature in Occitan from the thirteenth to fifteenth centuries, autonomous developments characterized by the supernatural and by Franciscan spirituality (Saint Bonaventure); the Breviari d'amor is the dominant text, inspired by Hugh of Saint Victor's De arrha animae, an inspiration in turn for Raymond Llull.]

1509.

Lemaître, Jean-Loup. Les troubadours et l'église. Entre histoire et légende. Ussel: Musée du Pays d'Ussel, 2002. [Catalogue of an exposition from 2002; historical information, vidas, and documentation on fifteen poets: three who wrote poetry while remaining in orders, three who left their orders to become troubadours, and nine who converted or retired to the church after a career as troubadours; reproductions from manuscripts $I$ and $K$, giving two portraits of each in ornamented initials; no poems are printed.]

\section{0.}

Ricketts, Peter T. "Deux petits textes occitans: une oraison de la Vierge et une lettre du Christ, tombée du ciel." CDT7 (2004): 845-49. [Texts reedited as part of COM3: a prayer to the Virgin asking for her protection, and a supposed letter from Jesus reminding the faithful to observe Sunday rest; brief introduction, editions with a few textual notes, no translations.] 
1511.

Wahl, Angelika. Die altprovenzalische Übersetzung des Liber Scintillarum. Munich: Fink, 1980. [A devotional collection of sayings of Jesus and the saints, compiled at the end of the seventh century by a Benedictine monk called Defensor from the priory at Ligugé near Poitiers; critical edition, with close comparison to the Latin source text; rich glossary.]

\section{2.}

\subsection{Religious Lyric}

Salvat, Joseph. "Poésies religieuses en occitan." In 38, DLF, 1993, p. 1199. [Brief historical survey; also pp.1478-79: "Poésies à la Vierge dans la littérature occitane": listing of poems from the eleventh-century versus (see under "Monuments"), to the thirteenth-century paraphrases of the Ave Maria, many poems to the Virgin by later troubadours (Peire Cardenal, Guiraut Riquier, etc.), quotes in the Breviari, the drama Esposalizi de Nostra Dona, and the symbolic poem Gardacors de Nostra Dona Santa Maria verges e pieucela.]

1513.

Salvat, Joseph, and Geneviève Brunel-Lobrichon. "Flors de paradis, PC 461,123.” In - 38, DLF, 1993, p. 453. [An anonymous thirteenth-century invocation to the Virgin, mentioned in the Leys d'Amors; 242 lines in twenty-two stanzas, probably from a Benedictine abbey (St. Martial de Limoges?); the metrical structure, taken from a canso by Gaucelm Faidit, was in turn used satirically by Guilhem Figueira in his violent diatribe against Rome, PC 217,2; edited in $\mathbf{1 5 1 7}$, Oroz Arizcuren, 1972, pp. 430-53, and in Barbara Spaggiari, "La 'poesia religiosa anonima' catalana o occitanica," Annali della scuola normale superiore di Pisa, s. III, 7, no. 1 (1977): 117-350, at pp. 314-30; this edition also available online at http://www.rialc.unina.it; without introduction, translation, or notes.]

\section{4.}

Colby-Hall, Alice. "Chant grégorien et liturgie latine et occitane dans un manuscrit méconnu de l'abbaye de Saint-Guilhem-le-Désert." Études héraultaises 37-38 (20078): 23-28. [Historical and paleographical information on two early thirteenthcentury prosimetra, "épitres farcis" on the martyrdom of St. Stephen, modeled on a French original; nineteen Occitan stanzas are intercalated to paraphrase the Latin prose passages; for music and text of the vernacular pieces, see $\mathbf{6 1 4}$, Gennrich, Der musikalische Nachlass, 1958-60, 1:4-24 and 2:4-5, 13-15.]

1515.

De Caluwé, Jacques. "Les sources bibliques dans la poésie religieuse des troubadours d'après le corpus d'Oroz Arizcuren." In Proceedings of the Second Conference on Medieval Occitan Language and Litereature, University of Birmingham, 28-30 March, 1982. Typescript copy from the Faculty of Arts, University of Birmingham, 1982, pp. 24-38. [Analysis of fifty-five religious texts presented by Oroz Arizcuren in $\mathbf{1 5 1 7}$, La lírica religiosa, 1972; the biblical element in troubadour lyric is characterized by rarity, nonrepetitiveness, and fidelity to unquestionable Christian sources such as the Gospels.] 


\section{6.}

Majorossy, Imre Gábor. Amors es bona volontatz: chapitres de la mystique de la poésie des troubadours. Budapest: Akadémiai Kiado, 2006. [After defining mysticism, Majorossy demonstrates its presence in eight representative poets, showing that they share a common influence and inspiration with religious mystics; specific poems are analyzed to demonstrate several types of mysticism: (1) a belief in the omnipotence of God and his creation of love, requiring submission to the domna and to himself (Jaufre Rudel, Raimbaut d'Aurenga, Giraut de Bornelh); (2) love of Jesus, demonstrated through spiritual purification and holy crusade (Marcabru); (3) the hidden message in the alba, which makes it the best expression of love (Folquet de Marselha); (4) the ambiguous relationship between the domna and the Virgin (Rigaut de Barbezieux); (5) frank adoration of Mary (Guiraut Riquier); and (6) theological richness and biblical references, forming part of the poetic art (Peire Cardenal), reinforced by its counterpart, a religious poem which borrows troubadour language to speak of Jesus (the Jubilus of Bernart de Clairvaux); secular love in troubadour poetry is much closer to religious mentality than appears at first; divine love can only be described using the vocabulary of human love.]

\section{7.}

Oroz Arizcuren, Francisco Javier. La lírica religiosa en la literatura provenzal antigua. Pamplona: Institucion príncipe de Viana (EXCMA), 1972; Tübingen, 1975. [Anthology of fifty-five lyrics chosen for their religious orientation; the corpus is necessarily flexible, since the dividing line between religious and secular is difficult to draw; critical texts with Spanish translation, textual notes, and glossary.]

\section{8.}

Ricketts, Peter T. "Deux textes occitans portant sur la vie de la vierge Marie, une chanson de la nativité et une plainte." RLaR 105 (2001): 235-46. [Edition of two texts, one edited in 1871 by Bartsch, one unedited; brief introduction, notes; no translation.]

\section{9.}

Secor, John R. "The Planctus Mariae in Provençal Literature: A Subtle Blend of Courtly and Religious Traditions." In 104, Spirit of the Court, 1985, pp. 321-26. [The grieving of Mary at the foot of the Cross is a popular theme which often uses vocabulary and emotions similar to those of courtly poems; information on eight planctus in Occitan from the thirteenth to the fifteenth century, in which mystical love is described in terms of secular love, as Mary laments the loss of her son, her father, and her lover.]

\section{0.}

Seláf, Levente. Chanter plus haut: La chanson religieuse vernaculaire au Moyen Âge: essai de contextualisation. Paris: Champion, 2008. [A comparative investigation of the corpus of pious lyrics in Occitan, Old French, and Galician from the twelfth and thirteenth centuries; the tradition in Galician is clearly defined, but in the other two cases the generic borders are fluid and confused, and overall, the two are not alike; Seláf establishes a corpus of seventy pieces in Occitan, as opposed to almost 
three hundred in Old French and about fifty in Galician; special attention is given to bilingual songs at the beginning of the tradition (Sponsus) and to the technique of contrafacture; six hitherto unedited songs are printed from MS 43, Faculty of Medicine, Montpellier.]

\section{1.}

See 296, Verlato, "Il pretesto trobadorico," 2009. [Explores the possibility of another stream of poetic development, alongside the courtly stream that developed in Italy building on the troubadour tradition. The religious moralizing stream reflected in the Wolfenbüttel manuscript may represent a separate development not well preserved in the chansonniers; the poetry of Alberico da Romano may be a link between the two traditions and may indicate the forces at work at the moment of consigning the classic poetic tradition to the chansonniers.]

\section{2.}

\subsection{Non-Lyric}

Bianchi de Vecchi, Paola. "Un opuscolo inedito in lingua d'oc: Ayssi son las collatios de XII. Sanz Payres ermitas (MS 9 della Biblioteca della Chiesa Nuova di Assisi)." In Miscellanea di studi romanzi offerta a Giuliano Gasca Queirazza. Edited by Anna Cornagliotti et al. 2 vols. Alessandria: Edizioni dell'Orso, 1988, 1:23-47. [Introduction gives historical background, information on the manuscript, and linguistic analysis; the text is Franciscan, early fourteenth century, probably translated from an unknown Latin source, destined for community reading in support of Beguine spirituality; text with Italian translation, glossary.]

1523.

Centili, Sara. "Frammento di volgarizzamento in antico occitanico del De Claustro Animae di Hugo de Folieto." Rom 127.3-4 (2009): 416-45. [Edition of a fragment found on the binding cover of a fourteenth-century manuscript of notarial acts; the only known medieval translation of the allegorical text on monastic spirituality, containing the final part of Hugo's chapter 1 and all of chapters 2 to 4; language study places the text ca. mid-thirteenth century; Occitan text with facing-page Latin original and added Italian translation; critical apparatus is inserted after each paragraph.]

1524.

Davies, Peter V. "Le texte occitan d'un livre d'heures (Brunel no. 60); Médiathèque de Rodez, Ms 138): Edition critique.” RLaR 107 (2003): 343-97. [The Rodez manuscript is one of three fifteenth-century Books of Hours which have Occitan rubrics and texts among the Latin prayers and psalms; separate editions of the calendar, a Latin Ave Maria with intercalated stanzas in Occitan, and eight Occitan rubrics introducing Latin texts.]

1525.

Giannini, Gabriele, and Marianne Gasperoni. Vangeli occitani dell'infanzia di Gesù. Edizione critica delle versioni I e II. Bologna: Pàtron, 2006. Introduzione, note ai testi e glossario di Gabriele Giannini, testi a cura di Marianne Gasperoni. [Three different 
apocryphal versions of the infancy of Jesus and the nativity of Mary from the beginning or middle of the fourteenth century; see important review article by Jean-Pierre Chambon, RLiR 72 (2008): 268-86.]

\section{6.}

Harris, Marvyn Roy. "The Occitan Story of Susanna (Ms BNF, fr 2426).” In - 140, Etudes Ricketts, 2005, pp. 153-62. [Fifteenth century, in Provençal dialect of Occitan, derived perhaps from a French tradition, perhaps a direct translation from the Latin Vulgate; careful edition with textual notes, no translation, short glossary.]

1527.

Hasenohr, Geneviève. "Modèles de vie féminine dans la littérature morale et religieuse d'oc." Cabiers de Fanjeaux 23: La femme dans la vie religieuse du Languedoc (XIIIe-XIVe s.). Paris: Privat, 1988. [Moral and religious guides for women are rare in Occitan compared to French, Italian, and Spanish; the image of the model wife is difficult to formulate alongside the model offered by the powerful finamor model of the domna; the Breviari d'Amor did not manage to reconcile the two and in fact, it disintegrates into incoherence by trying to do so; the only practical advice offered (by men) is to entrust oneself to the care of divine charity.]

1528.

Hasenohr, Geneviève. "Quelques opuscules spirituels du XIIIe siècle en langue d'oc (ms. Egerton 945)." In Devis d'amitié. Mélanges en l'honneur de Nicole Cazauran. Edited by J. Lecointe, C. Magnieu, I. Pantin, and M. C. Thomine. Paris: Champion, 2002, pp. 493-509. [Seven texts from the thirteenth century, imbued with the confident love of life characteristic of the South, aiming at the union of the soul with God; one of these is a translation of the famous Cistercian hymn Dulcis Jesu memoria, attributed to Saint Bernard but more likely by an English Cistercian, perhaps Saint Aelred; critical editions with notes, glossary, no translations.]

\section{9.}

Meliga, Walter. "Les sept douleurs et les sept joies de la Vierge en occitan du ms. London, Br Lib, Egerton 945." In 140, Etudes Ricketts, 2005, pp. 163-75. [Introductory remarks on previous scholarship; edition of the two fourteenth-century versions of the text, with notes, language study; no translation; Meliga notes that there are in fact seven joys, but only five sorrows in the extant version.]

1530.

Ricketts, Peter T. "Prayers in Medieval Occitan: Critical Edition, Translation and Notes." In Studies on Ibero-Romance Linguistics Dedicated to Ralph Penny. Edited by Roger Wright and Peter Ricketts. Newark: Juan de la Cuesta, 2005, pp. 127-51. [A collection of prayers in Occitan and French from the early fourteenth century, some in verse, some in prose; edition of twenty-six prayers with facing-page English translation, notes.]

\section{1.}

Ricketts, Peter T. "An Evangelium Infantiae in Medieval Occitan (Ms. Paris, BNF, nouv. acq. fr. 10453)." RPh 58 (2004): 1-49. [Edition, with a few textual notes; no translation; this is the most complete of the five versions in verse; for details 
of the history of Occitan translations of the Evangelium, see Giovanni Caravaggi, Vangeli provenzali dell'infanzia, Modena: STEM-Mucchi, 1963; this has the edition of a different version; Huber's edition of 1908 gives the Latin text at the foot of each page.]

\section{2.}

Ricketts, Peter T. "Un décalogue retrouvé, Lo Premier Comandamen: le texte occitan du ms. Paris, B.N.F., lat. 5030.” In 158, Studi Bertolucci Pizzorusso, 2006, 2:1383-95. [A hitherto unknown text of the Ten Commandments is identified as an introductory chapter extracted from the Libre dels vicis e dels vertutz, an Occitan translation of the Somme le roi; critical edition of the extract only, no translation, with variants from the other five Occitan manuscripts of the Libre dels vicis (which Ricketts is editing).]

\subsection{Sermons}

\section{3.}

See 38, DLF, 1992, p. 1376. [Contains an article by Geneviève Brunel-Lobrichon: "Sermons occitans"; general overview of sermons from the first half of the twelfth to the fifteenth century.]

\section{4.}

Hasenohr, Geneviève. "La prédication aux fidèles dans la première moitié du XIIe siècle. L'enseignement des 'sermons limousins.'” Rom 116 (1998): 34-71. [A reexamination of the "sermons limousins," to situate them more accurately in their cultural and religious context; close analysis of several manuscripts, including the collections of Tortosa and Organya, which give valuable insight into predication to ordinary people in the vernacular in the first half of the twelfth century and which deserve to be better known.]

\section{5.}

Indini, Maria Luisa. "L'Arlabeca provenzale, anonimo poemetto della fine del XIII secolo." $\operatorname{ZrP} 101$ (1985): 197-225. [Critical edition, based on both manuscripts, of the late thirteenth-century anonymous verse text on death and the vanity of the world; text with Italian translation, notes; the poem seems to fit with the gloomy and dispirited atmosphere of the post-crusade period, reflecting preaching to the common people by the mendicant orders, with stress on death and hellfire.]

\section{6.}

Pulega, Andrea. I sermoni in verso e l'Arlabeca. Bergamo: Istituto universitario di Bergamo, 1983. 365 pp. [A broadly based survey of Romance verse sermons and a detailed study of the Arlabeca, the only one found in Occitan; critical edition, with notes and glossary.]

1537.

Teulat, Roger. Sermons de Sant-Marçal, s. XII. Aurillac: Lo Convise, 1999. [Edition of the eighteen earliest sermons limousins from ca. 1120, perhaps from St. Martial de Limoges; texts with a brief introduction, translation into modern Occitan, notes, and glossary; the last sermon has been edited also in $\mathbf{2 4 2}$, Bec, Anthologie, 1987, 2:69-73.] 
1538.

Zink, Michel. La Prédication en langue romane avant 1300. Paris, 1976. [Presents documentary information on thirty Occitan sermons from the thirteenth century, as well as six Catalan sermons with Occitanisms; twenty-two Occitan sermons with Catalanisms; and three fifteenth-century Occitan sermons.]

1539.

Zorzi, Diego. Testi inediti francescani in lingua provenzale. Miscellanea del Centro di studi medievali, 1. Milan: Società editrice "Vita e Pensiero," 1956, pp. 249-324. [Detailed description of the manuscript in the Chiesa Nuova, Assisi; edition of two prayers, a confession, and twenty exempla, probably written by Mathieu de las Bosiguas as material for sermons to the common people; critical texts, full notes, no translation.]

\section{0.}

\subsection{The Bible and Apocrypha}

Fumagalli, Marina. "Ancora sui sette fratelli (Maccabei II, 7, versione valdese)." In 142, Studi Melli, 1998, 1:333-52. [Study and edition of an Old Testament text, translated into Occitan for the purpose of exhorting Waldensian Christians to put up with persecutions; part of a larger group of biblical translations intended for use in support of confessionals and penitentials; new critical edition, pp. 343-51, with copious notes, no translation; the Vulgate Latin text has been used to fill in the missing lines at the beginning.]

\section{1.}

Gasperoni, Marianne, with introduction, notes, and glossary by Gabriele Giannini. Vangeli occitani dell'infanzia di Gesù: edizione critica delle versioni I e II. Bologna: Pàtron, 2006. [Critical editions of version 1 and two separate redactions of version 2, to complete the modern edition of all three Occitan versions; critical editions by Gasperoni; introduction, commentary, glossary and index of proper names by Giannini; the detailed study of language and style leads to the hypothesis of a sort of koiné which may have been used in religious literary texts in southeastern France; see also the important review article by Jean-Pierre Chambon, RLiR 72 (2008): 268-86, with detailed remarks on lexical items and dialectal features.]

\section{2.}

Gosman, Martin. La Lettre du Prêtre Jean. Les Versions en ancien français et en ancien occitan. Textes et commentaires. Groningen: Bouma, 1982. [Study of the history, contents, and manuscript tradition of the legend; critical edition of several texts, including two Occitan versions, pp. 505-34, notes, pp. 564-68; for a key reference to Prester John by Cerveri de Girona, see Gosman's article in $\mathbf{9 4 ,}$ AIEO 1, 1987, pp. 219-27.]

\section{3.}

Harris, M. Roy. The Occitan Translations of John XII and XIII-XVII from a FourteenthCentury Franciscan Codex (Assisi, Chiesa Nuova MS 9). Transactions of the American Philosophical Society 75. Philadelphia: American Philosophical Society, 1985. 
[Detailed study of the manuscript and the sociocultural setting of its texts, translated possibly for the use of Franciscan Beguines; the two texts were probably done by two different translators.]

1544.

Harris, M. Roy. "The Occitan Epistle to the Laodiceans: Towards an Edition of MS PA 36 (Lyons, Bibliothèque municipale).” In Miscellanea di studi romanzi offerta a Giuliano Gasca Queirazza. Edited by Anna Cornagliotti et al. 2 vols. Alessandria: Edizioni dell'Orso, 1988, 1:427-46. Also available online, 2004, at http://www. rialto.unina.it. [Critical edition of the late thirteenth-century translation, with introduction, notes.]

\section{5.}

Harris, Marvyn Roy. "The Occitan Story of Susanna (MS BN, ffr 2426).” In 140, Études Ricketts, 2005, pp. 153-62. [Fifteenth-century text, in Occitan dialect of Provence, derived perhaps from a French tradition or perhaps a direct translation from the Latin Vulgate; careful edition with textual notes, no translation, short glossary.]

1546.

Harris, M. Roy, and Peter T. Ricketts. Nouveau Testament de Lyon (Lyon, Bibliothèque de la Ville, A.I.54/Palais des Arts 36). Online at http://www.rialto.unina.it. ["Forward" gives a brief description and localization of the manuscript; the electronic text complements that of Wunderli, 1552, 2009-10, and provides rich and copious textual notes, many of which discuss decisions taken by Wunderli; the latter's printed edition, along with the text, provides a full introduction, linguistic study, and glossary.]

1547.

Hasenohr, Geneviève. "Une passion inédite du XIe siècle." In Les cathares devant l'histoire: mélanges offerts à Jean Duvernoy. Edited by Martin Aurell, Anne Brenon, and Christine Dieulafait. Cahors: L'Hydre, 2005, pp. 207-31. [A retelling of the Passion, based on the four Gospels, intended to serve as a basis for individual meditation; edition, pp. 210-19; no translation; copious textual notes, pp. 219-31.]

1548.

Hershon, Cyril P. "Johan de Caulibus: Contemplatio vitae et miraculorum Jesu Christi (version occitane).” FL 140 (2005): 175-331.

\section{9.}

Izquierdo, Josep. "The Gospel of Nicodemus in Medieval Catalan and Occitan Literatures." In The Medieval Gospel of Nicodemus: Texts, Intertexts and Contexts in Western Europe. Edited by Zbigniew Izydorczyk. Tempe: Arizona Center for Medieval and Renaissance Studies, 1997, pp. 133-64. [Detailed exploration of the use of the Evangelium Nicodemi along with other texts in various Occitan and Catalan retellings of the life of Jesus; four texts, two in verse, two in prose, are analyzed in depth.] 1550.

Larzac, Jean. "La Bible en occitan." In Juifs et source juive en Occitanie. Enèrgas: Vent Terral, 1988, pp. 139-71. [A survey of extant biblical texts, pp. 141-50: the only remaining Occitan translations from the New Testament are those prepared by the Waldensians and the Cathars; although they are orthodox in content, they were 
preserved secretly or as evidence by the Inquisition, all others having been outlawed after the Albigensian Crusade; six books of the New Testament are extant, along with several books and individual episodes from the Old Testament, perhaps translated by the effort of Franciscans.]

\section{1.}

Wunderli, P. “Die mittelalterlichen Bibelübersetzungen in Südfrankreich.” Zeitschrift für Religions- und Geistesgeschichte 22 (1970): 97-112. [Overview of the field, including identification of texts and review of past research; suggests new structures for basic investigation of the Occitan biblical translations, combining expertise in theological, philological, and linguistic areas; many texts remain to be edited, and rigorous language studies of manuscripts and individual texts will be required before overall groupings may be studied reliably and the place of each text understood within the social context.]

\section{2.}

Wunderli, Peter. Le Nouveau Testament de Lyon (ms. Bibliothèque de la ville A.i.54/ Palais des arts 36). Vol. 1: Introduction et édition critique. Vol. 2: Analyse de la langue, Lexique et Index des noms. Tübingen: Francke, 2009-10. [Detailed description of the manuscript, review of recent scholarship; critical edition of the complete biblical text; linguistic study, glossary, index of proper names; complementary material may be found in the electronic edition by Harris and Ricketts 1546 , which has very rich and copious notes.]

\section{Hagiography}

[For Sainte Foy (Canso de Sancta Fides), see 17.8; for Brendan, see 18.5.]

\subsection{General Studies}

\section{3.}

Salvat, Joseph. "Vies de saints (en occitan)." In 38, DLF, 1992, pp. 1477-78. [Chronological listing of hagiographical texts.]

\section{4.}

Grange, Huw. "The Dragon-Heathen Allegory in Occitan Hagiography." In Actes du colloque Nouvelle recherche en domaine occitan: approches interdisciplinaires (Albi, 11-12 juin 2009). Turnhout: Brepols, in press. [Many Occitan saints' lives feature an encounter between a saint and a dragon, and in many cases the vernacular versions exaggerate the monstrosity of the beast and interpret variously its symbolism; four saints' lives are examined to determine how the interpretations reflect a society in flux.]

\section{5.}

Gaunt, Simon. "Si les anges avaient un sexe ... l'hagiographie occitane et son rapport avec la poésie lyrique des troubadours." In $\mathbf{9 6}$, AIEO 3, 1992, pp. 895-906. [Identifies three separate competing social models governing sexuality: (1) the feudal lay model using temporary virginity as an enhancement in dynastic marriage negotiations; (2) the church model, attempting to control marriage by advocating mutual 
freedom of choice, and chastity as a moral good; and (3) the courtly poetic model, subversively advocating free movement of women in society; all three were governed by masculine-controlled interests; a close look at how Occitan hagiographical texts responded to these complex forces, principally Sainte Foy, Sainte Enimie, and Saint Honorat.]

\section{6.}

Brunel, G. "Les saints franciscains dans les versions en langue d'oc et en catalan de la Legenda aurea." In Legenda aurea: sept siècles de diffusion: actes du Colloque international sur la Legenda aurea: texte latin et branches vernaculaires à l'Université du Québec à Montréal, 11-12 mai 1983. Edited by Brenda Dunn-Lardeau. Montréal: Bellarmin, 1986, pp. 103-15. [Overview of the three relatively independent Occitan versions of the Legenda aurea, probably derived from an older lost Catalan version; the life of St. Anthony of Padua is examined in detail in Occitan and Catalan manuscript traditions; in appendix, pp. 113-15: edition of the life of St. Anthony from the oldest Occitan manuscript, no translation.]

1557.

Tausend, Monika. Die altokzitanische Version B der Legenda Aurea. Beihefte zur ZrP 262. Tübingen: Niemeyer, 1995. [Detailed outline of contents of all the Catalan and Occitan versions of the Legenda; edition of 106 saints' lives, with notes; no translations; detailed language study, glossary, index of proper names.]

\section{8.}

Zinelli, F. "La Légende dorée catalano-occitane. Étude et édition d'un nouveau fragment de la version occitane." In 124, L'occitan: une langue du travail, 2009, pp. 263-350. [Very detailed analysis of recent scholarship concerning hagiographical texts in Occitan and Catalan, in particular the Legenda aurea; detailed linguistic study of the main versions; critical edition of the new fragment, with copious notes and complete photographic reproduction.]

\subsection{Barlaam et Josaphat}

\section{9.}

[Occitan prose translation, late thirteenth or early fourteenth century.]

Pitts, Monique Bonnier. Barlam et Jozaphas. Roman du XIVe siècle en langue d'Oc (BN fr 1049). Edition critique, traduction, notes et commentaires. Paris: Publications de l'Institut de langue et littérature d'oc, 5. Paris: Presses de l'Université de Paris IV, 1989. [Detailed description of manuscript; critical edition with facing-page French translation, notes, commentary; analysis of text structure, personages, themes, sources; no definitive link is found with Cathar traditions.]

1560 .

See Brunel-Lobrichon, Geneviève, in 38, DLF, 1992, pp. 125-26. [History of the legend in European literature.]

1561.

Bräm, Toni. La version provençal de Barlaam et Josaphat, une oeuvre cathare? Constanz: Hartung-Gorre, 1990. [A very careful analysis of the Occitan text, and a 
meticulous comparison with the Latin source, support and strengthen the conclusion by Monique Pitts that there is no direct Cathar influence on the translation.]

\subsection{Vida de la Benaurada Sancta Doucelina}

[The life of Douceline de Digne, 1214-74, Beguine nun, sister of the Franciscan Hugues de Digne; text from ca. 1297 in fifteen chapters, probably by Philippine de Porcellet, who succeeded her as head of the beguinage.]

\section{2.}

Gout, Raoul. La Vie de Sainte Douceline; texte provençal du XIVe siècle, traduction et notes. Paris: Bloud et Gay, 1927. [Introduction gives information about her life, the author, the social role of Douceline, and her mysticism; text in French translation, with the original Occitan below it, notes, and description of the manuscript.]

\section{3.}

Garay, Kathleen, and Madeleine Jeay. The Life of Saint Douceline, a Beguine of Provence. Cambridge: D. S. Brewer, 2001. [Text in English only, with introduction, notes, and interpretive essay.]

\section{4.}

Bonnet, Marie-Rose. "Douceline et le Christ, ou la fenêtre ouverte." In Par la fenestre: études de littérature et de civilisation médiévales. Actes du 27e colloque du CUER MA, février 2002. Edited by Chantal Connochie-Bourgne. Aix-en-Provence: Publications de l'Université de Provence, 2003, pp. 43-55. [Analysis of ritualistic elements in the text of Douceline's life, which place it firmly in the tradition of the hagiographic genre; in particular, the image of the window in the sick man's cabin seems to demarcate a boundary between the real world and the divine.]

\section{5.}

Brunel-Lobrichon, Geneviève. "Vie de Sainte Douceline." In Voix de femmes au Moyen Âge: savoir, mystique, poésie, amour, sorcellerie XIIe-XVe siècle. Edited by Danielle Régnier-Bohler. Paris: Robert Laffont, 2006, pp. 283-370. [Introduction, bibliography; text in modern French translation only.]

\section{6.}

Jeay, Madeleine, and Kathleen Garay. "Douceline de Digne: de l'usage politique de l'extase mystique." RLR 106 (2002): 475-92. [The carefully orchestrated details of Douceline's ecstatic paranormal powers are designed to enhance the political prestige of Charles I of Anjou and his family, as well as to strengthen the threatened position of the religious Beguine community.]

\section{7.}

Marinoni, Maria Carla, "Il drago e la principessa. Considerazioni su una Vita di S. Giorgio occitanica." ACME 57.3 (2004): 161-82. [Comparison of lines 571-94 of the Occitan text with equivalent sections in the Legenda aurea, and in three Old French versions; edition of lines 32-270 containing the episode with the dragon, with Italian translation; study of the figure of the dragon in legend and hagiography.] 


\subsection{Vida de Santa Enimia}

[Beginning of thirteenth century; two thousand lines, written by Bertran de Marselha, at the request of the prior of the monastery of Sainte-Enimie en Lozère, in order to legitimize the cult of the saint's relics and increase the prestige of the institution; from a twelfth-century Latin Vida, with some rearrangement, and the addition of two new miracles; Enimia was the daughter of Clovis.]

\section{8.}

Brunel, Clovis. Bertran de Marseille: la Vie de Sainte Enimie, poème provençal du XIIIe siècle. Paris: Champion, 1916. [Introduction to the poet; sources, manuscript, structure, and versification; text, notes, no translation.]

1569.

Okada, Machio. "La Vie de Sainte Enimie, texte établi d'après le manuscript unique, Bibliothèque de l'Arsenal 6355." Journal of Social Sciences and Humanities (Tokyo Metropolitan University) 255 (1994): 1-48. [Notes are in French.] 1570.

Álvares, Cristina. "Le corps féminin dans La Vie de Sainte Enimie de Bertrand de Marseille." In 99, AIEO 6, 2001, pp. 301-9. [Study of the structure of Enimie, seen as a dialectic between sacré and saint, between her life as a living body and the actions of her body after death; her saintly relics are appropriated by the masculine church to serve its purposes. The Life too is a masculine construct, making the female body serve to enhance the prestige of the monastery.]

\section{1.}

Álvares, Cristina. "L’ange et la nuit: corps et lieu de la vérité dans la Vie de Sainte Enimie de Bertrand de Marseille." RLaR 110 (2006): 351-61. [Explores traces of very ancient motifs of mythology and folklore, such as the appearance of dragon and angel at night; the saint's relics are important because they lead to exploitation and confrontation between the monarchy and the church, between Paris and the provinces, between men and women; men hesitate and calculate at the words of the angel, but Enimie believes and accepts immediately; the revelation of her miraculous body by the angel suggests the imagery of the Incarnation of Jesus.]

1572.

Álvares, Cristina. La peau de la pierre: étude sur la "Vie de Sainte Enimie" de Bertrand de Marseille. Braga: Universidad do Minho, Centro de Estudos Humanisticos, 2006. [A study of the structures and narrative techniques of the work, to clarify the ideological, literary, and religious aspects of its background.]

\section{3.}

Gouiran, Gérard. "Le regard sur l'autochtone: Sainte Enimie en Gévaudan." In Actes du colloque Languedoc et langue d'oc (Toulouse, janvier 1996). Perspectives médiévales, special number, supplement to 22 (1996): 105-17. [A rather bemused telling of the legend of Sainte Enimie, favoring the solid characteristics of the native Gevaudanais, and of Enimie herself, over the arrogant French who tried (in vain) to take away the saintly relics for themselves; maybe the unknown author, Bertran de Marselha, shared the folk characteristics of his people.] 


\subsection{Vida del Glorios Sant Frances}

[Occitan translation of the biography of St. Francis of Assisi by St. Bonaventure, 1263.]

1574.

Arthur, Ingrid. La "Vida del glorios Sant Frances," version provençale de la "Legenda maior sancti Francisci” de Saint Bonaventure. Uppsala: Almqvist and Wiksells, 1955. [Study of the manuscript, language; edition of text, notes, glossary; no translation.] 1575.

Arthur, Ingrid. Miracles que Dieus ha mostratz per Sant Frances apres la sua fi: version occitane de la Legenda maior sancti Francisci, miracula de Saint Bonaventure, édition critique et étude de la langue. Uppsala: Almqvist and Wiksell, 1992. [Detailed study of the manuscript; comparison of the Occitan text with the Latin source; language study; critical edition, pp. 142-73, with notes, glossary, proper names; no translation; see additional lexical material added by Max Pfister, $\operatorname{ZrP} 111.1$ (1995): 126-32, by J.-P. Chambon, RLiR 58 (1994): 565-72, and by Roy Harris, Rph 49 (1996): 429-49.]

\section{6.}

Cholakian, Rouben. "Saint Francis and the Provençal Connection." Tenso 17.2 (2002): 35-53. [Saint Francis is a "troubadour" in the Oedipal sense that he is searching for "perfect joy" (fin'amors); the idealized woman is unattainable; desire arouses distancing and timid awe; the father (rival/gilos) renders the quest precarious; the goal is a romance that is abstract, otherworldly, and self-valorizing.]

\subsection{Vida de Sant Honorat}

[Verse text of 9,275 lines by Raimon Feraut, adapted from a Latin prose vita; a Cistercian abbey was founded on the Ile de Lérins ca. 410 by Honorat, hermit, monk, later bishop of Arles.]

1577.

Ricketts, Peter T. La Vida de Sant Honorat. With the collaboration of Cyril P. Hershon. Turnhout: Brepols, 2007. [Incorporates Ingegärd Suwe's 1943 edition of the first two books, the life of Honorat, with minor changes, and adds the final three books: the miracles of St. Honorat and the history of the Lérins monastery; the Occitan text is accompanied by critical apparatus, notes on the facing page; glossary; no translation; a synopsis in French of the first two books may be found in Suwe's 1943 edition, pp. iii-xxii.]

1578.

Busby, Keith. "Hagiography at the Confluence of Epic, Lyric and Romance: Raimon Feraut's La Vida de Sant Honorat." ZrP 113 (1997): 51-64. [Raimon was cultivated and widely read, influenced by several genres, religious and secular: epic, lyric, and romance, as well as hagiography; his work is situated in the center of the vernacular literary traditions of his time.] 


\subsection{Viatge al Purgatori de Sant Patrici}

[Catalan or Occitan text by Ramon de Perillos, 1398; some content taken from Henri de Saltrey's twelfth-century Latin prose Tractatus de purgatario s.

Patricii. Recounts Ramon's pilgrimage to the Irish sacred site to save the soul of John I of Aragon, who had died in 1396 without confession; similar to Bernat Metge's contemporary text Lo Somni.]

1579.

Jeanroy, Alfred, and A. Vignaux. Voyage au Purgatoire de Saint Patrice, Visions de Tindal et de Saint Paul, textes languedociens du quinzième siècle. Bibliothèque méridionale, 8. Toulouse: Privat, 1903. [Historical introduction; linguistic study fixing the language as in the area of the Toulousain/Albigeois; the possibility of a lost Catalan original is mentioned, but not corroborated; critical text with textual notes, no translation.]

\section{0.}

Colón, G. "Filiation des textes du Voyage au Purgatoire de Raimon de Perillós. Mise au point." MR 7 (1980): 429-40. [Comments on his earlier article in MR 1 (1974): 44-60, and his disagreement with Finazzi-Agro, 1582, 1974: detailed dialectal evidence still points to the likelihood that the lost original of the Viatge was written in Catalan.]

\section{1 .}

Di Febo, Martina. "Viatge al Purgatori de Sant Patrici di Ramon de Perelhos: dalla visione al viaggio." Parola del testo (2008): 309-30. [Comparison of the various versions of the narration, stressing the ironic nature of Ramon's position as both narrator and protagonist.]

1582.

Finazzi-Agro, E. "Originale provenzale o catalano? Recenti contributi allo studio del Viagio al Purgatorio di Sant Patrizio." CN 34 (1974): 163-79. [Discussion of previous scholarship on the textual history of the Viatge, including close analysis of Colón's article; on the basis of Ramon's widespread voyages and diplomatic activities across the Catalan and Occitan areas, the text was more likely to have been written in Occitan, to appeal to the Occitan audience that Ramon was anxious to reach.]

\subsection{Other Saints}

\section{3.}

Cambell, P. Jacques, OFM. Vies occitanes de Saint Auzias [=Elzéar] et de Sainte Delphine avec traduction française, introduction, notes. Rome: Athénée Pontifical SaintAntoine, 1963. [Text originally in Latin, translated into Albigeois near the end of the fourteenth century; Elzéar de Sabran (1285-1323) and his wife Delphine (12831360) lived chastely and did many good works; Elzéar was canonized 1369; Delphine founded the Beguines at Marseille, was beatified, not canonized, but is popularly called Saint Delphine, celebrated 26 November.]

1584.

Cierbide Martinena, Ricardo. “Consideraciones lingü.sticas al poema La Vie de Saint 
Trophime de Bertrand de Boysset (s. XIV).” In 102, AIEO 9, 2011, pp. 171-82. [Description and history of the manuscript containing the Roman d'Arles and several other texts; linguistic study of the anonymous text on the legendary Saint Trophime, copied by Bertrand from an unknown source; concludes that the language traits reflect precisely the usage at Arles in the late fourteenth century.]

1585.

Gambino, Francesca. "Vita e miracoli di santa Flora di Beaulieu. Edizione del testo provenzale con note e glossario." ZrP 124 (2008): 1-84. [Sainte Flour, a nun, 130947 , entered the convent at fourteen in 1324; canonized 1360, formally in 1482; her Latin vita, written by her confessor, but now lost, was translated into Occitan before 1482; the introduction gives the historical background of her family from 1238 on, and a language study; text in 109 chapters, with notes, glossary; also online, 2010, at http://www.rialto.unina.it, with facing Italian translation.]

\section{6.}

Manetti, Roberta. La passione di santa Margherita d'Antiochia. Testo occitano del XIII secolo. Florence: Alinea, 2012. [Legendary life and passion of the popular saint swallowed by the Devil in the form of a dragon, freed by the sign of the cross and venerated in many vernacular poems; critical edition of the long version, with introduction, Italian translation, commentary, and complete glossary.]

1587.

Marinoni, Maria Carla. Il poemetto occitanico sulla Vita di Maria Maddalena. Edizione critica. Milan: CUEM, 2002. [Close analysis of the two manuscripts of the text confirms that there was a lost common archetype.]

\section{8.}

Pomponio, Rita, and Michael Routledge. "La Vie de Sainte Marie-Madeleine du manuscrit de Bertran Boysset.” In > 97, AIEO 4, 1994, pp. 275-86. [Historical study of the legend of Marie-Madeleine; analysis of the manuscript of Aix compared with other versions in Latin, English, and French, showing that this version is richer and more fully developed; the text with French translation has now been published, based on the manuscript of Aix, by Michael Routledge in FL 125 (1997): 9-89.]

For Saint Vou, see PC 175,1 Geneys lo joglars.

\section{Nonliterary Texts}

\subsection{General}

\section{9.}

See 242, Bec, Anthologie de la prose, 1987 and 1997. [A wide selection of prose texts from different fields; vol. 1 has the texts of seven vidas, five razos, six extracts from chronicles, six letters, and seventeen prose narrative extracts, with brief introductions, notes, and French translation; vol. 2 has six extracts each from grammatical treatises, moral-religious literature, and juridical texts, nine extracts from scientificdidactic works, all with French translation, notes; twelve inscriptions, with brief 
notes, no translations; the glossary in vol. 2 covers both volumes; see comments and suggestions by Gouiran, RLaR 92 (1988): 410-17.]

1590.

Fleischman, Suzanne. "The Non-lyric Texts." In 281, Handbook, 1995, pp. 167-84. [A survey of the wide variety of Occitan non-lyric literature, from narrative romance through the novas, epics, saints' lives, drama, didactic texts, grammars, and scientific works; rich bibliography.]

\section{1.}

Gouiran, Gérard. "Jeux de mains et jeux de langue: quelques questions à propos de la langue des textes médiévaux de prose occitane." Roundtable discussion: "Les problèmes de l'édition de textes occitans non-littéraires du Moyen Âge." In \ 95, AIEO 2, 1993, 2:1043-48. [Guiding principles for the edition of nonliterary prose texts in Occitan; it will continue to be difficult to specify dialectal traits until more archival materials have been published, providing a sort of linguistic atlas for the medieval period, as projected by Dees; allowance must also be made for the fact that the written documents may reflect influences from the literary koiné rather than the living spoken language, except through slips and errors.]

\section{2.}

Vielliard, F. "Les traductions des classiques dans la littérature médiévale occitane." In - 124, Loccitan: une langue du travail, 2009, pp. 223-37. [A survey of the diffusion of texts through translation, starting with a listing of the relatively few Latin classics that were available in Occitanian libraries; legal, medical, moralistic texts: Lo Codi, the Secretum secretorum, a half-dozen moralistic works; works of history, politics, and mythology, frequently translated into French, were not translated into Occitan, perhaps because the southern culture thought of its own troubadours as authorities.]

\subsection{Flora and Fauna}

1593.

Capaccioni, Francesco, and An Smets, "Aucunas medecinaz per l'esparvier: édition de quelques recettes vétérinaires en ancien occitan et en franco-provençal." Rom 125 (2007): 229-38. [Introduction; critical edition with following French translation and glossary; annex: listing of marginal translations in Occitan; see also the review by Zufferey, Rom 125 (2007): 511-15, who comments on vocabulary, localization, and date: Dauphiné/Provence, fifteenth century, and shows that the eighth recipe is French, not Francoprovençal.]

\section{4.}

Corradini, Maria Sofia. "Formalisation des variantes à des fins computationnelles: vérification de l'hypothèse expérimentale sur un texte occitan." In $\ \mathbf{1 4 0}$, Études Ricketts, 2005, pp. 355-68 [An experimental stemma of the Occitan translation of Odo de Meudon's De viribus herbarum (Macer Floridus) using computer technology; the result is a confirmation of her traditional study in SMV 37 (1991): 31-132.]

1595.

Milani, Matteo. "Appunti lessicali su un erbario occitano (Firenze, Biblioteca 
Nazionale Centrale, Palatino 586)." In Giornate di studio di lessicografia romanza: il linguaggio scientifico e tecnico (medico, botanico, farmaceutico e nautico) fra Medioevo e Rinascimento. Atti del convegno internazionale, Pisa, 7-8 novembre 2003. Edited by M. Sofia Corradini and Blanca Perinán. Pisa: Edizioni ETS, 2004, 109-41. [Description of the manuscript; detailed glossary of 184 herbs, pp. 113-28; edition of the text, pp. 128-41; no translation; this is a follow-up to his previous article on the same text in La parola del testo 8 (2004): 369-91.]

\section{6.}

Ricketts, Peter T. "Le lexique des plantes médicinales en occitan médiéval." In Giornate di studio, see 1595, Giornate di studio di lessicografia romanza, 2004, pp. 17379. [Outlines the state of research in the area, much advanced in recent years, and the promise of much more information to come in the DOM and COM; botanical identification requires further research, as well as the varied designations of some sicknesses and plants; as an example, Ricketts explores the rich lexical complexities of a single medicinal flower, the larkspur/pied d'alouette/consoude/delphinium /comfrey.]

\subsubsection{Romans dels auzels cassadors}

[Verse treatise on falconry by Daude de Pradas; mid-thirteenth century; 3,792 lines; inspired by a number of Latin treatises (Alexander medicus, Grisofus medicus, Gerardus falconarius, De cura accipitrum of Adelard of Bath, and probably the apocryphal letter to Ptolemy, king of Egypt; Daude also composed seventeen lyric poems (see PC 124) and El romanz de quatre vertutz principals (see 22.9).]

\section{7.}

Schutz, Alexander Herman. The Romance of Daude de Prades called "Dels Auzels Cassadors." Edited with introduction, summary, notes, and glossary. Columbus: Ohio State University Press, 1945. [Introduction on the author, the manuscripts, sources, and versification; detailed résumé in English, pp. 25-50; text, pp. 65-203, with notes, brief glossary, no translation; see the review article by Kurt Lewent, Studia neophilologica 35 (1963): 3-17: detailed discussion of eleven difficult passages.]

\section{8.}

Capaccioni, Francesco. "Le fonti del Roman dels auzels cassadors di Daude de Pradas." In La caza en la edad media. Edited by José Manuel Fradejas Rueda. Tordesillas: Seminario de Filología Medieval, Universidad de Valladolid, 2002, pp. 25-37. [Detailed study of the five extant manuscripts; precise analysis of Daude's use of several Latin sources; Capaccioni is preparing a new critical edition: see his thesis: Lavore preliminare alla edizione critica del trattado "Dels auzels cassadors" di Daude de Pradas. Unpublished doctoral thesis, Università degli Studi di Perugia, 2000.]

\section{9.}

Evans, Dafydd. "Le traité de fauconnerie en vers provençaux Dels auzels cassadors, son intérêt culturel." In La Chasse au Moyen Âge. Actes du colloque de Nice (22-24 juin 1979). Nice: Centre d'études médiévales de Nice/Belles Lettres, 1980, pp. 9-17. [Analysis of sources and the relationship of the text to other treatises.] 
1600.

Evans, Dafydd. "Les noms des plantes employés par Daude de Pradas dans son traité Dels auzels cassadors." Marche romane 33 (1983): 65-73. [Lexical presentation by word groupings of the names of plants and trees used in the section on remedies; the translator worked very diligently to find precise Occitan equivalents for the Latin terms of his sources.]

\section{1.}

Evans, Dafydd. "Difficulties in the Botanical Lexis of the Old Provençal Falconry Treatise: Daude de Pradas and Adelard of Bath.” In 159, Studia occitanica, 1986, 2:281-89. [Close comparison of a passage of the Auzels cassadors with one of its Latin sources indicates the generally high reliability of Daude's treatise, though some of the plant names may be lacking in precision.]

\section{2.}

\subsection{Legal}

Akehurst, F. R. P. “The Legal Background of the Troubadours and Trouvères.” In - 110, Cultural Milieu, 1994, pp. 16-33. [Survey of the three types of law: feudal, customary, and Roman (civil) law; the troubadours do not use specific legal terminology, but the vocabulary and practices of feudal law serve as figurative representations of the relationship between lover and lady, depicted as that between vassal and lord; a detailed look at the words and images of Bernart de Ventadorn shows that these have nothing to do with the formal law of inquest but represent a petition for favor rather than a legal claim.]

1603.

Akehurst, F. R. P. The "Costuma d'Agen": A Thirteenth-Century Customary Compilation in Old Occitan Transcribed from the "Livre Juratoire." Turnhout: Brepols, 2010. [Collection of customary laws from the Agenais region; edition with facing-page English translation; the introduction gives information on thirteenth-century society: economic concerns, social relations among classes and within families, and law enforcement; legal vocabulary used figuratively by the troubadours; index, several appendices.]

\section{4.}

Biu, Hélène. "Prolégomènes à une édition critique de l'Arbre des batailles d'Honorat Bovet et de ses traductions en langues romanes." Revue d'histoire des textes n.s. 2 (2007): 211-49. [Text composed in 1386-89, in French, to clarify the juridical implications of war and duels; Biu has undertaken a preliminary classification of the one hundred or so manuscripts, including translation into several languages; see pp. 228-35 for a description of the unedited Occitan version, from the early fifteenth century; several manuscripts of the French long version contain Occitanisms.]

\section{5.}

Paden, William D. "A Notarial Roll in Latin and Occitan from Asprières (Aveyron), 1284, in the Newberry Library, Chicago." CN 63 (2003): 7-55. [Critical edition of eight charters, with English translation, notes, and glossary; much information 
on town life, property ownership, and historical context; see also Paden's "Roll vs. Codex," RST 6-7 (2004-5): 153-83, in which he finds that both forms were widely used, with rolls more frequent in the South than in the North, determined not by the physical properties of either format but by regional tradition.]

\section{6.}

Santomá Juncadella, Luís. "El milagro de la mujer lapidada. Crítica literaria de la versión en occitano cispirenaico aragonés/The Miracle of the Lapidated Woman. Literary Study of the Cispyrenaic Aragonese Occitan Version.” Revista de Filología Románica, 1 January 2010, at http://readperiodicals.com/201001/2101077741. html. [Historical and literary study of an exemplum used to support the establishment of juridical practices in the earliest Aragonese customary text, the Fuero de Jaca, from the second half of the thirteenth century.]

\section{7.}

\subsection{Scientific}

Bernard, Katy. "L’arbre et ses dérivés dans les traités divinatoires et magiques occitans: configuration astrale et figures géomantiques." In L’Arbre au moyen âge. Paris: Presses de l'Université Paris-Sorbonne, 2010, pp. 33-52. [Analysis of Occitan texts from two Paris manuscripts demonstrates the use of wood, cleanliness, and natural materials in the practice of geomancy and necromancy; astral signs seem to have been more important in determining the best time to plant trees or crops, or to take a wife or build a castle, than any "scientific" understanding of the forces involved.]

\section{8.}

Calvet, Antoine. Le Rosier alchimique de Montpellier. Lo Rosari. Paris: Presses de l'Université de Paris-Sorbonne, 1997. [Lo Rosari is a fourteenth-century Occitan translation of the Latin alchemy text of Arnald of Villanova, describing the transmutation of metal into gold; the introduction provides information on the author, the manuscript, the Latin source, and the language; edition of the Occitan text, with facing-page French translation and glossary; see the detailed review by J-P.Chambon, RLaR 101.2 (1997): 250-56.]

\subsubsection{Elucidari (Elucidari de las proprietatz de totas res naturals)}

[Ca. 1350; translation/adaptation, for Gaston Phebus, into Occitan rhyming prose of the twenty books of De rerum proprietatibus by Bartholomaeus Anglicus; illustrated by the same artists as the Breviari; maybe translated by a Dominican monk who is pictured in the manuscript; an added verse prologue of 184 lines is called Palaytz de Savieza.]

1609.

Scinicariello, Sharon Guinn. A Critical Edition of Books I-VII of the "Elucidari de las proprietatz de totas res naturals." PhD diss., University of North Carolina, 1982. DAI 43:5, Ann Arbor, \#1538A. [Edition includes the Palaytz de Savieza prologue.]

1610.

Badia, Lola. "Pour la version occitane du De rerum proprietatibus de Barthélemy 
l'Anglais (XIVe siècle)." In \$99, AIEO 6, 2001, pp. 310-26. [Detailed description of the whole MS Paris, Ste Geneviève 1029, and its subdivisions; analysis of past scholarship; edition of book 8, chapter 28: Del Solelh, chosen because Gaston III used the sun as a symbol in his coat of arms, three centuries before Louis XIV.]

\section{1.}

Ventura, Simone. Cultura enciclopedica nell'Occitania dei trovatori: il libro XV dell' "Elucidari de las proprietatz de totas res naturals." Florence: Sismel, 2010. [Critical edition, with Italian translation and commentary, of book 15: De las proensas et regios del mon, which provides a fourteenth-century perspective on world geography.]

\section{2.}

Crespo, Roberto. "Il Palaytz de Savieza e la Consolatio philosophiae." MR 6 (1979): 315-19. [Comparison of the prologue to the Occitan Elucidari with the Latin text of Boethius shows a number of striking parallels, especially between the descriptions of Savieza and Philosophia; the Consolatio must have been very familiar to the translator, who drew inspiration from it without translating directly.]

1613.

Evans, D. "L'emploi de la rime dans l'Elucidari." CN 38 (1978): 87-93. [The text contains some traditional verse, arranged in distichs, and, more frequently, rhymed prose, following the example of the Latin original, and of the contemporary Ramon Llull, who used a mixture of prose and verse, as well as rhymed prose.]

\section{4.}

Ricketts, Peter T. "La traduction du De proprietatibus rerum de Bartholomé l'Anglais en occitan." In Froissart á la cour de Béarn: l'écrivain, Pau/Orthez, octobre 2006. Turhout: Brepols, 2008, pp. 215-21. [Brief overview of the lengthy work itself, and the team project to edit it all; a few words of comment on book 4, comparing the Latin source text with the French and Occitan translations.]

\section{5.}

Ricketts, Peter T. “L'ouïe et la surdité dans l'Elucidari de Barthélémy l'Anglais." In 101, AIEO 8, 2009, 1:451-55. [Exploration of medieval thinking about hearing and deafness and the difficulties of expressing these thoughts in vernacular translation; hearing problems could be caused by noise, damage to the nerves or brain, worms, or excessive commerce with women; the Occitan translation is sometimes abbreviated, sometimes expanded by commentary or redoubled vocabulary, occasionally reformulated in elegant fashion.]

1616.

Ventura, Simone. "Autour de la version occitane du De proprietatibus rerum de Barthélémy l'Anglais." In Textes et cultures: réception, modèles, interférence. Edited by Pierre Nobel. 2 vols. Besançon: Presses Universitaires de Franche-Comté, 2004, 2:47-64. [Analysis of the complex chain of procedures that are involved in the production of such an ambitious codex; outline of the overall structure of the Paris MS, Ste Geneviève, 1029, with its division into twenty books, marked by colored initials and decoration, interior chapters marked by rubrics, with alternating blue and red paraphs showing further subdivisions; two alphabetical tables, one at the beginning 
by incipit and one at the end by concept; Ventura shows that the manuscript was ordered by Gaston III as part of his political affirmation of independence in the late 1360s; he probably composed PC 494,1.]

\subsection{Medical}

1617.

Corradini, Maria Sofia. Ricettari medico-farmaceutici medievali nella Francia meridionale Vol. I. Florence: Olschki, 1997. [Vol. 1 is the only one that has appeared: it contains the edition of texts from three manuscripts, preceded by a detailed historical and linguistic study of all three; eight texts are reproduced online at http:// www.rialto.unina.it, with a few corrections, no notes: (1) Ricettario di Princeton, (2) Ricettari di Auch, (3) Ricettari di Chantilly, (4) Las vertutz de las herbas, (5) Lettera di Ippocrate a Cesare, (6) Thesaur de pauvres, (7) Appendix to Thesaur de pauvres, and (8) Rimedi per le febbri; vol. 2 will give texts from two further manuscripts; vol. 3 will present a cumulative lexicon.]

\section{8.}

Corradini Bozzi, Maria Sofia. "La Fachliteratur médico-pharmaceutique en ancien occitan dans le contexte européen: des facettes culturelles et linguistiques." In $\mathbf{1 0 1}$, AIEO 8, 2009, 1:437-49. [Demonstration of the cultural and historical importance of "professional" medical texts; an attempted classification of texts taken from eight manuscripts into coherent groups, with a view to determining characteristic genetic traits; linguistic study will allow localization of centers of medical activity and the development of a technical language in keeping with scientific advances.]

1619.

Paterson, Linda M. "La médecine en Occitanie avant 1250." In \$4, AIEO 1, 1987, pp. 383-99. [A general survey of medical practices, texts, and translations in Occitania, especially the early development of surgery in Montpellier; mentions the possible use of medical terminology by the troubadours; in appendix, statistical count of "medical" personnel in Occitania compared with northern France; chronological list of medical works by authors from the South.]

\section{0.}

Zamuner, Ilaria. "Per l'edizione critica dei volgarizzamenti provenzali dell' Epistola ad Alexandrum de dieta servanda." In $\mathbf{1 0 0}$, AIEO 7, 2003, pp. 739-59. [Introduction to the pseudo-Aristotelian Secretum secretorum and its Arabic and Latin sources; the Epistola is a portion of the Secretum, dealing with political and moral exhortations, followed by advice on hygiene, diet, and pharmacology; as preparation for her critical edition of the Occitan versions, Zamuner studies the history of all Romance translations of the text, and in detail the Occitan manuscripts, which she places in late thirteenth century, in the context of active scientific enquiry in Montpellier; reprinted in The Medieval Translator, 11, Turnhout: Brepols, 2007, pp. 165-84.]

\section{1.}

Zamuner Candiani, Ilaria. "Un nuovo testimone della Chirurgia di Ruggero Frugardo in lingua occitanica (Siviglia, Biblioteca Capitular y Colombina, 5-5-20)." In 
Translatar i transferir. La transmissió dels textos i el saber (1200-1500). Primer colloqui internacional del Grup Narpan "Cultura i literatura a la baixa edat mitjana" Barcelona 22-24 novembre 2007. Santa Coloma de Queralt: Obrador Edendum/URV, 2010, pp. 191-240. [Comments on the relative lack of scholarship on scientific texts in Occitan and the need for information on authors, audiences, sources, and diffusion, working toward more critical editions and cumulative lexical studies; exploratory study of the transmission of the Occitan Chirurgia in its three manuscripts, especially the language and interrelationship of the two prose versions; study of the reception of the text and its influence.]

\subsubsection{Albucasis}

[Fourteenth-century translation into Occitan, by way of a Latin version by Gerardus of Cremona, late twelfth century, of chapter 20 of the Arabic medical encyclopedia Al-Tasrif by Abul Kassim Khalaf Ibn Abbas al-Zahrawi, late tenth century; made for Gaston Phebus in the court of Béarn, fourteenth century; similar in presentation to the Elucidari but not necessarily by the same translator.]

\section{2.}

Elsheikh, Mahmoud Salem. Abu'l-Qasim Halaf ibn 'Abbas al-Zahrawi [dit Albucassis], La Chirurgia: versione occitanica della prima metà del Trecento. Florence: Malesci, 1992. [Introduction gives detailed history of the text and its relationship to the Latin and to the original Arabic; edition, notes, partial language study, glossary; no translation; eight color plates.]

\section{3.}

Grimaud, Jean, and Robert Lafont. La Chirurgie d'Albucasim (ou Albucasis), texte occitan du XIVe siècle. Montpellier: Centre d'Études Occitanes, 1985. [Critical text, notes, language study, glossary; no translation; contains drawings of surgical instruments by Claude Fabre as found in the manuscript; see corrections and suggestions by Max Pfister, $\operatorname{ZrP} 104$ (1988): 387-92.]

\section{4.}

Trotter, David A. "Arabic Surgery in Eastern France and the Midi: The Old French and Occitan Versions of the Chirurgie d'Albucasis." Forum for Modern Language Studies 35 (1999): 358-71. [A provisional study of the transmission of technical vocabulary from Arabic through Latin into Old French and Occitan; the editions by Grimaud and Elsheikh do not provide sufficient textual accuracy nor lexical information.]

\section{5.}

Trotter, David A. "Fonction des gloses dans les textes latins, occitans et français de la Chirurgia Albucasis, in Textes et cultures: réception, modèles, interférence, vol. 2: Interférences et modèles culturels. Edited by Pierre Nobel. Besançon: Presses universitaires de Franche-Comté, 2004, pp. 23-46. [Sketch of the textual history of the treatise from its Arabic original through the Latin and vernacular versions; detailed comparative study of the use of specialized vocabulary in the Latin, Old French, and Occitan texts, showing that Arabic words posed a problem calling for help through 
illustrations (surgical instruments) and glosses; meticulous consideration of various types of glossing, with numerous examples.]

1626.

Trotter, David. "Per fort desir de saber: la Cyrurgia d'Albucasis, Gaston Fébus, et la science en occitan.” In Froissart á la cour de Béarn: l'écrivain (Pau/Orthez, octobre 2006). Edited by Valérie Galent-Fasseur. Turnhout: Brepols, 2008, pp. 195-213. [Remarks on the intellectual background of the court of Gaston Phébus at Béarn, plurilingual, deeply involved in current political events, and anxious to be part of the intellectual effervescence of the time; questions still unanswered about the targeted vernacular readers of such a specialized work; provisional study of twenty-three items as a sample of the lexicographic riches to be drawn from the text.]

\subsubsection{La Notomia}

[Anonymous translation into Occitan, by way of the French version, of book 1 of Henri de Mondeville's Latin Chirurgia, 1312.]

\section{7.}

Combes, Laure. La "Notomia de Anric de Mondavilla," traduction occitane de l'Anatomia" d'Henri de Mondeville. Publication for the Diplôme d'archiviste paléographe, École nationale des chartes, Paris, 2008. Résumé online: Positions des thèses de l'École des chartes, 2008, at http://theses.enc.sorbonne.fr. Full thesis available from the Archives nationales, Paris: AB XXVIII 1454. [Historical background of Mondeville and surgical practices of the fourteenth century; nature of the translation and its prologue; critical edition, glossary, study of scientific vocabulary; no translation.]

\section{8.}

Cornagliotti, Anna. "Il trattato occitano di Notomia di Anric De Mondavilla (Firenze, Laurenziana, Ashburnham 104).” Parola del testo (2009): 275-322. [Suggests that the text was used for practical teaching purposes for medical training; only Anatomia has come down to us in Occitan, the first of the five books of Mondeville's work; critical edition; Cornagliotti was unaware of Combes's edition.]

1629.

Gorosch, Max. La Notomia de Anric de Mondavilla. Montpellier: Centre d'études occitanes, 1975. [Critical edition with glossary and partial linguistic analysis.]

1630.

\subsection{History, Chronicles, Archives}

Léglu, Catherine. Research project announced by Catherine Léglu and a research team, Alexander Ibarz and Federico Botana: http://blogs.reading.ac.uk/manuscriptegerton-1500/. [Edition of Abreviamen de las Estorias (MS London, British Library, Egerton 1500), the only Occitan translation of the Chronologia magna of Paulinus of Venice, perhaps from the papal library but in any case attached to Avignon; contains at least nine texts in central Occitan, probably commissioned by a powerful family from the central area which moved to Avignon; Botana will study the complex program of illustration, a visual scheme as important for teaching purposes as the textual content.] 
1631.

Biu, Hélène. "La traduction occitane des Flores chronicorum de Bernard Gui." In - 124, Loccitan: une langue du travail, 2009, pp. 247-62. [An exploratory study comparing the Occitan translation with its possible Latin source in the fourth of ten versions of the Flores; Biu's goal of discovering the personality of the translator comes to nothing; analysis of two chapters of the work reveals a competent if uninspired translator, and a text that should be edited for its historical and linguistic value.]

\section{2.}

Laborie, Yan, Jean Roux, and Bernard Lesfargues. Johan Thoyr, "Lo libre de Vita": Le Livre de la Vie 1379-1382: Bergerac au coeur de la Guerre de Cent Ans. Gardanne: Fédérop, 2003. [Transcription of 120 legal depositions covering three years of turmoil during the Hundred Years' War; introductory study (Laborie), edition and detailed notes on the text (Roux), with French translation (Lesfargues).]

\section{3.}

Macé, Laurent. Catalogues Raimondins (1112-1229). Actes des comtes de Toulouse, ducs de Narbonne et marquis de Provence. Sources de l'histoire de Toulouse, 1. Toulouse: Archives Municipales de Toulouse, 2008, \#439) [List of documents from 1112 to 1229 , with an edition of those that were previously unedited.]

\section{4.}

Wüstefeld, W. C. M. "Las Merevilhas de la terra de Ybernia: une traduction occitane et son modèle." In \$4, AIEO 1, 1987, pp. 529-37. [Study of a description of Ireland in its Occitan and Latin forms; the Occitan translation of ca. 1324-30 had a moralizing, didactic intent; Wüstefeld demonstrates the interest of further study of the text along with several closely related works.]

\section{5.}

Hershon, Cyril P., and Peter T. Ricketts. "Las Merevilhas de la terra de Ybernia." FL 148 (2009): 233-97. [A condensed reworking, fourteenth century, of a Latin original by Gerald of Wales into Occitan (fifty-two chapters instead of the original fifty-four); the book is a report of the remarkable things seen in this distant land: fish, birds, animals, lack of serpents, magic, miracles, saints, and early history.]

\section{6.}

Widmayer, Jefferey S. "The Chronicle of Montpellier H119: Text, Translation and Commentary." In The Medieval Chronicle, \#4. Edited by Erik Cooper. Amsterdam: Rodopi, 2006, pp. 231-61. [The oldest of the manuscripts recording the local history of Montpellier, supposedly from 816 to1364, though the chronicle was probably started only in 1141, the earlier years having been filled in sporadically by collective memory; critical edition with English translation.]

1637.

Mandach, André de. Chronique dite Saintongeaise. Beihefte zur $\operatorname{ZrP}$, 120. Tübingen: Niemeyer, 1970. [A prose Franco-Occitan chronicle, thirteenth century; a detailed linguistic analysis distinguishes several historical substrata and reveals references to Old French epics; the language is composite and corrupted, making it sometimes difficult to understand.] 


\section{Related Fields (Diffusion, Influences)}

[See also 3.3. History of Occitan Scholarship, Reception Studies, Medievalism]

\section{Modern Occitan}

1638.

Bec, Pierre. Per un païs. Poitiers: IEO Vienne, 2002. [Collection of articles (19572001) on modern Occitan, mostly linguistic, some literary.]

1639.

Calin, William. “The Occitan Tradition: Interpreting Love Poetry of the Baroque." In 104, Spirit of the Court, 1985, pp. 120-28. [Especially Bellaud de la Bellaudiere, sixteenth century.]

1640.

Calin, William. "Occitan Literature Today: Cultural Identity and the Sense of the Past." Tenso 11 (1995-96): 64-77. [An explanation of the modern cultural awareness of Occitan identity through nostalgia and other factors.]

1641.

Davies, Peter. "Occitan Literature (Post-Medieval)." New Oxford Companion to Literature in French. Edited by Peter France. Oxford: Oxford University Press, 1995. Online at http://www.answers.com: topic: "post-medieval Occitan literature."

1642.

De Caluwé, Jacques. "Le mythe des troubadours dans la littérature occitane contemporaine.” Neo 64 (1980): 493-502. [Manifestations of the myth in the nineteenth century compared with a few occurrences in contemporary Occitan literature.]

1643.

Dupuy, André. Histoire chronologique de la civilisation occitane. 3 vols. Geneva: Slatkine, 1998. [Vol. 1: origins to 1599; vol. 2: 1600-1839; vol. 3: 1840 to the present; many illustrations, maps, index at end of vol. 3.]

1644.

Gardy, P., and F. Pic. Vingt ans de littérature d'expression occitane, 1968-1988: Actes du colloque international 1989. Montpellier: Section française de l'AIEO, 1990.

1645.

Hart, Thomas R. "Creating a Literature: Mistral and Modern Provençal." Journal of European Studies 21 (1991): 175-88.

\section{6.}

Lafont, Robert, and C. Anatole. Nouvelle histoire de la littérature occitane. 2 vols. Paris: Presses universitaires de France, 1970.

\section{7.}

Lafont, Robert. Baroques occitans: anthologie de la poésie en langue d'oc 1560-1660. Montpellier: Publications de l'université Paul-Valéry Montpellier 3, 2003. [Synthesis of Lafont's work since the late 1950s on Occitan writers of the Baroque period, with supporting texts.]

1648.

Sumien, Domergue. La Standardisation pluricentrique de l'occitan. Nouvel enjeu 
sociolinguistique, développement du lexique et de la morphologie. Turnhout: Brepols, 2007. [A practical guide to the use and teaching of modern Occitan in its various regional forms.]

\section{9.}

\section{Medieval Latin}

Bergner, Heinz, et al. Lyrik des Mittelalters: Probleme und Interpretationen. Stuttgart: Reclam, 1983. [Chapters on medieval Latin, Old Provençal, northern French lyric in vol. 1.]

1650.

Huglo, Michel. "La chanson d'amour en latin à l'époque des troubadours et des trouvères." CCM 25 (1982): 197-203.

1651.

Ladányi-Turóczy, Csilla. "Clerc et chevalier comme amoureux dans la poésie féminine des XIe et XIIe siècles (Domna Constantia, le Recueil de Ratisbonne et les poèmes des trobairitz)." In Études de littérature médiévale: Recherches actuelles en Hongrie. Edited by Katalin Halász. Debrecen: Debreceni Egyetem, 2000, pp. 63-79.

1652.

Rossi, Luciano. "I trovatori e l'esempio ovidiano." In Ovidius redivivus: von Ovid zu Dante. Edited by M. Picone and B. Zimmermann. Stuttgart: M \& P Press, 1994, pp. 105-48.

1653.

Brunel-Lobrichon, Geneviève. "La formation des troubadours, hommes de savoir." Cahiers de Fanjeaux 35 (2000): 137-48. [Sources of classical and religious literature available to the troubadours.]

\section{Catalan}

[About twenty-four poets are recognized as Catalan in origin, who used Occitan in whole or in part as their poetic language.]

\section{4.}

Els Trobadors. Website for Catalan trobadors: twenty poets; sociohistory, poems: http://www.xtec.es/ - malons22/trobadors/trobadors.htm. [A lively, colorful website.]

\section{5.}

Fratta, Aniello. "I trovatori nella memoria: citazioni trobadoriche nei poeti catalani dei secoli XIV e XV." In 107, Ab nou cor, 2004, pp. 229-40. [Mostly about narrative and didactic literature, inspired by Occitan traditions.]

\section{6.}

Gadea I Gambús, Ferran. En so vell i antic. Antologia de trobadors catalans. Barcelona: La Magrana, 1990. [Poems by eighteen poets: Berenguer d'Anoia; Berenguer de Palou; Alfons I de Catalunya, II d'Aragó, el Cast; Ponç de la Guàrdia; Guillem de Cabestany; Guillem de Berguedà; Uc de Mataplana; Pons d'Ortafa; Cerverí de Girona; Amanieu de Sescas; Formit de Perpignan; Guillem Ramon de Gironella; 
Peire Salvatge; Raimon Vidal de Besalú; Peire II de Catalunya-Aragó, el Gran; Jofre de Foixà; Jaume II de Catalunya-Aragó, el Just; Guerau de Cabrera.]

1657.

Grifoll, Isabel. "Combas e valhs, puigs, muntanyes e colhs: Andreu Febrer i els trobadors." In 162, Trobadors a la Península Ibèrica, 2006, pp. 195-221. [Detailed study of Andreu's poem and of the influence of Arnaut Daniel and other troubadours on Catalan poetry.]

\section{8.}

Ibáñez Rodríguez, Miguel. "Trovadores occitanos en la ruta jacobea riojana,"in Aspectos en torno al camino de Santiago en la Edad Media: IV Semana de Estudios Médiévales, Nájera, 2 al 6 de agosto de 1993. Logrońo: Instituto de Estudios Riojanos, 1994, pp. 225-34.

\section{9.}

See 65, Ibarz, "État présent," 2011. [Stresses the close connection between Catalan and Occitan poetry and the need for collaborative research.]

1660.

Concheff, Beatrice Jorgensen. Bibliography of Old Catalan Texts. Madison, WI: Hispanic Seminary of Medieval Studies, 1987.

1661.

See 1122, Annicchiarico, Narracions en vers, 2003. [Bibliographical listings and introductory analysis for Blandin de Cornualha, La Faula (by Guillem de Torroella), Frayre-de-joy e Sor-de-plaser, and two dozen Catalan works.]

\section{2.}

Asperti, Stefano. "Flamenca e dintorni. Considerazioni sui rapporti fra Occitania e Catalonia nel XIV secolo.” CN 45 (1985): 59-103.

\section{3.}

Asperti, Stefano. "I trovatori e la Corona d'Aragona. Riflessioni per una cronologia di riferimento." Mot, so, razó 1 (1999): 12-31. [Also in Bollettino del rialc: http://www. rialc.unina.it.]

\section{4.}

Cabré, Miriam. "Italian and Catalan Troubadours." In 282, Troubadours, 1999, pp. 127-40.

\section{5.}

Cabré, Miriam. "Mécènes et troubadours dans la Couronne d'Aragon.” Europe. Revue littéraire mensuelle 86 (2008): 126-36.

\section{6.}

Cabré, Miriam, Sadurní Martí, and Marina Navàs. "Geografia i història de la poesia occitanocatalana del segle XIV: poetes, corts i cançoners." In Translatar i transferir. La transmissió dels textos i el saber (1200-1500). Primer colloqui internacional del Grup Narpan "Cultura i literatura a la baixa edat mitjana" Barcelona 22-24 novembre 2007. Santa Coloma de Queralt: Obrador Edendum/URV, 2010, pp. 349-76. [Exploratory study of the interrelationship of Catalan and Occitan courts, poets, and manuscript traditions, especially the role of the Toulouse School and the poets Ramon de Cornet 
and Joan de Castellnou in the evolution of Occitano-Catalan lyric.]

1667.

Coderch, Marion. "Lo rossinhols s'esbaudeya (70,29): Bernart de Ventadorn, Courtly Ethics and the Catalan Tradition.” Glossator 4 (2011): 101-14. [Detailed analysis of themes and structures in the poem that influenced Catalan poets, at a time when the elite classes were increasingly fearful of losing their privileges to the rising bourgeoisie.]

\section{8.}

Radatz, Hans-Ingo. "Der (wirklich) letzte Trobador: Jordi de Sant Jordi und die okzitanische Sprache." In 125, Okzitanistik, Altokzitanistik, 2000, pp. 133-45. [The troubadour tradition flourished in Catalunya for one hundred years longer than in Occitania; when Jordi died in 1424, the tradition came to its final end, making him, not Guiraut Riquier, the last troubadour.]

1669.

Riquer, Isabel de. "Poemas catalanes con citas de trovadores provenzales y de poetas de otras lenguas." In O Cantar dos trobadores. Actas do Congreso celebrado en Santiago de Compostela entre os dias 26 e 29 de abril de 1993. Santiago de Compostela: Xunta de Galicia, 1993, pp. 289-314.

1670.

Riquer, Martí de. "Els trobadors catalans." In Història de la literatura catalana. Vol. 1. Edited by Martí de Riquer, Antoni Comas, and Joaquim Molas. Barcelona: Ariel, 1986, pp. 21-196.

1671.

Rossell, Antoni. Els trobadors catalans. Barcelona: Dinsic, 2006. With a CD: Els trobadors catalans. [A popular introduction to medieval Catalan poetry, music, and general culture.]

1672.

Smith, Nathaniel B. "Medieval and Renaissance in Catalan Courtly Literature." In -99, ICLS 3 Court and Poet, 1981, pp. 297-307.

\section{3.}

\section{Spanish}

Alvar, Carlos. Textos trovadorescos sobre España y Portugal. Madrid: Cupsa Editorial, 1978. Also: La poesia trovadoresca en España y Portugal. Madrid: Cupsa, 1977. [Allusions to Castile, Navarre, Léon, and Portugal in troubadour lyrics; Occitan lyric presence in the peninsular courts.]

1674.

Aubrey, Elizabeth. "La langue musicale de dévotion: les cantigas de loor et les chansons de Guiraut Riquier.” In 111, L'Espace lyrique, 2006, pp. 219-29. [Guiraut at the court of Alfonso X le Sage, ca. 1270.]

1675.

Beltrán, Vicenç. La corte de Babel: Lengas, poética y política en la España del siglo XIII. Madrid: Gredos, 2005. 
1676.

Bertolucci Pizzorusso, Valeria, Carlos Alvar, and Stefano Asperti. Le letterature medievali romanze d'area iberica. Rome: Laterza, 1999. [Pp. 340-61: "La lirica dei trovatori e la letteratura cortese occitanica," by Stefano Asperti, treats seven Catalan poets who composed in Occitan, and Jaufre.]

1677.

Boase, Roger. The Troubadour Revival: A Study of Social Change and Traditionalism in Late Medieval Spain. London: Routledge, 1978. [Claims that the revival of courtly and chivalric ideals and practices in the fifteenth century in Spain was a response by the aristocracy to the perceived decline of medieval values.]

\section{8.}

Brunel-Lobrichon, Geneviève. "Les troubadours dans les cours ibériques." In $>\mathbf{9 7}$ AIEO 4, 1994, pp. 37-45. [Information on the political background and poetic activity at the courts of Castille and Barcelona.]

1679.

D’Agostino, Alfonso. "La corte di Alfonso X di Castiglia." In 129 Lo spazio letterario del medioevo, 2. Medioevo volgare, vol. 1, part 2: La produzione del testo. Edited by Piero Boitani, Mario Mancini, and Alberto Varvaro. Rome: Salerno Editrice, 2001, pp. 735-85.

\section{0.}

Gier, Albert. "Alphonse le Savant, poète lyrique et mécène des troubadours." In - 96, ICLS 3 Court and Poet, 1981, pp. 155-65.

\section{1.}

Martínez Blanco, Carmen María. "Proverbis de Guillem de Cervera: posible modelo en provenzal para la literatura didactica de la peninsula iberica.” In $\mathbf{9 6}$, AIEO 3, 1992, pp. 1025-30. [The Proverbis rimats, written 1180 and their possible influence on Centiloquio, Livre de paraules e dits, Doctrina moral.]

\section{2.}

Snow, Joseph T. "The Iberian Peninsula." In 281, Handbook, 1995, pp. 27178. [Information on early indigenous lyric in the jarchas, the Galician cantigas d'amigo and the Spanish villancicos, and on the troubadours who visited the Spanish courts.]

\section{3.}

\section{Northern French (Trouvères, etc.)}

Nelson, Deborah H. "Northern France." In 281, Handbook, 1995, pp. 255-61. [A sketch of similarities and differences between Occitan and northern French lyric: the North is more straightforward in structure and less openly sensual in content.]

\section{4.}

Eliot, Robert. "Gace Brulé et la tradition provençale: contacts et points de rencontre.” FL 136 (2003): 9-115. [From Eliot's Sorbonne D.E.A., 1977, and further work undertaken up to his death in 1979, completed by Suzanne Thiolier-Méjean.] 
1685.

Formisano, Luciano. "La lyrique d'oil dans le cadre du mouvement troubadouresque." In Les chansons de langue d'oil. Vol. 1: L'art des trouvères. Edited by MarieGeneviève Grossel and Jean-Charles Herbin. Valenciennes: Presses universitaires de Valenciennes, 2008, pp. 101-15.

1686.

Galano, Sabrina. "Enchâssement des textes lyriques occitans dans les romans français: Guillaume de Dole et Roman de la violette." In 100, AIEO 7, 2003, pp. 325-41. [An important factor for the transfer of fin'amors ideology directly to the North.] 1687.

Gally, Michèle. "Entre sens et non sens: approches comparatives de la tenso d'oc et du jeu-parti arrageois." In 113, Il genere tenzone, 1999, pp. 223-35. [Traces the historical development of the tenso through the partimen to the jeu-parti, especially in Arras, with the loss of connection with the court.]

1688.

Huot, Silvia. “Troubadour Lyric and Old French Narrative." In $\mathbf{2 8 2}$, Troubadours, 1999, pp. 263-78. [Examines the reception of troubadour lyrics in the North and their transposition into the narrative mode, using as examples the motifs of the nightingale and the heart.]

1689.

Jung, Marc-René. "Rencontres entre troubadours et trouvères." In $>$ 96, AIEO 3, 1992, pp. 991-1000. [A study of seasonal openings in Jaufre Rudel, Marcabru, Bernart de Ventadorn, and ten French poems.]

1690.

Kirsch, Fritz Peter. "Okzitania und Frankophonie." In 125, Okzitanistik, Altokzitanistik, 2000, pp. 57-70. [Probing reflection on the attitude of the French toward their cultural and linguistic minorities, especially Occitania.]

1691.

See 884, Meneghetti, Il pubblico, 1984, 1992, pp. 138-44. [Examines possible influences of the troubadours on Chrétien de Troyes.]

1692.

Pollina, Vincent. "Troubadours dans le nord: observations sur la transmission des melodies occitanes dans les manuscrits septentrionaux." RZL 9 (1985): 263-78.

1693.

Rieger, Angelica. “Trobadors und Trouvères.” In Mittelalter. Edited by Ulrich Mölk. Tübingen: Stauffenburg, 2008, pp. 73-94. Also available online at http://www.angelica-rieger.de/ netveroeffent/rudel_lyrik_definitiv.pdf. [Analysis of the similarities and differences between the southern fin'amors and the northern amour courtois.]

1694.

Rosenberg, Samuel N., and Hans Tischler. Chanter m'estuet: Songs of the Trouvères. Bloomington: Indiana University Press, 1981.

1695.

Touber, Anton. "Les relations entre les lyriques médiévales occitane et française à 
l'intérieur de l'Hexagone et leur rayonnement en Europe." In Oc et oül. Complémentarité et antagonisme de deux histoires littéraires de la France. Études de littérature française et occitane présentées dans le cadre du 5 e congrès de l'Association des Francoromanistes des pays de langue allemande (Halle an der Saale, Université Martin Luther, 26-29 septembre 2005). Edited by Fritz Peter Kirsch. Toulouse: Section Française de l'AIEO, 2008.

1696.

Unlandt, Nico. "Un dialogue poétique entre Bertran de Born et Conon de Béthune." In Oc et oïl. Complémentarité et antagonisme de deux histoires littéraires de la France. Études de literature française et occitane présentées dans le cadre du 5 e congrès de l'Association des Francoromanistes des pays de langue allemande (Halle an der Saale, Université Martin Luther, 26-29 septembre 2005). Edited by Fritz Peter Kirsch. Toulouse: Section Française de l'AIEO, 2008.

\section{Galician}

1697.

Brea, Mercedes, Co-ordinator. Lírica profana galego-portuguesa: corpus completo das cantigas medievais, con estudio biográfico, análise retórica e bibliografía específica. Santiago de Compostela: Centro de Investigacións Lingü.sticas e Literárias Ramón Piñeiro, 1996. [A huge anthology of 1071 pages, with poems by 156 named poets, notes, indexes, no translations.] See also database online at http://www.cirp.es/pls/ bdo2/f?p=MEDDB2. [Rich information, texts, and bibliography.]

1698.

Alvar, Carlos, and Vicente Beltrán. Antología de la poisía gallego-portuguesa. Madrid: Alhambra, 1984.

\section{9.}

Bánki, Éva. "Temps lyrique et conception de la nature dans les poésies provençale et galégo-portugaise médiévales." In Études de littérature médiévale: recherches actuelles en Hongrie. Edited by Katalin Halász. Debrecen: Debreceni Egyetem, 2000, pp. 5-22. 1700.

Bertolucci Pizzorusso, Valeria. "La funzione encomiastica nei trovatori provenzale e galego-portoghesi." In 128, Le Rayonnement, 1998, pp. 41-50.

1701.

Brugnolo, Furio. “Da Don Dinis a Raimbaut de Vaqueiras.” CDT7 (2004): 617-36. [The Galician-Portuguese troubadour most influenced by Raimbaut, especially in his pastorela.] 1702.

Corral, Esther. "Feminine Voice in the Galician-Portuguese cantigas de amigo." In 121, Medieval Woman's Song, 2002, pp. 81-98.

1703.

Diogo, Américo António Lindeza. Lirica galego-portuguesa: antologia. Braga: Angelus Novus, 1998.

1704.

Ferrari, Anna. "Parola-rima." In O Cantar dos trobadores: Actas do congreso celebrado en Santiago de Compostela entre os dias 26 e 29 de abril de 1993. Santiago 
de Compostela: Xunta de Galicia, 1993, pp.121-36. [An attempt to define the specificity of early Galician poetry in relation to other Romance traditions, especially Occitan.]

1705.

Fidalgo, Elvira. "Troubadours et trobadores: les premiers contacts." Europe. Revue littéraire mensuelle 86 (2008): 137-49; see also Dominique Billy, "La contrafacture de modèles occitans dans la lyrique galégo-portugaise: examen de quelques propositions récentes," RST 8-9 (2010): 31-60.

1706.

Gouiran, Gérard. “'Os meum replebo increpationibus' (Job XXIII, 4). Comment parler à Dieu sans prier, ou la contestation contre Dieu dans les lyriques occitane et galaïcoportugaise." In $O$ Cantar dos trobadores. Actas do congreso celebrado en Santiago de Compostela entre os dias 26 e 29 de abril de 1993. Santiago de Compostela: Xunta de Galicia, 1993, pp. 77-98.

1707.

See 916, Grutman, "Le système triplement bilingue," 1994, pp. 465-75. [Redefines bilingualism as "literary," "poetic," or "referential"; reformulates the theory of influence in sociolinguistic terms, arguing that the troubadours temporarily "filled an empty slot" in the "defective systems" of French, Italian, and Galician poetry.]

1708.

Hart, Thomas R. En maneira de proençal: The Medieval Galician-Portuguese Lyric. London: Department of Hispanic Studies, Queen Mary and Westfield College, 1998. [A concise survey of critical concerns; compares the cantiga de amor and the cantiga de amigo with the troubadour canso, finding major differences.]

1709.

Jensen, Frede. Medieval Galician-Portuguese Poetry: An Anthology. New York: Garland, 1992.

1710.

Mermier, Guy R. "The Diaspora of the Occitan Troubadours: Influence of Occitan Troubadour Lyrics on the Poetry of the Galician-Portuguese trovadores." Mediterranean Studies 7 (1999): 70-71.

1711.

Paden, William D. "Contrafacture between Occitan and Galician-Portuguese (2): The Case of Bonifaci Calvo.” Tenso 13.2 (1998): 50-71. [Bonifaci was Italian but left nineteen poems in Occitan and two in Galician.]

1712.

Paden, William D. "The Beloved Lady in Medieval Galician-Portuguese and Occitan Lyric Poetry." La Corónica: A Journal of Medieval Spanish Language and Literature 32 (2004): 69-84.

\section{3.}

Resende de Oliveira, António. "Le surgissement de la culture troubadouresque dans l'occident de la Péninsule Ibérique (I): compositeurs et cours." In $\ \mathbf{1 2 8}$, Le Rayonnement, 1998, pp. 85-95. [The Occitan influences at work at the beginnings 
of Galician poetry; see companion article by Ribeiro Miranda, in $\mathbf{1 2 8}$, Le Rayonnement, 1998, pp. 97-105.]

1714.

Ribeiro Miranda, José Carlos. "Le surgissement de la culture troubadouresque dans l'occident de la Péninsule ibérique (II): les genres, les thèmes et les formes." In - 128, Le Rayonnement, 1998, pp. 97-105. [Sources of the gloomy, despairing attitudes in the earliest Galician poetry at the beginnng of the thirteenth century; see companion article by Resende de Oliveira, in 128, Le Rayonnement, 1998, pp. 85-95, pp. 85-95.]

\section{5.}

Snow, Joseph T. “The Iberian Peninsula." In 281, Handbook, 1995, pp. 271-78. [An overview of the reciprocal influences of Occitan and Iberian poetic cultures.]

\section{6.}

Tavani, Giuseppe. Tra Galizia e Provenza: Saggi sulla poesia médiévale galego-portoghese. Rome: Carocci, 2002.

\section{Sicilian}

1717.

Antonelli, Roberto, Costanzo Di Girolamo, and Rosario Coluccia. Poeti della scuola siciliana. 3 vols. Milan: Mondadori, 2008. [Vol. 1 treats Giacomo da Lentini; vol. 2 treats poets of Frederick's court (Guido delle Colonne); and vol. 3 treats I Siculotoscani; detailed introductions, critical editions with notes, no translations.]

1718.

Brugnolo, Furio. "La scuola poetica siciliana." In Storia della letteratura italiana. Edited by Enrico Malato. 14 vols. Rome: Salerno, 1995-2005, vol. 1: "Dalle origini a Dante," 1995, pp. 265-337.

\section{9.}

Brugnolo, Furio. "I siciliani e l'arte dell'imitazione: Giacomo da Lentini, Rinaldo d'Aquino e Iacopo Mostacci 'traduttori' dal provenzale." La parola del testo 3 (1999): 46-74.

1720.

Emmi, Silvia. "Influences de la poétique troubadouresque dans la tradition rhétorique des poètes de la Magna Curia." ZrP 126 (2010): 407-23.

1721.

Formisano, Luciano. "Troubadours, trouvères, siciliens." In $\mathbf{1 2 8}$, Le Rayonnement, 1998, pp. 109-24. [Finds more influence than hitherto recognized by the trouvères on the beginnings of Sicilian poetry, as well as the preponderant influence by the troubadours.]

1722.

Fratta, Aniello. Le fonti provenzali dei poeti della Scuola Siciliana: i postillati del Torraca e altri contributi. Florence: Le Lettere, 1996.

1723.

Giannini, Gabriele. "Qualità dei gallicismi e fenomeni di attrazione del significante 
presso i poeti federiciani." QRF (Lingua, rima, codici. Per una nuova edizione della poesia della scuola siciliana) 12/13 (1999): 327-50. [Influence of troubadour vocabulary and eloquence on the Sicilian School poets.]

1724.

Giannini, Gabriele. “Tradurre fino a tradire. Precisazioni siciliane.” CDT3.3 (2000): 903-46. [Sicilian poets were more concerned with reproducing stylistic echoes than preserving the content of the original troubadour poems.]

1725.

Giannini, Gabriele. "In margine a Madonna, dir voglio." In $\mathbf{1 1 5}$, Interpretazioni, 2001, pp. 305-20. [A Sicilian poem with many intertextual references to Occitan poets.]

1726.

Jensen, Frede. "Les troubadours et l'éveil poétique en Italie." In $\ \mathbf{9 6}$, AIEO 3, 1992, pp. 983-89. [A study of themes, images, vocabulary, and rhetoric shows that the Sicilian School, the Siculo-Tuscan school, and the early Italian poets took inspiration from troubadour traditions.]

1727.

Touber, Anton. “Troubadours, Minnesänger, Siciliens." In 100, AIEO 7, 2003, pp. 685-94. [Adaptations to vocabulary that were required in order to adapt troubadour poetic conventions to the German and Sicilian languages.]

\section{Italian}

1728.

Vallet, Edoardo. "Les troubadours et l'Italie." Europe: Revue littéraire mensuelle 86 (2008): 115-25. [Introductory overview of the presence and influence of troubadours in Italy.]

1729.

See 164, I trovatori nel Veneto, 2008. [Fourteen articles treat the diffusion of poetry into northern Italy and the Veneto early in the thirteenth century, the use of Occitan by some Italian poets, and troubadour poetic forms as models for the earliest poetry in Italian.]

1730 .

Asperti, Stefano. "Dante, i trovatori, la poesia." In Le culture di Dante: studi in onore di Robert Hollander. Atti del quarto Seminario dantesco internazionale, University of Notre Dame, 25-27 settembre 2003. Edited by Michelangelo Picone, Theodore J. Cachey, Jr., and Margherita Mesirca. Florence: Franco Cesati, 2004, pp. 61-92.

1731.

Barolini, Teodolinda. "Dante and the Troubadours: An Overview." Tenso 5 (198990): 3-10.

1732.

Beltrami, Pietro G. "Arnaut Daniel e la "bella scuola" dei trovatori di Dante." In Le Culture di Dante: Studi in onore di Robert Hollander. Atti del quarto Seminario dantesco internazionale, University of Notre Dame, 25-27 settembre 2003. Edited 
by Michelangelo Picone, Theodore J. Cachey, Jr., and Margherita Mesirca. Florence: Franco Cesati, 2004, pp. 29-59.

1733.

Bellotti, Michele. "Lintertexte italo-occitan dans le nord-ouest de l'Italie: quelques pistes de recherche sur la lyrique des troubadours." RlaR 114.1 (2010): 139-52. [Documentation concerning the spread of troubadour influence into northern Italy by way of Genoa to Venice.]

\section{4.}

Bertolucci Pizzarusso, Valeria. "La réception de la littérature courtoise en Italie aux XIIIle et XIVe siècles": plenary lecture, Ninth triennial congress of the ICLS, University of British Columbia, Vancouver and Simon Fraser University, Harbour Centre, July 25-31, 1998. Edited by Barbara K. Altmann and Carleton W. Carroll. Cambridge: W. S. Brewer, 2003, pp. 3-13.

\section{5.}

Bertolucci Pizzorusso, Valeria. "Nouvelle géographie de la lyrique occitane entre XIIe et XIIIe siècle: I'Italie nord-occidentale." Plenary paper in 100, AIEO 7, 2003, pp. 1313-22. [The spread of Occitan lyric into Italy from the end of the twelfth century, led by Raimbaut de Vaqueiras, who demonstrated how to adapt the poetic traditions to a new environment.]

1736.

Burgwinkle, William E. “The Form of our Desire': Arnaut Daniel and the Homoerotic Subject in Dante's Commedia." Gay and Lesbian Quarterly 10 (2004): 565-97. 1737.

Cabré, Miriam. "Italian and Catalan Troubadours." In 282, Troubadours, 1999, pp. 127-40. [Treats in particular Aimeric de Peguilhan, Cerveri de Girona, and Sordello.]

1738.

Caïti-Russo, Gilda. Les Troubadours et la cour des Malaspina. Montpellier: Publications de l'Université Paul-Valéry Montpellier 3, 2005. [Study of the success of Occitan trobar in Italy, with many details about the social context of the courts; critical edition of thirty-six poems by eight troubadours and a few anonymous, attached to the Court of the Malaspina family; careful analysis of manuscript history for each text; see also 306, Salvatori, "Les Malaspina," 2008, and Caïti-Russo, "Dante occitaniste," in 101, AIEO 8, 2009, 1:251-63.]

1739.

Cherchi, Paolo. "Dante e i trovatori." In Le culture di Dante: studi in onore di Robert Hollander. Atti del quarto Seminario dantesco internazionale, University of Notre Dame, 25-27 settembre 2003. Edited by Michelangelo Picone, Theodore J. Cachey, Jr., and Margherita Mesirca. Florence: Franco Cesati, 2004, pp. 93-103.

\section{0.}

Cucinotta, Cosimo. "Le anime dei trovatori." In $\mathbf{1 0 0}$, AIEO 7, 2003, pp. 25770. [Dante's purpose in including Bertran de Born, Arnaut Daniel, and Folquet de Marselha in his Commedia.] 
1741.

Martinez, Ronald. "Italy." In 281, Handbook, 1995, pp. 279-94. [Overview of troubadour influence on the Sicilian School, the early Tuscan poets, Dante, and Petrarch; rich bibliography.]

\section{2.}

Fuksas, Anatole Pierre. "Toponomastica del Monferrato nella lirica trobadorica." In Dalla Provenza al Monferrato. Percorsi medievali di testi e musiche. Edited by Sonia Maura Barillari. Alessandria: dell'Orso, 2007, pp. 77-85. [The use of Italian placenames and personal names as rhetorical structures in poems by Peire Vidal and Raimbaut de Vaqueiras.]

1743.

Gallo, F. Alberto. Musica nel castello: trovatori, libri, oratori nelle corti italiane dal XIII al XV secolo. Bologna: Il Mulino, 1992. English: Music in the Castle: Troubadours, Books and Orators in Italian Courts of the Thirteenth, Fourteenth and Fifteenth Centuries. Translated by Anna Herklotz. Chicago: University of Chicago Press, 1995.

1744.

Keller, Hans-Erich. "Italian Troubadours." In $\mathbf{2 8 1}$, Handbook, 1995, pp. 295-304. 1745.

Perugi, Maurizio. "A proposito di alcuni scritti recenti su Petrarca e Arnaut Daniel." SM 32 (1991): 369-84.

\section{6.}

Rando, Daniela. "I luoghi della cultura nella Marca del Duecento." In $>164$, I trovatori nel Veneto, 2008, pp. 3-25. [Historical background, social and cultural activities at the courts of the Marca; the role of the mendicant orders in education and cultural awareness.]

\section{7.}

See 306, Salvatori, "Les Malaspina," 2008. [Historian's perspective on materials published in 1738, Caïti-Russo, 2005; stresses the need to further analyze the poetry as a valuable source of information about the society and its functioning.]

1748.

Shapiro, Marianne. De vulgari eloquentia: Dante's Book of Exile. Lincoln: University of Nebraska Press, 1990. [Includes translation of Raimon Vidal de Besalu's Razos de trobar and of the anonymous Doctrina de compondre dictatz. Discusses the influence of Occitan material on Dante and on his discussions of poetry.]

1749.

Solimena, Adriana. "Traditions métriques comparées: les troubadours et les poètes italiens du XIIIe siècle.” RLaR 107 (2003): 75-87.

1750.

Stäblein, Patricia H. "La genèse de la fureur: Bertran de Born, Inferno XXVIII et Gerusalemme liberata VIII." In 151, Mélanges Bec, 1991, pp. 193-206. [Dante's and Tasso's use of the (mythological) figure of Bertran de Born.]

1751.

Tavera, Antoine. "Des troubadours italotropes." See 749, ICLS 7, 1994, pp. 
85-93. [General presentation of the careers of three traveling troubadours: Aimeric de Peguilhan, Cerveri de Girona, and Peire Raimon de Tolosa.]

1752.

Tufano, Ilaria. "Boccaccio, i trovatori e il Monferrato." In Dalla Provenza al Monferrato. Percorsi medievali di testi e musiche. Atti del Convegno di Rocca GrimaldaOvada, 26-27 giugno 2004. Edited by Sonia Maura Barillari. Alessandria: dell'Orso, 2007, pp. 87-99.

1753.

\section{German Minnesänger}

Alvar, Carlos. Poesía de trovadores, trouvères, minnesinger: (de principios del siglo XII a fines del siglo XIII). Madrid: Alianza, 1982. [Introductory material on social background of the troubadours and their public.]

\section{4.}

Jackson, William E. "Persona and Audience in Two Medieval Love Lyrics." Mosaic 8 (1975): 147-59. [Comparative analysis of Bernart de Ventadorn's Lo tems vai e ven e vire and a poem by Heinrich von Morungen.]

1755.

Kasten, Ingrid. Frauendienst bei Trobadors und Minnesängern im 12. Jahrhundert. Zur Entwicklung und Adaption eines literarischen Konzepts. Germanisch-Romanische Monatsschrift, Beiheft 5. Heidelberg: Winter, 1986. [A study of love-service to the beloved lady in troubadours down to 1170 , and its adaptation by the Minnesänger; simplified analysis for nonspecialists; no reference to scholarship after 1982.]

\section{6.}

Kasten, Ingrid. "The Conception of Female Roles in the Woman's Song of Reinmar and the Comtessa de Dia.” In 121, Medieval Woman's Song, 2002, pp. 152-67. [The Comtessa's assertiveness is contrasted with the timidity of the women in Reinmar's Frauenlieder.] 1757.

Mertens, Volker. "Kontrafaktur als intertextuelles Spiel: Aspekte der Adaptation von Troubadour-Melodien im deutschen Minnesang." In $\mathbf{1 2 8}$, Le Rayonnement, 1998, pp. 269-84.

1758.

Ricketts, Peter T., and Felicity Rash. "Le reflet de joi et jauzimen chez les Minnesänger.” Perspectives médiévales 16 (1990): 35-46.

1759.

See 891, A. Rieger, "Relations interculturelles," 1998, pp. 201-25. [A case study of a network, involving Raimbaut de Vaqueiras, Elias Cairel, Conon de Béthune and Albrecht von Johansdorf, pp. 215-20; finds reciprocal relationships instead of "origin and influence"; see the same subject treated in German in "Singen auf dem Kreuzweg." In Internationalität nationaler Literaturen. Beiträge zum ersten Symposion des Göttinger Sonderforschungsbereichs. Edited by Udo Schöning et al. Göttingen: Wallstein, 2000, pp. 485-500.] 
1760.

Sayce, Olive. "Linfluence de la lyrique occitane sur les Minnesänger: quels poètes allemands montrent une connaissance directe des troubadours?" Perspectives médiévales 16 (1990): 59-69. [Considers especially the influence of Folquet de Marselha and Peire Vidal on the Minnesänger.]

1761.

Touber, Anton. "Les formes métriques dans la poésie médiévale en France et en Allemagne." In 122, Métriques du Moyen Âge, 1999, pp. 289-302. [Use of the program Anastrof to allow comparative study of Romance and Germanic metrical structures; among the Minnesänger, 70 percent of stanzaic structures were first used by the troubadours and trouvères; there are more than two hundred cases of the use of metric structures found originally in Jaufre Rudel; text of a poem by Albrecht von Johannsdorf is analyzed alongside its Occitan model (PC 296,1a) by Marques de Montferrat.]

1762.

Touber, Anton. “Troubadours, Minnesänger, Siciliens." In 100, AIEO 7, 2003, pp. 685-94. [Occitan structures, motifs, and images may be used which take the Occitan tradition for granted, making the German poetry difficult to understand except by reference to the Occitan models.]

1763.

Touber, Anton. "L'importance des troubadours et des trouvères pour le Minnesang allemand." In 140, Etudes Ricketts, 2005, pp. 727-41.

\section{4.}

Touber, Anton. "Les biographies des troubadours, les miniatures du Codex Manesse et le manuscrit $N$ des troubadours." In 102, AIEO 9, 2011, pp. 555-68. [Occitan and French influences on miniatures in the Minnesänger Codex Manesse, similar to the influences visible in the creation of the vidas and razos.]

1765.

Unlandt, Nico. "La sextine occitane et la virtuosité des Minnesinger (essai de comparaison)." In 100, AIEO 7, 2003, pp. 695-712. [The sestina did not foster successful copies in German poetry, but other forms of structural complexity are found.] 1766.

Van d'Elden, Stephanie Cain. "Diversity Despite Similarity: Two Middle High German Contrafacta of an Occitan Song." In 159, Studia occitanica, 1986, 1:323-38. [Contrafacta by Friedrich von Hausen and Rudolph von Fenis, based on a poem by Folquet de Marselha: in fact the poems show some borrowings of motifs and rhythmic forms but are otherwise original.]

1767.

Van d'Elden, Stephanie Cain. "The Minnesingers." In 281, Handbook, 1995, pp. 262-70.

1768.

Zotz, Nicola. Intégration courtoise: Zur Rezeption okzitanischer une französischer Lyrik im klassischen deutschen Minnesang. Heidelberg: Winter, 2005. 
1769.

\section{Cathar Heresy}

Pales-Gobilliard, Anne. "Cathares." In 38 DLF, 1992, pp. 224-27. [Rich bibliography.]

1770.

Bec, Pierre. "Le Rituel cathare." In 242, Anthologie de la prose, 2, 1987, pp. 75-82. [Brief introduction, edition of the Consolamentum, with French translation, notes.] 1771.

Blum, Jean. A la recherche des Cathares. Monaco: Éditions du Rocher, 1997. 1772.

Bordes, Richard. "Avant-propos." In 130, Troubadours et cathares, 2004, pp. 11-20. [History of scholarship concerning the relationship between the troubadours and the Cathar heresy, and regarding the essence of Catharism itself.]

1773.

Borghi Cedrini, Luciana. "Nuove indagini sulla antica letteratura valdese." In $>\mathbf{1 0 0}$, AIEO 7, 2003, pp. 133-42. [A call for collaborators to study the field of "heretical" texts (Bestario valdese, etc.); there are about twenty Occitan manuscripts awaiting study.]

1774.

Brenon, Anne. "Las Tribulacions: traité vaudois, texte A (MS de Dublin)." Heresis 1 (1983): 25-31.

1775.

Brenon, Anne. "Sur les marges de l'état toulousain. Fin'amor et catharisme: Peire Vidal et Raimon de Miraval entre Laurac et Cabaret." In 131, Les troubadours et l'état toulousain, 1994, pp. 139-54. [The notion that troubadour poetry is a form of "coded" Catharism is an unjustified myth; however, the two social codes of Catharism and finamor shared some common attitudes, making them quite compatible, though not attached by any link of cause or effect.]

1776.

Brenon, Anne. "Hérésie, courtoisie et poésie. A la recherche de traces de catharisme dans la littérature occitane du Moyen Âge." In 130, Troubadours et cathares, 2004, pp. 61-79. [See also her comments in the three "Débats," esp. pp. 181-85. Heresy and courtesy did not meet; the only sign of religious belief in the poetry is indirect and filtered.] 1777.

Duvernoy, Jean. La religion des cathares. Toulouse: Privat, 1992. [Duvernoy has dedicated his scholarly life to editing archival material from the Inquisition relating to the Cathars; see also 130, Troubadours et cathares, 2004, pp. 182-83; a variety of material is available on his website http://jean.duvernoy.free.fr.]

1778.

Hancke, Gwendoline. Les Belles hérétiques. Etre femme, noble et cathare. Cahors: L'Hydre, 2001. [Gormonda de Monpeslier was the first woman in France to write a political poem; hostile to Catharism and to her "confrère" Guilhem Figueira, whom she thinks should be burned.] 
1779.

Harris, M. Roy. “Cathar Ritual (ms. Lyon Bibl. mun., PA 36).” Online, 2005, at http://www.rialto.unina.it. [A critical edition of the only known Occitan Cathar ritual.]

1780.

Lambert, Malcolm. The Cathars. Oxford: Blackwell, 1998. [Examines the lasting influence of the Cathar heresy across Europe through detailed analysis of social and historical sources.]

1781.

Ricketts, Peter T., and Roy Harris. "Une paraphrase du Pater noster en occitan médiéval.” RLaR 108 (2004): 523-32. [Edition of a medieval Occitan devotional poem, with French translation, notes.]

1782.

Roquebert, Michel. Histoire des Cathares. Hérésie, Croisade, Inquisition du XII au XIVI siècle. Paris: Perrin, 1999.

1783.

Rubinelli, Ezio. La crociata contro i catari: cronaca dell'annientamento dell'Occitania. Carmagnola: Arktos, 2005. [An inside view of the aims and practices of the Cathars.] 1784.

Snyder, Susan Taylor. “Cathars.” In \45, Schaus, Women and Gender, 2006.

1785.

Vallette, Jean René. "Le miracle aux frontières du sens: hérésie et orthodoxie dans l'Historia albigensis et dans la Chanson de la croisade albigeoise." In Si a parlé per moult ruiste vertu. Mélanges de littérature médiévales offerts à Jean Subrenat. Edited by Jean Dufournet. Paris: Champion, 2000, pp. 533-44.

1786.

Veltman, Willem Frederik. Sänger und Ketzer: Troubadourkultur und Katharertum in der provenzalischen Welt des Mittelalters. Translated from Dutch by Eva Julius-Koch. Stuttgart: Urachhaus, 1997.

1787.

Zambon, Francesco. La cena segreta: trattati e rituali catari. Milan: Adelphi, 1997. [Introduction concerning the recent history of edition and study of Cathar texts; all the principal texts are edited in Italian translation only.]

1788.

Zambon, Francesco. "Le sirventès contre Rome de Guilhem Figueira." In $>\mathbf{1 3 0}$, Troubadours et cathares, 2004, pp. 87-99. [There is no proof of his adherence to Cathar theology, but he was certainly influenced profoundly by Catharist morality in his views against the church.]

1789.

Zemplényi, Ferenc. "Troubadours et cathares"in \$ 98, AIEO 5, 1998, pp. 249-52. [No secret symbolism can be demonstrated that links troubadour poetic ideas with Cathar principles; the troubadours' use of biblical imagery is in fact contrary to Cathar belief.] 
1790.

\section{Arabic/Hispano-Arabic}

See 332, Abu-Haidar, Hispano-Arabic, 2001. [Only part 3, chapters 10-12, concern Occitan lyric; the rest treats Arabic popular literature (part 1) and the zajal and muwashshah (part 2); in part 3, Abu-Haidar systematically denies any Arabic parallels with the troubadour poetry, but he neglects significant recent contradictory scholarship.]

1791.

Bellamy, James A., and Patricia Owen Steiner. Ibn Sa īd al-Maghribi. The Banners of the Champions (Rāyāt al-mubarrizin): An Anthology of Medieval Arabic Poetry from Andalusia and Beyond. Madison, WI: Hispanic Seminary of Medieval Studies, 1989. [Anthology chosen from the best of The Banners, a choice made already in 1243 by Ibn Sa'ì from his immense anthology; 194 poems are translated into English prose; preface by Roger Boase, introduction, index of poetic images; the organization of the poems by theme facilitates comparison with the early troubadour lyrics.]

1792.

Cantarino, Vicente. "Wa-hiya taklifu ghannat: Genre and Gender in Hispano-Arabic Poetry." In 120, Paden, Medieval Lyric, 2000, pp. 255-72.

1793.

Corriente, Federico. "The kharjas: An Updated Survey of Theories, Texts, and Their Interpretation." RPh 63 (2009): 109-29.

1794.

Frank, Margit in 312, GRLMA, vol. 2, book 1, fascicle 2: Les Genres lyriques, Heidelberg, 1979, pp. 25-79, especially pp. 46-73. [Article providing a synthesis of knowledge to ca. 1978 on the harjas and muwashshahas; see also 934, Meneghetti, Le origini, 1997, and 1799, Mallette, "Misunderstood," 2004.]

1795.

Galmés de Fuentes, Álvaro. El amor cortes en la lirica arabe y en la lirica provenzal. Madrid: Catedra, 1996.

1796.

Galmés de Fuentes, Álvaro. La épica románica y la tradición árabe. Madrid: Gredos, 2002. [Concerns mostly French epics; some information on Arabic influences on Daurel e Beton, Ronsasvals, Roland a Saragossa, Girart de Rossilhon, and a number of troubadours.]

1797.

Haines, John. "The Arabic Style of Performing Medieval Music." Early Music 29 (2001): 369-78.

1798.

See 144, Jayyusi, Legacy of Muslim Spain, 1992. [Articles by several scholars on the history and culture of Andalusian Spain and on the connections with Occitan.] 1799.

Mallette, Karla. “Misunderstood.” New Literary History 34 (2004): 677-97. [A study of the intersecting textual threads of philology and orientalism, through the consideration of the muwashshaha, alongside a modern song (Don't Let Me Be) Misunderstood, 
in order to demonstrate the relevance of careful orientalist philology to contemporary intellectual history and to its own disciplinary history; reviews the recent controversies surrounding the kharja.]

1800.

Meneghetti, Maria Luisa. "Le più antiche testimonianze del volgare in area iberica." In 934, Meneghetti, Le origini, 1997, pp. 132-39. [Definitions, history, and characteristics of the Romance-language harja forms.]

1801 .

Menocal, Maria Rosa. The Arabic Role in Medieval Literary History: A Forgotten Heritage. Philadelphia: University of Pennsylvania Press, 1987. [Arabic cultural presence in the court of William of Aquitaine, Frederick II, and its importance for Dante and Boccaccio; Menocal renews the Arabic thesis, arguing that it seemed entirely plausible until the heyday of European colonialism, when it suddenly came to seem unthinkable, for obvious reasons of cultural prejudice.]

1802.

Monroe, James T. Hispano-Arabic Poetry: A Student Anthology. Berkeley: University of California Press, 1974. [Arabic texts with English translation.]

1803.

Nieten, Ulrike-Rebekka. "Arabic Poetry and the Songs of the Troubadours." In Reflections on Reflections: Near Eastern Writers Reading Literature: Dedicated to Renate Jacobi. Edited by Angelika Neuwirth, Andreas Christian Islebe, and Beatrice Gruendler. Wiesbaden: Reichert, 2006, pp. 253-59. [Outline of scholarship dealing with the influence of Arabic and Jewish literature and music on the troubadours; a call for more cooperative research.]

1804.

See 88, Paden, "State of Medieval Studies," 2006, pp. 137-55. [Isolates three pressing themes that require further study, one of which is the question of Arab influence on Occitan literature, strongly acknowledged until the nineteenth century, when it fell out of favor for sociopolitical reasons.]

1805.

Reynolds, Dwight. "Music." In Literature of Al-Andalous. Edited by Maria Rosa Menocal, Raymond P. Scheindlin, and Michael Sells. Cambridge: Cambridge University Press, 2000, pp. 60-82. [Review of recent musicological scholarship on Arabic origins.]

1806.

See 341, Robinson, In Praise of Song, 2002. [Concerns mostly the theory of Hispano-Arabic origin of troubadour poetry; rich bibliography.]

1807.

Sells, Michael. "Love." In Literature of Al-Andalous. Edited by María Rosa Menocal, Raymond P. Scheindlin, and Michael Sells. Cambridge: Cambridge University Press, 2000, pp. 126-58. [Review of recent scholarship on Arabic origins of finamor; see also Dwight Reynolds on musicological origins in the same book, pp. 60-82.] 


\section{Jewish}

1808.

Juifs et source juive en Occitanie. Enèrgas: Vent Terral, 1988. [Fifteen articles on the history and the importance of Jewish presence in Occitania from medieval to modern times.]

1809.

Einbinder, Susan L. No Place of Rest: Jewish Literature, Expulsion, and the Memory of Medieval France. Philadelphia: University of Pennsylvania Press, 2009. [Chap. 1: Isaac Hagorni; chap. 4: Crescas Caslari's Esther; two versions in verse, one in Occitan, one in Hebrew.]

1810.

Halevi, Meir Ben Eliezer. Isaac Hagorni: Satyr in Provence: Thirteenth-Century Jewish Troubadour (Translated and Introduced). Los Angeles: Deer Mountain Press, 2004.

1811.

Fleischer, Ezra. "Contributions hébraïques à une meilleure compréhension de quelques aspects de la poésie européenne du haut Moyen-Age." In Gli Ebrei nell'Alto Medioevo. 2 vols. Spoleto: Sede del Centro italiano di studi sull'alto medioevo, 1980, 2:815-66. [An argument for Hebrew influences on Guilhem de Peitieus.]

1812.

Hershon, Cyril P. Faith and Controversy: The Jews of Mediaeval Languedoc. Birmingham: AIEO, 1999.

1813.

Izquierdo, Josep. "La Presumpta influència dels Proverbis de Guillem de Cervera sobre els Proverbios morales del rabí Sem Tob." In Actes del Vuitè Col' loqui Internacional de Llengua I Literatura Catalanes. 2 vols. Barcelona: Abadia de Montserrat, 1989, 2:245-59.

1814.

Meneghetti, Maria Luisa. "Marcabru e le origini iberiche della pastorella." In $\mathbf{1 5 6}$, Das Schöne, 2002, pp. 135-42. [Earlier Arabic and Jewish poems (serranilli) may have been adapted by Marcabru.]

\section{5.}

Menocal, Maria Rosa. The Literature of Al-Andalus. Edited by María Rosa Menocal, Raymond P. Scheindlin, and Michael Sells. Cambridge: Cambridge University Press, 2000. [Emphasizes convivencia, the mingling of Islamic, Jewish, and Christian cultures; traces some of the "creative intersections and confluence" of the three in literature, architecture, and music.]

\section{6.}

Paden, William D. "Troubadours and Jews." In 140, Études Ricketts, 2005, pp. 471-84. [Survey of Jewish presence alongside troubadours, but with little contact or reciprocal influence; anti-Semitic slander in some troubadours and in the Breviari.]

1817.

Schippers, Arié. "Les troubadours et la tradition poétique hébraïque en Italie et en 
Provence: les cas d'Abraham ha-Bedarshi et Immanuel ha-Romi." In $\mathbf{1 2 8}$, Le Rayonnement, 1998, pp. 133-42. [Exploration of Hebrew poetry in Arabic Spain and its connection with that of Provence and Italy in the thirteenth and fourteenth centuries; see also his "Forme, style et thématique dans les poésies strophiques occitanes, arabes et hébraïques." In $>\mathbf{1 0 0}$, AIEO 7, 2003, pp. 651-60.]

1818.

Teulière, Gérard. "Interpénétration culturelle dans le trobar: Montanhagol, Blacasset, et la kabbale." Tenso 2 (1986): 37-50. [Exploration of the tone of social and religious tolerance in a joc partit, in which can be seen cross-influences from Cathar and Jewish sources; see a similar study of the same poem $\mathbf{2 1 6 3}$, Hutchinson, "A lunel lutz," 1983.]

1819.

Wine, Women and Song: Hebrew and Arabic Literature of Medieval Iberia. Edited by Michelle M. Hamilton, Sarah J. Portnoy, and David A. Wacks. Newark, DE: Juan de la Cuesta, 2004. [Nine broadly based articles on early poetry in Spain and the later tradition.]

\section{The Troubadours, Trobairitz}

Poets are listed numerically, according to the standard number originally assigned by Bartsch, adopted by Pillet and Carstens $>\mathbf{1}$, abbreviated as PC or BdT, extended by Frank, 57, and Zufferey, 13, with revisions by Distilo, 4, and on the electronic database $49, B E d T$. The names of the poets may occur out of alphabetical sequence, on account of scholarly revisions to the form of the accepted name, in which case cross-reference is made to the appropriate PC number.

Of some 450 named troubadours and trobairitz (2,739 poems in all), only those who have attracted recent scholarly attention are listed here: 217 named, plus nine anonymous poets whose works appear under the rubric PC 461, plus three poets of the Toulouse School (see Zufferey, 13.)

Note that 149 poets are treated individually in $\mathbf{3 1 2}$, GRLMA, vol. 2, book 1, fascicle 7, 1990; for an index to these by name, see $\mathbf{3 8}, D L F, 1993$, pp. lix-lxi. For each poet, significant variant spellings of the name are given, followed by dates or approximate period of poetic activity $(f$. $)$, presence of vidas or razos, summary indication of the lyric corpus, preserved melodies and non-lyric works, brief biographical information, and occasional remarks on characteristic features of the poetry.

In the selected listings for each poet, reference is made first to the best available edition(s), then to a choice of recent scholarly investigations and studies of individual poems.

\section{PC 1. Ademar. See PC 3. Ademar lo Negre}

\section{PC 2. Ademar Jordan (Aimar, Azemar)}

[fl. 1198-1233; no vida; one cobla; one sirventes modeled after a poem by Bertran de Born; Viscount of Saint-Antonin and Seigneur of Paris (= Parisot, a dependency 
of Toulouse); the son of Raimon Jordan; mentioned in Canso de la crozada as a bold defender of St-Antonin-de-Rouergue in 1212 against Simon of Montfort (laisse 112, lines 10-11) and imprisoned along with his cousin Pons, Viscount of St.-Antonin (laisse 114, 1-3).]

1820.

See 255, Guida, Trovatori minori, 2002, pp. 181-223. [Critical edition of both poems, with Italian translation, copious information on manuscripts and background of poet, notes.]

1821.

See 1440, Pirot, Recherches, 1972, pp. 294-97. [Genealogical details, with a table, p. 297; establishes his identity as the son of Raimon Jordan; his father was undoubtedly dead as of 1198; Ademar is attested as late as 1233 as "Seigneur de Paris."]

\section{PC 3. Ademar Lo Negre (Aimar, Azemar; probably the same as Ademar PC 1)}

[fl. 1210-17; vida; one tenso (PC 1,1) with Raimon de Miraval = PC 406,32; five cansos and one of unlikely attribution PC 202,13, presently attributed to Guilhem

Ademar but more likely to be by Gaucelm Faidit or Arnaut de Maruelh.] 1822.

Gourc, Jacques. Azemar lo Negre, troubadour albigeois du XIIIe siècle. Paris: Éditions du CNRS, 1991. [Introduction outlines Azemar's connection to the court of Raimon VI; critical edition of five poems, with French translation; this edition precedes the discovery of a possible (but unlikely) sixth poem. See detailed suggestions and corrections by Gouiran, RLaR 96 (1992): 439-43.]

\section{3.}

Gourc, Jacques. “D’Outre-Pyrénées aux régions transalpines, d'Elias Cairel a Ramberti de Buvalel, un troubadour albigeois au coeur d'un réseau intertextuel." In $\mathbf{9 5}$, AIEO 2, 1993, 1:131-52. Also in La Revista occitana 1 (1993): 97-109. [Explores the nature of trobar as a constantly renewed debate, through the poems of Ademar lo Negre, who cleverly contradicts Raimon de Miraval's mala canso PC 406,21 in his tenso; but Bertran de Born had already responded to the same poem in his PC 80,5; thus Ademar is responding to both of these; further links are explored between his poems and those of Raimon de Miraval, Peire Vidal, Ramberti de Buvalel, and Peire d'Alvernhe; Ademar's five poems in appendix.]

\section{4.}

Longobardi, Monica. "Frammenti di un canzoniere provenzale nell'Archivio di Stato di Bologna.” SMV 36 (1990): 29-55. [Diplomatic edition (no analysis, no translation), of a newly discovered manuscript fragment; an unknown vida of Peire Milon and five of his poems (already known); four poems attributed to Ademar lo Negre, one correctly (PC 3,4), the second in fact by Gaucelm Faidit, the third by Bernart de Ventadorn, the fourth (Si faz bona canson) also attributed to Ademar, but problematic because of the two preceding wrong attributions.] 
1825.

Borghi Cedrini, Luciana. "Una recente acquisizione trobadorica e il problema delle attribuzioni." MR 20 (1996): 3-44. [A new diplomatic edition, correcting a few errors by Longobardi; analysis of problems posed by two missing lines, identity of $m a<r>q u e s$ in last line, and attribution: nothing is characteristic of Ademar in metrics or themes; the other two songs attributed to Ademar may not be by Gaucelm Faidit and Bernart de Ventadorn after all; the last song Si faz might belong to any of the poets with similar names; this leads to the serious opinion that much will have to be reexamined in the general area of troubadour attributions: this discovery of one small unica has led to a shake-up of at least three attributions hitherto considered solid, calling much scholarly work into question.]

\section{6.}

Gourc, Jacques. "Le retour d'Azemar." In 99, AIEO 6, 2001, pp. 405-10. [Unaware of Borghi Cedrini's 1996 article; critical edition, with French translation and study, of Si faz, attributed to Ademar lo Negre, which may belong more plausibly to Arnaut de Maruelh or Gaucelm Faidit; Gourc thinks it is complete in its three stanzas and is a canso-sirventes, on the theme of renouncing poetry and love, probably not by Azemar.]

1827.

See 249, Bec, Florilège en mineur, 2004, pp. 45-49. [Text of vida and PC 3,1 (from Gourc), with French translation, no notes.]

\section{PC 5. Ademar de Rocaficha (Aimar; Aimeric de Rochafiza) [fl. ca. 1250; two cansos and one incomplete sirventes.]}

\section{8.}

Cura Curà, Giulio. "Amore, ragione e nobiltà: il trittico di Ademar de Rocaficha." Parola del testo (2008): 205-44. [Edition of all three poems, with introduction, Italian translation, notes.]

1829.

Guida, Saverio. "Trovatori poco noti del Biterrese agli inizi del '200 (Berengier de Puysserguier, Ademar de Rocaficha, Peire de Pommairols).” CN 71.3-4 (2011): 167-209. [Pp. 192-202: Guida has discovered an archival reference from 1212 to Ademarius de Roccafixa, who seems to have been a prominent member of the powerful family de Rocaficha in Agde, some of whose members were influential in the ecclesiastical circles of the bishop of Agde; the social position of the family and the style of Ademar's poems, modeled after those of Raimon de Miraval, make the tentative identification plausible.]

\section{PC 7. Aicart del Fossat (the same as Aicart PC 6a)}

[fl. 1250-68; one tenso, PC 6a, 1 = PC 175a,1, with the Italian poet Girardo Cavalazzi about the nature of heaven and hell; one sirventes, PC 7,1, about the impending conflict between his patron Charles d'Anjou and Duke Conradin of Swabia before the battle of Tagliacozzo in 1268, in which Conradin was defeated and executed.] 
1830.

Bastard, Antoine de. "Aicart del Fossat et les événements en Italie (1268)." In - 1326, Mélanges Boutière, 1971, 1:51-73. [Historical background and critical text of sirventes PC 7,1 with French translation, notes.]

\section{1.}

Gresti, Paolo. "Un nuovo trovatore italiano? Osservazioni sul partimen tra Aycard de Fossat e Girard Cavalatz, Si Paradis et Enfernz son aital (BdT 6A.1).” In 113, Il genere tensone, 1999, pp. 341-54. [Critical edition of the tenso PC 6a, 1 = PC 175a, 1, with Italian translation, notes; Aicart was probably Italian, but the documents are ambiguous as to dating: at least there was a Fossati family presence in Novara and several Aycardi or Aycardini; edition also in $\mathbf{2 5 6}$, Harvey and Paterson, Troubadour "Tensos," 2010, 1:5-11.]

\section{PC 9. Aimeric de Belenoi}

[ $f$. 1216-43; nineteen poems, plus seven of doubtful attribution; the nephew of Peire de Corbiac (author of Thezaur); only the opening line is extant of a lost tenso PC 9,2 with Arnaut Catalan = PC 27,1; his sirventes 9,21 is a contrafact response to that of Albertet de Sisteron, PC 16,13; one poem with music Nulhs hom en res no falh, PC 392,26, is probably by Raimbaut de Vaqueiras, attributed to Raimbaut in eleven manuscripts, to Aimeric in three; music in - 607, van der Werf, Extant, 1984, p. 3.]

\section{2.}

Poli, Andrea. Aimeric de Belenoi: Le poesie. Firenze: Positivamail, 1997. [Detailed study of sociohistorical background, manuscripts, language; critical edition of vida and 19 poems, with Italian translation, notes; edition of PC 16,13 by Albertet de Sisteron for comparison with the response by Aimeric, PC 9,21.]

1833.

Lalande, Denis. "Un troubadour médocain, raisonneur et précieux du XIIIe siècle: Aimeric de Belenoi." In La Littérature régionale en langue d'oc et en français à Bordeaux et dans la Gironde. Actes du colloque organisé par le Centre d'études des cultures d'Aquitaine et d'Europe du sud (CECAES), Centre de recherche de l'Univ. de Bordeaux III, les 21 et 22 octobre 1988. Bordeaux: Presses Universitaires de Bordeaux, 1989, pp. 201-11. [Analysis of Aimeric's poetic techniques: rich formalistic poetry, more intellectual than emotional; Aimeric proceeds by analogy, etymology, and scholastic justifications; his rhetorical techniques include allegory, personification, contradictions, and metaphors; he seems to have believed that personal sentiments get in the way of real poetry.]

1834.

Lefèvre, Yves. "Deux poètes médoquins du XIIIe siècle (Aimeric de Belenoi et Peire de Corbian)." Revue historique de Bordeaux 13 (1964): 123-31. Also in Le Médoc. Histoire, art, économie. Bordeaux: Bière, 1964, 99-107. [Historical study of Aimeric and his uncle Peire de Corbiac; thinks that Belenoi might be a nickname meaning "charming melancholy" or "joyful despair"; sketch of his social background; analysis of Thezaur: 520 lines, along with a padded version of 824 lines by a continuator "even 
more maladroit than Peire"; glimpses of the wider family of Peire and Aimeric, of humble means but intellectual ambitions.]

1835.

Melani, Silvio. "Aimeric de Belenoi, Thibaut de Champagne e le crociate." RST 1 (1999): 137-58. [Considers the attribution of Consiros, com partitz d'Amor to be doubtful, though given to Aimeric by both manuscripts; reference to a "Count who would be king," taken to be Richard Coeur-de-lion, would date the poem to 1187 , too early for Aimeric; if the reference is to Thibaut de Champagne, the dating of 1239 is not problematic, but other reasons for doubt require more study; see discussion of the problem by Poli, 1997, pp. 114-19, in which most of the other reasons for doubting the attribution are set aside.]

1836.

Nelson, Jan A., Carlos Garcia-Aranda, Barnett DeRamus, Karl Fattig, and Nanda Hopenwasser. "Aimeric de Belenoi's Aissi com hom pros afortitz: A New Critical Edition." Tenso 1 (1985-86): 1-8. [Text of PC 9,4, with English translation; the theme of "contradictions brought on by love" is typical of Aimeric: contradictory behavior (cowardly/bold, foolish/wise, courtly/boorish) on the part of the lover is proof of his pure and constant love.]

1837.

See 227, Riquer, 1975, 3:1298-1310. [Brief introduction, vida, three poems: planh PC 9,1; PC 9,12; PC 9,17, with Spanish translation.]

\section{PC 10. Aimeric de Peguilhan}

[fl. 1190-1221; vida in two versions; fifty-two poems, six with melodies; one salut; traveled widely in Catalonia, Spain, and Italy; participated in an exchange of coblas in which Guilhem Figueira's $217,1 \mathrm{~b}$ is answered by his 10,13 , which is then answered by Bertran d'Aurel's 79,1, answered in turn by Lambert's 280,1;

tenso with Guilhem Raimon PC 10,35 = 229,2, a conversational dialogue discussing the capabilities of the new ten-year-old Marquis Azzo VII of Ferrara under the tutelage of his mother; took part in the debate about "nothingness," see 1849, Lawner, "Tot es nien," 1971.]

1838.

Shepard, William P., and Frank M. Chambers. The Poems of Aimeric de Peguilhan. Evanston, IL: Northwestern University Press, 1950. Reprint, New York: AMS, 1983. [Philological and literary introduction, critical texts with English translation, notes, glossary; no melodies transcribed: for these, see $\mathbf{6 0 7}$, van der Werf, Extant, 1984, and 613, Rossell i Mayo, Monodia cortesana, 1986.]

1839.

Bossy, Michel-André. “Aimeric de Peguilhan's partimens.” NM 80 (1979): 123-32. [Edition of the seven partimens: PC 10,3; 6; 7a; 19; 28; 37; 50.]

1840.

Guida, Saverio. “La 'Biografia' di Aimeric de Peguilhan.” RST 3 (2001): 221-34. [Assembles many historical indications that Uc de Saint Circ knew Aimeric well; 
numerous parallels with other vidas known to have been composed by Uc show that this one should probably be attributed to him as well.]

1841.

Gouiran, Gérard. "Sur quelques troubadours qui franchirent les Alpes du temps de la croisade contre les Albigeois." In $\ \mathbf{1 6 4}$, I trovatori nel Veneto, 2008, pp. 97-133. [Aimeric seems to have shared the dissolute lifestyle of the young Sordello, along with his penchant for insulting his rivals.]

\section{2.}

Mancini, Mario. “Aimeric de Peguilhan, 'rhétoriqueur' e giullare.” In Il Medioevo nella Marca: Trovatori, giullari, letterati a Trevisonei secoli XIII e XIV. Atti del convegno. Edited by M. L. Meneghetti and F. Zambon. Treviso: Premio Comisso, 1991, pp. 45-89. Slightly revised in 401, Mancini, Metafora feudale, 1993, pp. 207-43. [Detailed look at Aimeric's very active and successful career, using Köhler's Marxist-sociological analysis; his reputation for wild living and witty style was shared with his companion Sordello; he parodied poems of several contemporaries through intertextuality.]

\section{3.}

See 2451, Negri, "Guillem Figueira-Aimeric de Peguillan," 2010. [Two coblas that have been interpreted as an integral "exchange of coblas," are here interpreted as an attempt by the compiler of the manuscript to put together a number of disparate coblas esparsas to make them a unified series.]

\section{4.}

Rossi, Luciano. "Aspetti dell'invettiva nell'Occitania del XIII secolo: Aimeric de Peguilhan e I suoi sodali." In Cecco Angiolieri e la poesia satirica médiévale. Atti del Convegno (Siena, 26-27 ottobre 2002). Edited by Stefano Carrai and Giuseppe Marrani. Florence: Il Galluzzo-SISMEL, 2005, pp. 31-49. [Studies the use of invective in various forms: sly or malicious ambiguity in the vidas and razos; an exchange of insults by Aimeric and his "friends" Guillem Figueira, Bertran d'Aurel, and Rambertino Buvalelli, in what we see as vulgar terms but which are in fact highly crafted literary works; analysis of Aimeric's flabel PC 10,44, a suggestive parody of epic vocabulary.]

1845.

See 360, Rüdiger, Aristokraten, 2001. [Part of Rüdiger's study of the mentality of twelfth- and early thirteenth-century Toulouse is illustrated by the analysis of Aimeric de Peguilhan's PC 10,38, Nulhs hom non es tan fizels vas senhor, read as a political text about "parity" and the fundamental concept of convenientia based on honor; the clash between the worlds of equality and hierarchy led finally to the collapse of the society after the Albigensian Crusade 1226-29.]

\section{6.}

Tavera, Antoine. “Des troubadours italotropes." In 749, ICLS 7, 1994, pp. 85-93. [General presentation of the careers of three traveling troubadours: Aimeric de Peguilhan, Cerveri de Girona, and Peire Raimon de Tolosa.]

1847.

Uhl, Patrice. "La tenso de non-re (Aimeric de Peguilhan et Albertet de Sisteron): un 
débat en trompe l'oeil." In Pour une poétique de l'échange philosophique: Le dialogue d'idées et ses formes littéraires. Edited by Marie-Françoise Bosquet and J.-M. Racault. Paris: L'Harmattan, 2008, pp. 65-76. [Nothingness was a theme common to classical literature, medieval sermons, and troubadour poetry; the poem by Guilhem de Peitieus, PC 183,7, comes out of contemporary intellectual dialectic; the tenso between Aimeric and Albertet, PC 10,6 = 16,5, probably composed at the court of the Este or the Malaspina, reopens the debate one hundred years later: the poem is a thing, not a non-re. See also $>\mathbf{8 1 9}$, Roubaud, La Fleur inverse, 1986, pp. 23-53, who explores poems about nothingness by several poets, seeing the theme as the central dilemma of fin'amor.]

\section{8.}

Agamben, Giorgio. "El lenguaje y la muerte: séptima jornada." In Teorías sobre la lírica. Edited by Fernando Cabo Aseguinolaza. Madrid: Arco/Libros, 1999, pp. 10526. In Italian: Il linguaggio e la morte. Turin: Einaudi, 1982, pp. 82-93. [Aimeric's tenso PC 10,6 = Albertet de Sisteron PC 16,5 is reproduced with Italian translation, as an example of theory of discourse which Agamben sees as the origin of modern poetry, along with a poem by Giacomo Leopardi; discourse requires "love" in its initial phase in the Christian interpretation: in the beginning is the Word (love); for the troubadours, love and poetry are the same, an attempt to express the inexpressible; poetic discourse comes out of nowhere and does not exist anywhere.]

\section{9.}

Lawner, Lynne. "Tot es nien.” CN 31 (1971): 155-70. [The tenso PC 10,6 with Albertet is linked to a network of "nothing" poems by Guilhem de Peitieus, Raimbaut d'Aurenga, Marcabru, Giraut de Bornelh, and Bernart de Ventadorn.]

\section{0.}

See 553, Maillard, "Descort, que me veux-tu?" 1982. [Analysis of the melody of Aimeric's poem PC 10,45, which is preserved in two versions; one melody is quite atypical within the troubadour tradition, filled with distortions perhaps meant to reinforce the expression of the poet's distress, while the other is more subtly discordant.]

1851.

See 227, Riquer, 1975, 2:963-82. [Detailed biographical introduction, vida, edition of five poems, PC 10,22, 26, 32, 34, 35, with Spanish translation.]

\section{2.}

Barbieri, Luca. Edition of the salut PC 10,I, Bona dompna, pros ez onrada, in $\mathbf{5 2 0}$, Gambino, Salutz, 2003, pp. 654-75. [Critical text with Italian translation, abundant notes; attributed to Aimeric because of the rare word ancessis, which occurs twice more in the poet's works but also elsewhere; there are a few other resemblances to Aimeric, but even more to Arnaut de Maruelh; the poem should be considered anonymous until further insights are available; language traits point to a late Italian poet. For ancessis, see Frank M. Chambers, "The Troubadours and the Assassins," Modern Language Notes 64 (1949): 245-51.] 


\section{PC 11. Aimeric de Sarlat}

[fl. 1190-1210; vida, five cansos, one of which, PC 9,11, was formerly attributed to Aimeric de Belenoi.]

1853.

Fumagalli, Marina. "Le canzoni di Aimeric de Sarlat." Travaux de linguistique et de literature 17 (1979): 121-69. [Introduction, critical edition of five poems with Italian translation, notes.]

\section{4.}

See 227, Riquer, 1975, 2:806-10. [Introduction, edition of one canso PC 11,1, with Spanish translation, notes.]

PC 12. Alaisina Yselda (probably not two names Alais and Na Yselda) [Unknown poet, perhaps in a convent; thirteenth century; tenso with an older $\mathrm{Na}$ Carenza, a type of mother figure, asking whether she should marry.]

\section{5.}

See 735, A. Rieger, 1991, pp. 155-65. [Introduction, critical text with German translation, notes; Rieger finds several close parallels with a poem by Arnaut de Maruelh PC 30.16, allowing dating for this poem after 1195, and even allowing the possibility of a direct influence by Arnaut on the poem itself (he might even be the unnamed suitor); indirect hints may indicate that Alaisina Yselda is toying with Cathar principles, or parodying them, while Carenza represents a traditional down-to-earth attitude.]

1856.

McCash, June Hall. "Alaisina Yselda." In 46, Women in the Middle Ages, 2004, pp. 13-14. [Points out several puzzling qualities of the poem: the uncertain number of participants, the enigmatic references to Cathar beliefs, the ambiguous advice to get married but to preserve virginity, and a satirical comment on the three estates of women; these mysteries are heightened by the poor state of transmission of the text.] 1857.

Anderson, Patricia. "Na Carenza al bel cors avinen: A Test Case for Recovering the Fictive Element in the Poetry of the Women Troubadours." Tenso 2 (1987): 55-64. [A close study of the tenso concludes that the two ladies are stylized types, not "real" subjective courtly women; they have been created by the anonymous poet in order to transmit a dramatic message, entertaining and clever, albeit satirical and unflattering to the image of woman; the satire is aimed at the whole social convention of fin'amor and the domna.]

1858.

Bec, Pierre. "Avoir des enfants ou rester vierge? Une tenson occitane du XIIIe siècle entre femmes." In Mittelalterstudien: Erich Köhler zum Gedenken. Edited by Hemming Kraus and Dietmar Rieger. Heidelberg: Winter, 1984, pp. 21-30. [Diplomatic edition, plus a new provisional transcription, with French translation; detailed analysis of the poorly transmitted poem, seen as a burlesque parody of the male-oriented courtly tradition.] 
1859.

See 797, Bruckner, "Mathematical Bodies," 1999. [Discussion of how to distinguish real from fictional bodies in the troubadour lyric; three poems are studied: Bernart de Ventadorn's Era.m cosselhatz, senhor (PC 70,6), Guilhem de Peitieus's Farai un vers de dreit nien (PC 183,7) and the exchange of coblas between $\mathrm{Na}$ Carenza and Alaisina Iselda_or is it Carenza/Alais/Iselda (PC 12,1 and 108,1); if we cannot prove or disprove the reality of a body in a poem, nor its fictional construct, in "fuzzy logic" it is both at the same time.]

\section{PC 12a. Alamanda}

[Second half twelfth century; participant in a tenso with Giraut de Bornelh PC 12a, 1 = PC 242,69; some believe that she is fictitious, created by Giraut de Bornelh (Jeanroy, Appel, Köhler), others that she is real (A. Rieger, Zufferey, Paden); Rieger suggests that the "anonymous" ladies of PC 461,56 may well be Alamanda (donzela) and Escaronha (bona domna): see 1863, Guida, "Trobairitz fantomatiche," 2001. 1860.

See 735, A. Rieger, Trobairitz, 1991, pp. 183-203. [Edition of razo to PC 242,69; critical edition of PC 12a, $1=242,69$, with German translation, notes, analysis; plausibly identifies Alamanda as Alamanda de Castelnou, at the court of Raimon V; the subject of this and three other masculine/feminine tensos may be connected to the marital problems between Raymond V and Constance de France; points out similarities with a tenso between Raimbaut d'Aurenga and an anonymous domna.]

\section{1.}

Bruckner, Matilda Tomaryn. "Alamanda." In 46, Women in the Middle Ages, 2004, pp. 15-16. [Interlocutor in a witty tenso with Giraut de Bornelh, Alamanda may have been a real woman active around the turn of the thirteenth century; real or not, she stands up vigorously to Giraut in a lively exchange and may have served as a role model for women of her society.]

\section{2.}

See 758, Chambers, "Las trobairitz soiseubudas," 1989. [Claims that all tensos in which the female speaker is unnamed were probably composed by male poets; doubts the existence of Alamanda and Domna H.]

\section{3.}

Guida, Saverio. "Trobairitz fantomatiche? I casi Alamanda ed Escaronha." In $>$ 99, AIEO 6, 2001, pp. 411-33. [Some of the anonymous poets were probably women; the recent idea that some of the female-voiced participants in tensos may have been fictitious trobairitz has no more or less validity than saying that the anonymous malevoiced participants may have been women; Alamanda d'Estanc and Escaronha Jordan were two very real women; the sirventes PC 404,5: No puesc mudar no digua mon vejaire, attributed to $\mathrm{R}$. Jordan, is female-voiced; the copyist may have misread $E$. Jordan and written down $R$. Jordan; this may be the Escaronha de l'Isla Jordan known to Arnaut Guilhem de Marsan and/or the domna sung by Giraut de Bornelh; the anonymous ladies of PC 461,56 may well be Alamanda (donzela) and Escaronha (bona domna).] 
1864.

MacDonald, Aileen Ann. "The Female tenso: Alamanda's Response to Guiraut de Bornelh." In The World and Its Rival: Essays on Literary Imagination in Honor of Per Nykrog. Edited by Kathryn Karczewska and Tom Conley. Amsterdam: Rodopi, 1999, pp. 79-92. [An overview of the so-called donzella tensos; MacDonald is undecided as to the reality of Alamanda, but internal evidence makes her lean toward acceptance.]

\section{5.}

Rieger, Angelica. "Alamanda de Castelnau — une trobairitz dans l'entourage des comtes de Toulouse?" $\operatorname{ZrP} 107$ (1991): 47-57. With revisions and corrections in 131, Les troubadours et l'état toulousain, 1994, pp. 183-92. [Suggests a historical identity for bell' ami' Alamanda, in a debate poem with Giraut de Bornelh, based on evidence of her influence and intertextuality; perhaps attached to the important Alaman family of Toulouse, perhaps even to be identified as an historical lady, Alamanda de Castelnau; identification doubted by some scholars, since its only justification is an untrustworthy razo.]

PC 12b. Alberjat and PC 13. Albert (probably the same)

[Thirteenth century; one tenso with Gaudi, PC 12b,1 = PC 170.1; one partimen with Simon Doria, PC 13,1 = PC 436,2.]

1866.

Radaelli, Anna. "Partimen of Alberjat and Gaudi PC 12b.1 = 170.1 Gaudi, de donzella m'agrat." In 256, Harvey and Paterson, Troubadour "Tensos, "2010, 1:61-67. [Introduction, critical edition with English translation, notes.]

1867.

Marshall, J. H. "Deux partimens provençaux du chansonnier T.” In $\mathbf{1 5 2}$, Miscellanea Roncaglia, 1989, 3:809-13. Also in CN 48 (1988). [Simon Doria and Albert. PC 13,1 = PC 436,2; Enric and Arver. PC 139,1 = 35,1; critical editions, French translation, notes.]

\section{8.}

See 249,Bec, Florilège en mineur, 2004, pp. 185-89. [Edition of tenso with Gaudi, PC 12b, 1 = 170,1, with French translation, no notes; the text is from Adolf Kolsen, Trobadorgedichte, Halle: Niemeyer, 1925, pp. 1-2.]

\section{PC 15. Albert Marques (Alberto, Marquis of Malaspina)}

[Born 1160-65, died 1206; poet, patron of troubadours, brother-in-law of Boniface of Montferrat; one tenso with Raimbaut de Vaqueiras (PC 15,1 = PC 392,1); probably also the (fictive?) tenso with Domna, PC 296,1a, attributed wrongly to Marques de Canilhac or Albertet de Sisteron, now reassigned plausibly to Albert

\section{9.}

Marques by A. Rieger 735, Trobairitz, 1991, pp. 356-66.]

Linskill, Joseph. The Poems of the Troubadour Raimbaut de Vaqueiras. The Hague: Mouton, 1964, p. 108. [Critical edition from eight manuscripts of the tenso with Raimbaut de Vaqueiras PC 15,1 = PC 392,1, with English translation, detailed notes, and commentary; probably composed in 1195.] 
1870.

See 249, Bec, Florilège en mineur, 2004, pp. 191-95. [Edition of the tenso PC 296,1a, between Marques and Domna; brief introduction, text from A. Rieger, French translation, no notes.]

1871.

See 735, A. Rieger, Trobairitz, 1991, pp. 356-66. [Edition of tenso PC 296,1a (formerly attributed to Marques de Canilhac), with German translation; attribution to Albert Marques plausibly reestablished; suggests that the anonymous lady participant in the poem might be Alberto's own wife or perhaps the trobairitz Isabella (PC 252); Rieger refutes Chambers's idea in $\mathbf{7 5 8}$, Chambers, "Las trobairitz soiseubudas," 1989, p. 53, that a stanza must be missing to account for the lady's sudden change of attitude.]

\section{PC 16. Albertet (de Sisteron) (Sestaro)}

[ $f$. 1195-1221; twenty-three poems, plus two of uncertain attribution: fifteen cansos, one descort, six tensos, and the humorous sirventes énumératif PC 16,13a that provoked a response from Aimeric de Belenoi: PC 9,21 Tant es d'amor honratz; Albertet was known especially for the beauty of his melodies, of which three are preserved.]

\section{2.}

Boutière, Jean. "Les poésies du troubadour Albertet." SM n.s. 10 (1937): 1-129. [Introduction on the poet, the corpus, discussion of individual poems, edition of twenty-one poems, with French translation, notes, glossary; in appendix 1: four poems of doubtful attribution, with French translation; in appendix 2: Aimeric de Belenoi's response, PC 9,21, to Albertet's 16,13.]

\section{3.}

Sanguineti, Francesca. "Pour une nouvelle édition critique des poèmes d'Albertet." RlaR 114.1 (2010): 121-38. [Reinterpretation of the literary interest of Albertet's poetry; clarification of biographical details and attribution problems, revealing an itinerant joglar who rose to the position of a very popular troubadour through his cleverness and musicality.]

\section{4.}

Giangrande, Mario. L'opera di Albertet de Sisteron e la sua posizione nella poesia provenzale. Collana di studi e ricerche 17. Lanciano: Rocco Carabba Editore, 1986. [Analysis of Albertet's corpus within its cultural tradition: the historical figure, dating, thematic analysis, poetic techniques, metrical characteristics; no edition of the poetry, but he attributes to Albertet two poems that Boutière had put into appendix as dubious: PC 303,1 = 16,17, a tenso between Albertet and Monge, and PC 12b,1 = 170,1, a tenso between Gaudi and the unknown Alberjat; for the texts, see 256, Harvey and Paterson, Troubadour "Tensos," 2010, 1:99-105 and 61-67.]

\section{5.}

See 1832, Poli, Aimeric de Belenoi, 1997. [New edition of En amor truep tan de mal senhoratge PC 16,13 by Albertet de Sisteron, pp. 278-314.] 
1876.

Beggiato, Fabrizio. "Raimbaut de Vaqueiras e Albertet: percorsi ed incontri trobadorici nel Monferrato, riflessioni ed interrogativi." In Dalla Provenza al Monferrato. Percorsi medievali di testi e musiche. Edited by Sonia Maura Barillari. Alessandria: Orso, 2007, pp. 19-27. [Exploration of parallels and references that link Albertet with Raimbaut and several other poets between 1197 and 1201; no new information is offered on the identity of the name Engles or on the nature of the intertextual links, but a chart of resemblances among a dozen poems is presented, in the hope that other scholars may carry the research further.]

1877.

See 2697, Guida, "Questioni relative," 2008. [Pp. 251-73: the exchange of coblas between Raimbaut and Albertet is confirmed to be between Raimbaut de Vaqueiras and Albertet de Sisteron, and to belong to about 1195; pp. 273-301: the dispute between Albertet de Sistero and Monge concerning the relative merits of the French and the Catalans seems to reflect the period of threat preceding the Albigensian Crusade.]

1878.

Lawner, Lynne. "Tot es niens." CN 31 (1971): 155-70. [Analysis of tenso PC 10,6 = PC 16,5 between Aimeric de Peguilhan and Albertet de Sisteron concerning contemporary philosophical questions about being and nothingness; links with poetry of Guilhem de Peitieus, Raimbaut d'Aurenga, Marcabru, Giraut de Bornelh, and Bernart de Ventadorn.]

\section{9.}

Marshall, J. H. "The descort of Albertet and its Old French Imitations." $\operatorname{ZrP} 95$ (1979): 290-306. [Shows that Albertet's poem PC 16,7a, Bel m'es oimes, was the first and that the Old French poems are contrafacta of it.]

1880 .

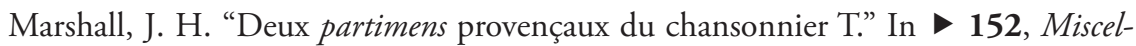
lanea Roncaglia, 1989, 3:809-18. Also in CN 48 (1988): 809-18. [Simon Doria and Albert, PC 13,1 = PC 436,2; Enric and Arver, PC 139,1 = 35,1; critical editions, with French translation, notes.]

\section{1.}

See 227, Riquer, 1975, 2:1129-38. [Introduction, vida, canso PC 16,18 and a partimen between Albert (maybe Albertet de Sisteron) and Monge, PC 16,17 =303,1.]

\section{2.}

Sanguineti, Francesca. "Albertet: En amor trob tantz de mals seignoratges (PC 16,13)." Lecturae tropatorum, 2008, 34 pages. Online at http://www.lt.unina.it. [Within his fifteen cansos, this one stands out as an "enumerative sirventes"; meticulous study of the poem in its sociocultural setting; critical edition with Italian translation, detailed textual notes.]

1883.

Sanguineti, Francesca. "Albertet Donna pros e richa PC 16.11." Online, 2009, at http://www.lt.unina.it. 25 pp. [Notes the close interrelationships with the Carros 
PC 392,3 and other poems of Raimbaut de Vaqueiras (PC 392,7, 392,16 and the Kalenda maia), and with poems of Raimbaut d'Aurenga; analysis of the unusual alternating tone between praise and vituperation for the lady, indicative of a profound transformation of courtly poetry at the turn of the century, in which poets began to criticize openly the uncooperative domna and threaten her with abandonment (mala canso, comjat, camjar); critical edition of PC 16,11, with Italian translation and copious notes.]

\section{4.}

See 1847, Uhl, "La tenso de non-re," 2008. [The tenso between Aimeric and Albertet, PC 10,6 =16,5, composed on the theme of nothingness, probably at the court of the Este or the Malaspina, reopens the debate begun one hundred years earlier by Guilhem de Peitieus; see also \$ 819, Roubaud, La Fleur inverse, 1986, pp. 23-53, who explores poems about nothingness by several poets, seeing the theme as the central dilemma of fin'amor.]

\section{PC 16a. Albric (Alberico da Romano)}

[Died 1260; brother of Ezzelino; patron of Uc de Saint Circ, with whom he participated in an exchange of cobla PC 16a, $1=$ PC 457,20a and perhaps a canso, PC 93,1, if he is to be identified with Bietris de Roman; Bietris would

then be removed from the list of trobairitz; her PC 93,1 would become his PC 16a,2; but this is controversial.]

1885.

Bertoni, Giulio. I trovatori d'Italia. Modena: Orlandini, 1915, pp. 66-68 and 26568. [Introduction, pp. 66-68; edition of the canso PC 16a,2 and the exchange of coblas PC 16,a1 = 457,20a, with Italian translation.]

\section{6.}

See 764, Poe, "Dispassionate Look," 1992, pp. 147-49. [Points out the close relationship of a poem by Bietris to one by Uc de Saint Circ, also addressed to Na Maria; she assumes that the poem was composed by a man, assigning it rather arbitrarily to Albric because of similarity of name and the fact that he was Uc's patron and fellow participant in a tenso.]

\section{7.}

See 296, Verlato, "Il pretesto trobadorico," 2009. [Explores the possibility of an alternate religious moralizing stream of poetry, not well preserved in the chansonniers but evident in the Wolfenbüttel manuscript, that developed in Italy alongside the troubadour tradition; the poetry of Rambertino Buvalelli, Lanfranc Ciagala, Bertolome Zorzi, and especially Alberico da Romano may be a link between the two traditions and indicate the forces at work at the moment of fixing the troubadour tradition in the chansonniers.]

\section{PC 16b. Aldric (del Vilar)}

[Unknown; first half twelfth century; one impertinent sirventes PC 16b,1 Tot a estru, addressed to Marcabru, linked to one or two witty poems by Marcabru: 
PC 293,43, Seigner n'Audric, and PC 293,16, D’aisso lau Dieu; Marcabru's vida in $A$ claims that he was a foundling, raised by Aldric; he may be the "Audricx" referred to by Peire d'Alvernhe in PC 323,15.]

1888.

See 876, Chambers, "D'aisso lau Dieu," 1982. [Intertextual links and identical metrical form among the sirventes by Aldric, Tot a estru, PC 16b,1, and Marcabru's two poems, D'aisso lau Dieu, PC 293,16, and Seigner n'Andric, PC 293,43, suggest that the first was a direct reply to Marcabru's D'aisso and that the third was an answer by Marcabru to Aldric; Chambers hypothesizes that Marcabru was not boasting in D'aisso lau Dieu but was speaking in bitter parody.]

1889.

See 2622, Gaunt et al, Marcabru: A Critical Edition, 2000, pp. 221-24 (note to lines 58-60). [Detailed analysis of the plentiful scholarship concerning the cycle of three poems; suggests the sequence D'aisso laus Dieu >> Tot a estru >> Seigner n'Andric; the whole cycle may have been an elaborate parody of an arrogant patron, dependent for its effect on careful collaboration in performance.]

1890.

Meneghetti, Maria Luisa. "Aldric, Marcabru e il poemetto Eu aor Damrideu." In L'Ornato parlare. Studi di filologia e letteratura romanze per Furio Brugnolo, 2007, pp. 3-19. [Critical appraisal of the controversy surrounding the cycle of three poems, including previous contradictory theories by herself, Roncaglia, Chambers, Spaggiari, and others, leading to the suggestion that Aldric's poem Tot a estru initiated the cycle with parodic intent, using form and content of an early religious poem, answered by Marcabru in two poems of increasing severity; D'aisso lau Dieu would be the last of the cycle, not the first, as others have claimed.]

1891.

Roncaglia, Aurelio. "Il gap di Marcabruno." SM 17 (1951): 46-70. [D’aissi lau Dieu, PC 293,16, is puzzling because it seems to espouse immoral concepts that Marcabru has attacked in his other poems; this is not a literary joke, but a frustrated cry of provocation to his uncaring audience: he is bitterly denouncing the immorality of the bad poets and the enemies of fin'amor, as in his other works, but here in the mode of bitter parody; thorough study of the manuscript tradition and a new critical edition of the song, with Italian translation, copious notes.]

1892.

See 2666, Spaggiari, Barbara. Il nome di Marcabru, 1992. [Interpretation of Marcabru's poetic dispute with Aldric del Vilar, different from those of Roncaglia, 1951, Chambers, 1982, and Meneghetti, 2000 and 2007.]

\section{PC 17. Alegret}

[ 7 . 1143-57; one canso; one sirventes in praise of Alfonso VII of Castile but harshly critical of other powerful men and unfaithful husbands; named as joglar by Bernart de Ventadorn PC 70,4; the twenty-two-line fragmentary salut d'amor, PC 17.I, Dompna, c'aves la segnoria, is probably not by Alegret.] 
1893.

See 261, Viel, Troubadours mineurs gascons, 2011. [Introduction analyzes the cultural context, problems of attribution, manuscript tradition, and language and metrics; critical edition of PC 17,1 and 2, with French translation and detailed notes; rich glossary; see also his preliminary study in CDT 8 (2005): 803-39, which examines the intertextual connections among Alegret, Marcabru, and Peire d'Alvernhe and reevaluates Alegret's distinctive poetics.]

\section{4.}

Tortoreto, Valeria. "Per l'attribuzione di Bel m'es qan la rana chanta (BdT 293, 11) (e di Belha m'es la flors d'aguilen, BdT 323,5).” CN 67 (2007): 253-317. [Includes editions of both; thinks 293,11 is probably by Alegret, not Marcabru, and that 323,5 is by Bernart Marti, not Peire d'Alvernhe; Tortoreto is preparing a new edition of Alegret.]

\section{5.}

Viel, Riccardo. "L'Estruma in Alegret: dall'agiografia mediolatina ad un verso trobadorico." Rom 128 (2010): 234-50. [Linguistic and sociological study of estruma and related vocabulary associated with lumps, tumors, and growths, which were thought to be outward signs of carnal concupiscence, especially in saints' lives; used in Alegret's poem PC 17,2 as a symbol of the moral decay in society that must be reversed in order to restore the former virtues of cortesia.]

\section{6.}

See 249, Bec, Florilège en mineur, 2004, pp. 109-13. [Text of PC 17,2 from Jeanroy, 1923; the two manuscript versions are mixed without notes or explanation.]

\section{7.}

See 227, Riquer, 1975, 1:236-40. [Introduction, sirventes PC 17,2, text from Dejeanne, with Spanish translation, notes.]

\section{8.}

Barbieri, Luca, in 520, Gambino, Salutz, 2009, pp. 690-93. [Critical edition of the fragmentary salut PC 17.I, Dompna, c'aves la segnoria, with brief introduction and Italian translation; cannot be by Alegret, as claimed by G. M. Barbieri, on account of chronology, rhyme, and links to Arnaut de Maruelh and his imitators; an inexact rhyme suggests that it may have been composed by an Italian poet; it should be listed as anonymous pending further investigation.]

\section{PC 18. Alest, lo Senher d' (Peire Pelet, Senher d'Alest)}

[fl. 1274-1303; one tenso (torneiamen), PC 18,1 with Enric II, comte de Rodez, his brother-in-law $=$ PC 140,2, and Guiraut Riquier = PC 248,76; he was very close to Enric and active in the cultural life of the court at Rodez.]

\section{9.}

Guida, Saverio. "Guiraut Riquier_Enric de Rodez-Peire Pelet." In Jocs poetici alla corte di Enrico II di Rodez. Modena: Mucchi, 1983, pp. 173-205; also online, 2002, at http://www.rialto.unina.it. [Introduction, p. 57; critical edition of the three-part tenso PC 248,76, with Italian translation, copious notes, glossary; the debate centers 
on the relative importance of the courtly virtues of largueza, proeza, and fes, all three essential to the symbiotic functioning of courtly society.]

\section{PC 20. Almuc de Castelnou (Almois)}

[Late twelfth, early thirteenth century; vida; one cobla (part of a fragmentary tenso), PC 20,2, a response to PC 253,1 by Iseut de Capio; some think that both she and Iseut are fictive, that both poems may have been written by Uc de Saint Circ, but Colrat de

Montrozier has demonstrated her existence in documents from ca. 1155 on.] 1900.

See 735, A. Rieger, Trobairitz, 1991, pp. 166-73. [Text of the razo from Boutière/ Schutz; critical edition of the fragmentary tenso, with German translation, notes, detailed commentary; demonstrates the close relationship to Uc de Saint Circ's Anc enemics PC 457,3, which served as a model; the anonymous cobla 461,102b may originally have been part of this poem, or of Uc's.]

\section{1.}

McCash, June Hall. "Almuc de Castelnou." In $>$ 46, Women in the Middle Ages, 2004, pp. 23-24. [The power of the domna's will in the courtly love relationship is demonstrated in the dialogue with her friend Iseut de Capio; both women and Almuc's lover seem to be real, though precise historical identification remains controversial.]

1902.

Colrat de Montrozier, Bruno. "Amour parodique de comtoresse: Le cas des trouveresses Almus de Chastelnou et Iseut de Chapiou." FL 146 (2008): 152-72. [Detailed genealogical history of the Tournel dynasty and the families of Almuc and Iseut; supposes their acquaintance with Uc de Saint Circ, because of parallel language in their poem and his PC 457,3; suspects that the poem may be a humorous prank.]

1903.

See 764, Poe, "Dispassionate Look," 1992. [Casts doubt on the historical reality of five of the seven named trobairitz, maintaining only Garsenda and Guilhelma de Rosiers; Poe claims that Uc de Saint Circ may have composed the exchange of coblas between Iseut de Capio and Almuc de Castelnou; but resemblance to Uc's style may reflect only his influence, not his authorship.]

\section{PC 21. Amanieu de la Broqueira (Broquiere) [Ca. 1180; two cansos.]}

1904.

See 261, Viel, Troubadours mineurs gascons, 2011. [Introduction gives cultural context, considers questions of attribution, manuscript tradition, language, and metrics; critical edition of PC 21,2 and 1, with French translation, detailed notes; rich glossary.]

1905.

See 2470, Guida, "Cartulari e trovatori," 1999, pp. 86-97. [A historical trace of Amanieu has been found near Armagnac; he is linked to Raimon de Durfort by 
virtue of having the same jongleur, leading to a possible date of ca. 1180; uncertain conclusions about the social position, dates, and provenance of Amanieu are drawn from his poem PC 21,2 and from the possible identification of the joglar mentioned in the poem.]

1906.

See 249, Bec, Florilège en mineur, 2004, pp. 19-23. [Edition of PC 21,1; slightly altered text from Jeanroy 1923, with French translation, no notes.]

\section{PC 21a. Amanieu de Sescas (Sescars)}

[ fl. 1274-1305; two saluts and two ensenhamens (de l'Escudier and de la Donzela).] 1907.

See 2470, Guida, "Cartulari e trovatori," 1999, pp. 107-29. [Makes a strong case for the need to ally historical research with literary; shows convincingly through archival documentation that Amanieu de Sesca's years of poetic activity are to be revised to $1274-1305$ and that he is definitely Gascon.]

1908.

See 1441, Sansone, Testi, 1977. [Introductory study of the ensenhamen, critical text with Italian translation, notes.]

1909.

Guadagnini, Elisa. Edition of two saluts by Amanieu de Sescas: $A$ vos que ieu am deszamatz, PC 21a,I, and Dona, per cuy planc e sospir, PC 21a,II, in 520, Gambino, Salutz, 2009, pp. 564-605. [The poems are characterized by dialogue structures, realism in detail, and down-to-earth language (physical handicaps, hangings, market, clothing); 21a,II makes use of many proverbs, as well as direct discourse, inserted refrains, and rather colorful or coarse language. See also $>227$, Riquer, 1975, 3:1653-61: introduction, text of the salut PC 21a,I from Appel, with Spanish translation, notes.]

\section{PC 22a. Andrian del Palais (Adrian). See PC 315. Palais}

\section{PC 23. Anfos (King Alfons II of Aragon)}

[Born 1154, king 1162-96; vida; one canso, one tenso with Giraut de Bornelh; possibly mentioned as Anfos in Guerau de Cabreira's ensenhamen, but Pirot

-1440, Recherches, 1972, finds this unconvincing.]

\section{0.}

227, Riquer, 1975, pp. 566-73. [Introduction, vida, and both poems, with Spanish translation, notes.]

\section{1.}

Cluzel, I.-M. "Princes et troubadours de la maison royale de Barcelone-Aragon." $B R A B L B 27$ (1957-8): 324-34. [Introduction gives information about the court of Alfons II, who was patron of at least twenty troubadours; edition of his canso PC 23, 1 and his tenso with Giraut de Bornelh, PC 242,22 = 23,1a, with French translation.] 
1912.

Rieger, Angelica. "L'image d'Alphonse II d'Aragon dans les vidas des troubadours." In $O$ Cantar dos trobadores. Actas do congreso celebrado en Santiago de Compostela entre os dias 26 e 29 de abril de 1993. Santiago de Compostela: Xunta de Galicia, 1993, pp. 263-87. [An attempt to restore the maligned figure of Anfos found in the vidas and razos, where he is unjustly accused of treachery because of political actions in which he opposed the popular counts of Toulouse, and perhaps because Uc de Saint Circ wanted to present "his" troubadours in the most dramatic light; he is praised for his generosity and as the protector of finamor in seeking vengeance for the unjust murder of Guilhem de Cabestanh in the history of the eaten heart.]

1913.

Rüdiger, Jan. "Herrschaft und Stil bei Peter II. von Aragon." Frühmittelalterliche Studien 39 (2005): 177-202. [Analysis of the tenso between Alfonso and Giraut de Bornelh, a debate about whether a powerful king can or should submit to the laws of courtly behavior.]

\section{PC 26. Arnaut de Brancalo (Brantalon)}

[Late thirteenth century; one pious song, perhaps Cathar, a confession of his own sins; one newly discovered anti-French sirventes.]

1914.

See 1517, Oroz Arizcuren, La lírica religiosa, 1972, pp. 66-73. [Edition of the PC 26,1, with Spanish translation, notes.]

1915.

Gasca-Queirazza, Giuliano. "Un nouveau fragment de chansonnier provençal." Marche romane 33 (1983): 93-99. [Discovery of a manuscript with twenty-one poems, some previously unknown; one new sirventes attributed jointly to Arnauz de Brantalon and an unknown Guillems de Gap; a provisional transcription and interpretation was published in $\mathbf{9 4}$, AIEO 1, 1987, pp. 213-17, but the promised definitive edition has not appeared.]

1916.

See 249, Bec, Florilège en mineur, 2004, pp. 260-63. [Text of the religious poem from Oroz Arizcuren, with French translation, no notes.]

1917.

See 255, Guida, Trovatori minori, 2002, pp. 263-82. [Copious information on manuscripts, background of poet; critical edition of PC 26,1 with Italian translation, notes; could not include the newly discovered sirventes with joint attribution to Arnaut de Brancalo and an unknown Guillem de Gap, since Gasca-Queirazza has not yet revealed details of the manuscript he discovered, nor the definitive edition that he promised in 1987.] 


\section{PC 27. Arnaut Catalan}

[ $f$. 1220-53; no vida extant; perhaps the same as one or other of the Arnauts in PC 25; eleven poems, including a prayer-like song of repentance, plus the opening line of a lost tenso with Aimeric de Belenoi (= PC 9,2); he is the author of

PC 25,1, an exchange of scabrous coblas with Raimon Berenguer IV,

1918.

Count of Provence $=$ PC 184,1, and another with Alfonso X.]

Blasi, Ferruccio. Le poesie del trovatore Arnaut Catalan. Biblioteca dell'Archivum romanicum 24. Florence: Olschki, 1937. [Introduction: life and travels of the poet, corpus, literary study, metrics; edition of five cansos, with Italian translation, notes, and glossary; in appendix: the prayer and five poems that Blasi considered to be of doubtful attribution.] 1919.

Pellegrini, Silvio. "Arnaut (Catalan?) e Alfonso X di Castiglia." Saggi e ricerche in memoria di Ettore Li Gotti. Palermo: Centro di studi filologici e linguistici siciliani, 1962, vol. 2, pp. 480-86. [Reproduces Blasi's text of a partimen, supposedly between Arnaut Catalan and either Raimond Berenger V or the count of Rodez; closely connected to this is another dialogue poem in a Portuguese manuscript, in GalicianPortuguese and Occitan, between Alfonso X of Castille and don Arnaldo, who is given the title Almiral Sisom after a bird known proverbially for its continuous farting; see also $S M V 8$ (1960): 165-72, esp. p. 170, which questions the date and attribution of the well-known partimen del pet PC 25,1 = 184,1 between Arnaut and the Coms de Proensa; new edition of the bilingual poem, which retains many of its mysteries.] 1920.

See 227, Riquer, 1975, pp. 1349-54. [Introduction, edition of PC 27,6 and the exchange of coblas, with Spanish translation, notes.]

1921.

Rossell, Antoni, "Les Cantigas de Santa Maria: stratégie et composition, de l'élément métrique à l'élément idéologique.” In 111, L'Espace lyrique, 2006, pp. 231-49. [Pp. 242-43: analysis of the semiobscene spoof of Bernart de Ventadorn's Quan vei in the exchange of coblas between Arnaut Catalan and Alfonso X; pp. 243-44: a cantiga may show Alfonso's hostility to the troubadours' courtly love: a contrafactum based on an alba by Cadenet, turned back into a religious poem by Alfonso: a slap in the face of troubadour sensuality, if in fact Alfonso did it on purpose!]

\section{PC 28. Arnaut de Comminges (Cumenge)}

[First half thirteenth century; one sirventes against the Orders; he is undoubtedly the Arnaut who participated in the tenso PC 25,1a with Bernart de la Barta; cousin of Bernart VII, count from 1187 to 1226 , shared in the defense of Toulouse against Simon of Monfort; very critical of the avidity and the arrogance of the clerics, especially against the establishment of a mendicant order on his own land.]

1922.

Jeanroy, Alfred. Jongleurs et troubadours gascons. Paris: Champion, 1928, pp. vii and 75. [Introduction, critical text, with French translation.] 
1923.

Guida, Saverio. "Arnaut de Cumenge: l'avversione di un signore-trovatore per l'ordo Praedicatorum." SM 51 (2010): 611-69. [Attributes to Arnaut de Comminges the participation in the tenso with Bernart de la Barta PC 25,1a $=58,1$, formerly attributed to an unknown Arman (Marshall) or to one of the unknown Arnauts (Asperti); note that in 256, Harvey and Paterson, Troubadour "Tensos," 2010, 1:114, Bernart's interlocutor is still called Arman.]

1924.

See 270, Guida, "Sospette paternità," 2010, pp. 277-321. [Many details concerning the life and poetry of Arnaut de Comminges; suggests that PC 25,2 and 25,3, now attributed to an unknown Arnaut, are probably by Arnaut de Comminges, as well as the tenso PC 25,1a previously attributed to him by Guida.]

\section{PC 29. Arnaut Daniel}

[Born ca. 1150; $f$. 1169-94; vida; eighteen poems, plus two of disputed attribution: one probable (PC 411,3, Entre.l taur e.l doble signe) and one uncertain (PC 29,14a, Mout m'es bel el tems d'estiou); sixteen cansos, one obscene sirventes, one sestina; two preserved melodies, see $\mathbf{6 0 7}$, van der Werf, Extant, 1984, pp. 13*-14*.]

\section{Editions}

[Five editions of Lo ferm voler are reproduced side by side at http://www.rialto. unina.it, including two by Perugi (1978 and 1996), with detailed notes by Aniello 1925.

Fratta. Four other poems by Arnaut are presented in a similar way.]

Toja, Gianluigi. Arnaut Daniel: Canzoni. Edizione critica, studia introduttivo, commento, e traduzione. Florence: Sansoni, 1960. [Eighteen songs; detailed philological and linguistic introduction; sensitive literary analysis.]

1926.

Perugi, Maurizio. Le canzoni di Arnaut Daniel. Documenti di filologia 22. Milan: Ricciardi, 1978. Two vols. [The most complete and reliable edition; very rich introduction and linguistic study; explores numerous links between Arnaut Daniel and other troubadours; paleographical study and edition of eighteen songs, with Italian translation, copious notes; no melodies; see also 1961, Perugi's "Linguistica e trobar clus," SM 38 (1997): 341-75: a very close study of variant readings for three passages in Arnaut, in the author's continuing pursuit of a text as close to definitive as one can attain; penetration of rare dialectal forms as the base for metaphors, leading to a better understanding of Arnaut's use of difficult language, and a fuller appreciation of the complexity of his poetry; Perugi is working toward a new synoptic critical edition of all of Arnaut's poems.]

1927.

Perugi, Maurizio. "Nuovi restauri danielini: il plurilinguismo come polisenso." Annali della Scuola Normale Superiore di Pisa 10 (1980): 203-18. [A number of precise ameliorations to his edition of 1978; emphasizes the necessity of moving 
back behind the leveling process of the thirteenth-century scribes to rediscover the dialectal and plurilinguistic richness of the vocabulary and phonology, especially in PC 29,13, L'aura amara, which may have been specifically aimed by Arnaut at a Catalan audience.]

\section{8.}

Perugi, Maurizio. "Per una nuova edizione critica della sestina di Arnaut Daniel." AMod 2 (1996): 21-39. Special issue: La Sestina. [Presentation of methodological principles of his editorial techniques, featuring close analysis of the manuscript tradition, metrics, prosody, morpho-phonetic, and lexico-semantic elements, to approach and restore the original form; several allusions by Arnaut in his sestina and elsewhere are shown to have come from Chrétien de Troyes.]

1929.

Eusebi, Mario. Arnaut Daniel. Il Sirventese e le canzoni. Milan: All'Insegna del Pesco d'Oro/Scheiwiller, 1984. Reissued in 1995 with a seven-page introduction and a few revisions: Arnaut Daniel. "L'aur'amara." Paradossi e rituali dell'amor cortese. Parma: Nuova Pratiche Editrice, 1995. [Edition of the standard corpus of eighteen poems, plus one of probable attribution in appendix; an accessible, simplified presentation that does not replace earlier editions; limited literary analysis.]

1930.

Riquer, Martin de. Arnaut Daniel, poesias; traducción, introducción, y notas. Barcelona: Quaderns Crema, 1994. [Not a new edition: follows Eusebi's text for eighteen poems, Marshall's for \#19, Zufferey's for \#20; substantial introduction, including analysis of Arnaut's influence on Catalan poets of the fifteenth century; notes, Spanish translation; no variants; no melodies.]

1931.

Wilhelm, James J. The Poetry of Arnaut Daniel. New York: Garland Press, 1981. [Edition of nineteen poems, including Entre.l Taur e.l doble signe, with English translation, rich textual notes that add sensitive poetic insights, glossary; musical transcription for Lo ferm voler by H. van der Werf; simplified presentation does not replace earlier editions.]

1932.

Lachin, Giosuè. Arnaut Daniel. Sirventese e canzoni. Translation by Fernando Bandini. Turin: Einaudi, 2000. [Accessible edition for nonspecialists; eighteen poems, in Italian translation by Bandini, with facing-page original and detailed notes by Lachin; Bandini has tried to preserve the original stylistic refinements of metrics and musicality, along with the complexities of meaning.]

\section{3.}

See 227, Riquer, 1975, 2:605-46. [Introduction, vida, edition of eight poems: PC 29,11, 5, 13, 10, 8, 18, 17, and 14, with Spanish translation, notes; see also pp. 859-62 for analysis of Arnaut's influence on Dante.]

\section{4.}

De Conca, Massimiliano. "Storia di tradizioni ed interpretazioni: il caso di Arnaut Daniel.” In 118, La lirica romanza, 2009, pp. 175-95. [Review of scholarship 
on Arnaut, especially the editions of his works; three examples of complex and still unsolved textual problems to show that a definitive edition is still needed; appendix, pp. 190-95: review of all seven editions of Arnaut's poetry.]

\section{Attribution Studies}

[PC 411,3, Entre.l taur e.l doble signe, attributed to Raimon Vidal de Besalù, and PC 29, 14a, attributed to Arnaut but considered by some scholars to be anonymous; other poems have been attributed to him in the manuscripts, but are not serious contenders.]

\section{5.}

Marshall, John H. "La chanson provençale Entre.l taur e.l doble signe (PC 411,3), une dix-neuvième chanson d'Arnaut Daniel?" Rom 90 (1969): 548-58. [Critical edition; poem traditionally attributed to Raimon Vidal de Besalù; probably by Arnaut, based on similarities of theme, vocabulary and metrics; attribution accepted by Wilhelm, Paden, and Poe but not by Toja, Perugi, nor Ibarz.]

1936.

Paden, William D. "Un plazer dels mes, vingtième chanson d'Arnaut Daniel? Mout m'es bel el tems d'estiu (PC 29, 14a)." CCM 26 (1983): 341-54. Shorter version in English in 127, 1989, Poetics of Love, 1989, pp. 187-97. [Edition of the poem, which partakes of two traditions: the theme of the occupations of the months and a tradition of plazer poems that list the poet's "favorite things" and the corresponding negative enuegs: a humorous satire directed against overused themes such as the seasons of love and the unsatisfied passions of the courtly lover, mocking Raimon de Miraval, Peire Vidal, and Guilhem Ademar; attribution denied by Zufferey and Vatteroni.]

1937.

Poe, Elizabeth W. "A Fiery Arrow from the Flanks: Defending Arnaut Daniel's Claim to PC 411,3." Rom 112 (2004): 111-34. [Convincing claim that Entre.l taur is by Arnaut; Poe regards some of Marshall's arguments as inconclusive, but adds new considerations, based on an intricate network of words, images, and themes, typical of all of Arnaut's acknowledged corpus, especially the frankly erotic and humorous imagery and the insistence on craftsmanship in composing; new edition with English translation, textual commentary, four emendations, detailed interpretation; Poe's opinion is challenged by Alexandre Ibarz, "État présent des recherches sur les troubadours catalans: essai d'un bilan et perspectives," in 102, AIEO 9, 2011, pp. 413-22, favoring the attribution to Raimon Vidal.]

1938.

See 2937, Tavani, "La poesia di Raimon Vidal," 1996, pp. 131-49. [Close study of the two manuscript copies of Entre.l taur, diplomatic edition of both, detailed discussion of variant readings and attempted restoration of the text on pp. 143-45, with Italian translation; suggests that the poem is not by Arnaut Daniel but rather a mosaic parody of his style; until further proofs are available, the poem must remain attributed to Raimon Vidal.] 
1939.

Zufferey, François. "Un plazer attribué à Arnaut Daniel." In $\mathbf{1 5 2}$, Miscellanea Roncaglia, 1989, 4:1503-13. Also in CN 49 (1989): 1503-14. [Edition of PC 29,14a Mout m'es bel el tems d'estiou, which he would deny to Arnaut, renumbering it PC 461,170d, seemingly unaware of Paden's edition, 1983; Paden accepts his emendations to lines 65 and 73 but maintains the attribution to Arnaut; Vatteroni clarifies a difficult reading in CN 68 (2008): 367-71 but also denies the attribution to Arnaut.]

\section{Detailed Literary Studies}

[For the sestina Lo ferm voler, and the poems of the "Cornilh affair," see below 1965-81 and 1982-92.]

1940.

Asperti, Stefano. "Postille testuali a margine delle canzone de Arnaut Daniel." $C N$ 47 (1987): 61-70. Also in 152, Miscellanea Roncaglia, 1989, 1:77-86. [Detailed analysis of four difficult passages in Arnaut's corpus; intensive study of vocabulary and syntax produces new and clearer meanings.]

1941.

Barbiellini Amidei, Beatrice. "Dante, Arnaut e le metamorfosi del cuore: A proposito di Sols sui qui sai lo sobrafan qe.m sortz, vv. 26-28." Parola del testo 6.1 (2002): 91-108. Also in Barbiellini Amidei, Beatrice. Non lasciare l'oro per il piombo: Elementi di intertestualità trobadorica e di critica del testo. Milan: CUEM, 2003, pp. 5-21. [Detailed analysis of three lines in PC 29,18, Sols sui, in which the image of the heart is depicted as a liquid force; the lines are edited and translated differently by five different scholars; stresses the importance to Arnaut of the heart as a symbol of love in all its transformations, a symbol borrowed and developed widely by Dante.]

\section{2.}

Barbiellini Amidei, Beatrice. "Sotto le maschere di Arnaut: appunti in margine all'esegesi di Arnaut Daniel.” Rom 123 (2005): 28-50. Also in: Barbiellini Amidei, Beatrice. Non lasciare l'oro per il piombo: Elementi di intertestualità trobadorica e di critica del testo. Milan: CUEM, 2003, pp. 23-44. [The influence on Arnaut of the Medieval Latin text Dialogus Salomonis et Marcolphi, specifically as the source of his paradoxical identifiers "hunting the hare with an ox" and "swimming against the current"; Arnaut identified with the verbal audacity of Marcolphus, which supported his own characteristic propensity to juxtapose the cultivated and the sacred with the popular and obscene, in the manner of the Latin vagantes; some parallels are identified between the Dialogue and Arnaut's sirventes in the "Cornilh affair."]

\section{3.}

Burgwinkle, William E. “'The Form of our Desire': Arnaut Daniel and the Homoerotic Subject in Dante's Commedia." Gay and Lesbian Quarterly 10 (2004): 565-97. [Analysis of Dante's attraction to Arnaut's poetry and the ambiguous placing of several sodomites in Inferno or in Purgatorio; the linkage of sexuality with poetry and with homoerotic desire is explored with fine discernment in both poets.] 
1944.

Burle, Elodie. "Le sujet lyrique médiéval en question." In L'expérience lyrique au Moyen Âge. Perspectives médiévales 28 (2002): 21-31. [Trobar implies enriching the tradition rather than changing it, using forms and themes and language that are part of a tradition; 27-31: whereas Bernart de Ventadorn remains apart from the "I" of the poem, seeking to understand and explain the nature of love, Arnaut Daniel is focused more on the poem itself as a structure than on themes or images; he is aiming for poetic perfection in a song that is a work of art.]

1945.

Canettieri, Paolo. "Il miglior fabbro, il men famoso Arnaldo e altre novelle dal Purgatorio" Online, 2008, at http://paolocanettieri.wordpress.com. [Suggests the possibility of a confusion, conscious or not, of Arnaut Daniel and Arnaut de Maruelh in Dante's evaluation, which may account for some of the surprising remarks made about Arnaut Daniel.]

\section{6.}

De Conca, Massimiliano. "Approximations métriques et parcours poétiques du troubadour Arnaut Daniel.” RST 2 (2000): 25-79. [Intensive analysis of technical aspects of Arnaut's poetry; internal and external intertextuality is traced through metric and thematic structures, in the work of Marcabru, Raimbaut d'Aurenga, Guilhem de Peitieus, and Bertran de Born; attempts a chronology of Arnaut's poems based on metric forms but has to admit that several hypothetical arrangements are possible and that Arnaut does not seem to have formed a "canzoniere" himself; see also $\mathbf{8 0 4}$, Kay, Subjectivity, 1990, pp. 13-16, who notes internal intertextuality between several of Arnaut's songs, especially L'aur'amara PC 29,13, which has many echos with his other poems.]

\section{7.}

De Conca, Massimiliano. Online edition of Arnaut Daniel, Sols soi qui sai lo sobrafan qui" $m$ sortz (PC 29,18), http://www.lt.unina.it. 33 pages. [Detailed study of manuscripts; critical edition with Italian translation, copious notes.]

\section{8.}

De Conca, Massimiliano. Lessico dei trovatori del periodo classico (LTC). Vol. 1: Arnaut Daniel (progetto pilota). Doctoral thesis, Geneva, 2008. [Directed by Maurizio Perugi, this thesis is the first part of a wider lexical project meant to include all the classical troubadours; presentation of the complete lexical resources of Arnaut, in all seven editions of his poetry, plus that in COM2, and also all the variant forms from the chansonniers, critically examined; for preliminary justification of the overall project, see Maurizio Perugi, "Modelli critico-testuali applicabili a un lessico dei trovatori del periodo classico (LTC),” SM 31 (1990): 481-544.]

1949.

Di Girolamo, Costanzo. "Longino che vide: una riflessione sulle preghiere formulari e una nota per Arnaut Daniel." Rom 123 (2005): 384-405. [The widespread tradition of epic prayer is outlined as background to Arnaut's parodic, near-blasphemous use of the formula in PC 29,8, Doutz braitz e critz; whereas the legendary Longinus 
achieved revelation by the light of faith, and his sight was restored miraculously by the blood of Jesus, Arnaut prays for the illumination of a real lamp so that he can better see and enjoy the naked body of his domna.]

\section{0.}

Fratta, Aniello. "Arnaut Daniel, Lancan son passat li giure (BdT 29.11)." Lecturae tropatorum, 2008, 20 pages. Online at http://www.lt.unina.it. [Literary introduction to the poem's warning about the dangers of fals'Amors, analyzed in comparison with Raimbaut d'Aurenga's similar theme in PC 389,10, Apres mon vers; critical edition with Italian translation, rich textual notes.]

\section{1.}

Fratta, Aniello. "Parodia antirudelliana in Arnaut Daniel: il caso di Autet e bas (BDT 29.5)." MR 33.1 (2009): 93-105. [An attempt to solve several difficult passages in Arnaut's poem, which seems to be a complex and subtle parody of Jaufre Rudel's attitude to love.]

\section{2.}

Gaunt, Simon. "Poetry of Exclusion: A Feminist Reading of Some Troubadour Lyrics." MLR 85 (1990): 310-29. [Examines poems by five troubadours (Arnaut Daniel, Bernart de Ventadorn, Guilhem de Peitieus, Marcabru, and Raimbaut de Vaqueiras) to see how women are presented in relation to love; questions the assumption that the poetry is about women and attempts to expose the patriarchal structures within the texts written by men; works of the trobairitz are excluded; homosocial desire is more important than the fictional poet/lady relationship; many lyrics are directed to a male rather than a female listener.]

\section{3.}

Gaunt, Simon. "Obscene Hermeneutics in Troubadour Lyric." In Medieval Obscenities. Edited by Nicola McDonald. Woodbridge: York Medieval Press (Boydell and Brewer), 2006, pp. 85-104. [Three parts: (1) general idea of obscenity in the troubadour tradition; (2) relationship between erotics and poetics in the troubadour lyric; sexual or obscene innuendo (Guilhem de Peitieus Ben vueill); and (3) analysis of Arnaut Daniel's sestina: many ambiguities are dissected using Lacan's insights on sexual language. Gaunt's 1993 article concentrated on aesthetics: obscenity used to generate humor and satire; this one has a different perspective, examining hermeneutics rather than aesthetics.]

\section{4.}

Gouiran, Gérard. "La carrière poétique d'Arnaut Daniel a-t-elle commencé avant 1180?" in 160, Studia Riquer, 1986-91, pp. 443-57. [A reference in one of the poems of the "Cornilh affair" to a slaughter in Béziers refers not to that of 1209 but to an earlier one in 1167 , thus dating the poetic cycle to shortly after this date; Arnaut Daniel's literary career began around 1169, a dating supported by Lazzerini in RST 1 (1991): 119-35.]

\section{5.}

Hishikawa, Eiichi. A Concordance to Arnaut Daniel's Poems. Kobe: Kobe University, 1989. Distributed by E. H., 13-36-203 Toyotsu-cho, Suita-shi, Osaka 564, Japan. 
1956.

Kuzmenko, Laura. La sémantique de la perception dans la poésie d'Arnaut Daniel. $\mathrm{PhD}$ diss., University of Toronto, 2005. Available online at http://www.etudes-francaises.net/ dossiers/kuzmenko/intro.htm; http://www.etudes-francaises.net/dossiers/kuzmenko/ analog.htm; http://www.etudes-francaises.net/dossiers/kuzmenko/struct.htm

1957.

Kuzmenko, Laura. "Valorisation axiologique et analogique positionnelle chez Arnaut Daniel." Florilegium 22 (2005): 191-216. [A cognitive-semantic approach to the understanding of Arnaut's difficult metaphors; the relationship of the poet's personal natural world to the abstract universal macrocosm; sensory and positional images create a three-dimensional world in Arnaut's poetry that has not been clearly recognized before; sensorial metaphors define Arnaut's affective world.]

1958.

Marchesi, Simone. "Dante Alighieri, Purgatorio XXVI. 139-148." Glossator 4 (2011): 73-80. [A word-by-word analysis of the eight lines given by Dante to Arnaut Daniel.] 1959.

Paterson, Linda. "Fin' amor and the Development of the Courtly Canso." In $>282$, Gaunt and Kay, Troubadours, 1999, pp. 28-46. [Guilhem de Peitieus's poem Pos vezem de novelh florir is analyzed to show some of the distinctive features of the canso; after a discussion of some key concepts of the code of courtly love, the chapter turns to an examination of Arnaut Daniel's Si.m fos Amors, which represents "a dazzling linguistic performance, a heady erotic and emotional brew, and a self-conscious reflection upon the traditional mechanisms of fin' amor" (p. 43); by organizing the chapter around these two poetic texts, Paterson makes the notion of fin'amors accessible to nonspecialists.]

\section{0.}

Perugi, Maurizio. "Arnaut Daniel L'Aura amara (PC 29,13): esercizi di stratigrafia lessicale e testuale." In 149, Mélanges Michel Burger, 1994, pp. 289-99. [Detailed study of codicology, phonetics, syntax, and dialectology to clarify the meaning of lines 64-65 of the poem, incorrectly understood by most of the editors of Arnaut Daniel.]

\section{1.}

Perugi, Maurizio. "Linguistica e trobar clus.” SM 38 (1997): 341-75. [Three studies of difficult readings in Arnaut; neo- or post-Lachmannian approach, based on close study of variant readings and use of dialectal vocabulary and phonology.]

\section{2.}

Perugi, Maurizio. “Toponomastica Danieliana.” MR 29 (2005): 211-78. [Very detailed study of toponymics from Roman times to medieval and their use by Arnaut Daniel (often misunderstood by scribes and by modern editors; clarification of several passages in Arnaut Daniel by reference to well-known epics and crusades.]

\section{3.}

Perugi, Maurizio. "Aux origines de l'aura de Pétrarque: La femme blonde chez 
Chrétien de Troyes et Arnaut Daniel (avec une note sur Arnaut c'amas l'aura)." CCM 52 (2009): 265-76. [Chrétien's Soredamors is the source of the wordplay in Arnaut's PC 29,10, En cest sonet coind'e leri (rhymes in -aura, daura, aura, saura, eisaura, restaura, laura, l'aura), which in turn inspired Petrarch's creation of Laura; Arnauz qu'amas l'aura does not mean "embraces the air" but rather "reaps the windstorm."] 1964.

Rea, Roberto. "Il cuore inondato (Arnaut Daniel tra aemulatio e Scritture)." CDT 8 (2005): 315-31. The image of the loving heart as a river in flood in Sols sui, PC 29,18 , is a metaphor of biblical origin, symbolizing the inundation of the Christian soul by the Holy Spirit; its use by Arnaut was inspired by Bernart de Ventadorn's poetic manifesto in PC 70,15 Chantars no pot gaire valer; a similar metaphor is that of amorous rain in Arnaut's Ab gai so, PC 29,10, lines 12-14.]

\section{Lo ferm voler (PC 29, 14) (The Sestina)}

[Five editions of Lo ferm voler are reproduced side by side at http://www.rialto.unina. it, including two by Perugi (1978 and 1996), with detailed notes by Aniello Fratta.]

\section{5.}

Barbiellini Amidei, Beatrice. "L'immagine del desiderio e la metafora feudale nella sestina di Arnaut Daniel.” CN 64.3-4 (2004): 443-73. Also in: Barbiellini Amidei, Beatrice. Non lasciare l'oro per il piombo: Elementi di intertestualità trobadorica e di critica del testo. Milan: CUEM, 2003, pp. 45-67. [Sensitive analysis of the ambiguous mixture of symbolisms and suggestions inherent in the use of vocabulary and images; biblical, feudal, and erotic interpretations of the tornada in particular are inseparable and necessary to the complete message, to which must be added the values of phonological and musical overtones.]

\section{6.}

Beltrami, Pietro G. "Lo ferm voler di Arnaut Daniel: noterella per una traduzione." AMod, special issue: La Sestina 2 (1996): 9-19. [A new metrical translation into Italian; striking links are demonstrated between Arnaut Daniel and Jaufre Rudel.]

\section{7.}

See 534, Canettieri, La sestina e il dado: sull'arte ludica del trobar, Collana: Poeta ludens; Rome: Colet, 1993. [Reviews the presence of gaming imagery in a number of troubadours; proposes that the metrical structure of Arnaut Daniel's sestina was inspired by the arrangement of numbers on the dice; the figure of gambling suggested by this structure represents the capricious influence of Fate on human love and the poet's belief that love of the domna and love of poetry are analogous.]

\section{8.}

Canettieri, Paolo. "Un'idea di Arnaut." In Arnaut Daniel, Canti di scherno e d'amore. Rome: Fazi, 1997, pp. 9-55. [Translation by Pietro Tripodo of all Arnaut's poems, trying to preserve the phono-symbolic content; introduction by Canettieri deals with Arnaut's personality and poetics, as well as his presumed Jewish origins, and an interpretation of the sestina, in particular its echoes from goliardic poetry and Raimbaut d'Aurenga's trobar ric.] 
1969.

Canettieri, Paolo. Il gioco delle forme nella lirica dei trovatori. Testi studi e manuali, Dipartimento di studi romanzi, Università di Roma La Sapienza. Rome: Bagatto Libri, 1996. [(In response to 532, Billy, "La sextine," 1993.) A history of the use of gaming imagery and structures by Arnaut Daniel and other troubadours; exhaustive analysis of Arnaut's poem, including the chronology of influences leading to the chosen form; Arnaut's passion for dice and gambling as a symbol of the jongleuresque alternative lifestyle, and a figure of the deceptiveness of language; the poem is a victory over the forces standing between him and the fulfillment of his joyful union with the domna (or the joyful completion of a masterful poem).]

1970.

Cavaliere, Alfredo. "Arnaut Daniel und seine Sestine." In $>155$, Romania cantat, 1980, 2:353-61. [Trobar ric is taken to its most refined development by Arnaut, a master craftsman in language; he uses bold metaphors, inversion, periphrasis, regionalisms, and neologisms to express his complex feelings in the most complete manner possible.] 1971.

Cholakian, Rouben Charles. "Master of Words and Women: Arnaut Daniel." In - 832, Troubadour Lyric, 1990, chapter 5, pp. 117-54. [A controversial reading of the sestina depicts it as a complex Oedipal drama with infant trauma at its origin; Arnaut seeks to exclude the female presence and reaffirm male authority over the text.]

1972.

D’Agostino, Alfonso. Il pensiero dominante: la sestina lirica da Arnaut Daniel a Dante. Milan: CUEM, 2009. [A complete and detailed study of the sestina: possible sources, characteristic structural elements, detailed interpretations, influences on poems by other troubadours and Dante; critical edition of six sestinas, with Italian translation, notes, and evaluation of major earlier studies: Raimbaut d'Aurenga, PC 389,16, Arnaut Daniel, PC 29,14, Guilhem de Saint Gregori, PC 233,2, Bertolome Zorzi, PC 74,4, Pons Fabre d'Uzès, PC 376,2, and Dante Alighieri, Al poco giorno; diplomatic, codicological, philological, and lexical materials for Arnaut Daniel's poem; in appendix, the text of seven lyrics and other texts referred to in the study.]

1973.

D’Agostino, Alfonso. "La sestina di Arnaut Daniel (PC 29, 14): revisione ecdotica." Parola del testo 13.1 (2009): 7-70. [A comparative ecdotic analysis of six critical editions of the poem; it is not possible to establish a stemma; only the methodology of Eusebi, 1984, is found to be valid.]

1974.

Di Girolamo, Costanzo. "Past Participles with Active Meaning: An Interpretation of Two Troubadour Passages (BdT 29,14, line 39 and 293,25, line 67).” RPh 61 (2007): 235-42. [The possibility of an active meaning assigned to a past participle may shed new light on a passage in the tornada of Arnaut Daniel's sestina: if desirat is interpreted as "full of desire" rather than as a senhal "Desirat," then son desirat means "song of desire," i.e., his poem which, once memorized by the addressee, can enter the chamber, from which the lover is banned.] 
1975.

Fo, Alessandro, Carlo Vecce, and Claudio Vela. Coblas: il mistero delle sei stanze. Milan: All'Insegna del Pesce d'Oro, 1987. [A witty and erudite discussion of numerology, complex rhyme structures, and interior "secret" messages to be detected in the poetry of Arnaut Daniel, Dante, and Petrarch, in particular the patterns and inner forces at work in Arnaut Daniel's sestina.]

\section{6.}

Le Vot, Gérard, Pierre Lusson, and Jacques Roubaud. "La Sextine d'Arnaut Daniel: essai de lecture rythmique." In Musique, littérature et société au moyen âge. Actes du colloque du Centre d'études médiévales de l'Université de Picardie. Edited by D. Buschinger and André Crépin. Paris: Champion, 1980, pp. 123-57. [Analysis of the sestina according to principles developed by the authors in previous work, based on equal treatment of melody, text, and rhymes; the basic underlying meter of the poem is anapestic.]

1977.

Picone, Michelangelo. "Versi di romanzi: una lettura semantica della sestina di Arnaut Daniel." In 134, Cantarem, 1995, pp. 113-26. [Develops the notion that Arnaut is following Raimbaut d'Aurenga in removing the obstacles to carnal fulfillment that were cultivated in the love ethic of the early troubadours; Arnaut goes even so far as to celebrate the erotic encounter, in reality or in a dream; Picone stresses the expansion of the canso as a genre to admit aspects of the narrative, especially in the sestina, which has a beginning, development and conclusion; close analysis of the poem, stanza by stanza, to demonstrate its narrative movement.]

\section{8.}

See 537, Roncaglia, "L'invenzione della sestina," 1981. [Arnaut was not working in a vacuum but was influenced by Raimbaut d'Aurenga, Chrétien de Troyes, and Béroul in his invention of the sestina.]

\section{9.}

Shinnick, Julia Wingo. "Singing Desire: Musical Innuendo in Troubadour and Trouvère Song." In Sexuality in the Middle Ages and Early Modern Times. Edited by Albrecht Classen. Berlin/New York: de Gruyter, 2008, pp. 293-324. [Musical structures in Lo ferm voler show a conscious design to add additional layers of meaning within the music to those already present in the text and metrics; six recurring pitches reinforce the sixfold use of recurring rhyme-words; assertive repetition of the three pairs of end pitches emphasize the central metaphor of determination to reach a goal; the overall melodic contour and repetitive echoes in the poem are consciously designed to support the thematic movement through fear and increasing desire to apparent fulfillment through increasing physical contact; the musical narrative toward conjunction is as strong as the textual one.]

\section{0.}

Switten, Margaret. "De la sextine: amour et musique chez Arnaut Daniel." In - 151, Mélanges Bec, 1991, pp. 549-65. [Detailed analysis of the circular structure of PC 29,14, with parallels in Plato's Timaeus; the rhyme-words evoke different forms 
of love; parallels between melodic structure and rhyme structure; as the demiurge of Plato seeks to reestablish the musical harmony of the universe by reconciling its contraries, Arnaut seeks to create, as an artisan of language, a poetic view of harmony through love.]

\section{1.}

Ţârău, Paul. "Aspects combinatoires dans l'analyse de texte: étude linguistique et mathématique d'une sextine d'Arnaut Daniel." Revue roumaine de linguistique 26 (1981): 469-83. [An exploratory analysis using techniques of mathematical and semiotic linguistics; among the interesting findings, Ţârău is able to calculate that the rhyme-word structures used by Arnaut would have allowed him to compose eight hundred million different sestinas!]

\section{2.}

\section{Cornar lo Corn: The Cornilh Affair}

Agamben, Giorgio. "Corn: dall'anatomia alla poetica." In Le Moyen Âge dans la modernité: mélanges offerts à Roger Dragonetti. Edited by Jean R. Scheidegger. Paris: Champion, 1996, pp. 3-20. Also in English translation as "Corn: From Anatomy to Poetics." In The End of the Poem: Studies in Poetics. Stanford: Stanford University Press, 1999, pp. 23-42. [A careful review of research on the precise meaning of corn in the cycle of poems and elsewhere; along with the direct obscene level, allegorical, tropological, and anagogical, even mystical levels may be added, making Ayna the ultimate flor enversa, the inversion of Ania, the muse of intellect.]

\section{3.}

See 244, Bec, Burlesque, 1984, pp. 138-53. [Brief introduction, reproduction of all four texts with French translation, notes; see also further introductory material, pp. 16-17.]

\section{4.}

Canettieri, Paolo. "Arnaut Daniel e il gioco dei dadi": http://paolocanettieri.wordpress.com, 2007. [Manuscript history of the exchange of poems in the "Cornilh affair"; it is an elaborate parody on the feudal and courtly tradition of the kiss; much of the underlying parody depends on the structure and metaphorical vocabulary of the game of dice.]

\section{5.}

D’Agostino, Alfonso. "Per la tornada del sirventese di Arnaut Daniel." MR 15 (1990): 321-51. [A very careful attempt to restore the wording of the four final lines of the poem, involving hypothetical neo-Lachmannian restorations of the archetype in several stages; the result is a more rational poem, in which Arnaut does not contradict himself by telling Bernat to go ahead and obey his Lady.]

\section{6.}

Gruber, Jörn. A BLOG as part of his La science du trobar en marche, 2008: "L'Affaire Cornilh" at http://gruberphi.blogspot.com/2008/06/jrn-gruber-laffairecornilh-1169-juge.html. [A critical, sometimes abrasive, analysis of current scholarship on the question, and his own definitive answers, subject to revision at any time.] 
1987.

Jewers, Caroline. "The Cornilh Affair: Obscenity and the Counter-Text in the Occitan Troubadours, or the Gift of the gap." Mediterranean Studies 11 (2002): 29-43. [A close look at some of the vulgar, obscene poems in the troubadour corpus, to better evaluate their place within the courtly tradition; they establish a countertext, parodying some of the excessive rituals of fin'amor; the gross vulgarity of the poems in the Cornilh cycle is countered by the astonishingly rich use of language and imagery and the humor involved in turning upside down the ideals of courtly behavior.]

\section{8.}

836, Lacan, Léthique, pp. 191-94; English translation, pp. 161-64. [Arnaut Daniel's obscene poem is a paradox: sublimation does not have to work only in the direction of the sublime: even the crudest of sexual gaming can be the object of poetry, albeit ambiguously; in debating the limits of the lover's service to the wishes of the Lady, there is a sudden reversal which reduces the idealized Lady with derision to the lowest level instead of the highest; this is still a sublimation of desire, revealing the profound ambiguity of the sublimating imagination.]

\section{9.}

Lazzerini, Lucia. "Cornar lo corn: sulla tenzone tra Raimon de Durfort, Truc Malec e Arnaut Danielm.” MR 8 (1981-83): 339-70. [Very precise and detailed study of the vocabulary and references, utilizing dialectology and regional phonetics to grasp the full lexical and suggestive power of the four texts in the cycle; there is no doubt that corn has the clear meaning of cul; much of the vocabulary comes from the specialized field of wine-making; reproduction of the four texts, with detailed textual notes, no translation; additional information on the form raboi "behind, ass" in MR 14 (1989): 39-50.]

\section{0.}

Lazzerini, Lucia. "Il nome della dama del corn." RST 1 (1999): 119-36. [Review of scholarship on the "Cornilh affair" and the meaning of cornar lo corn; the uninhibited lady, called by various names in the manuscripts (Ena, Aima, Aina, Aya, Enan, etc.), is probably the same as the forthright lady Ayma in Raimbaut d'Aurenga's poem Escoltatz, mas no say que 'é (PC 389,28); possible link to Ania, referring to Urania, goddess figure of intelligence; this would make the "Cornilh affair" a grotesque inversion of the quest for knowledge and joi, perhaps even a parody of Chretien de Troyes's Erec, who sounded his horn to lead on to the "Joie de la cort."]

1991.

See 245, Nelli, Ecrivains anticonformistes, 1977, pp. 79-96. [Reproduces all four texts, with introduction and French translation.]

1992.

See 246, Sansone, I trovatori licenziosi, 1992, pp. 88-101. [Reproduces all four texts, with Italian translation, a few explanatory notes.] 


\section{PC 30. Arnaut de Maruelh}

[ $f$. 1171-95; vida, five saluts d'amor, one ensenhamen (Razos es e mezura) and twenty-five or twenty-six cansos, six with melody: see 607, van der Werf, Extant, 1984, pp. 15*-20*; he is satirized in stanza nine of Monge de Montaudon's satirical gallery PC 305,16 as being very sentimental and lacrimose; considered by his 1993. contemporaries as a model of courtly poetic orthodoxy.]

Johnston, Ronald C. Les poésies lyriques du troubadour Arnaut de Mareuil, publiées avec une introduction, une traduction, des notes et un glossaire. Paris: Droz, 1935. Reprint, Geneva: Slatkine, 1973. [Introduction on Arnaut's life and career, his constant preoccupations with the description of his lady, and the dream mode in which his love is fulfilled; the use of senhals in his poems, linked to his long, sad love story; no commentary on melodies; edition of the vida, twenty-five poems, plus four of doubtful attribution, with French translation, notes, glossary.]

1994.

Barbieri, Luca, "Pour une nouvelle édition du troubadour Arnaut de Maruelh." In 99, AIEO 6, 2001, pp. 141-56. [Arnaut's work consists of seven saluts, edited by Bec, 1961, one ensenhamen, Eusebi, 1969, and twenty-five or twenty-six cansos, Johnston. 1935; Johnston did not do a thorough study of attributions; Barbieri considers metrical structure, which is highly original in Arnaut, many cases of hiatus, often corrected by scribes, and lexical and syntactic originality; his study of imagery and formulas suggests that Arnaut is not as dull and humdrum as critics have thought.]

1995.

Bec, Pierre. Les Saluts d'amour du troubadour Arnaut de Mareuil: textes publiés avec une introduction, une traduction et des notes. Toulouse: Privat, 1961. [Detailed introductory study of saluts in Occitan and Old French, with a particular study of the genre in Arnaut; edition of five saluts, plus two others of doubtful attribution, with following French translation; literary analysis of each, notes, glossary; an earlier study concentrated rather on formal composition: see $\mathbf{2 1 4 0}$, Mélanges Istvan Frank, 1957, pp. 39-50.]

1996.

Gambino, in 520, Salutz, 2009, pp. 268-397. [Edition of all five saluts, PC 30, $\mathrm{I}$ to $\mathrm{V}$, each one based on an independent codicological study; two others that were attributed to Arnaut with some hesitation by Bec (PC 10,I and 17,I), rather than to Aimeric de Peguilhan and Alegret, should be considered anonymous until further clarification; they are edited in the same volume by Luca Barbieri, pp. 654-75 and 690-93.]

\section{7.}

Billy, Dominique. "Hasard et intertextualité: à propos d'un cas de contrafacture: Arnaut de Mareuil, La grans beutatz e.l fis ensenhamens)." In Vettori e percorsi tematici nel mediterraneo romanzo. L'Apollonio di Tiro nelle letterature euroasiatiche dal Tardo-antico al medioevo, Roma, Villa Celimontana, 11-14 ottobre 2000: Atti. Edited by Fabrizio Beggiato and Sabina Marinetti. Soveria Manelli: Rubbettino, 2002, pp. 
89-115. [The use of newly available electronic databases can reveal the repetition of rhyme-words, indicating possible cases of intertextuality; the information must be used with prudence, in conjunction with other criteria, before intertextuality can be demonstrated; nineteen poems with the same rhyme scheme are analyzed to clarify the ambiguous role of rhyme-words in contrafacture.]

1998.

Chaillou, Christelle. "L'architecture musico-poétique dans les chansons d'Arnaut de Mareuil et de Raimbaut de Vaqueiras." Cognitive Philology 3 (2010). 64 pp. Online at http://ojs.uniroma1.it/index.php/cogphil. [A new look at the musical classification of troubadour melodies through a detailed analysis of five melodies of Arnaut and seven of Raimbaut; the traditional classifications do not take into account the full complexities of the stanza; the melodic structures typical of oral composition and transmission help to give a mental image to the poem in performance and aid in its memorization.

1999.

Eusebi, Mario. "L'ensenhamen di Arnaut de Mareuil.” Rom 90 (1969): 14-30. [Critical text of Razos es e mezura with Italian translation, notes.]

2000.

See 227, Riquer, 1975, 662-69. [Edition of the salut d'amor PC 30,III, one of the most delicate expressions of fin'amor in troubadour poetry.]

\section{PG 31. Arnaut Peire d'Agange}

[Probably late twelfth century; one incomplete canso, in which he complains about the rigidity of his domna.]

2001.

Ricketts, Peter. Contributions à l'étude de l'ancien occitan: textes lyriques et non-lyriques en vers. Birmingham: AIEO, University of Birmingham, 2000, pp. 5-10. [Edition of PC 31,1, with French translation, notes; text also available online at http://www. rialto.unina.it, without translation, introduction, or notes.]

2002.

Sakari, Aimo. "La canso d'Arnaut Peire d'Agange." Mélanges offerts à Rita Lejeune. Gembloux: J. Duculot, 1969, pp. 277-90. [Structural study, no literary analysis; critical edition, with French translation, textual notes.]

2003.

Thiolier-Méjean, Suzanne. “Ganges et son troubadour Arnaut Peire.” FL 126 (1998): 193-207. [Sakari's identification of l'avinens emperaire in the tornada with Alfonso $\mathrm{X}$ the Wise led him to date the work in the later thirteenth century; instead, it must refer to Alfonso VIII the Good, placing the poem in the late twelfth century; this is confirmed in the content of the song: his slightly disillusioned mockery of love, use of an ironical winter opening, and several characteristic images and expressions echo the work of Marcabru, Cercamon, Marcoat, Raimbaut de Vaqueiras, and Peire Vidal, who seem to have been his contemporaries.] 
PC 34. Arnaut de Tintinhac (the same as PC 228, Guilhem de

Quintenac, and PC 247, Guirart de Quintinac)

[ $f$. mid-twelfth century; four cansos, plus a fifth that is probably his;

Arnaut may be the poet featured in stanza five of Peire

d'Alvernhe's satiric gallery poem PC 323,11.]

2004.

Mouzat, Jean. Les poèmes de Gaucelm Faidit, troubadour du XIIe siècle; suivi de Guilhem Peire de Cazals, troubadour du XIIIe siècle et le troubadour Arnaut de Tintinhac: éditions critiques. Geneva: Slatkine, 1989. [Only the Slatkine edition has the additional materials; the Tintinhac edition originally appeared as "Cel de Tintinhac: introduction à Arnaut de Tintinhac, troubadour limousin," in Bulletin de la Société des Lettres, Sciences et Arts de la Corrèze, Tulle, four articles 1953-56, and separately as: Le troubadour Arnaut de Tintinhac. Tulle: Juglard-Ogier, 1956. Pp. 687-720: introduction on manuscripts, life of Arnaut, attributions, critical edition of four poems, with French translation, notes.]

2005.

Guida, Saverio. “Il Limosino di Briva." CN 57 (1997): 167-97. [The troubadour in stanza five of Peire d'Alvernhe's satiric gallery poem is Arnaut de Tintinhac, not Bernart de Ventadorn; Arnaut was a precursor and mentor of Bernart, addressed by Bernart in several poems as Lemozi; many intertextual links to Bernart's poetry; confirmation to Arnaut of PC 411,2, Bel m'es quan l'erba reverdis, formerly attributed to Raimon Vidal de Besalù, and proposed new attribution of PC 392,27, Can lo dous temps comensa, assigned at present to Raimbaut de Vaqueiras, quoted in extract in the Breviari under the name of Guiraut [sic] de Quintenac; further study of Arnaut's work, crucial to the early development of trobar, is required.]

2006.

Mouzat, Jean. "La langue de l'amour courtois chez le troubadour Arnaut de Tintinhac." In 2140, Mélanges Istvan Frank, 1957, pp. 480-86. [Arnaut was a contemporary of Marcabru and Bernart Marti; his poetry is characterized by a moralizing tendency without the bitterness of Marcabru; the songs show unique linguistic forms from the Forez, near Tulle.]

2007.

See 227, Riquer, 1975, 2:781-84. [Edition of PC 34,3, Molt dezir l'aura doussana, with introduction, Spanish translation, notes.]

2008.

Tavani, Giuseppe. "La poesia di Raimon Vidal. II. Belh m'es quan l'erba reverdis." In Romanica vulgaria. Quaderni 13-14 (1994): 5-24. [A close comparison of the two manuscript copies of PC 411,2 leads to the conclusion that the song is more likely by Arnaut than by Raimon, though the attribution is not yet clear enough to justify a change in ownership; diplomatic edition of both copies and a new critical text, with Italian translation, notes.] 


\section{PC 42a. Azalais d'Altier}

[Ca. 1220; one salut d'amor, perhaps addressed to Clara d'Anduza; canso in response by Clara PC 115,1; some scholars deny the historical reality of both ladies, believing that their writings were by Uc de Saint Circ.]

2009.

See 735, A. Rieger, Trobairitz, 1991, pp. 675-89. [Edition of the salut PC 42a, with German translation; literary analysis pp. 684-89.]

2010.

Morlino, Luca: edition of the salut in 520, Gambino, Salutz, 2009, pp. 528-49. [Part of the so-called love story between Uc de Saint Circ and Clara d'Anduza, which includes PC 457,4, and 115,1, according to which Azalais interceded with Clara to ask her to forgive Uc's "fling" with Ponsa and take him back; Poe and Jeanroy think that the whole exchange may have been composed by Uc himself, but Morlino sees little proof of this and thinks Poe's interpretation is "fantasy"; in the absence of proof, or a more convincing hypothesis, he agrees with Guida that the salut should remain attributed to Azalais.]

\section{1.}

See 731, Bec, Chants d'amour, 1995, pp. 185-92. [Introduction on the characteristics of the salut as a genre, and on the unique position of this text as the only salut by a woman addressed to another woman; reproduces A. Rieger's text, with French translation.]

\section{2.}

Bruckner, Matilda Tomaryn. "Azalais d'Altier." In 46, Women in the Middle Ages, 2004, pp. 52-53. [The salut may be addressed to Clara d'Anduza, asking her to be true and clara to her lover, who is identified in a razo as Uc de Saint Circ; Azalaïs's historical reality is controversial; the whole exchange may be part of a literary game.] 2013.

Guida, Saverio. Primi approcci ad Uc de Saint Circ. Soveria Mannelli: Rubbettino, 1996, p. 68, n. 54. [Has not found any archival evidence of Azalais's real existence, but there is a long history of an Altier family and a manor-house, just as there are historical traces for the family of Almuc de Castelnou and Iseut de Capion in the same region; disputes Poe's "reluctant" conclusion that Uc de Saint Circ was the real author of works supposedly by Azalais and Clara d'Anduza; tends to believe that all three ladies were real.] 2014.

Nicholson, Francesca. "Seeing Women Troubadours without the '-itz' and '-isms."” In 745, Troubled Vision, 2004, pp. 63-76. [The notion of "an open vista of gender interplay" is more productive than the tendency to over-feminize the trobairitz and force them into a closed and limiting female identity; a Lacanian reading of two poems is offered: Bietris de Roman, Na Maria, pretz e fina valors, PC 16a,2, and Azalais d'Altier, Tanz salutz e tantas amors, PC 42a,1; in both, the "I" is saying that its position and identification are changeable: the two trobairitz sometimes take on the identity of a male lover and sometimes speak as women.] 
2015.

See 764, Poe, "Dispassionate Look," 1992. [Argues for the possibility that Uc de Saint Circ was the author of Azalais d'Altier's salut, as well as the response to it by Clara d'Anduza; see similar analysis by Poe, "Un poème marginal," in $\mathbf{9 5}, A I E O 2$, 1993, 1:283-88.]

\section{PC 43. Azalais de Porcairagues}

[fl. 1170-73; vida; one canso: Ar em al freg temps vengut (PC 43,1); close ties with the courts of Raimbaut d'Aurenga and of Ermengarde de Narbonne; her vida claims that she loved Gui Guerrejat, the cousin of Raimbaut d'Aurenga.] 2016.

See 735, A. Rieger, Trobairitz, 1991, pp. 480-504. [Critical edition of PC 41,1, comparing the text of $N$ with that of CDIKd; German translation, very detailed notes; rich analysis of the intertextual connections of the poem with Comtessa de Dia and especially with several poems of Raimbaut d'Aurenga; the heterogeneous structure of the poem seems to indicate a tormented textual transmission.]

2017.

See 737, Mölk, Romanische Frauenlieder, 1989, pp. 52-55 and 193-95. [Edition of PC 43,1, with commentary, German translation, notes.]

2018.

See 731, Bec, Chants d'amour, 1995, pp. 65-70. [Edition from A. Rieger, with French translation.]

2019.

Braet, Herman. "Azalais de Porcairagues." In $\$$ 46, Women in the Middle Ages, 2004, pp. 53-55. [Azalais takes part in a cycle of poems debating whether a lady should accept a lover of higher rank (see $\$$ 2021, Sakari, 1949); she seems to have been closely linked with several highly esteemed poets.]

2020.

See 452, Paden, "System of Genres," 2000, pp. 44-57. [Contains the critical edition and English translation of all three versions of Azalais de Porcairagues's poem $\mathrm{Ar}$ em el freg temps vengut PC 43,1, with detailed notes and analysis of her awareness of genre definitions.]

2021.

Sakari, Aimo. "Azalais de Porcairagues, le joglar de Raimbaut d'Orange." NM 50 (1949): 23-43, 56-87, and 174-98. [The third stanza of her poem seems to contribute to a poetical debate begun by Guilhem de Saint-Didier as to whether a lady is dishonored by taking a lover who is richer than herself. Raimbaut d'Aurenga also commented in his poem $A$ mon vers dirai chanso, followed by a partimen between Dalfi d'Alvernhe and Perdigon, then a tenso between Giraut de Bornelh and King Alfonso II of Aragon; see the supplementary article by Sakari in $\$$ 95, AIEO 2, 1993 , 1:369-74, where it is shown that Azalais earned the senhal of Joglar in her poem from 1169 and that the series of fourteen Joglar poems from 1170-71 by Raimbaut d'Aurenga refer to her.] 
PC 44. Azar (Asar)

[End of twelfth century; jongleur; two incomplete poems: first line and three stanzas from a canso; participant in an incomplete tenso between Gaucelm, now identified as Gaucelm Faidit, and Peire, formerly called Peire de Mont Albert, now 2022. recognized as Azar; the father of Albertet de Sisteron.]

Boutière, Jean. "Les poésies du troubadour Albertet." Studi medievali 10 (1937): 1-129. [See p. 10 and note 1: first line and three stanzas of a poem that is probably by the father of Albertet.]

2023.

Guida, Saverio. "Un trovatore di meno, un componimento di più." Tenso 25 (2010): 1-22. [Peire de Mont Albert PC 350 does not exist; he is in fact the same as N'Azars PC 44, the father of Albertet de Sisteron; the tenso PC 350,1 = 165,3 is to be attributed to Gaucelm Faidit and N'Azars; new critical look at basic matters of textual history, particularly the attitudes and actions of scribes and modern editors, all of whom try to "improve" the texts; note that in $\mathbf{2 5 6}$, Harvey and Paterson, Troubadour "Tensos," 2010, 3:981-87, the participants are still called Peire de Mont Albert and Gaucelm.]

\section{PC 45. Baussan (Bauzan)}

[Unknown; listed by PC only because s/he is mentioned in PC 448,1 (Uc); not listed by Frank or Distilo; plausibly resuscitated by Harvey, who postulates that Baussan may be a woman.]

\section{4.}

Harvey, Ruth. "Textual Transmission and Courtly Communities: The Case of Baussan.” Tenso 17.1 (2002): 32-55. [Study of an exchange of three sirventes (PC 448,1a, 119,1, and 448,1) which have overall the traditional structure of a partimen; the identity of the speakers is problematic; Harvey tries to untangle the succession of poems by positing two distinct redactions of the exchange, the first involving three sirventes in which Baussan begins (PC 448,1a), followed by a replique by Dalfi d'Alvernhe (PC 119,1), and a final riposte by Baussan $(448,1)$; the second redaction has only two poems, and only one of the original performers: an opening poem by Uc $(448,1 \mathrm{a})$, and a replique by Baussan $(119,1)$, with Baussan taking a different side; Uc may be Uc de la Bacalaria or Uc de Saint Circ; Baussan remains unknown.]

\section{PC 46. Comtessa de Dia (Beatritz de Die)}

[Mid- to late twelfth century; vida; perhaps one tenso with Raimbaut d'Aurenga = PC 389,6; four cansos, one with music, for which see

- 607, van der Werf, Extant, 1984, p. 21*.]

2025.

Bruckner, Matilda Tomaryn. "La Comtessa de Dia." In The Feminist Encyclopedia of French Literature. Edited by Eva Martin Sartori. New York: Greenwood, 1999, pp. 152-53. [Tentatively identifies her as Béatrice, wife of Guilhem II of Poitiers, 
Count of Valentinois, a contemporary of Raimbaut d'Aurenga; she seems to have participated in a circle of poets that included Raimbaut, Azalais de Porcairagues, and Bernart de Ventadorn; her complex poetic voice combines that of the abandoned woman, the worthy domna projected in male songs, and the suffering figure of the troubadour's own lyric persona.

2026.

Cheyette, Fredric L., and Margaret Switten. "Women in Troubadour Song: Of the Contessa and the Vilana." Women and Music 2 (1998): 26-46. [Detailed analysis of words and music of Comtessa de Dia's poem $A$ chanter m'er (PC 46,2) and Marcabru's L'autrier jostuna sebissa (PC 293,30); in both, strong women's voices demand their rights and resist exploitation; the authors also trace the varied political roles of Occitan noble women and the social setting in which these two songs might have been performed; see a shorter version: "Women, Poets and Politics," in Aristocratic Women

698, 1999, pp. 171-74.

2027.

See 743, Jewers, "Reading and Righting," 1998. [Stresses the need to reevaluate trobairitz on their own terms, through their own poetic language, not from without; analysis of the notion of value and worth in the poetry of the Comtessa de Dia.]

2028.

Phan, Chantal. "The Comtessa de Dia and the Trobairitz." In Women Composers: Music through the Ages. Vol. 1. Composers Born before 1599. Edited by Martha Furman Schleifer and Sylvia Glickman. New York: G. K. Hall, 1996, pp. 61-8. [Includes Occitan text, English translation, and modern performance scores for Comtessa de Dia's $A$ chantar mier and Estat ai en greu cossirier, along with Raimon de Miraval's Loncx temps ai avut cossiriers whose melody, in simplified form, was used for the Comtessa's Estat ai.]

2029.

Pollina, Vincent. "Melodic Continuity and Discontinuity in $A$ chantar m'er of the Comtessa de Dia." In Miscellanea di studi romanzi offerta a Giuliano Gasca Queirazza. Edited by Anna Cornagliotti et al. 2 vols. Alessandria: Edizioni dell'Orso, 1988, 2:887-95. [This is the only surviving trobairitz melody; variations by performer or listener may influence the cognitive perception of the melody; Pollina concludes that in this song "continuity bears discontinuity within it."]

2030.

Braet, Herman. "Comtessa de Dia." In 46, Women in the Middle Ages, 2004, pp. 207-9. [Speculates on the identity of the Comtessa and of her supposed lover, Raimbaut d'Aurenga, grandnephew of the famous troubadour; she shifts the traditional masculine perspective of trobar, taking on a positive, aggressive role for herself, while retaining some aspects of her privileged position as the domna and experimenting with a variety of self-images.]

2031.

See 735, A. Rieger, Trobairitz, 1991, pp. 585-626. [Critical edition of the four poems, with German translation, notes; detailed analysis, pp. 608-26.] 


\section{PC 47. Berenguier de Palazol (Palau, Palol)}

[ $f$. mid to later twelfth century; vida; nine poems plus four of doubtful attribution; eight melodies: see $\mathbf{6 0 7}$, van der Werf, Extant, 1984, pp. 22*-29*; he expressed the classic themes and forms of fin'amor to his domna Maria de Perelada, whose daughter was given Guillem de Cabestanh's heart to eat, according to the famous legend.]

\section{2.}

Beretta Spampinato, Margherita. Berenguer de Palol: Poesie. Modena: Mucchi, 1978. [Introduction on the author, metrical structures, themes, style, and language; critical edition of thirteen poems, four of which are of doubtful attribution; Italian translation, notes, rimarium; all twelve poems available online at http://www.rialto.unina. it, brief notes, no introduction, no translation.]

\section{3.}

Newcombe, Terence H. "The Troubadour Berenger de Palazol: A Critical Edition of his Poems." Nottingham Medieval Studies 15 (1971): 54-95. [Introduction on the love themes in the poetry: Berenguier as suppliant, lover, rejected lover, and repentant lover; edition of vida and twelve poems, with English translation, notes, and glossary.]

2034.

Guida, Saverio. "Per il profilo biografico di Berenguer de Palazol." MR 6 (1979): 22-36. [The poet's historical identity and his social and literary role have not yet been defined: in Guida's analysis, he comes across as a quiet, respectful, modest man, in tune with his modest local community, a most traditional courtly country gentleman believing in mezura.]

2035.

See 227, Riquer, 1975, pp. 300-310. [Introduction, edition of vida and poems PC 47,6, 11, and 10, with Spanish translations, notes.]

\section{PC 54. Bernart Arnaut d'Armagnac}

[ $f$. early thirteenth century; count of Armagnac 1217-26; vida; one exchange of coblas (two coblas and one tornada) with Lombarda, PC 54,1 = 288,1, prior

to 1217 , transmitted within a razo; he takes the name Lombard in honor of his lady, and she responds by calling herself Bernarda.]

\section{6.}

See 735, A. Rieger, Trobairitz, 1991, pp. 242-54. [Edition with German translation, notes; stresses the political dimension of the exchange, hitherto unrecognized: Bernart is on the side of Raymond VI of Toulouse in his struggle with the French crusaders, at a time when his own brother was coming to terms with Simon of Monfort; the difficult poem suggests a close circle of poets who were interacting in ways and for purposes that are difficult to penetrate; political tensions between the French king and Raimond VI of Toulouse are implied through the use of place-names that stand for family names; love and politics are inextricably mixed in the dialogue; Rieger points to parallels with poems by Peire Vidal, Peire Bremon Ricas Novas, Bertran de Born, Guiscarda, Alamanda, and Giraut de Bornelh.] 
2037.

Heidenreich Findley, Brooke. "Reading Sincerity at the Intersection of Troubadour/ Trobairitz Poetry: Two Poetic Debates." Romance Quarterly 53 (2006): 287-303. [The trobairitz seem to have the role of voicing concerns over sincerity in men's poems; as outsiders to the masculinevoiced tradition, they are able to speak from a more credible perspective; one of the debates is an exchange of coblas between Lombarda and Bernart Arnaut; the exchange is embedded in a razo, which paradoxically seems to form an integral part of the message; Lombarda is upset that she cannot get a clear idea of Arnaut's sincere feelings for her; his failure to communicate outside the poetic universe raises the question of whether poetry can ever be "real," and suggests that the female role in the discourse may be to shake up the assumptions of the masculine tradition.]

2038.

See 783, Labbie, "Vacant Mirror," 1995. [Curiously unaware of 792, Sankovitch, "Lombarda's Reluctant Mirror," 1989, which covers much of the same ground; postulates Lombarda as the sole composer of the tenso, who created the figure of Bernart Arnaut d'Armagnac as a fictive masculine voice; to him she can respond freely, claiming back her liberty and maintaining her sense of self; she satirizes the male gaze, undermining its narcissism; the mirror must be destroyed before either can know the other.]

\section{PC 55. Bernart Arnaut de Moncuc (Montcucq)}

[First quarter thirteenth century; one sirventes-canso combining war with love.] 2039.

Sakari, Aimo. "Er can li rozier de Bernart Arnaut de Montcuq." In 147 , Mélanges Rostaing, 1974, pp. 949-64. [Critical edition and study of PC 55,1, with French translation; the structure is unusual: the first half of each stanza is devoted to warlike themes concerning the politics of the Albigensian Crusade, merging in the second half to notions of love and gallantry.]

2040.

Sakari, Aimo. "Lattribution de Anc mais tan gen no vi venir pascor." In $\mathbf{1 5 0}$, Mélanges Camproux, 1978, pp. 225-31. [PC 335,4 has been attributed variously to Peire Cardenal or to Bernart Arnaut, since each was named in one manuscript; after careful analysis, Sakari shows that it belongs to Peire.]

2041.

Vatteroni, Sergio. "Le poesie di Peire Cardenal V." SMV 42, 1996, pp. 169-251, esp. 193-99. [PC 335,4, Anc mais tan gen, was rejected from Peire Cardenal's poems in favor of Bernart Arnaut by several scholars, accepted by others; Vatteroni reviews all the opinions and decides that there is no proof either way, but he leaves it with Peire because MS $C$ is a more trustworthy witness for his works.]

2042.

Chambers, Frank M. "Three Troubadour Poems with Historical Overtones." Speculum 54 (1979): 42-54. [Edition of Er can, PC 55,1, with historical introduction, critical text with English translation, notes.] 


\section{PC 57. Bernart d'Auriac (d'Aurillac)}

[Second half thirteenth century; died 1290; called mayestre de Bezers in MS C, otherwise unknown; four poems: a licentious canso, PC 57,4, a poem to the Virgin, PC 57,1, two sirventes, the second of which, PC 57,3, initiates a cycle with four other troubadours, and a political debate during the 2043. conflict of 1285 between France and Aragon.]

Riquer, Martin de. "El ciclo de sirventeses de 1285." In $>$ 227, Riquer, 1975, 3:15901600. [A cycle involving five troubadours, showing the importance of the sirventes as a political weapon; Bernart d'Auriac supports the king of France, Philippe III le Hardi (PC 57,3); Peire III of Aragon replies on his own behalf (PC 325,1), supported by Peire Salvatge (PC 357,1); Count Roger Bernart II of Foix replies on the side of the French (PC 182,2), supported by an anonymous poet (PC 182,1); historical outcome: Peire won, as the king of France died on the way home; edition of the complete cycle, with introduction, Spanish translation, notes.]

\section{4.}

Hershon, Cyril P. Les troubadours de Béziers. Introduction, textes, notes et traductions. Béziers: Société archéologique, scientifique et littéraire de Béziers, 2001. [Edition of the four poems of Bernart d'Auriac, pp. 55-73, with introduction, French translation, notes.]

2045.

Gouiran, Gérard. "Les troubadours de Béziers." In Béziers, ville occitane? Actes des rencontres tenues à Béziers le 18 novembre 2006. Perpignan: Presses Universitaires de Perpignan, 2007, pp. 9-27. [Analysis of four poems by Bernart, along with nine by Raimon Gaucelm and eleven by Joan Esteve, looking for signs of similarity in style or inspiration that would make them typical of Béziers; found a common bond of religiosity, a new loyalty to the French king, conscious dating of poems that anchors them in time, a simple bourgeois tone, an emphasis on sincerity and a warm feeling for their town of Béziers.]

2046.

See 244, Bec, Burlesque, 1984, pp. 46-48. [Introduction, text of PC 57,4, Sieu agues tant de saber, with French translation, notes; see also $\mathbf{2 4 9}$, Bec, Florilège en mineur, 2004, pp. 155-59, with brief introduction, edition of PC 57,3 from Hershon, with French translation.]

\section{PC 58. Bernart de la Barta (the same as Berta, fraire PC 73)}

[ $f$. 1229; three tensos, one cobla from a lost sirventes, and a sirventes in which he attacked the unjust terms of the Treaty of Meaux 1229,

2047. which ended the Albigensian Crusade.]

Anatole, Christian. "Le troubadour Bernart de la Barta." AM 101 (1989): 225-33. Also in Via Domitia 26 (1981): 62-76, with the addition of the text of PC 58,4, reproduced from Chambers, with a French translation done with the help of Ernest 
Nègre. [Refutes in detail the identification of Bernart with a homonym Bernart de La Barta, archbishop of Auch, who has no connection with the troubadour; Bernart remains unknown historically but was strongly partisan of the Counts of Toulouse, against the French and the clerics.]

\section{8.}

Chambers, Frank M., "Three Troubadour Poems with Historical Overtones." Speculum 54 (1979): 42-54. [Edition of PC 58,4, Foilla ni flors, with historical introduction, English translation, notes.]

2049.

Marshall, John H. "Les trois tensons du troubadour Bernart de la Barta." In Estudios románicos dedicados al prof. Andrés Soria Ortega en el XXV aniversario de la Cáthedra de Literaturas Románicas. Edited by Jesús Montoya Martinez. 2 vols. Granada: Universidad de Granada, 1985, 1:443-57. [Introduction; edition of the three tensos: PC 227,7 $=58,2$ with Guilhem Peire de Cazals, PC 25,1a = 58,1 with N'Armant (Arnaut?), and PC 292,1 =73,1 with an unknown Maitre; French translation, notes; see also $>$ 274, Asperti, "Testi e frammenti, 2009, pp. 269-75, who shows that PC 25,1a is not to be attributed to Arman PC 24, but to one of the Arnauts listed under PC 25; text available also online at http://www.bedt.it; note that in 256, Harvey and Paterson, Troubadour "Tensos," 2010, 3:981-87, the interlocutor of PC 25,1a is still called Arman.]

2050.

Ricketts, Peter. "Foilla ni flors, ni chautz temps ni freidura de Bernart de la Barta: édition critique et traduction." FL 142 (2006): 141-45. [New critical edition with French translation; no literary analysis.]

\section{PC 60. Bernart de Durfort}

[End twelfth century, first half thirteenth; vida; listed in MS D as author of a humorous sirventes on the respective merits of old and young women, a work attributed also to Gausbert de Poicibot.]

2051.

Gouiran, Gérard. "Le cycle de la bataille des jeunes et des vieilles." In Per Robert Lafont: Estudis oferts a Robert Lafont per sos collègas e amics. Montpellier-Nîmes: Centre d'Estudis Occitans/Université Paul-Valéry Montpellier 3, 1990, pp. 109-33. [Study done independently of that by Marshall; critical edition of the three poems debating the merits of old versus young women, with French translation and discussion; Gouiran shows that the tenso (1), based on a sirventes by Marcabru, started the cycle, followed by 2 and 3; expresses a slight preference for Bernart de Durfort over Guilhem Augier in 2, and confirms Gausbert de Puycibot and Bertran de Preissac in 1, Bertran de Preissac in 3.]

\section{2.}

See 256, Harvey and Paterson, Troubadour "Tensos," 2010, 1:173-82. [Edition of the tenso, with introduction, English translation, notes, agreeing on its attribution to Bernart de Preissac and Gausbert de Puycibot; takes no stand on attribution of the two sirventes nor on the respective order of the three elements.] 
2053.

Latella, Fortunata. "Un indiscusso caso di intertestualità trobadorica." Pluteus 5-6 (1988-89): 45-65. [Analysis of the poetic debate as a valuable key to the understanding of taste and thought patterns of the society just before the Albigensian Crusade; new critical editions of the three texts, with notes, no translation; prefers the order 1/3/2 as proposed originally by Shepard in 1931 and sees the author of 2 as Guilhem Augier rather than Bernart de Durfort; see also her "Premessa all'edizione in linea del dibattito sulle donne vecchie e giovani”: http://www.rialto.unina.it, 2002.]

\section{4.}

See 439, Malm, Dolssor, 2001, pp. 102-17. [Seems unaware of Gouiran, 1990; confirms the order $1 / 2 / 3$ as in Marshall; analysis of the three-part debate in which traditional values of fin'amor are challenged by material comfort; misogyny becomes more and more pronounced in Bernart's poem 2 as he stresses the unattractive qualities of older women and in Bertran's 3, which stresses the immorality of young women who sell their favors; Malm places the debate in the context of medieval concepts of beauty and the human body in philosophical and theological thinking.]

2055.

Marshall, John H. "Les jeunes femmes et les vieilles: une tenso (PC 88.2 = 173.5) et un échange de sirventes (PC 173.1a + 88.1)." In 151 Mélanges Bec, 1991, pp. 325-38. [Critical edition with notes, glossary, French translation of three texts: (1) a classic tenso between Bertran de Preissac (old) and Gausbert de Puycibot (young) and an exchange of sirventes elaborating on the same positions; (2) PC 173,1a (formerly 37,1) Era, quan l'iverns nos laissa, mistakenly attributed to Gausbert but in reality a defense of Gausbert attributed either to Bernart de Durfort or to Guilhem Augier; and (3) PC 88,1 (formerly 174,2) Eras quan plou et iverna, a final replique by Bertran de Preissac, in favor of older women, but perhaps ironic.]

\section{PC 63. Bernart Marti (Lo Pintor)}

[Mid-twelfth century; unknown, perhaps a disciple of Marcabru; no vida; five or six cansos, four sirventes (some attributions are uncertain);

his poetry is enigmatic, satirical.]

\section{6.}

Beggiato, Fabrizio. Il trovatore Bernart Marti: edizione critica. Modena: Mucchi, 1984. [Introduction, edition of nine poems with Italian translation, notes, glossary; indicates two further fragments of songs quoted by Jean de Nostredame from a lost manuscript and two contested attributions, pp. 41-52.]

2057.

Bec, Pierre. "Bernart Marti." In $>$ 38, DLF, 1992, pp. 157-58. [Stresses the variety and originality of his poetry, the combination of misogyny and sensuality in his attitude to women; Bernart blames courtly love for the decline in morality.]

2058.

Cingolani, Stefano Maria. "Farai un vers ab son novelh; note sulle relazioni letterarie del trovatore Bernart Marti.” Romanica Vulgaria. Quaderni 10-11 (1989): 45-63. 
[Presentation of recent scholarly work on intertextuality among the earlier poets; analysis of Bernart's interconnections with Cercamon, Marcabru and Peire d'Alvernhe allow for a fuller understanding of his place in the poetic developments; he was not a close disciple of Marcabru but interacted more with Bernart de Ventadorn and Peire d'Alvernhe.]

\section{9.}

See 803, Gaunt, Troubadours and Irony, 1989, pp. 80-96. [Discussion of Bernart's light ironic tone, based on new readings of the texts involved; close analysis of Amar dei, PC 63,1, Quan l'erb'es, PC 63,8, and Companho, per companhia, PC 63,5, with complete texts and English translation; the poetry is subjective, the meaning difficult to grasp because Bernart is wryly subverting the conventions of fin'amor in an ambivalent, self-critical manner.]

2060.

Guida, Saverio. "Bernart Marti lo pintor." RPh 64 (2010): 53-72. [Analysis of the personality and social attitudes of Bernart reveals a cultivated poet with a pragmatic, ironic attitude toward women and love; he cultivates complex levels of meaning and ambiguous paradox, attaching the innuendo of sexual prowess to the notion of wielding a phallic paintbrush, in the manner of a gap by Guihem de Peitieus; sexual playfulness may be camouflaged or direct but is ever-present.]

\section{1.}

Payen, Jean-Charles. "Bernart Marti et la légende de Tristan." In Chrétien de Troyes and the Troubadours: Essays in Memory of the Late Leslie Topsfield. Edited by Peter S. Noble and Linda M. Paterson. Cambridge: St. Catherine's College, 1984, pp. 34-43. [Argues the existence of a Tristan tradition earlier than Béroul 1160, based especially on veiled references in Bernart Marti, especially in PC 104,2.]

\section{PC 67. Bernart Sicart de Marvejols (Sicat)}

[fl. 1230; one sirventes, dedicated to James I of Aragon, against the French, the military orders, the clerics, and the Albigensian Crusade.]

\section{2.}

Chambrun, Gilbert de. "A la recherche de Bernat Sicart de Marvejols." Revue du Gévaudan, des Causses et des Cévennes 20 (1974): 41-48. [Comparison of Bernart's sirventes with the canso of Guilhem de Cabestanh, PC 213,5 which served as its model, and with the sirventesca of Peire Basc, PC 327,1, modeled on both; the two poems protest to the king of Aragon against the occupation of the French and the excesses of the Inquisition; text of the first two stanzas of each, with French translation, the rest of each in French translation only.]

2063.

See 227, Riquer, 1975, pp. 1202-6. [Edition of PC 67,1, with introduction, Spanish translation, notes.]

2064.

See 260, Vatteroni, Falsa clercia, 1999, pp. 140-42. [Text of PC 67,1 from 227, Riquer, 1975, who took it from Raynouard, 1821; Italian translation, no notes; pp. 
65-66: Bernart's poem from 1230 laments the French occupation of the South, with criticism of the clerics couched in subtle irony; linguistic nationalism leads him to criticize his compatriots for using French; the metric structure and rhymes are based on a poem by Guilhem de Cabestanh.]

2065.

See 262, Zambon, I Trovatori e la crociata, 1999. [Edition of PC 67,1 by Bernart Sicart de Maruejols, with Italian translation, notes; the introduction analyzes the now-discredited scholarly myth of the Cathar heresy; claims that the troubadours and heretics shared a common spirit and cause on a deeper level of morality.]

\section{PC 69. Bernart de Tolmon (Tot-lo-Mon)}

2066.

[Second half thirteenth century; two sirventes-cansos, one plazer.]

Appel, Carl. Provenzalische Inedita aus Pariser Handschriften. Leipzig: Reisland, 1890, pp. 43-49. [Edition of three canso-sirventes, one of which, PC 69,2, pp. 45-47, is called a plazer.]

2067.

See 2001, Ricketts, Contributions, 2000, pp. 16-21. [Edition of PC 69,1 Be magrada, with French translation, notes.]

2068.

Guida, Saverio. "Bernart (de) Tot-lo-mon ou de Tolmon?" In 140, Etudes Ricketts, 2005, pp. 439-46. [Correction of his name to de Tolmon based on documentation concerning the forest of Tolmon and its population and on the dedication of a poem to the viscount of Bruniquel; Bernart's style is characterized by the use of coblas desfrenadas: Leys d'Amors, "disordered, stammering stanzas," repetitions chosen deliberately to draw attention to vocabulary and sounds; his joyful, positive attitude is typical of the court of Henry II of Rodez.]

\section{PC 70. Bernart de Ventadorn}

[ $f$. 1147-70; vida; forty-four poems, of which forty-one are of certain attribution, eighteen are accompanied by melody: see $\mathbf{6 0 7}$, van der Werf, Extant, 1984, pp. $30^{*}-71^{*}$; three are tensos, with Peire d'Alvernhe, Peirol, and Lemozi; little is known 2069.

of his origin or his life beyond the legendary information in the vida.]

Lazar, Moshe. Bernart de Ventadour, troubadour du XIle siècle: Chansons d'amour. Bibliothèque française et romane, ser. B: Éditions critiques de textes, 4. Paris: Klincksieck, 1966. Reprint, Chansons d'amour de Bernard de Ventadour, with preface by Geneviève Brunel-Lobrichon, pp. v-xviii. Moustier Ventadour: Carrefour Ventadour, 2001. 2070.

Mancini, Mario. Bernart de Ventadorn, Canzoni. Rome: Carocci, 2003. [Introduction, choice of eighteen poems, with facing-page Italian translations, notes.]

2071.

See 75, Ippolito, Bernard de Ventadour, 2001. [Romanticized reconstitution of 
the life of Bernart; poems by Guilhem de Peitieus, Eble II (the courtly poems of Guilhem!), and Bernart are given, with French translation, interspersed with details of Bernart's life and times that are largely imaginary.]

2072.

Allegretti, Paola. "Parva componere magnis. Una strofa inedita di Bernart de Ventadorn (BdT 70,33) e due schede per BdT 461,127.” RST 1 (1999): 9-28. [A series of transmission questions in various chansonniers, dealing with poems of Bernart de Ventadorn, Peire Vidal, and several anonymous poets; identifies a cobla esparsa PC 461,80a as a fifth stanza to Bernart's PC 70,33; edition with interpretation of its meaning within the poem.]

\section{3.}

Bec, Pierre. "La douleur et son univers poétique chez Bernard de Ventadour: Essai d'analyse systématique." CCM 11 (1968): 545-71 and 12 (1969): 25-33. [Analysis of the abundant repertory of about sixty lexemes utilized by Bernart to explore the nuances of love-induced suffering.]

2074.

Bec, Pierre. "L'antithèse poétique chez Bernard de Ventadour." In $\mathbf{1 3 2 6}$, Mélanges Boutière, 1971, 1:107-37. [Classic study of the uses of opposing terms to capture the nuances of emotional states in Bernart's songs.]

2075.

Bec, Pierre. "Stagnation et accélération du temps chez Bernard de Ventadour." In Le Nombre du temps, en hommage à Paul Zumthor. Paris: Honoré Champion (1988): 29-37. Also slightly revised, with French translation of the Occitan passages, as "Temps-durée et temps-fulgurance chez Bernard de Ventadour." In Ecrits sur les troubadours et la lyrique médiévale (1961-1991). Caen: Paradigme, 1992, pp. 233-42. [Exploration of the notion of time in its various aspects, from the long frustrating wait for a sign of love from the domna to the sudden and dangerous explosion of joi in moments of real or imagined acceptance; this polarization represents as well the long, painful gestation of a poem and the brief rapture of creative release when it is finished.]

2076.

See 363, Bloch, Medieval Misogyny, 1991, pp. 143-48. [Bernart de Ventadorn's Can vei as an archetypal expression of the link between romantic love, virginity, and the ascetic impulse; sees the poem as a work full of contradictions: the Lady as wicked and worshiped; love as a paradox of knowledge and ignorance; the pride in the poetic voice coupled with a fear of speaking, use of a song to renounce singing; the lyric has little to do with women, bearing more on the poet's relationship to himself.] 2077.

Brunel-Lobrichon, Geneviève. "Bernart de Ventadorn." In $\mathbf{3 8}, D L F, 1992$, pp. 160-62. [Bernart portrays exclusively the classical themes of finamor, often with nostalgic melancholy, stressing his own sincerity and poetic prowess; known especially for his striking imagery, delicate music, and intuitive feeling for subtle human emotions; copious bibliography to 1998 .] 
2078.

Burle, Elodie. "Le sujet lyrique médiéval en question." L'expérience lyrique au Moyen Âge. Perspectives médiévales 28 (2002): 21-31. [Trobar implies rediscovering something that exists already, using forms, themes, and language that are part of a tradition; the poet is enriching the tradition rather than changing it; pp. 25-27: for Bernart de Ventadorn, the poem has a didactic purpose; it is a learning experience for the poet, not a personal cry of suffering; the poet remains apart from the "je" of the poem, seeking to understand and explain, or at least to illustrate the nature of love; pp. 27-31: by contrast, Arnaut Daniel is focused on the poem itself as a structure, rather than on themes or images; he is aiming for poetic perfection in a song that is a work of art.]

2079.

Coderch, Marion. "Lo rossinhols s'esbaudeya (PC 70,29): Bernart de Ventadorn, Courtly Ethics and the Catalan Tradition.” Glossator 4 (2011): 101-14. [Text and English translation of the poem, with a detailed analysis of themes and structures that influenced Catalan poets in the thirteenth and fourteenth centuries, at a time when the elite classes were increasingly fearful of losing their privileges to the rising bourgeois economic forces.]

2080.

Grange, Huw. "A Musico-Literary Commentary on Bernart de Ventadorn's Qan vei la laudeta mover." Glossator 4 (2011): 81-99. [A meticulous analysis of the interrelationship of music and text in Bernart's song; the music seems to guide and reinforce the text, helping the joglar to memorize the poem.]

2081.

Gubbini, Gaia. "Il tatto e il desiderio in una querelle trobadorica: Bernardo di Ventadorn e Marcabruno." CDT 8 (2005): 281-313. [The senses of touch and taste are shown to be central to Bernart's expression of desire, especially in the kiss; Bernart's PC 70,13, Be.m cuidei de chanter sofrir, is analyzed as a reaction against Marcabru's Bel m'es can s'esclarzis as Bernart defends desire against Marcabru's accusation of sexual depravity by turning his words back on him; Peire d'Alvernhe's PC 323,7 is also linked to this dialogue through words and rhymes, confirming the reality of a poetic quarrel, as well as dating Bernart's poem to 1157-58.]

2082.

Gubbini, Gaia. "Filtri d'oïl in Bernardo di Ventadorn.” CDT 12.1 (2009): 133-52. [Analysis of vocabulary in Bernart's PC 70,8, A! tantas bonas chansos, indicates that Bernart was familiar with the Old French Tristan tradition of Béroul and Thomas, as well as that of the Enéas.]

2083.

Kaehne, Michael. Studien zur Dichtung Bernarts von Ventadorn: Ein Beitrag zur Untersuchung der Entstehung und zur Interpretation der höfischen Lyrik des Mittelalters. Munich: Fink, 1983. [Vol. 1 is a relentlessly documented analysis of previous research that was responsible for making Bernart de Ventadorn into a precursor of Romanticism; vol. 2 presents a new analysis of Bernart's entire corpus, based on the theories of Erich Köhler, for whom the game of courtly love stood for other basic social values.] 
2084.

Köhler, Erich. "Can vei la lauzeta mover: Überlegungen zum Verhältnis von phonischer Struktur und semantischer Struktur." In Estudis de llengua i literatura catalanes offerts a R. Aramon I Serra. Barcelona: Curial, 1979, pp. 337-49. Reproduced in Semiotics and Dialectics: Ideology and the Text. Edited by Peter V. Zima. Amsterdam: Benjamins, 1981, pp. 445-68. [As a sequel to his 1964 historicosociological analysis of the poem, Köhler offers a renewed structural-semiotic interpretation; key words and phonemes are identified that awaken intertextual echoes in the cultivated listeners, who could place the song within the rich background texts of the poetic tradition and establish for themselves a unified poetic message, part of a ritualized, cultlike (hopeful) initiation into membership in the exclusive aristocratic ruling class.]

2085.

See 480, Marshall, "Dialogues of the Dead," 1987. [A hypothesis that some tensos and partimens may be fictitious, pretending to be debates between well-known troubadours; new critical edition of PC 70,32 = 366,23, Peirol, cum avetz, between Peirol and fictional Bernart de Ventadorn, and PC 52,3 = 165,2, Gaucelm, no.m puesc estener, between Bernart and Gaucelm, with critical notes and English translation; see also new editions in 256, Harvey and Paterson, Troubadour "Tensos," 2010, 1:141-46 and pp. 117-24, who agree with Marshall that both are staged debates.]

\section{6.}

See 651 and 887, Monari, "Osservazioni, 2009. [A tenso between Bernart de Ventadorn and Peire (d'Alvernhe?) Amics Bernartz de Ventadorn; Peire is mocking Bernart's typical style, and Bernart is being untypical (for humorous purposes?); the melody is similar in structure to others by Bernart, but its status is just as ambiguous: perhaps it is part of Peire's parody of Bernart, perhaps it is Bernart being humorous himself; see the new edition in 256, Harvey and Paterson, Troubadour "Tensos," 2010, 3:964-71.]

2087.

Paden, William D. "Bernart de Ventadour le troubadour devint-il abbé de Tulle?" In 151, Mélanges Bec, 1991, pp. 401-13. [It is possible, but not proved, that Bernart is the historical son of Eble III; if so, Bernart's dates would be altered: not mid- but late twelfth century (born ca. 1150, died ca. 1237); he would not be the traditional poor servant-class figure accepted by scholarship but aristocratic; poetic activity would be 1170-1200 (abbot of Tulle 1210); he would belong to a quite different generation, contemporary with Bertran de Born.]

2088.

Pezzimenti, Sara. "Bernart de Ventadorn non fu abate di Tulle." MR 33.2 (2009): 392-401. [Was Bernart the same person as the Benedictine monk, son of Eble III, who became abbot in 1210 and died in 1217? He would have had to join the order at a very young age, and church authorities would have allowed him to compose his frankly profane poetry; if he entered only late in life, he would have be about twenty years younger than is traditionally thought; other historical facts make the identification impossible.] 
2089.

Pollina, Vincent. "Canso mélodique et canso métrique: Era.m cosselhatz, senhor de Bernart de Ventadorn.” In 94, AIEO 1, 1987, pp. 409-22. [Detailed metrical and melodic analysis of Bernart's song (two melodic versions); both melodies reflect a clear awareness of the rhythmic structure of the poem and consciously support its rhyme structure; the metric structure seems to be the key to the functioning of the poem; further study of songs with multiple melodic notation will be required to verify this.]

2090.

Rosenstein, R. "Latent Dialogue and Manifest Role-Playing in Bernart de Ventadorn.” NM 91 (1990): 357-68. [Close analysis of the double structures on several levels in Bernart's Non es meravelha PC 70,31, to show that the real dialogue is not between lover and his domna but between lover and poet; the emotion of the lover is contrasted with the rhetoric of the poet.]

2091.

Riquer, Isabel de, “C'autra n'am, plus bel'e melhor (PC 70,19, v. 22).” Tenso, 23.1-2 (2008): 28-39. [The theme of the camjar and the comjat in Bernart, in which the lover justifies his abandonment of the domna orgolhosa by her failure to live up to her side of their unspoken agreement; Bernart is less harsh toward his lady than others who took part in the series of mala domna poems: see $\$$ 471-77, mala canso/mala domna.]

2092.

Steel, Matthew C. "A Case for the Predominance of Melody over Text in Troubadour Lyric: Bernart de Ventadorn's Can vei la lauzeta mover." Michigan Academician 14 (1982): 259-71. [The song appears in twenty-eight different manuscripts, its melody in three, and in seven further contrafacts outside Occitan; the melody seems more stable than the text, perhaps because of its strong connection with the trope style of chant repertory; detailed analysis of the version in MS $R$, in which text and melody are very closely linked, controlled by the central mirror image of the text, which is like the mirrored structure of the melody: the music reflects the poem and the poem reflects the music in a finely tuned, complementary relationship.]

2093.

Gaunt, Simon. "Discourse Desired: Desire, Subjectivity and mouvance in Can vei la lauzeta mover." In Desiring Discourse: The Literature of Love, Ovid through Chaucer. Edited by James J. Paxson and Cynthia A Gravlee. Selinsgrove, PA: Susquehanna University Press, 1998, pp. 89-110. [Outline of previous scholarship dealing with the poem; analysis of Appel's standard version to show that it was put together to fit the editor's notion of a typical courtly poem; to show that our understanding of the poet's status and the nature of his desire are subject to the instability of the written transmission and its reshaping by modern editors, Gaunt prints a new version based on $A$ and demonstrates how the focus of the poem has changed, becoming more amenable in fact to a feminist reading.] 
2094.

Zinelli, Fabio. "Un cas d'attribution douteuse? Bernart de Ventadorn, Amors, enquera. us preyara (BdT 70, 3).” In 102, AIEO 9, 2011, pp. 577-92. [The song is attributed to Bernart de Ventadorn in manuscripts CMSRa, to Peire Vidal in DH; Zinelli examines closely a number of traits that even Appel saw as untypical of Bernart: paradoxical images, disjointed syntax, rimas estrampas, and several lexical items, but none of these is sufficient to deny the attribution to Bernart; in any case, it cannot belong to Peire Vidal.]

\section{PC 71. Bernart de Venzac (Veuzac)}

[ $f$. 1162-1209; five poems and a religious alba; probably from Veuzac, between Cahors and Rodez; his moralizing tone is like that of Marcabru.]

2095.

Picchio Simonelli, Maria. Lirica moralistica nell'Occitania del XII secolo, Bernart de Venzac. Modena: STEM-Mucchi, 1974. [Introduction covering historical background, versification, themes, moral polemic, Cathar motifs; critical edition of all five poems, with Italian translation, notes.]

2096.

Beggiato, Fabrizio. “Belha m'es la flors d'aguilen (Bd T 323,5).” CN 48 (1988): 85-112. [Historical analysis leads to a dating 1187-90 and a probable attribution to Bernart de Venzac instead of Peire d'Alvernhe; this is rejected by 2193, Spaggiari, "Venzac e 'Rascas," 1996; see also 1894, Tortoreto, "Per l'attribuzione di Bel mees," 2007, who attributes it to Bernart Marti.]

2097.

Guida, Saverio. "Rechercher dans les archives en Pays d'Oc." In 107, Ab nou cor, 2004, pp. 51-86. [New material for the identification of Bernart de Venzac and dating of one of his poems to ca. 1162; he seems to have been a scribe closely attached to the Cistercian abbey of Loc-Dieu, from the village of Veuzac (not Venzac).]

\section{PC 74. Bertolome Zorzi (Bertolomeo)}

[fl. 1268-71; vida, eighteen poems: two to the Virgin, a planh for Conradin of Sicily and Frederick of Austria who were decapitated at Naples in 1268; one sestina; one romance (jugement d'Amour); an educated merchant from Venice, imprisoned

by Charles d'Anjou and the Genoans, to whom he expressed hostility.] 2098.

Levy, Emil. Der Troubadour Bertolome Zorzi. Halle: Niemeyer, 1883. Available online at http://books.google.ca. [Introduction on the life of Bertolome, literary analysis of the poems, metrics, edition of two vidas and eighteen poems, with textual notes, no translation; PC 74,7 L'autrier quan mos cors (“Jugement d'amour"), is edited on pp. 63-67: a romance of 149 lines in which the poet recounts the pleas of two lovers appealing the judgment of the God of Love and the final verdict; the poem is a mixture of allegory, lyric, and narrative.] 
2099.

Gresti, Paolo. "La canzone S'ieu trobes plazer a vendre di Bertolome Zorzi (PC 74,15).” In Italica-Raetica-Gallica. Studia linguarum literarum artiumque in honorem Ricarda Liver. Edited by Peter Wunderli, Iwar Werlen, and Matthias Grünert. Tübingen: G. Narr, 2001, pp. 521-37. [Critical edition of Bertolome's poem, with Italian translation, notes; comparative study alongside three other poems of identical structure, in an attempt to arrange them in chronological order; several possibilities are examined, but no firm conclusion is reached; in appendix, texts of the songs by Bernart de la Fon, PC 62,1, Uc de Saint Circ, PC 457,8 and pseudo Giraut de Bornelh, PC 242,38.]

\section{PC 76. Bertran d'Alamano (de Lamanon)}

[fl. 1229-66; vida; twenty-two poems, mostly sirventes and tensos; three cansos, one planh for Blacatz, one alba, PC 76,23, of contested attribution, perhaps

by Gaucelm Faidit; PC 76,4 is his famous anticlerical diatribe against the archbishop of Arles, whom he accuses of all seven mortal sins.]

2100.

Salverda de Grave, Jean-Jacques. Le Troubadour Bertran d'Alamanon. Toulouse: Privat, 1902. [Introduction on Bertran's political activities, leading to his accompaniment of Charles of Anjou on campaign in Italy; points out the similarities in tone to the poetry of Bertran de Born and the originality of his metric structures; critical edition of twenty-one poems, plus three of uncertain attribution, with French translation, notes.] 2101.

Asperti, Stefano. "Sul sirventes Qi qe s'esmai ni.s desconort di Bertran d'Alamanon e su altri testi lirici ispirati dalle guerre di Provenza." In 134, Cantarem, 1995, pp. 169-234. [Very detailed study of a group of politically active troubadours, with new editions of four poems: Bertran d'Alamanon PC 76,16 Qi qe s'esmai, with Italian translation, notes; the dating of Bertran's poem PC 76,16 is confirmed as 1233 , in agreement with Salverda de Grave, against Aurell.]

2102.

Asperti, Stefano. "Miei-sirventes vueilh far dels reis amdos (BdT 80,25)." CN 58 (1998): 165-323. [A rigorous study of the manuscripts dates the poem to 1257-58, concerning the rivalry of Richard of Cornwall and Alfonso X the Wise for the position of emperor; it is not by Bertran de Born; it could be by Bertran d'Alamanon, but there is no proof; the poem was probably composed in Provence, but the poet cannot be identified; the song must remain anonymous.]

2103.

Aurell i Cardona, Martí. "Le poème Qi qe s'esmai ni.s desconort (1215) attribué à Bertran de Lamanon.” Provence historique 36 (1986): 339-43. [Analysis of the political sirventes; no text; by a study of historical references, Aurell dates the poem to 1215 , too early for attribution to Bertran d'Alamanon; it must be considered anonymous; see above, Asperti's article on the same poem, dating it to 1233 and confirming its attribution to Bertran in a group of engaged poems.] 
2104.

Aurell, Martin. La Vielle et l'épée. Troubadours et politique en Provence au XIIIe siècle. Paris: Aubier, 1989, pp. 101-12. [Life and political activity of Bertran in support of Count Raimon Bérenger V in his struggles to maintain the independence of Provence; his activism continued after Count Raimon's death, with his diatribe against Archbishop Joan Baussan of Arles and diplomatic missions into Italy on behalf of Charles of Anjou; he was chief judiciary of Naples up to his death in 1270.]

2105.

Aurell i Cardona, M. "Le troubadour Bertran de Lamanon (c. 1210-1270) et les luttes de son temps.” BRABLB 41 (1987-88): 121-62. [Analysis of the political content in sirventes about the reigns of Raimon Berenger V and Charles of Anjou; the poems offer a glimpse into Bertran's social milieu and the politics of the court life in which he moved during a period of upheaval; Bertran remained independent, at times critical of his patron, even admiring some of the "enemy."]

2106.

Beltrán, Vicenç, “Tipos y temas trovadorescos (X): Dos Bertran d'Alamanon." Romanica vulgaria. Quaderni 13-14 (1994): 25-40. [Beltrán believes there were two Bertrans: three of the poems are sirventes, out of character for the troubadour; two are critical of the poet's patron Charles d'Anjou, and one is strongly critical of the papacy; all of these would represent poor political moves, damaging for his patron Charles; they may have been composed by Bertran's son, also called Bertran d'Alamanon or Beltranet Alamano.]

2107.

See 2746, Fuksas, "Il corpo di Blacatz," 2001. [A cycle of three planhs, started by Sordello, who suggested that the political leaders of Europe should eat some of Blacatz's heart to acquire his courage; Bertran d'Alamanon transformed Sordello's warlike discourse into a courtly, perhaps parodic, one in PC 76,12, Mout m'es greu, replying that none of these great leaders was worthy and that the heart should be entrusted to a number of superior courtly ladies instead; he identified four by name and indicated more from various Occitan regions; Peire Bremon Ricas Novas was to change the focus again, more overtly parodic, by making Blacatz into a kind of Christian courtly saint.]

2108.

See 2697, Guida, "Questioni relative," 2008. [The partimen between Monge and Bertran d'Alamanon, about 1232, was an opportunity for the two rivals to demonstrate their technical poetic skills within the refined court of Raimond Berengier $\mathrm{V}$ in Aix.]

2109.

Noto, Giuseppe. "Una nuova edizione della tenso Granet/Bertran d'Alamano (BdT 189.2 = 76.6) De vos mi rancur, compaire." Lecturae tropatorum, 2010. Online at http:/www.lt.unina.it. [Introductory study of the text in its manuscript context; literary analysis; critical edition with Italian translation, notes; see also $\mathbf{2 5 6}$, Harvey and Paterson, Troubadour "Tensos," 2010, 2:437-42.] 


\section{PC 80. Bertran de Born}

[ $f$. pre-1181-98; born ca. 1150, died ca. 1215; two vidas and several razos; forty-three poems, plus four of doubtful attribution; six are classic love poems, the others mainly sirventes, concerned with politics and knightly values; Bertran sided in his poetry with the young King Henry Plantagenet against Henry II and Richard, then with England against the French king Philippe Auguste;

Dante assigned him to Inferno as a sower of discord; two melodies: see - 607, van der Werf, Extant, 1984, pp. 72*-74*.]

\section{0.}

Gouiran, Gérard. L'Amour et la guerre: L'Oeuvre de Bertran de Born. Aix-en-Provence: Publications de l'Université de Provence, 1985 (distribution by Lafitte, Marseille). Also published as Le Seigneur-Troubadour d'Hautefort. L'Oeuvre de Bertran de Born. Aix-en-Provence: Univers, 1987. [Study of manuscripts, edition of forty-three poems plus four of doubtful attribution, with French translation, notes, glossary.]

2111.

Paden, William D., Tilde Sankovitch, and Patricia H. Stäblein. The Poems of the Troubadour Bertran de Born. Berkeley: University of California Press, 1986. [Introduction, critical edition of forty-seven poems, with English translation, notes, glossary; presented in facing-page format, extra-wide pages]. Available online at http://books. google.fr/books?id=jC3JVwTDHekC\&printsec.

2112.

Thuillat, Jean-Pierre. Bertran de Born: Histoire et Légende. Périgueux: Fanlac, 2009. [Historical background, life of Bertran; no poems.]

\section{3.}

Asperti, Stefano. "L'eredità lirica di Bertran de Born." CN 64 (2004): 475-525. [A nuanced study of Bertran's reputation as a poet of arms, promulgated by Dante; this is a fuller treatment of his paper from $\ \mathbf{1 0 0}$, AIEO 7, 2003 (Messina).]

2114.

Beltrami, Pietro G. "Variazioni di schema e altre note di metrica provenzale: a proposito di Bertran de Born Puois Ventadorns e Sel qui camja," SMV 35 (1989): 5-42. [Fine analysis of complex metric structures in Bertran's PC 80,33 and 80,10 in relation to the structures found in forty other poems; new critical editions of the two poems, with Italian translation, copious notes.]

2115.

Beltrami, Pietro G. "Bertran de Born poeta galante: la canzone della dompna soiseubuda." In 139, Mélanges Marc-René Jung, 1996, 1:101-17. [Bertran's poem creates an artificial, imaginary, composite woman who represents ideal feminine beauty; rather than a love poem, it is a gallant courtly expression of praise offered by a vassal to his suzerain; critical edition of PC 80,12 Dompna, puois de mi no.us cal, with Italian translation.]

2116.

Beltrami, Pietro G. "Giochi di corte per Bertran de Born (Chasutz sui de mal en pena)." In 158, Studi Bertolucci Pizzorusso, 2006, 1:165-85. [Exploration of the 
curious mixture of politics and love: the love themes are secondary, a signal of elevated style as well as being essential to the rhetorical public performance, and a means by which the poet can put himself into the poem; the central message is of himself as a figure who plays a role among the great and powerful; the text of PC 80,9 is reproduced from Appel, 1932, with Beltrami’s "poetic" Italian translation pp. 184-85.]

2117.

Beltrami, Pietro G. "Bertran de Born fuori da Altaforte. Qualche nota su Ges no mi desconort," in 109, Comunicazione e propaganda, 2007, pp. 133-50. [Bertran's successful plea for restitution of Autafort, within the series of twelve poems from 1182-83 that treat of his struggles with family and authority; pp. 146-50: stanzaby-stanza analysis of PC 80,21, given in Italian translation, with Appel's Occitan text from 1932 in footnotes.]

2118.

Carapezza, Francesco. "Canzoni 'date in moglie' a sirventesi nella vida II di Bertran de Born.” CN 68 (2008): 315-33. [Analysis of Bertran's second vita, especially a reinterpretation of a phrase in which King Alfonso II of Aragon wanted to marry Giraut de Bornelh's melodies to Betrtran's sirventes; instead of being praise for Bertran's sirventes in preference to Giraut de Bornelh's cansos, it refers to Bertran's common practice of using canso melodies by other troubadours as a basis for his sirventes, for example his PC 80,13, based on Giraut's 242,69.]

\section{9.}

See 73, Dauzier, "Bertran de Born," 1986 and 1997. [An account of the mythification of Bertran and his poetry, from Dante to the present.]

2120.

Gouiran, Gérard. "Bertran de Born, poète de l'amour." In Chrétien de Troyes and the Troubadours: Essays in Memory of the Late Leslie Topsfield. Edited by Peter S. Noble and Linda M. Paterson. Cambridge: St. Catherine's College, 1984, pp. 52-61. [The themes of war and love are constantly juxtaposed in his poetry, because for Bertran, love was a general term applied to the central organizing force of his world; in a sort of reciprocal rivalry, his choice of the best domna increased his worth as well as hers, as did her acceptance of him; a constant striving for superiority (in war and in love) was essential to the value system of the aristocratic society.]

2121.

Gouiran, Gérard. "Le poète et le prince: le cas de Bertran de Born." In 131 , Les troubadours et l'état toulousain, 1994, pp. 211-18. [Bertran's implications in the struggles for power among Henry II of England and his sons; Bertran could risk supporting Richard the Lion-Heart and criticizing the king of Aragon and the young King Henry because of his position as a prominent seigneur.]

2122.

Mancini, Mario. "Scenografie di Bertran de Born." In 160, Studia Riquer, 198691, pp. 507-26. Slightly revised, with translation of Occitan quotations, in $\mathbf{4 0 1}$, Mancini, Metafora feudale, 1993, pp. 133-61. [Cinematic-style staging is a conscious part of Bertran's dramatic presentation, especially in PC $80,8 \mathrm{a}$, Be.m platz, which 
Mancini analyzes stanza by stanza; numerous intertextual references to themes found in Marcabru, Jaufre Rudel, and other early poets suggest that Bertran was very aware of suggestive nuances that he used to show his participation in poetic concerns of his contemporaries, indicating that his compositions are more complex than has been thought.]

2123.

Paden, William D. "De l'identité historique de Bertran de Born." Rom 101 (1980): 192-224. [Historical investigation that separates legend from fact in the life of Bertran and his ancestry; the poetic myth propagated by Dante and Jeanroy is an important one, but it is not real history; Paden fixes his origins in Dordogne, born around 1150, died 1215; was seigneur of Hautefort from 1182, retired to the abbey of Dalon ca. 1195, no poems are later than 1198; Bertran was a forceful and outspoken member of his feudal society but did not exercise the powerful influence over kings and princes that was attributed to him in legend.]

2124.

Paden, William D. "Pour un modèle de la communication chez Bertran de Born.” In - 139, Mélanges Marc-René Jung, 1996, 1:119-29. [A study of performance, using a sociolinguistic communication model; Bertran's poetry involves communication of various sorts with all aspects of his world; intertextuality plays an important role as he interacts with themes and attitudes of his contemporaries.]

2125.

Paden, William D. "Gender in the World of William Marshal and Bertran de Born." Essays in Medieval Studies 19 (2002): 44-60. [Dismisses the misogynist bias of Duby regarding the life and personality of William Marshal; points to similarities between the knight William and the poet Bertran, suggesting that Bertran's high consideration of women was undoubtedly true for William as well; analysis of Bertran's poem Belh mes quan vey camjar, PC 80,7, which treats in successive stanzas the old lady, the young lady, the young man, and the old man; the poem is reproduced in appendix, with English translation; other sources strengthen the view that Bertran's world, and probably William's, "had a place for both spirited men and spirited women."]

2126.

Poe, Elizabeth W. "Strange Bedfellows: Giraut de Bornelh and Bertran de Born." In - 161, Studies in Honor of Hans-Erich Keller, pp. 359-81. [Alfonso II's "marriage" of Giraut de Bornelh's cansos to Bertran de Born is a joke for the initiated, since the composer of the razos knew that the king of Aragon, who had betrayed Eudoxia by marrying his original betrothed Sancha, was not to be trusted insofar as marriages were concerned, nor in political matters. The biographer is laughing at Alfonso, Giraut de Bornelh, and Bertran de Born.]

2127.

Rubio Flores, Antonio Rafael. "La llamada épica al combate en mío Cid y Bertrán de Born." In Les chansons de geste: Actes du XVIe Congrès int. de la Soc. Rensesvals, Granada, 21-25 juillet 2003. Edited by Carlos Alvar and Juan Paredes. Granada: Universidad de Granada, 2005, pp. 579-90. [The love of battle portrayed in Bertran's 
poetry, similar to the glorification of danger, honor, and heroism portrayed in the epic, brings a new, invigorating element into troubadour song, which had until his time emphasized the refinement and tranquillity of the court.]

2128.

Stäblein, Patricia Harris. "Love Poems with Political Hearts: Bertran de Born and the Courtly Language of War." In 159, Studia occitanica, 1986, 1:291-300. [Bertran is waging poetic war by pitting the sirventes against the canso; close analysis stanza-bystanza of the poem PC 80,34, Qan la novella flors par, illustrates the ways in which Bertran contrasts the intense, absolute experience of war with the mediocre, frustrating, unstable world of love and politics; the classic patterns of finamors are negated by political satire; the dynamic of conflict infuses his poetry with brilliant energy.]

2129.

Sunderland, Luke. "The Art of Revolt: Rebellion in the Works of Bertran de Born and Julia Kristeva." Comparative Literature 62 (2010): 22-40. [An examination of the ethics of revolt as a constant and necessary process of social renewal and regeneration, as developed by Kristeva but seen already in Bertran's poetry; revolt is not only a political concept but also an ethical and artistic activity that guarantees man's integrity and creative capacities by fostering resistance to dominant cultural forces.]

2130.

[Thiolier-]Méjean, Suzanne. "Contribution à l'étude du sirventes joglaresque." In - 1326, Mélanges Boutière, 1971, 1:377-95. [Bertran de Born used the genre for satirical poems of a lower order destined for a more common audience, or for performance by a mediocre joglar; see also $\mathbf{5 8 9}$, Léglu, "Reading," 1996, for further analysis of the insulting nature of the semigenre.]

\section{PC 82. Bertran Carbonel}

[fl. 1252-65; merchant from Marseilles, otherwise unknown; eighteen lyrics: eight cansos, six sirventes, three fictitious tensos, one to his heart, two to his horse, one planh; seventy-two coblas plus one of probable attribution.]

2131.

Routledge, Michael J. Les Poésies de Bertran Carbonel. Birmingham: AIEO, University of Birmingham, 2000. [Analysis of literary qualities, life, social context, and versification; critical edition of eighteen lyrics, seventy-two coblas plus one that is likely his; English translation, glossary.]

2132.

Babin, Malte-Ludolf. "Bertran Carbonel imitateur de Peire Cardenal." In $\mathbf{9 6}$, AIEO 3, 1992, pp. 777-94. [Finds Bertran rather uninteresting, but the manner of imitating his model is not as straightforward as once thought; detailed comparison of Bertran's five sirventes with their sources in Peire Cardenal proves Peire's greater mastery of vocabulary, but Bertran is able to match him in the use of motifs and features of style, particularly those drawn from his own commercial sphere and from his wider experience with juridical expression.] 
2133.

Brunel-Lobrichon, Geneviève, “Bertran Carbonel.” In 38, DLF, 1992, p. 169. [Though his work is not exciting, there is much to learn about the society of his time, such as poetic competitions at Marseilles; PC 82,8 strikes a personal note as he recounts his regrettable erotic boldness in church.]

2134.

See 227, Riquer, 1975, 3:1396-1402. [Introduction, edition of five poems, PC $82,16,20,41,27$, and 33, with introduction, Spanish translation, notes.]

2135.

Scarpati, Oriana. Edition of Bertran Carbonel Per espassar l'ira e la dolor BdT 82.12. Online, 2009, at http://www.rialto.unina.it. [Brief introduction; text from Contini, 1937; no translation.]

2136.

See 260, Vatteroni, Falsa clercia, 1999. [Study of anticlerical themes and traditions, and what constitutes heresy; pp. 83-87: Bertran's poems are inspired by those of Peire Cardenal, but the criticisms are more generalized, less sharp; edition of Bertran's PC 82,12, Per espassar, pp. 157-59, with Italian translation, no notes.]

\section{PC 83. Bertran Folcon d'Avignon}

[ $f$. 1202-1233; two coblas in response to an attack by Gui de Cavaillon; one tenso with either Raimon de las Salas or Raimon de Miraval, though Guida believes that the Bertran cannot be Bertran d'Avignon.]

2137.

Guida, Saverio, "Per la biografia di Gui de Cavaillon e di Bertran Folco d'Avignon." CN 32 (1972): 189-210; also \$ 2400, "L'attività poetica," 1973). [The first article, pp. 206-10, traces Bertran's military and political activities in detail and indicates his close ties to Gui, with whom he shared common interests, humorous exchanges, and social ideology; the second, pp. 259-64, provides the text of an exchange of coblas PC 192,2 = 83,2 between Gui and Bertran Folco, a cry for help during the siege of Castelnou.]

2138.

See 270, Guida, "Sospette paternità," 2010, pp. 277-321. [Wide-ranging historical investigation of poetic and political activity around the court of Toulouse in the early thirteenth century; pp. 320-21, n. 104: a tentative suggestion that the Folc who participated in the triple tenso PC 150a,1 with Arnaut de Commenge and Guilhem Peire de Cazals may be Bertran Folco d'Avignon.]

2139.

See 256, Harvey and Paterson, Troubadour "Tensos," 2010, 1:343-50. [Critical edition of PC 406,16 = 83,1; and 3:1105-11: edition of PC 150a, 1 =25,3 = 201,5a; both with English translation, notes; the Bertran in the first poem is obviously Italian and cannot be Bertran Folco d'Avignon.] 


\section{PC 85. Bertran de Paris de Roergue (de Parisot)}

[fl. 1270-90; ensenhamen, perhaps incomplete, for a joglar named Gordo; called by Bertran a sirventes; ten stanzas of eight lines plus three tornadas; the four series of rhymes and complex versification has led to the hypothesis that it is a unique response or contrafact involving four other poems, for comic or satirical purposes,

2140. and that it was probably sung to four different melodies.]

Chambers, Frank M. "The ensenhamen-sirventes of Bertran de Paris." In Mélanges de linguistique et de littérature romanes à la mémoire d'István Frank. Saarbrücken: Universität des Saarlandes, 1957, pp. 129-40. [A continuation of his article from 1957, which studied the origins of the poem's apparently simple form; many of the names used in the song are clarified, though some remain mysterious; critical edition, notes, no translation.]

2141.

See 1440, Pirot, Recherches, 1972, pp. 596-614. [Survey of previous scholarship, codicological study of the two manuscripts, metrics, intertextuality, biography, and genealogy of Bertran and the court of Rodez; dating is confirmed to 1270-90; diplomatic editions of both manuscripts, followed by the critical text, with French translation stanza by stanza; Paris (Parisot) was a dependency of Saint-Antonin and Toulouse, and, from 1214, of Rodez; probably Bertran was part of a poetic circle including Ademar Jordan and the Rodez group: Guilhem de Mur, Austorc d'Alboy, Guiraut Riquier, Marques de Canilhac, Peire d'Estanh, Peire Pelet, and perhaps Enric de Rodez.]

2142.

Colrat de Montrozier, Bruno. "Le Gourdon du troubadour Bertrand de Paris de Rouergue et son entourage: essai d'histoire littéraire et féodale sur un sirventès du milieu du XIIIe siècle." Revue du Rouergue 67 (2001): 321-56. [History of Rodez and its principal families, especially in their connection with the troubadours; text of Bertran's poem is given in French translation only, with stanza-by-stanza commentary; extra information on Marques de Canilhac, the Countess, Gordo, and his fellow joglar Cardalhac.]

\section{PC 87. Bertran del Pojet (Poget; de Puget)}

[fl. 1222-45; vida, two poems: a tenso or exchange of coblas with an anonymous lady, perhaps fictive, and a sirventes about the relative merits of largess or accumulating riches, in which he claims that he prefers to give away his money as soon as he gets some; another poem, PC 409,1, is of disputed attribution, either by Bertran or by Raimon de las Salas.]

\section{3.}

De Lollis, C. "Di Bertran del Pojet, trovatore dell'età angioina." In Miscellanea in onore di Arturo Graf. Bergamo: Istituto italiano d'arti grafiche, 1903, pp. 691-710. [Historical investigation of Bertran's life and political activities at the court of Raymond Berengier V; edition of the sirventes, pp. 706-8, and the tenso, pp. 708-10, with textual notes, no translation.] 
2144.

See 2425, Calzolari, "Guillem Augier Novella," 1986. [Poems by Bertran and by Peyre Cathala dedicated to Guillem Augier reveal close intertextual links among the three, who dialogued back and forth; Bertran imitated the content, the similarities of argumentation and the structure of Guilhem's poems; all three were part of the inner circle of Raymond Berengier's court.]

\section{5.}

Larghi, Gerardo. "Per l'identificazione del trovatore Bertran de Puget." CN67 (2007): 79-129. [Detailed historical investigation that identifies Bertran almost certainly with a lesser noble in the Var region, vassal and companion of Raimon Berengier V; Bertran played an influential role in the poetic and political circles of Raimon's court; his son served under Charles I of Anjou in Italy.]

2146.

See 738, Nappholz, Unsung Women, 1994. [Examines the tenso debate between Bertran del Pojet (PC 87,1) and a bona domna, claiming to hear therein "a distinctly female voice"; edition, with English translation; see $>\mathbf{7 6 8}$, Bruckner, "Fictions of the Female Voice," 1992, for an analysis of ways to recognize the feminine voice in literature.]

2147.

See 735, A. Rieger, Trobairitz, 1991, pp. 320-30. [Critical edition of the tenso, with introduction, German translation, copious notes; sees a definite feminine viewpoint portrayed by the lady, in a similar fashion to that of other acknowledged women tenso participants, though there is no documentary proof of the domna's historic reality.]

\section{PC 88. Bertran de Preissac (the same as Bertran de Pessars PC 86 and Bertran de Saissac PC 90?)}

[fl. 1190-1235; two poems: one tenso with Gausbert de Puycibot 173,5 = 88,2, followed by two sirventes, $173,1 \mathrm{a}$ and 88,1 , that continue the debate.]

\section{8.}

See 2051-55, Gouiran, Harvey and Paterson, Latella, Malm, and Marshall, 1988-2002. [Discussion of a tenso and two sirventes that debate the relative merits of younger and older women, especially the attribution and relative chronology of the three elements.]

\section{PC 93. Bietris de Roman}

[ $f$. first half thirteenth century; Bieiris is a misreading of the manuscript, corrected by Zufferey in 132, Paden, Voice, 1989, pp. 32-33; her identity is questioned by some: if Bietris were to be identified with Albric (= Alberico da Romano PC 16a) as proposed already by Schultz-Gora in 1891, and again by Poe 1992, then canso PC 93,1 should be reclassified as PC 16a,2, but this remains controversial;

Huchet has attributed it to Folquet de Romans in 761, "Les femmes troubadours," Zufferey "possibly” to Gui d'Ussel 132, Voice.] 
2149.

See 735, A. Rieger, Trobairitz, 1991, pp. 505-17. [Edition of PC 93,1 = 16a,2, with German translation, detailed textual notes, commentary; a unique poem, by a woman to another woman; the emotion is not lesbian but more like a normal expression of tenderness between women; Rieger suggests the possibility that Bietris could be the author of the anonymous planh, PC 461,2, by a woman for the death of her (male) lover.]

2150.

Braet, Herman. "Bietris de Roman." In $\$ 46, Women in the Middle Ages, 2004, p. 95. [Takes no stand regarding the poet's gender, suggesting that the song could be a playful countertext.]

2151.

Ganze, Alison. "Na Maria, pretz e fina valors: A New Argument for Female Authorship." RN 49.1 (2009): 23-33. [Denies that the poetic relationship in PC 93,1 must be interpreted only in sexual terms; following A. Rieger's demonstration that the language falls within the normal articulation of sympathy and friendship customary to Maria's time, found in numerous troubadour and trobairitz poems, Ganze shows that the same language is used broadly to express loyalty in clearly political contexts such as oaths of fidelity and vassalage, often with distinctly passionate overtones; it expresses the social and political ideals of the society through erotic imagery.]

2152.

Nicholson, Francesca. "Seeing Women Troubadours without the '-itz' and '-isms." In 745, Troubled Vision, 2004, pp. 63-76. [The notion of gender interplay is more useful than the tendency to overfeminize the trobairitz and force them into a limiting female identity; trying to align a gendered poetic practice with the supposed biological identity of the poet is unproductive. Two poems are analyzed: Bietris de Roman Na Maria, pretz e fin valors, and Azalais d'Altier, Tanz salutz e tantas amors, PC 42a,1; in both, the protagonist is saying that the position and identification of that figure is changeable. Nicholson argues that the two trobairitz speak sometimes with the voice of a male, sometimes with that of a female.]

2153.

Rieger, Angelica. "Was Bieris de Romans Lesbian? Women's Relations with Each Other in the World of the Troubadours." In 132, Paden, Voice, 1989, pp. 73-94. [Rieger denies "lesbianism" in Bietris de Romans, seeing the erroneous interpretations as a product of modern misreading of friendly affection.]

2154.

Sankovitch, Tilde. "The Trobairitz." In 282, Troubadours, 1999, pp. 113-26, esp. p. 122. [Interprets Bietris's poem as consciously subversive and ludic, in which the poet uses the language of a man to address a woman, for its unsettling effect of disturbing the too exclusively masculine parameters of the standard poetry.]

2155.

See 764, Poe, "Dispassionate Look," 1992. [Casts doubt on the historical reality of five of the seven unknown trobairitz, maintaining only Garsenda and Guilhelma 
de Rosiers. Bietris de Romans may be in fact Alberico da Romano (as Schultz-Gora thought in 1891).]

\section{PC 94. Lo Vesques de Bazas (Bischof von Basaz)}

[Perhaps Galhart de la Mota, bishop, 1186-1213; one canso of three stanzas.] 2156.

See 255, Guida, Trovatori minori, 2002, pp. 81-123. [Information on the manuscript tradition, historical background involving the nature of the bishopric of Bazas, the influence of Uc de Saint Circ, the possible identity of the bishop-troubadour; critical edition of PC 94,1, with Italian translation, copious notes.]

\section{PC 95. Lo Vesques (Robert) de Clarmon (Clermont)}

$[f$. first quarter thirteenth century; two coblas and one sirventes directed

2157.

against his cousin Dalfi d'Alvernhe.]

Aston, Stanley C. "The Poems of Robert, Bishop of Clermont 1195-1227)." In - 147, Mélanges Rostaing, 1974, 1:25-39. [Provides detailed political background to struggles with his brother Guy and his cousin Dalfi d'Alvernhe; reproduces all three texts, two from Kolsen's edition, 1925, the third from Boutière/Schutz Biographies, pp. 286-88, with English translation, notes.]

2158.

Hérilier, Christian, and Jean-Pierre Chambon. "Sur l'identité de maistre Audefers chez Dauphin d'Auvergne (PC 119,4).” RLaR 108 (2004): 183-87. [Audefers is corrected to Audefres: magister Aldefredus, abbot of the monastery of Chantoin, confessor at Clermont, executor of the will of Dalfi's wife, the Countess G., well known as a confidant of both Dalfi and his cousin Bishop Robert and a natural moderator in the humorous dispute aired in their exchange of coblas (PC 95,3 and PC 119,4); corrections are proposed to the tornada, giving it a regular form.]

\section{PC 96. Blacasset}

[ $f$. 1233-42; son of Blacatz; vida; ten to twelve poems: three cansos; a planh for two young and beautiful ladies entering a convent: a replique by Pujol defends their religious vocation: PC 386,2; two sirventes, four coblas; three humorous debates with Montanhagol and an unknown Alexandre; one melody: see - 607, van der Werf, Extant, 1984, p. 75*.]

2159.

Klein, Otto. Der Troubadour Blacassetz. Städtische Realschule zu Wiesbaden, Jahresbericht über das Schuljahr 1886/87. Wiesbaden: Ritter, 1887. 24 pp. [Introduction, critical texts, with German translation.]

2160.

See 2101, Asperti, "Sul sirventes," 1995. [Detailed study of activities of a group of troubadours, and their poetry (sirventes); new edition of four poems, including Blacasset PC 96,3a, De guerra, pp. 225-28, with notes and Italian translation.] 
2161.

See 249, Bec, Florilège en mineur, 2004, pp. 223-27. [Brief introduction, vida, edition of the planh (composite text from Audiau-Lavaud), French translation.]

2162.

Favero, Alessandra. "La canzone di Blacasset Mos volers es qez eu m'eslanz (BdT 96,7a)." SMV 52 (2006): 55-79. [Detailed study of the poem in its manuscript tradition; critical edition, with Italian translation, copious notes; the text is dated before 1237; many similarities with PC 330,12 by Peire Bremon Ricas Novas are noted, but it is not possible to say which poem inspired the other.]

\section{3.}

Hutchinson, Patrick. "A lunel lutz una luna luzens: une exploration du thème de la lumière à partir du jeu-parti de Guilhem de Montanhagol et de Blacasset.” In Le Soleil, la lune et les étoiles. Sénéfiance 13. Àix-en-Provence: Publications du CUER MA, 1983, pp. 177-93. [Exchange of coblas with Blacasset, which show close affinities to kabbalistic doctrines prevalent in the area of Lunel at the time; Hutchinson seems unaware of Ricketts's 1964 edition and of Teulière's 1979 article.]

2164.

Paterson, Linda M. "Alexandre-Blacasset (19.1-96,4)." [Edition of the tenso, a fictive debate with an unknown person, perhaps a moneylender; Occitan text, notes, no translation.]

\section{5.}

See 2460, Ricketts, Les poésies de Guillem de Montanhagol, 1964. [Exchange of coblas with Guilhem de Montanhagol: pp. 49-53, critical edition of A Lunel lutz PC 225,1, with French translation; in appendix, p. 139, edition of Blacasset's replique Amics Guillem PC 96,1, no translation, no notes.]

\section{6.}

See 227, Riquer, 1975, 3:1288-97. [Introduction, vida and text from Klein of sirventes PC 96,6, text from Appel of planh PC 96,10a, and cobla PC 96,9 in reply to Sordello PC 437,7.]

\section{7.}

Teulière, Gérard. "Interpénétration culturelle dans le trobar: Montanhagol, Blacasset, et la kabbale.” Tenso 2 (1986-7): 37-50. [Continuation of an earlier exploration (1979) of social and religious tolerance and cross-influences in an exchange of coblas with Montanhagol, PC 225,1 A lunel lutz, and PC 96,1 Amics Guillem, in which can be found references from Cathar and Jewish sources, demonstrating close contacts with kabbalistic traditions of their time and region; texts from Riquer, without translation; cf. 2163, Hutchinson 1983 for a similar study of the same poem; Teulière seems unaware of Ricketts's 1964 edition of Montanhagol and did not see Hutchinson's article in time to use it.]

\section{PC 97. Blacatz}

[fl. 1165-1236; vida; twelve or thirteen poems: one canso, three partimens, six tensos, two exchanges of coblas; a model of the perfect courtly patron and poet, father 
of Blacasset; Sordello composed a famous planh, PC 437, 24, on his death, encouraging all to eat some of his heart to acquire some of his qualities.]

2168.

Soltau, Otto. "Die Werke des Trobadors Blacatz." ZrP 23 (1899): 201-48 and 24 (1900): 33-60. [Introduction on Blacatz and his contemporaries; corpus; chronology; metrics; rejected poems; critical edition of eleven poems, notes, no translation; textual notes and glossary are in the second article.]

2169.

See 2746, Fuksas, Anatole Pierre. "Il corpo di Blacatz e i quattro angoli della cristianità.” In 115, Interpretazioni, 2001, pp. 187-206. [In his planh for Blacatz, Sordello suggested that the political leaders of Europe should eat some of Blacatz's heart to acquire his courage; Bertran d'Alamanon and Peire Bremon Ricas Novas transformed this by parody into proposals that the heart should be eaten by illustrious ladies instead or that the whole body should be shared over the entire world in a sort of parody of Christ's sacrifice.

2170.

See 245, Nelli, Ecrivains anticonformistes, 1977, pp. 115-25. [Texts of PC 52,5 = 97,12, Segner Blacaz, ben mi platz, and PC 97,4 = 388,3, En Raimbautz, ses saben, tensos, with an unknown Bernart and Raimbaut (probably Raimbaut de Vaqueiras); texts from Suchier 1883 and de Rochegude 1819, no translation, no notes.]

PC 100. Bofils (Bonfils, Bofil)

[Second half thirteenth century; Jewish poet from Narbonne; one tenso with Guiraut Riquier, PC 100,1 = 248,16.]

2171.

Serper, Arié. "Guiraut Riquier, Bonfils et les Juifs de Narbonne.” RZL 2 (1978): 42129. [Critical edition of the tenso; historical background, French translation, notes; see also 256, Harvey and Paterson, Troubadour “Tensos,"2010, 2:735-43, edition with English translation, notes.]

2172.

Paden, William D. "Troubadours and Jews." In 140, Études Ricketts, 2005, pp. 471-84. [Survey of Jewish presence alongside troubadours; notes little contact or reciprocal influence, apart from Bofils; there is anti-Semitic slander in the troubadours and in the Breviari d'amor; in the tenso, Guiraut Riquier hesitates to sing with Bofils, because of the Jews' treatment of Jesus.]

2173.

Viguier, Marie-Claire. "Un troubadour juif à Narbonne au XIIIe siècle.” In Juifs et source juive en Occitanie. Enèrgas: Vent Terral, 1988, pp. 81-92. [Bofils is tentatively identified as Abraham ben Isaac Bedersi, a contemporary of Guiraut Riquier, known as a lively, erudite, combative poet capable of assuming playfully the pseudonym of Bofils.]

2174.

See 245, Nelli, Ecrivains anticonformistes, 1977, pp. 292-99. [Text from Chabaneau 1889, with French translation, notes.] 


\section{PC 101. Bonifaci Calvo}

[ $f$. 1250-66; vida; nineteen poems in Occitan, mostly sirventes, one planh on the death of his domna; one poem in Occitan, Galician, and French; two cantigas d'amor in Galician-Portuguese; Bonifaci spent much of his career at the court of Alfonso X of Castile; after 1266, he was back in Genoa, involved in political hostilities with Venice.]

2175.

Branciforti, Francesco. Le rime de Bonifacio Calvo. Catania: Università di Catania, 1955. [Historical introduction, critical edition, with Italian translation, notes.]

2176.

Horan, William D. The Poems of Bonifacio Calvo: A Critical Edition. The Hague: Mouton, 1966. [Introduction on Bonifaci's life, themes in his poetry, manuscript history; critical edition of nineteen Occitan poems and two Portuguese cantigas de amor, with English translation, brief notes.]

2177.

Piccat, Marco. "Le cantigas d'amor di Bonifacio Calvo." $\operatorname{ZrP} 105$ (1989): 161-77. [Introduction to Bonifaci's life and social context; critical edition of the two Galician poems, with Italian translation, study of metrics and style, textual notes.]

2178.

Beltrán, Vicente, "Los trovadores en las cortes de Castilla y León (I): Bonifaci Calvo y Ayras Moniz d'Asme." CN 45 (1985): 45-57. [Analysis of fact and legend surrounding Bonifaci's ten-year stay at the Spanish court and of the rivalry between the Occitan and Galician schools of poetry; see additional historical details in Revista de literatura medieval 1 (1989): 9-13.]

2179.

Blasco, Eduardo. "Il mistilinguismo poetico médiévale: una fata morgana? (Analisi della lingua del sirventes plurilingue di Bonifacio Calvo)." Beiträge zur romanischen Philologie 26 (1987): 57-89. [Theoretical linguistic analysis of the phenomenon of multilinguism: definitions of different types and their use by Raimbaut de Vaqueiras, Cerveri de Girona, and Bonifacio Calvo; detailed linguistic analysis of stanza two of Bonifacio's poem, which uses "languages" for rhetorical effect (the stanza is more or less NavarroAragonese) to persuade the Castilian king to take back control of Navarre.]

2180.

Fleming, John V. “Le cantigas d'amor di Bonifacio Calvo.” ZrP 105 (1989): 161-77. [Study and edition of the two poems composed in Galician-Portuguese.]

2181.

See 915, Formisano, "Un nou sirventes," 1993. [In his poem, Bonifaci Calvo was inciting Alfonso the Wise to war against Navarre and Aragon, in order to replace the young Thibaut II; in addition to his learned poetic language Occitan, he used Galician-Portuguese, the literary language of Alfonso's court, and Old French, the language of Thibaut II of Champagne; the languages were not only culturally and politically appropriate to the military controversy but they also served to show off the poet's versatility.] 
2182.

Marcenaro, Simone. "Bonifacio Calvo alla corte di Alfonso X: la regalità assente." CDT 10.3 (2007): 9-32. [Analysis of the activity and influence of Bonifaci at the court, engaged in diplomatic missions and giving frank advice to the king; his poems give insight into the political difficulties and hesitations of Alfonso; in appendix: texts of three political sirventes, no translation.]

2183.

Paden, William D. "Contrafacture between Occitan and Galician-Portuguese (2): The Case of Bonifaci Calvo." Tenso 13.2 (1998): 50-71. [Reciprocal influence on and from Galician-Portuguese poetry through the use of the same melodic and metrical structures; Paden finds several cases of possible contrafacture between Bonifaci and Galician as well as Occitan poems; he detects a continuity or permeability between Occitan and Galician lyric, in an "imitative process including models and imitations in both languages in every possible combination."]

2184.

Schulze-Busacker, Elisabeth. "Topoi." In 281, Handbook, 1995, pp. 425-37. [Detailed analysis of the planh by Bonifaci (PC 101,12) to illustrate the complexities of rhetoric structure in troubadour poetry, especially the use of recurring themes and topoi from classical times or in earlier troubadours; a detailed look at the syntactic and lexical aspects of the three central motifs in the poem.]

2185.

Speroni, Gian Battista. "Due note provenzali." In Studi di cultura francese ed europea in onore di Lorenza Maranini. Fasano: Schena, 1983, pp. 73-83. [The second study considers Bonifaci Calvo's multilingual poem PC 101,17, addressed to Alfonso X of Castile, in Occitan, Galician-Portuguese, French, and a mysterious language; a new analysis reestablishes stanza four as Old Italian, along with the last line of three: the original forms were "corrected" by Branciforti into Occitan! The Old Italian is more precisely Ligurian, making it easier to confuse it with Occitan.]

2186.

Tavani, Giuseppe. "Il plurilinguismo nella lirica dei trovatori." In Documenti letterari del plurilinguismo. Edited by Vincenzo Orioles. Rome: Editrice Il Calamo, 2000, pp. 123-42. [The analysis of poems by Raimbaut de Vaqueiras, Bonifaci Calvo, and Cerveri de Girona shows that each case is unique and that the use of multiple languages does not follow any general principle; in the case of Bonifaci, pp. 138-39, his choice of three languages was based on the prestige of Occitan, the Galician-Portuguese of the Castilian court, and the French of Thibaut, as he urged Alfonso X to attack Navarre and Aragon.]

2187.

Tavani, Giuseppe. "Il plurilinguismo poetico e il caso di Bonifacio Calvo (A proposito di Un nou sirventes ses tardar, BdT 101,17)." CDT 13.1 (2010): 17-40. [A reconsideration of the language used by Bonifaci in the second stanza of his poem and an investigation of his reasons for using it; in spite of his earlier opinion, and that of Blasco 1987, the language can only be Galician, not Aragonese.] 
PC 102. Bonifaci de Castellana (Boniface VI)

[ $f$. 1252-62; no vida; lord of Castellana from 1249; three sirventes against

Charles of Anjou and against clerics; in 1262, he led the unsuccessful revolt of the Marseillais against Charles of Anjou, leading to the destruction of his castle and his banishment.]

\section{8.}

Parducci, Amos. "Bonifazio di Castellana.” Rom 46 (1920): 478-511. [Detailed biography of Bonifaci from 1244 on, emphasizing his heroic, revolutionary, anti-French, and antiadministrative tendencies, as he fought for the independence of Provence against Charles d'Anjou; critical edition of all three poems, with Italian translation, notes.]

2189.

Bec, Pierre. "Contribution à l'interprétation des poésies du troubadour Boniface de Castellane." In Mélanges de langue et de littérature du moyen âge et de la Renaissance offerts à Jean Frappier. Geneva: Droz, 1970, pp. 83-88; also in Ecrits sur les troubadours et la lyrique médiévale (1961-1991), Caen: Éditions Paradigme, 1992, pp. 259-64. [Working toward a new edition, Bec offers suggestions for improved interpretations of Parducci's texts: discussion of eleven short passages, with integral French translations of all three poems; no Occitan texts; the proposed edition has not appeared.]

2190.

See 2104, Aurell, La Vielle et l'épée, 1989, pp. 187-206. [The political role of Bonifaci, especially seen in his sirventes; he urged Henry III of England and James I of Aragon to stand up to Charles of Anjou in defense of their territories against the centralization of power in the hands of the French; his poems support the communal rights of the cities and the virtues of direct warfare against the new bureaucratic administration by functionaries, though he had to admit final defeat and flee, first to Montpellier, then to Spain.]

2191.

See 249, Bec, Florilège en mineur, 2004, pp. 149-53. [Brief introduction, text of PC 102,1, Era, pueis iverns, from Parducci with a few modifications, French translation, no notes; see also 227, Riquer, Los Trovadores, 1975, 3:1381-85: introduction, text of PC 102,3 from Parducci, with some emendations from Bec, others of his own, Spanish translation, notes.]

\section{PC 104. Bermon Rascas (Bremon)}

[Lord of Uzès 1211-34; one canso, probably from ca. 1200, before the death of his older brother in 1211.]

2192.

Guida, Saverio. "Il trovatore Bermon 'Rascas." In Miscellanea di studi romanzi offerta a Giuliano Gasca Queirazza. Edited by Anna Cornagliotti et al. 2 vols. Alessandria: Edizioni dell'Orso, 1988, 1:369-403. [Close examination of historical and archival materials succeeds in placing the otherwise unknown poet in his social and cultural 
context; as lord of Uzès, his father was closely linked with Raymond V and VI of Toulouse; Bermon II "Rascas" is known in detail from 1208 to 1234 in twenty-eight archival references; born probably in the 1170 s, he seems to have led an intense and agitated life, first as one of the insecure iuvenes seeking adventure and pretz through poetry until the death of his brother, then 1211-34 as lord of Uzès struggling with the church and the French in defense of his feudal rights; his inner strength and pride are found in his poem, edited critically with Italian translation and copious notes.]

2193.

Spaggiari, Barbara, "Venzac e 'Rascas'? Postilla a Il nome di Marcabru (1992) in margine a tre edizioni (BdT 323,5; 104,2; 104,1) e a una recensione." SM 37 (1996): 347-85. [Contests the attribution by Beggiato of PC 104,2, Lancan lo douz temps, to Bernart Marti; it is more likely by Marcabru or by one of his many imitators, possibly Bermon Rascas or Bernart Marti; also contests Guida's attribution of PC 104,1, Dieus et amors et merce, to Bermondo II "Rascas" (first half thirteenth century); she suggests that the degraded linguistic state of the poem indicates a late fourteenthcentury Italo-Provençal origin, perhaps Uzès or Avignon; see the very strong replique by Guida: "Messa a punto su Bermon "Rascas." SM 58 (1997): 879-89, refuting Spaggiari's proposal and confirming the attribution to Bermond II of Uzès.]

\section{PC 105. Cabrit}

[Early thirteenth century; once thought to be a pseudonym for Gui de Cavaillon, now identified as Guilhem Aldebert Cabrit; one humorous tenso with Ricau de Tarascon.]

2194.

Guida, Saverio. "Pour l'identification du troubadour Cabrit." CCM 52 (2009): 21-36. [Renewal of an earlier study and edition (CN 47, 1987, pp. 197-221, partly reproduced online in 2007 at http://www.rialto.unina.it), in the light of new evidence; following up on the work of Aurell, Guida shows that Cabrit is to be identified not with the troubadour Gui de Cavaillon but with Guilhem Aldebert Cabrit, an important member of the municipal administration in Arles; his identification leads to better understanding of the complex social and political forces at the beginning of the thirteenth century around Arles; poetry is seen as cement linking together the prominent members of the society in a period of social and political upheaval.] 2195.

Meliga, Walter. "Ricau de Tarascon e Cabrit, Cabrit, al meu vejaire (BdT $422.2=$ 105.1)." Lecturae tropatorum, 2008, 22 pages. Online at http://www.lt.unina.it. [Introduction, literary analysis, paleographical study, and critical edition with Italian translation, detailed notes; this is now part of the edition of all tensos and partimens in

256, Harvey and Paterson, Troubadour "Tensos,"2010, 3:1129-37.]

\section{PC 106. Cadenet}

[fl. 1204-38; vida; twenty-five poems, plus one of uncertain attribution PC 276,1; his pastorela, PC 106,15, is "one of the most gracious of the twenty or so Occitan 
pastorelas"; one alba which is also a "chanson de mal-mariée," the only one of his poems preserved with melody: see $\$$ 607, van der Werf, Extant, 1984, p. 76*.] 2196.

Zemp, Josef. Les poésies du troubadour Cadenet. Berne: Lang, 1978. [Introduction on the manuscripts, the life and poetry of Cadenet; analysis of themes, versification, and the two preserved melodies; edition of twenty-five certain poems and one of uncertain attribution, with introduction, critical text, French translation, notes; extensive glossary.]

2197.

See 624, Cullin and Chaillou, "La mémoire," 2006, pp. 152-58. [Close analysis of Cadenet's S'anc fui belha, PC 106,14, to demonstrate the ways in which memorization is utilized to produce a harmonious interlacing of text and melodic structures; in Cadenet's alba, the textual and melodic structures are based on rhetorical principles: the first stanza sets out the résumé of the poem, followed by an introduction, a presentation of the protagonists, a dispute, and a conclusion; text and musical transcription in appendix.]

2198.

Sigal, Gale. "The Pit or the Pedestal? The Dichotomization of the Lady in Troubadour Lyric." RR 84 (1993): 109-42. [Analysis of the contrast between the idealized and ephemeral courtly domna in the canso, and her depiction in the more realistic pastorela by Marcabru, L'autrier jost'una sebissa, in the alba by Cadenet, S'anc fui belha, and in several other Old French and Middle High German songs.]

2199.

Squillacioti, Paolo. "BdT 276,1 Longa sazon ai estat vas Amor." RST 2 (2000): 185215. [A comjat used as a model by the Sicilian poet Jacopo Mostacci in his Umile core fino e amoroso; detailed discussion of all possible attributions, including Cadenet, Peire de Maensac, Pons de Capduelh, Rostanh de Merguas, and Jordan de l'Isla de Venessi, with no final decision; critical text based on $M$, with Italian translation; two other versions of the text are given; see also analysis of the same poem compared to Mostacci's in 2596, Heintze, "Die Rezeption," 2002.]

2200.

See 518, Zufferey, "L'aube de Cadenet," 2010. [A searching reevaluation of the typical structures of the alba, applied to a critical appraisal of all six existing editions of Cadenet's poem PC 106,14, all of which he finds to be seriously flawed, presenting in fact a monstrous poem that does not represent any of the eleven extant copies; a new critical edition and interpretation, with French translation and copious notes.]

\section{PC 107. Calega Panzan}

[fl. 1252-1313; one violent sirventes from 1268 against Charles d'Anjou; a rich merchant of Genoa, hostile to the French and to bad clerics.] 2201.

See 260, Vatteroni, Falsa clercia, 1999. [Study of anticlerical themes and traditions, and what constitutes heresy; pp. 80-82: invective by Calega against Charles of 
Anjou and the decadence of clerics in his Ar es sazos from 1268; pp. 160-64: edition of the sirventes, with Italian translation, no notes.]

\section{PC 108. Carenza}

[Unknown; early thirteenth century; participated in a tenso or exchange of coblas with Alaisina Yselda, PC 12,1 = PC 108,1, debating the value of marriage and children over the unmarried state without children; controversial in interpretation.] 2202.

See 733, Bruckner, Shepard, and White, Songs of the Women Troubadours, 1995, pp. 177-79. [Critical edition of the tenso with English facing-page translation, notes.]

2203.

Anderson, Patricia. "Na Carenza al bel cors avinen: A Test Case for Recovering the Fictive Element in the Poetry of the Women Troubadours." Tenso 2 (1987): 55-64. [A close study of the exchange, in which the ladies are examined as types that were created by the anonymous poet to transmit a dramatic message: Carenza the virgin, Alais the peasant, Iselda the aristocratic woman, together standing for womankind and providing a composite satire of the domna.]

2204.

See 797, Bruckner, "Mathematical Bodies," 1999. [Discussion of how to distinguish real or fictional bodies in the troubadour lyric; three poems are studied: Bernart de Ventadorn's Era.m cosselhatz, senhor (PC 70,6), Guilhem de Peitieus's Farai un vers de dreit nien (PC 183,7), and the tenso, or rather coblas, between $\mathrm{Na}$ Carenza and Alaisina Iselda; or is it Carenza/Alais/Iselda? (PC 12,1 and 108,1); Bruckner suggests that we cannot prove or disprove the reality of a body in a poem, or its fictional construct, so that in fuzzy logic it is both at the same time.]

2205.

See 735, A. Rieger, Trobairitz, 1991, pp. 155-65. [Outlines the difficulties presented by the text and its interpretation: the number of participants, the order of the stanzas, the poor state of transmission, the controversial interpretations of the message; believes that there are only two interlocutors; points to several parallels with Arnaut de Maruelh's PC 30,16, La grans beutatz, allowing a dating to the early thirteenth century; finds hints of Cathar attitudes, treated ambiguously with humor or irony.]

\section{PC 109. Castelloza}

[First half thirteenth century; unidentified; possibly the wife of Turc de Mairona mentioned in Dalfi d'Alvernhe's sirventes, PC 119,9; vida; three cansos, and a fourth, PC 461, 191, which is certainly by her.]

2206.

See 735, A. Rieger, Trobairitz, 1991, pp. 518-69. [Critical edition of all four poems, with German translation, commentary and detailed notes; Rieger identifies her close connections with several troubadours and the court of Dalfi d'Alvernhe.] 
2207.

Braet, Herman. "Castelloza." In \$ 46, Women in the Middle Ages, 2004, pp. 139-40. [Succinct outline of Castelloza's unique poetic stance, taking on the traditional active male role in her songs, offering herself as his servant, swearing fidelity in feudal and religious terms, combining joy with suffering in the paradoxical expression of her love.]

2208.

Paden, William D., with Julia C. Hayes, Georgina M. Mahoney, Barbara J. O’Neill, Edward J. Samuelson, Jeri L. Snyder, Edwina Spodark, Julie A. Storme, and Scott D. Westrem. "The Poems of the trobairitz Na Castelloza." RPh 35 (1981): 158-82. [Detailed introduction to previous scholarship, biographical details, relations with other poets, literary and psychological features of her poetry; critical edition of the four cansos, with English translation, notes.]

2209.

Bruckner, Matilda Tomaryn. "Na Castelloza, Trobairitz, and Troubadour Lyric." RN 25 (1985): 239-53. [Discussion of the uniqueness of Castelloza's poetry in relation to troubadour poetry and in relation to that of other trobairitz; she demonstrates a troubled self-awareness different from other women poets; she adopts for herself the typically humble male persona while attributing characteristic traits of the traditional domna to her lover; presents some criteria for identifying the feminine voice in trobairitz poetry.]

2210.

Riquer, Isabel de. "El guante robado de Castelloza." Anuari de filologia 14 (1991): 49-60. [Analysis of variations on the literary motif of the gift given by the lady to her lover (ring, cord, belt, glove), specifically the motif of the glove in Castelloza's Ja de chantar, PC 109,2, compared to other gifts in poems by Giraut de Bornelh, Peire Vidal, Cerveri, and others; the masculine tradition is reversed by Castelloza, who stole a glove from her lover but gave it back and gave him up because she was unworthy; the poem is printed in appendix based on the text in $\mathbf{2 2 7}$, Riquer, 1975, with Spanish translation.]

2211.

Sankovitch, Tilde. "The Trobairitz." In 282, Troubadours, 1999, p. 121. [Shows that Castelloza's poetry is unique in that she dwells constantly on the pain of love, the pleasure and satisfaction that she experiences from her submission and her suffering, exaggerating these qualities of the troubadour tradition in her reversal of the classic gender roles.]

2212.

Siskin, H. Jay, and Julie A. Storme. "Suffering Love: The Reversed Order in the Poetry of $\mathrm{Na}$ Castelloza." In 132, Paden, Voice, 1989, pp. 113-27. [An examination of the negative, suffering love characteristic of Castelloza, allied paradoxically with an extraordinary sense of self-esteem.]

2213.

Van Vleck, Amelia E. "Tost me trobaretz fenida: Reciprocating Composition in the 
Songs of Castelloza." In 132, Paden, Voice, 1989, pp. 95-111. [In Amics, s’iéus trobes avinen, Castelloza makes the argument that women should compose their share of the world's love poetry; Van Vleck finds that Castelloza's poems are concerned with verbal power, as are those of the troubadours, as she tries to provoke from her lover a "reciprocal" text.]

2214.

See 780, Dronke, "Provençal trobairitz: Castelloza," 1984. [Analysis of Castelloza's unique poetic output; she is characterized by her frank declarations of love, actively seeking response, not waiting to be chosen; the four songs are given in English translation only, without Occitan texts.]

\section{Caudairenga. See PC 169 (formerly called Gaudairenga)}

\section{PC 112. Cercamon}

2215.

[fl. 1135-45; vida; eight poems, plus one of uncertain attribution.]

Rossi, Luciano. Cercamon. Oeuvre poétique. Edition critique bilingue avec introduction, notes et glossaire. CFMA, 161. Paris: Champion, 2009. [The first in-depth literary study of Cercamon's identity and poetry, establishing his importance in the formulation of fin'amor, and perhaps as the teacher of Marcabru; some hints that his name may hide his identity as Eble II, though Rossi does not claim this outright; critical edition of the nine poems, with French translation, notes; see the detailed comments and suggestions by Tortoreto, $C N 70$ (2010): 187-203, Billy, RLaR 114 (2010): 512-21, and Beltrami, Rom 129 (2011): 1-22; replique by Rossi, CN 71.3-4 (2011): 335-61.]

\section{6.}

Tortoreto, Valeria. Il trovatore Cercamon: edizione critica. Modena: STEM-Mucchi, 1981. [Critical texts, with Italian translation; partial study of language, limited glossary; Tortoreto accepts the vida's claim that Cercamon is Gascon, even though

1440, Pirot, Recherches, 1972, has shown the three supposedly Gascon features listed by Tortoreto to be invalid; this strengthens the link to Eble II and the Limousin.]

\section{7.}

Tortoreto, Valeria. Online edition of PC 112,3a, Pueis nostre temps comens'a brunezir: http://www.rialto.unina.it, 2009. [Some revisions to her 1981 edition; text, Italian translation, notes.]

\section{8.}

Bec, Pierre. "Cercamon et Bernard de Ventadour ou le Gascon et le Limousin." In Le Limousin et son patrimoine culturel. Limoges: UER des lettres et sciences humaines, 1982, pp. 157-71; also in Ecrits sur les troubadours et la lyrique médiévale (1961-1991). Caen: Éditions Paradigme, 1992, pp. 243-57. [Cercamon is the true precursor of Bernart de Ventadorn's classical perfection of trobar; Jaufre Rudel is too exclusively idealist and Marcabru too moralistic, but Cercamon's songs are polyvalent, using several genres and various registers, an inspiration for much of Bernart's poetry; Bec compares themes and formal structures in Quant l'aura doussa 
and Quan vei la lauseta; in appendix, the two poems in normalized Occitan with French translation.].

2219.

Fassò, Andrea. "La diffrazione e le fate. Guglielmo IX, Ben vueill que sapchon li pluzor." In 117, Le letterature romanze, 2000, pp. 239-68. [Fassò suggests the possibility that the Coms de Peitieus may have been Guilhem X, and that therefore the beginnings of troubadour lyric may have been characterized by an intermingling of back-and-forth exchanges among a group of poets, Guilhem, Jaufre Rudel, Cercamon, and Marcabru trading ideas at the court of Poitiers.]

2220.

Harvey, Ruth. "Joglars and the Professional Status of the Early Troubadours." MAev 62 (1993): 221-41. [Harvey calls for a reconsideration of the meaning of the terms joglar and trobador, in light of new investigations showing that there was no clear definition of status or social activity attached to the titles; a special analysis is made of Cercamon, treated as typical of the joglars but who may have portrayed himself as a poor wandering performer in spite of his solid position at court; the common notion of professional court performers may be a romanticized notion not based in fact.]

2221.

Marshall, John H. "Tradition and Innovation in Editorial Practice: Cercamon, $A b$ lo pascor." Proceedings of the Second Conference on Medieval Occitan Language and Literature, University of Birmingham, 28-30 March, 1982. Edited by P. T. Ricketts. Typescript copy from the Faculty of Arts, University of Birmingham. [Analysis of R. Lejeune's edition of the poem, accompanied by full edition.]

2222.

Rossi, Luciano. “L'énigme Cercamon." In 139, Ensi firent, 1996, pp. 67-84. [Examines the identity and status of Cercamon: not just a modest joglar but a master of trobar, with direct access through his high rank in Poitou society (not Gascon) to the courts of Eble de Ventadorn and Guilhem de Peitieus; suggests the possibility of an identification with Eble II because of contemporaneity, lack of other candidates, possibility of his taking the pseudonym Cercamon, but cannot conclude because of lack of any direct evidence; includes a new edition of PC 112,1a, Ab lo pascor m'es bel, and a renewed consideration of the lo cor Tristan/tristan debate.]

2223.

Rossi, Luciano. "Du nouveau sur Cercamon. La complainte de Guillaume X d'Aquitanie (BdT 112,2a): planh ou sirventes politique?" In $\mathbf{1 3 5}$, Carmina semper, 2000, pp. 87-104. [Critical edition of the planh with French translation, copious notes, Latin planctus in appendix; it is both a planh and a sirventes, because it is being manipulative politically as well as expressing genuine grief at Guilhem's death; the poet seems to belong to the "in group" of the time and his attitudes are those of a leader; Rossi thinks Cercamon could be a sobriquet for Eble de Ventadorn himself.] 2224.

Rossi, Luciano. "Ebolo II di Ventadorn, Cercamon e la nascita della fin'amor." In Italica-Raetica-Gallica. Studia linguarum literarum artiumque in honorem Ricarda 
Liver. Edited by P. Wunderli, I. Werlen, and M. Grünert. Tübingen: G. Narr, 2001, pp. 539-58. [An investigation of the historical presence of Eble II and traces of his poetic principles, opposed by Marcabru, who stands for the Ovidian approach to love; what is known of Eble and Cercamon would allow for their common identity, but this must remain only a possibility, since hard proof is lacking.]

Cerveri de Girona/Guillem de Cervera. See PC 434, 434a

\section{PC 115. Clara d'Anduza}

[First half thirteenth century; unknown; perhaps the same as the dame Clara mentioned as Uc de Saint Circ's beloved in the razo to his PC 457,4; one canso, a complaint against the calumny of the lauzengiers, showing intertextual links with several poets.]

2225.

See 735, A. Rieger, Trobairitz, 1991, pp. 570-84. [Critical edition of PC 115,1, with German translation, notes, commentary; finds distinctly "feminine" characteristics in Clara's poem; sees Clara and Azalais d'Altier as real women poets.]

2226.

Cluzel, I.-M, and Geneviève Brunel-Lobrichon. "Clara d'Anduze." In $\$ 38, DLF, 1992, p. 307. [Brief presentation of her poem, which outlines her complaints against cruel gossipers; the possibility of a love story involving Uc de Saint Circ is an appealing hypothesis.]

2227.

Perkal-Balinsky, Deborah. "The Minor trobairitz: An Edition with Translation and Commentary.” DAI 47 (1987): 2577A. PhD diss., Northwestern University, 1986. [Pp. 153-56: a new edition of Clara's canso, with literary study, English translation, notes.]

2228.

See 737, Mölk, Romanische Frauenlieder, 1989, pp. 56-57 and 196-97. [Edition of PC 115,1, with German translation, notes.]

2229.

Albert-Birot, Arlette. "Du côté de Clara d'Anduze." In Mélanges de littérature du moyen âge et du XXe siècle offerts à Mademoiselle Jeanne Lods. 2 vols. Paris: École normale supérieure de jeunes filles, 1978, 1:19-27. [Popular presentation of the tourist region of Anduze and the history of the Anduze family; information about Uc de Saint Circ and his supposed spat with Clara; text of her song, with French translation by Gratien Charvet.]

2230.

See 764, Poe, "Dispassionate Look," 1992. [For Clara, see pp. 151-53: Poe casts doubt on her existence, wondering whether her poem was really the work of Uc de Saint Circ, part of a poetic exploration along with his PC 457, 26. Her poem seems to be a response to a salut ostensibly sent to her by Azalais d'Altier, which may also have been composed by Uc.] 
2231.

Bruckner, Matilda Tomaryn. "Clara d'Anduza." In $>$ 46, Women in the Middle Ages, 2004, pp. 193-94. [Clara's canso is linked by intertextual evidence with several troubadour songs, especially to the salut d'amor of Azalais d'Altier and to Uc de Saint Circ's PC 457,4 and its accompanying razo, all of which may be linked in an elaborate literary game of love.]

La Comtessa de Dia. See PC 46 (formerly called Beatriz de Dia)

\section{PC 117. Comunal}

[Pseudonym for both Garin d'Apchier and Torcafol in a sirventes; Torcafol is already a pseudonym for an unknown poet who exchanged five sirventes with Garin d'Apchier.]

\section{PC 118. Cossezen}

[Named in Peire d'Alvernhe's satirical poem PC 323,11, line 78; this may be a place-name.]

2232.

Guida, Saverio. “Us vielletz lombartz cossezen (BdT 323,11: 73-78).” CN 65 (2005): 7-26. [This is a supplement to Guida's 1977 article in CN 57 and another in AMod 3 (1997): 201-26, exploring the possible identity of Cossezen, the twelfth to be insulted in Peire d'Alvernhe's poem; presents evidence of a poet from Concesio in Italy, the village of origin of Pope Paul VI; not further identified, but it seems likely that he was a considerable personage who stood up to Henry II to complain about the suffering state of Lombardy.]

2233.

Lejeune, Rita. "Le troubadour lombard de la 'galérie littéraire' satirique de Peire d'Alvernhe (XIIe siècle)." Marche romane 25 (1975): 31-47; also in her Littérature et société occitanes au Moyen Âge. Liège: Marche romane, 1979, pp. 313-28. [The identity of the oldest known Italian troubadour, satirized in stanza thirteen, has remained mysterious; perhaps his presence among the other poets at Puivert in Catalonia suggests that the gathering was for the marriage of Queen Rica to Count Raymond Berenger II in 1161; the poet Peire de la Caravana fits all the descriptive qualities in stanza thirteen.] 2234.

Speroni, Gian Battista. "Due note provenzali." In Studi di cultura francese ed europea in onore di Lorenza Maranini. Fasano: Schena, 1983, pp. 73-83. [Study 1 explores the identity of Cossezen in Peire d'Alvernhe's poem (Peire de la Cavarana according to Rita Lejeune and Martín de Riquer); Speroni disagrees, thinks that the troubadour must have created poems in literary Italian, now lost, earlier than any preserved works.]

\section{PC 119. Dalfin d'Alvernhe}

[fl. 1160-1235; vida; ca. ten poems; his name is Dalfin, probably not Robert; was the patron of Uc de Saint Circ and of poetic competitions at Le Puy en Valay.] 
2235.

Brackney, Emmert M. A Critical Edition of the Poems of Dalfin d'Alvernhe. Typescript thesis, University of Minnesota, 1936. [Introduction, edition of eleven poems, vida, razos, with English translation, notes, glossary; a new edition projected by S. C. Aston has not appeared.]

2236.

Boldini, Loredana. "Il cavaliere villano e il villano valente; contributo per una rilettura di Perdigo, ses vassalatge (BdT 119,6 = 370,11)." RST 6-7 (2004-5): 47-89. [Reinterpretation of the tenso between Dalfi d'Alvernhe and Perdigon; Perdigo defends the exclusive right of the nobility to participate in fin'amor, while Dalfi argues for the superiority of inherent nobility of the heart; detailed study of the manuscript tradition, new critical edition with Italian translation and copious textual notes.]

\section{7.}

Fèvre, Mavis. "Un nouveau regard sur le partimen entre Dalfi et Perdigon, Perdigons, ses vassalatge (PC1 19,6 = 370,11).” RLaR, 112 (2008): 73-88. [Unaware of Boldoni's study and edition of the poem 2005; stresses the dramatic quality of the presentation which shows that the two poets were conscious of playing a part, using irony and humor; analysis of the role of Dalfi's court in discussions about the nature of love, based on resemblances among several other partimens; in appendix, pp. 84-86: a list of judges named in the tornadas of twenty-nine debate poems.]

\section{PC 120. Dalfinet}

[fl. 1220-41; no vida; one mieich-sirventes using the metrical structure and rhyme scheme of Bertran de Born's Be.m platz lo gais temps de pascor; text by Kolsen, $\operatorname{ZrP} 39$ (1919): 163-65.]

2238.

Guida, Saverio. "Nuovi documenti su alcuni trovatori del XIII secolo." CN39 (1979): 81-105. [Pp. 100-102: despite conjectures by Chabaneau and Jeanroy that he was the son or vassal of Dalfi d'Alvernhe because of his name and the proud, energetic tone of his poem, Guida demonstrates his existence in three archival documents, proposing that Dalfinet is doubtless a nickname based on his place of origin, Dalfinum, between Manosque and Forcalquier in the Basse-Alpes; he is attested 1220-41, influential among adherents of the count of Forcalquier; Guida comments on the restless, arrogant tone and the sarcastic pomposity of language in his poem.]

\section{PC 121. Dante da Maiano}

[Italian poet, second half thirteenth century to first quarter fourteenth; his two sonnets are the earliest known in Occitan.]

\section{9.}

See 248, Bec, Pour un autre soleil, 1994. [The introduction emphasizes that the sonnet form has its origins in the Occitan language and territory, was codified in Sicily before spreading to northern Italy and the rest of Europe; pp. 4-5: text of a poem 
by Paolo Lanfranci da Pistoia and two by Dante da Maiano, in highly Italianized Occitan, with French translation.

2240.

Bec, Pierre. "Les deux sonnets occitans de Dante da Maiano (XIIIe siècle)." In Languedoc et langue d'oc: Actes du colloque (Toulouse, janvier 1996). Perspectives médiévales special number, supplement to 22 (1996): 47-57. [Brief history of the sonnet, invented in Sicily, and of the poet Dante de Maiano; study of the language, versification, and themes; edition of the two poems in their original contaminated form, followed by an emended and normalized text, and French translation.]

2241.

Kleinhenz, Christopher. "A Trio of Sonnets in Occitan: A Lyrical Duet and an Historic Solo." Tenso 13 (1998): 33-49. [The three known sonnets in medieval Occitan, by two Italian poets of the late thirteenth century; two graceful love poems by Dante da Maiano of the Siculo-Tuscan school and an encomium for the Aragonese king Peter III by Paolo Lanfranchi of Pistoia: evidence of the esteem in which Occitan was held for the composition of lyrics.]

\section{PC 124. Daude de Pradas}

[fl. 1191-1244; vida; seventeen poems of various genres: cansos, anti-courtly satirical poems, one religious poem and a planh for Uc Brunenc: one melody is preserved: see 607, van der Werf, Extant, 1984, p. 78*; Daude is also the author of two treatises: Dels auzels cassadors: see 25.2a., and De quatre vertutz principals: see 22.9; the Breviari considered him one of the best troubadours.]

2242.

Schutz, Alexander Herman. Poésies de Daude de Pradas. Bibliothèque Méridionale 22. Toulouse: Privat, 1933. Reprint, New York, 1971. [The life of Daude in his social context; critical edition of seventeen poems: twelve cansos, three humorous satiric poems, one religious song, one planh, with French translation, notes; in appendix: two poems and a cobla dobla of uncertain attribution; the notes are grouped at the end, pp. 99-106.]

2243.

Lafont, Robert, and Geneviève Brunel-Lobrichon. "Daude de Pradas." In $\mathbf{3 8}$, $D L F, 1992$, pp. 370-71. [Outline of his high-level church appointments and official activities; in his scholarly, detached manner, Daude outlined an elegant, abstract concept of fin'amor, though in one poem, PC 124,2, he spoke of three levels of love: the chaste service to his domna, discreet sensual flirting with a piusela, and full gratification with a soudadeira.]

2244.

Larghi, Gerardo. "Daude de Pradas trovatore, canonico e maestro ( . . 1191-1242 ... )." CN 71.1-2 (2011): 23-54. [Analysis of the active literary, scientific, and administrative life of Daude, his connections with Uc Brunenc, Bernart de Venzac, perhaps Gui d'Ussel; he favored the Albigensian Crusade, was appointed canon of the cathedral at Rodez, then magister, and helped found the Arts Faculty at Montpellier.] 
2245.

See 1517, Oroz Arizcuren, La lírica religiosa, 1972, pp. 118-25. [Edition of Daude's single religious poem PC 124,16, with Spanish translation, notes.]

2246.

See 227, Riquer, 1975, 3:1545-49. [Introduction, vida, edition of the humorous song vaunting three-level love: PC 124,2, with Spanish translation, notes.]

2247.

Tavera, Antoine, "De Bergerac à Narbonne: trop de troubadours négligés!" in - 98, AIEO 5, 1998, pp. 133-51. [Brief mention of seven poets worthy of further study, but closer analysis of only Daude de Pradas, pp. 136-48; generalized survey of Daude's poetic output, emphasizing his originality in themes and structures.]

\section{PC 130. Eble II de Ventadorn}

[Referred to by several troubadours and by Geoffroy de Vigeois, but no poems are extant; perhaps he is Cercamon (Rossi), or perhaps he is responsible for the courtly half of Guilhem de Peitieus's poetry (Dumitrescu).]

2248.

Dumitrescu, Maria. "Eble II de Ventadorn et Guillaume IX d'Aquitaine.” CCM 11 (1968): 379-412. [Speculation that the four "courtly" poems may be Eble's, the others William's.]

2249.

See 2223, Rossi, "Du nouveau," 2000. [Points out that Cercamon seems to belong to the "in group" of his time, and that his attitudes are those of a leader; Rossi wonders whether Cercamon could be a sobriquet for Eble II of Ventadorn himself, which would make Cercamon not an obscure jongleur but a master poet, one of the initiators of fin'amors.]

2250.

See 2224, Rossi, "Ebolo II," 2001. [What is known of Eble and Cercamon would allow for their common identity, but hard proof is lacking.]

\section{PC 132. Elias de Barjols}

[ $f$. 1191-1230; vida; fifteen poems: twelve cansos, two descorts, one tenso; no melodies preserved; his canso PC 132,5, known as cavalher soisseubut, was imitated from Bertran de Born's PC 80,12, domna soisseubuda; it outlines the qualities of the ideal courtly knight, a composite of qualities taken from eleven contemporary men.] 2251.

Stronski, Stanislaw. Le Troubadour Elias de Barjols. Bibliothèque Méridionale 10. Toulouse: Privat, 1906. Reprint, New York/London, 1971. [Introduction on historical background, literary study, and analysis of language; critical edition of the fifteen poems, with notes and glossary.]

2252.

See 256, Harvey and Paterson, Troubadour "Tensos," 2010, 1:277-84. [Elias's interlocutor Jaufrezet is likely Jaufre Reforzat de Tres PC 419,2, the same as Reforsat 
de Forcalquier PC 418, and the poem is dated 1215-30; Na Biatris may be Beatrice of Savoy, who married Count Raimon Berenguer V of Provence in 1219, and if so, the jest on the impotence of Jaufre would be sharpened since the three ladies in the poem were all recently married.]

\section{3.}

See 648, Marshall, "Pour l'étude des contrafacta,"1980, esp. p. 302. [The metrical structure and melody of poem PC 132,5 by Elias, the cavalher soisseubut, is imitated from Raimon de Miraval's PC 406,22; this permits a possible dating of 1191 for Elias's song.]

2254.

See 227, Riquer, 1975, 3:1193-1201. [Introduction, vida, edition of PC 132,5 and the cavalher soisseubut PC 132,5, with Spanish translation, notes.]

\section{PC 133. Elias Cairel}

[ $f$. 1204-22; little is known about his life; two contradictory vidas; fourteen poems: ten cansos, a tenso with Ysabella, a descort, a sirventes and a crusade song; went on the Fourth Crusade, living at the court of Boniface of Montferrat in Thessalonica for a number of years.]

2255.

Jaeschke, Hilde. Der Trobador Elias Cairel. Romanische Studien 20 (1921). [Critical text of the fourteen poems, with German translation, notes.]

2256.

Paterson, Linda M. "Lédition des poèmes dialogués." In 100, AIEO 7, 2003, pp. 593-608. [The current state of the projected edition of all tensos and partimens that she and Ruth Harvey have taken over from John Marshall; example (604-8) of edition of a tenso PC 252,1 = 133,7 (dame Isabella and Elias Cairel); now in 256, Harvey and Paterson, Troubadour "Tensos," 2010, 2:841-49.]

2257.

See 891, A. Rieger, "Relations interculturelles, 1998, pp. 201-25. [A case study of a poetic network, involving Elias Cairel along with Raimbaut de Vaqueiras, Conon de Béthune, and Albrecht von Johansdorf, illustrating the complexity of connections and intertextuality encouraged in large part by intercultural mixing during the Crusades; the phenomenon is posed in terms of give and take rather than of origin and influence, the idea of cultural exchange as multiple, many-sided, and manydirectional; a shortened German version in Internationalität nationaler Literaturen (Göttingen: Wallstein, 2000), pp. 485-500.]

2258.

See 227, Riquer, 1975, 2:1144-53. [Introduction, both vidas, PC 133,1 and 9, with Spanish translation, notes.]

\section{PC 134. Elias Fonsalada}

[Late twelfth, early thirteenth century; vida; two cansos.] 
2259.

Fumagalli Mezzetti, Marina. "Le canzoni di Elias Fonsalada: testo critico." Acme. Annali delle Facoltà di Filosofia e Lettere dell'Università Statale di Milano 30 (1977): 41-68. [Introduction to Elias, about whom little is known; analysis of poetic structures; critical edition of the two cansos with Italian translation, notes.]

2260.

Raupach, Manfred. "Elias Fonsalada: kritische Ausgabe.” ZrP 90 (1974): 141-73. [Introduction on the life of Elias and historical background; critical edition of the vida and the two cansos, with notes; no translation.]

Falquet de Romans. See PC 156 [formerly called Folquet]

PC 136. Elias d'Ussel (Uisel)

[fl. 1190-1240; cousin of the three brothers Eble, Gui, and Peire; six tensos, two coblas.]

2261.

Audiau, Jean. Les poésies des quatre troubadours d'Ussel. Paris: Delagrave, 1922. [Introduction on historical and biographical background of the four poets; analysis of metrical structures in their twenty-six poems; edition of eight pieces by Elias: four tensos with his brother Gui, another with Bernart (de Rouvenac?), and a sixth with Aimeric de Peguilhan, plus two coblas.]

\section{2.}

Camproux, Charles. "On the Subject of an Argument between Elias and His Cousin.” In The Interpretation of Medieval Lyric Poetry. New York: Columbia University Press, 1980, pp. 61-90. [A sensitive analysis of the poem that Camproux calls "one of the most important texts in Old Provençal poetry." The tenso is a dispute between Gui as a professional troubadour, playing the standard game of fin'amor, and Elias, an honest and sincere fin'amant totally in love with his wife; Gui prefers to court ladies as a subservient courtly lover for social and artistic gain, while Elias chooses the complete, secure, private bond of marriage; Camproux claims that the poem shows the falsehood of the common myth of finimor as a necessarily adulterous relationship.]

2263.

Billet, Léon. Généalogie de la famille d'Ussel: les quatre troubadours “d'Ussel. " Leur biographie et celle de la maison " $d$ 'Ussel." Leurs chansons; manuscrits et notes. Tulle: Orfeuil, 1982. [Twenty-six poems with French translation: twenty by Gui d'Ussel and six by his brothers Eble, Elias, and Peire; in appendix a choice of charters and historical material; useful historical background, texts not for scholarly use.]

2264.

See 256, Harvey and Paterson, Troubadour “Tensos," 2010, 1:285-89. [Edition of PC 136,1a = 194,4 between Elias d'Uisel and Gui d'Uisel on whether it is better to court a lady distinguished but untruthful, or lowly but true; text with English translation, notes.] 


\section{PC 137. En Genim d'Urre de Valentines (Engenim, Genin d'Eurre)}

\section{5.}

[His life is unknown; one sirventes against the "bad barons."]

Björkman, Sven. "Pois pres séen fui qe non troba guirensa, un sirventès du troubadour Engenim d'Urre de Valentinès." In Mélanges publiés en hommage à Gunnel Engwall. Edited by Inge Bartning, Johan Falk, Lars Fant, Mats Forsgren, Ritva Maria Jacobsson, and Jane Nystedt. Stockholm: Almqvist and Wiksell, 2002, pp. 35-41. [Sees the name as Engenim, based on the Latin Ingenuimus, to name a free-born person; edition with French translation and a study of versification, syntax, style, content, and poetic merit; the cynical, ironic message counsels resistance by the petty vassals against the abuses of power by the strong lords.]

\section{PC 140. Enric II Comte de Rodez}

[fl. 1274-1302; married to Mascarosa, daughter of Bernart VI of Comminges; brother-in-law of Peire Pelet; Henry participated in about fifteen dialogue poems; three partimens with Guiraut Riquier, and another in which he

2266. was judge; an avid patron of poetry.]

See Guida, "Jocs" poetici, 1983. [Study of the social and poetic activity at the court of Rodez, second half thirteenth century, especially under Count Henry II, whose court was very generous, a somewhat anachronistic model of the troubadour ideal; edition of seven tensos, with Italian translation, all discussing courtly values, all involving the count; five of them involve Guiraut Riquier; four Guilhem de Mur; two Marques de Canilhac, one Peire Pelet, Austorc d'Alboy, and Peire d'Estanh.]

\section{PC 142. Esperdut (a nickname for Gui de Cavaillon: see PC 192)}

[One canso, one nasty sirventes, one partimen with Pons de Montlaur.]

\section{PC 154. Folquet de Lunel}

[fl. 1244-84; nine poems: one sirventes in favor of Alfonso X of Castille, two tensos with Guiraut Riquier; six cansos, three of which are songs to the Virgin; active at the court of Rodez; his Romans de mondana vida, 539 lines, written in 1284, is an impi2267. ous presentation of vices and flaws in the society of his time.]

Betti, Maria Pia. "Le tenzoni del trovatore Guiraut Riquier." SMV 44 (1998): 7-193. [Contains the edition of two tensos with Folquet: PC 154,2b, pp. 111-17, and PC 154,2a, pp. 176-82; with introduction, Italian translation, notes; also available online, 2002, at http://www.rialto.unina.it; edited also in 256, Harvey and Paterson, Troubadour "Tensos,"2010, 1:351-57 and 359-65.]

2268.

Bianchi, Federica. Folquet de Lunel. Online, 2003, at http://www.rialto.unina.it. [Introduction (Premessa), critical edition of the sirventes PC 154,1 and the six cansos, PC 154,2 to 7 , with Italian translation.] 
2269.

Ricketts, Peter T. "Le Romans de mondana vida de Folquet de Lunel: édition critique et traduction." CN 48 (1988): 1121-37. Also in 152, Miscellanea Roncaglia, 1989, 3:1121-37. [Brief introduction, critical edition with French translation, no notes.]

\section{0.}

Tavani, Giuseppe. Folquet de Lunel: Le poesie e il romanzo della vita mondana. Alessandria: Edizioni dell'Orso, 2004. [Introduction, critical texts with Italian translation, notes; the lyrics are also available online, 2007 at http://www.rialto.unina.it, with Italian translation, textual notes, no introduction.]

2271.

Ricketts, Peter T. "Le troubadour Folquet de Lunel." In Colloque international d'études occitanes, Lunel, 25-28 août 1983. Montpellier: Centre d'estudis occitans, 1984, pp. 111-21. [Folquet's works are useful in the study of religious and political attitudes in the second half of the thirteenth century.]

2272.

Tavani, Guiseppe. "Il sirventese Al bon rei di Folquet de Lunel (BdT 154,1). Proposta di revisione testuale e di traduzione." CDT 4 (2001): 347-56. [A critical reading and Italian translation of Folquet's only political poem, late 1272 or early 1273 , in favor of the election of Alfonso X as emperor, opposed by the pope.]

\section{PC 155. Folquet de Marselha}

[ $f$. 1179-95; became a monk ca. 1195 at Thoronet, then abbot; bishop of Toulouse 1205-31; died 1231; vida and razos; twenty-seven poems, of which five are uncertain; includes one tenso and an exchange of coblas with Tostemps (Raimon de Miraval), an exchange of coblas with Vermillon, a planh for Barral de Marseille, and two crusade songs; thirteen melodies are preserved: see - 607, van der Werf, Extant, 1984, p. 79*-108*.]

\section{3.}

Squillacioti, Paolo. Le poesie di Folchetto di Marsiglia. Biblioteca degli Studi mediolatini e volgari. Nuova serie 16. Ospedaletto (Pisa): Pacini, 1999; 2nd revised edition, 2009: the first volume, without texts, is available online at http://trobadors.iec.cat/ documents/35.pdf. [Introduction on Folquet's life, establishment of the chronology of the corpus with respect to the manuscript history; detailed literary commentary on the works; critical edition of twenty-two songs, plus five of uncertain attribution, with Italian translation, notes.]

2274.

Schulman, Nicole M. Where Troubadours Were Bishops: The Occitania of Folc of Marseille (1150-1231). New York: Routledge, 2001. [Very detailed historical analysis of Folquet's life and the complex social and political events of his time; claims that Folquet urged peaceful resolution of the heretical conflicts, rather than the severities of the Inquisition; in appendix, reproduction, from Stronski 1910, of nineteen songs, plus two of unsure attribution, with English translation and commentary.] 
2275.

See 487, Cropp, "Partimen," 1980. [Edition of PC 155,24=444,1, based on Stronski, 1910, with English translation; see also the edition in $\mathbf{2 5 6}$, Harvey and Paterson, Troubadour "Tensos," 2010, 1:367-78.]

\section{6.}

Jensen, Frede. "Folquet de Marselha and the Classical Tradition." In The Influence of the Classical World on Medieval Literature, Architecture, Music and Culture. Edited by Fidel Fajardo-Acosta. Lewiston, NY: Mellen, 1992, pp. 54-65. [Analyzes the vigorous survival of ancient culture in Folquet's poetry, in quotations from classical authors and erudite rational style; shows how he embraced and absorbed prehumanistic expression similar to that of the Renaissance.]

2277.

Le Vot, Gérard. "Intertextualité, métrique et composition mélodique dans les cansos du troubadour Folquet de Marseille." In 96, AIEO 3, 1992, pp. 637-67. [Examines the process of adaptation in the transmission of melodies; emphasizes that much prudence is required before any conclusions may be drawn.]

2278.

Locher, Caroline. "Folquet de Marseille and the Structure of the Canso." Neo 64 (1980): 192-207. [Investigates the importance of stanza order in the canso, to see whether the principles of interior unity or articulated progression are important; shows that Folquet has experimented with techniques to link stanzas and subordinate one to the other in a carefully planned structure; close analysis of five songs illustrate how Folquet uses techniques of syntax, rhyme scheme, figures of repetition, and self-reference to enhance the unity and continuity of his songs; this justifies Dante's high regard for Folquet and suggests that he has been neglected by modern scholars.] 2279.

Pfeffer, Wendy. "Ben conosc e sailQue merces vol so que razos dechai: l'emploi du proverb chez Folquet de Marselha.” In \$94, AIEO 1, 1987, pp. 401-8. [The numerous proverbs emphasize Folquet's sententious style and his love of contradiction.]

2280.

See 477, Winter-Hosman, "Un texte peut en cacher," 2001. [A study of intertextual links between Folquet de Marselha's S'al cor plagues, PC 155,18, and songs by several poets, including Gaucelm Faidit, Peire de Barjac, Gui d'Ussel, Raimbaut de Vaqueiras, Maria de Ventadorn, and Gui d'Ussel; these make a series of malas cansos turning against fin'amors and speaking of a mala domna; see also $\mathbf{8 9 0}$, A. Rieger, "La mala canso de Gui d'Ussel," 1992.]

\section{PC 156. Falquet de Romans}

[fl. 1220-33; vida; fourteen poems of various genres.]

2281.

Arveiller, Raymond, and Gérard Gouiran. L'oeuvre poétique de Falquet de Romans, troubadour: édition critique, traduction, notes. Aix-en-Provence: Université de Provence, CUER MA, 1987. [Verifies the spelling of the poet's name in archival documents, 
formerly Folquet; introduction on the life of Falquet, versification, rhymes, manuscripts; edition of the vida, fourteen poems, plus three of doubtful attribution, with French translation, notes, glossary.]

2282.

Di Luca, Paolo. Edition of Falquet de Romans, Ma bella dompna, per vos dei esser gais, PC 156,8. Online, 2010, at http://www.lt.unina.it. 25 pp. [Introduction, critical edition, with Italian translation, detailed notes.]

\section{3.}

Gouiran, Gérard. "Sur quelques troubadours qui franchirent les Alpes du temps de la croisade contre les Albigeois." In 164, I trovatori nel Veneto, 2008, pp. 97-133. [As a friend of Hughes de Berzé, Falquet followed the example of Raimbaut de Vaqueiras by going to Italy to seek a patron at the court of the Marquess William of Montferrat and at other courts; Gouiran wonders whether he did not provide military as well as poetic service to his lord, and whether this was not often the case for Occitan poets who came to offer their services to Italian nobles.]

2284.

See 1517, Oroz Arizcuren, 1972, pp. 154-71. [Edition of the two religious poems PC 156,10 and 15, with Spanish translation, notes.]

2285.

See 227, Riquer, 1975, 3:1215-24 [Introduction, edition of PC 156,8 and 15, with Spanish translation, notes.]

2286.

Squillacioti, Paolo. Edition of PC 156,I Domna, eu pren comjat de vos in $\mathbf{5 2 0}$, Gambino, Salutz, 2009, pp. 466-507. [Confirms attribution of the salut to Falquet, but no new facts or arguments; edition based on $c$, almost identical to that of Arveiller/ Gouiran; text with Italian translation, notes.]

\section{PC 162. Garin d'Apchier}

[Second half twelfth century; vida; eight poems, four of which are of doubtful attribution; used the same senhal as Torcafol, Comunal, in a series of sirventes; composed the first Occitan descort, of which only two lines are preserved in a vida.] 2287.

Latella, Fortunata. I sirventesi di Garin d'Apchier e di Torcafol. Modena: Mucchi, 1994. [Three sirventes by Torcafol (PC443) and eight by Garin d'Apchier, some incomplete; detailed introduction, notes, critical texts with Italian translation, glossary, full concordance; also available online, 2002, texts only, with brief notes at http://www.rialto.unina.it, with "Premessa all'edizione in linea dei sirventesi di Garin d'Apchier e Torcafol."]

\section{8.}

Spetia, Lucilla. "Gatti rossi e gatti neri: un mistero felino alle origini della pastorella?" In 102, AIEO 9, 2011, pp. 543-54. [Reference to songs by Guilhem de Peitieus and Marcabru help to explain the presence of a black cat in Garin d'Apchier's pastorela L'autrier trobei tras un foquier and to better understand the poem.] 


\section{PC 163. Garin lo Brun}

[ $f$. 1150; died around 1156; vida, one fictive tenso between Meysura and Leujairia, called a tenson rapportée by Billy, a débat intérieur by Zufferey; Garin also wrote the first ensenhamen: El termini d'estiu; see 1451-53.]

2289.

Carapezza, Francesco. "Una cobla oscena di $G(\mathrm{BdT} 461,57)$ e il suo modello ritrovato." RST 3 (2001): 97-112. [Discovery of the model for the anonymous obscene parody cobla: it is lines 369-78 of Garin lo Brun's Ensenhamen alla dama.]

2290.

Carapezza, Francesco. "Garin lo Brun, Nueyt e iorn suy en pessamen (BdT 163.1)." Lecturae tropatorum 1, 2008, 26 pages. Online at http://www.lt.unina.it. [Detailed paleographical study; new critical edition with Italian translation, copious textual notes; see also 2291, Pulsoni, "Nueyt e iorn suy en pessamen (BdT 163,1)," 2007.]

2291.

Pulsoni, Carlo, "Nueyt e iorn suy en pessamen (BdT 163,1)." In L'Ornato parlare. Studi di filologia e letteratura romanze per Furio Brugnolo. Padua: Esedra Editrice, 2007, pp. 21-52. [Very detailed study of metrics, stanza order, and paleography; similarities of vocabulary and style indicate a probable attribution to Garin; new critical edition, with Italian translation, copious textual notes and literary commentary; see also

2290, Carapezza, "Garin lo Brun,” 2008.]

\section{Garsenda. See PC 187. Comtessa de Proensa}

\section{PC 167. Gaucelm Faidit}

[fl. 1173-1202; born ca. 1150; his vida is an extravagant invention; five razos; sixty-five poems, fourteen with music: see $\mathbf{6 0 7}$, van der Werf, Extant, 1984, p. 109*-50*; one rotrouenge, perhaps the only French poem composed by a troubadour; participated in the Third and Fourth Crusades; planh for Richard Lion-Heart; perhaps one alba; he debates questions of fin'amors with well-known troubadours in eight or nine tensos.]

2292.

Mouzat, Jean. Les poèmes de Gaucelm Faidit, troubadour du XIIe siècle; suivi de Guilhem Peire de Cazals, troubadour du XIIIe siècle et du troubadour Arnaut de Tintinhac. Geneva: Slatkine Reprints, 1989. (Originally Paris: Nizet, 1965). [The Slatkine edition has the editions of Guilhem Peire de Cazals and Arnaut de Tintinhac, as well as extra material from 1970 about Gaucelm Faidit, pp. 610-16: his marriage in 1165 to Alès, and his departure for the Fourth Crusade in 1202, where he may have died; two further poems are probably his: Amors (en) que vos ai forfag PC 132,3, formerly attributed to Elias de Barjols, and Si ja Amors autre pro no.m tengues, PC 392,30, formerly attributed to Raimbaut de Vaqueiras.]

\section{3.}

Meliga, Walter. "Une nouvelle édition du troubadour Gaucelm Faidit." In \$99, AIEO 6, 2001, pp. 236-43. [Points out the desirability of a new edition; Mouzat's 
text of 1965 (reprinted 1989 with additional material) is the best so far, good for historical background of the poems, but unsatisfactory for manuscript history, stemma, critical apparatus, linguistic analysis.]

2294.

Rossell i Mayo, Antoni. Gaucelm Faidit. Text i Música. Edició, estudi dels textos i les melodies, I traducció dels textos. Bellaterra: Publicacions de la U Autònoma de Barcelona, 1988. Available on microfiche.

2295.

Gaucelm Faidit. Amours, voyages et débats. Trobada tenue à Uzerche les 25 et 26 juin 2010. Moustier Ventadour: Carrefour Ventadour, 2011. [Nine articles devoted to Gaucelm, illustrating the latest research on one of the most versatile and prolific of the troubadours: studies on biography, vocabulary, themes, travel, debates, and music. Introduction à la Trobada, par Pierre Bec; Les faidits et le trobar: esquisse de lexicographie poétique, par Gilda Caïti-Russo; Gaucelm Faidit et la (les) croisade(s), par Walter Meliga; Gaucelm Faidit en Hongrie, ou l'aventure orientale des troubadours, par Levente Seláf; Le troubadour Gaucelm Faidit et ses interlocuteurs, par Ruth Harvey; Gaucelm Faidit et Maria de Ventadorn vivaient-ils encore en 1235?, par Robert Lug; Musique et poésie dans l'oeuvre de Gaucelm Faidit, par Christelle Chaillou; L'amant tenu par la bride. Itinéraires d'un motif courtois chez Gaucelm Faidit et sur un coffret limousin, par Catherine Léglu; L'art mélique de Gaucelm Faidit, par Francesco Carapezza; Le prestige de la forme chez Gaucelm Faidit, par Dominique Billy; Conclusions de la Trobada, par Peter Ricketts.]

2296.

Bec, Pierre. "A propos de deux partimens bilingues. Tenson réelle ou tenson fictive?" In Sempre los camps auràn segadas resurgantas: Mélanges offerts au professeur Xavier Ravier par ses collègues, disciples et amis. Edited by Jean-Claude Bouvier, Jacques Gourc, and François Pic. Toulouse: CNRS/Université de Toulouse-Le Mirail, 2003, pp. 413-28. [Study of a tenso between Raimbaut de Vaqueiras and Conon de Bethune, and another between Gaucelm Faidit and Le Comte de Bretagne; the content is similar in both cases, a difference in attitude that is like a courtly game; we cannot tell whether there were two actual poets present, or whether a single poet composed each of the exchanges, but Bec emphasizes that in a performance, there would always be two singers.]

2297.

Boynton, Susan. "Emblems of Lament in Latin and Vernacular Song." In The Church and Vernacular Literature in Medieval France. Edited by Dorothea Kullmann. Toronto: Pontifical Institute of Mediaeval Studies, 2009, pp. 224-50. [A broadly based study of lament poems in various cultures, showing that each composition draws upon ritual conventions of the genre but creates its own unique presentation; examines the text-melody relationship in Gaucelm Faidit's planh for the death of Richard Coeur-de-lion, PC 167,22, pp. 232-34; the descent from A to D is associated with profound grief in the first stanza, and becomes an emblem of lament through the song; the first stanza of the text is presented in appendix, with its melody and English translation, pp. 242-43.] 
2298.

Guida, Saverio. “Un trovatore di meno, un componimento di più.” Tenso 25 (2010): 1-22. [A careful, meticulous study of all aspects of text transmission leads to the identification of a phantom poet, Peire de Mont Albert, PC 350, whose corrupted name really stands for "father of my Albert," referring to N'Azars, PC 44, the father of Albertet de Sisteron; Guida further postulates artistic activities at Dalfi's court involving Albertet and his father, along with Gaucelm as director of entertainments, at which the tenso PC 350,1 = 165,3 between Gaucelm and N'Azars was performed; the two missing stanzas may be explained by the scribe's mistaken identification of N'Azars, causing him to eliminate stanzas addressed to someone other than Peire de Mont Albert.]

2299.

Le Vot, Gérard. “'Trascrittore, traditore'? Essai sur la transcription de la canso Si tot ai tarzat mon chan de Gaucelm Faidit." In Polyglotte Romania. Homenatge à T. D. Stegmann. Edited by Brigitte Schlieben-Lange and Axel Schönberger. 2 vols. Frankfurt: Domus Editoria Europaea (DEE), 1991, 2:543-58. [Differences between the two extant melodies and multiple text versions lead to editorial problems; since we cannot know how the melodic variations came about, Le Vot calls for an extension of the principle of mouvance to the modern performer or editor, whose sensitivity to both text and melody and to the medieval tradition, will guide the interpretation; both melodic versions of the song are edited together, followed by a new compound musical version.]

2300.

Mölk, Ulrich. "A propos de la tradition manuscrite de la chanson PC 167,50 de Gaucelm Faidit." In 100, AIEO 7, 2003, pp. 555-64. [Gaucelm tried to compose his poem Can vei reverdir les jardins in French, but did not entirely succeed; this makes it impossible to establish the authentic original, since we do not know how "correct" it was to start with and since its Occitan scribes re-Occitanized it.]

2301.

Paden, William D. "Dramatic Formalism in the Alba Attributed to Gaucelm Faidit." NM 83 (1982): 68-77. [A close analysis of Gaucelm's poem in terms of its dramatic qualities: the layered performative functions of three speakers, the narrator, the lover, and the watchman, along with aspects of sound repetitions and phonetic qualities that combine with classic dramatic structures of exposition, complication, and dénouement to create a work of exquisite emotional intensity.]

2302.

Pollina, Vincent. "Word/Music Relations in the Work of the Troubadour Gaucelm Faidit: Some Preliminary Observations on the planh." In $\mathbf{1 5 2}$, Miscellanea Roncaglia, 1989, 3:1075-90. Also in CN 47 (1987): 263-78. [Looks specifically at the planh for Richard Coeur-de-lion; musical features are used to draw attention to the text, particularly the word Richartz in line 6; Pollina has announced the preparation of a complete study of text/melody relationships in the poetry of Gaucelm Faidit: see

- 94, AIEO 1, 1987, p. 410.] 
2303.

Pollina, Vincent. "Structure verbale et expression mélodique dans Mon cor e mi du troubadour Gaucelm Faidit." In \$ 96, AIEO 3, 1992, 2:669-78. [Exploration of the techniques of musical mimetism ("madrigalism"): in troubadour lyrics; points to several instances in Gaucelm's poem PC 167,37 where the melodic effects may enhance or illustrate the complex underlying emotions of the text.]

\section{4.}

Rossell, Antoni. "Aspects mélodiques et structurels dans les chansons du troubadour limousine Gaucelm Faidit.” Anuario Musical (CSIC) 47 (1992): 1-35. [Intricate analysis of melodic structures in all copies of Gaucelm's works allows Rossell to identify structural schemas, with melodic variations in the different copies, perhaps by Gaucelm, perhaps due to jongleurs or copyists; Gaucelm was responsible for the basic melodic structure and its link with the text.]

2305.

Rossell, Antoni. "Intertextualidad, tradición literaria e imitación en Chant e deport, joi, dompnei e solatz del trovador Gaucelm Faidit (mot, so y razo)." In Actas del VI Congreso Internacional de la Asociación Hispánica de Literatura Medieval (Alcalá de Henares, 12-16 de septiembre de 1995). Edited by José Manuel Lucía Megías. 2 vols. Alcalá de Henares: Servicio de Publicaciones, Universidad de Alcalá, 1997, 2:1367-81. [By means of a study of specific vocabulary and similarities of theme, Rossell is able to follow a trail of influences from Marcabru through Bernart de Ventadorn, Giraut de Bornelh, and others, to the culminating statement of the theme in Gaucelm Faidit, PC 167,15, which then served as a contrafact source for eleven further songs; the study of the melody of 167,15 and its influence is reserved for a future study.]

2306.

Seto, Naohiko. "Le vocabulaire féodal dans Gaucelm Faidit: sur jove senhoratge (PC 167,52, v. 43)." In 102, AIEO 9, 2011, pp. 519-32. [A new critical edition of the poem, with French translation, notes, followed by an extensive commentary on the dynamic use of feudal terms, leading to a new explanation of the use of jove senhoratge by the lady as an insult to the aspiring lover.]

2307.

Vatteroni, Sergio. "Ancora sulle fonti provenzali della sestina di Dante (con una nuova edizione di Ar es lo mont [ç] vermelltç e vertç di Gaucelm Faidit, BdT 167,10)." SMV 37 (1991): 169-77. [New edition, with Italian translation, notes; Vatteroni looks for a possible influence of the poem on Dante's sestina, but resemblances are slim.]

2308.

Vatteroni, Sergio. "Per lo studio dei Liederbücher trobadorici. II: Gaucelm Faidit." CN 58 (1998): 46-78. [Finds that the existence of a Liederbuch and Liederblätter is probable for Gaucelm's poems, but their nature and usage are difficult to ascertain; the lack of a definitive edition of Gaucelm makes further precision difficult; new full critical edition of PC 167,43, with Italian translation, notes.] 


\section{PC 169. Caudairenga (formerly called Gaudairenca)}

$[f$. beginning of the thirteenth century; no poems are preserved, though she is said to have composed coblas and dansas; she was apparently married to Raimon de

Miraval and was repudiated because of her poetic talent.]

2309.

Gégou, Fabienne. "En lisant les Vidas: lumière nouvelle sur les trobairitz." Marche romane 33 (1983): 101-7. Also in Bulletins de l'AIEO 4 (1989): 29-35. [Suggestions in the vidas and razos are used to propose that certain ladies were trobairitz whose work has been lost: Gaudairenca (Caudairenga), wife of Raimon de Miraval, Guillelma Monja, Helis de Montfort, and Garsenda de Provence.]

2310.

Gégou, Fabienne. "Trobairitz et amorces romanesques dans les 'biographies' des troubadours.” In 159, Studia occitanica, 1986, 2:43-51. [Romantic adventures recounted in the vidas and razos are used to introduce two trobairitz whose work has been lost: colorful sketches are established to bring alive the figures of Gaudairenca (Caudairenga), the wife of Raimon de Miraval, and Guillelma Monja, the wife of Gaucelm Faidit.]

\section{1.}

Rieger, Angelica. "La Poétesse de Carcassonne de Paul Heyse, ou: comment 'moraliser' la fin'amor?" In 151, Mélanges Bec, 1991, 485-96. [Study of a nineteenth-century fictionalized biography of Caudairenga, wife of Raimon de Miraval.]

2312.

See 735, A. Rieger, Trobairitz, 1991, pp. 98-105. [Analysis of information about Caudairenga from various razos shows that they resemble closely a standard vida, and may well have been composed as an introduction to her songs, now lost; judging from a sirventes by Uc de Mataplana dedicated to her, it seems clear that the idea of a woman poet was considered to be natural and praiseworthy in the society of the time, despite Raimon's outrageous treatment of her.]

2313.

Rosenstein, Roy. "Gaudairenca." In 46, Women in the Middle Ages, 2004, pp. 355-58. [Lively sketch of the legends surrounding the relationship of Caudairenga with her estranged husband Raimon de Miraval; the stories give insight into the complex attitudes of the troubadours toward marriage and mistresses, as well as toward women performers and trobairitz.]

2314.

See 754, Rosenstein, “Ubi sunt?" 2005. [Caudairenga was a historically real trobairitz, sometime wife of Raimon de Miraval; many legendary stories circulated about the love adventures of the couple, in several razos, in a sirventes by Uc de Mataplana, and in a reply to it by Raimon himself; she is depicted as a very strong woman and a composer of coblas and dansas, though no songs are extant.]

\section{PC 170. Gaudi}

[Probably thirteenth century; one tenso with Alberjat, PC 12b,1 = 170,1; not likely the same as Guillem Godi, PC 219, though both poets show the influence of Marcabru.] 
2315.

Rosenstein, Roy. "Le(s) troubadour(s) G. Godi/Gaudi et les deux visages de Marcabru." In Actas do XIX Congreso internacional de lingü.stica e filoloxía románicas (Santiago de Compostela, 1989). International Congress of Romance Linguistics and Philology, 19th. Edited by Ramón Lorenzo. La Coruña: Fundación Pedro Barrié de la Maza, 1994, VII, pp. 559-66. [Detailed investigation of the identities of the poets involved and the content of their poems reveals that Godi is probably from the twelfth century, following closely the serious moralizing tendencies of Marcabru, while Gaudi, who seems to be merely game-playing with the same principles, is probably from the thirteenth century.]

\section{PC 172. Gausbert Amiel}

[ $f$ l. thirteenth century, before 1254; vida, one ironic canso, a satire of contemporary courtly themes, attacking rich and powerful men and their pursuit of younger women; affinities in content with the work of Marcabru.]

2316.

See 261, Viel, Troubadours mineurs gascons, 2011. [Introduction gives cultural context, considers questions of attribution, manuscript tradition, language, and metrics; critical edition of Gausbert's vida and PC 172,1, with French translation, detailed notes; rich glossary.]

2317.

See 227, Riquer, 1975, 3:1669-71. [Brief introduction, edition of PC 172,1, with Spanish translation, notes.]

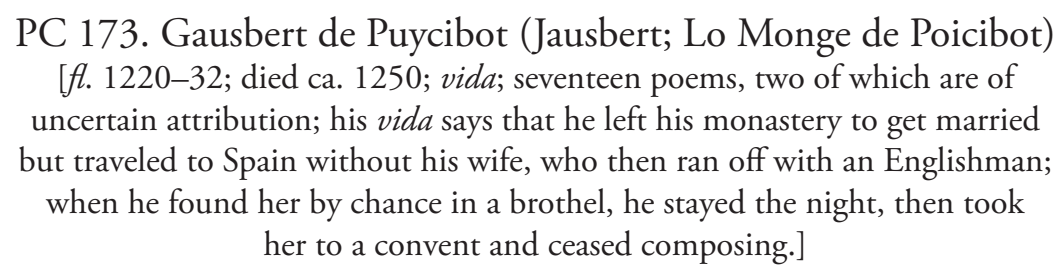

\section{8.}

Shepard, William P. Les poésies de Jausbert de Puycibot. Paris: Champion, 1924. [Introduction on life of Gausbert and his corpus, study of manuscripts, versification, and language; edition of all seventeen texts, with French translation, textual notes; in appendix: the vida and a list of passages quoted in other works.]

2319.

Andolfato, Francesca. "Gausbert de Puycibot Be.s cuget venjar Amors (BdT 173.2)." Lecturae tropatorum, 2010, 30 pages. Online at http://www.lt.unina.it. [Detailed introduction, critical edition with Italian translation, copious notes.]

2320.

See 2051-55, Gouiran, Harvey and Paterson, Latella, Malm, and Marshall, 1988-2002. [Discussion of a tenso involving Gausbert, and two sirventes that debate the relative merits of younger and older women, especially the attribution and relative chronology of the three poems.] 
2321.

190, Nichols, "Reading \& Seeing," 2006. [Theories of communication from Hugh of St. Victor are applied to a complex reading of Gausbert's songs and accompanying marginal decorations; dialectical interactions between text and paintings are interpreted in three imagined scenarios.]

2322.

See 227, Riquer, 1975, 3:1207-14. [Introduction, vida, edition of PC 173,9 and 11, with Spanish translation, notes.]

\section{PC 174. Gavaudan}

[ $f$. 1195-1215; ten poems of varied genres; his poetry is difficult, and he proclaimed himself "unlike other troubadours" in a sort of manifesto poem, PC 174,5 that claims his poetry is only meant for the initiated; his two pastorelas are unusual in that the knight and shepherdess turn to each other with real, though not courtly, love.] 2323.

Guida, Saverio. Il trovatore Gavaudan. Modena: STEM-Mucchi, 1979. [Edition of all ten poems; detailed introduction, texts with Italian translation, notes, glossary.] 2324.

See 227, Riquer, 1975, 2:1046-58. [Introduction, edition of the crusade song PC 174,10, the pastorela PC 174,6 and the planh for his lady, PC 174,3, with Spanish translation, notes.]

2325.

Tato Garcia, Cleofé. “Goitz? Una voz extraña en la poesía de Gavaudan.” Verba 12 (1985): 383-91. [Clarification of a puzzling term (goutz or goiz in the manuscripts), thought to mean "Goths," but shown to have here a double meaning: a depreciative term for Muslims in general, or the name of a particular tribe in Turkey; this enriches our grasp of Gavaudan's style, who is seen to be playing with difficult ambiguities, as did Arnaut Daniel, probably even beyond the comprehension of his listeners.]

Giraut de Bornelh. See under PC 242 (formerly listed as Guiraut).

\section{PC 175. Geneys lo Joglar}

[Not a poet's name but a legendary minstrel; the prayer attributed by CReg to Geneys, lo joglars a cuy lo voutz de Lucas donet lo sotlar ("Genèis the jongleur to whom the crucifix of Lucca gave the slipper") belongs likely to Arnaut Catalan, PC $27,4 \mathrm{~b}$, as given in $M$, or less likely to Peire d'Alvernhe, as given in $C$.] 2326.

See 1517, Oroz Arizcuren, La lírica religiosa, 1972, pp. 74-81. [Edition of the poem attributed to Arnaut Catalan, with Spanish translation, notes.]

2327.

Seto, Naohiko. "Geneys lo joglars, la légende de Saint Vou dans le manuscrit $C$ occitan.” FL 138 (2004): 251-70. [Critical edition of PC 175,1 (at present 27,4b, attributed to Peire d'Alvernhe), with French translation, notes; Saint Vou (<sanctus vultus) 
refers to a miraculous sculpted crucifix made by Nicodemus; according to legend, a joglar called Geneys played music for Jesus before the crucifix in Lucca and was rewarded with a valuable slipper; a scribe must have thought that the poem corresponded to the legendary prayer that Geneys had sung and attributed it to him; later it was ascribed to Peire d'Alvernhe because he used the term vout three times; modern scholars have given it to Arnaut Catalan on sociohistorical grounds.]

\section{PC 177. Gormonda (de Monpeslier)}

[fl. 1226-9; one sirventes of 220 lines, in response to Guilhem Figueira PC 217,2,

2328.

written in defense of the papacy of Rome.]

See 733, Bruckner/Shepard/White, Songs of the Women Troubadours, 1995, pp. 106-19 and 182-85. [Critical edition, with English translation, notes; also edited in 735, A. Rieger, Trobairitz, 1991, pp. 714-28: critical edition, with German translation, notes; analysis pp. 724-28.]

2329.

McCash, June Hall. "Gormonda of Montpellier." In $>$ 46, Women in the Middle Ages, 2004, pp. 373-75. [Gormonda composed the first known political poem in France by a woman, as a rebuttal to Guilhem de Figueira's brazen attack on Rome and the papacy; she contradicts Guilhem stanza by stanza, urging his execution as a heretic and supporting strongly the Albigensian Crusade.]

2330.

Pfeffer, Wendy. "Gormonda de Monpeslier: Greu m'es a durar (between 1227-1229)." In Writings by Pre-Revolutionary French Women: From Marie de France to Elizabeth Vigée-Le Brun. Edited by Anne R. Larsen and Colette H. Winn. New York: Garland, 2000, pp. 17-33. [Introduction; text in English translation only, with facing text of poem by Guilhem Figueira (also in English).]

2331.

See 788, A. Rieger, “Un sirventes féminin," 1987, esp. pp. 433-37. [A unique feminine sirventes, presenting a vigorous defense of the papacy in reply to the attack by Guilhem Figueira in PC 217,2; Guilhem's song itself is related to two other poems whose chronology within the series is studied here in detail; new critical edition with French translation, notes; detailed contrastive analysis with Guilhem's poem.]

2332.

Städtler, Katharina. "The sirventes by Gormonda de Monpeslier." In $>132$, Paden, Voice, 1989, pp. 129-55. [A penetrating study of intertextuality in Gormonda's sirventes as a response to a poem by Guilhem Figueira; see also her study of Gormonda's personality in 736, Altprovenzalische Frauendichtung, 1990.]

2333.

See 721, Hancke, "La poésie des trobairitz, 2004. [Introductory material on the role of the trobairitz and their integration into the masculine world of trobar; detailed commentary of the poem by Gormonda, the first woman in France to write a 
political poem; almost fanatically hostile to Catharism and to her "confrère" Guilhem Figueira.]

\section{PC 183. Guilhem de Peitieus}

[1071-10 February 1126; seventh Count of Poitiers, ninth Duke of Aquitaine from 1086; for the form of his name, see 2378, R. Taylor, "Assessment," 2006, p. 877; took part (disastrously) in the second wave of the First Crusade; vida; eleven poems, one of which is of doubtful authenticity; two melodies preserved as fragmentary contrafacts, PC 183,3 and PC 183,10: see

- 609, Fernandez de la Cuesta, Las cançons, 1979, pp. 45-48 (both melodies), and 607, van der Werf, Extant, 1984, p. 151* (only the second).]

\section{4.}

\section{Editions}

Bec, Pierre. Le Comte de Poitiers, premier troubadour: à l'aube d'un verbe et d'une érotique. 2nd edition. Montpellier: CEO/REDOC, 2004. [Outline of the historical and legendary Guilhem, his possible sources, sensitive literary analysis of his poetry; edition of eleven poems, based on Pasero's texts with a few emendations; extensive discussion of points of controversy and interpretation is provided in notes, but Bec does not take into account much recent scholarship since the early to mid-1990s.]

2335.

Bond, Gerald A. The Poetry of William VII, Count of Poitiers, IX Duke of Aquitaine. New York: Garland Press, 1982. [Life of Guilhem, his poetry, sources, influence; critical edition of vida and ten poems, with English translation; critical notes for all poems, pp. 55-84; PC 183,6, of doubtful attribution, in appendix; many historical documents concerning Guilhem, pp. 92-145; transcription of the melody to PC 183,10 from the Jeu de Sainte Agnes by H. van der Werf, pp. 144*-45*.]

\section{6.}

Eusebi, Mario. Guglielmo IX: Vers. Parma: Nuova Pratiche, 1995. 2nd edition, Rome: Carocci, 2006. [Practical teaching text, small format; brief introduction presents problems of attribution, and philological comments on the language (Poitevin?); new edition of ten poems, using a variety of base manuscripts, with variants, textual notes, Italian translation; denies authenticity of PC 183,6, puts it into appendix.]

2337.

Jensen, Frede. Provençal Philology and the Poetry of Guillaume of Poitiers. Odense: Odense University Press, 1983. [New edition of all eleven poems, with very detailed word-for-word philological annotations and English translation; retains PC 183,6, since it has not been shown absolutely that it is not Guilhem's; the book offers an introduction to Old Occitan philology through a close examination of Guilhem's corpus, making it into a kind of self-teaching textbook; full glossary.]

2338.

Pasero, Nicolò. Guglielmo IX d'Aquitania: Poesie. Subsidia al Corpus dei Trovatori, 1. 
Rome: Mucchi, 1973. [Edition of vida and ten poems, with PC 183,6 in appendix; introduction to each poem, with Italian translation, detailed notes, glossary.]

2339.

Zufferey, François, has announced a new edition of Guilhem de Peitieus, but it has not yet appeared (E-mail communication, February 2006).

2340.

Asperti, Stefano. "A ritroso: Bertran Carbonel, Sordello, Guglielmo di Poitiers." Rom 128 (2010): 273-98. [A demonstration of the careful use of lectio difficilior in textual criticism; through a detailed study of the form entrenan in Bertran's PC 82,12 and, working backwards by way of Sordello and twenty others to Guilhem de Peitieus PC 183,1, line 15, Asperti is able to reestablish the variant reading qu'esta sobre l'arbr'entreman "upright, steadily" instead of sobre l'arbr'en creman "fearfully," removing the one negative element from the stanza which is otherwise devoted entirely to the joy of gratification.]

2341.

Banniard, Michel. "Les deux voies de la poésie savante au XIe siècle: entre tropes latins et tropes lyriques d'oc." In L’Aquitaine des littératures médiévales (XIe-XIIIe siècle). Edited by Jean-Yves Casanova and Valérie Fasseur. Paris: Presses de l'Université ParisSorbonne, 2011. [Asserts that Guilhem de Peitieus had a broadly based education, was aware of sociocultural innovations in Latin poetry and religious music, and participated in them through his own idiosyncratic poetry, influenced by sociocultural movements such as those of Robert d'Arbrissel and perhaps by the subconscious trauma of illegitimacy that they shared; Guilhem's originality is firmly rooted in the innovative fabric of his time.]

2342.

Barbiellini Amidei, Beatrice. Guglielmo IX, Farai un vers de dreit nien el'immaginazione melanconica. Milan: CUEM, 2010. [An original interpretation of PC 183,7, suggesting that the poem is the description of the medieval morbus melancholicus, the depressive love sickness, and includes the allegorical representations of love and death.]

2343.

Beech, George. "Contemporary Views of William the Troubadour, IXth Duke of Aquitaine, 1086-1126." In Medieval Lives and the Historian: Studies in Medieval Prosopography. Proceedings of the First International Interdisciplinary Conference on Medieval Prosopography, University of Bielefeld, 3-5 December, 1982. Edited by Neithard Bulst and Jean-Philippe Genet. Kalamazoo, MI: Medieval Institute Publications, 1986, pp. 73-89. [A meticulous evaluation of all recorded references to Guilhem in his own time leads Beech to the surprising conclusion that the duke was not admired as a leader or warrior by his own subjects and was virtually unknown for his poetry or sense of humor.]

2344.

Beech, George. "L'attribution des poèmes du Comte de Poitiers à Guillaume IX d'Aquitaine." CCM 21 (1988): 3-16. [Claims that the historical record contains no clear trace of Guilhem IX as a poet, and even as a historical figure, he was forgotten 
until the seventeenth century; Beech sketches in detail the rediscovery of the political figure and the poet and the way in which the two were merged with minimal verification; absolute proof of the poet's identity is still lacking.]

2345.

Benozzo, Francesco. "Guglielmo IX e le fate: il Vers de dreit nien e gli archetipi celtici della poesia dei trovatori." MR 21 (1997): 69-87. [Invokes Celtic archetypes for the earliest troubadours, who seem to continue the superstitious belief in fairies or supernatural women: supernatural contacts at night on a mountain, dream visions, returning asleep by horseback, unresolved tension between reality and unreality.]

2346.

Bianchini, Simonetta. Sconvenienti convenienze. Sondaggi guglielmini. Rome: Bagatto, 2000. [Four detailed studies of interpretation in Guilhem's poetry, dealing with vocabulary and structural problems, and their influence on later poets.]

2347.

See 363. Bloch, Medieval Misogyny, 1991. [A provocative work, reviving the theory put forward in 1940 by Bezzola, that Guilhem promulgated or even invented courtly love as a competitive secular response to the spiritual seductions of Robert d'Arbrissel; believes that Guilhem shows the inherent paradox of love and misogyny in his "two-faced" poetry, as does Andreas Capellanus in his contradictory treatises, 1 and 2 praising love, 3 denouncing it; likewise, Jaufre Rudel loves only an abstraction of the Lady; his poetry reveals the paradox of virginity which makes the absent lady the most desirable; Bernart de Ventadorn's Can vei is seen as an archetypal expression of the link between romantic love, virginity and the ascetic impulse, a poem full of contradictions.]

2348.

Bologna, Corrado, and Tiziana Rubagotti. "Talia dictabat noctibus aut aequitans: Baudri de Bourgueil o Guglielmo IX d'Aquitania?” CDT, 1.3 (1998): 891-917. [Several links between the poetry of Baudri and Guilhem suggest that they may have known one another in the early 1100s and that Guilhem may be reacting to Baudri in some of his anti-courtly poems, in particular that he may be parodying Baudri's themes of composing poetry on horseback or while sleeping; Guilhem's hostile remarks about Normans and French may be references to the Loire School.]

2349.

Bond, Gerald A. The Loving Subject: Desire, Eloquence and Power in Romanesque France. Philadelphia: University of Pennsylvania Press, 1995. [A searching investigation into all aspects of literature and its social bases around 1070-1130, when the traditional social values turned gradually toward a subjective approach favoring a new construct of "person"; in chapter 4, pp. 99-128, Bond shows through analysis of Guilhem's poetry how the secular emphasis on individual identity and emotion led to new forms of lyric, stressing sexuality and language as forms of power.]

2350.

Burgwinkle, William E. "Troubadour Song and the Art of Juggling." Pacific Coast Philology 26 (1991): 13-25. [Post-structural analysis of Guilhem de Peitieus Farai 
un vers de dreit nien (PC 183,7) as a poetic statement about the nature of poetry and reality; believes that troubadour poems are inherently dramatic oral performances whose meaning depends on the social culture in which they are performed and the expectations of the audience; Guilhem is playing ironically with the poetic traditions of his time, reacting against the code which must predate him.]

2351.

Capusso, Maria Grazia. "Guglielmo IX e i suoi editori: osservazioni e proposte." SMV 33 (1987): 135-256. [A very detailed look at editorial problems concerning William's poems, including the attribution of PC 183,6; detailed comments on all recent editions.]

\section{2.}

Cerdà Subirachs, Jordi. "Guilhem de Peitieu i la penalitat del gat." In $>$ 162, Trobadors a la Peninsula Ibèrica, 2006, pp. 151-69. [The word tizo in PC 183,12 is a juridical term, referring to the punishment for fornication which involved putting a live ember in the mouth of the man; Guilhem utilizes different referential threads to mix legal concepts with folk beliefs, to construct a complex poem about power and sex and manipulation.]

2353.

Cholakian, Rouben. "Guillaume d'Aquitaine: Toward a New Paradigmatic Interpretation of fin'amors." Assays 3 (1985): 3-17. [A somewhat simplified Lacanian analysis of Guilhem's persona which is seen to have an overriding need for dominance and control in sexual, political, social, and poetic spheres; the persona achieves identity in the creative act itself, with the final goal always the dominance of the male; fin'amors is essentially androcentric, not female-centered at all; see also his $\mathbf{8 3 2}$, Troubadour Lyric, 1990, which portrays Guilhem as anxious about his love/hate relationship to women.]

\section{4.}

Duggan, Joseph J. “Guilhem IX's Poem about Nothing and the Generation of Meaning." In 137, Contez me tout, 2006, pp. 827-37. A review of the scholarly attempts to explain the poem's meaning; in the poem, a series of affirmations is followed by immediate denials, suggesting a riddle; but no obvious key has been found that would unlock its mysteries, and Duggan is inclined to see it as an elaborate jest.]

\section{5.}

Fassò, Andrea. "Fate, diffrazione e una congettura per Guglielmo IX." QRF (Lingua, rima, codici. Per una nuova edizione della poesia della scuola siciliana) 12/13 (1999): 289-326. [Wonders if "lo Coms de Peitieus" refers to Guilhem X; in any case he imagines Guilhem in contact with Cercamon, Eble, Jaufre Rudel, and a large group of poets at the court of Poitiers, rather than an isolated Guilhem solely responsible for the beginning of troubadour poetry.]

\section{6.}

Ferrante Joan. "Farai un vers de dreyt nien: The Craft of the Early Trobadors." In Vernacular Poetics in the Middle Ages. Edited by L. Ebin. Kalamazoo, MI: Medieval Institute Publications, 1984, pp. 93-128. [A sweeping analysis of the nature and 
evolution of vernacular lyric from Guilhem through Dante; the emphasis on pure structure in Guilhem's dreit nien develops in complex ways through the work of Marcabru, Jaufre Rudel, Bernart de Ventadorn, Raimbaut d'Aurenga, and Arnaut Daniel; perceptive analysis of structures, themes, and poetic styles leading to Dante; Guilhem composes a poem containing "nothing" but structure, Dante one that embraces the world and its creator.]

2357.

Gambino, Francesca. Guilhem de Peitieus Ab la dolchor del temps novel (BdT 183,1). http://www.lt.unina.it. $51 \mathrm{pp}$. [Review of previous scholarship; paleographical study; critical edition, with Italian translation, copious notes.]

2358.

See 803, Gaunt, Troubadours and Irony, 1989. [Pp. 19-29: Gaunt uses Guilhem's poetry to illustrate how irony has functioned in troubadour poetry from the beginning; p. 27: the poem Farai un vers de dreit nien revolves around a feeling of incongruity and is undoubtedly ironic, but has been interpreted in countless different ways by scholars, whereas Guilhem may simply be making fun of his listeners' efforts to understand; in several of his poems, there seems to be a dialectic involving competition within a community of poets, with irony used to put down his rivals or to question the assumptions of the courtly code itself, as many other troubadours were to do.]

2359.

Goddard, Richard. "The Ladies Agnes and Arsen and William IX's Compagno, farai un vers [qu'er] covinen." Forum for Modern Language Studies 24.2 (1988): 156-62. [Counteracts some of the more abstract interpretations of earlier scholars by clarifying the historical and geographical background to the poem; he shows that the ladies are real and are attached to the localities of Gimel and Nieuil; for some political reason, Guilhem must have wanted to insult the two husbands by claiming their wives as his mistresses, as he had done in the "red cat" poem.]

2360.

Hilty, Gerold, and Federico Corriente. "La fameuse cobla bilingue de la chanson V de Guillaume IX: une nouvelle interprétation.” VR 65 (2006): 66-71. [Review of previous scholarship on the enigmatic "Arabic" words, in particular that of Uhl

342, 1991; claims that the dialectal features of the lines are distinctly Syrian and that the metric structure fits authentic Arabic traditions; supposes that Guilhem remembered the erotic verse from his stay in Syria and inserted it into his poem as a hint for initiated listeners of the sexual adventures to come; if this hypothesis is correct, it would verify the existence of real contacts between Occitan and Arabic poetry.]

2361.

See 834, Huchet, L'Amour discourtois, 1987. [A simplified Freudian or Lacanian explanation of the early troubadour love ethic, which he sees as basically sexual; chapter 2 analyzes Guilhem's attitude to women, made up of obscenity, misogyny, and psychological fears such as taboos and castration complex.] 
2362.

Jensen, Frede. "Philological Comments on the Poetry of the Earliest Troubadour." $R P h 38$ (1985): 436-74. [A critical appraisal of all current editions, and analysis of all extant manuscripts containing Guilhem's poems; extensive textual comments on specific passages in all eleven songs.]

2363.

Lafont, Robert. "Lecture du Comte de Peitieus." In 105, L'Imaginaire courtois, 1991, pp. 63-82. Reprinted in La Source sur le chemin, Paris: Harmattan, 2002, pp. 59-80 [Very usefully distinguishes between the historical count/duke and the poet-figure, claiming that there is no proof that the two are connected; examines the establishment of the major manuscripts that preserve Guilhem's poetry, trying to see what message each was trying to suggest; the figure of the poet may have been largely created by the compilers of the chansonniers for their own purposes, as the chroniclers did for their own aims.]

2364.

Manetti, Roberta, and Sergio Vatteroni. "Osservazioni sul primo trovatore." In 118 , La lirica romanza, 2009, pp. 17-58. [Manetti points out that several intertextual indications seem to show that Guilhem was reacting by parody to verses of Jaufre Rudel, but problems of chronology remain; identifying the troubadour with the traditional Guilhem IX lacks historical proof, but claims that the poet might in fact be Guilhem X have not been persuasive; the relative chronology of Jaufre and Guilhem cannot be certain until more precise dates have been fixed for Jaufre; Vatteroni points to two themes from patristic literature to show that Guilhem had surprisingly close ties to church traditions.]

\section{5.}

Martindale, J. "Cavalaria et orgueill: Duke William IX of Aquitaine and the Historian." In The Ideals and Practice of Medieval Knighthood. Edited by Christopher Harper-Bill and Ruth Harvey. 3 vols. Woodbridge: Boydell, 1986-90, 2:87-116. Also in her Status, Authority and Regional Power. Aldershot: Variorum, 1997, pp. 87-116. [Guilhem's personal image has changed from that of a licentious buffoon to that of a complex and sophisticated poet; similarly, his historical image as an ineffective ruler demands revision; Martindale finds that he was constantly active throughout his lands, defending his power and properties, conferring numerous grants and privileges on religious houses, and going on crusade both to the Holy Land and into Spain; an evaluation of his poetic output shows that he was well educated and aware of the major social movements of his time; Martindale finds no sense of psychological crisis in the confident man seen in historical and poetic sources.]

2366.

Melani, Silvio. "Il cammino della croce e gli artigli della lussuria: ipotesi sulle 'perdute' cantilenae composte da Guglielmo IX in occasione della sua crociata." In 117 , Le letterature romanze, 2000, pp. 281-94. [Thinks that a little digging might restore the "lost" works that Guilhem performed "before kings and magnates and Christians" after his escape from defeat in 1101; claims that his "farewell song," PC 183,10, was probably written just before he left for crusade in 1101, as a sign of humble, if ironic, 
penitence; PC 183,12 may be a parody of a pilgrimage made to St. Leonard's sanctuary at Noblat after his deliverance from the disaster of the crusade; a mockery is made of the pilgrim's virtues of abstinence in terms of warmth, food, and sex.]

2367.

Meneghetti, Maria Luisa. "Mon Esteve: à propos du destinataire de Guilhem IX d'Aquitaine dans Pos vezem de novelh florir." In 140, Etudes Ricketts, 2005, pp. 461-69. [A possible identification of Mon Esteve with Etienne-Henri, count of BloisChartres 1090-1102 (died 1102 on the First Crusade, a close acquaintance of Guilhem at Antioch and Jerusalem; if correct, then the poem must have been composed ca. 1099-1101; the lady in the poem may have been Adèle de Blois, daughter of William the Conqueror, eulogized by Baudri de Bourgueil; the rules of courtly love outlined in the poem may indicate a circle of initiated poets gathered to sing the praises of Adèle, or even to inaugurate fin'amors, placing this poem at the very origins of European courtly love.]

\section{8.}

Meneghetti, Maria Luisa. "Maistre (Certa): niveaux de savoir et conception du monde chez Guillaume IX d'Aquitaine." CDT 9 (2006): 765-73. [An attempt to apply to Guilhem's poem PC 183,2, the theories of Max Black on the use of models and archetypes, to imagine God creating the world by a throw of the dice; this places Guilhem's image on a different level from the traditional gaming and sexual ones; the anagogical or archetypal concept is that of an allpowerful force that governs the world by the single law of chance; Meneghetti wonders whether Guilhem has portrayed himself as a rival to this superpowerful God in his arrogant claim to have mastered the forces of creation.]

2369.

Newman, Jonathan. "Preference, Prerogative, and Prowess in the Lyrics of Guilhem de Peitieus," in Satire of Counsel, Counsel of Satire: Representing Advisory Relations in Later Medieval Literature. PhD diss., University of Toronto, 2008, chapter 3.3, pp. 152-72. Online at http://www.tspace.library.utoronto.ca/bitstream/1807/16806/1/ Newman_Jonathan_M_200811_PhD_thesis.pdf. See revised version in Tenso 27 (2012):25-44. [Guilhem's poetry, especially in the companho poems, asserts his poetic, political, and sexual authority over his favored vassals and by implication over his public domains; his writing of poetry may be seen as a subversive act, meant to appropriate the clerical monopoly on writing and the use of the vernacular instead of Latin; humor is generated by the disparity between the low-level rivalry in the private domain of sexuality and the high-level area of politics and warfare, but in all fields, Guilhem is careful to maintain his dominance.]

2370.

Payen, J-Ch. Le Prince d'Aquitaine: essai sur Guillaume IX, son oeuvre et son érotique. Paris: Champion, 1980. [A romanticized account of Guilhem's life and poetry; edition of the vida and eleven poems, based on Jeanroy's edition, with new French translation and intuitive commentaries; information is not always substantiated, and recent scholarship is often ignored.] 
2371.

Pulega, Andrea. Amore cortese e modelli teologici: Guglielmo IX, Chrétien de Troyes, Dante. Milan: Jaca Book, 1995. [The introduction gives valuable insights into the theological, cultural, and literary debates of the time, along with an analysis of the reciprocal influences of French, Occitan, Italian, and Latin literatures on one another; pp. 61-174 are entirely devoted to a searching study of Guilhem's Vers de dreit nien, PC 183,7, with a stanza-by-stanza reading, pp. 115-64.]

2372.

Rieger, Dietmar. Der Vers de dreyt nien Wilhelms IX. von Aquitanien: rätselhaftes Gedicht oder Rätselgedicht? Untersuchung zu einem "Schlüsselgedicht" der Trobadorlyrik. Heidelberg: Winter, 1975. [Demonstrates that the poem is difficult, but that it not designed to be a riddle; there is no key word or concept that would explain the contradictions and obscurities; believes that Guilhem may be teasing us by hinting at a riddle.]

2373.

Rollo, David. "Sexual Escapades and Poetic Process: Three Poems by William IXth of Aquitaine.” RR 82 (1990): 293-311. [Guilhem subverts many of the conventions of courtly love poetry - the elevated, chaste domna is sometimes characterized as promiscuous or bestial, and the poetry continually shifts between bawdy and meditative registers; though the poems can be read as the narrator's boasting over sexual exploits, some of the language suggests an underlying theme of male impotence.]

2374.

Roncaglia, Aurelio. "Guillaume IX d'Aquitaine et le jeu du trobar (avec un plaidoyer pour la déidéologisation de Midons).” In \$ 96, AIEO 3, 1992, pp. 1105-17. [Believes that Guilhem was the initiator of an original type of poetry; he was not bifronte but projected in his poetry a frank, enthusiastic, and ambiguous mixture of joc and joi, including within itself both sides of the dialectic that developed later between opposing schools of idealized love and misogynist reaction; Roncaglia supports the choice of con in MS C instead of Es cors in Mout jauzens, making this, with the adjacent joi, an isotopy that forms the central key to the poem; this original poetic creativity is found also by Vallín $\mathbf{2 3 8 0}$, in the proposed reading vert for vers in $A b$ lo dolchor.]

2375.

Ruiz-Doménec, José Enrique. Amor y moral matrimonial: el testimonio de Guilhem de Peitieu. Bellaterra: Universidad Autónoma de Barcelona, 1983. [A radical look at a number of William's idiosyncratic poems to test the hypothesis that nobles, threatened by the church's new policies toward marital morality, reacted by inventing a new form of love polarized between the two opposed ideals of boastful sexual freedom and the preaching of marital restraint; this leads to unexpected readings of the cat poem, seen as the aristocratic male reasserting his power by attacking female frigidity, and the farewell poem which is turned into the inward journey of a tormented soul discovering filial love.]

2376.

Ruiz-Doménec, José Enrique. La identitat de Guilhem de Peitieu. La flor inversa, 5. 
Barcelona: Columna, 1999. [Review of research on Guilhem over three hundred years; historical biography of the Count; texts of eleven poems taken from various editions, with Catalan translation by Rosa Pons, brief notes.]

2377.

Stanesco, Michel. "L'étrange aventure d'un faux muet: blessures symboliques et performances sexuelles dans un poème de Guillaume IX d'Aquitaine." CCM 32 (1989): 115-24. [Links the "red cat" poem to folkloric coming-of-age rituals in which sexuality is associated with blood and death, illuminating some of the deeper parts of the human psyche; instead of being a glorification of lubricity, the text resembles primitive rites in which a young man was tortured into a state of sexual frenzy indicating his maturity; the echo of the folk ritual underlies the altered message of Guilhem's poem about the contrast between knightly and clerical love.]

2378.

Taylor, Robert A. "Guilhem de Peitieus: An Assessment of What We Know and Don't Know about the 'First Troubadour." In 137, Contez me tout, 2006, pp. 875-93. [A review of recent research and a summing up of what has been clarified about Guilhem and what remains uncertain: his name, dates, factual versus legendary biography, corpus, contemporary judgments of his character, the problem of matching the historical Guilhem with the poet, and attempts at probing the poet's psyche through psychocritical analysis.]

2379.

See 342, Uhl, "Guillaume IX," 1991. [Reinterprets the "Arabic" lines of PC 183,12 in MS C as authentic, suggesting that they make erudite reference to the Jewish/Islamic legend of the fallen angels Harut and Marut, who condemned themselves by succumbing to the wiles of a woman; Guilhem may have heard the legend in a story or song performed by an Andalusian slave and referred to it obliquely/ironically to provide a key to his own poem.]

2380.

Vallín, Gema. "Lo vers del novel chan?" Rom 119 (2001): 506-17. [Probes the question of Guilhem's poetic genius in support of Roncaglia's claim that he was the sole initiator of the new poetry (see $\mathbf{2 3 7 4}$, Roncaglia, "Guillaume IX," 1992); a detailed study of PC 183,1, Ab lo dolchor, in which she proposes to read lo vert instead of lo vers in line four; this would solve a lengthy debate over the unsatisfactory readings of all manuscripts, substituting a semantically rich form that would fit the poem's central theme by stressing renewal, the "greening" of nature.]

2381.

Wolterbeek, Marc. “A New Date for William of Aquitaine's 'Song of Penance' (Song 11)." NM 107 (2006): 335-46. [Survey of earlier scholarship on the dating of Guilhem's PC 183,10; analysis of a letter sent by Guilhem to Archbishop Diego Gelmirez in Santiago de Compostela in late 1120 or early 1121, and comparison of language and themes, leads to the belief that the two are contemporary and closely related; if so, then Guilhem VII of Poitiers is confirmed in identity with the first troubadour, and his poem is firmly dated to $1120-21$; in addition, a link is established between the two worlds of literature and history.] 
2382.

Zufferey, François. "Les exploits du Comte de Poitiers sous les rayons ultraviolets." CN 53 (1993): 135-49. [Zufferey has subjected a badly damaged folio of MS $V$ to ultraviolet radiation and has been able to decipher a number of new significant readings in Guilhem's famous poem 5, including a possible stay of not eight but forty-one days that the poet spent in sexual exploits with his two ladies!]

\section{PC 184. Coms de Proensa (Raimon Berenguier IV, Count of Provence 1209-45)}

[First half thirteenth century; two tensos, one with Arnaut Catalan about farting, and one with his horse Carn-et-Ongla; exchange of coblas with Bertran d'Alamanon; he was the son of the trobairitz Garsenda de Forcalquier; esteemed patron of trou2383.

badours, along with his wife, Beatrice of Savoy.]

Cluzel, I.-M. "Princes et troubadours de la maison royale de Barcelone-Aragon." BRABLB 27 (1957-8): 335-48. [Edition of five poems by Raimon Berenguer IV of Provence (1209-45), including the tenso with Arnaut PC 184,1 = 25,1, a fictive tenso with his horse Carn-e-Ongla, a tenso with Rodrigo, and two exchanges of coblas; texts with French translation, notes.]

2384.

See 227, Riquer, 1975, 3:1353-54. [Introduction, Blasi's text of the tenso PC 25,1 = 184,1, Amics N'Arnauz, the so-called chanson du pet, with Spanish translation, notes.]

\section{PC 187. Garsenda de Forcalquier}

(Garsenda de Proensa; Comtessa de Proensa)

[fl. 1200-1209; coquettish exchange of coblas with Gui de Cavaillon; Countess of Provence from 1193 as wife of Count Alfonse II of Provence, Countess of

Forcalquier from 1209; regent for her son from 1213 to 1220; Elias de 2385.

Barjols dedicated four songs to her before she retired to a convent.]

See 733, Bruckner/Shepard/White, Songs of the Women Troubadours, 1995, pp. xxxv-xxxvi, 54-55 and 162-63. [Edition of the exchange of coblas with Gui de Cavaillon, Vos qe.m semblatz dels corals amadors, PC 187,1 =192,6, in which she encourages Gui to court her more boldly; historical introduction, critical text with English translation, notes.]

2386.

See 735, A. Rieger, Trobairitz, 1991, pp. 204-13. [Historical introduction; Garsenda's poem is modeled after Gaucelm Faidit's PC 167,30, which Rieger thinks may have been addressed to her, especially since her cobla, as well as Gui's, seems to make direct reference back to Gaucelm's poem; both Garsenda and Gui are playing openly with the concepts of fin'amors.]

2387.

Blakeslee, Merritt R. "Garsenda of Forcalquier." In $\$ 46, Women in the Middle Ages, 
2004, pp. 353-55. [Historical introduction to Garsenda's complex political life in Aix; both coblas exhibit delicate wit and a fine sense of irony; Blakeslee points out that the attribution of the poetic exchange to her and to Gui lacks firm documentation.]

\section{PC 189. Granet}

2388.

[fl. 1240-57; five poems; was a jongleur for Bertran d'Alamanon.]

Parducci, Amos. Granet, trovatore provenzale. Rome, 1929. [Historical introduction; edition of five poems, with Italian translation, notes.]

2389.

See 2104, Aurell, La Vielle, 1989, pp. 157-58. [PC 189,1 contains respectful but forthright criticism of Charles of Anjou for his lack of generosity, for his hesitation to fight for his property rights in the Gapençais, and for the injustices done by his administrators in Provence.]

2390.

Noto, Giuseppe. "Una nuova edizione della tenso Granet—Bertran d'Alamano (BdT 189.2 = 76.6) De vos mi rancur, compaire," Lecturae tropatorum, 2010, 14 pages. Online at http://www.lt.unina.it. [Paleographical and literary introduction, critical edition, with Italian translation, copious notes; available also in $\mathbf{2 5 6}$, Harvey and Paterson, Troubadour "Tensos,"2010, 2:437-46.]

2391.

Paterson, Linda M. "Granet," on Rialto, 2011: http://www.rialto.unina.it. [Critical edition of the sirventes PC 189,4, Pos al comte es vengut, appended to the tenso PC $437,10=76,2$ between Sordello and Bertran d'Alamano, in which Granet mocks both of their choices in the debate; introduction, notes, no translation; for the circumstances of the poem, see 256, Harvey and Paterson, Troubadour "Tensos," 2010, 3:1214-15.]

\section{PC 190. Grimoart Gausmar}

[Third quarter twelfth century; known only by his inclusion in Peire d'Alvernhe's satirical gallery poem, PC 323,11; one canso treating the abstract concepts of fin'amor.] 2392

Ferrari, Anna. "Rime derivata e critica testuale: Grimoart Gausmar Lanquan lo temps renovelha (BdT 190.1)." CN 51 (1991): 121-206. [Considers Grimoart an accomplished poet, in touch with the literary developments of his time, noteworthy for formal virtuosity and verbal inventiveness; diplomatic transcriptions from both $C$ and $e$; critical text with full critical apparatus, Italian translation, detailed notes, and comments on structure and metrics.]

2393.

See 227, Riquer, 1975, pp. 272-75 [Introduction, edition of the canso, with Spanish translation, notes.] 
PC 192. Gui de Cavaillon. (The same as Guionet, PC 238, Esperdut, PC 142, and perhaps Guigo (de Cabanas), PC 197)

[fl. 1200-1229; at least fifteen poems including those attributed under a pseudonym, all rich in historical and social allusions, caustic and ironic in tone; a partisan of the counts of Toulouse; he is probably the author of the second part of the Canso de la Crozada.]

2394.

See 256, Harvey and Paterson, Troubadour "Tensos," 2010, 2:455-62 [Critical edition of PC 192,2a = 147,2 between Gui and an unidentified Falco, with introduction, English translation, notes; Gui makes cruel fun of Falco's supposed mutilation (he had his tongue cut out), but this may be an in-joke.]

2395.

See 2001, Ricketts, Contributions, 2000, pp. 33-35. [Edition of the tenso between Guionet and Cadenet, PC 238,1 = 106,11, with French translation, notes.]

2396.

Aurell, Martin. "Le troubadour Gui de Cavaillon (vers 1175-vers 1229): un acteur nobiliaire de la croisade albigeoise." In Les voies de l'hérésie. Le groupe aristocratique en Languedoc, XIe-XIIIe siècles. Vol. 2: Avant et après la croisade: seigneurs et seigneuries. Carcassonne: Centre d'Études Cathares/René Nelli, 2001, pp. 9-36. [An investigation of the social, moral, and religious motivations of one of the chief opponents of Simon de Montfort's invaders; through archival records and fifteen lyric poems, mostly political dialogues and ironic comments about love and loyalty, Aurell paints the life of a tragic knight and poet, entirely devoted to the defense of Toulouse and the South.]

2397.

Brusoni, Andrea. "Il partimen En Raimbaut, pro domna d'aut paratge (BdT 238,2)." AMod, 3 (1997): 227-44. [Edition and study of the tenso between Guionet (= Gui de Cavaillon) and Raimbaut (de Vaqueiras), dated to ca. 1210, in Provence; close analysis of the manuscripts; critical text with Italian translation, notes; see also - 256, Harvey and Paterson, Troubadour "Tensos," 2010, 2:671-81.] 2398.

Brusoni, Andrea. "Problèmes d'attribution dans le chansonnier de Gui de Cavaillon." In Actes du colloque: Jeunes chercheurs en domaine occitan, in Bulletins de l'AIEO 14 (1998): 25-29; also in MR 22 (1998): 209-31. [Outlines the difficulty of attributing poems given in manuscripts to Guigo, Guionet, Esperdut; further information reinforces the attribution to Gui of works by Guionet and Esperdut, perhaps Guigo, but the question still needs further research; Brusoni is working on a new critical edition of Gui de Cavaillon, the revision of a doctoral thesis.]

2399.

Ghil, Eliza Miruna. "The Triumph of the sirventes in Thirteenth-Century Troubadour Poetry." Medieval Perspectives 9 (1994): 48-62. [Believes that the sirventes came of age as a reaction to the Albigensian Crusade; in opposition to the opinion of Georges Bordonove, who claimed that the troubadours did not react sincerely to the invasion 
by Simon of Montfort, shows that Gui de Cavaillon was a combatant for the Count of Toulouse in the war at Beaucaire 1216, participated in a tenso, PC 192,4 = 209,2, and appears in the second half of the Canso de la Crozada, laisse 154, as an eloquent epic hero; it is even proposed that he may be the author of the second half of the Canso.]

2400.

Guida, Saverio. "Lattività poetica di Gui de Cavaillon durante la crociata albigese." CN 33 (1973): 235-71. [Edition of four poetic exchanges between Gui and participants in the struggle between France and Occitania, offering insight into the high emotions of the historic moment: PC 192,5 =186,1, between Gui and Count Raymond VII of Toulouse, in which both swear to fight rather than negotiate with the enemy; PC 192,4 and 209,2 between Gui and his bitter rival Guilhem dels Baus; PC 192,2 = 83,2, between Gui and his close colleague Bertran Folco of Avignon, a cry for help during the siege of Castelnou; PC 330,20 = 192,1, between Gui and his friend Peire Bremon Ricas Novas, a disagreement over Gui's bad treatment of a guest in Gui's own castle.]

2401.

Guida, Saverio. "La tenzone fra Ricau de Tarascon et Cabrit." In 152, Miscellanea Roncaglia, 1989, 2:637-61. Also in CN 47 (1987): 197-221. [Detailed study of the manuscript tradition and the sociohistorical background, dating the poem to ca. 1215-16; critical edition with Italian translation; Guida thought in this article that Cabrit was a nickname for Gui de Cavaillon, but has since identified him as Guilhem Aldebert Cabrit, an important member of the municipal administration in Arles: see - 2194, Guida, "Pour l'identification," 2009.]

2402.

Guida, Saverio. "Lautore della seconda parte della Canso de la crotzada." CN 63 (2003): 255-82. [A careful and persuasive investigation into the possibility, suggested by Rostaing, Roncaglia, Ghil, Aurell, and others, that Gui de Cavaillon may have composed the continuation of the Canso in 1228; Gui was one of the most faithful confidants and advisors of Raymond VII of Toulouse, was intimately involved in the intrigues and negotiations connected with the "crusade," and was known for his passionate and heroic patriotism for Toulouse and the South; to scholars who considered Gui's style banal and unworthy of the accomplished epic presentation of the crusade epic, Guida presents a convincing analysis of close similarities in Gui's lyrics to passages in the Canso.]

2403.

Poe, Elizabeth Wilson. "Suppressing the Memory of the Crusade: The Manuscript Tradition of the Poems of Gui de Cavaillon." Tenso 10.2 (1994): 139-57. [An exploration of the placing of poems by Gui in the manuscripts, but with little result: there is no real proof of any intent to suppress memory of the crusade.]

2404.

See 227, Riquer, 1975, 3:1185-92. [Historical introduction to Gui's career; suggests the possibility that Gui was the author of the second part of the Canso de 
la crozada; edition of the vida, the hostile sirventes against Guilhem dels Baus, PC 192,4, and the exchange of coblas with Garsenda PC 187,1 = 192,6, with Spanish translation, notes.]

2405.

See 227, Riquer, 1975, 3:1407-10. [Edition of a cobla by Bertran d'Alamanon, PC 76,1, followed by the response of Guigo de Cabanas (= probably Gui de Cavaillon), PC 197,1.]

\section{PC 194. Gui d'Ussel}

[fl. 1190-1225; vida, razos; eight cansos, three pastorelas, nine tensos; four melodies are preserved; Gui shared a family property with his two brothers Eble and Peire and his cousin Elias; Gui is best known for a tenso, PC 194,2, with Elias on whether it is best to be a lady's lover or her husband, a canso, PC 194,19, on the mala domna theme, and a tenso with Maria de Ventadour, PC 295,1 = 194,9, outlining the

2406. reciprocal rights and duties of lovers.]

See 2261, Audiau, Les Poésies des quatre, 1922. [Introduction on historical and biographical background of the four poets; analysis of metrical structures in their twenty-six poems; claims that Gui was probably born about 1170, died about 1225; in 1209 or earlier, he was forced to swear to the pope's legate that he would compose no more lyrics; critical edition of his twenty poems; in appendix: quotes from Gui to be found in the Breviari and in So fo el temps; the melody to his PC 194,8 is transcribed pp. 116-17, but the other three are not given; for these, see $\mathbf{6 0 7}$, van der Werf, Extant, 1984, pp. $152^{*}-55^{*}$.]

2407.

Billet, Léon. Généalogie de la famille d'Ussel: les quatre troubadours "d'Ussel." Leur biographie et celle de la maison "d'Ussel." Leurs chansons; manuscrits et notes. Tulle: Orfeuil, 1982. [Twenty-six poems with French translation: twenty by Gui d'Ussel, and six by his brothers Eble, Elias, and Pierre; in appendix, a choice of charters and historical material; useful historical background, texts not for scholarly use.]

2408.

Callewaert, Augustijn. "Autotextualité et renommée littéraire. A propos des pastourelles du troubadour Gui d'Ussel." In 137, Contez me tout, 2006, pp. 815-25. [Gui's most influential poem was his mala canso, an anti-courtly comjat outlining the faults of his lady; Gui makes auto-reference to this poem in both of his pastorelas, in order to defend his opinion and relieve his own discomfiture at being blamed for unworthy treatment of his domna; in the second pastorela, Gui tries to be conciliatory to the angry shepherd, only to be upbraided again for his inconstancy in a tenso with Maria de Ventadorn and his insistence that he was right.]

2409.

Jung, Marc-René. "Ben feira chanso (PC 194,3)." In - 159, Studia occitanica, 1986, 1:101-8. [Detailed interpretation of the very popular poem; shows that Gui d'Ussel was reflecting on the nature of his poem as he composed, exploring his own 
motivations and his place vis-a-vis his lady and other members of the courtly society; Gui questions the traditional rules of finamor at the turn of the twelfth century and sets new conditions, with the poem itself as a model.]

2410.

Lafont, Robert. "Un personnage textuel: Eble (d'Ussel?).” In 151, Mélanges Bec, 1991, pp. 285-94. Reprinted in La Source sur le chemin, Paris: Harmattan, 2002, pp. 97-109. [Attribution studies must be reconsidered according to new understanding of the manuscript tradition; reconfirms the attribution of 194,16=129,4 to Gui and Eble d'Uisel but looks closely at the complex question of attributions; pp. 292-94: Lafont thinks that Guilhem de Peitieus is the founder of trobar but points out the difficulties of identifying the Coms de Peitieus as Guilhem and of attributing the contradictory poems to a single poet.]

2411.

See 890, A. Rieger, "La mala canso de Gui d'Ussel," 1992. [Study of a network involving Gui d'Ussel, Maria de Ventadorn, Raimbaut de Vaqueiras, and others; analysis of PC 194,19, Si be.m partetz, mala domna, de vos; for a study of the mala canso as a genre, see 468, D. Rieger, Gattungen, 1976, pp. 303-18; the mala domna in troubadour poetry is analyzed by $\mathbf{4 7 2}$, Leube-Fey, Bild und Funktion, 1971.]

2412.

Seláf, Levente. "Frère mineur ou frère cadet? Cor ay e voluntatz: rapports d'imitation d'une chanson religieuse provençale." RLaR 112 (2008): 61-72. [Analysis of possible intertextual connections of poem PC 159,1 with an Occitanized Old French alba and with poems by Gui and Eble d'Ussel, Bertran d'Alamanon, and several others; if the unknown poet could be called the "younger brother" rather than "Franciscan Friar," then he might be identified as Peire d'Ussel; other possible interconnections are explored without a definitive conclusion.]

\section{PC 197. Guigo (de Cabanas; probably a sobriquet for Gui de Cavaillon: see PC 192)}

[Five tensos, two exchanges of coblas with Bertran d'Alamanon, one with Esquileta.]

\section{PC 200. Guilhelma de Rosiers (Rougiers)}

[ $f$. perhaps 1245-57; moved to Genoa after the death of Raimon Berengier 1245; one tenso with Lanfranc Cigala, PC 200.1 = PC 282,14, preceded by a razo.]

\section{3.}

See 735, A. Rieger, Trobairitz, 1991, pp. 224-41. [Text of the razo from Boutière/ Schutz; critical text of the tenso, with German translation; edition of an anonymous poem, PC 461,204, in praise of Guilhelma; her identity remains problematic, but she must be real, perhaps even a professional trobairitz. See also the new edition in - 256, Harvey and Paterson, Troubadour "Tensos," 2010, 3:902-12.]

2414.

Blakeslee, Merritt R. "Guilielma des Rosers." In $\$ 46, Women in the Middle Ages, 2004, pp. 390-92. [Sees the tenso as a thinly veiled sexual encounter, in which a 
witty skirmish between Guilhelma and her suitor, both struggling for dominance, is resolved to their mutual satisfaction.]

2415.

See 764, Poe, "Dispassionate Look," 1992. [By way of the vidas and razos, casts doubt on the historical reality of five of the seven named trobairitz, but maintains the reality of Guilhelma de Rosiers and Garsenda.]

\section{PC 202. Guilhem Ademar (Azemar)}

[fl. 1195-1217; vida; satirized in the Monge de Montaudon' poem, PC 305,16, lines 36-42; sixteen or seventeen poems, one with music: see $\mathbf{6 0 7}$, van der Werf, Extant, 1984, p. 156*; Guilhem was close to Alfonso VIII in the Castilian court and probably wrote his poem PC 202,9 to urge Raymond VI of Toulouse to join

2416.

Alfonso in his crusade against the Almohads.]

Almqvist, Kurt. Poésies du troubadour Guilhem Adémar. Uppsala: Almqvist \& Wiksells, 1951. Reprint, New York: AMS, 1983. [Survey of previous scholarship, biography, poetic corpus, study of manuscripts, versification; edition of the vida and twelve poems, plus four more attributed to him; French translation, notes.]

2417.

See 624, Cullin and Chaillou, "La mémoire," 2006, pp. 152-58. [Close analysis of Guilhem Ademar's Lanquan vei flurir, PC 202,8, to demonstrate the ways in which memorization is utilized to produce a harmonious interlacing of text and melodic structures; the melody may adopt the poem's architecture, emphasizing the two final lines of each stanza and facilitating memorization; text and musical transcription in appendix.] 2418.

See 439, Malm, Dolssor conina, 2001, pp. 92-94. [Analysis of Guilhem's PC 202,7 Ieu ai ja vista, as an example of antifeminist satire.]

2419.

See 244, Bec, Burlesque, pp. 57-60, "Contre les femmes," and 209-12, "Coblas refranchas." [Edition of two poems by Guilhem, with introduction, French translation, notes; the first, PC 202,7, is a misogynistic sirventes, complaining that uncourtly lovers win favors from ladies, while courtly aspirants, like himself, are left out; the second is a linguistic tour de force, playing on morphological variations of a single root, or words that sound alike.]

2420.

See 227, Riquer, 1975, 2:1100-1107. [Introduction, vida, two poems, a canso (PC 202,1), and the misogynistic sirventes PC 202,7, with Spanish translation, notes.]

\section{PC 203. Guillem d'Anduza}

[fl. 1254-77; one canso; Guiraut Riquier dedicated his fifteenth canso to him; his family was disinherited by the king of France after the Albigensian Crusade.] 2421.

See 255, Guida, Trovatori minori, 2002, pp. 283-321. [History of the family; 
believes that Guillem may have influenced members of the Scuola di Rodez rather than being influenced by them, since he came first chronologically; edition of PC 203,1, with Italian translation, copious notes.]

\section{PC 204. Guillem Anelier de Tolosa}

[Last third thirteenth century; maybe one poet or two, possibly related; four sirventes, complaining about various things: the decline of liberality toward troubadours, the Inquisition, clerics, the French; perhaps the same as the author of the epic text La Guerra de Navarra (see 1099-1103).]

\section{2.}

Straub, Richard E. F. "Les sirventes de Guilhem Anelier de Tolosa." In 134, Cantarem, 1995, pp. 127-68. [Close analysis of the four poems to clarify the sociohistorical background and their possible connection to the Guerra de Navarra and the Canso de la Crozada; critical edition with French translation, notes, study of metrics and rhymes; Straub was unaware of the 1995 edition of the Guerra by Santano.]

2423.

See 260, Vatteroni, Falsa clercia, 1999, pp. 88-91. [Draws close parallels between Guillem Anelier's works and poems of Peire Cardenal; also similarities with the Canso de la crozada.]

\section{PC 205. Guilhem Augier Novella (Augier, Augier Novella (PC 37), Augier de Saint-Donat, Ogiers de Vienne; maybe the same as Guillem de Beziers) \\ [ $f$. 1209-28; nine or ten poems, including a planh for Roger Trencavel de Béziers; known for virtuosity of form and language; was exiled to Italy, probably for anti-French feelings.]}

2424.

Calzolari, Monica. Il Trovatore Guillem Augier Novella: Edizione critica. Subsidia al Corpus des Troubadours, 11. Modena: Mucchi, 1986. [Bibliography, introduction, vida, nine poems with information on two others attributed erroneously to him; careful codicological study, notes, Italian translation, glossary.]

2425.

Calzolari, Monica. "Guillem Augier Novella, Bertran del Pojet e Peyre Cathala: un altro caso di intertestualità nella Provenza del XIII secolo." CN 46 (1986): 17-21. Also in 152, Miscellanea Roncaglia, 1989, 1:257-61. [Guillem is identified with a magistrate for Raymond VII of Toulouse; intertextual references show close connections among the three poets; both Bertran and Peyre dedicated poems to Guillem and imitated aspects of his style; all three poets were active in the court of Raymond Berengier V after 1220, when Guillem had returned to Provence from Italy.]

2426.

Guida, Saverio. "Problemi di datazione e di identificazione de trovatori: 1: Rigaut de Berbezilh; 2: Sifre e Mir Bernart; 3: Guillem Augier [Novella].” Romanica vulgaria. Quaderni 10-11 (1989):87-126. [Critical of Calzolari's attempts to identify Guillem 
with a historical figure, a highly placed judge, whom Guida sees as entirely inappropriate.]

2427.

See 2044, Hershon, Les troubadours de Béziers, 2001, pp. 139-55. [Edition of two poems by Guillem de Béziers (= Guilhem Augier Novella), PC 205,2 and PC 205,3, with introduction, French translation, notes.]

PC 206. Guilhem d'Autpol (de Hautpoul; maybe the same as Daspols) [fl. 1265-70; four poems: an alba to the Virgin, a religious pastorela, a planh on the death of Saint Louis IX of France, and a tenso with God.]

\section{8.}

Paden, William D., et al. "The Poems of the Troubadours Guilhem d'Autpol and Daspol." RPh 46 (1993): 407-52. [Survey of previous scholarship on the identity of the two poets; the first is plausibly recognized as the Baron of Hautpoul, 1231-89, but it is impossible to decide whether Daspol, or D'Aspol, or D'Aspel is the same person, though both refer to the same times, places, and social worlds; all four poems-an alba, a pastorela, a tenso, and a planh - are analyzed to show the evolution toward increased religious content and stricter genre definition by the late thirteenth century.] 2429.

See 227, Riquer, 1975, pp. 1519-23. [Introduction, text of the fictive tenso with God, Spanish translation, notes.]

\section{PC 210. Guillem de Berguedan}

[ $f$. 1175-92; vida; thirty poems, mostly violent sirventes; he was rebellious and made many enemies, one of whom had him assassinated ca. 1196.]

2430.

Riquer, Martin de. Guillem de Berguedà. Vo1. 1: Estudio histórico literario y lingüistico; vo1. 2: Edición critica, traducción, notas y glosario. Barcelona: Abadía de Poblet, 1971, slightly revised 1996. [Vol. 1 has a detailed literary and historical analysis and study of language; vol. 2 has critical texts with Spanish translation, notes, glossary; also online, 2003, at http://www.rialto.unina.it: thirty poems, with brief introduction to each, no translation, no notes.]

2431.

See 227, Riquer, 1975, 1:519-42. [Historical introduction, vida, seven poems: PC 210,11, 12, 8, 1, 9, 20, 2a, with Spanish translation, notes.]

2432.

Forner, Climent. Guillem de Berguedà i altres trobadors. Obra poetica: edició bilingüe. Barcelona: Albi, 1986, pp. 19-212. [Brief introduction to the three troubadours of Berguedan: Guillem de Berguedan, Uc de Mataplana, and Guillem Ramon de Gironela; popular presentation of all thirty lyrics by Guillem and the Epistola to an anonymous friend and its response, with introduction, Catalan translation, brief notes.]

2433.

Rieger, Dietmar. "Lop es nomnat lo pes, e lop no es: un devinalh sans solution?" In 
- 151, Mélanges Bec, 1991, pp. 497-506. [Analysis of the supposed devinalh, an exchange of coblas PC 210,10b = 342b,1 between Guilhem de Berguedan and an unknown Peire de Galceran; the enigma is solved through examination of key passages in other troubadours and minor emendations to the text: the heavy pes, "burden" of love, is an obsessive affliction; in popular belief, a man can dominate a wolf if he is first to see it, but here the lover has failed to gain dominance over his lady; Peire claims in more direct terms that it is worth continuing to strive, since the ecstasy of sexual union, likened to death, is absolute.]

2434.

Salvador, Vicent. "Sobre la poesia del trobador Guillem de Berguedà; recursos estilístics I pragmàtica del discurs." In Stylistique, rhétorique et poétique. Actes du XVIIe Congrès international de linguistique et philologie romanes (Aix-en-Provence, 29 août-3 sept. 1983. Aix-en-Provence: Université de Provence, 1986, vol. 9, pp. 321-30. [A preliminary exploration of promising avenues of research into Guillem's poetry: examples of stylistic features of his language, metrics, and semantics, the relationship between poetic persona and audience, where Guillem is constantly projecting his own image as a combatant and as a lover, his attempts to involve the listeners in his act of poetic creation, and the satirical mode that gives repeated expression to his anger and disdain.]

\section{PC 213. Guilhem de Cabestanh}

[ $f$. 1180-1215; vida; eight cansos; the vida is famous for the legend of the eaten heart, which may have been created in response to his canso PC 213,5 Lo dous 2435. cossire; he may have been satirized by Monge in his gallery sirventes.]

Cots Vicente, Montserrat. "Las poesías del trovador Guillem de Cabestany." BRABLB, 40 (1985-86): 227-330. [Survey of previous scholarship, study of manuscripts, versification, language, and themes; critical edition of all eight poems, with Catalan translation, notes; in appendix, text of PC 213,1a of doubtful attribution and an apocryphal stanza to PC 213,7; see also her article in BRABLB 37 (1977-78): 23-66, for a study of the vida and the sociohistorical context which served as a base for the legend; information on twelve persons connected with Guilhem and archival documents demonstrating his historical reality.]

2436.

Cots Vicente, Montserrat. "Pervivencias de una leyenda medieval: el corazón comido." In 160, Studia Riquer, 1986-91, pp. 401-10. [Detailed review of literature concerning the possible origins of the pervasive legend and its subsequent history.]

2437.

Gaunt, Simon. "'Le coeur a ses raisons': Guillem de Cabestanh et l'évolution du thème du Coeur mangé." In $\mathbf{1 0 0}$, AIEO 7, 2003, pp. 363-74. [A psychoanalytical interpretation of the legend as the embodiment of the sacrificial desire of finamor, representing the fulfillment of the male's fantasy of being absorbed, incorporated by his lady; for fuller development, see 396, Gaunt, Love and Death, 2006.] 
2438.

Grange, Huw. "Guilhem de Cabestanh's Eaten Heart, or the Dangers of Literalizing Troubadour Song.” Tenso 27 (2012): 92-108. [Analysis of the razo found in $P$ shows that its author was aware of the danger of reducing the polyvalent symbol of the heart to stark corporeality, just as Guilhem's poem itself, PC 213,5, was composed to show the difference between the poetic semblance of love and the real thing.]

2439.

See 227, Riquer, 1975, 2:1063-78. [Introduction, vida, and texts of PC 213,3, 5 and 6, with Spanish translation, notes.]

2440.

Rossi, Luciano, and A. Ziino. "Mout m'alegra douza vos per boscaje." CN 39 (1979): 69-80. [Doubts the probability of the backward restitution of Guillem's lost melody to PC 213,7 by way of a borrowing by Gautier de Coinci and Alfonso the Wise; analysis of another contrafact by Bertran de Born lo Filh shows that Guillem's text was as well known as the melody, making the ingenious chain of events proposed by Marshall in Rom 98 (1977): 245-49 less persuasive; musicological analysis by Ziino adds further doubt regarding Marshall's hypothesis and points to other Old French songs that are more likely to have furnished the musical model for Gautier's poem.]

2441.

Rossi, Luciano. "Il cuore, mistico pasto d'amore: dal Lai Gurun al Decameron." Romanica Vulgaria. Quaderni 6 (1983): 28-128. [Claims that the legend of the eaten heart may be based more on fact than has been thought; the poem behind the legend provides an important basis for understanding the dynamics of finamor, giving a more graphic image of the sacrificial nature of troubadour desire than Jaufre Rudel's more ephemeral notion of distant love.]

2442.

Thomas, Patrick Michael. "Guilhem de Cabestanh: The Onomatopoeia of Emotion." Acta litteraria academiae scientiarum Hungaricae 32 (1990): 233-43. [An attempt to analyze the link between vowel sounds and emotions in Guilhem's poem Egan res qu'ieu vis; the timbre of the stressed vowels in the line may help to express the poet's feelings, whether used consciously or subconsciously: sadness for the low notes $a$ and $u$, hopefulness for the high notes $i$ and $e$; the vacillation between surging hope and dark despair is echoed in the vocalic interplay.]

2443.

Thomas, Patrick Michael. "Le point d'appui du cinquième vers: la balance structurelle dans la Canso II de Guilhem de Cabestanh.” Les Lettres romanes 46 (1992): 163-73. [Claims that the fifth verse in each stanza of Guillem's PC 213,2, Anc mais no.m fon semblan, and PC 213,1a, Al plus leu q'ieu sai far chanssons, acts as a key structural pivot separating the contrasting developments of the first four and last four verses.] 


\section{PC 214. Guillem de Durfort}

[ $f$. 1204; two sirventes; he and his wife Raimonde were Cathars; he fought unsuccessfully against the invading French in the Albigensian Crusade, had his property confiscated, and went into exile in Catalonia.]

\section{4.}

Nelli, René, and Louis Alibert. Sept troubadours du pays d'Aude. Cressé: Éditions des Régionalismes Pyrémonde Princi Negue, 2011. [Reissue of the book published by Nelli in 1948, containing the works of Guillem de Durfort, Guillem Fabre, Bernart Alanhan, Berengier de Poivert, Mir Bernart, Bernart de Rouvenac, and one Anonymous, with French translation; nonscholarly presentation.]

2445.

Careri, Maria. "Alla ricerca del libro perduto: un doppio e il suo modello ritrovato." In 119, Lyrique romane, 1991, pp. 329-78. [An eighteenth-century Madrid manuscript, the copy in eighty-four folios of Miquel de la Tor's collection of poems, thought lost; fully documented rubrics; contains copies of two sirventes by Guillem de Durfort, one hitherto unknown; a later article in VR 48 (1989/91): 77-84 contains a diplomatic edition of the two sirventes, no translation.]

\section{PC 217. Guillem Figueira}

[f. 1215-40; vida; twelve poems; he was banished from Toulouse, took refuge in Lombardy; wrote against the church and the French; famous for his satirical sirventes against Rome and the pope, PC 217,2, answered by Gormonda, PC 177,1; Guillem participated in a cycle of coblas: his own PC 217,1b answered by Aimeric de Peguilhan's PC 10,13, answered in turn by Bertran d'Aurel's PC 79,1, which is answered by Lambert's PC 280,1.]

\section{6.}

Levy, Emil. Guilhem Figueira, ein provenzalischer Troubadour. Berlin: Liebrecht, 1880. [Edition with German translation, notes; Gianfelice Peron has announced preparation of a new edition: see Tenso 8 (1993): 128.]

2447.

Billy, Dominique. "Une canso en quête d'auteur: Ja non agr'obs que mei oill trichador (PC 217,4b)." In 93, Atti del XXI Congresso, 1998, vol. 6, pp. 543-55. [A complex song, that probably has been attributed wrongly to Guilhem Figueira, was very popular among a number of French trouvères, especially the Chastelain de Couci; Billy suggests three possible candidates for the Occitan author: Aimeric de Peguilhan, Peirol, and Peire Vidal, but declines to make a choice.]

2448.

Garreau, Joseph. "Hérésie et politique chez Guilhem Figueira et Peire Cardenal." Kentucky Romance Quarterly 31 (1984): 243-49. [After detailed analysis, concludes that there is no indication that either poet was Cathar, though they and their families lived in a symbiotic relationship with the Cathars; both were politically engaged against the French, the crusaders, and the Inquisition.] 
2449.

See 2399, Ghil. "Triumph of the sirventes," 1994, pp. 50-54. [In opposition to the opinion of Georges Bordonove, who claimed that the troubadours did not react sincerely to the invasion by Simon of Montfort, shows that Guilhem's poem attacking the papacy for the sins of greed and seeking secular power shows great daring and personal involvement against the church and the Crusade, and that it continued to influence public opinion for at least another fifty years.]

\section{0.}

Hutchinson, Patrick. "Lonh de paradis: géopolitique méditerranéenne, thématique courtoise et religieuse dans D'un sirventes far de Guilhem Figueira.” In - 98, AIEO 5, 1998, pp. 237-48. [Sweeping analysis of the various currents to be found in and around Guilhem's poem of 1227-28: historical, religious, courtly, and geopolitical events, involving sociocultural turning points as widespread as the Albigensian Crusade, the consultations between Sicily and the sultan of Egypt, the crusade of Frederick II, and the installation of Pope Gregory IX, as well as cultural evolutions in literature and religion that were underway at the same time.]

\section{1.}

Negri, Antonella. "Guillem Figueira-Aimeric de Peguillan: Anc tan bel colp de joncada (BdT 217.1a)_Anc tan bella espazada (BdT 10,9)." Lecturae tropatorum 3, 2010. Online at http://www.lt.unina.it. [Two coblas that are linked in several ways, analyzed along with eight others in manuscripts $H$ and $P$; although some scholars have interpreted them as a real exchange of coblas, attached to an historical event, Negri believes that the whole series may be an attempt by the compiler of the manuscripts to put together a number of disparate coblas to make of them a unified series.]

\section{2.}

Peron, Gianfelice. "Il conselh di Guilhem Figueira a Federico II (BdT 217,4)." AMod 4 (1999): 217-39. [Meticulous review of previous editorial scholarship on the poem; new critical edition using all three manuscripts, with Italian translation, copious notes, and commentary; the sirventes urges Frederick II to take the initiative against the Lombards, and to uphold the traditional courtly virtue of generosity.]

2453.

See 227, Riquer, 1975, 3:1270-79. [Introduction, edition of PC 217,2, the sirventes against Rome and the Catholic church, with Spanish translation, notes.]

2454.

See 260, Vatteroni, Falsa clercia, 1999. [Study of anticlerical themes and traditions, and what constitutes heresy; pp. 129-39: texts of PC 217,2, D'un sirventes far, and 217,5, No.m laisserai, with Italian translation, no notes; Guilhem compares the attack on Toulouse to the crusaders turning against Constantinople, accusing the papacy of political corruption and greed; the second poem is more strictly anticlerical, directed mostly against the Dominicans.] 


\section{PC 219. Guillem Godi}

[Probably twelfth century; one canso-sirventes; not likely the same as Gaudi, PC 170, who has a tenso with Alberjat = PC 12b,1, though both poets show the influence of Marcabru.]

\section{5.}

See 2302, Rosenstein, "Le(s) troubadour(s) G. Godi/Gaudi," 1994. [Detailed investigation of the identities of the poets involved and the content of their poems reveals that Godi is probably from the twelfth century, following closely the serious moralizing tendencies of Marcabru, while Gaudi, who seems to be merely gameplaying with the same principles, is probably from the thirteenth century.]

\section{PC 223. Guilhem Magret}

[fl. 1200-1215; vida; eight poems, two with melody: see $\mathbf{6 0 7}$, van der Werf, Extant, 1984, pp. 157*-58*.]

2456.

Naudieth, Fritz. Der Trobador Guillem Magret. Halle: Karras, 1913. Also in Beihefte zur $\operatorname{ZrP}$ 52. Halle: Niemeyer, 1914. [Introduction on Guilhem's life and work; edition of eight poems, with German translation, notes; in appendix, PC 47,2, assigned to Berenguer de Palol, but also attributed in some manuscripts to four other poets, including Guilhem.]

2457.

See 249, Bec, Florilège en mineur, 2004, pp. 133-37. [Introduction, text from Naudieth of the sirventes PC 223,1, Aigua pueja contramon, with French translation, no notes, no melody given.]

2458.

See 227, Riquer, 1975, 2:915-24. [Introduction, vida, PC 223,3, 4 and 6, with Spanish translation, notes.]

2459.

Sánchez Palomino, Dolores, and Gema Vallín. "Guilhem Magret, un trovador provenzal en las cortes peninsulares." In Convivio. Estudios sobre la poesía de cancionero. Edited by Vicente Beltrán Pepió and Juan Salvador Paredes Núñez. Granada: Universidad de Granada, 2006, pp. 739-46. [A study of the career of Guilhem Magret, who was highly regarded by several Iberian kings and nobles; his language is sharp and colorful, using rich and often popular terms, with precise literary and cultural references.]

\section{PC 225. Guilhem de Montanhagol}

[fl. 1233-68; fourteen poems: seven cansos, six sirventes, one partimen with Sordello; for Guilhem, finamors is essentially mezura, urged against the repressive tendencies of the Inquisition; turns the emphasis of poetry from moral elevation to a search for religious perfection.]

2460.

Ricketts, Peter T. Les poésies de Guillem de Montanhagol, troubadour provençal du XIIIe 
siècle. Toronto: Pontifical Institute of Mediaeval Studies, 1964. [Philological introduction, critical texts with French translation, notes, complete glossary.]

2461.

Melli, Elio. "Interpretazione di Montanhagol." In Critica testuale ed esegesi del testo: Studi in onore di Marco Boni. Bologna: Pàtron, 1984, pp. 97-142. Finds that Montanhagol is firmly entrenched in troubadour traditions but reflects as well the new emphasis on spirituality, with an interest in political matters; a firm supporter of Raymond VII of Toulouse.]

2462.

Teulière, Gérard. "Interpénétration culturelle dans le trobar: Montanhagol, Blacasset, et la kabbale." Tenso 2 (1986-87): 37-50. [Exploration of the tone of social and religious tolerance in a joc partit by Montanhagol and Blacasset, in which can be seen cross-influences from Cathar and Jewish sources; see a similar study of the same poem in Patrick Hutchinson, "A lunel lutz," in Le Soleil, la lune et les étoiles. Sénéfiance, 13. Aix-en-Provence: Publ du CUER MA, Université de Provence, 1983, pp. 177-93.]

2463.

See 260, Vatteroni, Falsa clercia, 1999. [Study of anticlerical themes and traditions and what constitutes heresy; pp. 143-45: text of PC 225,4 by Guilhem, with Italian translation, no notes; Guilhem blames clerics for the destruction of courtly virtues and for the unfair practices of the Inquisition.]

2464.

See 227, Riquer, 1975, 3:1429-46. [Introduction, vida, edition of PC 225,7, 2, 12 and the cobla PC 225,1 with the response by Blacasset.]

\section{PC 226. Guilhem de Mur (Murs)}

[fl. 1271; one crusade song, six partimens, five of which are with Guiraut Riquier; perhaps the pastiche PC 233,4 of an Arnaut Daniel poem, Razo e dreyt ay, now attributed to Guilhem de Saint Gregori, is by Guilhem de Mur, according to Perugi-see Beltrami, Rivista di letteratura italiana (RLI) 5 (1987): 9-89 (p. 13).]

\section{5.}

Guida, Saverio. “Guillem de Mur.” Online, 2004, at http://www.rialto.unina.it. [Edition of two torneiamens: Guiraut Riquier, segon vostr'essien between Guillem de Mur and Guiraut Riquier, judged by Henry II of Rodez, PC 226,8 = 248,42 = 140,1; also De so don yeu soy doptos, PC 226,1 =248,25 =140,1a =296,1; the texts are from - 1891, Guida,'Jocs' poetici, 1983, without the translation or notes; each text introduced by "Premessa."]

2466.

See 1891, Guida,'Jocs' poetici, 1983. [Study of the social and poetic activity at the court of Rodez, second half thirteenth century, especially under Count Henri II; edition of four tensos involving Guilhem de Mur; Henri was a judge in PC 226,8 = $248,42=140,1$, with Italian translation, notes.]

2467.

Perugi, Maurizio. "Ancora un partimen da ascrivere a Guilhem de Murs.” In Trovatori 
a Valchiusa. Un frammento della cultura provenzale del Petrarca. Padova: Antenore, 1985, pp. 230-50. [Prints a known poem by Guillem: Guillem d'un plag novel, PC 140,1c = 226,6a, and a new one between L'Oste (probably Henry II) and Guillem (de Mur): Guilhem, raizon ai trobada, a pastiche of Arnaut Daniel's Razo e dreyt; see also Beltrami, "Appunti su Razo e dreyt," Rivista di letteratura italiana 5 (1987): 9-89.]

\section{PC 227. Guilhem Peire de Cazals (Guilhem Peire Cazals de Caortz)}

[First half thirteenth century; ten cansos, one partimen with Bernart de la Barta, perhaps two further tensos; nine of his poems are dedicated to Ardit, his friend and joglar.]

\section{8.}

Mouzat, Jean. Les poèmes de Gaucelm Faidit, troubadour du XIIe siècle; suivi de Guilhem Peire de Cazals, troubadour du XIIIe siècle et le troubadour Arnaut de Tintinhac: éditions critiques. Geneva: Slatkine, 1989. [Only the Slatkine edition has the additional material on Guilhem Peire: the edition originally appeared as Guilhem Peire de Cazals, troubadour du XIIIe siècle. Paris: Les Belles Lettres, 1954. Pp. 616-86: background history, manuscripts, previous scholarship, life and literary circle of the poet, corpus, metrics, style, language; critical edition of eleven poems, with French translation, notes, glossary.]

\section{9.}

See 274, Asperti, "Testi e frammenti," 2009, pp. 269-76. [Demonstrates the need to take MS $R$ into account in editing the tenso PC 201,5 = 25,2; the interlocutor Guilhem may be Guilhem Peire de Cazals.]

\section{0.}

Guida, Saverio. "Cartulari e trovatori. 1. Arnaut Guilhem de Marsan; 2. Amanieu de la Broqueira; 3. Guilhem Peire de Cazals; 4. Amanieu de Sescas." CN 59 (1999): 71-129, esp. pp. 97-107. [Makes a strong case for the need to ally historical research with literary; no direct identification of Guilhem Peire de Cazals, but a probable link to Quercy can be assumed.]

2471.

See 270, Guida, "Sospette paternità," 2010. [Wide-ranging historical investigation of poetic and political activity around the court of Toulouse in the early thirteenth century; many details about the names and activities of little-known or poorly identified poets are brought to light, particularly Arnaut de Comenge, Guilhem Peire de Cazals, and Bertran Folc d'Avignon; the possibility of identifying Guilhem or Guilhem Peire with Peire Guilhem is firmly denied; the Guillem who participated in tenso PC 150a,1 with Arnaut and Folc is shown to be Guilhem Peire de Cazals.]

2472.

See 256, Harvey and Paterson, Troubadour "Tensos," 2010, 2:527-37. [Unaware of Guida, 2010; the tenso PC 201,5 =25,2 is tentatively attributed to Guilhem Peire de Cazals; the same Guilhem and Arnaut participated in PC 150a, $1=201,5 a=25,3$, along with an unknown Folc; a reference to Domna Elena (tenso PC 227,7 = 58,2) 
and to Sévérac links these poems to Guilhem Peire de Cazals and Bernard de la Barta, helping to date the poems to 1211-15.]

Guilhem de Peitieus. See PC 183 (formerly called Grafvon Poitiers/lo Coms de Peiteus)

\section{PC 230. Guilhem Raimon de Gironela (Gironella, Gironells)}

[fl. 1260-76; three cansos, one of which, called a retroensa, has a refrain; one tenso with Ponzet, PC 383; uses traditional themes but unique metrical structures]. 2473.

See 2432, Forner, Guillem de Berguedà $i$ altres, 1986, pp. 241-55. [Popular edition of two poems by Guillem Raimon, PC 230,1a =383,1 and PC 230,2, with introduction, Catalan translation, brief notes; the other two poems were judged too fragmentary and unintelligible to be presented.]

2474.

See 256, Harvey and Paterson, Troubadour “Tensos," 2010, 2:613-19. [Edition with introduction, English translation, notes, of the tenso with Ponzet, who is verified as Catalan, along with Guilhem Raimon.]

2475.

See 227, Riquer, 1975, 3:1672-80. [Introduction, edition of the tenso and PC 230,2, with Spanish translation, notes; two stanzas from PC 230,1 and one from PC 230,3 are printed, otherwise these are available only in Carl Appel, Provenzalische Inedita, Leipzig: Reisland, 1892, pp. 146-52.]

\section{PC 231. Guilhem Rainol d'At (Apt)}

[Early thirteenth century; vida, five poems: three tensos (two of which are humorous, with a lady, perhaps his wife, the other with Guilhem Magret; two sirventes,

2476. one of which, PC 231,1a, may belong to Tomier e Palazi.]

Bonaugurio, Rossella. Il trovatore Guilhem Rainol d'At. Edizione critica e studio. Tesi di laurea in Filologia romanza, U degli studi di L'Aquila, 2002. Online: Rialto, 2003, at http://www.rialto.unina.it. [Edition of all five poems with introduction Premessa, notes, no translation.]

2477.

See 256, Harvey and Paterson, Troubadour "Tensos," 2010, 2:620-29. [Edition of PC 231,3 $=223,5$, the tenso with Guilhem Magret, with French translation, no notes.]

2478.

See 750, Krispin, "La tradition manuscrite," 1993. [Close study of the place of the trobairitz poems in MS $H$; identifies three more female voices in an anonymous planh and two tensos under the name of Guilhem Rainol, thus enriching the registre féminin.]

2479.

Paterson, Linda. "Guillem Rainol d'At Quant aug chantar lo gal sus el erbos (BdT 
231,4)." Lecturae tropatorum 3, 2010. Online at http://www.lt.unina.it/Paterson-2010.pdf. [Critical edition with detailed commentary, English translation, notes; the genre is indistinct; Chambers 1989 called it a "domestic quarrel between husband and wife ... on a barnyard level"; Paterson concludes that the poem was composed for comic performance, that Guillem was the sole author, and that both personae were fictional.]

2480.

See 227, Riquer, 1975, 3:1236-46. [Introduction, vida, edition of PC 231,2, 4 and the tenso with Guilhem Magret, PC 223,5 =231,3.]

2481.

See 735, A. Rieger, Trobairitz, 1991, pp. 331-55. [Critical editions of PC 231,1 and PC 231,4, with analysis, notes, German translation; considers both to be parodies; doubts that the lady is intended to be Guillem's wife.]

2482.

See 249, Bec, Florilège en mineur, 2004, pp. 167-71. [Introduction, text of the tenso with Guilhem Magret, French translation, no notes.]

\section{PC 233. Guilhem de Saint Gregori}

[ $f$. 1194-1236; three poems, plus one of probable attribution, one doubtful (Beltrami); a parody of Arnaut Daniel's sestina, directed against

Aimar de Poitiers; a tenso with Blacatz.]

2483.

Beltrami, Pietro G. "Remarques sur Guilhem de Saint Gregori." In $>$ 95, AIEO 2, 1993, 1:31-43. [Study of five poems, three of which are of reasonably sure attribution: the sirventes PC 233,1 (listed under Bertran de Born 80,8a), the canso PC 233,4, Razo e dreyt, and the tenso with Blacatz, PC 233,5; a fourth is probable: the sestina PC 233,2; a fifth is doubtful: the canso PC 233,3; the sirventes PC 233, 1 has been attributed variously to six troubadours but is reaffirmed as belonging to Guilhem de Saint Gregori and not to Bertran de Born, in agreement with Lewent but against Gouiran and Paden.]

2484.

Loporcaro, Michele. "Be.m platz lo gais temps de pascor di Guilhem de Saint Gregori." SMV34 (1988): 27-68. [Editions of PC 233,1 by Gouiran and Paden (attribution to Bertran de Born) vary widely; Loparco undertakes a systematic recensio and concludes that the poem is probably by Guilhem, composed at the end of 1219; critical edition with exhaustive apparatus, Italian translation, notes.]

2485.

Loporcaro, Michele. "Due poesie de Guilhem de Saint Gregori (BdT.233.2 e 233.3)." MR 15 (1990): 17-60. [Outlines problems of attribution for Guilhem's poems; detailed study of metrics, manuscript history, historical context, and edition of PC 233,2 and 3, the sestina modeled on Arnaut Daniel Ben grana avolesa intra and the canso Nueyt e jorn ai dos mals, with Italian translation, copious notes.] 


\section{PC 234. Guillem de Saint-Didier (Saint-Leidier)}

[fl. 1170-80; vida and two razos; satirized by the Monge de Montaudon (PC 305,16); seventeen poems, one with melody: see $\mathbf{6 0 7}$, van der Werf, Extant,

1984, p. 159*; one tenso, PC 234,12, uses topoi of fin'amors in an allegorical dream of love; composed the allegorical work Lo Vergiers d'amor and perhaps also Lo Somni, unless this is by the Catalan Bernat Metge; PC 234,8 is a fictive tenso between a husband and wife, in which she complains of his sexual inadequacy.] 2486.

Sakari, Aimo. Poésies du troubadour Guilhem de Saint-Didier, publiées avec introduction, traduction, notes et glossaire. Mémoires de la société Néophilologique de Helsinki 19. Helsinki: Société Néophilologique, 1956. Reprint, New York: AMS, 1983. [Introduction on life and works of Guilhem, literary evaluation, language, and versification; edition of the vida in two versions, two razos, thirteen poems, plus two of doubtful attribution, with French translation, notes; complete glossary; Emilia Muratori is preparing a new critical edition.]

2487.

Bambeck, Manfred. "Zu einer strittigen Passage im Vergiers d'amor des Guillem de Saint-Didier, oder das Problem der Herkunft der allegorischen Liebesdichtung im Mittelalter." RF93 (1981): 37-54. Also in Wiesel und Werwolf: typologische Streifzüge durch das romanische Mittelalter und die Renaissance. Stuttgart: Franz Steiner, 1990, pp. 137-54. [Gives many examples in the Bible and exegetical writings of the advantage of disposing of unhealthy branches for the positive development of the vines; the lauzengiers serve to cleanse and purify love so that it can develop more fully.]

\section{8.}

Barattelli, Bianca. "Appunti per una rilettura della canzone Dompna, ieu vos sui messatgiers di Guillem de Saint-Didier." Quaderni di Lingue e Letterature 11 (1986): 399412. [Study of the figure of personification applied to the poem itself by several poets; detailed analysis of Guilhem's use of the figure; the text is reproduced from Sakari's edition, with Italian translation, extensive commentary, notes.]

2489.

See 1381, Jung, "Les poèmes allégoriques," 1971, pp. 128-32. [The allegorical poem PC 234,12 is in the form of a tenso, in which the poet explains his own dream of a garden; the trees and flowers represent ladies, the lion a jealous husband, dogs the lauzengiers, various birds are lovers and other courtiers, indistinctly characterized.]

2490.

Muratori, Emilia. "Per una biografia del trovatore Guillem de Saint Didier." In - 142, Studi Melli, 1998, pp. 555-73. [Presents new biographical, historical, and geographic clarifications from archival sources, along with further analysis of the vida and two razos; casts doubt on Sakari's attribution of PC 234,8 to Peire Duran; Muratori is preparing a new edition of Guillem de Saint-Didier.]

2491.

See 735, A. Rieger, Trobairitz, 1991, pp. 462-71. [Edition of PC 234,8, with German translation, notes; shows that it is probably a fictive tenso, between a husband 
and wife disputing the size and use of his member, and is judged to be by Guillem, not by Peire Duran.]

2492.

Martorano, Antonella. Edition of PC 234,7, Domna, eu vos sui messagiers, in $\mathbf{5 2 0}$, Gambino, Salutz, 2009, pp. 234-67. [Very detailed paleographical study of seventeen manuscript copies; critical text using $K$ as base, with Italian translation, notes; the poem itself speaks to the lady throughout, until the tornada.]

\section{PC 236. Guillem de la Tor}

[fl. 1215-30; vida; thirteen poems, one of which is of uncertain attribution: $L a$ Treva from 1216, PC 236,5a, a laudatory sirventes singing the praise of ladies who ended a long feud at the Malaspina court; another sirventes, PC 236,11, is probably not by him, more likely by Palais; two tensos, one with Imbert, one with Sordello.] 2493.

Negri, Antonella. Le liriche del trovatore Guilhem de la Tor. Soveria Mannelli: Rubbettino, 2006. [Detailed historical introduction; study of Guilhem's adaptation of classic fin'amors traditions to the mercantile civic culture of northern Italy; close comparative study of Guilhem's poems in their manuscript tradition; critical edition of the vida, thirteen poems, plus one of doubtful attribution, with Italian translation, notes.]

2494.

Monestier, Jean. “Guilhem de la Tor, troubadour périgourdin.” Lo Bornat 4.2 (1991): 1-56. [Introduction; texts from Blasi 1934: vida, eight cansos, one descort, two sirventes, two tensos, and La Treva, with facing-page French translation, no notes, no bibliography; not a scholarly edition.]

2495.

Fedrigucci, Samanta. "Guilhem de la Tor, il trovatore a due facce: tra cortesia e goliardia." Website created for a course in information systems at the University of Urbino Carlo Bo: http://www.uniurb.it/Filosofia/bibliografie/GuilhemDeLaTor/index2. html. [Outline of the life and works of Guilhem; edition of two poems: the canso PC 236,10, Una, doas, tres, in which the poet complains of the extreme vigor of his lady partner's love-making, and the tenso with Imbert = Umberto di Biandrate, PC 236,8, with Italian translation and commentary.]

2496.

Noto, Giuseppe. "Ricezione e reinterpretazione della lirica trobadorica in Italia: la vida di Guillem de la Tor." In 158, Studi Bertolucci Pizzorusso, 2006, 2:1105-37. [A study of the vida of Guillem in relation to other vidas shows that it falls outside of the standard ritualized format in the depiction of Guillem's near insanity but remains within folkloric grieving practices of the time, similar to those found in the epics; separate diplomatic editions of the vida from both $I$ and $K$, critical edition using $I$ as base, with copious notes and Italian translation.]

2497.

Sakari, Aimo. "Une satire virulente de l'amour troubadouresque." In $>152$, Miscellanea Roncaglia, 1989, 4:1211-22. [PC 234,17; Lewent saw this as an unimaginable 
attack on the Marquise de Polignac if it was by Guillem de Saint-Didier; Sakari shows that it is probably by Guillem de la Tor and is a parody of courtly love, in which the lover is a kind of panderer for his beloved, a lady who seems ready to take on the whole mercenary army from the Brabant; critical edition, with French translation, notes.]

\section{PC 238. Guionet (see PC 192. Gui de Cavaillon)}

[Four or five tensos.]

\section{PC 240. Guiraudo lo Ros (Guiraut)}

[End twelfth century; vida; five to eight poems; satirized by the Monge de Montaudon 1195.]

\section{8.}

Finoli, Anna Maria. "Le poesie di Guiraudo lo Ros.” SM, 3rd ser., 15 (1974): 10511106. [Brief introduction; edition of eight poems with Italian translation, notes; poems six and seven are of disputed attribution, and number eight, a partimen with comte Anfos, has "nothing in common with the rest of his corpus."]

2499.

See 256, Harvey and Paterson, Troubadour "Tensos," 2010, 2:691-97. [Critical text with English translation, notes.]

2500.

Rosenstein, Roy. "Guiraudo lo Ros ou le conventionnalisme exemplaire." In $\mathbf{1 3 1}$ Les troubadours et l'état toulousain, 1994, pp. 193-210. [A study of the life, corpus, poetry, originality, and influence of the poet; Guiraudo proves his versatility by parodying himself, in his last tenso, in a sort of auto-pastiche, or fictive tenso, ridiculing his own exemplary stance.]

2501.

See 754, Rosenstein, "Ubi sunt?" 2005. [Alis, the real name hidden under the senhal Alixandres or Belhs Alixandres in two poems by Guiraudo lo Ros; Alis also appears as an acrostic in a third poem and as a corrected equivocal rhyme in a fourth; out of seven poems, four are found to be addressed to Alis/Elis, thereby confirming securely their attribution to Guiraudo.]

\section{PC 242. Giraut de Bornelh (Guiraut; Borneil)}

[fl. 1160-1200; vida, six razos; ca. seventy-six poems of varied genres, mostly cansos, four with melodies: see 607, van der Werf, Extant, 1984, pp. 160*-65*; a cerebral poet, obsessed with rhetoric and style; for the spelling Giraut, see $\mathbf{2 5 2 0}$, Thomas, "Giraut de Borneil," 1906.]

2502.

Sharman, Ruth Verity. The Cansos and Sirventes of the Troubadour Giraut de Borneil: A Critical Edition. Cambridge: Cambridge University Press, 1989. [An imposing and complex edition, presented in two parts: the cansos first, then the sirventes and other genres, with slightly different methodology and presentation in each; edition of seventy-five poems plus two of dubious attribution, with English translation, notes; 
the vida and seven razos are in the appendix, along with transcriptions of the four melodies; brief glossary, no table of proper names.]

2503.

Nelson, Jan A. "Giraut de Bornelh's Quan la brun'aura s'eslucha: An Experiment in Textual Criticism.” Tenso 9 (1993-94): 1-23 and Tenso 10 (1994-95): 1-8. [A review of Kolsen's and Sharman's editions, with a new critical edition of PC 242,59; discussion of problems in editing troubadour poems, specifically those of Giraut; claims that Kolsen's methodology was inconsistent and arbitrary, with flawed critical apparatus; these weaknesses were not avoided by Sharman; Nelson applies the process of recensio systematically as a starting point, achieving a new critical edition of the poem from fifteen manuscripts, using $B$ as base; very detailed critical apparatus, English translation, notes; there is little difference between the text of Nelson's edition and that of the earlier editions, but it is grounded in firmer methodology.]

2504.

Peyrebrune, Georges. Les Chants de Giraut de Bornelh, troubadour limousin (XII s.). Tulle: Éditions Lemouzi, 1999. [Many historical points are usefully clarified, but the poems are arranged artificially before and after the glove incident, with a third rubric "other"; a popular edition, does not replace Kolsen or Sharman.]

2505.

Beltrami, Pietro G. Giraut de Borneil e altri trovatori del XII secolo: scelta dei testi. Pescara: Libreria dell'Università di Pescara, 1998. [Materials for a university course; brief introduction to Giraut's life and works; texts of the vida, a selection of twentyone poems by Giraut and twenty by his contemporaries, no translation, no notes; reproduction of two classic studies on Giraut by Salverda de Grave, 1938, and Picchio Simonelli, 1974.]

2506.

Beltrami, Pietro G. "Giraut de Borneil plan e clus." In $>$ 115, Interpretazioni, 2001, pp. 7-43. [Stresses that Giraut's poetry was composed to be interpreted on a variety of levels; trobar clus and trobar plan have no special significance, since he worked in a free manner, using whatever forms or styles were appropriate for each poem.

2507.

Beltrami, Pietro G. "Giraut de Borneil, la pastorella 'alla provenzale' e il moralismo cortese.” ZfSL 111 (2001): 138-64. [Analysis of Giraut's Lo dolz chans d'un auzel alongside two other poems by him and three by Marcabru, tracing the early history and development of the pastorela as an Occitan genre, varied in its basic morality and attitudes toward the relationship between poet and shepherdess, unlike the same genre in northern France, strongly ritualized in action and social divisions.]

2508.

Corcoran, Mary Cynthia. "Song 53 of Giraut de Bornelh: Nonsense Rhyme or Lover's Lament?" NM 88 (1987): 320-30. [Edition and commentary of Un sonet fatz malvatz e bo, with English translation; instead of the traditional interpretation of the poem as the depiction of a lover so perturbed by rejected love that his thoughts are confused and contradictory to the point of insanity, Corcoran suggests that the poet 
was consciously but indirectly criticizing his domna and threatening to leave her for a more accommodating uncourtly sweetheart; Sharman, unaware of this article for her edition of 1989, has maintained traditional readings of several lines.]

\section{9.}

Corcoran, Mary Cynthia. "Ambiguous Vocabulary and Expression of Emotion in Giraut de Borneil's Gen maten.” MAev 59 (1990): 275-88. [An exploration of various interpretations of Giraut's song depending on the meaning given to vague or ambiguous words and expressions; the poem may express the standard submission of the lover or the bitterness of rejected love-or both.]

2510.

Di Girolamo, Costanzo. "L'angelo dell'alba: una rilettura di Reis glorios." CN 69 (2009): 59-90. [Review of previous studies of corpus, chronology, and genre definitions of the alba; a close study of Girart's alba within its cultural and philological history; new critical edition based on Mün, six stanzas only, with diplomatic transcriptions of all five additional apocryphal stanzas; claims that the meaning of the poem is deliberately ambiguous, to be understood on both erotic and religious levels; the origins of the poem and its melody are connected to the liturgical tradition of morning prayers; the watchman is the protagonist's guardian angel, trying to save him from sin and darkness, but the erotic level is ambiguously present and would have been appreciated by a contemporary audience; also available online, 2009, at http://www.rialto.unina.it, with paleographical introduction, complete text with Italian translation of the first six stanzas, without literary commentary.]

\section{1.}

See 803, Gaunt, Troubadours and Irony, 1989, pp. 145-82. [Points out Giraut's sense of humor and liveliness; he uses all forms of classic rhetorical irony as well as sexual innuendo to criticize his lady and the courtly code; detailed analysis of Ailas, co muer, PC 242,3, which would have to be imagined in a performance to realize the full comic effect of his mockery of love's suffering; Giraut's comments on trobar leu are clearly ironic, and he seems to have composed frequently in both clus and leu styles, wanting to be popularly understood, but ironically scornful of audiences who wanted easy poetry.]

\section{2.}

Kay, Sarah. "Text(s) and Meaning(s) in the alba of Giraut de Bornelh." In The Art of Reading: Essays in Memory of Dorothy Gabe Coleman. Edited by Philip Ford and Gillian Jondorf. Cambridge: Cambridge French Colloquium, 1998, pp. 1-10. [Rich and provocative analysis of the poem in the light of its many intertextual and referential complexities; the poem in its mouvance contains many intertwined meanings and suggestions that defy any straightforward untangling.]

\section{3.}

Majorossy, Imre. "Le troubadour prend congé: Giraut de Borneil." In 1516, Amors es bona volontatz, 2006, pp. 49-61. [Analysis of the sirventes PC 242,26, Be veg e conosc, which paints the world blackly as the source of all sin; as in Ecclesiastes and Job, we must show blind faith in God and seek repentance; the poet reveals a direct, 
mystical rapport with God, as also in his alba and two crusade songs, to the point where he seems almost to be condemning fin'amor.]

2514.

Peyrebrune, Georges. "Giraut de Bornelh: planh du vicomte de Limoges, Adhémar V, décédé en 1199." Lemouzi 98 (1986): 127-39. [Outlines the historical and biographical background of Giraut and his time, especially his connection with Adhemar and with his rival Richard Coeur-de-lion, then links many indirect references in Giraut's planh to precise factual happenings, revealing a rich historical and moral commentary; Giraut's planh for Adhemar is compared with that of Gaucelm Faidit for Richard, showing that the two troubadours distinguished with precision the best qualities of each lord.]

\section{5.}

Peyrebrune, Georges. "Sirventès de Giraut de Bornelh: réplique au planh de Gaucelm Faidit après la mort de Richard Coeur de Lion." Lemouzi 129 (1994): 49-61. [Edition and study of PC 242,73, Si per mon Sobretotz, with French translation, detailed commentary; Giraut is shocked at the planh of Gaucelm Faidit, seeing it as a false glorification of Richard; Giraut himself paints an entirely negative portrait of Richard and his actions.]

2516.

See 2126, Poe, "Strange Bedfellows," 1993. [Alfonso II’s "marriage" of Giraut de Bornelh's cansos to Bertran de Born is a joke for the initiated; the biographer is laughing at Alfonso, Giraut de Bornelh and Bertran de Born.]

2517.

See 2210, Riquer, "El guante robado," 1991. [Study of the literary motif of the gift given by the lady to the troubadour; specifically the motif of the glove in Castelloza's Ja de chantar non degr'aver talan in relation to other gifts in the masculine poetry of Giraut de Bornelh, Peire Vidal, Cerveri, etc.; the poem is given in appendix, with Spanish translation.]

2518.

Riquer, Martin de. "Zu Giraut de Bornelh und seiner alba: Reis glorios." In 155, Romania cantat, 1980, 2:341-44. [Claims that Giraut is a subtle and masterful poet and that PC 242,64 is rich in suggestiveness, along with its pure and straightforward presentation; although Picchio Simonelli, 1974, convincingly shows its religious side and declares the seventh stanza apocryphal, Riquer is unwilling to give up the concluding replique and maintains that the poem is essentially profane, with religious coloring; Spence calls it transitional in \$ 897, "Revelations as Intertext," 1981; Fuente Cornejo concludes for profane in \$ 506, "Canción de alba," 2003.] 2519.

Sigal, Gale. "Reis glorios: An Inverted alba?" Medieval Perspectives 4-5 (1989-90): 185-95. [Giraut's poem speaks more explicitly to the bond between the two male companions than to that of the two lovers; the companion implores God's aid in spite of his friend's sin; Sigal makes the point that there is no standard alba: each one is exceptional.] 
2520.

Thomas, Antoine. “Giraut de Borneil ou Guiraut de Bornelh.” Rom 35 (1906): 106-9. [Shows that the poet's name, of Germanic origin, should be pronounced with a palatalized ds and written as Girart (not Guiraut), following the phonetic traditions of the Dordogne; the family name should be Borneil, not Bornelh, since $l h$ was not used for palatalized $l$ before the end of the twelfth century.]

2521.

See 518, Zufferey, "L'aube de Cadenet," 2010. [A searching reevaluation of the typical alba structures; a study of parallels between Cadenet's poem PC 106,14 and Giraut de Bornelh's Reis glorios sheds new light on Giraut's alba and confirms the authenticity of the final stanza, which is essential to the poem's meaning.]

\section{PC 242a. Guiraut de Cabreira}

[fl. 1145-79; composed the ensenhamen: Cabra joglar; see 22.5.a.]

\section{PC 243. Guiraut de Calanso}

[fl. 1202-12; vida; eleven poems, including one allegorical canso: Celeis cui am de cor e de saber, PC 243,2, for which see 22.2.d; also composed the sirventes-ensenhamen critical of his joglar Fadet: Fadet joglar, for which see 22.5.a.]

2522.

See 1440, Pirot, Recherches, 1972, pp. 197-261 and pp. 563-95. [Survey of previous scholarship, historical background; brief analysis of Guiraut's entire corpus, dating; diplomatic editions of both manuscripts are followed by critical editions and French translation, stanza by stanza; constant references in notes are made to the study and edition by W. Keller, RF 22 (1908): 99-238.]

\section{PC 244. Guiraut d'Espanha}

[ $f$. 1245-65; ca. sixteen poems, of which ten are dansas, one with music, as well as a pastorela in the form of a dance and a graceful baladeta; seven poems are dedicated to the countess Beatrice of Provence, the wife of Charles of Anjou.]

\section{3.}

Hoby, Otto. Die Lieder des Trobadors Guiraut d'Espanha. Freiburg: St. Paulus, 1915. [Edition of fourteen poems, plus three of doubtful attribution, with German translation, notes.]

\section{4.}

Radaelli, Anna. "Pastorella danzante (BdT 244,8)." In 107, Ab nou cor, 2004, pp. 263-86. [Study of the structure and language of the dansa genre, noting a number of features typical of northern French traditions; edition of Guiraut's poem, with Italian translation, copious notes.]

2525.

Radaelli, Anna. Dansas provenzali del XIII secolo. Appunti di genere ed edizione critica. Florence: Alinea, 2004. [Critical edition of twenty dansas, with introduction, Italian translation, notes; all are anonymous except for six by Guiraut d' Espanha.] 
2526.

See 227, Riquer, 1975, 3:1386-91. [Introduction, edition of the dansa PC 244,12 and the pastorela in dance form, PC 244,8, with Spanish translation, notes.]

\section{PC 248. Guiraut Riquier}

[fl. 1254-92; ca. 105 poems, forty-eight with melodies: see $\mathbf{6 0 7}$, van der Werf, Extant, 1984, pp. 166*-214*; his Libre comprises three series of poems, all dated;

the first has fifty-seven songs, made up of cansos, vers, retroenchas, and religious poems to the Virgin; the second has six pastorelas forming a unit; the third has six lyrics of various genres; in addition there are fifteen didactic verse epistles and ca. twenty tensos shared with other poets; his request to Alfonso X for professional distinctions among classes of poets, Supplicatio, was answered by Alfonso's Declaratio; he analyzed a poem by Guiraut de Calanson in his Exposition.]

\section{Editions}

[The only complete edition is by Pfaff, 1853, but the various groups of Guiraut's output have since been edited separately.]

2527.

Mölk, Ulrich. Guiraut Riquier: Las Cansos: Kritischer Text und Kommentar. Studia Romanica, 2. Heidelberg: Winter, 1962. [Introduction; critical edition of twentyseven poems, with notes, no translation, brief glossary.]

2528.

Longobardi, Monica. "I vers del trovatore Guiraut Riquier." SMV 29 (1982-83): 17-163. [Brief philological introduction, edition of twenty-six vers (number twelve is missing from both manuscripts), with Italian translation, notes.]

\section{9.}

Linskill, Joseph. Les Epîtres de Guiraut Riquier, troubadour du XIIIe siècle: edition critique avec traduction et notes. London: AIEO, 1985. [Edition of the fifteen epistles, with French translation, an index of proper names, notes on grammar and versification, glossary.]

2530 .

Betti, Maria Pia. "Le tenzoni del trovatore Guiraut Riquier." SMV 44 (1998): 7-193. [Edition of fifteen tensos, all except the five edited by Guida in $\mathbf{1 8 9 9}$, Jocs poetici, 1983; rich introduction and study, texts with Italian translation; included is the tenso with four participants, PC 248,77 = 272,1 = 403,1 = 319,7a, which is also online, 2002, at http://www.rialto.unina.it, and in 256, Harvey and Paterson, Troubadour "Tensos," 2010, 2:811-17.]

2531.

See 1517, Oroz Arizcuren, La lirica religiosa, 1972, pp. 208-95. [Edition of fourteen religious poems by Guiraut, with Spanish translation, notes.]

2532.

Bertolucci Pizzorusso, Valeria. "Un progetto di edizione del Libre di Guiraut Riquier ed alter osservazioni." Tenso 9.2 (1994): 106-25. [Outline of the state of Riquier scholarship; she intends to edit all of Guiraut's works, 101 poems in eight genres).] 
2533.

Bertolucci Pizzorusso, Valeria. "La Supplica di Guiraut Riquier e la risposta di Alfonso X di Castiglia." SMV 14 (1966): 10-135. [Guiraut requested an official declaration to define the distinctions among the various classes of poets and performers and was answered by Alfonso in his Declaratio, which was probably formulated by Guiraut himself; edition with Italian translation and commentary.]

2534.

See 227, Riquer, 1975, 3:1609-46. [Introduction, edition of a serena PC 248,4, a retroencha, PC 248,65, a song of repentance to the Virgin, PC 248,44, a sirventes critical of his patron Alfonso X, PC 248,68, and the complete series of six pastorelas written over twenty-two years.]

2535.

Studies

Bertolucci, Valeria. "Il canzoniere di un trovatore: il libro di Guiraut Riquier." In her Morfologie del testo médiévale. Bologna: Il Mulino, 1989, chapter 6, pp. 87-124. [An edition of the eighty-six rubrics that structure Guiraut's Libre; shows that Guiraut structured his collection rationally for didactic purposes, as a manual of poetic composition for less experienced troubadours; in appendix, the rubrics of the poems of Joan Esteve, PC 266, and Raimon Gaucelm, PC 401.]

\section{6.}

Bertolucci Pizzorusso, Valeria. "Strategie testuali per una morte lirica: Belh deport." In Convergences médiévales, épopée, lyrique, roman: Mélanges offerts à Madeleine Tyssens. Edited by Nadine Henrard et al. Brussels: De Boeck université, 2001, pp. 89-102. [The senhal is traced through a long succession of poems to show that it refers to the Virgin Mary as well as to the memory of a real lady; the double presence of Belh Deport holds together the long cyclical story of Guiraut's poetic life and mission.]

2537.

Bertolucci Pizzorusso, Valeria. "Guiraut Riquier e il genere della pastorella." In - 162, Trobadors a la Península Ibèrica, 2006, pp. 121-33. [Reviews recent scholarly work on Guiraut; study of the cycle of six dated pastorelas, showing their physical and moral progression toward Guiraut's conclusion that the only true motivation for poetry is the praise of God and the Virgin.]

2538.

Billy, Dominique. "La canso redonda ou les déconvenues d'un genre." MR 11 (1986): 369-78. [Structural analysis of the two very different poems that Guiraut labeled canso redonda, showing the characteristic evolutive progression of timbres in one case, of beginning and ending lines in the other, leading in both cases to a song that ends just where it is ready to start all over again, and which therefore cannot have a tornada; the term redonda was used descriptively and does not indicate a new genre.]

2539.

Bossy, Michel-André. "Cyclical Composition in Guiraut Riquier's Book of Poems.” Speculum 66 (1991): 277-93. [Several troubadours may have collected their own 
poems, but only Guiraut has left clear evidence that he arranged the disparate poems in his Libre into a coherent entity, showing date, genre, and numerical ordering for each poem; Bossy analyzes Guiraut's grand overall design, with its complex arithmetic symmetries of distribution, and its goal of narrating his personal poetical career; in appendix a detailed outline of the arrangement of poems, showing the numerical presentation of the various elements.]

\section{0.}

Bossy, Michel-André. "Twin Flocks: Guiraut Riquier's pastorelas and His Book of Songs." Tenso 9.2 (1994): 149-76. [Studies the interlinking of the pastorela cycle with the main body of his works, revealing the closely coordinated numeric architecture of his libre; the pastorela cycle provides a key to the harmonic balance of the whole.]

2541.

Bossy, Michel-André. "Cours méditerranéennes et politique d'empire dans le chansonnier de Guiraut Riquier." SMV 42 (1996): 67-78. [Analysis of references to contemporary historical events in three poems, PC 248,66, 79, and 62; examines the enmity, then reconciliation, of the viscounts of Narbonne with the Capetians, which may have caused some adjustments to Guiraut's Libre.]

2542.

Bossy, Michel-André. "The Ins and Outs of Court: Guiraut Riquier's Poetics of Ostracism." In 106, ICLS 9, 2003, pp. 275-84. [The saga of Guiraut's quest for honor, distinction, and wealth across the courts of southern France and Spain, as told indirectly in his Libre; his criticism of vulgar and nonprofessional poets turns gradually toward bitterness as he laments the decline of true nobility and the impossibility of finding the ideal patron.]

\section{3.}

Capusso, Maria Grazia. L'exposition di Guiraut Riquier sulla canzone di Guiraut di Calanson "Celeis cui am de cor e de saber." Ospedaletto: Pacini, 1989. This is a corrected and updated version of the articles in SMV 30 (1984): 117-66 and 31 (1985): 5-189. [A study of Guiraut de Calanson's poem, pp. 37-46, Guiraut Riquier's Exposition, pp. 47-97, and the Testimoni, a sort of guarantee of authenticity, pp. 98-109; critical edition of the Exposition, with Italian translation, detailed notes; see comments and corrections by G. Gouiran, RLaR, 93 (1989): 476-82.]

2544.

Cholakian, Rouben. "Riquier's Letras: An Epistemology of Self." Tenso 11 (1996): 129-47. [Study of the fifteen verse epistles, revealing the persona's personality, critical of society, obsessed with himself.]

\section{5.}

Hogetoorn, Corry. "Une vie de femme au XIIIe siècle: la bergeira de Guiraut Riquier." In 97, AIEO 4, 1994, pp. 139-46. [Analysis of the cycle of six pastorelas composed over twenty-two years that tell of Guiraut's acquaintance with a humble woman, depicted as a shepherdess, then a mother, a widow, an innkeeper, giving a rare glimpse of an ordinary woman of the time at various stages of her life.] 
2546.

Holmes, Olivia. Assembling the Lyric Self: Authorship from Troubadour Song to Italian Poetry Book. Minneapolis: University of Minnesota Press, 2000, pp. 101-19. [A study of Guiraut as a poet conscious of the decline of Occitan culture, who compiled his own work into a coherently structured book per la sua man; the chronological ordering constructs a fictional world, and an official, authoritative version of his poems; other semilegalistic works, his Suplicatio and Declaratio, and his explication of a poem by Guiraut de Calanson, are analyzed as indications of the poet's wish to stabilize officially the expression of poetry in the vernacular.]

2547.

Longobardi, Monica. "Osservazioni metrico-retoriche sui vers di Guiraut Riquier." SMV 31 (1985): 247-57. [Of Guiraut's twenty-six vers, eight are unique in metric structure and four others are rare; no rhyme schemes have been borrowed; wordrhymes are used often, sometimes with great complexity, two pairs of nine in vers XXI; in all his works, Guiraut displays dense and virtuosic originality, but it is at its highest development in the vers; in appendix, a table showing metrical schemes in all the vers, with detailed notes.]

\section{8.}

Longobardi, Monica. "Sondaggi retorici nelle epistole di Guiraut Riquier. Figure di ripetizione e proverbio.” CDT 6 (2003): 665-720. [Rhetorical study of the fifteen epistles to establish their argumentative and expository structures; figures of speech, proverbs.]

\section{9.}

Minetti, Francesco Filippo. Il libre di Guiraut Riquier secondo il codice 22543 della Nazionale di Parigi con la varia lectio dell'856 (C). Parte prima. Turin: Giappichelli, 1980. [Edition of the first twelve poems in the Libre, with one religious poem, number twenty-one; edition with full annotation from $R$, with Italian translation and varia lectio from $C$.]

2550.

See 494, Paden, Medieval Pastourelle, 1987. [Texts of twenty-five Occitan pastorelas by fifteen poets, including the six by Guiraut Riquier, with English translation, succinct textual notes.]

2551.

Pfeffer, Wendy. "Guiraut Riquier and the Study of Proverbs." Tenso 11.2 (1996): 148-62. [Guiraut was sparing in the use of proverbs, using only twenty in his eightyeight lyric and debate poems, but they are more frequent in those composed in Castile at the court of Alfonso X.]

2552.

Phan, Chantal. "Le style poético-musical de Guiraut Riquier." Rom 108 (1987): 66-78. [Guiraut's texts show an acrobatic virtuosity in metrical structure; a detailed analysis of his musical style reveals a constant and very close link between versification and melody; his keywords are consistently emphasized by musical sonorities, along with assonance and alliteration; the use of melismas emphasizing key vocabulary and 
syntax strongly underlines the message; overall, Phan finds that Guiraut has managed to use very rigid formal structures without sacrificing the equilibrium of meaning, phonetic patterns, and musicality; he has brought the traditional techniques of troubadour song to a high point of synthesis while innovating in the concepts of interstrophic symmetry and written indications of melismas, both of which signal the end of oral transmission.]

2553.

Phan, Chantal. "Structures poético-musicales du chant mélismatique chez Guiraut Riquier et Alphonse le Sage.” Tenso 11.2 (1996): 163-78. [Melismas are carefully planned, not calling for improvisation by the performer; they point the way, as in the melodies of Alfonso, to the more fixed musical forms of the fourteenth century.] 2554.

See 404, Riquer, Isabel de. "Lo donars," 2006, pp. 311-33. [Analysis of the theme of liberality, especially among the later troubadours after the Albigensian Crusade: Guiraut Riquier and other poets in Spain and at the court of Rodez, who were anxious to be treated as professionals; a list of the nine tensos between Guiraut Riquier and various poets.]

2555.

Zink, Michel. "Guiraut Riquier, du premier au dernier vers." In Devis d'amitié: Mélanges en l'honneur de Nicole Cazauran. Edited by Jean Lecointe, Catherine Magnien, Isabelle Pantin, and Marie-Claire Thomine. Paris: Champion, 2002, pp. 511-23. [Believes that Guiraut was looking back with nostalgia when he made up his Libre; the poetry evolves from profane to sacred, in the pastorela cycle as well as overall; close analysis, with text, of two poems: PC 248,1, Ab lo temps agradiu gai, and PC 248,17, Be.m degra de chantar tener.]

\section{PC 249a. Domna H}

[fl. after 1230-40; perhaps from northern Italy, more likely from Provence; one tenso with Rofin, PC 249a, 1 = 426,1; Rofin may be a nickname (Rosin, Rofian?), "hack, nag" or "libertine, dissolute"?]

\section{6.}

See 735, A. Rieger, Trobairitz, 1991, pp. 291-306. [Thorough investigation of possibilities for identifying the participants, with no definite conclusion, though Rieger suggests Hugueta of Baux as a possibility; survey of scholarship on the reality or fiction of the asag; new critical edition of the tenso, with German translation, notes.]

2557.

Blakeslee, Merritt R. "H., Domna." In 46, Women in the Middle Ages, 2004, pp. 401-3. [Outline of the inconclusive research concerning the identity of Rofin and Domna H; believes that the transposition of sex roles and the exaggerated rhetoric of the lady indicate that the poem is a playful fiction, a satirical subversion of the fin'amor ethic.]

2558.

See 733, Bruckner/Shepard/White, Songs of the Women Troubadours, 1995, pp. 
xxx-xxxii, 172-73. [Agrees with A. Rieger that Hugueta of Baux may provide the historical identity of Domna $\mathrm{H}$, since she was closely linked to the court of Raymond Berenguer IV; another candidate may be some member of the Este family in northern Italy; edition of the tenso, with English translation, notes.]

2559.

See 256, Harvey and Paterson, Troubadour “Tensos," 2010, 2:829-40. [Critical edition, with English translation, copious notes; Rofin is tentatively identified as Rufinus, a twelfthcentury canon lawyer and expert in sexual law, here parodied for humorous purposes; the ladies chosen as arbiters may add a further ironic reversal, Cobeitosa suggesting lustfulness, Agnesina innocence.]

\section{PC 252. Isabella (Ysabella)}

[Unknown; late twelfth or early thirteenth century; one intensely personal tenso with Elias Cairel; she may be the anonymous Dona in a tenso, PC 296,1a, with Albert Marques (PC 15): see 735, A. Rieger, Trobairitz, 1991, pp. 356-66.] 2560.

See 256, Harvey and Paterson, Troubadour "Tensos," 2010, 2:841-49. [Introduction and edition of PC 252,1 = 133,7, with English translation, notes; the poem dates from 1204-6, while Elias Cairel was in Greece; Isabella is identified as Isabella dalle Carceri.]

2561.

See 735, A. Rieger, Trobairitz, 1991, pp. 275-90. [Introduction, critical text of the tenso, with German translation, notes; presentation of the historical background which places Isabella with Elias Cairel in Greece with Boniface I of Montferrat during the Fourth Crusade; the trobairitz is thought to be either Isabella of Montferrat or Isabella Malaspina; stresses the unconventional attitudes of both Isabella and Elias, as they move back and forth over the borderline between reality and courtly ritual.]

2562.

Blakeslee, Merritt R. "Ysabella, Domna." In $>$ 46, Women in the Middle Ages, 2004, pp. 964-65. [Outlines the scholarship concerning Isabella's identity; points to the unusual exchange, in which the lady berates the poet for leaving her for another, while he claims that his professed love was not real but only part of the courtly ritual.]

Iselda (Yselda)—_ee Alaisina Yselda

PC 253. Iseut de Capion (Chapieu)

[Late twelfth century; vida; one stanza extant, as a fragmentary tenso or part of an exchange of coblas with Almuc de Castelnou

(Almois de Chateauneuf), PC 253,1= PC 20,2.]

2563.

See 735, A. Rieger, Trobairitz, 1991, pp. 166-73. [Text of the razo from Boutière/ Schutz; critical edition of the fragmentary tenso, with German translation, notes, detailed commentary; points out the close relationship to Uc de Saint Circ's Anc 
enemics, PC 457,3, which served as model; the anonymous cobla 461,102b may have been originally part of this poem or of Uc's.]

2564.

McCash, June Hall. "Iseut de Capio." In 46, Women in the Middle Ages, 2004, pp. 459-60. [Born ca. 1140; one stanza of a tenso with Almuc de Castelnou, in which she intervenes with Almuc on behalf of Gui de Tournon, who committed some unspecified deceit against Almuc; Almuc is unrelenting but promises to reconsider if Iseut can make him truly repent.]

2565.

See 1902, Colrat de Montrozier, "Amour parodique," 2008. [Detailed genealogical history of the Tournel dynasty and the families of Almuc and Iseut; supposes their acquaintance with Uc de Saint Circ, because of parallel language in their poem and his PC 457,3; suspects that the poem may be a humorous prank.]

2566.

Dronke, Peter. Women Writers of the Middle Ages: A Critical Study of Texts from Perpetua (†203) to Marguerite Porete ( $† 1310)$. Cambridge: Cambridge University Press, 1984. [Pp. 100-101: presents an exchange of coblas between Almuc de Castelnou and Iseut de Capio; the text is reproduced, with English translation; Dronke detects an ironic edge in Iseut's language, with its echoes of suggestively religious vocabulary; the lover is being examined with a sardonic eye, and the active choice to forgive is the woman's.]

\section{PC 262. Jaufre Rudel}

[f. 1120-48; but see a new hypothesis of Lug, below, proposing a birth ca. 1190, death ca. 1220; vida, six songs, plus one of doubtful attribution; four preserved melodies: see 607, van der Werf, Extant, 1984, pp. 215*-22*.]

2567.

Pickens, Rupert T. The Songs of Jaufre Rudel. Toronto: Pontifical Institute of Mediaeval Studies, 1978. [Introduction on Jaufre's life, study of the manuscript tradition; edition of the vida and six songs in all extant versions, plus one poem of dubious attribution, Qui no sap esser chantaire, all with English translation, notes, glossary, table of proper names.]

\section{8.}

Wolf, George, and Roy Rosenstein. The Poetry of Cercamon and Jaufre Rudel. Garland Library of Medieval Literature, Series A, 5. New York: Garland, 1983, pp. 92-173. [The vida and historical background, evaluation of Jaufre's artistry, sources and influence; edition of six poems, with English translation, notes; pp. 175-202: a study of Jaufre's music by Hendrik van der Werf, with manuscript reproductions and transcriptions of the four extant melodies.]

2569.

Chiarini, Giorgio. Il canzioniere di Jaufre Rudel. L'Aquila: Japadre, 1985. Also as: L'amore di lontano. Rome: Carocci, 2003. [Introductory commentary in which Jaufre epitomizes the existential drama of medieval Christianity, condemned by destiny to be drawn between earth and heaven, sai and lai; edition of the vida and seven poems, 
with Italian translation, full glossary; poem seven, Qui no sap esser chantaire, is probably not by Jaufre.]

2570.

Allegretto, Manuela. Il "luogo dell'amore": Studio su Jaufre Rudel. Biblioteca dell'Archivum romanicum, 1, 146. Florence: Olschki, 1979. [Outline of previous research; analysis of Jaufre's spring opening links it to the notion of perfect love, in harmony with the cosmos; lonh and lonc are blended into designation of both time and space, and lai adverb of space is used especially for dreamed or remembered time; the themes of the poetic power of the dream and the impersonal nature of the beloved suggest the later developments of the stilnovisti.]

2571.

Bec, Pierre. "La postérité poétique de Jaufre Rudel et de son amour de loin." RLaR 113 (2009): 139-76. [Studies the creation of the myth of amor de lonh as a poetic force capable of regeneration at different historical moments and in different cultures, symbolizing the necessary element of separation, the perpetually unsatisfied desire that energizes poetic creation; see also the complementary work by A. Rieger, -79, Trobador-Mythen, 2005.]

2572.

See 363, Bloch, Medieval Misogyny, 1991. [Claims that Jaufre Rudel desires not the Lady, whose distance makes her difficult to attain, and therefore most worthy, but her absence; the paradox of virginity makes the absent lady the most desirable; he loves only an abstraction.]

2573.

Cholakian, Rouben C. "Love by Remote Control." In $\mathbf{8 3 2}$, Troubadour Lyric, 1990, chapter 5, pp. 83-116. [Would like to discover not who Jaufre's lady is in history but what she represents psychologically; finds egocentrism, narcissism, fear of sexual impotence, yearning for motherly passive love; the poet cannot decide between carnal and spiritual love but wants both.]

2574.

Gambino, Francesca. "Osservazioni sulle attribuzioni 'inverosimili' nella tradizione manoscritta provenzale (I).” In > 99, AIEO 6, 2001, pp. 372-90. [Jaufre Rudel Qui non sap esser, PC 262,7, is usually considered of doubtful attribution except by Lafont, 1992; another, PC 190,1, denied to Jaufre may indeed be his according to Lafont, in spite of the fact that Grimoart names himself in the poem; these two cases illustrate the vicious circle of attribution decisions made on the basis of style, vocabulary, structure or themes, or especially on the basis of a poet's typical tone.]

2575.

Gaunt, Simon. "Peire d'Alvernha affronte Jaufre Rudel: les troubadours et la deuxième croisade." In La Croisade, réalités et fictions: Actes du colloque d'Amiens. Göppinger Arbeiten zur Germanistik, 503. Lauterburg: Kümmerle, 1989, pp. 119-31. [Study of poems by Peire d'Alvernhe and Marcabru that use intertextual irony to turn around Jaufre Rudel's popular images of sensual love, to speak instead in favor of spiritual values, specifically the virtue of going on crusade; Jaufre seems to have 
changed his mind in PC 262,6, Quan lo rossinhols el foillos, perhaps in response to their opinions; new critical edition of Peire d'Alvernhe's Al dessebrar del païs (PC 323,3), with French translation.]

\section{6.}

Gerez, Pau. "Jaufré Rudel's 'Love from Afar' and Distant Love via Chat; a Metaphorical Approach.” Digithum 8 (2006): 1-6. Online at http://digithum.uoc.edu/ ojs/index.php/digithum/. [A whimsical look at the nature of Rudel's love, which is compared to modern-day chat relationships.]

2577.

Gruber, Jörn. "L'art poétique de Jaufre Rudel. Analyse philologique, musicologique et herméneutique de la chanson No sap chantar qui so non di (262,3)." In La Chanson française et son histoire. Edited by Dietmar Rieger. Tübingen: Gunter Narr, 1988, pp. 15-25. [Scholars have attempted many different interpretations of Jaufre's song without success; Gruber's close study of themes, structure, and music in the first stanza reveals a complex parodic interplay with poems of Guilhem de Peitieus, in which a dialectic principle of inversion controls the delicate new statement, a refined and systematic contradiction of Guilhem's poetic message in all its elements, razo, motz, and son.]

2578.

Gubbini, Gaia. “Auzelhs de lonh.” CDT 12.2-3 (2009): 39-47. [A probable source for Jaufre's link between the sweet singing of far-off birds and the memory of a distant love is found in the tradition of Cicero's Rhetorica ad Herrenium, where the link between vium dulcedo "sweetness of bird-song" and -vium "remote, far-off land" is used as an example for annominatio, repeated further in Isodore's Etymologia and elsewhere; the figure is known and used by Jaufre in several poems.]

\section{9.}

Kay, Sarah. "Continuation as Criticism: The Case of Jaufre Rudel.” MAev 56 (1987): 46-64. [A close analysis of the continuing transmission of Jaufre's poetry from the thirteenth century on, in an attempt to discern the understanding that later poets and copyists had of his songs and how they changed them to fit their own interpretations; a plea to look more carefully at the intuitions displayed by later writers, even though they may seem less worthy of attention than our own attempts at reconstruction.]

2580 .

Lug, Robert. "Jaufre Rudel rajeuni." In Jaufre Rudel, prince, amant et poète; trobada tenue à Blaye les 24 et 25 juin 2011. Moustier Ventadour: Carrefour Ventadour, 2012, pp. 57-79. [New interpretation of the life and works of Jaufre that places his poem Lanquan li jorn and its melody toward 1219 instead of the traditional date of 1147; Lug claims that the Marcabru who dedicated the song PC 293,15 to Jaufre Rudel outra mar was a different Marcabru, and that the crusade was the fifth, in which Jaufre may have participated and died in 1219 or 1220; the "legendary" countess of Tripoli was in fact the historically real Melisande of Lusignan, married to Count Boémond IV of Tripoli in January 1218; if these hypotheses are confirmed, much of the early history of trobar will have to be reconsidered.] 
2581.

Majorossy, Imre. "La confiance mystique: Jaufre Rudel." In 1516 , Amors es bona volontatz, 2006, pp. 15-25. [Finds new subtle meaning under some of Jaufre's vocabulary, suggesting that there is a tendency toward mysticism, stemming from the confidence with which the poet places himself in the hands of God; claims that in Lancan li jorn the love between man and woman is treated as a means to approach the deity.] 2582.

See 2364, Manetti and Vatteroni, "Osservazioni sul primo," 2009. [Manetti, pp. 17-37: review of previous research; cannot fix precise dates for Jaufre Rudel; several intertextual indications that Guilhem de Peitieus reacted by parody to verses of Jaufre must remain hypothetical; attempts to identify the poet with his son, Guilhem X, have not been persuasive; the relative chronology of Jaufre and Guilhem cannot be certain, but Guilhem does seem to be parodying a poem very similar to some of Jaufre's.]

\section{3.}

Rosenstein, Roy. "Les années d'apprentissage du troubadour Jaufre Rudel: de l'escola N'Eblo à la segura escola." AM 100 (1988): 7-15. Also in English: "Retour aux origines du troubadour Jaufre Rudel: L'escola N'Eblo," in \160, Studia Riquer, 1986-91, 2:603-11. [Archival documents point to earlier dates for Jaufre's poetry, 1120-47; Pirot speculated that Jaufre might have spent his early years at the court of Guilhem de Peitieus, alongside Marcabru and Cercamon, but Rosenstein finds it more likely that he joined Bernart de Ventadorn at the court of Ebles II; Bernart is clearly attached to the "school of Ebles," and Jaufre's Pro ai del chan has several parallels with Bernart's poems that show his adherence to the same concepts, before he turned away from any prescriptive school in favor of religion.]

2584.

Rosenstein, Roy. "La vida es sueño: grammaires d'absence et de présence dans la vida sostenguda de Jaufre Rudel." In 101, AIEO 8, 2009, 1:171-84. [Analysis of Jaufre Rudel's vida, especially the short version, manuscripts $I K$, stressing the power

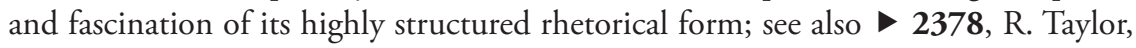
"Assessment," 2006, pp. 881-82, who finds similar powerful rhetorical structures in the vida of Guilhem de Peitieus.]

\section{5.}

See 754, Rosenstein, "Ubi sunt?" 2005. [Sarrazina is identified as the wife of Hugh VII of Lusignan, mentioned at the end of Jaufre Rudel's song Quan lo rius; on her grave, Hugh swore to go on the Second Crusade, where he and probably Jaufre died.] 2586.

Zufferey, François. "Nouvelle approche de l'amour de loin." CN 69 (2009): 7-58. [New interpretation of PC 262,2, liberated from the seven-hundred-year-old legend of the vida; a meticulous study of the manuscript history reveals a double tradition, with three songs of longing for an impossible distant love and three later poems in which the poet seeks reciprocity from his domna and mentions the possibility of going on crusade to seek a higher form of devotion; the distant love of Lancan il jorn has nothing to do with crusade or pilgrimage, the two themes having been mixed by 
Uc de Saint Circ in the vida; new critical edition, with French translation, detailed analysis and interpretation.]

\section{PC 266. Johan Esteve (Olier de Bezers)}

[ $f$. 1270-89; eleven songs, one a religious poem preguieyra in the form of a descort, two planhs, three sirventes, three pastorelas (one of which is called a vaqueira), two cansos/retroenchas.]

2587.

See 2044, Hershon, Les troubadours de Béziers, 2001, pp. 75-137. [Edition of the eleven poems, with introduction, French translation, notes.]

\section{8.}

Vatteroni, Sergio. Le poesie del trovatore Johan Esteve. Biblioteca degli Studi medievali e volgari, 10. Pisa: Pacini, 1986. [Critical edition of the eleven songs, with introduction, Italian translation, notes, complete glossary.]

2589.

See 1517, Oroz Arizcuren, La lirica religiosa, 1972, pp. 296-309. [Edition of PC 266,8 , a religious poem called a preguieyra, with Spanish translation.]

2590.

Gouiran, Gérard. "Les troubadours de Béziers." In Béziers, ville occitane? Actes des rencontres tenues à Béziers le 18 novembre 2006. Perpignan: Presses Universitaires de Perpignan, 2007, pp. 9-27. [Analysis of eleven poems by Joan Esteve, along with four by Bernart d'Auriac and nine by Raimon Gaucelm, looking for signs of similarity in style or inspiration that would make them typical of Béziers; found a common bond of religiosity, a new loyalty to the French king, conscious dating of poems which anchors them in time, a simple bourgeois tone, an emphasis on sincerity, and a warm feeling for their town of Béziers.]

2591.

Hershon, Cyril P. “Johan Estève de Béziers: Solutions.” RLaR 96 (1992): 391416. [Adds many informative details to those in Vatteroni's edition; background history of the life and poems of Johan, his relationship with Amalric de Narbonne and with Guillem de Lodève, for each of whom Guillem composed a planh; clarifies also the disaster or massacre in Béziers in 1284 on the Feast of Ascension, which shook Guillem badly and about which he composed a touching and eloquent planh.]

2592.

See 227, Riquer, 1975, 3:1601-8. [Edition of PC 266,6, asking the French king to seek the release of Guilhem de Lodeva, and PC 266,9, the vaqueira.]

2593.

Vatteroni, Sergio. "Quelques considérations sur Johan Esteve, troubadour de Beziers." In Biterris: Béziers et son rayonnement culturel au Moyen Âge. Actes des XIIes "Rencontres de Béziers." Edited by Carlos Heusch. Perpignan: Presses universitaire de l'Univerité de Perpignan, 2003, pp. 25-36. [Considers certain aspects of the personality and works of the poet, and the sociopolitical background in the South after the 
Albigensian Crusade; places Johan in the context of other late bourgeois poets; he and Guiraut Riquier are critical of popular Cathar religiosity of the time.]

2594.

See 249, Bec, Florilege en mineur, 2004, pp. 217-21. [Edition of the planh for Guilhem de Lodêve PC 266,10, with French translation, no notes.]

\section{PC 276. Jordan de l'Isla de Venessi (de l'Isle-sur-Sorgue)}

[Third quarter thirteenth century; one canso, which is also attributed to six other poets, Longa sazon ai estat vas Amor; Heintze says it is a comjat and also a camjar.] 2595.

Squillacioti, Paolo. "BdT 276,1 Longa sazon ai estat vas Amor." RST 2 (2000): 185215. [Careful study of manuscript tradition, prudent restoration of text; detailed discussion of possible attribution to Peire de Maensac, Pons de Capduelh, Cadenet, Rostanh de Merguas, or Jordan de l'Isla de Venessi, with no final decision; critical edition based on $M$, with Italian translation; two other versions of the text are given; see also 2596, Heintze, “Die Rezeption," 2002.]

2596.

Heintze, Michael. "Die Rezeption des provenzalischen Abschiedsliedes in Jacopo Mostaccis Umile core e fino e amoroso." In 156, Das Schöne, 2002, pp. 93-123. [Attempts to define the comjat and to differentiate it from the camjar; analysis of PC 276,1, Longa sazon ai estat vas Amor, compared with Jacopo's song; lists and statistical tables in appendix.]

\section{PC 276a. Jordi de Sant Jordi}

[Early fifteenth century; eighteen poems; not listed by PC because he was considered Catalan, not Occitan; Radatz claims that he wrote basically in Occitan (though many disagree), and that he, not Guiraut Riquier, is truly the last troubadour, born at least a century after Guiraut's death; esteemed as a musician, though no melodies are preserved; he was influenced especially by Peire Vidal and Peire Cardenal; for an analysis of Jordi's rhyme patterns and stanzaic structures, see 3084, Billy, "L'art des réseaux," 2003.]

2597.

Riquer, Martí de, and Lola Badia. Les poesies de Jordi de Sant Jordi: cavaller valencià del segle XV. Valencia: E. Climent, 1984. [Introduction on background history, biography of Jordi; literary study of themes, style, versification; critical edition of eighteen poems, with individual presentation of each, Catalan translation, notes, glossary; in appendix is a chart of metrical forms and rimarium.]

2598.

Roca Ricart, Rafael. Obra poetica. Jordi de Sant Jordi; introducció i edició. Valencia: Edicions Alfons el Magnànim, 1994. [A popular edition, based on that of Riquer and Badia; introduction to the life of Jordi, who lived only twenty-six years; literary evaluation of his poetry; eighteen poems in modern orthography, without notes or translation.] 
2599.

Fratta, Aniello. Poesies. Jordi de Sant Jordi; edició crítica. Barcelona: Editorial Barcino, 2005. [Introduction to Jordi's life; literary analysis of his poetry; study of language, manuscript tradition, and the senhals used; critical edition of eighteen poems, with Catalan translation, glossary, rimarium.]

2600.

Radatz, Hans-Ingo. "Der (wirklich) letzte Trobador: Jordi de Sant Jordi und die okzitanische Sprache." In 125, Okzitanistik, Altokzitanistik, 2000, pp. 133-45. [Claims that the troubadour tradition continued to flourish in Catalunya for one hundred years after it had died out by 1300 in Occitania proper; when Jordi de Sant Jordi died in 1424, the tradition came to its final end; Radatz believes that his poetic language was Occitan, that he was conscious of writing in Occitan; therefore, Jordi is the last troubadour, not Guiraut Riquier.]

2601.

Siviero, Donatella. Jordi de Sant Jordi: L'amoroso cerchio: poesie dell'ultimo trovatore (ca. 1400-1424). Milan: Luni, 1997. [Introduction on bilingualism in Catalan poetry; edition of eighteen poems, with Italian translation, critical and textual notes.]

\title{
2602.
}

Tavani, Giuseppe. "Strutture metriche e strofiche nella poesia di Jordi de Sant Jordi." In Miscellanea di studi romanzi offerta a Giuliano Gasca Queirazza. Edited by Anna Cornagliotti et al. 2 vols. Alessandria: Edizioni dell'Orso, 1988, 2:1033-45. [A study of the metric structure in seventeen of Jordi's poems, all except the Passio amoris; a listing of seven structural types, following the traditional format established by Istvàn Frank, with rimarium and supplementary information.]

2603.

Terry, Arthur. "Jordi de Sant Jordi and the Ethics of Chivalry." In Three FifteenthCentury Valencian Poets. London: Department of Hispanic Studies, Queen Mary and Westfield College, 2000, pp. 24-38. [Introduction on the cultural milieu and biography of Jordi; text and analysis of three poems, with English translation: Presoner, written while he was a prisoner of Francesco Sforza, in which he makes a model statement of the concept of chivalry, Stramps, a delicate love poem addressed to an imaginary lady of exquisite goodness and virtue, and Comiat, a farewell poem in which he leaves his heart behind with his lady but expresses his complex emotions in very direct and personal terms.]

\author{
PC 281. Rambertino Buvalelli \\ (Ramberti, Lamberti de Buvalel, Bonanel, Lambertino) \\ [ $f$. 1201-21; seven poems; he was a judge and diplomat, as well as a poet; \\ probably the first native Italian troubadour.]
}

2604.

Melli, Elio. Rambertino Buvalelli: le poesie. Edizione critica con introduzione, traduzione, note e glossario. Bologna: Pàtron, 1978. [Introduction on biography and political activity; study of themes, structures, intertextual echoes, language, manuscript 
tradition; critical edition of seven poems, plus four of dubious attribution, all with Italian translation, notes, glossary.]

2605.

Capusso, Maria Grazia. "Rambertino Buvalelli, Ges de chantar no'm voill gequir (BdT 281.5).” Lecturae tropatorum 4, 2011. Online at http://www.lt.unina.it. [Detailed introduction to Rambertino and his place in the society of his time; characteristics of his poetry and connections with contemporary troubadours; detailed study of the poem, with stanza-by-stanza commentary; critical edition with Italian translation, copious notes.]

2606.

Verlato, Zeno. Edition of PC 281,3, D'un saluz me voill entremetre, in $\mathbf{5 2 0}$, Gambino, Salutz, 2009, pp. 442-65. [Confirms the probable attribution to Rambertino; codicological study of the six manuscripts; critical text with Italian translation, notes.]

\section{PC 282. Lanfranc Cigala}

[ $f$. 1235-57; vida; thirty-four poems: nine cansos, one chan-plor (planh), PC 282,7, for the death of Lady Luresana, nine tensos, eight sirventes, two crusade songs, four religious poems, one cobla; he was a judge from Genoa, the leader of a group of Italian poets composing in Occitan; the esthetic, spiritualized nature of his love ethic makes him a precursor of the Stilnovisti.]

2607.

Branciforti, Francesco. Il canzoniere di Lanfranco Cigala. Biblioteca dell'Archivum romanicum 37. Florence: Olschki, 1954. [Introduction on biography, historical context, dating, corpus, analysis of his poetic art; edition of vida and thirty-two poems, with Italian translation; see corrections by K. Lewent, Mélanges Li Gotti, 3 vols. Palermo: Centro di studi filologici e linguistici siciliani, 1962, 1:171-92.]

2608.

Capusso, Maria Grazia. "Un duello oitaneggiante: lo scambio di sirventesi Lanfranco Cigala-Lantelmo." In 126, Poeti e poesia, 2006, pp. 9-42. [Analysis of chansonniers that preserve songs of a group of Italian troubadours: Lanfranc Cigala, Bonifaci Calvo, Bartolome Zorzi, and Lantelm; study of an insulting exchange between Lanfranc and Lantelm in two sirventes which are reproduced in appendix, without translation; suggests that the supposed battle of erudition between the two poets, involving references to northern French literature, may be a fictive quarrel composed entirely by Lanfranc Cigala.]

2609.

Radaelli, Anna. "Partimen of Lanfranc Cigala and Rubaut (PC 282.1a = 429.1) Amics Rubaut, de leis, q'am ses bauzia." In 256, Harvey and Paterson, Troubadour "Tensos, "2010, 3:885-90.

2610.

See 227, Riquer, 1975, 3:1359-69. [Introduction, edition of vida and three poems: PC 282, 5, 25, and 10, with Spanish translation, notes.] 


\section{PC 283. Lantelm}

[fl. ca. 1247; one abusive sirventes in response to Lanfranc Cigala's PC 243,1, a partimen with an unknown Raimon and a second sirventes, PC 284,1, listed under Lantelmet d'Agulhon; a joglar associated with the court of the Este, admired and 2611. imitated Bertran de Born's poetry; he may have been blind.]

See 2608, Capusso, "Un duello," 2006. [Suggests that PC 284,1, the supposed battle of erudition between the two poets, involving references to northern French literature, may instead indicate that Lanfranc Cigala composed both poems himself as a "fictive quarrel."]

\section{2.}

See Radaelli, Anna. "Partimen of Lantelm and Raimon (PC $283.2=393.2$ ), Raimond, una dona pros e valenz." In $>$ 256, Harvey and Paterson, Troubadour "Tensos," 2010, 3:913-20. [The participant Raimon is unknown, as are the two ladies asked to serve as arbiters.]

\section{PC 285. Lanza Marques (Manfredi Lancia)}

[fl. 1168-1215; comically abusive exchange of coblas with Peire Vidal, PC 364,19.] 2613.

Noto, Giuseppe. "Lo scambio di coblas tra Manfredi I Lancia e Peire Vidal (e alcune riflessioni sull'Occitania Ligure-Piemontese)." In 126, Poeti e poesia, 2006, pp. 163-88. [Historical background of the court of Boniface I of Montferrat, where both Manfredi and Peire were active in the late twelfth century; penetrating analysis of the semihumorous exchange, in particular its references to traditional costumes and drunken practices of Carnaval, in which the King of Carnaval is tried and condemned; critical edition of PC 285,1 = 364,19 based on that of Avalle 1960, with Italian translation, copious notes.]

\section{PC 287. Linhaura}

[Not a person, but a senhal used by Giraut de Bornelh for Raimbaut d'Aurenga; see PC 389; also applied to a lost romance, from which a sixteen-line résumé is inserted 2614. into the Ensenhamen de l'Escudier (see 22.5.d.), lines 217-33.]

Riquer, Isabel de. "Linhaure: cent ans d'études sur un senhal." RLaR 96 (1992): 41-67. [Wide-ranging study of the circle of colleagues and friends of Raimbaut d'Aurenga, several of whom used Linhaure as a senhal referring to him, in a series of poetic exchanges typical of the golden age of trobar around 1170; the name of the tragic lover Linhaure/Ignaure in narrative is probably unrelated.]

\section{PC 288. Lombarda ( $\mathrm{Na}$ Lombarda)}

[First half thirteenth century; vida; exchange of coblas with Bernart Arnaut IV d'Armagnac: two coblas and a tornada, in response to Bernart's PC 54,1, dated 1213-19.] 
2615.

See 735, A. Rieger, Trobairitz, 1991, pp. 242-54. [New critical edition of the exchange of coblas, with German translation, notes; love and politics are ambiguously mixed in the dialogue; Lombarda herself remains historically unknown, but she comes through as a strong presence, capable of interweaving the themes of fin'amors with political innuendo; the wordplay with senhals and the mirror motif show a poet in full control of the complexities of trobar.]

\section{6.}

Bruckner, Matilda Tomaryn. "Lombarda." In 46, Women in the Middle Ages, 2004, pp. 561-62. [The exchange of coblas with Bernart Arnaut d'Armagnac plays on proper names and geography, a game picked up by Lombarda as they explore the image of self and other.]

2617.

See 783, Labbie, "Vacant Mirror," 1995. [Compare with 792, Sankovitch, “Lombarda’s Reluctant Mirror," 1989, which covers much of the same ground.]

\section{PC 289. Peire de Lunel (Cavalier Lunel de Montech)}

[fl. 1326-49; a member of the Toulouse School, where he was one of the seven mantenedors; three poems and a series of moralizing coblas; his sorrowful sirventes, Meravilhar no.s devo pas was composed during the height of the plague in Toulouse; also wrote Ensenhamen del Guarso 1326, for an aspiring poet looking for advice on how to compose: see 22.5.e; also a poem to the Virgin in Latin: Ho flors odorifera.]

\section{8.}

See 2001, Ricketts, Contributions, 2000, pp. 36-49. [Edition of the four lyric poems of Peire Lunel, not the ensenhamen, nor his Latin poem; also available online at http://www.rialto.unina.it/pLun.]

2619.

Chabaneau, Camille. "Poésies inédites de divers troubadours." RLaR 33 (1889): 117-21. [Edition of the Latin poem, dated 1336, without commentary, translation, or notes, from BnF, fr. 22543, folio 141 verso.]

2620.

See 1441, Sansone, Testi, 1977, pp. 291-328. [Introductory study, biography, dating of the ensenhamen (1326), language, metrics; critical text with Italian translation, notes.]

2621.

See 249, Bec, Florilège en mineur, 2004, pp. 339-49. [Brief introduction on ensenhamens; extracts of 136 lines, from the beginning: lines 1-125, and the end: lines 372-82; text from Sansone, 1977.]

\section{PC 293. Marcabru}

[fl. 1130-49; two vidas; ca. thirty-eight poems, four with melodies: see $\$$ 607, van der Werf, Extant, 1984 , pp. $224^{*}-27^{*}$; social satire and moral allegory; his themes, style, and vocabulary influenced many later troubadours.] 
2622.

Gaunt, Simon, Ruth Harvey, and Linda Paterson. Marcabru: A Critical Edition. Cambridge: D. S. Brewer, 2000. [Introduction on Marcabru's name and career, the manuscript tradition, language, and versification; edition of the two vidas, forty-four songs, plus two of doubtful attribution, with English translation, notes; see remarks on editorial methodology by Perugi, SM 44 (2003): 533-600, and by M. Taylor, Tenso 18 (2003): 3-38.]

\section{3.}

Bruckner, Matilda Tomaryn. "Marcabru et la chanson de croisade: d'un centre à l'autre." CCM 53 (2010): 219-35. [An intertextual study of perspective in two crusade poems by Marcabru and one by the trouvère Guiot de Dijon, which reveal a complex restructuring of the traditional fin'amor contrast between "here" and "there" in the social and amatory climate of fin'amor; in crusade poems, sai and lai can take on many values, referring to place (homeland, diaspora), time (present, past, memory, dream), or sentiment (together, apart); all three songs are reproduced in appendix.]

2624.

Carapezza, Francesco. "La voix de Marcabru: écarts tonaux et clausules mélodiques dans le Vers del lavador (BdT 293.35)." In 101, AIEO 8, 2009, 1:157-69. [Discussion of the performative aspect of Marcabru's poetry, his voice, the dynamic changes of perspective between the I and the You, which seem typical of a preacher, especially in his crusade song; analysis of the melody reveals a recitative tone, leading up to the key word lavador and a dramatic lifting of the voice in the last couplet to emphasize the climax of each stanza; Carapezza claims that the melody invented for the first stanza seems then to control the syntactic structure of the other stanzas, emphasizing the oratory strength of the preacher, rather than his pleasing voice.]

\section{5.}

Carapezza, Francesco. "A propos du son desviat de Marcabru (BdT 293.5)." RLaR, 114 (2010): 5-22. [Structural and stylistic similarities are found between Marcabru's poem and two others, one (PC 104,2) attributed either to Bernart Marti or to Bermon Rascas, the other anonymous (PC 461,197) forming a sort of thematic mirror image of the first; the rubric to PC 461,197 mentions the theme of the "wild man" (li sons derves del home sauvage), perhaps indicating a close relationship between it and Marcabru's song, and a possible source for its melody, referred to enigmatically as son desviat.]

2626.

See 2026, Cheyette and Switten, "Women in Troubadour Song," pp. 26-46. [Detailed analysis of words and music of Marcabru's L'autrier jost'una sebissa (PC 293,30).]

\section{7.}

Cholakian, Rouben C. "Marcabru's A la fontana del vergier: A Hybrid Form.” Tenso 3 (1987-88): 1-14. [Analysis of the genre designations of the poem: neither pastorela nor chanson de toile, it "provides the poet with a more complex form in which to play 
out his erotic fantasies," while the woman is fictionalized to conform to male needs and apprehensions.]

2628.

Cholakian, Rouben C. "Marcabru and the Art of Courtly Misogyny." NM 90 (1989): 195-206. [A study of the contradictory perpetuation of misogyny within fin'amors, a curiously integral part of the ideology from the beginning; a specific analysis of Marcabru's L'autrier jost'una sebissa, a "feminist" poem which seems to contrast with his usual misogynist attitude but which in fact objectifies and demeans the shepherdess; she is the poetic projection of his male erotic fantasy.]

2629.

Economou, George D. "Marcabru, Love's Star Witness: For and Against." Tenso 7 (1991-92): 23-39. [Attempts to define Marcabru's distinction between good and bad love, especially in Al son desviat chantaire: good is trobar naturau, defined in his Doas cuidas; in the pastorela, L'autrier jost'une sebissa, the shepherdess represents the finest level of trobar naturau, i.e., she is the truly noble soul.]

2630.

Eusebi, Mario. "En abriu s'esclairo.il riu." CN 62 (2002): 181-92. [Study of the metrical structure of Marcabru's PC 293,24; diplomatic transcriptions of the text from eight manuscripts; new critical edition with several readings that differ from those of Dejeanne and Gaunt; Italian translation, notes.]

\section{1.}

Fuksas, Anatole Pierre. "Il baptesme de Jordana nel discorso marcabruniano sulla fals'amor." CDT 3 (2000): 753-80. [A new reading of PC 293,21, Bel m'es quan la fuelh'ufana, with transcriptions of $C$ and $E$; the poem is a radical criticism of falsity and lying in love, a cry against the disappearance of virtue; false lovers are called falsa gen crestiana, and their sinful crime is likened to an impious pilgrimage to the realm of the infidel sultan.]

2632.

Gaunt, Simon, and Ruth Harvey. "Bibliographie commentée du troubadour Marcabru. Mise à jour.” MA 94 (1988): 425-55. [Updates Pirot's listings from MA 73 (1967): 87-126.]

2633.

Gaunt, Simon, and Ruth Harvey. "Text and Context in a Poem by Marcabru: Alprim comens de l'invernaill." In 163, Troubadours and the Epic, 1987, pp. 59-101. [Text by Gaunt, context by Harvey; a double edition, giving two versions, each considered legitimate, on account of the assumption that Marcabru wrote two versions for different patrons; see the contradictory article by Lazzerini $>\mathbf{2 6 4 3}$, 1992.]

2634.

See 803, Gaunt, Troubadours and Irony, 1989, pp. 39-79. [A study of Marcabru's use of irony in the traditional Latin rhetorical sense to mock, criticize, and denigrate, as well as to entertain; analysis of two poems: Emperaire, per vostre prez, PC 293,23, in which he seems to be praising Alfonso VII but in fact is criticizing him by innuendo for lack of support, and Cortesamen vuoill comensar, PC 293,15, which Marcabru sent to Jaufre Rudel.] 
2635.

Gaunt, Simon. "Marginal Men, Marcabru and Orthodoxy: The Early Troubadours and Adultery." MAev 59 (1990): 55-72. [Claims that Duby's notion of fin'amor as the result of powerless young nobles sublimating their frustrations by singing their love for the lord's wife is really more complicated; not only does fin'amor act as a safety valve in helping control the young men but it also can be directly subversive, since it refers to the religious controversy over the church's effort to impose a new model of marriage and attempts to set up a courtly model of its own; see also $>1755$, Kasten, Frauendienst, 1986.]

2636.

Goddard, Richard N. B., "The Iconography of the Whore in Marcabru's Soudadier, per cui es jovens, Marbod of Rennes and the Beatus of Liébana Manuscripts." RZL 11 (1987): 277-91. [A complex of learned sources for Marcabru's poem suggests that it may have been intended as propaganda for the Frankish armies fighting in Spain in the Reconquista; the whore may be meant to depict Islam.]

2637.

Green, Edward. "Marcabru and the Foundations of Modern Song." Ars lyrica 15 (2007): 79-101. [Detailed analysis of melody and words in the first stanza of Marcabru's Bel m'es quan son li fruich madur, PC 293,13, indicating how intricately the two elements are aligned and interdependent; believes that Marcabru was a compositional genius, used as a model by later troubadours and therefore responsible for much of the greatness of troubadour songs; his compositional style aimed at the creation of a tightly organized stanza built around unified verbal and melodic elements; Green presents fine structural subtleties of syllabic count, rhymes, melody, and dovetailing to support his contention; appendix contains the text and melody of the poem.]

\section{8.}

Haines, John. "Irregular Rhythm in the Music of Marcabru." Tenso 18 (2003): 50-66. [Detailed exploration of various types of irregularity in the few examples of attempted mensural notation to be found in the troubadour repertory, notably in two songs by Marcabru; careful analysis reveals that there is more information than has been thought, but no constant codification has been found; however, among the individual and idiosyncratic notations, there still remains much to be learned.]

2639.

Harvey, Ruth. The Troubadour Marcabru and Love. London: Westfield College, University of London, 1989. [Detailed analysis of Marcabru's dualistic concept of love, finamor in contrast to folia or amar, in which the negative, moralizing concept is more vividly developed than the positive ideal of courtly abstraction, both often distorted by his use of strong satirical tones; he seems to have taken as his mission the castigation of unacceptable behavior of the nobility, often in conflict with his fellow poets or illustrating his precepts with strong dramatization and vulgar language; very rich bibliography, pp. 255-76; see also \$ 803, Gaunt, Troubadours and Irony, 1989, pp. 192-96, with a list of fourteen of Marcabru's reedited poems, and Harvey, "Marcabru et la falsamor," RLaR 100 (1996): 49-80.] 
2640.

Harvey, Ruth. "Rhymes and 'Rusty Words' in Marcabru's Songs." French Studies 56 (2002): 1-14. [A study of irregular rhymes in Marcabru’s poetry, not as weakness but as proof of his originality, flair, and inventiveness; his repetition of the word roill in the last stanza of Lo vers comens cant vei del fau is an arrogant flaunting of tradition used to shock and amuse the audience, and to prove his own mastery.]

2641.

Jackson, William E. "Poet, Woman, and Crusade in Songs of Marcabru, Guiot de Dijon, and Albrecht von Johansdorf." Mediaevalia 22 (1999): 265-89. [Analysis of poems by the three poets indicates that they chose to express their anti-crusade sentiment through the figure of a woman in order to avoid the social censure of a direct statement in their own voice; this is typical of trobairitz poems too, in which provocative or abrasive statements can be made more openly than in the regular courtly tradition.]

2642.

Koelb, Janice Hewlett. "The Owl in Winter: The Final Tornada of Marcabru's Pastourelle L'autrier jost'una sebissa." Florilegium 25 (2008): 53-74. [Shows how Marcabru applied his personal theory of trobar naturau in the pastorela as he sought to create poetry conforming to the divine art found in nature and in the cosmic order; Koelb explores the theory and practice of natural art in various formulations, from Marcabru to fourteenth-century French musique naturelle to the Romantics who yearned for a natural discourse capable of mending the soul, and even to such modern versions of natural creative agency as Freud's dreamwork and Jung's living symbol.]

2643.

Lazzerini, Lucia. "Un caso esemplare: Marcabru, IV, Al prim comens de livernaill." $M R 17$ (1992): 7-42. [A very detailed analysis, stanza by stanza, with many tentative suggestions for improved readings; contrary to Gaunt and Harvey $\mathbf{2 6 3 3}$, 1987, Lazzerini believes that from a combination of the two versions, with minimal retouching, a better single text is restored: (Bédier vs. Lachmann?); new critical edition with full apparatus, Italian translation, notes.]

\section{4.}

Lazzerini, Lucia. "Un'ipotesi sul dittico dell'Estornel (con alcune osservazioni in merito a una nuova edizione di Marcabruno)." SMV 46 (2000): 121-66. [Interprets dialogic structures as evidence of an underlying debate between the liberal ideas of Ovid and Guilhem de Peitieus on the one hand, and the religious moral principles of William of St.-Thierry, Jaufre Rudel, and Marcabru on the other; edition of Marcabru's two estornel poems PC 293,25 and 26, with Italian translation, textual notes; argues that the poems have resisted rational explication and must be read as satirical, ambiguous parodies of the courtly poetic tradition; on the estornel poem, see also - 2650, Meneghetti, "Uno stornello nunziante," 1995, and $\mathbf{2 6 3 9}$, Harvey, Troubadour Marcabru, 1989, chapter 8.]

2645.

Léglu, Catherine. "La place du sermon dans le discours satirique de Marcabru." In 
97, AIEO 4, 1994, pp. 173-87. [Analysis of several poems by Marcabru, especially Bel m'es quan la rana chanta, comparing them with techniques of preaching found in the Sermoni subalpini, showing that there are many parallels, but a basic difference, in that the poem is performed in public, in the court, within the context of lyric songs that it satirically calls into question.]

2646.

See 439, Malm, Dolssor Conina, 2001, pp. 151-55. [Detailed study of the noncourtly side of troubadour, Galician and Latin poetry; detailed analysis of a number of poems by Marcabru, stressing the vulgar or obscene vocabulary.]

\section{7.}

Marshall, John H. "The doas cuidas of Marcabru." In Chrétien de Troyes and the Troubadours: Essays in Memory of the Late Leslie Topsfield. Edited by Peter S. Noble and Linda M. Paterson. Cambridge: St. Catherine's College, 1984, pp. 27-33. [Looks at textual problems and interpretations of the difficult poem PC 293,19 and proposes several emendations; clarifies Marcabru's distinction between two types of aspiration, misguided vs. true; the poem gives many examples of the first, leading to the disintegration of courtly society, but maintains the value of the second, on which fin'amors and joy depend.]

2648.

Melani, Silvio. "Intorno al vers del lavador. Marcabruno e la riconquista ispanica." MR 21 (1997): 88-106. [New dating of Emperaire per mi mezeis to 1145-46; critical edition of the vers del lavador, with Italian translation and commentary, with new information on scriptural sources of some of its vocabulary.]

\section{9.}

Meneghetti, Maria-Luisa. "Una serrana per Marcabru?" In O cantar dos trobadores. Actas do Congreso celebrado en Santiago de Compostela. 26-29 de Abrile de 1993. Santiago: Xunta de Galicia, 1993, pp. 187-98. [Proposes a location in the mountains of Spain for the poem L'autrier jost'una sebissa on the basis of regional customs and clothing, topoi, and vocabulary, especially the words mancipa, fanissa, and mestissa; Meneghetti is able to show that the shepherdess is a Moorish girl, a social outcast like the serrana, a finding that would make Marcabru's moral criticism of the upper classes more shocking and effective.]

2650.

Meneghetti, Maria-Luisa. "Uno stornello nunziante. Fonti, significato e datazione dei dui vers dell'estornel di Marcabru." In 134, Cantarem, 1995, pp. 47-63. [Claims that Marcabru's starling poems may not be simple parodies of Peire d'Alvernhe's two nightingale poems, as has been thought; points out differences in treatment and finds cynical parallels with an early bilingual hymn of Annunciation, In hoc anni circulo, which may be an important source; other religious texts stress the chastity of Mary with the expression "closed door," which contrasts parodically with Marcabru's amia, whose door is open to all.]

2651.

Mussons, Anna Maria. “Traduir el Vers del lavador." In 162, Trobadors a la Península 
Ibèrica, 2006, pp. 271-83. [Explores the meaning of folpidor, perhaps a creation of Marcabu; develops Ruggieri's idea that the stanza depends on the antithetical metaphor of the lavador, a purifying bath or moral cleansing of those who go on crusade, as opposed to the moral turpitude of those who remain back in the folpidor, perhaps meant to designate a pit of dirty wash-water.]

2652.

Nelson, Deborah. "Critical Positions on Marcabru: From Christian Misogynist to Spokesman for fin'amors." In $>$ 159, Studia occitanica, 1986, 1:161-68. [Traces the evolution in critical analysis of Marcabru from early confusion and frustration to modern balanced judgments; he criticizes severely the morals of the noble class and eschews for himself any attachment to amorous involvement, but expresses high regard for fin'amors as the remedy to restore social order; his new form of exalted profane love uses imagery borrowed from the Bible to distinguish self-indulgent carnality, amar, from the higher love nourished by courtly virtue, fin'amor; both forms of love are prominent in his poems, though the highly colored moral judgments against amar have drawn most attention and established his severe image.]

2653.

Paterson, Linda. "Marcabru's Rhetoric and the Dialectic of trobar: Ans que.l terminis verdei (PC 293,7) and Jaufre Rudel." In Conjunctures: Medieval Studies in Honor of Douglas Kelly. Edited by Keith Busby and Norris J. Lacy. Amsterdam: Rodopi, 1994, pp. 407-23. [Marcabru's response to Jaufre Rudel: an intertextual debate involving also Bernart de Ventadorn and Cercamon; Jaufre in turn may have been responding to Marcabru's poem in his Bels m'es l'estius; Paterson points to further evidence of connection between the two but suggests that Marcabru's poem may follow Jaufre's as a sarcastic retort to it; new edition of the poem, with English translation, notes.]

\section{4.}

Paterson, Linda M. "L'obscénité du clerc: le troubadour Marcabru et la sculpture ecclésiastique au XIIe siècle en Aquitaine et dans l'Espagne du nord." In Le Clerc au Moyen Âge. Sénéfiance, 37. Aix-en-Provence: CUER MA, 1995, pp. 471-87; also in Paterson, Culture and Society in Medieval Occitania, Farnham: Ashgate Variorum, 2011. [Relates Marcabru's satiric or licentious images with contemporary depictions of sexual immorality in church sculpture, which were intended to arouse disgust among the viewers but which may often have had an ambiguous effect on the learned and unlearned public, provoking as much sardonic humor as religious terror.]

2655.

Paterson, Linda. "Marcabru et le lignage de Caïn: Bel m'es cant son li frug madur (PC 293.13).” CCM 41 (1998): 241-55. [Close study of the relationship of Marcabru's poem to contemporary biblical commentaries on Genesis involving the sins of Cain and his progeny; Paterson finds sophisticated understanding of the exegetical texts that suggest that Marcabru's audience may have contained clerics capable of understanding his learned allusions.]

2656.

Paterson, Linda. "Syria, Poitou and the Reconquista (or: Tales of the Undead). Who 
Was the Count in Marcabru's Vers del lavador?" In The Second Crusade. Edited by Jonathan P. Phillips and Martin Hoch. Manchester: Manchester University Press, 2001, pp. 133-49. [The complex search for the identity of the count mentioned in the last stanza of the poem leads across Europe and the Holy Land; by a process of elimination, he is identified convincingly as Baldwin of Marash, lord of the cities of Marash and Kesoun, near Antioch; he is said to have died heroically at Edessa in 1146, though his body was never found for proper burial; the plea in Marcabru's poem is for God to give peace to the soul of the count in limbo.]

2657.

Payen, Jean-Charles. "Un moraliste qui se veut marginal: note sur la poétique du troubadour Marcabru." In 152, Miscellanea Roncaglia, 1989, 3:993-1003. [Stresses the contradictory qualities of Marcabru's poetry: popular and refined language, moralistic and rebellious attitude, conservative and innovative style; his language mixes obscene with refined, insults with idealism, is rich in neologisms and compound forms of invective, and at the same time serious and playful.]

2658.

Perugi, Maurizio. "Per il testo e il lessico di Marcabruno (BdT 293,2 A l'alena del vent doussa, e altro)." In 221, Saggi di linguistica, 1995, pp. 41-58. [Detailed discussion of editorial problems encountered by other scholars, with disparaging remarks; solves the problem of the complex metrical structure of the poem by restoring one of the rhyme-words; in several additional studies of passages in Marcabru's poems, stresses the need for sensitive and innovative philological methodology in dealing with such difficult texts, castigating the grave "paleolachmannian" habit of unnecesary interventions in manuscript readings.]

2659.

Pollina, Vincent. Si Cum Marcabrus Declina: Studies in the Poetics of the Troubadour Marcabru. Modena: Mucchi, 1991. [Very detailed analysis of two poems, PC 293,31 (pp. 43-114) and PC 293,32 (pp. 115-78): critical texts, English translation, and stanza-by-stanza commentary; Marcabru's understanding of the nature of poetry, and his own mastery of it, are exemplified most clearly in these two poems, where he claims to have aligned the two elements of form and content in a perfect balance, the epitome of fin'amor.]

2660.

Pollina, Vincent. "Les mélodies du troubadour Marcabru: questions de style et de genre." In 95, AIEO 2, 1993, 1:289-302. [Four melodies by Marcabru are extant, varied in style, as are the accompanying texts; Pollina questions whether the variations are due to differences in genre or register; characterizes briefly the four melodies, leaving a complete analysis for future study; all four melodies are transcribed in the appendix; see further analysis of their richness, variety, originality, and refinement in Tenso 18 (2003): 39-49.]

2661.

Ricketts, Peter T. "Lo vers comenssa de Marcabru (PC 293, 32): édition critique, traduction et commentaire." In Chrétien de Troyes and the Troubadours: Essays in Memory 
of the Late Leslie Topsfield. Edited by Peter S. Noble and Linda M. Paterson. Cambridge: St. Catherine's College, 1984, pp. 7-26. [History of the editorial problems facing editors of the difficult poem; study of manuscript tradition, critical edition with full variants, French translation, and full critical commentary.]

\section{2.}

Rieger, Angelica. "Structures pornographiques chez Marcabru." In $\ \mathbf{1 0 0}$, AIEO 7 , 2003, pp. 617-28. [Using basic feminist critical techniques of the 1970s and 1980s, and inspired by an anonymous trobairitz poem of the thirteenth century, Rieger proposes a tentative response to the difficult works of Marcabru, claiming that behind his moralistic stance he was a frustrated voyeur, a rapist in words, obsessed with sex that was beyond his reach.]

\section{3.}

Roncaglia, Aurelio. "Secundum naturam vivere e il movimento trovatoresco." In Da una riva e dall'altra: studi in onore di Antonio D'Andrea. Edited by Dante Della Terza. Fiesole: Edizioni Cadmo, 1995, pp. 29-39. [An inquiry into the meaning of Marcabru's trobar naturau in PC 393,33, v. 7: not in Abelard's liberal "humanistic" sense of love but according to William of Saint Thierry's repressive notion of Christian natura; Marcabru's meaning of fol and naturau are just the opposite of the courtly assertions found in Bernart de Ventadorn; a wide-ranging discussion of the poetic principles of the early troubadours, in which the liberal notion won out in the tradition of the troubadours, even though the two opposites were to be later reconciled by Dante.]

\section{4.}

Seto, Naohiko. "Falsamor de Marcabru selon un chansonnier occitan." In LesserUsed Languages and Romance Linguistics. Edited by Tullio De Mauro and Shigeaki Sugeta. Rome: Bulzoni, 2002, pp. 137-55. [Close analysis of manuscript tradition and meaning of PC 293,18; interprets the song as a free-form "happening" in performance, susceptible to change and additional stanzas at will.]

\section{5.}

Seto, Naohiko. "Le grondement de la montagne qui accouche d'une souris (Marcabru, PC 293,19: version courte).” FL 148 (2009): 125-44. [Edition of the sirventes, using the shorter text of $A$, with French translation, notes; in spite of previous editions by Dejeanne, Ricketts, and Gaunt and studies by Lejeune and Marshall, based on $I K$, none has managed to clear up all the difficulties of the poem; Seto contributes this relatively ignored copy, suggesting that it may give a more satisfying, if shorter, version.] 2666.

Spaggiari, Barbara. Il nome di Marcabru. Contributi di onomastica e critica testuale. Spoleto: Centro Italiano di Studi sull'Alto Medioevo, 1992. [Investigation of the origins of the poet's names, including the earlier Panperdut; Marcabru names himself in almost half his extant poems; interpretation of the poetic dispute with Aldric de Vilar, different from that of Chambers, 876, "D'aisso lau Dieu," 1982; see the detailed review by Claudia Panuccio, MR 19 (1994): 195-200.]

2667.

Sunderland, Luke. "Marcabru in Motion: Dire vos vuoill ses duptanssa in Chansonniers 
$A$ and $C$, and in Matfre Ermengaud's Breviari d'Amor." Glossator 4 (2011): 115-29. [Traces the vagaries of transmission of Marcabru's poem through a number of chansonniers and its particular use by Matfre Ermengaud in the Breviari to show the poet as the ultimate misogynist and maligner of love and ladies; for Matfre, Marcabru cannot be taken even as a negative authority on love, because he has never known love himself.]

2668.

Tavera, Antoine. "Les chants du crépuscule à l'aube du trobar." In La Fin des temps et temps de la fin dans l'univers médiéval. Sénéfiance, 33. Aix-en-Provence: CUER MA, 1993, pp. 493-517. [The theme of decadence in the present, nostalgia for the past, when things were ideal and perfect: an eternal theme in poetry from the beginnings of literature, overwhelmingly typical of Marcabru, then more or less absent during the period of greatest flowering of trobar, until the late twelfth century, when the theme of decadence and nostalgia returns to stay.]

\section{9.}

Taylor, Mark N. "The Lyrics of the Troubadour Marcabru: Vocabulary for Love as an Aid to Chronology." NM 94 (1993): 323-44. [By examining chronologically Marcabru's love terminology, Taylor claims to distinguish an early period, in which the use of amor designates only evil love, and a later period, in which there is a corresponding positive counterpart finamors to the evil falsamors or amars; the evolution is more in the area of expression than in morality, as harsh satire matures into fine irony; in appendix, a chronological chart of Marcabru's poetry.]

2670.

Taylor, Mark N. "The Cansos of the Troubadour Marcabru: Critical Texts and a Commentary." Rom 118 (2000): 336-74. [Extensive bibliography of Marcabru, genre criticism, versification; edition of two cansos, with many notes and commentary: Contra l'ivern, PC 293,14, and Lanquan fuelhon li boscatge, PC 293,28.]

2671.

See 1894, Tortoreto, "Per l'attribuzione," 2007. [Includes the edition of PC 293,11, which she claims is not by Marcabru but probably by Alegret.]

\section{PC 294. Marcoat}

[ $f$. 1160-70; two unusually cruel sirventes making fun of crippled jongleurs.] 2672.

See 261, Viel, Troubadours mineurs gascons, 2011. [Introduction gives cultural context, considers questions of attribution, manuscript tradition, language and metrics; critical edition of PC 294,1 and 2, with French translation, detailed notes; rich glossary.]

2673.

Meneghetti, Maria Luisa. "In limine. Qualque osservazione sue due primi esempi di satira "personale" romanza (BdT 294,1-2)." In Cecco Angiolieri e la poesia satirica médiévale. Atti del Convegno (Siena, 26-27 ottobre 2002). Edited by Stefano Carrai and Giuseppe Marrani. Florence: Il Galluzzo-SISMEL, 2005, pp. 
1-9. [Remarks on two sirventes by Marcoat poking cruel and semiobscene fun at crippled joglars.]

2674.

See 227, Riquer, 1975, 1:258-62 [Introduction, text of PC 294,1, Spanish translation, notes.]

2675.

See 249, Bec, Florilège en mineur, 2004, pp. 303-7. [Jeanroy's text of PC 294,2 with French translation.]

\section{PC 295. Maria de Ventadorn}

[ $f$. 1208-21; second wife, ca. 1190 of Eble V, Count of Ventadour, great-grandson of Eble II Cantador; Bernart deVentadour addressed a song to Maria's great-aunt Margarita de Torena; vida, tenso with Gui d'Ussel, PC 194,9 = 295,1; named as dedicatee by Gaucelm Faidit in thirteen 2676. poems, and by at least seven other poets; arbiter in five debate poems.]

See 735, A. Rieger, Trobairitz, 1991, pp. 255-74. [Text of razo from Boutière/ Schutz; critical text of tenso, with German translation, notes, analysis: outlines the importance of Maria and her husband as patrons of many troubadours at their court; close relationship with the four "troubadours d'Ussel," especially Gui, six of whose songs involve her.]

2677.

Blakeslee, Merritt R. "Maria de Ventadorn." In 46, Women in the Middle Ages, 2004, pp. 593-95. [Background history of Maria's family and her patronage of troubadours at the court of her husband Eble V of Ventadorn ; analysis of her debate with Gui d'Ussel, in which he speaks for equality between lover and lady, while she claims that the man may be equal in love but must not seek to dominate her as lord.]

2678.

See 608, Rosenberg, 1998, pp. 151-53. [The text of the tenso is reproduced from Audiau 1922, and its razo from Boutière/Schutz 1964, with English translation.]

2679.

See 890, A. Rieger, "La mala canso de Gui d'Ussel," 1992. [Study of a network of poems involving Raimbaut de Vaqueiras, Gui d'Ussel, Maria de Ventadorn, Gaucelm Faidit, and Peire d'Ussel; Maria's tenso with Gui is interpreted as her attempt to reestablish the traditional relationship of finamors between domna and troubadour, to combat the spreading trend of the uncourtly mala canso popularized by Gui.]

\section{PC 296. Marques (de Canilhac)}

[ $f$. 1274-85; identity is problematic, perhaps Albert, Marquis of Malaspina; participant in tensos with Count Henry II of Rodez, Guiraut Riquier, Guillem de Murs; another tenso with an anonymous domna wrongly attributed to Marques has been reassigned plausibly by A. Rieger to Albert Marques, Alberto, Marquis of Malaspina: see PC 15.] 
2680.

Guida, Saverio. "Jocs" poetici alla corte di Enrico II di Rodez. Modena: Mucchi, 1983. [Study of social and poetic activity at the court of Rodez in the second half of the thirteenth century, especially under Count Henry II; edition of seven tensos, all involving the count; five of them involve Guiraut Riquier, four Guilhem de Mur, two Marques de Canilhac, and one each Peire Pelet, Austorc d'Alboy, and Peire d'Estanh; Guida reconstructs of a piece of sociocultural history, revealing a very generous court, a model of the troubadour ideal, but something of an anachronism in its time.]

2681.

See 735, A. Rieger, Trobairitz, 1991, pp. 356-66. [Establishes the probable identity of Marques, who participated in a tenso with a domna: not Marques de Canilhac but Albert, Marquis of Malaspina, born ca. 1160-65, patron of troubadours, a poet himself, brother-in-law of Boniface of Montferrat; tenso composed between 1180/85 and 1206; the domna could be his wife, or the trobairitz Ysabella; edition of the tenso, with German translation, notes; disagrees with Chambers 758, "Las trobairitz soiseubudas," 1989, p. 53, who thought a stanza must be missing to account for the Lady's change of attitude.]

\section{PC 297. Matfre Ermengaud}

[Second half thirteenth century, died probably 1291; for his Breviari d'Amor, see 22.3; seven of the lyrics quoted in the Breviari are by Matfre himself; he also composed one canso with melody, PC 297,4, and one moralizing sirventes,

PC 297,8, which probably shared the same melody: see $\mathbf{6 0 7}$, van der Werf, Extant, 1984, p. 228*; a 138-line allegorical letter to his sister Na Suau:

Pistola a sa sor, is also known as the Roman del capon.]

\section{2.}

See 2044, Hershon, Les troubadours de Béziers, 2001, pp. 159-81. [Edition of nine pieces by Matfre Ermengaud, two of which are poems, the rest extracts from the Perilhos tractatz, with introduction, French translation, notes.]

2683.

See 1412, Bolduc, "Paradox," 2006. [Text and analysis of Matfre's poem Dregs de natura comanda, with English translation, pp. 122-27.]

2684.

Pfeffer, Wendy. "Christmas Gifts in Medieval Occitania: Matfre Ermengaud's Letter to His Sister." In 1306, Courtly Arts, 2006, pp. 517-25. [Analysis of the unusual mixture of advice on preparing food and the Christian allegory of Jesus's sacrifice, offered to his cara seror in a Christmas letter, written in rhyming couplets, in which he explains the symbolism of a Christmas capon.]

2685.

See 1428, Richter, Die Troubadourzitate, 1976. [Critical edition of all of Matfre's poems quoted in the Breviari.]

2686.

Richter, Reinhilt, and Max Lütolf. "Les poésies lyriques de Matfre Ermengau." Rom 
98 (1977): 15-33. [One canso, one sirventes; critical editions by Richter, with textual notes, no translation; musical analysis of the melody of Dregs de natura by Lütolf; the sirventes has the same metric structure and probably shared the same melody.]

\section{PC 304. Jofre de Foixà (Monge de Foissan)}

[ $f$. 1267-95; Catalan, the author of Regles de Trobar, 1289-91, an adaptation of Raimon Vidal de Besalù's Las razos de trobar, done for Jaques II of Aragon, interesting because the author tries to liberate himself from Latin grammar; three cansos and one cobla listing his favorite foods, all written probably when he was young; he 2687. became Franciscan, changed to Benedictine, was active politically.]

See 1374, Marshall, Razos de Trobar,1972. [Critical text of Regles de Trobar with full literary and philological study, notes; no translation: for this, see 1748 , Shapiro, De vulgari, 1990.]

\section{8.}

Allegretti, Paola. "Parva componere magnis. Una strofa inedita di Bernart de Ventadorn (BdT 70,33) e due schede per BdT 461,127.” RST 1 (1999): 9-28. [Investigates a series of transmission questions in various chansonniers, dealing with poems of Bernart de Ventadorn, Peire Vidal, and several anonymous poets; offers a new edition of an anonymous two-stanza plazer-enueg, PC 461,127, denying its attribution to Raimon de Miraval, suggesting instead Jofre de Foixà, based on similarities to Jofre's Subrafusa PC 304,4.]

\section{9.}

Pfeffer, Wendy. "Jofre de Foixa, Subrafusa ab cabirol (BdT 304.4)." Lecturae tropatorum 4 2011): 1-13. Online at http://www.lt.unina.it. [Introduction on Jofre's life, works and historical context; new critical edition, with English translation; the poem is placed in the context of the plazer/enueg genre and examined for its use of specialized culinary vocabulary, using information from Catalan and Occitan cookbooks from the fourteenth and fifteenth centuries.]

2690.

See 227, Riquer, 1975, 3:1647-52. [Edition of PC 304,1 Be m'a lonc temps menat, in which the last line of each stanza is taken from the incipit of poems by various authors, a structure that Jofre seems to have borrowed from Gace Brulé.]

\section{PC 305. Lo Monge de Montaudon (Pierre de Vic)}

[ $f$. 1180-1213; vida; was a monk, but left the cloister to become a troubadour; in charge of poetic competition at Le Puy en Valay; seventeen poems, two with melody: see 607, van der Werf, Extant, 1984, p. 229*; PC 305,16 is a satirical gallery of sixteen poets, including himself from ca. 1195; three enuegs, one plazer (things he dislikes or likes), three witty fictive tensos debating with God and saints.] 2691.

Routledge, Michael J. Les Poésies du Moine de Montaudon. Montpellier: Centre d'Études Occitanes de l'Université Paul Valéry, 1977. [Critical edition of nineteen 
poems, plus one of questionable attribution (PC 47,2), with French translation, notes, glossary.]

2692.

Mantovani, Dario. "Autra vetz fui a parlamen (BdT 305.7). Analisi ed edizione critica di un componimento del Monge de Montaudon." Parola del testo 9.2 (2005): 215-47. [A parodic complaint by statues against the abusive use of make-up by ladies, making the price go up; God's punishment is to decree that the make-up will be easily soluble in water; study of manuscript history, new critical text with Italian translation, notes.]

2693.

Mantovani, Dario. "Monge de Montaudon: L'autrier fui en Paradis (BdT 305,12)." La parola del testo 12 (2008): 7-34. Also in 258, Ans am ieu, 2008, pp. 85-99. [One of four parodic poems that treat of Paradise; accused by God of failing to support Richard Coeur-de-lion, he responds ironically that God himself has been negligent in allowing the imprisonment of his protector; detailed study of historical background and dating (1194); new critical text, with Italian translation, copious notes.] 2694.

Mantovani, Dario. "Varietà metriche e scenarî satirico-parodici: il caso di due componimenti del Monge de Montaudon.” CDT 12.1 (2009): 167-202. [Points out unusual features in Monge's work, especially the mixture of metric forms in his parodic and humorous poems; in appendix, three poems by Monge: L'autre jorn m'en pogei, Quan tuit aquist clam, and the conflictus, Manens e frairis, with Italian translation.]

2695.

See 883, Mantovani, "Prove di dialogo," 2009. [Monge participated in a cycle of poems that were probably composed as part of a puy meeting organized by Monge himself; it is likely that his satirical gallery of poets, PC 305, originated from a puy meeting, as did that of Peire d'Alvernhe; for the importance of these meetings, see - 305, Routledge, "Troubadours du Puy," 1992.] 2696.

Gandois, Jean-Lucien. Le Troubadour Pierre de Vic, moine de Montaudon, XIIe-XIIIe s.: la vie, l'homme et l'oeuvre. Clermont-Ferrand: Académie des sciences, belles-lettres et arts de Clermont-Ferrand, 2003. [Gandois died in 1979; his brother Maurice left a legacy upon his own death in 1991 to the Académie des sciences in Clermont, to be used to publish this study, which is the unrevised text of his Diplôme d'Études Supérieures presented to the Faculty of Clermont-Ferrand in 1942; life of Monge, pp. 9-106; analysis of his personality and his literary work, pp. 107-51; language, pp. 153-62; includes extensive bibliography up to 1941.]

2697.

Guida, Saverio. "Questioni relative a tre partimens provenzali (BdT 388,1; 16,17; 75,5).” CN 68 (2008): 249-309. [Pp. 273-301: the dispute between Albertet de Sistero and Monge concerning the relative merits of the French and the Catalans seems to reflect the period of threat preceding the Albigensian Crusade; the use of Monge as the personal name of a highly placed sensitive individual is well documented; pp. 301-9: the partimen between Monge and Bertran de Lamanon, 
around 1232, was an opportunity for the two participants to demonstrate their technical poetic skills within the culturally refined court of Raimond Berengier V in Aix.]

2698.

Routledge, Michael J. “The Monk Who Knew the Ways of Love." Reading Medieval Studies 12 (1986): 3-25. [A reevaluation of the poet's work, especially his use of legal settings and metaphors.]

2699.

See 227, Riquer, 1975, 2:1024-45. [Historical and biographical introduction, edition of vida and four poems, PC 305,10,8, 15, 12 and the satirical gallery poem PC 305,16, with Spanish translation, notes.]

\section{PC 306. Montan}

[ $f$. ca. 1276?; one obscene fictive tenso between himself and a donna, PC 306,2, also two coblas, one moralizing and one abusive, and one exchange of coblas in reply to Sordello's PC 437,8.]

2700 .

Cluzel, Irénée-Marie. "Le troubadour Montan (XIIIe siècle)." In $>147$, Mélanges Rostaing, 1974, pp. 153-64. [The only comprehensive edition of Montan; introduction on the notion of obscenity in the troubadours, with a subjective list of ten poems that should be on a sort of Index apart from the courtly corpus; commentary on each piece, indicating a certain admiration for the poet's comic verve; edition of the four texts, with French translation, except for the tenso, which is "beyond decency."]

2701.

Krispin, Arno. "La tenson Eu veing vas vos, seigner, faoda levada d'En Montan." Via Domitia 26 (1981): 49-51. [Edition of the tenso PC 306,2 with French translation.] 2702.

Poe, Elizabeth W. "Na Veilla Carcais. The Text and Contexts of Montan's Vostr'alens es tant putnais." In 146, Literatur Mölk, 1997, pp. 155-74. [New edition of the cobla PC 306,4, with a full examination of its place in relation to other similar poems and to the idealizing cansos; Poe sees the "old whore poems" as "a momentary escape from the civilizing constraint of the canso"; detailed study of the poem and its context.]

2703.

See 735, A. Rieger, Trobairitz, 1991, pp. 367-76. [If a female singer can be envisaged as playing the part of the domna in performance, then nothing excludes the possibility that a female poet may have taken part in the composition; Montan is not as likely as the lady to be fictive, since three other compositions are attributed to him; perhaps the poem was inspired by a humorous play on his name; the aim of the poem seems to be a parodic or satiric comment on the over-idealized precepts of the troubadour canso.]

2704.

Soutou, André. "L'amour à la hussarde: chanson du troubadour En Montan." Via domitia 29 (1983): 141-43. 
2705.

Uhl, Patrice. "La tenso entre Montan et une dame (PC 306.2): petit dialogue obscène entre amics fins." Expressions 31 (2008): 67-86. [Edition with French translation; detailed analysis shows that the poem belongs to the same level of structural and lexical intricacy as the standard courtly lyrics; traces complex intertextual links with several poems by Cerveri de Girona, Peire Duran, and the anonymous balada Coindeta sui PC 461,69; maintains that the anonymous female participant is just as "real" a trobairitz as any other; see also Uhl's more general article on obscenity in Les représentations de la déviance. Actes du colloque "Dérives et déviances" (Université de La Réunion, mai 2004), Paris: L'Harmattan, 2005, pp. 93-102.]

\section{PC 309. N'At de Mons (At de Mons)}

[fl. 1265-1275; died ca. 1290; one sirventes, PC 309,1, on the rights and duties of kings, addressed to James I of Aragon; one ensenhamen of 1,539 lines, Si tot non es enquistz, addressed to a jongleur; two epistles to the king of Aragon; two didactic poems, one of 2,059 lines and a fragment of 602 lines (a twenty-two-line quotation in the Breviari is perhaps from a lost part of this); three of the four quotations attributed to him in Leys d'Amors may be from further lost works.]

\section{6.}

Bernhardt, Wilhelm. Die Werke des Trobadors N'At de Mons. Altfranzösische Bibliothek, 11. Heilbronn: Henninger, 1887. Reprint, Wiesbaden 1968. [Edition of his five didactic works with German translation, notes, and his sirventes in appendix; points out the close similarities with Guiraut Riquier; the treatises are didactic, moralistic, and nostalgic in tone, deadly dull, according to early scholars.]

2707.

Cigni, Fabrizio. "Il lessico filosofico di N'At de Mons di Tolosa." In $\mathbf{1 0 0}$, AIEO 7, 2003, pp. 233-42. [Sketch of lexical riches to be found in At's works; words are listed in various categories, without detailed lexical information, pending his forthcoming complete edition of At's works.]

2708.

Cigni, Fabrizio. "Il trovatore N’At de Mons di Tolosa." Studi mediovali e volgari 47 (2001): 251-73. [Detailed background information on At and his texts, and an indication of his importance as a major contributor to the formulation of the Leys d'Amors, with its emphasis on morality and philosophy; meticulous review of former scholarship on At and his sociocultural context; detailed analysis of the contents of the moralizing treatises.]

2709.

Alvar, Carlos. "N'At de Mons de Tolosa et Alphonse X de Castille." In Actes du colloque Languedoc et langue d'oc (Toulouse, janvier 1996). Perspectives médiévales special number, supplement to 22 (1996): 21-32. [Analysis of At's epistle to the king of Castille concerning free will and the influence of the stars on human behavior; the text shows evidence of advanced scholastic culture and rigorous use of dialectics, indicating that At may have undertaken advanced studies; Alvar believes that King 
Alfonso may have outlined his response to the epistle, which was then completed by At himself.]

2710.

Kelly, Douglas. "The Late Medieval Art of Poetry: The Evidence from At de Mons and Raimon de Cornet." In 140, Etudes Ricketts, 2005, pp. 681-92. [See pp. 684-88: At de Mons is quoted frequently in the Leys d'Amors to illustrate features of the art as promulgated by the Consistori: emphasis is placed on religious and moral themes, so that the poems could be applied equally well to an honorable domna or to the Virgin.]

\section{PC 312. Olivier lo Templier (del Temple)}

[ $f$. 1269; one crusade song; he was a Knight Templar, enthusiastic supporter of James I of Aragon, the Conqueror, as he set out on his aborted crusade.] 2711.

Avenoza, Gemma, and Simone Ventura. "Estat aurai lonc temps en pessamen: Olivier le Templier propagandiste de Jacques Ier.” RLaR 113 (2009): 465-500. [Critical edition of Olivier's crusade song, with historical introduction, French translation, notes; analysis of the element of propaganda in troubadour poems supporting the diplomatic and military enterprises of the king of Aragon, notably Olivier's urging of his participation, ultimately aborted, in the crusade of 1269.]

\section{PC 314. Ozil de Cadartz (Cadars)}

[Thirteenth century; one popular canso offering advice for lovers, perhaps meant as a parody of the Artes poeticae of the time; the stanzaic form, metrics and rhymes are unique in troubadour poetry; a second poem is sometimes attributed to Ozil.] 2712.

Seto, Naohiko. "Ozil de Cadartz: une parodie des arts d'aimer?" In $>\mathbf{1 0 0}$, AIEO 7, 2003, pp. 661-74. [Critical edition of the unusual text, with French translation; analysis of the varied contents: advice to lovers, misogynistic remarks, advice on the best time of day to court ladies of different ages, corresponding to the theme of the four ages of mankind, which in turn correspond to the four seasons and the four elements, all treated by the poet in an offhand, comic manner, finishing with the final consolation that, if the advice does not work or, rather, if the lover fails because of the advice, at least he will have gained experience.]

2713.

See 255, Guida, Trovatori minori, 2002, pp. 23-79. [Detailed introduction on the identity, family history, social position, and literary context of Ozil; dated to the second half of the twelfth century; outlines his humorous anticonformist attitude that treated finamor with refined irony; new critical edition with Italian translation, copious notes.]

\section{PC 315. Palais (perhaps the same as Andrians del Palais)} [ $f$. 1230-40; five or six songs, plus perhaps ten lines of another, quoted by Terramagnino da Pisa in his Doctrina de cort; probably not to be identified with the troubadour and the joglar named Palais mentioned by Folquet de Marselha.] 
2714.

Ricketts, Peter T. "Le troubadour Palais: édition critique, traduction et commentaire." In 159, Studia occitanica, 1986, 1:227-40. [Brief introduction on biography and cultural background; critical edition of five poems with French translation, notes.]

2715.

Guida, Saverio. “(Andrian de) Palais, trovatore lombardo?” In 158, Studi Bertolucci Pizzorusso, 2006, 1:685-721. [An enquiry into the identity of Palais and the nature of his poetry; his works are light and humorous, revealing a rather caustic outlook on society, an attitude of disenchantment masked by a theatrical style, and refined structural techniques; in archival documents from Cremona in the 1230s is found the name of Andreanus de Palacio among lists of dignified and cultivated members of society, probably referring to our troubadour.]

2716.

See 249, Bec, Florilège en mineur, 2004, pp. 333-35. [Brief introduction, text of the obscene estribot PC 315,5, with French translation.]

\section{PC 317. Paolo Lanfranchi da Pistoia}

[ $f$. 1282-95; one sirventes in Occitan in the form of a sonnet, 1285, calling for an alliance of Aragon, Castile, and England against France; seven other sonnets in Italian.]

2717.

See 227, Riquer, 1975, 3:1662-65. [Introduction, text of sirventes with Spanish translation, notes.]

2718.

See 248, Bec, Pour un autre soleil, 1994. [The introduction emphasizes that the sonnet form has its origins in the Occitan language and territory, was codified in Sicily before spreading to northern Italy and the rest of Europe; pp. 3-5: text of a poem by Paolo Lanfranchi da Pistoia, called a sonnet-sirventes, and two by Dante da Maiano, in highly Italianized Occitan, with French translation.]

2719.

Kleinhenz, Christopher. "A Trio of Sonnets in Occitan: A Lyrical Duet and an Historic Solo." Tenso 13 (1998): 33-49. [The three known sonnets in medieval Occitan, by two Italian poets of the late thirteenth century; two graceful love poems by Dante da Maiano of the Siculo-Tuscan school, and an encomium for the Aragonese king Peter III by Paolo Lanfranchi of Pistoia: evidence of the esteem in which Occitan was held for the composition of lyrics.]

\section{PC 319. Paulet de Marselha}

[ $f$. 1262-68; nine poems, including cansos, sirventes, pastorela, planh, dansa; exiled from Marseilles, took refuge at the court of Peter of Aragon.]

2720.

Riquer, Isabel de. Paulet de Marselha: un provençal a la cort dels reis d'Aragon. Barcelona: Columna, 1996. See also the earlier version in BRABLB 38 (1979-82): 
133-205. [Introduction covers history of the Dels Baus family and the struggle for the freedom of Marseilles; Paulet in Catalunya; literary evaluation of his work, poetics, versification, language; edition of nine poems, with Catalan translation; detailed notes to each poem, pp. 137-55.]

2721.

Barca, Daniele. "Sulle scelte dei compilatori dei canzonieri $C$ ed $E$ nei confronti delle liriche di Paulet de Marselha." In $>$ 92, Actes du XXe Congrès, 1993, 5:29-37. [Suggests that the fifth stanza of PC 319,2, Aras qu'es lo gays pascors, present in $C$, is omitted in $E$, not for political reasons, as has been supposed, but due to a simple slip by the scribe; the fifth stanza is not addressed to Charles of Anjou at all but to the same James of Aragon named in the sixth stanza; the supposed inner contradictions of the poem and the insult to Charles would have to be abandoned.]

\section{PC 323. Peire d'Alvernhe}

[fl. 1149-68; vida; ca. twenty poems, including a prayer, a crusade song, a tenso with Bernart de Ventadorn, and a satirical "gallery of poets"; two melodies are preserved: see 607, van der Werf, Extant, 1984, p. 230*-31*.]

\section{2.}

Fratta, Aniello. Peire d'Alvernhe: Poesie. Rome: Vecchiarelli, 1996. [Introduction on the life and works of Peire; edition of twenty poems, with Italian translation; rich commentary, notes on each poem; no glossary; see the review article by Roncaglia, CN 57 (1997): 347-56, which provides rich and detailed remarks on all twenty of the poems.]

2723.

Bonafin, Massimo. "Un riesame del gap occitanico (con una lettura di Peire d'Alvernha, BdT 323,11).” In 139, Ensi firent, 1996, pp. 85-99. [Urges that the distinctiveness of the gap be respected and reexamined; detailed study of Peire d'Alvernhe's Cantarai d'aquests trobadors, attempting to show that it is a gap, and that it provides an example of total formalization in morphological and functional terms.]

2724.

See 677, Carapezza, "Implicazioni musicali," 2009. [Musical study of De josta is breus jorns, the only preserved melody for Peire, within an examination of all references to singing in his poetry and compared with Jaufre Rudel's Lancan li jorn, to which it may be a replique; Peire's melody is more ornamented and has greater range and structural leaps, with similarities of structure that echo the similar themes in the two poems; Peire's reputation as a composer is shown to be fully deserved; his musical style is complex and elaborate and served as a model for later troubadours such as Raimbaut d'Aurenga, Peire Cardenal, and Arnaut Daniel.]

2725.

Cunha, Viviane. "La poésie religieuse chez les troubadours: les chansons de Peire d'Alvernha." In 102, AIEO 9, 2011, pp. 339-48. [Four religious poems by Peire d'Alvernhe, one by Falquet de Romans; these are limited in number and very different in content from similar poetry in the North: they address God and Jesus, 
rather than presenting more popular themes, such as miracles, praise to the Virgin or lives of saints.]

2726.

Gaunt, Simon. "Peire d'Alvernha affronte Jaufre Rudel: les troubadours et la deuxième croisade." In La Croisade, réalités et fictions: Actes du colloque d'Amiens. Göppinger Arbeiten zur Germanistik, 503. Lauterburg: Kümmerle, 1989, pp. 119-31. [Study of poems by Peire d'Alvernhe and Marcabru which use intertextual irony to turn around Jaufre Rudel's popular images of sensual love and to speak instead in favor of spiritual values, specifically the virtue of going on crusade; Jaufre seems to have changed his mind in PC 262,6, Quan lo rossinhols el foillos, perhaps in response to their opinions; new critical edition of Peire d'Alvernhe's Al dessebrar del païs (PC 323,3), with French translation.]

2727.

See 803, Gaunt, Troubadours and Irony, 1989, pp. 97-120. [Close analysis of four poems by Peire d'Alvernhe: Al desebrar del païs,PC PC 323,3, in which Peire treats Jaufre Rudel's attitude to love with irony, Bel m'es quan la roza floris, PC 323,7, in which he supports Marcabru by referring ironically to the opinions of his enemies, Bel m'es qui a son bon sen, PC 323,8, in which Peire seems to be praising Raymond IV of Barcelona but is in fact praising his enemy Raymond V of Toulouse, and Chantarai pus vei, PC 323,12, in which he parodies several songs by Bernart de Ventadorn.]

2728.

Gizzi, Luca. "Un tassello per Sobre.l vieill trobar e.l novel (BdT 323,24). Peire d'Alvernhe e Guglielmo IX." AIUO 42 (2000): 307-13. [Notes parallel uses of rhyme-words in Peire and in Guilhem's Ab la dolchor: (novel, coutel, bel), as well as similar metaphors and phrases in William and other troubadours; this proves that William was known, valued, and used by Peire as already shown for Jaufre Rudel and Marcabru.]

2729.

Guida, Saverio. "Il Limosino di Briva." CN 57 (1997): 167-98. [Argues that in the fifth stanza the trobador limosino, also called joglar, is not Bernart de Ventadorn but Arnaut de Tintinhac and that Bernart's mention of Lemozi in several poems is referring to Arnaut in a tone of affectionate respect, suggesting that Arnaut was a precursor and maestro of Bernart; Lo joi comens en un bel mes is also attributed to Arnaut, on the authority of Matfre Ermengau.]

2730.

Guida, Saverio. "Dove e quando fu composto il sirventes Cantarai d'aquestz trobadors?" AMod 3 (1997): 201-26. [The key to understanding the poem is its localization and the circumstances of its composition; dated to 1168-70, for the marriage of Alfonso VIII of Castille to Eleonora, daughter of Eleanor of Aquitaine and Henry II of England; the location poi vert may be a corrupted form of Poitiers, referring to a celebratory festival held in that city.]

2731.

Guida, Saverio. “Us vielletz lombartz cossezen (BdT 323,11, lines 73-8)." CN 65 
(2005): 7-26. [This article provides the further information promised in his 1977 article in CN 57 and another from 1997 in AMod 3 concerning the identity of Cossezen, the twelfth poet to be insulted in Peire d'Alvernhe's poem; a poet from Concesio in Italy is not further identified, but it seems likely that he was a considerable personage who stood up to Henry II to complain about the suffering state of Lombardy.] 2732.

Harvey, Ruth. "Seigneurs, troubadours et princes Plantagenêts." In $\mathbf{1 0 9}$, Comunicazione e propaganda, 2007, pp. 359-68. [Detailed description of an important political gathering called by Henry II of England in February of 1173 at Montferrand and Limoges, attended by four kings, a number of bishops, a dozen counts, and many barons and lords from many countries, who seem to echo the varied personalities and provenances of the twelve amateurs of trobar who are targeted in Peire's satirical gallery.] 2733.

See 256, Harvey and Paterson, Troubadour "Tensos," 2010, 3:964-71. [PC 323,4 = 70,2 tenso with Bernart de Ventadorn.]

\section{4.}

Klingebiel, Kathryn. "Chantarai d'aquestz trobadors (PC 323,11)." Online: Trobar: http://www.tempestsolutions.com. [Rich information on dating, attributions, and location of his satirical gallery poem, with identification of poets mentioned and bibliographical references.]

2735.

Rossi, Luciano. "Per l'interpretazione de Cantarem d'aquestz trobadors." In $\mathbf{1 3 4}$ Cantarem, 1995, pp. 65-111. [Synthesis of earlier research on the poem and placement within the cultural context of its time; new critical edition with Italian translation and stanza-by-stanza commentary; for stanza ten (Raimbaut d'Aurenga), Rossi discusses Raimbaut's Ben s'eschai q'en bona cort, with critical text, Italian translation, and copious notes; concludes that this poem and that of Monge represent the beginning of literary analysis of trobar.]

\section{PC 324. Peire II King of Aragon}

(the Catholic; also Peire I Count of Barcelona)

[Born 1178, reigned 1196-1213; the son of Alfonso II of Aragon (see PC 23), with whom he is sometimes confused.]

2736.

Rüdiger, Jan. "Herrschaft und Stil bei Peter II. von Aragon.” Frühmittelalterliche Studien 39 (2005): 177-202. [Information in Raimon de Miraval's poetry about Peter's social and political style in negotiations with allies and enemies during the Albigensian Crusade, in which Peire II lost his life; the rules of courtliness played a surprisingly important role in the governance of his plans and communications, i.e., whether he obeyed or violated the rules.]

2737.

Guida, Saverio. "Pietro il Cattolico ed i trovatori." In 162 , Trobadors a la Península Iberica, 2006, pp. 223-40. [Exploration of the richly developed world of politics and 
culture during the period of Peter's reign, continuing and extending that of his father, a period in which he had contact with at least thirty poets and during which a new grouping of southern French and Catalan states seemed to be in the making; unfortunately, Peter did not survive the battle of Muret, and the excitement and momentum seems to have died with him.]

\section{PC 326. Peire de Barjac}

[First half thirteenth century; friend of Guillem de Balaun; fanciful vida, one canso (a comjat) of contested attribution, possibly by Berenguer de Palol, though Spampinato Beretta thinks it unlikely.]

\section{8.}

Archer, Robert, and Isabel de Riquer. Contra las mujeres: poemas médiévales de rechazo y vituperio. Barcelona: Quaderns Crema, 1998. [Edition with Catalan translation of the comjat, called mala canso, pp. 162-67, based on the text given in appendix by M. Spampinato Beretta in her edition of Berenguer de Palol, 1978.]

\section{9.}

Guida, Saverio. "Nuovi documenti su alcuni trovatori del XIII secolo.” CN39 (1979): 81-105. [Pp. 95-100: identifies Peire de Barjac in a half-dozen archival documents as a respected and generous lord of the castle of Cornillon near Barjac; the text of the poem is not reproduced.]

2740.

See 477, Winter-Hosman, "Un texte peut en cacher," 2001. [Peire de Barjac in his one extant poem refers to Folquet de Marselha's S'al cor plagues, PC 155,18, as did Gaucelm Faidit in his PC 167,39; Peire refers also to PC 167,39 and another by Gaucelm; together these make a series of malas cansos which turn against fin'amor and speak of a mala domna; Gui d'Ussel, PC 194,19, also participates in the mala domna series, influenced by Gaucelm Faidit and by Raimbaut de Vaqueiras and by a partimen between Maria de Ventadorn and Gui d'Ussel; for more on the mala canso, see $>\mathbf{8 9 0}$, A. Rieger, "La mala canso de Gui d'Ussel," 1992.]

\section{PC 327. Peire Basc}

[ $f$. 1230-45; one sirventes ("sirventesca") in a feminine voice, protesting against a new sumptuary law promulgated by the mendicants.]

\section{1.}

See 735, A. Rieger, Trobairitz, 1991, pp. 691-703. [Critical edition, with German translation, notes; analysis pp. 698-703: thinks it was perhaps written by a woman using P. Basc as a pseudonym.]

\section{2.}

Di Luca, Paolo. "Sirventesca: le sirventés parodié." RLaR 112 (2008): 405-34. [Wideranging study of a group of inventive poems from the later thirteenth century, characterized by innovation in metrics, register, and genre; Di Luca explores various types of burlesque parody of the canso tradition (peguesca, "song of the fool," gelosesca, "song 
of the jealous one," and saumesca, "song of the donkey"; study of two quite dissimilar sirventescas by Bernart de Rovenac and Peire Basc.]

\section{PC 328. Peire de Blai (Brau)}

[Dates uncertain; one canso.]

\section{3.}

Gresti, Paolo. "La canzone En est son far chansonet'ai noelha (BdT 328.1)." ZrP 116 (2000): 236-59. [Poem confirmed to be by Peire de Blai; edition with rich textual notes, Italian translation; detailed study of authorship shows it is not by Uc Brunenc; analysis of manuscript history, poetic structure, versification.]

2744.

Tavani, Giuseppe. "Peire de Blai: En est son fas chansoneta novelha (BdT 328.1)." Lecturae tropatorum 3, 2010, 31 pages. Online at http://www.lt.unina.it. [An improved text over his previous edition of 1999 and over Gresti's of 2000; introduction on manuscript history of $M$; previous scholarship; critical edition with Italian translation, notes.]

2745.

\section{PC 330. Peire Bremon Ricas Novas}

[fl. 1230-41; fourteen cansos; series of six sirventes involving a quarrel with his friend Sordello over a lady; exchange of coblas with Gui de Cavaillon; imitated Sordello's planh for Blacatz.]

Di Luca, Paolo. Il trovatore Peire Bremon Ricas Novas. Modena: Mucchi, 2008. Doctoral thesis, University of Naples, 2007, available as a PDF file at http://www.fedoa. unina.it/1749/1/Di_Luca_Filologia_Moderna.pdf. [Introduction on the poet, who left no historical trace but visited courts in Provence, Toulouse, and Marseille; he is distinguished from his homonym Peire Bremon lo Tort by his nickname Ricas Novas, but it is not clear which poet is referred to in Peire d'Alvernhe's satirical gallery; new critical edition of twenty-two certain attributions including cansos, sirventes, two planhs, and one epic letter, lassa epica, plus a tenso of uncertain attribution between Josbert and Peire Bremon.]

2746.

Fuksas, Anatole Pierre. "Il corpo di Blacatz e i quattro angoli della cristianità." In - 115, Interpretazioni, 2001, pp. 187-206. [Analysis of a cycle of three planhs, starting with Sordello's PC 437,24 suggesting that the political leaders of Europe should eat some of Blacatz's heart to acquire his courage; Bertran d'Alamanon in PC 76,12 claimed that none of these was worthy, and that the heart should be given to a number of superior ladies; Peire Bremon Ricas Novas in PC 330,14 declared that the whole body should be shared in all corners of the world, making Blacatz into a sort of lay courtly saint, in language that suggests a parody of Christ's sacrifice for mankind.] 2747.

See 2400, Guida, "L'attività poetica," 1973, pp. 265-71. [Exchange of coblas between Gui de Cavaillon and his friend Peire Bremon Ricas Novas, PC 330,20 = 
192,1, a disagreement over Gui's bad treatment of Peire's friend while he was a guest in Gui's castle; text with Italian translation, notes.]

\section{PC 331. Peire Bremon lo Tort}

[fl. 1147-87 or 1219-20?; vida; two cansos, perhaps two others; wrote from the Holy Land during the Second and Third Crusades; was perhaps satirized in Peire d'Alvernhe's sirventes (in a version of stanza eight found in two manuscripts), but this might refer to Peire Bremon Ricas Novas.]

\section{8.}

Boutière, Jean. "Peire Bremon lo Tort." Rom 54 (1928): 427-52. [Introduction reestablishes two poems to him; study of themes, vocabulary, rhymes, language; critical edition of two poems, PC 331,1 and PC 330,10, formerly attributed to Peire Bremon Ricas Novas, with textual notes, no translation.]

2749.

Marshall, J. H. "Le troubadour Peire Brémon lo Tort et deux chansons d'attribution douteuse.” MA 86 (1980): 67-91. [Examines the attribution of PC 356,2 and PC 70,11 ; after careful study of language, versification, and content, concludes that the first is not by Peire Rogier and the second not by Bernart de Ventadorn, rather, both by Peire Bremon lo Tort; edition of both, the first diplomatically, the second more critically, with indication of their bizarre linguistic state and the maladroit style of both.]

\section{PC 332. Peire de Boussignac}

[Late twelfth century; vida, two sirventes directed against the deceptive wiles of women; said to be a cleric from the petty nobility, contemporary of Bertran de Born, lived at his castle at Hautefort.]

2750.

Audiau, Jean, and René Lavaud. Nouvelle Anthologie des troubadours. Paris: Delagrave, 1928, pp. 173-76. [Brief introduction, edition of PC 332,1, Quan lo dous temps d'abril, with French translation, no notes; both sirventes are edited in Mahn, Die Werke der Troubadours, 4 vols., Berlin: Duemmler, 1846-53, 3:278-81, no translation, no notes.]

2751.

See 439, Malm, Dolssor Conina, 2001, pp. 87-91. [Analysis of PC 332,1 Quan lo dous temps d'abril.]

2752.

See 249, Bec, Florilège en mineur, 2004, pp. 309-15. [Brief introduction, vida, text of PC 332,1, Quan lo dous temps d'abril, from Audiau-Lavaud, with French translation, no notes.]

2753.

See 2123, Paden, “De l'identité historique," 1980, pp. 216-19. [In appendix to an article on Bertran de Born, reports on historical traces of Peire found in four archival documents; further mention is made of other members of the Boussignac family closely attached to Bertran de Born and to Hautefort.] 


\section{PC 333a. Peire Catalan (Peyre Cathala)}

[f. 1230-40; not listed by PC, Frank, or Distilo, who considered him to be a Catalan poet; historical documentation and intertextual connections to Guillem Auger

Novella and Bertran del Pojet prove that he was an Occitan troubadour.] 2754.

Fabre, Césaire. "Deux Poèmes de Peyre Cathala: i. Axi com celh que del tot s'abandona. ii. Mos cors se mor lenguen, mays morts non." RR 13 (1922): 1-17, 214-27, and 359-74. [Introduction on manuscript study, historical background; study of the two poems, the first in favor of Raimon VI in his struggle to regain Toulouse, 1230-35, the second was dedicated to Guillem Augier Novella as a perfect knight; critical edition of the two poems, with French translation; further information on Guilhem and on Bertran del Pojet.]

2755.

See 2425, Calzolari, "Guillem Augier Novella," 1986. [Research on the biography of Guillem Augier Novella has revealed poems by Bertran del Pojet and Peire Catalan dedicated to him: Bertran's PC 87,2 and Peire's 336a, Mos cors se mor lenguen; intertextual connections among the three poets show conclusively that Peire Catalan was a close member of the group of poets at the court of Raimon Berengier $\mathrm{V}$ and should be listed as an Occitan poet; his poem features many figures of rhetoric such as poliptoton, anafora, and alliteration.]

2756.

Guida, Saverio. "Nuovi documenti su alcuni trovatori del XIII secolo.” CN39 (1979): 81-105. [Pp. 102-5: finds documentary traces of Peire Catalan near Avignon, indicating that he may have been a friend of Augier Novella and an inner member of the poetic group at the court of Raimon Berengier V.]

\section{PC 334. Peire de la Cavarana (Caravana)}

[Second half twelfth century; perhaps mentioned in Peire d'Alvernhe's satirical poem, lines 73-78; one sirventes exhorting Lombards against Emperor

Frederick Barbarosa, unusual for its refrain; if Peire was Italian (there is no clear proof), then he was the earliest of the Italian troubadours.]

2757.

Jensen, Frede. "Sur l'italianité de Peire de la Cavarana." In $\mathbf{1 5 2}$, Miscellanea Roncaglia, 1989, 2:695-703. [A close linguistic analysis of Peire's poem shows no evidence of language use that is outside the norms of the Occitan koiné.]

2758.

See 249, Bec, Florilège en mineur, 2004, pp. 121-25. [Brief introduction, text from Bertoni, with French translation.]

\section{PC 335. Peire Cardenal}

[Born ca. 1180, died ca. 1278-80; about ninety-six poems, in many genres, three with melodies: see $\mathbf{6 0 7}$, van der Werf, Extant, 1984, pp. 232*-33*; his first period, up to 1208 , is devoted to love poetry, the second has eighty-eight ironical 
sirventes, showing a profound understanding of satire; Peire was strongly religious but anticlerical; he composed two sermons, predicansas.]

2759.

Lavaud, René. Poésies complètes du troubadour Peire Cardenal (1180-1278): texte, traduction, commentaire, analyse des travaux antérieurs, lexique. Bibliothèque méridionale, 2e série, 34. Toulouse: Privat, 1957. [Introduction on the life of the poet, the corpus, earlier scholarship and literary analysis, commentary on Peire's constant moralizing tone; study of metrics, music, structure; edition of the vida and ninety-six poems, with French translation, plus seven of dubious attribution; a new edition by Vatteroni is underway: see "Pour une nouvelle édition critique de Peire Cardenal," in 95, AIEO 2, 1993, 1:401-8, which includes a brief analysis of several difficult passages in PC 335,68.]

2760.

Vatteroni, Sergio. "Le poesie di Peire Cardenal (I-VI)." SMV 36, 39, 40, 41, 42, 45 (1990, 1993, 1994, 1995, 1996, 1999). [Very detailed philological study and critical edition of each of fifty-five poems so far, with Italian translation; no study yet of Peire's life or social context, no overall literary analysis of the poetry.]

2761.

Barbiellini Amidei, Beatrice. "Postille intertestuali: Peire Cardenal." SMV 47 (2001): 95-127. Also in: Barbiellini Amidei, Beatrice. Non lasciare l'oro per il piombo: Elementi di intertestualità trobadorica e di critica del testo. Milan: CUEM, 2003, pp. 69-95. [Exploration of Peire's tendency to moralism and didacticism, supported by analysis of passages inspired by the Roman de Renart and other allegorical figures found in works of his contemporary Jeun de Meun; in particular, the use of the figures of Isengrimus and Renart as the incarnation of greed and trickery leads to comparison of similar uses in other troubadours and in Dante.]

2762.

Barbiellini Amidei, Beatrice. "Il sirventese contro Dio di Peire Cardenal e il tema della disputa con Dio." SMV 49 (2003): 7-26. Also in: Barbiellini Amidei, Beatrice. Non lasciare l'oro per il piombo: Elementi di intertestualità trobadorica e di critica del testo. Milan: CUEM, 2003, pp. 97-113. [Analysis of Peire's outrageous threat to appeal God's judgment to a higher court, if he is refused admission to paradise, compared with poems by Monge de Montaudon and others that address or criticize God, or those in the Galician tradition of accusation against God for having created unrequited love; Peire's poem has a more serious tone, touching on blasphemy, as in the trials of Job or in Rutebeuf's Miracle de Theophile.]

2763.

Brunetti, Giuseppina. "Intorno al Liederbuch di Peire Cardenal ed ai libri d'autore: alcune riflessioni sulla tradizione della lirica fra XII e XIII secolo." In $\bullet \mathbf{9 2}$, Actes $d u$ $X X^{e}$ Congrès, 1993, 5:57-71. [Insight into the compilation and history of Peires's collection of poems in MS $T$ during his lifetime or shortly after.]

2764.

Crémieux, Geneviève. "De la folie à la mort: images de l'individu chez Peire Cardenal 
dans les pièces Una ciutatz fo no sai cals et Un sirventes novel vueill comensar." In - 159, Studia occitanica, 1986, 1:67-80. [Analysis of the theme of insanity and evil in Peire's poetry; in Una ciutatz, folia is equated to evil in the world where cortezia has fallen into decline and can only be remedied by an adherence to God; Un sirventes novel is set on the Day of Judgment, where each person comes alone to be saved or condemned; the poet pleads his case, finally claiming innocence because he did not ask to be born.]

2765.

See 2448, Garreau, "Hérésie et politique," 1984. [After detailed analysis, concludes that there is no indication that either Peire Cardenal or Guilhem Figueira was Cathar, though they and their families lived in a symbiotic relationship with the Cathars; both were politically engaged against the French, the crusaders, and the Inquisition.]

2766.

See 2399, Ghil, "Triumph of the sirventes," 1994, pp. 54-57. [In opposition to the opinion of Georges Bordonove, who claimed that the troubadours did not react strongly or sincerely to the invasion by Simon of Montfort, shows that Peire Cardenal composed about twenty scathingly virulent anticlerical and anti-French sirventes at the height of the violence of the crusade; their depiction of clerical greed and arrogance was still being enthusiastically quoted a century later.]

2767.

Marshall, John H. "Imitation of Metrical Form in Peire Cardenal.” RPh 32 (1978): 18-48. [Detailed study of the methods by which contrafacta may be identified; classification of sixty-six strophic pieces by Peire, forty-nine of which are well classified by Lavaud, seventeen requiring further detailed study; taken together, fifty-six of these songs are shown to be contrafacta, mostly based on works by classic poets such as Bernart de Ventadorn, Gaucelm Faidit, and Bertran de Born, along with four based on French songs; the groundbreaking study has allowed the recovery of melodies for twenty-eight of Peire's songs.]

2768.

Sakari, Ellen. "Observations sur l'ironie de la chanson Ar me puesc ieu lauzar d'amor $(335,7)$ de Peire Cardenal.” In 96, AIEO 3, 1992, pp. 1153-58. [Against the opinion of André Compan, in 1050, Mélanges Planche, 1984, pp. 127-36, who believes that the poem is a serious renunciation by Peire of his former worldly life, Sakari interprets it as a contre-chant, a stylistic form of irony composed in an exaggerated imitation of courtly style, with implied criticism, an extended parody of the traditional submissive and obedient lover of fin'amor.]

2769.

Schulze-Busacker, Elisabeth. "Si totz temps vols viure valans e pros (PC 335, 51a)." In Convergences médiévales: épopée, lyrique, roman. Mélanges offerts à Madeleine Tyssens. Edited by Nadine Henrard et al. Brussels: De Boeck université, 2001, pp. 441-57. [Study of a controversial sirventes attributed by some scholars to Peire Cardenal; demonstrates that it is not by him; it is a traditional moral statement of the duties of a young prince, inspired by the Facetus, which is otherwise absent from Peire 
Cardenal's works, there are frequent allusions to the Disticha Catonis, otherwise rare in his poetry, without any of the links to biblical and exegetic traditions that are so typical of Peire; in appendix, an exhaustive survey of possible sources and resemblances.]

2770.

Troncarelli, Fabio. "Escatologia e gioachimismo in Provenza." In La Vie culturelle, intellectuelle et scientifique à la cour des papes d'Avignon. Edited by Jaqueline Hamesse. Turnhout: Brepols, 2006, pp. 161-81. [A study of themes concerning the end of the world and the fate of mankind after death, from Joachim of Fiore, a mystic later declared heretical, who theorized the dawn of a new age in which the hierarchy of the church would be unnecessary; anticlerical ideas spread in his name along with anti-French sentiment among a few troubadours, particularly Peire Cardenal, but also Guilhem Figueiras, Peire Vidal, and Bertran de Lamanon.]

2771.

Vatteroni, Sergio. "Per lo studio dei Liederbücher trobadorici. I: Peire Cardenal; II: Gaucelm Faidit." CN 58 (1998): 7-89. [Pp. 7-45: finds evidence of two collections of Peire Cardenal's poems; explores the history of their creation and use, one called the vulgata, older and more trustworthy than the libre compiled by Miquel de la Tor.] 2772.

See 260, Vatteroni, Falsa clercia, 1999. [Study of anticlerical themes and traditions and what constitutes heresy; pp. 146-56: texts of four poems by Peire Cardenal from his 1990 edition, with Italian translation, no notes; Peire was not, strictly speaking, heretical in a religious or doctrinal sense but was heretical in the wider sense of being disobedient that was being propagated by the church and by political forces in southern France.]

2773.

Vatteroni, Sergio. "Verbum exhortationis e propaganda nella poesia provenzale del XIII secolo." In 109, Comunicazione e propaganda, 2007, pp. 653-79. [Didactic strategies in Peire Cardenal are likened to those of preachers who denounce errors in those around them in order to correct them; an annotated listing of eight poems by Peire illustrate his tendency to sermonize.]

2774.

See 227, Riquer, 1975, 3:1478-518. [Introduction, vida, eleven poems, with Spanish translation.]

\section{PC 338. Peire de Corbian (Corbiac)}

[First half thirteenth century; probably a lay canon; the uncle of Aimeric de Belenoi; one poem to the Virgin; his encyclopedic didactic work Thezaur (see - 1503-6), was composed early in the thirteenth century, 520 lines, all rhyming in -ens; a later version of 840 lines has interpolations by later copyists.] 2775.

See 1517, Oroz Arizcuren, La lirica religiosa, 1972, pp. 370-77 and 480. [Critical edition of PC 338,1, with Spanish translation, textual notes, no commentary.] 
2776.

See 1504, Canettieri, "Il tesoro," 2002, pp. 117-34. [Traces the effects of a radical change in methods of measuring and counting in the late twelfth century, coming from the Mediterranean and moving north, leading to a gradual change in cognitive mentality; Peire de Corbiac, author of the Thezaur, was exceptional, being both a poet and a mathematician, aware of the advantages of reciprocity between the worlds of literature and science; his text is newly dated to the early thirteenth century.]

2777.

Lefèvre, Yves. "Deux poètes médoquins du XIIIe siècle (Aimeric de Belenoi et Peire de Corbian)." Revue historique de Bordeaux 13 (1964): 123-31. [A historical study of Aimeric and his uncle Peire.]

2778.

See 249, Bec, Florilège en mineur, 2004, pp. 241-45. [Text of PC 338,1, with brief introduction, French translation.]

\section{PC 339. Peire Duran}

[Early fourteenth century; two cansos, one sirventes, plus two poems of doubtful attribution: one sirventes probably by Raimon de Miraval, one fictive tenso, in which a lady and her husband argue about the size of his penis.]

2779.

See 2490, Muratori, "Per una biografia," 1998. [Casts doubt on Sakari's attribution of PC 234,8 to Peire Duran, claiming that it is by Guillem de Saint-Didier.]

2780 .

See 735, A. Rieger, Trobairitz, 1991, pp. 462-71. [Edition of PC 234,8, with German translation, notes; shows that it is probably a fictive tenso between a husband and wife disputing the size and use of his member, and it is judged to be by Guillem de Saint-Didier, not by Peire Duran.]

2781.

Sakari, Aimo. "L'attribution de D'una domn'ai auzit dir que s'es clamada (234.8)." In 96, AIEO 3, 1992, pp. 1145-52. [A fictive tenso by Peire Duran, attributed wrongly by $C$ to Guillem de Saint Didier, was already edited by Sakari in 1957 and 1986, the first as a synoptic edition, since the two manuscript copies are so different, the second in which the poem was compared to the questioning in a courtroom trial; this third article was written to strengthen the attribution to Peire Duran because of doubts cast by Muratori; similarities are explored among a series of eleven poems by five troubadours.]

2782.

Sansone, Giuseppe E. "Per il testo della tenzone fittizia attribuita a Peire Duran." Rom 118 (2000): 219-35. [Careful study, edition, with Italian translation, notes; see also his article in 99, AIEO 6, 2001, pp. 478-86, which presents more evidence that the contre-texte is probably by Peire Duran, through structural and grammatical parallels with his first two cansos and thematic and rhetorical parallels with the sirventes; reproduction of all four of Peire's poems.] 


\section{PC 344 and 345. Peire Guilhem}

(known also, wrongly, as de Tolosa or de Luserna)

[fl. 1194-1230; vida; five poems; probably the same Peire Guillem who wrote an allegorical novas: see 19.15 Lai on cobra ses dregz estatz.]

\section{3.}

Morlino, Luca. Edition of the vida, five songs and the allegorical narrative Lai on cobra. Online at http://www.rialto.unina.it. [In the Boutière/Schutz and Favati editions, the vida is attached to Peire Guillem de Tolosa, according to a longstanding scholarly tradition that distinguished him from Peire Guillem de Luserna: in reality, the two are identical, as Morlino demonstrated in his graduating thesis, Il trovatore Peire Guillem. Identificazione ed edizione critica, University of Padua, 2005.]

2784.

See 260, Morlino, "Omonimi equivoci," 2009. [Demonstrates that the same troubadour is known as Peire Guillem, Peire Guillem de Tolosa, and Peire Guillem de Luserna, Luserna being a symbolic place-name meant simply to indicate a favorable opinion of him.]

\section{5.}

Paden, William D. "Contrafacture between Occitan and Galician-Portuguese [1]." La Corónica 26.2 (1998): 43-57. [Poems by Bernart de Ventadorn, Arnaut de Mareuil, and Peire Guilhem de Luserna imitated by Galician poets.]

2786.

Vitale-Brovarone, Alessandro. "Peire Guilhem de Luserna." In Peire Guilhem de Luserna e lo tems dals trobaires. Atti del Convegno Storico Internazionale (4 e 5 maggio 1991 in Luserna San Giovanni). Edited by Vera Cognazzo and Giuseppe Mocchia di Coggiola. Piasco: Ousitanio vivo, 1994, pp. 85-95, plus comments by Sansone, pp. 97-100. [Verifies the identity of Peire as a poet from Luserna San Giovanni in Piedmont, two of whose poems can be dated to 1226 and 1228; he seems to have belonged to the lesser nobility and to have moved in the poetic circle that included Sordello and the court of the da Romano.]

Peire Lunel. See PC 289 (formerly called Lunel de Monteg or Cavalier Lunel de Monteg)

\section{PC 348. Peire de Maensac}

[Early thirteenth century; vida; three cansos, and a sirventes are attributed to him by some manuscripts, but none has been attached definitively to his

2787. name; one canso remains a possibility.]

Betti, Maria Pia. "La canzone del trovatore Peire de Maensac Estat aurai de chantar (BdT 194,7)." In 158, Studi Bertolucci Pizzorusso, 2006, 2:227-60. [Introduction on manuscripts, biography and genealogical history, problems of attribution; critical edition, with Italian translation, copious notes; a final study of all pertinent aspects of distinction leads to a probable attribution to Peire de Maensac.] 
2788.

Squillacioti, Paolo. "BdT 276,1 Longa sazon ai estat vas Amor." RST 2 (2000): 185215. [Critical text of the comjat based on $M$, with Italian translation; two other versions of the text are given; explores possible attributions to Peire de Maensac, Pons de Capduelh, Cadenet, Rostanh de Merguas, and Jordan de l'Isla de Venessi, without a final decision; see also $\mathbf{2 5 9 6}$, Heintze, "Die Rezeption," 2002.]

2789.

Poe, Elizabeth W. "Lord Hermit and the Joglar from Velay: Peire de Maensac as the Author of Estat aurai de chantar (PC 194, 7)." In 157 De sens rassis, 2005, pp. 543-56. [Text reproduced from Audiau, 1922, with a few changes indicated in notes; English translation; should be renumbered PC 348,1 and removed from the corpus of Gui d'Uisel.]

\section{PC 349. Peire Milo}

[First half thirteenth century; his vida, discovered 1990, contains no real facts; eight cansos, one cobla, all written in a dialect very different from the standard literary language (“Alpine," according to Jeanroy).]

\section{0.}

Borghi Cedrini, Luciana. Il trovatore Peire Milo. Modena: Mucchi, 2008. [Analysis of previous scholarship, study of manuscripts, metrics, style, and language; edition of nine songs plus one of uncertain attribution, with Italian translation, notes; the very detailed study of the language shows that it is an Alpine dialect, unlike the troubadour koiné, probably from northeast Occitania close to Italy.]

2791.

Borghi Cedrini, Luciana. "Recuperi linguistici nella tradizione manoscritta dei trovatori (per l'edizione critica dell'opera di Peire Milo)." In \ 99, AIEO 6, 2001, pp. 171-9. [A preliminary study of Peire's unusual language leads to the conclusion that it was probably altered to some extent in transmission through efforts to correct and standardize it; restoring its original state is hampered by our distorted knowledge of the troubadour language; we can no longer base critical editions and choices of variants on the "standard" Old Occitan grammars; on the contrary, Old Occitan grammars need to be redone, based on a very careful new analysis of the manuscript traditions that will allow us to see what is "normal" and what is not.]

2792.

Borghi Cedrini, Luciana. "Una cobla di Peire Milo e un sonetto guittoniano." In - 158, Studi Bertolucci Pizzorusso, 2006, 1:261-81. [Analysis of Peire's paretimological cobla, along with similar examples of alphabetical wordplay by Cerveri de Girona, Cadenet, Sordello, Peire Bremon Ricas Novas, and in Flamenca; further analysis of the connection between love and death, amor and mor, in Occitan and Italian traditions, and especially in a sonnet by Guittone d'Arezzo, which may have inspired, or been inspired by, Peire Milo.] 


\section{PC 352. Peire de la Mula}

(de Sancto Egidio/Saint-Gilles; the same as Mola PC 302)

[fl. 1190-1208; vida; two sirventes, probably a tenso with Albertet de Sisteron, and two exchanges of coblas, unless one cobla is part of the first poem.]

\section{3.}

Guida, Saverio. "Trovatori provenzali in Italia: chiose al partimen tra Albert e Peire (BdT 16,15)." Revista de literatura medieval 21 (2009): 173-93. [Identifies Peire de la Mula as the probable interlocutor of Albertet de Sisteron in the tenso PC 16,15 = 322,1, En Peire, dui pro cavallier (attributed also to Raimon de Toloza the elder), and comments on the cultural importance of the court of the Marquis Otto del Carretto and of the two dedicatees or judges of the debate, Guglielmo and Maria Malaspina.] 2794.

Larghi, Gerardo. "Occitania italica: Peire de la Mula da Saint-Gilles.” In 102, AIEO 9, 2011, pp. 441-52. [Study of the development of troubadour poetry in the courts of Liguria and Piemonte in the late twelfth century, with detailed attention to Peire; new archival discoveries from 1190 and 1193 verify the information in Peire's vida concerning his origins in Languedoc and his influential and profitable attachment to the Piemontese court of the Marquis Otto del Carretto; he participated in poetic and political activities with Raimbaut de Vaqueiras, Albertet de Sisteron, and others in northern Italy and in the court of Aurenga.]

2795.

Pulsoni, Carlo. "Ia de razon no.m cal metre en pantais (BdT 352,2)." El Criticón 87 (2003): 719-28. [Edition of the sirventes, with Italian translation and full variant readings; the poem was attributed variously to Peire de la Mula and Falquet de Romans; careful study seems to point more toward Peire, but there is not enough evidence to allow for a clear decision; both poets were active at the same time, around 1220, at the court of Otto del Carretto.]

2796.

See 249, Bec, Florilège en mineur, 2004, pp. 127-31. [Text of vida and the two coblas, PC 352,1 and 3, with brief introduction, French translation.]

2797.

See 227, Riquer, 1975, 2:803-5. [Edition of the vida and the two-stanza cobla PC 352,1, with introduction, Spanish translation.]

\section{PC 355. Peire Raimon de Tolosa}

[fl. 1180-1225; vida; eighteen cansos in the purest style of fin'amors, one with melody; see 607, van der Werf, Extant, 1984, p. 234*.]

2798.

Cavaliere, Alfredo. Li poesie di Peire Raimon de Tolosa. Biblioteca dell'Archivum romanicum, 22. Florence: Olschki, 1935. Reprint, New York: AMS, 1983. [Introduction on the life of the poet, his corpus, style, metrics, and language; edition of eighteen poems, with Italian translation, notes, glossary; full variant readings for each poem, pp. 127-54; see the detailed review article by K. Lewent, Rom 66 (1940): 12-31.] 
2799.

Manetti, Roberta. "Per una nuova edizione di (o dei?) Peire Raimon de Tolosa." In - 98, AIEO 5, 1998, pp. 193-203. [Preliminary investigations leading toward a new edition to replace that of Cavaliere; covers manuscripts, historical references in the texts, distribution of texts in the manuscripts, attributions, intertextual links, especially to the poems of Giraut de Bornelh.]

\section{0.}

See 678, Chaillou, "Le chant du texte," 2009. [Mirror structures within Peire's Atressi cum la candela, PC 372,3, emphasize the fourth line of each stanza, in both text and melody; five musical techniques make the melody stand out in this line that contains the series of end-words which carry the meaning of the poem.]

2801.

Pfeffer, Wendy. "Les proverbes et les Toulousains: le cas de Peire Raimon." In $>\mathbf{9 8 ,}$ AIEO 5, 1998, pp. 109-13. [Peire uses proverbial expressions sparingly but with striking effect; the common wisdom lends a popular, realistic tone to his poetry, especially in PC 355,18, Tostemps aug dire, in which the lover's request is expressed delicately and indirectly; among six poets attached directly to Toulouse, Peire displays remarkable expertise in the use of paremiological materials.]

\section{PC 356. Peire Rogier}

[Third quarter twelfth century; vida; seven or eight cansos and one sirventes addressed to Raimbaut d'Aurenga; several coblas tensonadas, one of which has the monosyllabic dialogue later used in Flamenca; satirized in Peire d'Alvernhe's gallery poem.]

2802.

Nicholson, Derek E. T. The Poems of the Troubadour Peire Rogier. Manchester: Manchester University Press, 1976. [Introduction on biography and historical context, study of metrics, language; edition of the vida, eight cansos, one of which is of doubtful attribution, and Raimbaut d'Aurenga's reply, PC 389,34, to Peire's sirventes, PC 357,7, all with full critical apparatus, no translation; full glossary; in appendix, information about his patron, Ermengarde, viscountess of Narbonne, and her influence on other troubadours.] 2803.

Gourc, Jacques. “D’un exemple de permeabilitat e de mobilitat actancial a cap a un assag de redefinicion de la lyrica trobadorenca." In \$ 96, AIEO 3, 1992, pp. 919-26. [Compares the use of dialogic materials in three lyric poems, Peire Rogier, PC 356,4, Giraut de Bornelh, PC 242,3, Bernart de Ventadorn, PC 70,17, and in Flamenca; claims that our definition of "lyric" needs to be widened because of the areas where narrative and lyric overlap.]

\section{PC 362. Peire de Valeira (Valeria)}

[Mid-twelfth century; vida; two incomplete cansos; perhaps Gascon, perhaps a contemporary of Marcabru.]

2804.

See 261, Viel, Troubadours mineurs gascons, 2011. [Introduction gives cultural 
context, considers questions of attribution, manuscript tradition, language, and metrics; critical edition of the vida, PC 362,2 and 3, with French translation, detailed notes; rich glossary.]

2805.

See 227, Riquer, 1975, 1:241-44. [Introduction, edition of the double cobla PC 362,3 with Spanish translation, notes; the despairing lover cannot decide whether to gaze upon his lady, whose perfection will kill him, or avoid seeing her so that he can live, or pray to God to help him live so that he can continue to see and serve her.]

2806.

See 249, Bec, Florilège en mineur, 2004, pp. 25-27. [Brief introduction, text of the fragmentary canso PC 362,2, with French translation.]

\section{PC 364. Peire Vidal}

[ $f$. 1181-97; two vidas; forty-three cansos, one crusade song, one tenso, two abusive coblas; twelve melodies are preserved: see $\mathbf{6 0 7}$, van der Werf, Extant,

1984, pp 235*-53*; traveled to Hungary, Malta, Spain, and Italy; satirized by the Monge de Montaudon in PC 305,16.]

2807.

Fraser, Veronica. The Songs of Peire Vidal: Translation and Commentary. Frankfurt: Peter Lang, 2006. [Careful edition, with facing-page English translation; detailed historical, sociocultural and literary introduction; two razos, twenty-two cansos, twenty-one sirventes, both groups subdivided by theme; an exchange of coblas with the marquess of Busca, Manfredi Lancia, and a tenso with Blacatz; each poem is briefly analyzed, with English translation, notes.]

2808.

Avalle, d'Arco Silvio. Peire Vidal: Poesie. 2 vols. Milan and Naples: Riccardo Ricciardi, 1960. Reprinted in one volume, New York: AMS, 1983. [No translations; for these, see the earlier edition by Joseph Anglade: Les poésies de Peire Vidal. Paris: Champion, 1923.] 2809.

Bardell, Matthew. "The Allegorical Landscape: Peire Vidal's ric thesaur." French Studies 55 (2001): 151-65. [In the poem PC 364,38, Pus ubert ai mon ric thesaur, Peire displays his treasure store of poetical gems of praise and condemnation, bringing together many typical features of his poetry: praise of his patrons, sharp disdain of his opponents, devotion to his lady, and boasting of his own talent; in appendix, the text from Avalle's edition, 1960, with English translation.]

2810.

Ferrari, Anna. "Peire Vidal ou 'de la perfection'." In \$ 96, AIEO 3, 1992, pp. 879-91. [Close analysis of PC 364,29, Molt mes bon e bel, leads to the discovery of new structural complexities, making the poem less fixed, more mobile; a response by Antoine Tavera, pp. 892-94, points to even further complexities of a mathematical nature.] 2811.

Fraser, Veronica. "Les pérégrinations de Peire Vidal: ses séjours en Italie et l'évolution de son oeuvre poétique." In $\mathbf{1 0 0}$, AIEO 7, 2003, pp. 315-24. [Peire traveled to 
Provence, Languedoc, Spain, Italy, Palestine, and Hungary; most of his cansos were composed in Provence and his sirventes in Italy, where he followed and commented on political developments in dialogues with several poets, from Lombardy through Provence, Spain, and Italy to Malta, where he composed his last poems, featuring the gap, his characteristic extravagant boasting mode; his influence on Italian poets was deep and long-lasting, up to the time of Petrarch.]

\section{2.}

Harvey, Ruth, et al. "The Empress Eudoxia and the Troubadours." MAev 70 (2001): 268-77. [Partial elucidation of the confused legends and falsehoods surrounding the marital adventures of Eudoxia, daughter of the emperor of Constantinople; Peire Vidal may be referring in his poem to her proposed marriage to Ramon Berenguer of Provence; Raimbaut d'Aurenga may be speaking of the spurned fiancée Sancha rather than to Eudoxia in his poem; and Bertran de Born is certainly spreading vicious gossip and lies in his Pois lo gens terminis floritz; the full truth awaits further untangling, but Harvey has at least discounted much false information.]

\section{3.}

Sankovitch, Tilde. "Structure and Unity in the Poems of Peire Vidal." Neo 62 (1978): 374-85. [Symbolic structures bind the cansos together in a manner connected not to the arbitrary and varied incidents of the narration but to a more fundamental experience; deeper unity is found through a basic symbol or archetype, in vocabulary and images of woman/earth/Proensa expressing the poet's need for security and selfaffirmation.]

\section{4.}

Szabics, Imre. "Peire Vidal, troubadour toulousain." In $>\mathbf{9 8}$, AIEO 5, 1998, pp. 185-91. [Though he traveled a great deal, Peire remained closely attached to his birthplace Toulouse and to his lord Raimon V, called Castiat in his songs; even after the bitterness of his false accusation and exile, the nostalgic warmth remained, at least for Toulouse, as demonstrated in a number of quotations from his poems.]

\section{5.}

Tavera, Antoine. “Entrebesc: à propos d'une gageure de Peire Vidal.” In $>152$, Miscellanea Roncaglia, 1989, 4:1344-67. [A highly imaginative exploration of a hypothetical procedure by which Peire Vidal may have arrived at the inconceivably complex structure of his Molt m'es bon e bel.]

\section{PC 366. Peirol}

[ $f$. 1185-1221; vida; thirty-two poems, seventeen with melody: see 607, van der Werf, Extant, 1984, pp. 254*-75*; twenty-five cansos, one sirventes, two crusade songs, three tensos, exchange of coblas with Blacatz; 2816. satirized in both Peire d'Alvernhe's and Monge's gallery poems.]

Aston, Stanley C. Peirol, Troubadour of Auvergne. Cambridge: Cambridge University Press, 1953. Reprint, New York: AMS, 1983. [Introduction on Peirol's life and historical context; edition of the vida and thirty-two poems, with English translation, 
notes to each poem pp. 173-88; two poems of doubtful attribution without translation.]

2817.

Harvey, Ruth. "Two Partimens Involving Peirol: BdT 366,10=119,2 and BdT366,30." CN 64 (2004): 187-205. [New critical editions of dialogue poems with Dalfi d'Alvernhe, with English translation, notes; now included in 256, Harvey and Paterson, Troubadour "Tensos," 2010, 3:997-1003.]

\section{8.}

See 480, Marshall, "Dialogues," 1987, pp. 37-58. [Hypothesis that the tenso PC 70,32 = 366,23, Peirol, cum avetz tant estat, may be fictitious, pretending to be a debate between Peirol and Bernart de Ventadorn; critical edition with English translation, notes; now in 256, Harvey and Paterson, Troubadour "Tensos, "2010, 1:141-46, who agree with Marshall that the poem is probably fictive, made in the thirteenth century as a pastiche of characteristic elements in the songs of the two famous troubadours.]

\section{PC 370. Perdigon}

[fl. 1195-1212; two vidas, one positive, one negative; fourteen poems, three with melody: see 607, van der Werf, Extant, 1984, pp. 276*-79*.]

2819.

Chaytor, H.J. Les Chansons de Perdigon. Classiques Français du Moyen Âge, 53. Paris: Champion, 1926. [Introduction on the life of Perdigon, manuscript history, the corpus, study of versification and style; edition of the vida and twelve poems, plus two of doubtful attribution, with French translation, variants, notes; see important corrections and a new edition of PC 370,5 with German translation in Lewent's review $\operatorname{ZrP} 33$ (1909): 670-87.]

2820.

Boldini, Loredana. Le poesie del trovatore Perdigo. Saggio di edizione critica. Doctoral thesis, 2005. Abstract available as PDF file at http://www3.unisi.it/ricerca/dottorationweb/filologia_romanza/abstract/abstract_boldini.pdf. [General introduction to the poet, with brief analysis of each poem; edition is in preparation.]

2821.

See 2236, Boldini, "Il cavaliere villano," 2004-5. [New study of the tenso between Perdigon and Dalfi d'Alvernhe, in which Perdigon, a commoner, defends the exclusive right of the nobility to participate in finamor, while Dalfi, an aristocrat, argues for the superiority of inherent nobility of the heart; Perdigon uses similar arguments to those of Marcabru, in favor of resisting any change to the social order, while Dalfi stresses the value of the individual against that of social position; both are opposed to any privileged position being given to the unpropertied joves; critical edition, with Italian translation, copious notes.]

2822.

Fèvre, Mavis. "Un nouveau regard sur le partimen entre Dalfi et Perdigon, Perdigons, ses vassalatge (PC119,6 = 370,11).” RLaR, 112 (2008): 73-88. [A study of the 
element of performance in partimens, and the appointing of judges; Fèvre proposes that Dalfi's unusual choice of Gaucelm Faidit as judge probably was for comic effect, due to Gaucelm's questionable reputation among courtly circles; in appendix, a chart of judges appointed in twenty-nine partimens: all are aristocratic except for one other, who was, however, appointed by a fellow joglar; Fèvre is unaware of Boldini's 2005 study of the same poem.]

2823.

Marshall, John H. "Le partimen de Dauphin d'Auvergne et Perdigon (PC 119,6)."

In 147, Mélanges Rostaing, 1974, 2:669-78. [Shows that the original edition of the poem was faulty but has been accepted without change until now; new critical edition, with French translation, notes.]

2824.

Squillacioti, Paolo. "Perdigon, Trop ai estat mon Bon Esper no vi (BdT 370,14)." ZrP 121 (2005): 543-62. [Critical edition with full apparatus, Italian translation, notes; the poem was used as a model by Giacomo da Lentini of the Sicilian School.]

\section{PC 371. Perceval Doria}

[ $f$. first half thirteenth century; drowned in 1264 heading a military campaign for Manfred of Sicily against Charles of Anjou; one Occitan sirventes in favor of Manfred and one exchange of coblas with an unknown Felip de Valenza, PC 149a,1; two preserved melodies; also composed two Italian poems of the Sicilian School.] 2825.

Sansone, Guiseppe E. La poesia dell'antica Provenza: testi e storia dei trovatori. 1984. 2nd ed. Parma: Guanda, 1993. [Pp. 555-57: edition of two poems, a short tenso with Felip de Valensa and a vigorous sirventes in honor of Manfredi di Sicilia; Perceval was involved in politics and administration in Asti, Arles, Avignon, and Parma; the poem with Felip is humorous, sarcastically promising true friendship forever.]

\section{6.}

Gresti, Paolo. "Gian Vincenzo Pinelli et les coblas de Percival Doria et Felip de Valenza (Milan, Biblioteca Ambrosiana, R 105 sup.).” In 140, Etudes Ricketts, 2005, pp. 671-79. [Introduction, edition of the exchange of coblas (two stanzas), with French translation, detailed notes.]

2827.

See 227, Riquer, 1975, 3:1376-80. [Introduction, text of PC 371,1 Felon cor ai, with Spanish translation, notes.]

PC 372. Pistoleta (a nickname meaning "note, short letter")

[fl. 1195-1230; vida; eleven poems; his sirventes PC 372,3 was very popular, text and melody preserved in several versions in a mixture of Occitan and French; see 607, van der Werf, Extant, 1984, p. 280*.]

2828.

Hershon, Cyril P. "Pistoleta.” RLaR 107 (2003): 247-341. [Full introduction giving biographical details, his attachment to Arnaut de Maruelh and to various patrons, the 
qualities of his poetry, featuring suffering and patience, and his retreat from poetry to become a married merchant in Marseilles; study of the manuscript tradition, edition of the vida and eleven poems, with French translation, notes.]

\section{9.}

See 678, Chaillou, “Le chant du texte," 2009. [In Pistoleta's Ar' agues eu, PC 372,3 , the melody is designed to bring out the textual structures; in line five, the center of the stanza is made to stand out musically by the use of three repeated notes, ornamentations, and intervals.]

2830.

See 735, A. Rieger, Trobairitz, 1991, pp. 385-99. [Edition of tenso PC 372,4 between Pistoleta and an anonymous domna, with notes, analysis, and German translation; the coyly teasing lady may well be real, but it is difficult to identify her because Pistoleta had contacts with several trobairitz; Maria de Ventadorn would be the most likely candidate, but there is no proof.]

\section{PC 374. Pons Barba}

[Early thirteenth century; one sirventes, and one incomplete canso; probably fled to Catalonia before the Albigensian Crusade.]

\section{1.}

See 255, Guida, Trovatori minori, 2002, pp. 125-79. [Detailed exploration of previous scholarship and historical background locating Pons as a respected citizen of politically advanced city of Mirepoix; he seems to have played a marginal but professional part in the court of Peter II of Aragon, fitting well into the sociocultural climate of the last days of glory of the Aragonese court, before the disaster of Muret, in which Peter perished; critical edition of PC 374,1 and 2, with full apparatus, Italian translation, and copious notes.]

\section{PC 375. Pons de Capduelh (Capduoill, Chapteuil) \\ [ $f$. 1190-1220; two vidas; twenty-seven poems, four with melody: see 607, van der Werf, Extant, 1984, p. 282*_86*; a planh on the death of his lady Azalaïs; one poem is of problematic attribution.]}

2832.

Napolski, Max von. Leben und Werke des Trobadors Ponz de Capduoill. Halle: Niemeyer, 1879. Reprint, New York: AMS, 1983. [New editions have been announced by Rivière (1987) and Routledge (1993); Antonella Martorano has reedited Pons for her doctoral thesis, Florence 2007, "Ricerche sul testo delle poesie di Pons de Capduoill."]

2833.

Martorano, Antonella. "Il frammento ambrosiano del Gay descort di Pons de Capduoill (BdT 375,26) con una nuova edizione del testo." Cultura neolatino 64 (2004): 411-41. [Preliminary to a full edition: see her doctoral thesis Florence 2007: "Ricerche sul testo delle poesie di Pons de Capduoill”; this study offers a full analysis of the manuscripts, a diplomatic transcription of the fragment, along with a critical edition; also a critical edition of the full text, based on $C$, with full apparatus and Italian translation.] 
2834.

Poe, Elizabeth Wilson. "Old Provençal escars/escas: 'poor'? Reconsidering the Reputation of Pons de Capdoill.” Tenso 4.1 (1988): 37-58. [A careful investigation of the meaning of escars in Occitan demonstrates that its use in the vida of Pons is closely linked to its opposite larcs "generous" and must mean "careful with money" or "stingy" rather than "poor"; his reputation for miserliness may have a source that is lost to us, but it is toned down by Uc de Saint Circ, the author of his vida, probably because Uc was familiar with the mindset of a moneylender and shared the same tendency toward prudent management of money.] 2835.

Pulsoni, Carlo. "Lo senher que formet lo tro (PC 323,22) e alcune considerazioni sul corpus poetico di Pons de Capduelh.” Romanica vulgaria. Quaderni 13-14 (1994): 81-116. [Critical edition, with copious notes and Italian translation, followed by a study of Pons's historical context and dating.]

2836.

Rivière, Jean-Claude. "En prélude a une nouvelle édition de Pons de Capdoill: la chanson Us gais conortz me fai gajamen far (PC 375,27)." In 159, Studia occitanica, 1986, 1:241-51. [New critical edition, with French translation and detailed stanza-by-stanza commentary; the poem is a humorous tour de force in which each stanza is devoted to exploring the forms and meanings of one of the key words of the troubadours' vocabulary: gai, fin, humil, razon, merce.]

\section{PC 376. Pons Fabre d'Uzes}

[Second half thirteenth century; one sirventes, PC 376,1, one sestina, PC 376,2.] 2837.

Rochegude, Henri Pascal de. Le Parnasse occitanien. Toulouse: Benichet Cadet, 1819, pp. 366-67. Available online at http://archive.org/details/leparnasseoccita00touluoft. [Edition of the sirventes PC 376,1, no translation, no notes.]

2838.

Bec, Pierre. "La sextine de Pons Fabre d'Uzès: essai d'interprétation.” In Miscellanea mediaevalia. Mélanges offerts à Philippe Ménard. Edited by Alain Labbé, Danielle Quéruel, and Jean-Claude Faucon. Paris: Champion, 1998, pp. 91-100. [A historical survey of the development of the sestina from Marcabru through Arnaut Daniel and Dante into modern times; the text of the sestina, with an analysis of Fabre's fine fuzzy formal features, an attempted interpretation of its message, and finally a "transpoetization" of the poem into modern French.]

\section{PC 379. Pons d'Ortaffa}

[fl. 1217-46; two cansos, one with melody: see 607, van der Werf, Extant, 1984, p. 287*; Pons had a son, also named Pons, who may possibly be the troubadour (died sometime after 1251).]

2839.

See 227, Riquer, 1975, 3:1311-15. [Text of PC 379,2, with introduction, Spanish translation, notes.] 
2840.

Taylor, Robert A. "Pons d'Ortaffa: Images of Exile and Love." In 151 , Mélanges Bec, 1991, pp. 567-75. [Analysis of the ways in which Pons took up and renewed the traditional dialectic themes and motifs of joy and suffering; Pierre Bec's list of traditional topoi of antithesis is applied in detail to Pons's songs to show how he captured in new and striking images the frustration and despair of love and separation; edition of both poems from MS $C$, no translation.]

\section{PC 389. Raimbaut d'Aurenga}

[fl. 1144-73; vida; about forty poems, one with melody: see 607, van der Werf, Extant, 1984, p. 288*; idiosyncratic style, trobar clus; he is referred to as Linhaure by Giraut de Bornelh.]

\section{1.}

Pattison, Walter T. The Life and Works of the Troubadour Raimbaut d'Orange. Minneapolis: University of Minnesota Press, 1952. Reprint, New York: AMS, 1983. [Introduction on cultural background, Raimbaut's biography, and court positions; the corpus, dating, language, style, versification, and analysis of themes and content; edition of the vida, thirty-nine poems, plus three of doubtful attribution, with English translation, notes; Luigi Milone and Aimo Sakari have both announced new editions.]

2842.

Bauer, Franck. "Portrait de l'artiste en lauzengier? Sur la nature et la fonction de l'entrebescamen dans la chanson de la fleur inverse." RLaR 96 (1992): 89-104. [Analysis of Raimbaut's poem as a demonstration of the interlace technique that he invented; in a triangular movement, the poet may be drawn to his domna by the praise of a third party (lauzengier), the lauzengier then becoming his enemy; his praise of the lady makes him into the lauzengier, and the cycle goes on, positive becoming negative and negative positive in a topsy-turvy world.]

\section{3.}

Bossy, Michel-André. "The trobar clus of Raimbaut d'Aurenga, Giraut de Bornelh and Arnaut Daniel." Mediaevalia 19 (1996): 203-19. [Shows that Raimbaut's version of trobar clus is less abrasive and moralistic than that of Marcabru or Peire d'Alvernhe; he claims to place more emphasis on artistic virtuosity than on didactics, with the intention of limiting his audience to the most refined and initiated listeners, but it is hard to decide whether this is a serious stance or parodic, or selfparodic; Giraut de Bornelh and Arnaut Daniel also play with the imaginary and contradictory dilemma.]

2844.

Brusegan, Rosanna. "Le secret de la flors enversa." RLaR 96 (1992): 119-44. [The central poem of Raimbaut's creativity is based on paradox, signaled by the enigmatic term enversa; the poem is reproduced from Pattison's edition, followed by a detailed stanza-by-stanza analysis and by intertextual comparison with Bernart de Ventadorn's lark poem; the secret of the poem is in the reference to Narcissus, used by Bernart and 
by Guillaume de Lorris, reduced by Raimbaut to the essential image of the reflected flower as a symbol of the power of pure poetry.]

2845.

Carapezza, Francesco. "Raimbaut travestito da Fedra (BdT 389,1): sulla genesi del salut provenzale." Medioevo romanza 25 (2001): 357-95. [New edition and study of Raimbaut's poem shows some lexical intertextual influence of Ovid on the creation of the Old Occitan salut.]

\section{6.}

Corcoran, Mary Cynthia. "Intertextualité dans le devinalh (Guilhem IX, PC 18, 7; Raimbaut d'Aurenga, PC 389, 28; et Giraut de Bornelh, PC 242, 80).” In 96, AIEO 3, 1992, pp. 865-77. [Raimbaut's poem is used as a guide to William and his poem; confirms the phallic significance of the contraclau.]

2847.

Di Girolamo, Costanzo. "No say que ses e lo spazio lirico di Raimbaut d'Aurenga." MR 12 (1987): 261-73. [Analysis of Raimbaut's poetics, especially in PC 392, 28, in relation to similar poems by Guilhem de Peitieus and Giraut de Bornelh; Raimbaut is attempting to broaden the scope of traditional fin'amor poetics, in contrast to the parodic tone of the others, to treat seriously and deeply of physical love.]

2848.

Di Girolamo, Costanzo. Edition of Raimbaut d'Aurenga (Raimbaut de Vaqueiras?) PC 392.26a [nu]ils hom tan .. . [n]on amet; online at http://www.rialto.unina.it. [Information on editorial history; new critical edition, notes, no translation.]

\section{9.}

See 803, Gaunt, Troubadours and Irony, 1989, pp. 121-44. [Raimbaut constantly mocks the courtly circles in which he moves, through his robust sense of humor and irreverent treatment of convention.]

\section{0 .}

Hutchinson, Patrick. "Raimbaut d'Aurenga et l'allégorie: tropologie et hétérodoxie, la voie des formes." In 102, AIEO 9, 2011, pp. 395-412. [Enthusiastic analysis of Raimbaut's poetics, which he sees as closely connected with the new theories of Geoffrey of Vinsauf, called "dualistic stylistics," related to Raimbaut's interpretation of trobar clus; the dualism and provocative language bordering on blasphemy seems to place the poet close to beliefs that might have had him accused of heresy if he had lived at the time of the Inquisition.]

2851.

Lafont, Robert, “Ar resplan la flors enversa: la fleur du Gay Savoir.” RLaR 96 (1992): 105-17. Reprinted in La Source sur le chemin, 2002, pp. 111-23. [A strong statement of belief that the key to Raimbaut's sexuality and to his poetry is to be found in his castration, whether in realistic terms or as a psychological complex, and that the body of fin'amor poetry in general is based on male impotence.]

2852.

Majorossy, Imre. "Le dévouement par le trobar clus: Raimbaut d'Aurenga." In - 1516, Amors es bona volontatz, 2006, pp. 37-49. [The transcendent aspect of 
Raimbaut is seen in poem PC 389,12, Ara non siscla, where his use of trobar clus conceals biblical images from the psalms and the Cantica canticorum that are transformed into a statement of his ethereal love for his domna.]

2853.

Milone, Luigi. "Tre canzoni di Raimbaut d'Aurenga (389,1,2 e 11)." CN 63 (2003): 169-254. [Includes detailed manuscripts study, critical editions with Italian translation, full critical apparatus, copious notes.]

\section{4.}

Milone, Luigi. "Cinque canzoni di Raimbaut d'Aurenga (389, 3, 8, 15, 18, 37)." CN 64 (2004): 7-185. [Edition of five cansos, with Italian translation, detailed notes, bibliography.]

\section{5.}

Milone, Luigi. "Raimbaut d'Aurenga, Un vers farai de tal mena (BdT 389,41)." In L'Ornato parlare. Studi di flologia e letteratura romanze per Furio Brugnolo. Padua: Esedra Editrice, 2007, pp. 53-90. [Includes detailed study of manuscript history; critical edition, with Italian translation, full variant readings, copious notes; see also - 368, Cropp, "Courtly Lyric Style," 1976, pp. 30-34, for an analysis of the poem to illustrate the unity achieved by the interweaving of words and themes.]

\section{6.}

Planche, Alice. "Texte à l'endroit, monde à l'envers: sur une chanson de Raimbaut d'Aurenga." In 159, Studia occitanica, 1986, 1:213-26. [A delicately poetic explication of PC 389,16, Er resplan la flors enversa; the controlling image of the inverted flower suggests the lily with its extended popular and religious values, as well as being a symbol of mutation, leading to rich suggestions of metamorphosis: winter into spring or spring into winter under the positive or negative power of love; the notion of inversion echoes that of reversal: the joy of love protecting the poet from the slander of his enemies, and the joy of singing taking the place of the dangerous ecstasy of union; discussion of attempts to translate the poem, especially that of Pierre Bec in - 229, Nouvelle anthologie, 1970, pp. 206-8, followed by her own metrical transposition, offered humbly as proof of the vanity of trying to translate poetry.]

2857.

Renzi, Lorenzo. "Una lettura contestuale della Flor enversa di Raimbaut d'Aurenga." In Poetica e stile. Padua: Liviana, 1976, pp. 25-34. Reprinted in Le piccole strutture: Linguistica, poetica, e letteratura. Edited by Alvise Andreose, Alvaro Barbieri, and Dan Octavian Cepraga, with the collaboration of Marina Doni. Bologna: il Mulino, 2009, pp. 313-24. [Analysis of PC 389,16, moving from the initial exterior description of winter contrasting with spring and love into a complex metaphysical interpretation that shows a reintegration of shattered reality made possible within the act of poetic creation; in addition, Renzi provides a description of the intricate metrical and semantic aspects of the poem, accompanied by a chart showing its closed, circular structure.]

2858.

Riebold, Ute. "Le salut d'amour Donna, cel qeus es bos amics de Raimbaut d'Aurenga." 
In 100, AIEO 7, 2003, pp. 493-510; also in 520, Gambino, Salutz, 2009, pp. 207-33. [PC 389,I may be by Raimbaut de Vaqueiras but is more likely by Raimbaut d'Aurenga, composed near the end of his life, 1170-73; see also 2845, Carapezza, "Raimbaut travestito," 2001, showing the influence of Ovid on the origins of the Occitan salut.]

2859.

See 735, A. Rieger, Trobairitz, 1991, pp. 400-417. [Edition of PC 389,6 = 46,3; the lady may well be real but must have been very strong to rival Raimbaut in poetic skill: only the Comtessa de Dia or Azalais among known poetic contacts could be envisaged as capable of such subtle satire of Raimbaut's lyrics.]

2860.

Serper, Arié. "Amour courtois et amour divin chez Raimbaut d'Orange." In 159, Studia occitanica, 1986, 1:279-90. [Claims that in Raimbaut's poetry, love in its most elevated form can strive to go beyond the human and reach for the divine level of perfection, illustrated by several passages from his work, and especially in the poem PC 389,11, in which God is given a dominant role in his quest for love, merging with the personifications of Love and Chivalry; new critical edition of the poem, with French translation, detailed notes.]

2861.

Stanesco, Michel. "La fleur inverse et la belle folie de Raimbaut d'Orange." CCM 40 (1997): 233-52. [The flor enversa is a poetic symbol of love as a transcendent figure found in mystical sources as the arbor inversa having its roots in heaven and its branches reaching toward the earth; at the same time, it has resonances of the biblical lily, which grows upward but turns downward in humility, a symbol of purity applied to the Virgin; the esoteric symbol is found in various cultures since antiquity and can stand for the feeling of insanity that is produced in the poet by the ineffable emotion of love.]

2862.

Vuijlsteke, Marc. "Eléments de définition d'un mode de l'énoncé poétique: Raimbaut d'Orange et le trobar clus." In > 151, Mélanges Bec, 1991, pp. 587-98. [Detailed analysis of the tenso PC 242,14 = PC 389,10a, with a new interpretation of verses 16-17; shows that the debate between Giraut de Bornelh and Raimbaut d'Aurenga is more nuanced than generally believed; Raimbaut is calling not for a poetic form that excludes the profane and is accessible only to the aristocratic elite but, rather, one that is true to poetic principles and is appreciated only by those who understand the exaltation of fin'amor; at the end of the poem, both poets are in agreement about the worth of their poetic calling and the necessity of remaining true to its ethic.]

2863.

Vuijlsteke, Marc. "Le chant de la fiction chez Raimbaut d'Orange," in $\mathbf{1 0 5}$, L'Imaginaire courtois, 1991, pp. 211-21. [Discusses various interpretations of Raimbaut's Cars, douz e fenhz, PC 389,22, especially the sense of the difficult word fenhz, found also in Flamenca to indicate something that is imitated but also ideally true on the level of aesthetics.] 
2864.

Vuijlsteke, Marc M. “Raimbaut d'Orange et le trobar ric ou prim.” RLaR 96 (1992): 69-87. [In opposition to the definitions of clus, ric, and prim proposed by Pollmann and Mölk, denies that they had any precise meaning for Raimbaut; in fact, poems called by one or the other name all use similar structures and vocabulary and are similarly "difficult"; the principle of concealment of the domna's identity remained a constant feature of all the poems; appendix, pp. 79-87, presents the critical edition of PC 389,26, En aytal rimeta prima, with French translation, detailed notes.]

\section{5.}

Vuijlsteke, Marc. "Une chanson facile de Raimbaut d'Orange: Aussi moulun sonet nou (PC 389,3)." In 161, Studies in Honor of Hans-Erich Keller, pp. 337-58. [A close and detailed analysis of a poem that the poet himself called "easy"; after probing into many difficulties and paradoxes, we must conclude that he was not being straightforward; the passage of time may have masked a message that was relatively clear at the time, but it is more likely that Raimbaut was perversely leading his naive listeners into a trap by offering them a remarkable poem that is anything but easy.]

2866.

Zufferey, François. "Raimbaut d'Orange dans la tradition manuscrite." RLaR 96 (1992): 3-14. [A study of the place given to Raimbaut and the ordering of his songs in the dozen major chansonniers that transmitted his works; his normal place was among the major troubadours, but never in first place, occasionally near the end of the collections; half of his songs were widely distributed and seem to indicate the possibility that there was an early Liederbuch around 1173.]

\section{PC 390. Raimbaut de Beljoc}

[ $f$. 1218-20; one sirventes in praise of Frederick II of Hohenstaufen, Holy Roman Emperor 1215).]

2867.

Larghi, Gerardo. "Raimbaut de Beljoc tra poesia e politica." CN 66 (2006): 213-310. [A very detailed study of social and historical interconnections within a group of about ten contrafact poems by several troubadours and at least one trouvère (Gace Brulé or perhaps Hugues de Berzé), linked by metrical structure; in appendix, edition of PC 390,1 from $I, K$, with Italian translation; Larghi could not get access to the newly discovered copy of PC 390,1 in MS To, with a somewhat mutilated extra stanza: presented in general terms byGasca Queirazza, 1983, from a conference in 1981, the text has not yet been made available to the scholarly world.]

\section{8.}

Gresti, Paolo. "Ancora sui contrafacta provenzali di modelli francesi: il caso di Cerveri de Girona." Aevum 70 (1996): 263-71. [Follows upon a previous article by Asperti, "Contrafacta provenzali di modelli francesi," in Messana (Rassegna di studi filologici linguistici e storici) n.s. 8 (1991): 5-49, in which eight French models were studied as sources for poems by Cerveri de Girona; Gresti examines twelve more songs by 
Cerveri based on poems by various Occitan troubadours, and nine further French songs that may have served as sources for contrafacta.]

2869.

$$
\begin{gathered}
\text { PC 391. Raimbaut d'Eira (Hyeres) } \\
\text { [fl. 1244; razo; one cobla. }]
\end{gathered}
$$

Beltrán, Vicenç. "Poética del sirventés y modelos de escritura." In $\mathbf{1 0 9}$, Comunicazione e propaganda, 2007, pp. 21-30. [Critical edition of Raimbaut's cobla and its razo; Raimbaut is supporting Sancha of Aragon against harsh treatment by the count of Provence, reminding him of his courtly duties; Beltrán's analysis attempts to show the significance of the poem as a model for the passage from oral culture to written and the elevating of a localized criticism of the count into a universal and enduring formulation of proper courtly behavior.]

\section{PC 392. Raimbaut de Vaqueiras}

[fl. 1180-1207; died probably in 1207 along with his lord, Boniface of Montferrat, fighting against the Bulgarians; vida; twenty-six poems, eight with melodies: see

- 607, van der Werf, Extant, 1984, pp. 289*-97*; two plurilinguistic poems use a variety of languages, the earliest known use of several; in his Carros, PC 392,32, an allegorical chariot represents the Italian Communes defended by a number of women rivaling his domna Beatrice de Montferrat in perfection, in a sort of feminine tournament; one section of his three-part epic letter recounts adventures of his own life; his Kalenda maya is a famous estampida.]

\section{Editions}

2870 .

Linskill, Joseph. The Poems of the Troubadour Raimbaut de Vaqueiras. The Hague: Mouton, 1964. Reprint, New York: AMS, 1983. [Introduction on the life of Raimbaut, his corpus, style, versification, and an analysis of his literary place among the troubadours; edition of the vida, twenty-six poems, plus seven of doubtful attribution, with English translation, notes; also an edition of one of the epic letters, pp. 301-44; Federico Saviotti is preparing a new edition of Raimbaut's works: see below 2902.]

2871.

See 227, Riquer, 1975, 2:811-57 [Introduction, edition of eight poems and the epic letter, with Spanish translation, notes.]

2872.

\section{General Studies}

Agrigoroaie, Vladimir. "The Vlachs and the Troubadour: Brief Analysis of Three Poems by Raimbaut de Vaqueiras." Revue d'études sud-est européennes 47 (2009): 55-74. Available online at http://univ-poitiers.academia.edu. [Review and correction of Linskill's imprecise identification of the emperor's enemies and historic details 
mentioned in PC 392,9a, Conseil don a l'emperador, PC 392,24, No magrad'iverns, and the epic letter; no clear information about Raimbaut's connection with the Vlachs is to be found, though there is clarification of the poet's cultural and political life; in appendix, the three texts are reproduced, with Linskill's English translation and a rich bibliography to 2006.]

2873.

Beggiato, Fabrizio. "Raimbaut de Vaqueiras e Albertet: percorsi ed incontri trobadorici nel Monferrato, riflessioni ed interrogativi." In Dalla Provenza al Monferrato. Percorsi medievali di testi e musiche. Edited by Sonia Maura Barillari. Alessandria: Orso, 2007, pp. 19-27. [An enquiry into the identity of Engles in five of Raimbaut's poems, in three coblas of uncertain attribution, and elsewhere; it does not seem to indicate a person who is English, may be used for a feminine person, or may have a different meaning in each use; an inconclusive investigation, but rich in suggestions for further study.]

2874.

Cremonesi, Carla. "Raimbaut de Vaqueiras." In 38, DLF, pp. 1221-22. [Detailed sketch of his life, in particular his cultural, political, and military activities at the court of Boniface of Montferrat and at his patron's side on the Fourth Crusade, where both died; outline of his writings, with descriptions of several of his most interesting poems, the Carros, the epic letter, and the multilingual poems.]

2875.

Gouiran, Gérard. "Sur quelques troubadours qui franchirent les Alpes du temps de la croisade contre les Albigeois." In 164, I trovatori nel Veneto, 2008, pp. 97-133. [Study of the role played by Raimbaut de Vaqueiras, whose success at the court of Montferrat encouraged other poets to come to Italy.]

\section{6.}

See 2697, Guida, "Questioni relative," 2008. [Pp. 251-73: the exchange of coblas between Raimbaut and Albertet is confirmed to be between Raimbaut de Vaqueiras and Albertet de Sisteron and to belong to about 1195.]

\section{7.}

Lee, Charmaine. "La chanson de femme attribuita a Raimbaut de Vaqueiras, Altas undas que venez suz la mar." In - 158, Studi Bertolucci Pizzorusso, 2006, 2:865-81. [The poem stands out as unique in Occitan poetry, as do other texts by Raimbaut; it has more dynamic narrative content than the Galician traditions of the cantiga d'amigo, though it is possible that Raimbaut drew inspiration from the latter, adapting their presentations to his own purposes; even more likely is the influence of the French chansons de femme; the analysis confirms its probable attribution to Raimbaut and its intellectual complexity in combining influences from Galicia, France, and home, along with a hint of the Crusades.]

\section{8.}

McPeek, Gwynn S. "Kalenda maia: A Study in Form.” In Medieval Studies in Honor of Robert White Linker. Valencia: Editorial Castalia, 1973, pp. 141-54. [A brilliant study of melodic form in its relationship to the text; confirms the notion that the 
estampida is a variant of the canso; the text is reedited according to the new structural interpretation, with English translation.]

2879.

Paterson, Linda. "Insultes, amour et une trobairitz: la tenso de Raimbaut de Vaqueiras et Albert." In 101, AIEO 8, 2009, 1:227-36. [Edition of the tenso with English translation; believes that the tenso is a performance piece, not a serious dispute; likewise the bilingual tenso PC 392,7 is probably fictive, and the Genoese woman should be removed from the list of trobairitz; available also in $\mathbf{2 5 6}$, Harvey and Paterson, Troubadour "Tensos," 2010, 1:68-79.]

2880.

See 891, A. Rieger, "Relations interculturelles," 1998, pp. 201-25. [Case study of a poetic network, involving Raimbaut de Vaqueiras along with Elias Cairel, Conon de Béthune and Albrecht von Johansdorf, illustrating the complexity of connections and intertextuality encouraged in large part by intercultural mixing during the Crusades; the phenomenon is posed in terms of give and take rather than of origin and influence, the idea of cultural exchange as multiple, many-sided, and many-directional; a shortened German version in Internationalität nationaler Literaturen, Göttingen: Wallstein, 2000, pp. 485-500.]

2881.

Rossell, Antoni. "Reconstrucción musical de la Epistola de Raimbaut de Vaqueiras: una hipótesis." In Dalla Provenza al Monferrato. Percorsi medievali di testi e musiche. Edited by Sonia Maura Barillari. Alessandria: Orso, 2007, pp. 29-43. [A hypothetical and experimental melodic structure is proposed for the poem, based on psalmody, Gregorian chant, and the hagiographical and epic traditions.]

\section{2.}

Sakari, Aimo. "L'influence des autres troubadours sur Raimbaut de Vaqueiras." In - 97, AIEO 4, 1994, pp. 297-306. [Stresses the verve and originality of Raimbaut's work, along with inspirations that he took from his fellow troubadours, especially Bertran de Born and Guilhem de Saint-Didier, from contemporary epics, and from at least one trouvère, Conon de Bethune.]

2883.

See 306, Salvatori, “Les Malaspina," 2008. [An historian's perspective on the rich materials published by Caïti-Russo, 2005; stresses the need to further analyze the poetry, especially that of Raimbaut de Vaqueiras, as a valuable source of information about the society and its functioning.]

2884.

Saviotti, Federico. "Il viaggio del poeta e il viaggio del testo: per un approccio geografico a Raimbaut de Vaqueiras e alla sua tradizione manoscritta." Moderna 10.2 (2008): 43-59. [Outlines the richness of historical and geographical references in Raimbaut's poetry; the lack of references to Iberia shows that he simply did not travel west; his knowledge of Galician is still to be explained, but his popularity in the Catalan manuscript $S g$ along with Cerveri seems to have been a whim of the compiler rather than an indication of any rapport between the two poets; more attention to 
geography will be required to clarify the movement of poets and their works across their world.]

2885.

Unlandt, Nico. "Au sujet de la lettre épique Valen marques, senher de Monferrat du troubadour Raimbaut de Vaqueiras.” Francographies 1 (1995) 265-79.

2886.

Vallín, Gema. "Sobre el contenido de la Kalenda Maia." Romanica vulgaria. Quaderni 16-17 (1999): 131-39. [Sees the basic textual message as negative toward the courtly ideal, contrasted with the joyfulness of the melody.]

The Plurilingual Descort, PC 392,2, Eras can vei verdeiar, using five different languages

2887.

Bec, Pierre. "Note philologique sur la cobla gasconne du descort plurilingue de Raimbaut de Vaqueyras." MR 12 (1987): 275-88. [Diplomatic transcriptions of the Gascon lines in all seven manuscripts and the composite version of the text proposed by Tavani, 1986, followed by a detailed linguistic analysis of the piece, with emendations and suggestions and an alternate composite text with French translation.]

2888.

Brea, Mercedes. "La estrofa V del descort plurilingüe de Raimbaut de Vaqueiras." In

143, Homenaje Fuentes, 1985-87, pp. 49-64. [Study of the Galician lines of the poem, considering previous editions; a new provisional text is proposed, along with a list of problematic readings that may require further study.]

\section{9.}

Brugnolo, Furio. "Appunti in margine al discordo plurilingue di Raimbaut de Vaqueiras." In 159, Studia occitanica, 1986, 1:45-66. Also in Brugnolo, Furio, Plurilinguismo e lirica médiévale: da Raimbaut de Vaqueiras a Dante. Rome: Bulzoni, 1983, pp. 69-103. [Considers the possible irony in the French cobla and political motivation for writing it; this idea is expanded later by 2893, Tavani, "Accordi e disaccordi," 1989, to cover the possibility of a political motivation for the whole poem.]

2890.

Canettieri, Paolo, "Il novel descort di Raimbaut de Vaqueiras." Romanica Vulgaria. Quaderni 13-14 (1994): 41-80. [New critical edition of PC 392,16, with Italian translation, detailed notes, and literary analysis; demonstrates that the work was composed as a form of transition between two cycles of poems, one in which he renounces love, and the other in which he seeks reconciliation; the reference to Tristan and Marie de France is typical of Raimbaut's use of material from many sources.]

2891.

Fernandez Campo, Francisco. "Breves suxestións sobre o descort plurilingüe de R. de Vaqueiras (estrofa 5, vv. 33-36).” In Estudios galegos en homenaxe ó Profesor Giuseppe Tavani. Santiago de Compostela: Centro Ramón Piñeiro, 1994, pp. 57-64. [Study of four of the Galician lines, with proposals for alternate readings or interpretations; problems in the remaining lines are reserved for further study in future.] 
2892.

Saviotti, Federico. "Nella tradizione di Raimbaut de Vaqueiras: un caso di varianti d'autore?" In 118, La lirica romanza, 2009, pp. 217-39. [In the context of a longer project leading to a new critical edition of Raimbaut's works, this detailed paleographic study of the fourteen manuscripts and two fragments of PC 392,2 leads to division into three families, and the strong hypothesis of authorial intervention in the history of the text, though it is not possible to clarify the chronological ordering of the textual variants.]

2893.

Tavani, Giuseppe. "Accordi e disaccordi sul discordo plurilingue di Raimbaut de Vaqueiras." Romanica Vulgaria. Quaderni 10-11 (1989): 5-44. [Concerns the proper techniques for editing this unusual poem, trying to restore the original form without "correcting" Raimbaut where he mistakenly might have used inappropriate foreignlanguage forms but restoring those that were improperly copied by the scribes; speculates that Raimbaut might have had political reasons for composing the song (to support Boniface of Montferrat, who was about to take over direction of the crusade from Thibaut de Champagne, expressing pan-European unity against the enemy in five different languages).]

2894.

Tavani, Giuseppe. "Il plurilinguismo nella lirica dei trovatori." In Documenti letterari del plurilinguismo. Edited by Vincenzo Orioles. Rome: Editrice Il Calamo, 2000, 123-42. [The use of multilinguism by Raimbaut de Vaqueira, Bonifaci Calvo, and Cerveri de Girona does not necessarily imply the mastery of languages by the poets, nor the capability of understanding them on the part of the listeners; the languages are part of the style; in the case of Raimbaut's contrasto, the two languages emphasize the difference in social rank as well as gender of the participants; in the descort, the use of five different languages and melodies is meant to demonstrate his tumult and confusion at the change of heart of his beloved but may also hint at Raimbaut's awareness of a new pan-European identity that was beginning to replace the Latin cultural unity.]

2895.

Zink, Michel. "Plurilinguism, Hermeticism and Love in Medieval Poetics." Comparative Literature Studies 32 (1995): 112-30. (Translated by D. Rollo). [Pp. 120-25: analysis of Raimbaut de Vaqueiras, Eras can vei verdeiar, to show that each stanza is not only in a different language but that the poem reflects the cultural quality of the poetic tradition behind the language.]

Bilingual Tenso with a Genoese Woman, PC 392,7, Domna, tant vos ai preiada

2896.

Brugnolo, Furio. "Parodia linguistica e parodia letteraria nel contrasto bilingue Domna, tant vos ai preiada di Raimbaut de Vaqueiras." In Plurilinguismo e lirica médiévale: da Raimbaut de Vaqueiras a Dante. Rome: Bulzoni, 1983, pp. 11-65. 
[Believes that the exaggerated linguistic contrast between the poet and the Genoese woman heightens the contrasts in gender, in social position, and in literary register already present; the poet seems to be making fun of his own poetic vocation and of the traditional linguistic and literary clichés of his colleagues; Brugnolo suggests that the poem may be an erudite parody of the works of Arnaut de Maruelh and of the new genre salut d'amor created by him; many parallels between Raimbaut's poem and works of Arnaut are listed in support of this hypothesis.]

2897.

See 1738, Caïti-Russo, Les Troubadours et la cour, 2005, pp. 23-44. [New critical edition of Raimbaut's PC 392,7, Domna, tant vos ai preiada, with a study of the manuscript tradition, French translation, and notes; see also her historical and linguistic study "Appunti per una lettura malaspiniana del contrasto bilingue di Rambaldo di Vaqueiras," in 126, Poeti e poesia, 2006, pp. 189-204, in which she interprets the poem as an allegorical rivalry, in both social and linguistic terms, between the knightly class of the court and the increasingly self-aware, but inferior, mercantile classes.]

2898.

Gaunt, Simon. "Sexual Difference and the Metaphor of Language in a Troubadour Poem." MLR 83 (1988): 297-313. [Close analysis of Raimbaut's bilingual tenso; the difference in sex between the two participants is paralleled by the difference in language: the male speaks Occitan, the female Genoese; she rejects not only his sexual advances but also the language in which they are expressed; Gaunt disputes Brugnolo's idea that Raimbaut's part of the poem is a specific parody of Arnaut de Maruelh's saluts, or that Occitan is being glorified as the dominant language of courtly poetry; the woman is rejecting Occitan as a male language, and with it the masculine courtly rhetoric which barely disguises the poet's sexual advances; the probable Italian audience would have been delighted by the direct tone of the woman, who puts the hypocritical language of the man to shame.]

2899.

Guida, Saverio. "Una canzone provenzale in cerca d'autore." SMV 44 (2008): 49-76. [PC 70,11, Belh Monruelh, has been attributed variously to eight different poets; a close investigation of history, sociocultural characteristics, vocabulary, themes, and style leads to an attribution to Raimbaut de Vaqueiras, attaching Monruelh and $\mathrm{Na}$ Helis to the Malaspina family and to Raimbaut; see also the study by E. Salvatori and G. Caïti-Russo, "A proposito del testo trobadorico di ambito malaspiniano Belh Monruelh," CN 69 (2009): 7-28.]

2900.

Hutchinson, Patrick. "Lignes de partage sociales, culturelles et érotiques dans Domna, tant vos ai preiada de Raimbaut de Vaqueyras: ironie et mise en scène." In - 96, AIEO 3, 1992, pp. 967-81. [Self-irony is evident in many troubadours, who can see the ridiculous side of their love discourse; the ludic intent means that we cannot interpret the poems as simple reality or as sociohistoric documents; in his poem, Raimbaut parodies fin'amor, but parodies also the critics of fin'amor; ambiguity reigns, in a complex game.] 
2901.

See 735, A. Rieger, Trobairitz, 1991, pp. 418-36. [Edition of the bilingual tenso and its razo; analysis, notes, German translation; the date of composition is confirmed as 1190; the two languages represent two cultures, two ideologies; the woman rejects not only the poet's sexual advances but also his fancy language.]

2902.

Saviotti, Federico. "Raimbaut de Vaqueiras Bella, tan vos ai pregada." In $\mathbf{2 5 8}$, Ans am ieu, 2008, pp. 139-54. [Stresses the parodic elements, linguistic and literary, in both the Genoese and Occitan verses; critical edition, many textual notes, Italian translation; Saviotti is preparing a new edition of Raimbaut.]

Raimon Bistortz d'Arles. See PC 416

\section{PC 393a. Raimon d'Anjou (not listed by PC)}

[fl. 1120-1200; the author of six treatises, perhaps similar to ensenhamens, known only by their titles, preserved by Francesco da Barberino in his Documenti d'amore, with a few extracts, all noted in Latin translation.]

2903.

Paterson, Linda. "A propos de la datation de Raimon d'Anjou." RLaR 91 (1987): 307-19. [Raimon was an Occitan noble, ca. 1120-1200, a model of the perfect chevalier; no works are extant, except indirectly through some quotes, translated into Latin, by Francesco da Barberino in the early fourteenth century.]

2904.

See 1439, Monson, Les ensenhamens, 1981, pp. 132-38. [History of scholarship on Raimon, attempting to reconstitute some aspects of his lost works; probably they were types of scholastic treatises, perhaps all belonging to a single lengthy work; in any case, none seems to have been an ensenhamen.]

Raimon Berenguier IV d'Aragon, Comte de Provence. See PC 184. Coms de Proensa

\section{PC 396. Raimon de Castelnou}

[Second half thirteenth century; little is known of his life; five cansos, one sirventes, PC 396,6, of doubtful attribution, perhaps belongs to Peire Cardenal or perhaps it is a contrafactum by Raimon using themes and techniques of Peire (attributed to Peire and Raimon in three manuscripts each); Doctrinal, a treatise on Catholic 2905.

dogma and morality, four hundred lines in fourteen rhymed laisses.]

Giannetti, Andrea. Raimon de Castelnou. Canzoni e dottrinale. Biblioteca di filologia romanza, 33. Bari: Adriatica, 1988. [The introduction explores possibilities for dating and localization; critical edition of five cansos and the Doctrinal, with Italian translation, notes, and glossary; hereproduces the sirventes from Lavaud's 1957 edition, without critical apparatus or notes; the Doctrinal text is a mixture of readings from manuscripts $B$ and $A$.] 
2906.

See 249, Bec, Florilège en mineur, 2004, pp. 57-59. [Very brief introduction, edition of PC 396,4; text from Giannetti, with French translation, no notes.]

2907.

Beltrán, Vicenç. “Tipos y temas trovadorescos. XIV. Alfonso X, Raimon de Castelnou y la corte literaria de Rodez." In 128, Le Rayonnement, 1998, pp. 19-39. [Beltrán attributes the sirventes PC 396,6 to him and dates it plausibly to 1274-75: new critical edition, based on $C$, with translation into Catalan, copious historical notes; the poem was formerly attributed to Peire Cardenal (e.g., in the edition by Lavaud); Beltrán suggests that it is an extreme example of a contrafactum, using themes and techniques of Peire Cardenal but composed by Raimon during the trip by Alfonso X to southern France to meet the pope; Raimon was part of the group of poets patronized by Alfonso and by Enrique II of Rodez; see $\$ 1899, Guida, Jocs poetici, 1983.]

\section{PC 398. Raimon Escrivan}

[fl. 1218; an allegorical sirventes or fictive tenso, a dispute between two war engines, called cata (the French invaders) and trabuquet (the Occitan defenders of Toulouse), written from inside Toulouse while under siege by Simon de Montfort in June 1218, just before Simon was killed.]

2908.

See 249, Bec, Florilège en mineur, 2004, pp. 179-83. [Brief introduction, text of PC 398,1, with French translation.]

2909.

See 227, Riquer, 1975, 2:1108-12. [Introduction, explaining the nature of the two siege machines and their use as recounted in the Canso de la crozada; text with Spanish translation, notes.]

\section{0.}

Vatteroni, Sergio. "La fortuna de L'autrier jost'una sebissa e Raimon Escrivan: considerazioni sui generi della pastorelle e della tenzone fittizia." In $\mathbf{1 0 7}$, Ab nou cor, 2004, pp. 243-61. [Raimon's fictive tenso, Senhors, l'autrier vi ses falhida, PC 398,1, is modeled on Marcabru's pastorela, L'autrier jost'una sebissa, 293,30; comparison of the two shows that the genres of pastorela, tenso, and fictive tenso are variable and open, and cross-genre interference can touch on structure, vocabulary, and content; Vatteroni thinks that Raimon's song was written during the siege of Toulouse in 1218 during the Albigensian Crusade.]

\section{PC 401. Raimon Gaucelm de Bezers (Béziers)}

[fl. 1262-75; nine poems, including a planh for a bourgeois of Béziers 1262; perhaps also a crusade song previously attributed to Guilhem de Saint-Didier.] 2911.

Radaelli, Anna. Raimon Gaucelm de Béziers: Poesie. Florence: La Nuova Italia Editrice, 1995. [Introduction, edition of nine poems, with Italian translation, notes, glossary.] 
2912.

Gouiran, Gérard. "Les troubadours de Béziers." In Béziers, ville occitane? Actes des rencontres tenues à Béziers le 18 novembre 2006. Perpignan: Presses Universitaires de Perpignan, 2007, pp. 9-27. [Analysis of nine poems by Raimon Gaucelm, along with four by Bernart d'Auriac and eleven by Joan Esteve, looking for signs of similarity in style or inspiration that would make them typical of Béziers; found a common bond of religiosity, a new loyalty to the French king, conscious dating of poems which anchors them in time, an emphasis on sincerity and a warm enclosed feeling for their town of Béziers.]

2913.

See 2044, Hershon, Les troubadours de Béziers, 2001, pp. 11-53. [Edition of the nine poems of Raimon Gaucelm de Béziers, with introduction, French translation, notes.]

\section{PC 404. Raimon Jordan}

[fl. 1178; died after 1195; vida in two redactions; ca. thirteen poems, several of doubtful attribution, two with melody: see $\mathbf{6 0 7}$, van der Werf, Extant, 1984, p. 298*-304*; satirized in the Monge de Montaudon's gallery of troubadours, 1195.] 2914.

Asperti, Stefano. Il trovatore Raimon Jordan: edizione critica. Subsidia al Corpus des Troubadours, 12. Modena: Mucchi, 1990. [Introduction on biography and sociohistorical context, use of senhals, themes, metrics, language; the corpus; edition of twelve poems, with Italian translation, copious notes, extensive glossary.]

\section{5.}

Maillard, Jean. “A propos de deux mélodies de Raimon Jordan.” In $\mathbf{1 5 9}$, Studia occitanica, 1986, 1:121-30. [Outlines the history, the difficulties and the dangers of musical transcription of the troubadour melodies; analysis of each of Raimon's melodies PC 404,4 and 11, with simple transcription from the manuscript, followed by a rhythmic interpretation of each; words of the first stanza only are provided under the melody.]

\section{6.}

Poe, Elizabeth W. "At the Boundary between vida and razo: The Biography of Raimon Jordan.” Neo 72 (1988): 316-19. [An exploration of possible reasons for the confusing state of the poet's vida/razo in the manuscripts, with the ancillary conclusion that the distinction between the two genres was often not clearly made.]

2917.

See 735, A. Rieger, Trobairitz, 1991, pp. 704-13. [Critical edition of PC 404,5, with German translation, notes; analysis pp. 709-13: must be by a trobairitz, because of the attack against misogyny in the early troubadours; unknown, but could be Helis de Montfort or her sister Maria de Ventadorn.]

\section{PC 405. Raimon Menudet}

2918.

[End thirteenth century; one planh for a hitherto unknown person.]

Radaelli, Anna. "Il planh di Raimon Menudet." In Rendiconti dell'Istituto Lombardo. 
Classe di Lettere e Scienze Morali e Storiche 128 (1994): 489-514. [Meticulous research establishing that the planh was composed for a certain Déodat, a lord in Boussagues, and is a contrafact of a planh by his contemporary Raimon Gaucelm for Louis IX; critical edition with Italian translation, copious notes.]

\section{PC 406. Raimon de Miraval}

[fl. 1185-1213; vida, razos; thirty-seven cansos, five sirventes, a few others, a few coblas; twenty-two preserved melodies: see $\mathbf{6 0 7}$, van der Werf, Extant, 1984, pp. 305*-31*; "the ideal courtly lover," according to Raimon Vidal and Matfre Ermengaud; he may be the author of the first half of the novas So fu, attributed at present entirely to Raimon Vidal de Besalu.]

\section{9.}

Topsfield, Leslie T. Les Poésies du troubadour Raimon de Miraval. Les Clasiques d'Oc, 4. Paris: Nizet, 1971. [Introduction on the life of Raimon, his family, his patrons, his ladies; his literary status as the ideal courtly lover, contrasted with the egoistic, bitter man behind the courtly mask; comments on style, metrics, music, and the possibility that he wrote narrative works; edition of the vida and forty-four poems, with French translation, notes, plus seven of doubtful attribution, without translation.]

2920.

Switten, Margaret L. The "Cansos" of Raimon de Miraval: A Study of Poems and Melodies. Medieval Academy Books 93. Cambridge, MA: Medieval Academy of America, 1985. [Edition and detailed stylistic analysis of the thirty-seven cansos, including melody if extant, versification, syntax, content, English translation, and the relationship of melody and text by line, by stanza, and in the whole song.]

2921.

Guida, Saverio. "Il Pastoret e il Mantel di Raimon de Miraval." SMV 55 (2009): 37-63. [Raimon used senhals fifty-two times in forty-four poems: Audiart eighteen times for Raymond VI of Toulouse; others are more mysterious, but Guida finds convincing evidence that Pastoret stands for Bernard IV of Comminges, a confidant of Raymond and a skillful mediator between the count and his rivals, chosen because Bernard came from a sheep-raising area; Mantel probably stands for Maria of Montpellier, his wife, addressed by Aimeric de Peguilhan as la comtessa de Cumenge.]

2922.

Le Vot, Gérard. "La convenance du texte et de la mélodie dans la chanson des troubadours: Etude rythmique de la canso Bel mes qu'ieu chant e coindei de Raimon de Miraval (en collaboration avec Pierre Lusson et Jacques Roubaud).” In Itinéraires de la musique française. Edited by Anne Penesco. Lyon: P.U.L., 1996, pp. 63-85. [Analysis of Raimon's poem, taking into equal account the melody, the text, and the metric structure, based on the use of a computer-based algorithm.]

2923.

Nelli, René. Le Roman du troubadour Raimon de Miraval, suivi de ses chants d'amour. Paris: Albin Michel, 1986. Reprint, Paris: Michel, 2000. [Text found after Nelli's death; pp. 13-64: a poetical vie romancée of Raimon, somewhat fanciful, inspired 
by a dream in which Nelli was present at Raimon's death; the twenty-two poems are given only in Nelli's 1979 French translation; not for scholarly use.]

2924.

Rüdiger, Jan. "Raimon de Miraval et la diglossie culturelle." In $\$ 99, AIEO 6, 2001, pp. 469-77. [Analysis of the difference between the socialized ethic of cortesia found in the troubadour poems and the profound but unexpressed solidarity that linked Raimon de Miraval with his lord Raimon de Toulouse.]

\section{5.}

Zink, Michel. "Raimon de Miraval, entremetteur ou éternel mari ?" In L’homme dans le texte. Mélanges offerts à Stoyan Atanassov à l'occasion de son 60 e anniversaire. Edited by Bogdan Bogdanov, Dina Mantchéva, et al. Sofia: Presses universitaires de Sofia "Saint Clément d'Ohrid," 2008, pp. 29-38. [Claims that the razos which introduce some of the troubadour poems may be strange and exaggerated but that they often penetrate the underlying psychological content of the poetry itself; the razo to Raimon's poem Ar ab la forsa del freis is used to illustrate the theory.]

2926.

Borriero, Giovanni. Edition of PC 406,I, salut d'amor, in \$ 520, Gambino, Salutz, 2009, pp. 398-441. [Attribution to Raimon de Miraval has been seriously questioned, but in view of no certain proof to the contrary, the indication in $R$ has been accepted.]

\section{PC 409. Raimon de las Salas (de Marselha; La Sala)}

[fl. ca. 1215-30; vida; five or six poems: three cansos ("dialogues" with his lady); one partimen (PC 406,16 = 83,1) with an unidentified Bertran on the relative merits of Provence and Lombardy; one religious alba; the vida says he composed retroensas, but none is extant; PC 409,3 and 409,5 and his alba have a feminine respondent called Donna/Domna who is unknown, thought by some to be fictive; both poems

2927. show several close intertextual links with other poems.]

Chambers, Frank M. "Raimon de las Salas." In Essays in Honor of L. F. Solano. Edited by R. J. Cormier and U. T. Holmes. Chapel Hill: University of North Carolina Press, 1970, pp. 29-51. [Edition of the vida, five poems plus a partimen with Bertran d'Avignon of doubtful attribution, all with full variants, English translation, brief notes.]

2928.

See 249, Bec, Florilège en mineur, 2004, pp. 41-43. [Brief introduction, text of PC 409,1 , with French translation, no notes.]

2929.

Noto, Giuseppe. "Raimon de las Salas (?) = Bertran Folco d'Avigno (?) Bertran, si fossetz tant gignos (BdT 406.16 = 83.1)." Lecturae tropatorum 2, 2009. Online at http://www.lt.unina.it/Noto-2009b.pdf. [Edition of the tenso with analysis, notes, Italian translation; now in 256, Harvey and Paterson, Troubadour "Tensos, "2010, 3:1105-11, where Raimon de las Salas is confirmed as one of the participants, but Bertran remains unidentified.] 
2930.

Pulsoni, Carlo. "Dieus aydatz (BdT 409,2)." In 1 158, Studi Bertolucci Pizzorusso, 2006, 2:1307-28. [New critical edition of the alba, with Italian translation, notes; the poem is probably to be attributed to Raimon de las Salas instead of to Bernart Marti.] 2931.

See 735, A. Rieger, Trobairitz, 1991, pp. 437-54. [Edition of PC 409,3 and 5, with German translation, notes, and commentary; believes that the unnamed domna in these poems and in Raimon's alba is a real person, who may have participated with him in performances; several intertextual echoes with other trobairitz and troubadour songs are noted, indicating a closely woven net of contacts among the composers of dialogue poems.]

2932.

See 227, Riquer, 1975, 2:1094-99. [Introduction, edition of the tenso PC 83,1 = 406,16, with Spanish translation, notes; the date of 1216 is confirmed; Raimon praises the military prowess of the Provençals, while Bertran esteems that of the Lombards and accuses the Provençal forces of weakness for letting Simon of Montfort off too easily after the siege of Beaucaire.]

2933.

Guida, Saverio. "Nuovi documenti su alcuni trovatori del XIII secolo." CN 39 (1979): 81-105. [Pp. 93-95: a notarial act of 1224 identifies Raimundus de Salis de Massilia as a prominent bourgeois of Tolone; the Bertran of the partimen cannot be Bertran d'Avignon, who fought valiantly for Provence at Belcaire.]

\section{PC 411. Raimon Vidal de Besalù (de Bezaudun)}

[Catalan; first half thirteenth century; five poems (two cansos of uncertain attribution and three coblas that he inserted into his So fo); two novas in verse (Castia-gilos, So fo el temps), one ensenhamen (Abrils issi), one grammatical treatise (Las razos de trobar) and maybe its (anonymous?) continuation Doctrina de compondre dictatz; the poem Entre.l taur e.l doble signe (PC 411,3) may be by Arnaut Daniel.] 2934.

Field, William Hugh. Ramon Vidal de Besalú: Obra poètica. 2 vols. Barcelona: Curial, 1989 and 1991. [Introductory study of biography, attributions; texts of two novas, Abril issia in vol.1 and So fo e.l tems in vol. 2; also the ten-line Plazens plasers in vol. 2, pp. 177-90, attributed to Raimon Vidal here for the first time; and Castia-gilos, called "anonymous" by Field; critical texts with Catalan translation, notes, brief glossary.] 2935.

See 249, Bec, Florilège en mineur, 2004, pp. 67-71. [Brief introduction, text of PC 411,2, with French translation, no notes; the poem is attributed to Raimon and to Arnaut de Tintinhac in one manuscript each.]

2936.

See 1137, Majorossy, Unas novas, 2007, pp. 19-71. [A study of the use of JudeoChristian imagery and morality in seven novas, including three by Raimon: Abril issia, see 1470; Castia gilos, see 1179; and En aquel temps, see 1300.] 
2937.

Tavani, Giuseppe. "La poesia di Raimon Vidal. III. Entre.l taur e.l doble signe (PC 411,3): questioni attributive e proposte di restauro testuale." In $>139$, Ensi firent, 1996, pp. 131-49. [Close study of the two manuscript copies, diplomatic edition of both, detailed discussion of variant readings and attempted restoration of the text (pp. 143-45, with Italian translation); suggests that the poem is not by Arnaut Daniel but rather is a mosaic parody of his style; believes that until further proofs are available, the poem must remain attributed to Raimon Vidal.]

2938.

PC 416. Raimon (Ramon; Bistortz d'Arles)

[fl. 1230; four cansos, one cobla.]

Rivière, Jean-Claude. "Raimon Bistortz d'Arles.” L'Astrado 21 (1986): 29-71. [Edition of five poems, with translation into French by Rivière and into modern Occitan, Rhodanian dialect by Philippe Blanchet; no language study; see suggestions for textual correction and translation by Jean-Pierre Chambon, RLaR 99 (1995): 133-40.]

\author{
Rambertino Buvalelli \\ [See PC 281 (formerly called Lambertino).]
}

PC 417. Reculaire (nickname "retreater, coward")

[One tenso with Uguet PC 417,1 = 458,1; Uguet is probably Uc de Saint

Circ, and Reculaire is probably a nickname for Sordello.]

2939.

See 256, Harvey and Paterson, Troubadour “Tensos," 2010, 3:1262-70. [The identity of Uguet is not clear, and Reculaire himself is unknown.]

2940.

Guida, Saverio. "Sulla tensone tra Uget e Reculaire (BdT 458,1)." SMV 52 (2006): 99-130. [Rich and lengthy exploration of poetic practices and moral concepts on the lower levels of society at the turn of the twelfth century in southern Europe; claims that Uget is not Uc de Mataplana but Uc de Saint Circ, and that Reculaire is a nickname for Sordello; the text of the tenso is reproduced in appendix, without notes or translation.]

\title{
PC 420. Richard I of England (Richard Coeur-de-lion)
}

[Omitted by many scholars because the poetry is not thought to be native

Occitan; born 1157, died from an arrow wound 1199; son of Eleanor of Aquitaine and Henry II; grandson of Guilhem de Peitieus; king of England 1189-99; two sirventes in French: PC 420,1 is a reproach to Dalfi d'Alvernhe, answered in Occitan, with apology, in PC 119,8; PC 420,2 is a complaint, retroencha, from prison in Austria, with melody, in both French and Occitan versions; some believe the Occitan version to be apocryphal; Gaucelm Faidit composed a planh for him, answered by Giraut de Bornelh.] 
2941.

See 227, Riquer, 1975, 2:751-54. [Introduction; edition of PC 420,2, the first stanza of the French version and the complete text of the Occitan version, with Spanish translation, notes.]

2942.

Lee, Charmaine. "Le canzoni di Riccardo Cuor di Leone." In 93, Atti del XXI Congresso, 1998, 6:243-50. [Analysis of the language characteristics of the two poems indicates that both were probably composed in French and were Occitanized in the scribal tradition, the sirventes more than the canso because it was copied only in Occitan manuscripts along with the reply by Dalfi d'Alvernhe; Lee is preparing a critical edition of the two poems.]

\section{3.}

Lepage, Yvan G. "Richard Coeur de Lion et la poésie lyrique." In Et c'est la fin pour quoy sommes ensemble: Hommage à Jean Dufournet, professeur à la Sorbonne Nouvelle: littérature, histoire et langue du Moyen Age. 3 vols. Paris: Champion, 1993, 2:893910. [Richard's rotrouenge is a contrafactum of the Old French; his sirventes, originally in Occitan, deserves more attention.]

\section{4.}

Spetia, Lucilla. "Riccardo Cuor di Leone tra oc e oill (BdT 420,2)." CN 56 (1996): 101-55. [Study and critical edition of the rotrouenge, with two diplomatic versions and full variants, study of metrics and language; some scholars claimed that the poem was composed by Richard in both French and Occitan versions, so that he might be understood by all his subjects, and that the sirventes PC 420,1, Dalfin, je.us voill, was originally in Occitan, like Dalfi's response; Spetia shows that these are legends and that unique language forms are scribal contaminations; this article was used to justify the elimination of Richard's poems from Ricketts's COM1.]

\section{PC 421. Rigaut de Berbezilh (Richart de Berbezill; de Barbezieux)}

[ $f$. 1150s-1160s; dating is controversial; vida, razos; eleven or twelve poems; four preserved melodies: see $\mathbf{6 0 7}$, van der Werf, Extant, 1984, pp. 332*-39*; the poem PC 30.18, now attributed to Arnaut de Maruelh, may well be by Rigaut.]

\section{5.}

Varvaro, Alberto. Rigaut de Berbezilh: Liriche. Biblioteca de Filologia Romanza, 4. Bari: Adriatica, 1960. Reprint, New York: AMS, 1983. [This has become the standard edition: it is more conservative, has a detailed introduction and richer textual notes.]

2946.

Braccini, Mauro. Rigaut de Barbezieux: Le canzoni. Florence: Olschki, 1960. Reprint, New York: AMS Press, 1983. [Useful for detailed analysis of manuscript tradition.] 2947.

Carapezza, Francesco. [Online edition, 2004, based on both Varvaro and Braccini, with introduction (Premessa), notes, audio reproduction of melodies, no translation: http://www.rialto.unina.it.] 
2948.

Bianchini, Simonetta. “Tradizione e traduzione: la fenice.” AIUO 39 (1997): 24979. [Use of the phoenix as a symbol by Rigaut de Berbezilh, intertextuality with Italian poets, and other avian influences from Bernart de Ventadorn, influence on various Italian and Sicilian poets.]

2949.

Majorossy, Imre. "Le troubadour de la Miels-de-Domna: Rigaut de Barbezieux." In - 1516, Amors es bona volontatz, 2006, pp. 61-71. [In PC 421,3, Atressi con Persavaus, the poet expresses a purified sort of love in terms that could be applied to the Virgin; the lover is completely submissive to his lady, whose qualities raise her to a level beyond this world, capable of dispensing grace; it is difficult to say whether Rigaut sings of a woman who is almost divine, or of a divine power presented in human terms.]

2950.

Taylor, Robert A. "Les images allégoriques d'animaux dans les poèmes de Rigaut de Berbezilh." CN 38 (1978): 251-59. [Sketch of earlier studies of animal imagery in troubadour poetry; analysis of its striking presence in Rigaut's work, especially in PC 421,2, Atressi com l'orifanz, and PC 421,1, Atressi com lo leos; stressing the effectiveness of the simple straightforward presentation that would immediately be enriched among the listeners by the long and varied traditions that were ever-present in religious and moral symbols around them.]

2951.

Van Vleck, Amelia E. "Rigaut de Berbezilh and the Wild Sound: Implications of a Lyric Bestiary." RR 84 (1993): 223-40. [Analysis of the use of animal and natural images by Rigaut, compared with the practice of using vivid imagery in sermons and in church paintings and sculpture to aid in the teaching of moral lessons; his ornately colorful songs were meant for oral performance, filled with verbal miniatures that "restored the power of imagery back to the physical human voice where poetry began"; in Rigaut, the voice, even without words, seems to have an incantatory power, which becomes a life-giving force if or when it is used by the lady to show her approval, or by the audience to give approbation, in either case to restore his poetic life.]

\section{PC 422. Ricau de Tarascon}

[First third thirteenth century; vida; one canso (of uncertain attribution); one tenso with Gui de Cavaillon, PC 422,2 = PC 105,1, composed not later than 1220.] 2952.

Guida, Saverio. "Nuovi documenti su alcuni trovatori del XIII secolo." CN39 (1979): 81-105. [Pp. 81-90: rich documentation of the political activities of Ricau as partisan of Count Raimon Berenguier V against the bourgeoisie's attempt to acquire freedom for Tarascon; Ricau was active culturally as well alongside Bertran d'Alamanon, Bertran d'Avignon, Blacatz, Dalfinet, Falquet de Romans, Isnart d'Entrevenas, Peironet, Perceval Doria, Sordello, and Tomier; Guida comments on the standardized nature of the structure and themes of his poetry; no texts.] 
2953.

Guida, Saverio. "La tenzone fra Ricau de Tarascon et Cabrit." In $\mathbf{1 5 2}$, Miscellanea Roncaglia, 1989, 2:637-61. Also in CN 47 (1987): 197-221. [Detailed study of sociohistorical background, dating the poem to ca. 1215-16; philological study of manuscript tradition; critical edition with Italian translation; Cabrit is a nickname for Gui de Cavaillon, used reciprocally by Gui for Ricau, referring humorously to the unpleasant sound of the voice or the headstrong, capricious character; see also

256, Harvey and Paterson, Troubadour "Tensos," 2010, 3:1129-37.] 2954.

Ricketts, Peter T. "La chanson de Ricau de Tarascon (PC 422,1): édition critique, traduction et notes." RPh 57 (2003-4): 65-70. [Introduction, critical edition based on all manuscripts, with French translation, notes.]

\section{PC 423. Ricaut Bonomel (the same as Templier PC 439)}

[One sirventes, PC 439,1, ca. 1265, praising the courage of the Templars and Hospitallers, blaming the cowardice of the French aristocrats and the meddling of the pope for the defeat of the Christians at Arsûf; Ricaut was himself a Templar, present 2955. in the Holy Land at the time of the Eighth Crusade.]

Bastard, A. de. "La colère et la douleur d'un templier en Terre Sainte: Ir'e dolors s'es dins mon cor asseza." RLaR 81 (1974): 333-73. [Detailed analysis of the sirventes PC 439,1 from the historical perspective of the Holy Land menaced by the infidel, from the political perspective of imbricated intrigues by the pope in Italy and Sicily, and from the personal perspective of an individual knight-Templar, dismayed and angry at the lack of understanding and help from the West.]

2956.

Nicholson, Helen J. [English translation of PC 439,1, from de Bastard's edition, with introduction, notes; in ORB Online Encyclopedia: http://www.theorb.net/encyclop/ religion/monastic/ricaut.html.]

2957.

Puckett, Jaye. "Reconmenciez novele estoire: The Troubadours and the Rhetoric of the Later Crusades.” MLN, 116.4 (2001): 844-89. [Pp. 878-81: analysis of Ricaut Bonomel's poem; by reverse psychology, Ricaut claims that the Muslims show all the qualities that ought to be those of the Christians, in an attempt to prompt a reaction by the Christians and inspire new crusading efforts; pp. 884-87: Appendix I, "The Troubadours and the Crusades," contains a listing of fifty-three Occitan crusade songs or those containing reference to crusades.]

2958.

Thiolier-Méjean, Suzanne. "Saint Bernard et les ordres de chevalerie chez Raimon de Cornet et Rostanh Berengier de Marseille.” FL 142 (2006): 113-38. [Pp. 122-30: new edition, with French translation, of PC 427,6 by Rostanh, in honor of Foulques de Villaret, Grand Master of the Hospitallers, whose virtues are likened to those of six great figures of the Old Testament; pp. 131-38: divided opinions of the Hospitallers 
and Templars, including criticism by Bernart Sicart de Marvejols and even by Rostanh himself against both orders (PC 427,4), countered by praise from Sordello and Ricaut Bonomel; Bonomel is a Templier; a few excerpts from his sirventes, pp. 13234.]

\section{PC 434, 434a. Cerveri de Girona (Serveri; Guillem de Cervera)}

[ fl. 1259-82; no vida; 114 lyric poems of various genres; Proverbis (1197 quatrains); five narrative pieces: Maldit bendit (Maldit, a satire against women, followed by Bendit, in praise of love), 694 lines; Faula del rosinyol, 499 lines; Oracio de tot dia, 190 lines; Sermo, 203 lines; Testament, 187 lines.]

\section{9.}

Coromines, Joan. Cerveri de Girona: Narrativa. Barcelona: Curial, 1985. Coromines, Joan, and Beata Sitarz Fitzpatrick. Cerveri de Girona: Lirica. Barcelona: Curial, 1988. Coromines, Joan. Cerveri de Girona (Guillem de Cervera): Versos proverbials; edició critica i comentada. Barcelona: Curial, 1991. [Complete edition of Cerveri's works, with copious notes, Catalan translation.]

2960.

Riquer, Martín de. Obras completas del trovador Cerveri de Girona. Publicaciones sobre Filologia y Literatura. Barcelona: Instituto Español de Estudios Mediterráneos, 1947. [Complete edition, with Spanish translation, now superceded by that of Coromines, 2959, 1985-91; see also 227, Riquer, Los Trovadores, 1975, 3:1556-89. [Introduction, eight poems, with Spanish translation, notes.]

\section{1.}

Asperti, Stefano. "Generi poetici di Cerveri de Girona." In 162, Trobadors a la Peninsula Ibèrica, 2006, pp. 29-72. [Analysis of Cerveri's ambiguous place in the development of trobar; his poems are varied, numerous, and of high quality, and he occupies an esteemed position at the powerful Aragonese court, a leading figure in the development of later Catalan literature, but as a troubadour, he seems isolated and marginal; in the late manuscripts $E$ and $D$, Cerveri is characterized for his dansas, for the absence of tensos, and for the preponderance of cansos, vers, and sirventes; especially innovative in the poetry of Cerveri and Guiraut Riquier is the renewal of the vers in opposition to the canso, a genre for blaming rather than for praising, very similar to the sirventes in Cerveri, including also religious poems for Guiraut; the moralistic content is the principal characteristic, but Cerveri adds the notion of structural originality; the attempted reinstatement of the sirventes to its former elevated position in the form of the new vers was admirable in itself, even if it led no further.]

\section{2.}

Beltrán, Vicenç. “L'Enfant Pere, Cerveri de Girona i Pero Mafaldo.” SMV 39 (1993): 9-31. [Lengthy description of political entanglements among the powers of Aragon, England, and France around 1271-72 concerning succession rights to the county of Toulouse and the complex dispute between the young Peter and his father; edition of the sirventes Hom no pot far sirventes, with Catalan translation, notes.] 
2963.

Billy, Dominique. "Les influences galégo-portugaises chez Cerveri de Girona." In - 111, L'Espace lyrique, 2006, pp. 251-63. [Techniques of repetition, typical of Galician-Portuguese poetry, are used by Cerveri in PC 434a,54 and 83 and in the dansa 434a,71; various rhyme schemes are also borrowed.]

2964.

Billy, Dominique. "L'hybridation générique dans l'oeuvre de Cerveri de Girona." In

- 114, Les genres, 2010, pp. 25-37. [Cerveri invented many new genres and experimented with generic mixing; Billy analyzes five hybrid forms: mig vers e miga canso, sirventes-dansa, viadeyra, gelosesca, and dansa-balada, most of which were one-time creations, except for the viadeyra, really a parasitic form rather than a hybrid, using the structure of the Galician cantiga de amigo linked with the theme of the French malmariée, the only one of the mixed genres to become popular.]

2965.

Cabré, Miriam. Cerveri de Girona and His Poetic Traditions. Woodbridge: Boydell and Brewer, 1999. [Analysis of his life and output, his concept of poetry and poetic practices in a wide variety of forms: the vers, sirventes, dance-songs, pastorelas, La faula del rosinyol; Cabré emphasizes the narrative poems and the lyrics that reveal innovative and personal aspects of Cerveri's output, in particular his use of popular genres, wordplay, parody, and humor, to speak more directly to his audience; rich bibliography; see also

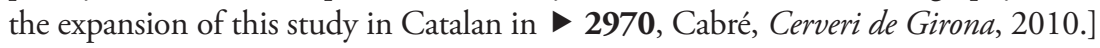

2966.

Cabré, Miriam. "Wisdom for the Court: The Verses proverbials of Cerveri de Girona."

In 140, Etudes Ricketts, 2005, pp. 393-404. [Exploration of the Verses proverbials as an early vernacular teaching handbook, meant for the education of Jaume II's two sons but addressed as well to a general vernacular audience; Cerveri is shown to be very successful as a combined sage and troubadour, teaching sen and saber to the unlearned members of the court.]

2967.

Cabré, Miriam. "En breu sazo aura.l jorn pretentori (BdT 434a,20): Jaume I i Cerverí interpreten els fets de 1274." In Actes del X congrés internacional de l'AHLM (Alacant, 2003). Valencia: IIFV, 2005, pp. 453-68. [Identification of the historical context clarifies the meaning of the poem: instead of 1269, preparations for the aborted crusade of 1274 as described in King James's Llibre dels fets give a more appropriate time-frame; James was ready to go, but the pope was uncooperative and some nobles were cheating or holding back; the criticisms and accusations in the poem are much more understandable in the new context, since they represent the message that the king wanted the court to receive; Cerveri was his mouthpiece.]

2968.

Cabré, Miriam. "El trobador de Pere el Gran.” Mot so razo 4 (2005): 59-68. [A popular and engaging outline of Cerveri's life and work as a loyal advisor to king Peter, under whose patronage he flourished as an influential member of the court and for whom he created the powerful and lasting image of a model king.] 
2969.

Cabré, Miriam. "Per a una cronologia dels sirventesos de Cerverí de Girona." In - 162, Trobadors a la Península Ibèrica, 2006, pp. 135-50. [The ten sirventes are dated 1269-75, all in support of Peter the Great, as is most of Cerveri's poetry; in appendix, a new edition of PC 434a,28, revealing Cerveri's intentions as a moral arbiter, as well as his reflection on the sirventes genre itself.]

2970.

Cabré, Miriam. Cerveri de Girona: un trobador al servei de Pere el Gran. Barcelona: Universitat de Barcelona, 2010. [A full study of the life, works, and political career of Cerveri and his influence on the court of Pere el Gran, where he played an important role as counselor and sensitive entertainer; his career provides a mirror of contemporary intellectual debates and political tensions, and his influence on the later development of Catalan literature was extensive; in appendix, a complete listing of his works.] 2971.

Cabré, Miriam. "Who Are Cerveri's Worst Enemies?” Glossator 4 (2011): 59-72. [Analysis of PC 434a,76, a trick riddle poem, based on a widespread fashionable conceit, typical of his witty and entertaining presence at the Aragonese court; the opening of the poem is similar to a political diatribe, violent and threatening; but his nameless enemies turn out to be his own eyes, guilty of revealing his domna to him and causing the suffering of his love.]

2972.

Cadart-Ricard, Odette. "The Shepherdess in Cerveri de Girona's Fourth Pastorela." Reading Medieval Studies 9 (1983): 34-44. [An objection to earlier interpretations of the pastorela as a projection of the poet's and audience's libidinal fantasies; instead, Cerveri shows that human value transcends social rank and foreshadows the humanist revolution; text from De Riquer's edition, 1947, without translation; the analysis of content shows that the love interest has been replaced by consideration of the king's tax-raising policies and the social inequalities involved; Cerveri has politicized the traditional genre in a surprisingly modern manner.]

\section{3.}

Cantavella, Rosanna. “Sobre el Maldit Bendit de Cerverí." Llengua \& Literatura, 3 (1988-9): 7-40. [Very detailed analysis and commentary of the work, section by section, with notes; no text is given; the form is that of a dialogue or debate, in which the antifeminist side is dominant until the king intercedes in favor of women, and Cerveri seems to feel obliged to change his stance to please his patron, albeit in ironical mode.]

2974.

Gosman, Martin. "Cerveri de Gérone et la lettre du Prêtre Jean: la réception d'un message." In \$4, AIEO 1, 1987, pp. 219-27. [Analysis of the technique of antithesis in PC 434a,82; Cerveri adapts the legendary letter for his own moral purposes, creating an ideal past kingdom against which he can criticize his present imperfect society.]

2975.

Grimaldi, Marco. "Cerveri de Girona, Entr'Arago e Navarra jazia (BdT 434.7a)," 
Lecturae tropatorum, 2008, 33 pages. Online at http://www.rialto.lt.unina.it. [Historical and biographical introduction; critical edition with Italian translation, detailed notes.]

2976.

Longobardi, Monica. "Cerveri e l'enigma del nome." In 158, Studi Bertolucci Pizzorusso, 2006, 2:899-919. [Analysis of Cerveri's Lo vers del serv as an indication of his change of name from Serveri (di Girona) to (Guillem de) Servera, based on the allegory of a stag (cervo) that eats a snake and vomits out its venom with the aid of holy water, in order to renew itself physically and morally to serve God.]

2977.

See 439, Malm, Dolssor conina, pp. 94-97. [Analysis of PC 434,1, A greu pot hom conoisser, known as "Lo vers de la falsa femna."]

2978.

Riquer, Martin de. "Guillem de Cervera est Cerverí de Girone.” RLaR 93 (1989): 403-14. [Against the opinion of Coromines that there were two separate poets, Riquer confirms, with new material from the fourteenth and fifteenth centuries, from parallels between works signed by one or the other, and finally from documents referring to Guillelmo de Cerveria id est Cerverino, that the two names refer to one poet.]

2979.

Riquer, Isabel de, and Andreu Comas. "Family Matters." Glossator 4 (2011): 53-58. [An outline of the varied nature of Cerveri's corpus and his place at court; text of Cerveri's gelosesca PC 434a,1a, telling of a repulsive husband, a cruel wife, and a miserable household.]

\section{0.}

Rossich, Albert, "Alternança de llengües en Cerverí de Girona.” Estudi general 22 (2002): 13-39. [Detailed study of Cerveri's plurilingual cobla: evaluation of earlier scholarship with comments on the difficulty of distinguishing early Romance forms; these distinctions were based on a conventional notion of language identity, not on the actual concrete articulations; what the poet sought was an abstract concept of the traits felt to be most characteristic of each language; the first two lines are Galician, not Aragonese or Castilian; three and four are Occitan; five and six French; seven and eight are Gascon and Italian; nine and ten, the tornada, are again Occitan; the "definitive" poem and its Catalan translation are given at the end.]

\section{1.}

Sitarz, Beata. "Towards an Appreciation of Cerveri de Girona's Craftmanship." In Catalan Studies (Estudis sobre el catalá): Volume in Memory of Josephine de Boer. Edited by Joseph Gulsoy and J. M. Sola-Solé. Barcelona: Borràs, 1977, pp.125-40. [A study of originality in Cerveri's poetry ( 83 of his 110 lyrics are original in verse form) and how it was achieved; analysis of stanza structure, including metrics, internal rhymes, and refrain words shows that Cerveri invented a large number of new schemes and that these were of uncommon complexity, indicating his venturesome spirit; tables of metrical and rhyme schemes are given in appendix.] 
2982.

Tavani, Giuseppe. "Il plurilinguismo nella lirica dei trovatori." In Documenti letterari del plurilinguismo. Edited by Vincenzo Orioles. Rome: Editrice Il Calamo, 2000, 123-42. [The use of multilinguism by Raimbaut de Vaqueira, Bonifaci Calvo, and Cerveri de Girona does not necessarily imply the mastery of languages by the poets, or the capability of understanding them on the part of the listeners; the languages are part of the style; in the case of Cerveri, the use of four languages in a single stanza of eight lines seems to be a mere humorous display of playful poetic versatility.]

\section{3.}

Trottier, Marc. "Vers breu and Vers estrayn: A Re-examination of Two Neglected Poems by Cerveri de Girona (PC 434a,66 and 68).” FL 136 (2003): 193-206. [The two sirventes are placed within the context of Cerveri's total output, especially alongside other lighthearted, playful poems, such as PC 434a,80, consisting mostly of one-syllable lines, and the Canso de les letres, in which each hemistich begins with a letter of the alphabet; the Vers estrayn is the coded form of the Vers brau, created by inserting a bisyllabic group within each syllable of the original, perhaps as an educational tool for use by children in the court, or simply as proof of poetic originality.]

\section{PC 437. Sordel}

[fl. 1220-69; vida in two versions; forty-three poems, including a planh for Blacatz and an exchange of coblas with Charles d'Anjou, PC 437,37; for his Ensenhamen d'onor, see 22.5.f; originally from Mantua, he traveled and enriched himself in

Provence and Spain before returning to Italy.]

\section{4.}

Boni, Marco. Sordello, le poesie. Bologna: Libreria Antiquaria Palmaverde, 1954; also in: Boni, Sordello, con una scelte di liriche tradotte e commentate. Bologna: Pàtron, 1970. [Introduction on Sordello's life in Italy, Spain, and Provence; analysis of his corpus, style, metrics, language, and the Ensenhamen d'onor; the formation of his legend in Dante and into the nineteenth century; edition of two versions of the vida, forty-two poems and the ensenhamen, with Italian translation, notes; in appendix, texts of two poems, an Old French motet and a "Lombard" sirventes, neither likely by him.]

\section{5.}

Wilhelm, James J. The Poetry of Sordello. New York: Garland, 1987. [Edition of fortytwo poems, plus the Ensenhamen d'onor, with English translation, textual notes.]

\section{6.}

Faccioli, Emilio. Sordello da Goito. Mantova: Tipografia Grassi, 1994. [Study of the life and works of Sordello and his legend; a selection of sixteen poems, with Italian translation; see also the popular website by Rodolfo Signorini http://www.sordello.it/ sordello.htm, based on the work of Faccioli and the further edition by Ilvano Caliaro of all forty-three poems and the ensenhamen (Verona: Mazziana, 2000).]

2987.

Beltrami, Pietro G. "Spigolature su Sordello e la poesia italiana del Duecento." In - 108, Atti Sordello, 2000, pp. 233-79. [Places Sordello in the Italian context, 
comparing his work with four early Italian poets, Petrarch and Aimeric de Peguilhan.] 2988.

Bortolami, Sante. "Los barons ab cui el estava. Feudalità e politica nella Marca Trevigiana ai tempi di Sordello." In $>\mathbf{1 0 8}$, Atti Sordello, 2000, pp. 1-43. [Study of the sociohistorical background, vida, and biography of Sordello that clarifies the complex intrigues with Cunizza, his marriage to Otta degli Strasso, and his disgrace.]

\section{9.}

See 2746, Fuksas, "Il corpo di Blacatz," 2001. [Sordello's planh PC 437,24 suggested that the political leaders of Europe should eat some of Blacatz's heart to acquire his courage; his poem was turned against him, first by Bertran d'Alamanon with the semiserious claim that none of these was worthy, and that the heart should be given to a number of superior ladies, then by Peire Bremon Ricas Novas in a more scandalous parody, declaring that the whole body should be shared by all, in language suggestive of Christ's sacrifice for mankind.]

2990.

Gouiran, Gérard. "A propos de l'esprit de Sordel.” In Et c'est la fin pour quoy sommes ensemble: Hommage à Jean Dufournet. Edited by Jean-Claude Aubailly et al. 3 vols. Paris: Champion, 1993, 2:645-59. [Traces the development of Sordello's sense of humor from the too-sensitive reactions of the younger poet, who took offense quickly and disastrously at criticisms and insults, to the more refined use of controlled satire by the more mature man.]

2991.

Gouiran, Gérard. "Salvan s'onor: l'honneur contre l'amour ou la conception sordellienne de la fin'amor." In 108, Atti Sordello, 2000, pp. 125-40. [Even though a standard code of behavior toward finamor seems to have existed among the troubadours, personal reactions to the lover's obligations can be seen in many poets; Gouiran explores the originality of Sordello's responses to the classic topoi, compared with those of model poets such as Bertran de Born and Bernart de Ventadorn; Sordello's love is beyond rational and is inescapable for himself and for his lady; his claim to place the domna's honor above everything places him in the masochistic position of urging her to resist his desire for the sake of her absolute honor-or is he playing with his audience?] 2992.

Gouiran, Gérard. "S'aisi son tuit freich cum el l'autre Lombart, non son bon ad amor ou la mauvaise réputation de Sordel." In 162, Trobadors a la Península Ibèrica, 2006, pp. 171-94. [Outlines the existing historical traces of Sordello, indicating that important parts of his life remain unknown; traces information provided through remarks of other troubadours; the story of his supposed abduction of Cunizza remains mysterious; Uc de Saint Circ, Guilhem de la Tor, Aimeric de Peguilhan, and Peire Bremon all commented on Sordello's reputation, but it remains unclear whether there is any truth to his image as an inveterate gambler, gay, debauched, and cowardly.]

2993.

Guida, Saverio. "Le biografie provenzali di Sordello." In Atti del Convegno Internazionale di Studi su Sordello da Goito (Goito-Mantova 13-15 nov. 1997). Edited by 
Stefano Asperti and Maria Careri, in CN 60 (2000): 89-123. [Detailed study of the dual vidas, the shorter of which portrays a relatively noble Sordello, in contrast to the longer one that paints a rather different portrait of a debauched habitué of taverns, a singer of nasty diatribes as well as idealized visions of courtly love.]

\section{4.}

See 2940, Guida, "Sulla tensone tra Uget e Reculaire," 2006. [Rich and lengthy exploration of poetic practices and moral concepts on the lower levels of society at the turn of the twelfth century in southern Europe; claims that Uget is not Uc de Mataplana but Uc de Saint Circ, and that Reculaire is a nickname for Sordello; the text of the tenso PC 458,1 is reproduced in appendix, without notes or translation.]

\section{5.}

Howie, Cary. "Inextricable." Glossator 4 (2011): 21-32. [An imaginative postmodern attempt to clarify the personal, social, and philosophical ramifications of lauzar, starting with a short poem by Sordello and embracing the Bible, Augustine, and Saint Francis of Assisi.]

\section{6.}

Mancini, Mario. "Sordello, o la fin'amors di un cortigiano." In $\mathbf{1 6 4}$, I trovatori nel Veneto, 2008, pp. 253-78. [The traditional noble figure of Sordello comes mostly from Dante's treatment in the Purgatorio, but in his poetry and in comments by his contemporaries, the figure that emerges is often anything but noble; behind the contradictions, Mancini finds an intriguing poet who is complex, original, and focused, characterized by the contrast of his earlier adventuresome life with his new, highly idealized notion of poetic love obsessed with the importance of the lady's honor, and insisting on the absence of physical desire; whether the nasty reactions to his new purity are based on fact or fiction, they reveal a colorful society that is at least as interesting as the poet.]

\section{7.}

Perugi, Maurizio. "Sordello: una vita irrequieta." Atti e memorie della Real Accademia Virgiliana di Mantova 56 (1988): 91-117. [A lengthy anecdotal recounting of the life of Sordello, mixed with comments about the poetry that accompanied his peregrinations.]

\section{8.}

See 1488, Schulze-Busacker, "Sordello, poète didactique," 2000. [Analysis of paremiological expression in three periods of Sordello's poetic life; almost no proverbs are found in the early works, but in his most productive period, 1233-46, he uses them in all major lyric genres, much more frequently than his contemporaries, and in the Ensenhamen we find the richest use to express his unusual concept of onor; see also the author's more detailed study of this text and its use of the Disticha catonis in RST 5 (2003): 99-109.]

\section{9.}

Schulze-Busacker, Elisabeth, "Sordello, Ensenhamen d'onor." RST 5 (2003): 99-109. [A general survey of scholarship in the field of didactic literature, with mention of a number of themes found in the Ensenhamen and an outline of work still to be done to identify the sources of Sordello's text.] 
3000.

Splittgerber, Lisa. "Sordello, Cunning Poet of lamar (la mar, l'amar)." Tenso 8 (199293): 42-56. [Shows him to be a gifted and amusing poet-punster with great rhetorical skill; "erotic harmonics" allow us to read an erotic undercurrent or subtext into the otherwise political poem Lai al comte mon segnor voill pregar (PC 437,18).]

3001.

Verlato, Zeno. Edition of PC 437,4, Dompna valen, saluz et amistaz, in $\mathbf{5 2 0}$, Gambino, Salutz, 2009, pp. 550-63. [The poem has only fourteen lines; may be obeying the preference of MS $\mathrm{H3}$ for two-stanza pieces, or it may be fragmentary; Verlato sees it as an abbreviated but "correct" salut.]

\section{PC 440. Na Tibors (de Sarenom)}

[First half thirteenth century; vida; fragment of a canso; she was an arbiter in a partimen between Uc de la Bacalaria and Bertran de Saint-Felitz, PC 449,1 = 91,1; any 3002. relationship to the troubadour Raimbaut d'Aurenga is probably a legend.]

See 735, A. Rieger, Trobairitz, 1991, pp. 641-51. [Critical edition of the eightline fragment, with German translation, notes, detailed analysis; believes that she is unconnected with Raimbaut d'Aurenga or his family and that she belongs probably to the first half of the thirteenth century.]

3003.

See 700, Dronke, Women Writers, 1984, pp. 99-100. [Tibors was the sister of Raimbaut d'Aurenga; only a fragment of a poem is extant, printed in note 50, p. 299; her verse shows her to be self-assured, simple, realistic, and frank in the expression of her joy in love.]

\section{PC 442. Tomier e Palaizi}

[ $f$. 1199-1226; vida; two sirventes, the first called also an esdemessa, a sirventes with refrain; a third sirventes, PC 231,1a, in support of Avignon under siege by Louis VIII, was thought to be of doubtful attribution by Frank, is claimed for them by Riquer.]

\section{4.}

Frank, István. "Tomier et Palaizi, troubadours tarasconnais (1199-1226).” Rom 78 (1957): 46-85. [Edition of vida and two sirventes, plus one sirventes of uncertain attribution, perhaps by Guillem Rainol d'At.]

3005.

Guida, Saverio. "Nuovi documenti su alcuni trovatori del XIII secolo." CN39 (1979): 81-105. [Pp. 90-92: documents of 1199 and 1226 attest the historical identity of the inseparable poets, citizens of Tarascon, who played an active role in the stormy political struggles of their time; a new document of 1236 witnessed by Palaizi alone (after Tomier's death?) shows his continued close participation in political events; Guida suggests a revised dating of the poem PC 442,1 to a period well before 8 June 1226, the start of the siege of Avignon by Louis VIII, when the arrival of Louis was still only a threat.] 
3006.

Klein, Karen W. The Partisan Voice: A Study of the Political Lyric in France and Germany, 1180-1230. Paris: Mouton, 1971, pp. 78-84 and 116-20. [Analysis of the sirventes Si co.l flacs molins as a representative example of the composition and structure of a lyric dealing with political activism; text with French translation and stanzaby-stanza commentary; pp. 116-20: discussion of all three sirventes by Tomier and Palaizi, written at the time of the sieges of Beaucaire, Toulouse, and Avignon against the French invaders from the North, going from the elated feeling of victory to that of despair.]

3007.

See 227, Riquer, 1975, 2:1154-60. [Introduction, edition of PC 231,1a with Spanish translation, notes.]

\section{PC 443. Torcafol (nickname)}

[End twelfth or beginning thirteenth century; three sirventes exchanged with Garin d'Apchier.]

3008.

Latella, Fortunata. I sirventesi di Garin d'Apchier e di Torcafol. Modena: Mucchi, 1994. [Three sirventes by Torcafol (PC 443) and eight by Garin d'Apchier (PC 162), some incomplete; detailed introduction, notes, critical texts with Italian translation, glossary, full concordance; also available online (texts only, brief notes) at http:// www.rialto.unina.it, along with "Premessa all'edizione in linea dei sirventesi di Garin d'Apchier e Torcafol” (2002).]

3009.

Bianchini, Simonetta. "BdT 443,2: Torcafol, Comunal, en rima clausa, v. 41.” AIUO 38 (1996): 267-70. [Analysis of Torcafol's sirventes and a correction to Mancini's article in 401, Mancini, Metafora feudale, 1993, "Cortigiani," pp. 13-62 (esp. pp. 23-24); the corrupted form barestella is reestablished as ses artella "senza difesa" = "defenseless."]

PC 444. Tostemps (perhaps a senhal for Raimon de Miraval) [One tenso with Folquet de Marselha, PC 155,24; Poe, 2007, suggests the possibility that tostemps in Judici d'Amor/So fo el temps/En aquel temps is used as a senhal to indicate Raimon de Miraval as author of the first half, perhaps "answered" in the second half by Raimon Vidal on behalf of

3010. his patron Uc de Mataplana; an intriguing hypothesis.]

See 487, Cropp, “Partimen," 1980. [Detailed study of PC 155,24= 444,1: manuscripts, poets, genre, and versification; analysis of the debate poem as a polished courtly game à la Neumeister (contrasted with a similar analysis by Camproux of a poem interpreted as a sociohistorical document à la Köhler); uses Stronski's text, with a few corrections; Tostemps is a senhal, perhaps for Raimon de Miraval; Poe $\mathbf{1 3 0 5}$ uses tostemps as a clue to postulate Raimon de Miraval as author of the first half of So fo.] 


\section{PC 447. Turc Malec (Truc)}

[Late twelfth century; vida; one sirventes in response to Raimon de Durfort, PC 397,1; response to both by Arnaut Daniel, PC 29, 15; see Cornilh Affair 1982-92.]

\section{PC 450. Uc Brunenc (Bru, Brunet, de Rodez)}

[End twelfth, beginning thirteenth century; three cansos, three sirventes; one preserved melody: see 607, van der Werf, Extant, 1984, p. 340*;

Daude de Pradas composed a planh on his death.]

3011.

Gresti, Paolo. Il trovatore Uc Brunenc. Edizione critica con commento, glossario e rimario. Beihefte zur $\operatorname{ZrP}$, 309. Tübingen: Niemeyer, 2001. [Introduction on biography, metrics, and manuscript study; edition of six cansos, with Italian translation, notes, rimarium, and full glossary; in appendix, the planh by Daude de Pradas for Uc's death, and two versions of the melody for PC 450,3, by Gennrich 1958 and van der Werf 1984.]

\section{2.}

Rosenstein, Roy. "A New Approach to Distant Love: Jaufre Rudel, Uc Bru and Sarrazina." In 95, AIEO 2, 1993, 1:349-67; also in Modern Philology 87 (1990): 225-38. [Close new analysis of Qan lo rius, in terms of the mid-1140s, around Jaufre and his circle; it is a crusade song, meant to inspire the widowed Hugh VII of Lusignan (Uc Bru) to turn from mourning his wife Sarrazina and to set out on crusade in search of the Heavenly Bride; the poem is a plea from his friend Jaufre to turn from secular concerns to seek Saint Bernard's immortal Bride in the Holy Land.]

\section{PC 452. Uc de l'Escura (de Lescure)}

[ $f$. 1190-1204; one sirventes addressed to the king of Castille.]

3013.

See 227, Riquer, 1975,2:927-30. [Introduction, edition of PC 452,1, with Spanish translation, notes.]

3014.

Guida, Saverio. “Giullari a Tolosa agli inizi del '200.” In Cenacoli: Circoli e gruppi letterari, artistici, spirituali. Edited by Francesco Zambon. Milan: Medusa, 2007, pp. 131-56. [New light on joglar performance activities, gleaned from archival documents; study of Uc's gab-sirventes and of the eight performers mentioned in the first stanza, all of low- or middle-class origin; documented information on Pelardit and Gualaubet, previously unknown, and on the dramatic activities of the group in Toulouse responsible for theatrical activities similar to the commedia dell'arte; each had a particular talent: Peire Vidal was an accomplished troubadour, Albertet a singer, Perdigon an instrumental musician, Aimeric de Peguilhan a composer of cansos, Arnaut Romieu a braggart, Elias Fonsalada a singer, Pelardit a mime, and Gualaubet a violist.] 


\section{PC 454. Uc de Mataplana (Huguet, Hug, probably the same as Uguet PC 458)}

[fl. 1185-1213; died of wounds after the battle of Muret; was a patron of Raimon Vidal de Besalù, in whose So fo el temps he appears as a judge in a conflict between two ladies over a lover; sirventes blaming his friend Raimon de Miraval for disowning his wife Caudairenga, answered by Raimon, PC 406,30; exchange of coblas with Blacatz, PC 454,2 = 96,5; the tenso with

Reculaire, PC 458,1 = 417,1 is now thought to be by Uc de Saint Circ.]

\section{5.}

See 2432, Forner, Guillem de Berguedà $i$ altres, 1986, pp. 215-37. [Popular edition of the exchange of coblas with Blacatz, the tenso with Reculaire (=Sordello?), and the sirventes against Raimon de Miraval, with its razo; introduction, Catalan translation, brief notes.]

3016.

Guida, Saverio. "Sulla tensone tra Uget e Reculaire (BdT 458,1)." SMV 52 (2006): 99-130. [Rich and lengthy exploration of poetic practices and moral concepts on the lower levels of society at the turn of the twelfth century in southern Europe; claims that Uget is not Uc de Mataplana but Uc de Saint Circ and that Reculaire is a nickname for Sordello; the text of the tenso is reproduced in appendix, without notes or translation.] 3017.

Riquer, Martin de. "El trovador Huguet de Mataplana." In Studia hispanica in honorem R. Lapesa. 3 vols. Madrid: Cátedra-Sem. Menéndez Pidal, 1972-75, 1:455-94. [A study of the historical background, identifying N'Uget as Uc de Mataplana and examining his close relationship with Raimon de Miraval and with Raimon Vidal de Besalù; claims that Uc's exchange of coblas was not with Blacasset but with Blacatz, when both were young; edition of three poems by Uc: an exchange of coblas with Blacatz, PC 454,2 = 96,5, a tenso with Reculaire, PC 417,1 $=458,1$, and a sirventes addressed to Raimon de Miraval, PC 454,1; also the response of Raimon de Miraval, PC 406,30, all with Spanish translation, notes.]

3018.

See 227, Riquer, 1975, 2:1088-93. [Introduction; edition of the sirventes against Raimon de Miraval, PC 454,1, and its razo, with Spanish translation, notes.]

3019.

$$
\text { PC 456. Uc de Pena (Penne) }
$$

[fl. 1248-83; vida; three cansos.]

See 249, Bec, Florilège en mineur, 2004, pp. 35-39. [Text of vida and PC 456,1 from Kolsen, 1925; French translation, no notes.]

3020.

Cura Curà, Giulio. "Le canzoni del trovatore Uc de Pena." CDT 10.2 (2007): 9-45. [Historical introduction, full critical editions, with Italian translation, notes, commentary.] 


\section{PC 457. Uc de Saint Circ}

[fl. 1210-53; vida, perhaps composed by Uc himself; forty-seven poems, thirteen of which belong to a coherent cycle; three preserved melodies: see

607, van der Werf, Extant, 1984, pp. 341*_43*; some scholars claim that he wrote the Donatz proensals under the name of Uc Faidit "exiled";

he is considered the author of many of the vidas and razos.]

3021.

Jeanroy, Alfred, and Jean-Jacques Salverda de Grave. Poésies de Uc de Saint-Circ. Bibliothèque Méridionale, Ist ser., 15. Toulouse; Privat, 1913. [Fabio Zinelli has prepared an edition of Uc de Saint Circ as a doctoral thesis for the University of Perugia, 1997.]

3022.

Rando, Daniela. "I luoghi della cultura nella Marca del Duecento." In $>164, I$ trovatori nel Veneto, 2008, pp. 3-25. [Historical background, sociocultural activities at the courts of the Marca, especially the court of Alberico da Romano at Treviso, where Uc was active over many years and even had his own house; the court itself was largely a literary creation, moveable, flexible; exploration of the role of the mendicant orders in education and cultural awareness; interest in elegance, manners, language.] 3023.

Burgwinkle, William E. "For Love or Money: Uc de Saint Circ and the Rhetoric of Exchange." RR 84 (1993): 347-76. [The poetry of Uc and other troubadours shows materialistic tendencies, animated by crude and cynical wish for gain; the love relationship may be reduced to a sort of transaction: service rendered, service rewarded, a seemingly shocking exchange of goods; Guida in CN 54 (1984): 181, n. 64, thinks that the hypothesis needs more work.]

3024.

Guida, Saverio. "Uc de Saint Circ e la crociata contro gli Albigesi." CN 57 (1997): 19-54. [Study of Uc's attitude toward the crusade through analysis of the vidas and razos of Folquet de Marselha and Perdigon, in which there is a curious omission of any information on Folquet's actions in the founding of the Dominican order or of his encouragement of the Albigensian Crusade, or of Perdigon's political activities; though Uc was openly critical of the church, he seems to have been careful to omit any direct reference to Catharism or Cathar sympathies from his writings.]

3025.

See 2946, Guida, "Sulla tensone tra Uget e Reculaire," 2006. [Rich and lengthy exploration of poetic practices and moral concepts on the lower levels of society at the turn of the twelfth century in southern Europe; claims that Uget is not Uc de Mataplana but Uc de Saint Circ and that Reculaire is a nickname for Sordello; the text of the tenso PC 458,1 is reproduced in appendix, without notes or translation.]

3026.

Holmes, Olivia. Assembling the Lyric Self: Authorship from Troubadour Song to Italian Poetry Book. Minneapolis: University of Minnesota Press, 2000, pp. 25-46. [Study of Uc as a poet at the turning point in the passage from oral to written culture, a 
bridge between poetic traditions in Occitania and Italy, and a key figure in efforts to systematize the body of Occitan lyric; detailed analysis of a sequence of twelve of his cansos that point the way to later autobiographical lyric cycles.]

3027.

Janzarik, Diether. "Uc de St. Circ_auteur du Donatz proensals?" ZrP 105 (1989): 264-75. [Study of the possible identity of Uc de Saint Circ and Uc Faidit; confirms the opinion of several earlier scholars (Gröber, Folena, Roncaglia) that the two were the same; further historical references and the claim by Uc himself to be a teacher strengthen the hypothesis to a quasi-certainty.]

3028.

See 526, Poe, "Another salut," 1990, pp. 314-37. [Argues for the status of PC $42 \mathrm{a}$ as a salut d'amor; examines the probability that it was composed by the trobairitz Azalais d'Altier or alternatively by Uc de Saint Circ; text in appendix, with notes, no translation; see also Poe, "Un poème marginal," in $\$ 95, AIEO 2, 1993, 1:283-88.] 3029.

Poe, Elizabeth Wilson. "L'autr'escrit of Uc de Saint Circ: The razos for Bertran de Born.” RPh 44 (1990): 123-36. [The expression l'autr'escrit refers to an early group of razos composed or compiled by Uc and circulated as a group; the collection is amorphous and incomplete, drawn from a variety of sources, but is quite separate from the other razos.]

3030 .

Poe, Elizabeth Wilson. "Unravelling a Woolly Text: Ma dompna cuit fasa sen.” Neo 74 (1990): 527-35. [Uc de Saint Circ, PC 457,19, is a teasing poem giving a "discomforting image of female sexual aggression and male impotence"; this is a portrait of a mala domna; Poe shows that it is not part of the so-called roman of Uc's unhappy love affair while in France; instead, it belongs to his later satirical period in Italy.]

3031.

Radaelli, Anna. "La danseta di Uc de Saint Circ (BdT. 457,41)." In 1 108, Atti Sordello, 2000, pp. 59-88. [Interpretation of the poem as an ironic, humorous piece partaking of the lively and competitive interchange of insults within the Romano court, poking burlesque fun at Sordello as he prepared to leave the court, with a lively rhythm suitable for dancing his rival on his way; new critical edition, with Italian translation, notes.]

3032.

Scarpati, Oriana. “Cocuda. Una nota per Uc de Saint Circ (BdT 457,38).” CN 67 (2007): 131-38. [Analysis of the sirventes directed by Uc against Manfred II Lancia of Milan, accusing him of many faults but not that of being cuckolded, as has been thought; cocuda refers directly to the cuckoo bird, who is crafty and unfair enough to give over its duties and responsibilities to others.]

3033.

Tavera, Antoine. "Des troubadours italotropes." In 749, ICLS 7, 1994, pp. 85-93. [General presentation of the work of three traveling troubadours: Aimeric de Peguilhan, Cerveri de Girona, and Peire Raimon de Tolosa.] 
3034.

Zinelli, Fabio. "La chanson Be fai granda follor (BdT 457,7). Un cas d'attribution controversée et la tradition manuscrite de Saint-Circ (avec une note sur l'iconographie de C)." SM 47 (2006): 589-651. [Critical edition from $C$ and $R$, with French translation, copious textual notes; confirms its attribution to Uc de Saint Circ.]

3035.

Zinelli, Fabio. Edition of PC 457,I: Belle domna gaia e valentz, in $\ \mathbf{5 2 0}$, Gambino, Salutz, 2009, pp. 508-27. [May be part of a series of poems forming a narrative sequence; closely related to PC 461,II; Poe, 764, "Dispassionate Look," 1992, pp. 155-57, thinks that this poem, along with 156 ,I, 457,3 and 457,1 , may be by Uc.]

\section{PC 458. Uguet (Uget; was thought to be Uc de Mataplana PC 454, but now convincingly identified as Uc de Saint Circ)}

[One tenso with Reculaire, probably a nickname for Sordello, PC 458,1 = PC 417,1.] 3036.

See 2001, Ricketts, Contributions, 2000, pp. 58-62. [Edition of tenso PC 458,1 = 417,1, Scometr.us vuoill, Reculaire, with critical apparatus, French translation, note; no comment on the identity of either participant.]

3037.

Guida, Saverio. "Sulla tensone tra Uget e Reculaire (BdT 458,1)." SMV 52 (2006): 99-130. [Rich and lengthy exploration of poetic practices and moral concepts on the lower levels of society at the turn of the twelfth century in southern Europe; claims that Uget is not Uc de Mataplana but Uc de Saint Circ and that Reculaire is a nickname for Sordello; the text of the tenso is reproduced in appendix, without notes or translation.]

\section{Yselda_see PC 12 Alaisina Yselda (perhaps Alaisina Yselda should be read as two women: Alais i Na Yselda)}

\section{PC 461. Anonymous Lyrics}

[There are 222 poems, some of which have now been attributed, or have been identified as parts of other poems; no complete edition of the anonymous songs exists; see the inventory in 3041, Gambino, "L'anonymat," 2000.]

\section{8.}

\section{PC 461.0. General Studies of Anonymous Lyrics}

See 2001, Ricketts, Contributions, 2000, pp. 63-74. [Edition of six anonymous poems: PC 461,34, 76a, 128, 189, 194, 204, with French translation, notes.]

3039.

Bond, Gerald A. “The Last Unpublished Troubadour Songs.” Speculum 60 (1985): 827-49. [Four songs (three and a fragment); all with music; all are dance songs; two have hybrid language: one Italian/Occitan, basically Italian; one French/Occitan, basically French (?), a semiobscene parody; the manuscript was written in Catalonia 
in the third quarter of the thirteenth century; Bond's renumbering has not been followed by Distilo; PC 461,27b (Bond's 24a) is a parody dansa: Ara lausetz, lauset, lauset, 215c (Bond's 215) is a dansa: sanc vos amei; 251b (the same in Bond) is a fragmentary dansa: era.us p [re]g; Bond's PC 461,20b, Amors, merce no sia, is not listed by Distilo because Frank considered it Italian, Catalanized by the scribe; discussion of sources, date of transcription, language, form, and content; edition of texts with notes, music, and commentary.]

3040.

Gambino, Francesca. "Caso, imitazione, parodia. Osservazioni sulle attribuzioni 'inverosimili' nella tradizione manoscritta provenzale (II)." SMV 46 (2000): 35-84. [A study of wrongly ascribed poems in the manuscripts; in a previous study, she dealt with Guilhem's Farai chansoneta nueva and Jaufre Rudel's Qui non sap esser chantaire; continued here, the result is a list of thirty-three texts divided into those whose author has been identified and those which remain anonymous; explores possible causes for the confusion.]

3041.

Gambino, Francesca. "Lanonymat dans la tradition manuscrite de la lyrique troubadouresque." CCM 43 (2000): 33-90. [Detailed exploration of the phenomenon of anonymity in twenty-six chansonniers; finds that anonymity is rare, except for poems that have suffered some material accident, those preserved only in musical manuscripts, trobairitz songs, and coblas esparsas; establishes a complete inventory of 222 anonymous lyrics, most of which are found in only one manuscript; calls for the updating of the category PC 461.]

\section{2.}

Gambino, Francesca. "Anonimi per caso, anonimi per scelta e nomi censurati: osservazioni sull'assenza del nome d'autore nella tradizione manoscritta trobadorica." In L'Eclissi dell'Artefice. Sondaggi sull'anonimato nei canzonieri medievali romanzi. Edited by Francesca Gambino et al. Rome: dell'Orso, 2003, pp. 7-30. [A study of the phenomenon of authorship and anonymity in the transmission of Occitan texts, in which anonymity is rare and the principle of naming each poet is firmly fixed; classifies different reasons for lack of name on works, whether accidental, by genre, or through censorship.]

\section{3.}

Gambino, Francesca. Canzoni anonime di trovatori e trobairitz: edizione critica con commento e glossario. Alessandria: Edizioni dell'Orso, 2003. [About 10 percent of troubadour poems are unattributed, most from minor genres or popular forms; it is unusual for sirventes and cansos to be unattributed; twenty-one anonymous cansos are here edited, with diplomatic transcription, critical text with Italian translation, and copious philological notes; one further controversial poem is given in appendix, which may belong to the Catalan fourteenth-century tradition rather than to the Occitan troubadours.]

3044.

Gourc, Jacques. "L'expression de la fin des temps chez les troubadours anonymes." 
In Fin des temps et temps de la fin dans l'univers médiéval. Sénéfiance, 33. Aix-enProvence: CUER MA (1993): 201-10. [Stresses the importance of the anonymous corpus, whose quality is as high as that of the named poets, especially the 148 coblas esparsas from the late thirteenth century, many of which show reactions against the social changes of the time, involving the loss of courtly liberalism, the linguistic prestige of Occitan, and an increase in religiosity and moral rigidity; these poems project a profound awareness of the end of fin'amor, an intensification of the negative counterpart of idealized love, which was present as a contretext of trobar from the beginning.]

\section{5.}

Indini, Maria Luisa. "L'Arlabeca provenzale, anonimo poemetto della fine del XIII secolo." ZrP 101 (1985): 197-225. [Sketch of earlier studies of the moralistic poem, which reflects on the inevitability of death and the necessity of appearing before the final Judgment, where sinners will be consigned to hell and torment; the name is Arabic, from the instrument known as rebec, or in Catalan codolada, both terms also designating poetic genres, in this case probably because of the grave moralistic tone; the gloomy religiosity of the poem reflects the despondency of Occitania at the end of the thirteenth century after the turmoil of crusade and inquisition; the style is one of direct and gripping communication with the listeners, typical of a skilled preacher.]

\section{6.}

Lamur, Anne-Claude. "Une pièce inédite contenue dans le chansonnier des troubadours M, Paris, B. N. 12474, Axi com cell qu'e-llmar es perilat." Estudis occitans 2 (1987): 18-25. [Also in 520, Gambino, Salutz, 2009, Appendix, pp. 217-25.]

\section{7.}

Macdonald, Aileen Ann. "A Refusal to Be Silenced or to Rejoice in Any Joy That Love May Bring: The Anonymous Old Occitan Canso Per ioi que d'amor mavegna." Dalhousie French Studies 36 (1996): 3-13. [Consideration of the problems posed by the change in persona in trobairitz poems, specifically in PC 461,191; the ethos of the male canso was the aspiration of the male after an ideal represented by the lady; the new gender perspective in the trobairitz poems requires more than a simple reversal of roles, since the man cannot easily take on the role of the domna; the possible attribution of the poem to Castelloza is left open; in appendix, text and translation of the poem from Bruckner et al.]

\section{8.}

Marinetti, Sabina. "Il salut d'amor Hai dolcha domna valentz." Rom 121 (2003): 289-328. [Critical edition of the anonymous salut PC 461,II, from MS L, which has two copies of the poem; analysis of the phenomenon of double transmission and its significance in understanding the make-up of the manuscript; suggests that $L$ may have resulted from the fusion of materials conceived for two separate manuscripts; also published in completely revised and shortened form, with addition of Italian translation, in 520, Gambino, Salutz, 2009, pp. 624-43.]

\section{9.}

Marshall, John H. "Trois fragments non identifiés du chansonnier provençal H." Rom 
97 (1976): 400-405. [Damage to the manuscript has left three poems fragmentary; two are unidentified and have no PC number; the third comes from Blacasset, PC 96,11; critical edition of the first two fragments, formalistic analysis, and a few suggestions to help place them; one is possibly by a trobairitz.]

\section{0.}

Nappholz, Carol Jane. "(Re)locating Lost Trobairitz: The Anonymous Female Voice in Provençal Debate Poems.” Tenso 7 (1991-92): 125-41. [Argues for the reality of many of the anonymous domnas in tensos, thought by Chambers to be fictitious; study of the tenso between Bertran del Pojet (PC 87,1) and a bona domna, PC 87,1, in which she claims to hear "a distinctly female voice." A. Rieger agrees in 735, Trobairitz, 1991, pp. 329-30, but Poe, in 764, "Dispassionate Look," 1992 casts doubt on the historicity of several trobairitz, even some generally considered historical; we need criteria to assess their identity as women.]

3051 .

Nappholz, Carol Jane. Unsung Women: The Anonymous Female Voice in Troubadour Poetry. New York: Peter Lang, 1994. [Texts and translation of twenty-six songs attributed by Nappholz to anonymous trobairitz; it is left uncertain whether some of the poems are by women or by men writing in a female voice.]

3052.

Paden, William D. "Bertran de Born in Italy." In Italian Literature: Roots and Branches. Essays in Honor of Thomas Goddard Bergin. Edited by Giose Rimanelli and Kenneth J. Atchity. New Haven, CT: Yale University Press, 1976, pp. 39-66. [Study of Bertran's legend in Italy, helping to explain the poet's strange role in Dante's Inferno; edition of three anonymous poems that helped create the legend.]

3053.

See 560, A. Rieger, "La cobla esparsa," 1988. [A preliminary exploration of the corpus of 136 anonymous coblas as part of an ongoing project which will define the genre, establish the corpus, and furnish a complete edition.]

3054.

See 735, A. Rieger, Trobairitz, 1991, pp. 704-13. [Poem PC 404,5, erroneously attributed to Raimon Jordan, may have been composed by a trobairitz; it offers a strong protest against the misogyny of Marcabru, and especially his crude references to the con.]

3055.

Stussi, Alfredo. "Note sul Sirventese lombardesco." In 108, Atti Sordello, 2000, pp. 281-310. [Meticulous analysis of earlier scholarship on an anonymous poem with regional traits characteristic of the Padana area, thought by some to be by Sordello, attribution denied by Stussi; new critical edition with copious notes; see also - 1156, Meneghetti, "Vidas e razos," 2008, who formerly had denied Sordello's authorship but thinks now that it might be by him after all.]

Some Interesting Anonymous Lyrics, Listed by PC Number 


\section{PC 461,2, Ab lo cor trist envirollat d'esmai}

[Text from mid-fourteenth century; the only extant planh by a woman; of controversial origin, perhaps Catalan, perhaps Occitan.]

3056.

Vidal i Alcover, Jaume. "El plant amorós Ab lo cor trist: assaig de restauració d'un text corrupte." In Miscellània Pere Bohigas. Associació Internacional de Llengua i Literatura Catalanes. 3 vols. Barcelona: Abadia de Montserrat, 1981-83, 2:85-95. Also in Estudi de literatura medieval $i$ moderna. Mallorca: Editorial Moll, 1996, pp. 125-33. [Edition and study of the anonymous planh, probably Catalan, maybe by a real trobairitz, lamenting the death of her lover.]

3057.

Scarpati, Oriana. "Anonimo: Ab lo cor trist, envirollat d'esmay (BdT 461.2)." Lecturae tropatorum, 2008, 17 pages. Online at http://www.lt.unina.it. [Claims that this is a Catalan planh by an anonymous trobairitz from the second half of the fourteenth century; it should perhaps be excluded from the Occitan corpus; see also $\mathbf{7 3 5}$, A. Rieger, Trobairitz, 1991: based on her text from MS a (Scarpati's is from Sg), claims that it has Catalanized forms but belongs still in the Occitan trobairitz corpus; Asperti, in $C N 45$ (1985): 98-99, claims that it is clearly Catalan.]

3058.

See 249,Bec, Florilège en mineur, 2004, pp. 229-33. [Thinks that the author might be Catalan, might be a woman; text slightly altered from A. Rieger, with French translation; Catalanisms are "normalized" to Occitan, though Bec admits that he could have gone the other way toward Catalan, especially since some of the rhymes are only possible in Catalan.]

3059.

Zufferey, François. "Toward a Delimitation of the trobairitz Corpus." In 132 , Paden, Voice, 1989, pp. 31-43. [Notes that the metrical scheme is the same as that of the controversial poem by Bietris de Romans, whose place in the trobairitz corpus is also disputed.]

3060.

See 735, A. Rieger, Trobairitz, 1991, pp. 662-74 [Text based on that of Vidal i Alcover, with German translation; the poem is unique in that it is the only planh by a woman; Rieger believes that the poet was a real woman, not fictive, and that the poem belongs in the trobairitz corpus; the poem was probably composed by an Occitan or northern Italian trobairitz in Catalonia, and therefore belongs in the Occitan corpus; parallels are seen with PC 137,1 by P. Basc, who could also be a woman.]

3061.

$$
\text { PC 461,3, Ab la gensor que sia [alba] }
$$

See 511, Poe, "Lighter Side," 1985. [PC 461,3 is a parody of the alba genre and a comic response to Giraut de Bornelh's Reis glorios, perhaps composed by the scribe of $C$.] 
PC 461,27b, Ara lausatz, lauset [dansa, with music]

3062.

See 3039, Bond, "Last Unpublished," 1985.[PC 461,27b, Bond's 24a, is a parody dansa: Ara lausetz, lauset, lauset; critical edition, with English translation, notes, music, and commentary, including a discussion of sources, dates of transcription, language, form, and content.]

3063.

\section{PC 461,83, Dieus vos sal, dona, de pretz sobeirana}

Zamuner, Ilaria. Edition of PC 461,83 in $>\mathbf{5 2 0}$, Gambino, Salutz, 2009, pp. 68085. [Critical edition with brief introduction, Italian translation.]

3064.

See 227, Riquer, 1975, 3:1709-10. [Introduction, text with Spanish translation, notes; also gives the text of the parody PC 461, 82 and makes reference to a similar parody of Bernart de Ventadorn in PC 461, 202.]

3065.

See 244, Bec, Burlesque, pp. 165-66. [Introduction, text with French translation, notes; this is a cobla esparsa or perhaps a fragment of a lost canso; Bec includes the scatological parody PC 461,82 that follows it immediately in MS G.]

\section{6.}

\section{PC 461,124, Gent me nais [Lai Markiol, with melody]}

Maillard, Jean. Anthologie de chants de troubadours. Nice: G. Delrieu, 1967. [Text and melody of twenty-one poems, including the Lai Markiol.]

3067.

Billy, Dominique. Deux lais en langue mixte: le lai Markiol et le lai Nompar. Beihefte zur $\operatorname{ZrP}$, 264. Tübingen: Niemeyer, 1995. [A penetrating treatment of French-Occitan hybrid language; the lyric lai is related to the Old Occitan descort; both genres have mixed language, probably from their origin. Billy gives a diplomatic edition of each lai with the music, and a critical edition with French translation, detailed notes, metrical and linguistic analysis; Occitan origin seems likely; the two texts are not necessarily by the same author, but they come obviously from the same tradition.]

\section{PC 461,127 [Anonymous two-stanza plazer-enueg, Ges no m’eschiu nuls]} 3068.

Allegretti, Paola. "Parva componere magnis. Una strofa inedita di Bernart de Ventadorn (BdT 70,33) e due schede per BdT 461,127.” RST 1 (1999): 9-28. [Edition of PC 461,127, a plazer-enueg that may be by Jofre de Foixà, based on similarities to his Subrafusa ab cabirol; Allegretti denies the possibility of its attribution to Raimon de Miraval.] 
PC 461,146, L'altrier cuidai aber druda.

3069.

[Parody of a canso, similar to a sirventes; with melody]

See 601, Aubrey, "Dialectic," 1997, pp. 16-23. [Analysis of the melody and structure of L'altrier cuidai aber druda and its musical source, the Agmina milicie; the variance between the versification schemes of the Latin and vernacular texts suggests that the melody was taken from an unrelated polyphonic motet and added to the preexistent text.]

3070.

Billy, Dominique. "L'altrier cuidai aber druda, pièce lyrique en langue mixte." RLaR 91 (1987): 109-20. [Detailed review article comparing three editions of PC 461,146 by Bec, 244, Burlesque, pp. 178-83, Gérard-Zai, 3071, and R. Taylor, 3072; see also Billy, "Une imitation indirecte de L'altrier cuidai aber druda: le motet Quant froidure trait a fin/Encontre la saison d'esté," Neo 74 (1990): 536-44.]

3071.

Gérard-Zai, Marie-Claire. "Edition d'une romance parodique occitane: L'altrier cuidai aber druda." In 159, Studia occitanica, 1986, 2:53-63. [Edition with French translation, notes, and commentary; reference is made to a number of medieval works based on the theme of the repulsive old woman, mostly in later literature; believes that language traits point to Franco-Provençal or the Dauphinois; the music is transcribed by Jürg Stenzl from two sources: the melody of $M$ is monophonic, without rhythmic indication; the rhythm is supplied from the duplum of the polyphonic three-part Latin motet Agmina milicie, from which the melody was taken.]

3072.

Taylor, Robert A. "L'altrier cuidai aber druda (PC 461,146): Edition and Study of a Hybrid-language Parody Lyric." In - 159, Studia occitanica, 1986, 2:189-201. [Edition with English translation, notes, basic transcription of the melody; a study of the language suggests that the poem was not an original Occitan composition but a pastiche done by a francophone poet, with artificial Occitanisms inserted to give a southern flavor; see comments on this and the preceding edition by BrunelLobrichon in Tenso 6 (1990-91): 21-22, and by Billy in RLaR 91 (1987): 109-20.]

\section{PC 461,206, Quan vei les praz verdesir}

[One of a group of four Occitan chansons de femme; belongs to the popularizing 3073. register, female voice, not in the courtly tradition.]

See 735, A. Rieger, Trobairitz, 1991, pp. 628-39. [Critical edition with German translation, notes, commentary.]

3074.

Mölk, Ulrich. "Quan vei les praz verdesir." In 151, Mélanges Bec, 1991, pp. 37784. [New text of the poem with minimal corrections; detailed line-by-line textual notes; the poem is one of a group of four Occitan chansons de femme.] 


\section{PC 461,247, Vai Hugonet}

[A plea for help against the French invaders addressed to King Peter II of Aragon just before the disastrous battle of Muret, in which Peter was fatally wounded.] 3075.

Guida, Saverio. "L'autore ed il latore di Vai Hugonet, ses bistensa (BdT 461, 247)." CN 66 (2006): 45-82. [Believes that the poem may be incomplete after four and a half stanzas, probably consisting originally of six stanzas and a tornada; Guida forms the working hypothesis that Raimon de Miraval may be the author and Uc de Saint Circ the messenger of the poem, while inviting further study and other proposals for attribution.]

\section{PC 461a (Listed as 462 by Zufferey)}

[Twelve poems by an anonymous penitent, preserved in the Wolfenbüttel manuscript; the lyrics are inserted into the longer text of 2,936 lines.]

\section{6.}

Levy, E. "Poésies religieuses provençales et françaises du manuscrit de Wolfenbüttel." RLaR 31 (1887): 173-288 and 420-35. [The complete Occitan text is on pp. 20288.]

3077.

See 312, GRLMA vol. 2, book 1, fascicle 7, 1990, pp. 529-31. [Detailed documentation includes dating to 1254 , discussion of metric structures and irregularities of the insecure Occitan language, perhaps contaminated by French and Italian scribes; twelve religious songs addressed to God, saints, and the Virgin are inserted into long penitential prayers.]

\section{8.}

Verlato, Zeno Lorenzo. "Occitania periferica. Il canzoniere religioso di Wolfenbüttel." RST 4 (2002): 173-247. [Analysis of the contents and interior structure of the manuscript; study of parallels with contemporary moral and religious texts from Italy in the body of the text, and of more obvious links to courtly practice in the lyric inserts; edition of five of the most interesting songs showing generalized but clear reference to themes and style of the troubadour tradition; critical texts with Italian translation, commentary, notes; the same five texts are also available online at http://www.rialto. unina.it, with a brief paleographical introduction and Italian translation.]

3079.

See 296, Verlato, "Il pretesto trobadorico," 2009. [Explores the possibility of another stream of poetic development alongside the courtly stream, that developed in Italy, building on the troubadour tradition; the religious moralizing stream reflected in this manuscript may represent a separate poetic development not well preserved; at the moment of fixing the troubadour tradition in the chansonniers, the anonymous poet and others may have used the prestigious troubadour language and structures, excluding their amorous and political interest in favor of religious themes.] 
PC 463-573 (also FZ same numbers) Toulouse School

[Poets from the fourteenth and fifteenth centuries, listed in 13 , Zufferey, Bibliographie des poètes provençaux des XIVe et XVe siècles, 1981. [A few general critical works and three named poets are included below.]

\section{General Studies}

[The Toulouse School, Consistori de la Subragaya Companhia del Gai Saber, was founded in 1323 by seven eminent citizens of Toulouse; the first winner of the violette d'or offered by the Consistori at the Jeux Floraux of 1324 was Arnaut Vidal de Castelnaudary, for his poem in praise of the Virgin Mary, published

by A. Jeanroy in Les Joies du Gai Savoir, Toulouse, 1914; Arnaut had written earlier a roman d'aventures, Guilhem de la Barra, 1318.]

3080.

See 38, DLF, 1992, pp. 329-30 and 868-69. [History of the Consistori and its continuations; Joies du gai savoir was the name given to the winning poems: violette, églantine, souci; poems in French were admitted in 1513, when the Consistori became Le Collège de Rhétorique.

\section{1.}

See 13, Zufferey, Bibliographie, 1981. [Description and editions of manuscripts, pp. xviii-xxxix; general bibliography, pp. 1-5; alphabetical list by poets, \#463-567, six anonymous under \#568 (Toulouse School) and forty-three more under \#569 (Leys d'Amors); plus five additional \#570-74, one of which (\#572) is listed also as PC 461,133.]

\section{2.}

See 4, Distilo, Per le concordanze, vol. 2, 2003. [A complete listing of troubadour poems by $\mathrm{PC} /$ Zufferey number, including anonymous; vol. 2 is for later poets, the École de Toulouse, etc., along with indices of incipits, explicits, genre indications, musical notation, names of poets, manuscripts, and bibliography of text editors.]

\section{3.}

Billy, Dominique. "L'héritage formel des troubadours dans la poésie occitane des XIVe et XVe siècles.” In $\$ 97, AIEO 4, 1994, pp. 19-35. [A projected new metrical repertory of later Occitan lyric to complement that of Frank for the classic period; in an analysis of fifty-eight sirventes and fifty-one cansos, statistical compilations indicate a simplification and standardization of forms in the later period, characterized by Billy as a floraison appliquée, rather dull in comparison to the greater vitality of Catalan development in the same period and beyond; in appendix, information about twelve contrafacta from the later period, based on earlier troubadour songs; more information at http://w3.erss.univ-tlse2.fr/textes/pagespersos/billy/REP.html.]

\section{4 .}

Billy, Dominique. "L'art des réseaux chez les néo-troubadours aux XIV-XVe siècles." RLaR 107 (2003): 1-40. [A study of the evolution of continuing structural traditions and occasional innovations from the classical period of trobar into the later period; analysis of rhyme patterns and stanzaic forms in the work of a number of 
poets, especially Ramon de Cornet, Uc del Valat, and Jordi de Sant Jordi, along with a number of Catalan poets.]

3085.

De Conca, Massimiliano. "La définition de la norme et les derniers troubadours: perspectives de recherches (travail en cours)." In 107, Ab nou cor, 2004, pp. 343-45. [Outline of projected research with Peter Ricketts in connection with COM: new editions of Cabra joglar and Fadet joglar, of the unica in MS C, and of the two manuscripts of the Académie du Gai savoir.]

\section{PC 482 Bernart de Panassac}

[ $f$. 1323-33; an allegorical vers PC 482,2, addressed to the Virgin, and a canso; Bernart was one of the seven founders of the Consistori in 1323, the only one who was aristocratic, the only one whose poetry was preserved; he was executed for

\section{6.} murder just before he was to be pardoned by the king.]

Cura Curà, Giulio. "Un commento provenzale trecentesco in versi: la Gloza di Raimon de Cornet." Parola del testo 11.1 (2007): 45-82. [Edition of Bernart de Panassac's allegorical poem to the Virgin, PC 482,2, along with Raimon's Gloza, with Italian translation, notes; Raimon's intent was to show that Bernart's poem might be applied to a real lady or to Mary, thus adhering to the rule that poems submitted to the Consistori must treat religious topics; see a similar commentary by Guiraut Riquier on a poem by Guiraut de Calanson in $\mathbf{2 5 4 3}$, Capusso, L'exposition, 1989.]

3087.

See 245, Nelli, Ecrivains anticonformistes, 1977, 2:312-17. [Introduction to the controversy over the banning of worldly poetry from the competitions of the Consistori and Bernart's ambiguous solution; text of the Vers PC 482,2, as preserved in Raimon de Cornet's Gloza, with references to Raimon's tongue-in-cheek proof that the poem was religious.]

3088.

See 249, Bec, Florilège en mineur, pp. 379-83. [Allegorical Vers, PC 482,2, addressed to the Virgin; brief introduction, text from Noulet-Chabaneau, 1888, with French translation.]

\section{PC 543 Peire de Ladils (de Bazas)}

[fl. 1325-55; nine poems, including a partimen with Raimon de Cornet; he was associated with the Consistori in Toulouse.]

3089.

Romieu, Maurice. "L'oeuvre poétique de Pèir de Ladils." Cahiers du Bazadais 138-39 (2002): 5-71. [Introduction on the poet and his background; edition of ten poems, with French translation.]

3090.

Pépin, Guilhem. "Le sirventes El dugat: une chanson méconnue de Pey de Ladils sur 
l'Aquitaine anglo-gasconne." Cahiers du Bazadais 152 (2006): 5-27. [Pépin claims that this anonymous poem, traditionally attributed to Raimon de Cornet, is by his contemporary Peire de Ladils; a study of the political background of struggle between the kings of England and France, and the evolving loyalties of the poet and the Gascons between the two sides; the poem is loyal to the English king, but critical, allowing for a possible transfer of allegiance; the tone of the poem seems more appropriate to Peire than to Raimon de Cornet; edition, with French translation by Pierre Bec.]

\section{PC 558. Raimon de Cornet}

[fl. 1324-40; forty-two poems; also wrote Vec te libret, giving moral and religious advice, Lo mieus cars filhs, giving advice to keep believers away from evil, Als trobayres, giving grammatical advice to a troubadour, and the Doctrinal de trobar, 556 lines, written in 1324.]

3091.

Noulet, Jean-Baptiste, and Camille Chabaneau. Deux manuscrits provençaux du XIVe siècle contenant des pièces de Raimon de Cornet, de Peire Ladils et d'autres poètes de l'École toulousaine. Montpellier: Société pour l'étude des langues romanes, 1888. Reprint, Geneva: Slatkine, 1973. [Pp.1-73 and 129-40: edition of Raimon's works, including three prize-winning poems and his Doctrinal de trobar; a new edition is projected by Massimiliano De Conca, 3085, "La définition," 2004.]

3092.

Cura Curà, Giulio. "Il Doctrinal de trobar di Raimon de Cornet e il Glosari di Johan de Castellnou." Parola del testo 9 (2005): 125-49. [Introductory analysis of the Doctrinal in relation to other contemporary grammatical treatises; edition of Raimon's text and the intercalated Glosari, which is intended to clarify and "correct" Raimon's Doctrinal; lines 428-526 constitute an incomplete sirventes in praise of poetry, warning against false poets; Cura Curà has prepared a critical edition of Raimon's lyrics as a doctoral thesis at the Università degli studi di Pavia, 1999.]

\section{3.}

Flynn, St. John E. "The Saint of the Womanly Body: Raimon de Cornet's Fourteenth-Century Male Poetics." In Sex and Gender in Medieval and Renaissance Texts: The Latin Tradition. Edited by Barbara K. Gold et al. Albany: SUNY Press, 1997, pp. 91-109. [Analysis and edition of the two Latin religious poems by Raimon, both of which may have been composed to glorify Saint Bernard on the two hundredth anniversary of his death; Latin texts, with English translation, notes.]

3094.

Huchet, J.-Ch. "Le style: symptôme de l'histoire (l'exemple du troubadour Raimon de Cornet)." In Styles et valeurs: pour une histoire de l'art littéraire au moyen âge. Edited by D. Poirion. Paris: SEDES, 1990, pp. 101-20. Also in: Histoire et littérature au moyen âge. Actes du Colloque du Centre d'Études médiévales de l'Université de Picardie (Amiens 20-24 mars 1985). Göppingen: Kümmerle, 1991, pp. 173-86. [Draws a parallel between the ambiguous, contradictory style of Raimon's poetry and the underlying subconscious scars stemming from his earlier traumatic experiences as a 
Franciscan and a Spiritualist, claiming to detect in the style a key to the inner person in conflict with his society; Huchet believes that poetry offered Raimon the means of exorcizing his transgressive trauma through highly colored sensual metaphors, rich vocabulary, and tormented intricacies of rhyme, sounds, and verbal play.]

\section{5.}

Olivella Madrid, Pilar. "A propos de l'oeuvre de Raimon de Cornet copiée en Catalogne." In Actes du colloque Jeunes chercheurs en domaine occitan, in Bulletins de l'AIEO 14 (1998): 51-63. [An outline of planned research in Barcelona, which will involve a critical edition of the eighteen poems by Raimon in MS $S g$ and in MS $A$ of the Jeux Floraux in Toulouse; see also "Raimon de Cornet: una mostra de poesia tolosana a Catalunya," in \$ 98, AIEO 5, 1998, pp. 167-77, which gives a detailed compilation of poems preserved in several Catalan and Occitan manuscripts.]

\section{6.}

Olivella Madrid, Pilar. "A propòsit de l'obscuritat en la poesia amorosa trobadoresca del segle XIV." In Convivio. Estudios sobre la poesía de cancionero. Edited by Vicente Beltrán Pepió and Juan Salvador Paredes Núñez. Granada: Universidad de Granada, 2006, pp. 585-610. [Obscurity in Raimon's poetry, and in fourteenth-century poetry in general, comes from the ambiguous use of language: the beloved is described in sensual terms, but also in terms applied to the Virgin Mary; the joy that the poet is seeking is a mixture of spiritual and highly sensual qualities; the senhal Rosa is applied variously to a real woman, a spiritualized figure, or to the Virgin; the poetry was purposely ambiguous, allowing for one or the other interpretation, depending on the listener; in appendix, the full text of Raimon's Gloza or explication of Bernard de Panassac's poem.]

3097.

See 3090, Pépin, "Le sirventes El dugat," 2006. [Claims convincingly that the anonymous poem, traditionally attributed to Raimon de Cornet, is by his contemporary Peire de Ladils.]

3098.

See 439, Malm, Dolssor Conina, 2001, pp.133-36. [Analysis of Raimon's trufa ("pleasantry"), PC 558,8, A Sant Marcel d'Albegés.]

3099.

Schulze-Busacker, Elisabeth. "Une réécriture chrétienne des Disticha Catonis: Lo libret de bos ensenhamens de Raimon de Cornet." In 146, Literatur Mölk, 1997, pp. 61-80. [Analysis of Raimon's work as a complete reworking of the Disticha Catonis; it is similar in content to his Gardacors de mal but adds many references to lay didactic texts, which augment the biblical and religious precepts of Gardacors; a lengthy catalogue of sources of the teachings found in the Libret shows that the main sources were the Disticha and related texts and that the author was anxious to provide moral and spiritual guidance to lay members of society in their own language.] 



\section{Index}

Names of modern scholars are in regular type; names of troubadours and trovairitz in are SMALL CAPS; titles of literary works, themes, and concepts are in italics; numbers refer to individual critical listings, not to page numbers; numbers in bold indicate the major listings for the given entry.

Ab lo cor trist. . . , 3056-60

Ab lo gensor que sia..., 3061

Abrils issi' e mays intrava, 1134, 1135, 1306, 1464-72, 2934

Abu-Haidar, Jareer A., 332, 1790

Acciai, Giovanni, 597

Adam, Cécile, 587

Ademar de Rocaficha, 1828-29

Ademar Jordan, 255, 1820-21, 2141

Ademar lo Negre, 880, 1822-27

Agamben, Giorgio, 1848, 1982

Agrigoroaie, Vladimir, 2872

Aicart del Fossat, 1830-31

Aigar e Maurin, 61, 1023-27

Aimeric de Belenoi, 1505, 1832-37, 1872

Aimeric de Peguilhan, 40, 186, 547 , 553, 554, 636, 802, 809, 850, $874,1427,1485,1737,1751$, 1838-52, 1878, 1996, 2261, 2447, 2451, 2921, 2987, 2992, 3014, 3033

Aimeric de Sarlat, 1853-54

Akehurst, F. R. P., 37, 57, 281, 287, 361, 412, 413, 1602, 1603

Alaisina Yselda, 740, 756, 757, 778, 797, 1855-59, 1856, 2204

Alamanda, 490, 724, 749, 758, 760, 763, 766, 790, 1860-65, 2036

Alba, bilingual, 320, 914, 934-38, 947-57

Alberjat (Albert), 1866-68
Alberni, Anna, 200

Albert Marques (Alberto, Marquis of Malaspina), 1869-71, 2681

Albert-Birot, Arlette, 2229

Albertet de Sisteron, 635, 1832, 1847, 1848, 1872-84, 2022, 2023, 2298, 2793, 2794, 2876

Albric (Alberico da Romano), 4, 764, 1152, 1357, 1521, 1885-87, 2155, 3022

Albucasis, 1622-26

AldRIC (DEL VILAR), 876, 1888-92, 2666

Alegret, 261, 269, 850, 909, 189398, 1996, 2671

Alest, lo Senher d' (Peire Pelet, Senher d'Alest), 1899, 2141, 2266, 2680

Alexandre, 938, 997-1000, 1021

Alfaric, Prosper, 976

Alibert, Laurent, 1265, 2444

Alibert, Louis, 2444

Allegorical Lyric by Guiraut De Calanso, 1381, 1384, 1385, 1388, 1391, 1405-9, 2522, 2543

Allegories, 1127, 1381-1409, 1439

Allegretti, Paola, 568, 2072, 2688, 3068

Allegretto, Manuela, 831, 2570

Almqvist, Kurt, 2416

Almuc de Castelnou (Almois), 740, 764, 1900-1903, 2013, 2564-66 
Alonso, Miquel, 50

Alvar, Carlos, 1105, 1673, 1698, 1753, 2709

Álvares, Cristina, 1570, 1571, 1572

Amanieu de la Broqueira, 261, 1904-6, 2470

Amanieu de Sescas, 251, 1441, 1454-57, 1491, 1656, 1907-9

Amtower, Laurel, 718

Anastrof, 72, 1761

Anatole, Christian, 1646, 2047

Anderson, Patricia, 756, 1857, 2203

Andolfato, Francesca, 2319

Andrian del Palais. See Palais

Andrieu de Fransa, 1138-41

Anfos (King Alfonso II of Aragon), 251, 1910-13

Annicchiarico, Annamaria, 1122, $1167,1193,1243,1661$

Anonymous, 3038-55

Antonelli, Roberto, 844, 1717

Appel, Carl, 2066, 2093, 2475

Ara lausatz, lauset . . , 3062

Arabic: origins, 332-42, 633; influence, 1620, 1622, 1624, 1625,

1790-1807, 1819; in Guilhem de Peitieus, 2360, 2379

Archer, Robert, 471, 2738

Arlt, Wulf, 1011

Arnaut Catalan, 656, 1918-21, 2326, 2327, 2384

Arnaut Daniel, 35, 40, 52, 218, 220 , 221, 318, 355, 392, 393, 394, $400,431,433,436,437,531-37$, $572,573,628,629,663,687$, 689, 741, 769, 798, 801, 810, $811,820,832,856,857,862$, $871,902,903,1732,1736,1745$, 1925-92, 2078, 2356

Arnaut de Brancalo, 255, 1914-17 Arnaut de Comminges, 1922-24

Arnaut De Maruelh, 519, 530, 640, $833,1463,1826,1852,1945$,
1993-2000, 2205, 2896, 2898

Arnaut de Tintinhac, 2004-8, 2292, 2729, 2935

Arnaut Peire d'Agange, 2001-3

Arthur, Ingrid, 1574, 1575

Arthur, Ross G., 1260, 1266

Arveiller, Raymond, 2281

Ashley, Kathleen, 987

Aslanov, Cyril, 1146

Asperti, Stefano, 1, 49, 179, 201, 213, 263, 274, 308, 309, 316, 760, $1213,1662,1663,1676,1730$, 1940, 2049, 2101, 2102, 2113, 2160, 2340, 2469, 2868, 2914, 2961, 3057

Aston, Stanley C., 2157, 2816

At de Mons. See N'At de Mons

Atturo, Valentina, 384

Aubrey, Elizabeth, 168, 549, 593, 594, 600-602, 611, 615, 621, 630, $631,632,674,821,1674,3069$

Audiau, Jean, 2261, 2406, 2750

Aurell, Martin (Aurell i Cardona, Martí), 309, 333, 463, 1050, 2103, 2104, 2105, 2190, 2389, 2396

Auzels cassadors, 1597-1601

Avalle, d'Arco Silvio, 178, 967, 1004, 2808

Avenoza, Gemma, 565, 2711

Azalais d'Altier, 527, 731, 745, 752, 764, 2009-15, 2152, 2230, 2231

Azalais de Porcairagues, 452, 697, 712, 717, 737, 740, 743, 776, 791, 2016-21

AZAR, 2022-23, 2298

Babin, Malte-Ludolf, 414, 1081, 2132

Badia, Alfred, 732

Badia, Lola, 1610, 2597

Baladier, Charles, 362

Baldinger, Kurt, 21, 26

Bambeck, Manfred, 2487 
$B A M B I, 215$

Bánki, Éva, 1699

Banniard, Michel, 343, 2341

Barattelli, Bianca, 2488

Barberis, Valerio, 845

Barbiellini Amidei, Beatrice, 1941, 1942, 1965, 2342, 2761, 2762

Barbieri, Luca, 180, 1852, 1898, 1994 , 1996

Barca, Daniele, 1312, 2721

Bardell, Maria Grazia, 1396

Bardell, Matthew, 1393, 2809

Bardin, Gay, 873

Barlaam et Josaphat, 1559-61

Barolini, Teodolinda, 1731

Bartoli, Renata Anna, 1042, 1267

Bastard, Antoine de, 1830, 2955, 2956

Battelli, Maria Carla, 912

Bauer, Franck, 253, 496, 497, 2842

Baumgartner, Emmanuèle, 228, 1121 , 1268

Baussan, 2024

Bazas, Lo Vesques de, 255, 2156

Beatritz de Die. See Comtessa de Dia

Bec, Pierre, 229, 242, 244, 248, 249, 323, 435, 439, 444, 457, 485, 510, 531, 555, 585,717, 719, 731, 748, 759-62, 771, 778, 842, 990, 1309, 1537, 1589, 1638, 1770, 1827, 1858, 1868, 1870, 1896, 1906, 1916, 1983, 1995, 2011, 2018, 2046, 2057, 2073-75, 2161, 2189, 2191, 2218, 2239, 2240, 2295, 2296, 2334, 2419, 2457, 2482, 2571, 2594, 2621, 2675, 2716, 2718, 2752, 2758, 2778, 2796, 2806, 2838, 2887, 2906, 2908, 2928, 2935, 3019, 3058, 3065, 3070, 3088, 3090

Beck, Alfons, 1005

BEdT (Bibliografia elettronica dei trovatori, Stefano Asperti), 1, 49, 60, 81,200
Beech, George, 268, 2343, 2344

Beggiato, Fabrizio, 1876, 2056, 2096, 2873

Bekker, Immanuel, 1078

Beldon, Valeria, 616

Bellamy, James A., 1791

Belletti, Gian Carlo, 1106

Bellotti, Michele, 1733

Belmon, Jérôme, 958

Beltrami, Pietro G., 54, 81, 1732, 1966, 2114-17, 2215, 2467, 2483, 2505, 2506, 2507, 2987

Beltrán Pepió, Vicenç, 1675, 1698, 2106, 2178, 2869, 2907, 2962

Benozzo, Francesco, 214, 350, 351, 385, 796, 2345

Berenguier de Palazol, 316, 663, 2032-35

Beretta Spampinato, Margherita. See Spampinato

Bergin, Thomas, 171

Bergner, Heinz, 1649

Bermejo, José María, 322

Bermon Rascas, 2192-93, 2625

Bernard, Katy, 498, 1214, 1607

Bernardi, Marco, 344

Bernart Arnaut d'Armagnac, 783, 858, 2036-38, 2616

Bernart Arnaut de Moncuc, 2039-42

Bernart D'Auriac, 2043-46, 2912

Bernart de Durfort, 2051-55

Bernart de la BARTA, 1923, 2047-50

Bernart de Panassac, 3086-88

Bernart de Tolmon (Tot-lo-Mon), 2066-68

Bernart de Ventadorn, 40, 221, 264, 273, 317, 364, 376, 384, 398, 410, 433, 450, 460, 480, 598, 628, 651, 654, 657, 662, 663, 664, 667, 669, 685, 688, 692, 741, 773, 797, 798, 805, $812,813,817,833,835,857$, 
$879,1602,1667,1754,1952$,

2005, 2069-94, 2204, 2218, 2305, 2347, 2356, 2583, 2663, 2688, 2727, 2729, 2785, 2803, 2818, 3068

Bernart de Venzac, 2095-97

Bernart Marti, 344, 803, 850, 877, 902, 909, 1894, 2056-61, 2096, 2193, 2625, 2930

Bernart Sicart de Marvejols, 260, 1068, 2062-65, 2958

Bernhardt, Wilhelm, 1474, 2706

Bernsen, Michael, 1147

Berschin, Helmut, 960

Berschin, Walter, 960

Berthe, Maurice, 1100

Berthelot, Anne, 1269

Bertolome Zorzi, 531, 570, 1887, 1972, 2098-99

Bertolucci Pizzorusso, Valeria, 202, 491, 1013, 1676, 1700, 1734, $1735,2532,2533,2535-37$

Bertoni, Giulio, 1023, 1503, 1885

Bertran Carbonel, 213, 260, 2131-36, 2340

Bertran d'Alamano, 309, 2100 2109, 2169, 2390, 2391, 2405, 2746

Bertran de Born, 34, 40, 73, 202, 308, 317, 399, 462, 465, 547, 589, 850, 880, 883, 1013, 1160, 1302, 1740, 1750, 1823, 2102, 2110-30, 2483, 2484, 2516, 2812, 2991, 3029, 3052

Bertran de Paris de Roergue, 1440, 1442-46, 2140-42

Bertran de Preissac, 2051-55, 2148 Bertran del Pojet, 2143-47, 2425, 2754, 2755, 3050

Bertran Folcon d'Avignon, 270, 2137-39, 2400, 2471, 2929

Betti, Maria Pia, 33, 2267, 2530, 2787 Bianchi, André, 169, 237
Bianchi, Federica, 2268

Bianchi de Vecchi, Paola, 1501, 1522

Bianchini, Simonetta, 297, 386, 1478, 2346, 2948, 3009

Bible, 911, 1172, 1540-52

Bibring, Tovi, 1244

Bietris de Roman, 712, 740, 745, 755, 764, 786, 789, 1885, 1886, 2014, 2149-55, 3059

Billet, Léon, 2263, 2407

Billy, Dominique, 29, 58, 256, 486, 499-501, 503, 532, 533, 550, 846-48, 922, 1705, 1997, 2215, 2295, 2447, 2538, 2963, 2964, 3067, 3070, 3072, 3083, 3084

Bischoff, Bernhard, 940, 961, 991

Biu, Hélène, 1604, 1631

Björkman, Sven, 2265

Blacasset, 1818, 2159-67, 2462, 2464, 3017, 3049

BlaCATZ, 482, 2107, 2168-70, 2483, 2746, 2807, 2989, 3015, 3017

Blakeslee, Merritt R., 46, 387, 458, 767, 2387, 2414, 2557, 2562, 2677

Blandin de Cornualha, 823, 917, 1122, 1126, 1163-73, 1247, 1661

Blasco, Eduardo, 913, 919, 2179

Blasi, Ferruccio, 1918

Bloch, R. Howard, 63, 348, 363, 704, 2076, 2347, 2572

Blodgett, E. D., 1205

Blum, Jean, 1771

Boase, Roger, 324, 334, 338, 1677 . 1791

Boeci, 850, 971-75, 1102

BofILs, 2171-74

Bogin, Meg, 732

Bohigas, Pere, 1192

Bohnet, Arthur, 556,

Boldini, Loredana, 2236, 2820, 2821

Bolduc, Michelle, 283, 1411-14, 2683

Bologna, Corrado, 344, 874, 2348 
Bonafin, Massimo, 580, 1330, 2723

Bonaugurio, Rossella, 2476

Bond, Gerald A., 325, 345, 607, 2335, 2349, 3039, 3062

Boni, Marco, 2984

Bonifaci Calvo, 188, 382, 540, 550, 913, 915, 918, 919, 1711, 2175-87, 2608, 2894, 2982

Bonifaci de Castellana (Boniface VI), 2188-91

Bonnarel, Bernard, 250, 479

Bonnet, Marie-Rose, 720, 1564

Bonse, Billee A., 646

Bordes, Richard, 1772

Borghi Cedrini, Luciana, 172, 181, 200, 217, 262, 569, 1500, 1773, 1825, 2790-92

Bornstein, Diane, 1379

Borriero, Giovanni, 388, 2926

Bortolami, Sante, 2988

Bossy, Michel-André, 903, 1839, 2539-42, 2843

Botana, Federico, 1415, 1630

Bottani, Giorgia, 352, 904

Bottin-Fourchotte, Colette, 1051

Bousquet, Jacques, 1264, 1416

Boutière, Jean, 1142, 1872, 2022, 2748

Boynton, Susan, 633, 634, 675, 696, 2297

Bozzi, Andrea, 215

Braccini, Giulio, 957

Braccini, Mauro, 2946

Brackney, Emmert M., 2235

Braet, Herman, 46, 389, 2019, 2030, 2150, 2207

Bräm, Toni, 1561

Branciforti, Francesco, 2175, 2185, 2607

Brea (Brea López), Mercedes, 390, 391, 1209, 1215, 1216, 1302, 1697. 2888

Brendan, 1040-43
Brenon, Anne, 1774-76

Breviari d'Amor, 929, 1410-34, 1508, 2172, 2667

Brodovitch, Elizabeth, 814, 924

Brossmer, Alfred, 1023

Bruckner, Matilda Tomaryn, 46, 713, 717, 733, 735, 749, 757, 768, 779, 797, 1859, 1861, 2012, 2025, 2146, 2202, 2204, 2209, 2231, 2328, 2385, 2558, 2616, 2623

Brugnolo, Furio, 1701, 1718, 1719, 2889, 2896, 2898

Brunel, Clovis, 182, 1568

Brunel-Lobrichon, Geneviève, 1, 10, 182, 313, 326, 697, 709, 1012, 1014, 1217, 1264, 1513, 1533, $1556,1560,1565,1653,1678$, 2069, 2077, 2133, 2226, 2243 , 3072

Brunetti, Giuseppina, 200, 2763

Brüning, Berit Irina, 1349

Brusegan, Rosanna, 2844

Brusoni, Andrea, 2397, 2398

Burger, Michel, 978, 981

Burgwinkle, William E., 318, 841, 1089, 1148, 1149, 1460, 1736, 1943, 2350, 3023

Buridant, Claude, 1079

Burland, Margaret Jewett, 1114

Burle, Elodie, 798, 1944, 2078

Burns, E. Jane, 364

Burrell, Margaret, 1040, 1043

Busby, Keith, 212, 216, 1013, 1168, 1275, 1578

Butterfield, Ardis, 657

Cabra joglar, 1442-46, 3085

Cabré, Miriam, 6, 44, 203, 392, 1479, 1480, 1664-66, 1737, 2965-71

CABrit, 2194-95, 2401, 2953

Cadart-Ricard, Odette, 2972

Cadenet, 346, 497, 504, 514, 518, 
624, 681, 731, 1319, 1921,

2196-2200, 2395, 2521, 2595,

2788, 2792

Caïti-Russo, Gilda, 1738, 2295, 2897, 2899

Calega Panzan, 188, 260, 2201

Caliaro, Ilvano, 1461, 2986

Calin, William, 365, 799, 1270, 1282, 1639, 1640

Callahan, Anne, 714

Callewaert, Augustijn, 415, 2408

Caluwé, Jean-Michel, 1123, 1150 , $1218,1303,1313,1468$

Calvet, Antoine, 1608

Calzolari, Monica, 1469, 2144, 2424, 2425, 2755

Cambell, P. Jacques, OFM, 1583

Camproux, Charles, 366, 902, 2262, 3010

Camps, Jean-Baptiste, 197

Canettieri, Paolo, 393, 445, 446, 533, 534, 551, 800, 801, 849, 875, 1504, 1945, 1967-69, 1984, 2776, 2890

Canova Mariani, Giordana, 204

Canso d'Antiocha, 1022, 1027, 1028-35

Canso de la Crozada, 182, 245, 262, 302, 929, 1020, 1022, 1044-69, 1485, 1785, 2399, 2402, 2404

Cantarino, Vicente, 1792

Cantavella, Rosanna, 2973

Capaccioni, Francesco, 1593, 1598

Capusso, Maria Grazia, 1383, 1400, $1407,1408,2351,2543,2605$, 2608, 2611, 3086

Carapezza, Francesco, 200, 521, 658, 676, 677, 2118, 2289-91, 2295, 2624, 2625, 2724, 2845, 2858, 2947

Carenza, 653, 700, 740, 756, 757, 778, 797, 1855, 1857, 1859, 2202-5
Careri, Maria, 200, 207, 275, 2445

Carros (Raimbaut de Vaqueiras), 1883, 2874

Carstens, Henry, 1

Casas Homs, Josep M., 1360, 1370

Castano, Rossana, 502, 809

Castelloza, 697, 701, 709, 712, 734, 742, 746, 768, 773, 776, 779, 780, 784, 787, 793, 795, 82, 853, 2206-14, 2517, 3047

Castia-gilos, 929, 1127, 1134-36, 1174-82, 2934

Cathar Heresy, 45, 245, 262, 289, 294 , 619, 721, 1475-77, 1769-89, 2205

Caudairenga, 78, 279, 280, 754, 2309-14, 3015, 3017

Cavaliere, Alfredo, 1, 1970, 2798

Cazal, Yvonne, 914

Centili, Sara, 622, 1523

Cepraga, Dan Octavian, 492

Cercamon, 264, 266, 267, 293, 303, $310,544,850,871,877,879$, 909, 2003, 2058, 2215-24, 2249, 2250, 2355, 2568

Cerdà Subirachs, Jordi, 2352

Ceron, Sandra, 581

Cerullo, Speranza, 520, 522

Cerveri de Girona, 36, 44, 251, 388, 392, 394, 443, 564, 576, 731, 913, 918, 919, 921, 1273, 1479, 1480, 1542, 1656, 1681, 1737, 1751, 1813, 1846, 2179, 2186, 2210, 2517, 2705, 2792, 2868, 2894, 2959-83, 3033

Chabaneau, Camille, 2619, 3091

Chaguinian Christophe, 499, 502, 503

Chahal Timery, Joumana, 335

Chaillou, Christelle, 623, 624, 659, 660, 678, 1998, 2197, 2295, 2417, 2800, 2829

Chambers, Frank, 1, 56, 57, 447, 647, $758,850,851,872,876,973$, 
1838, 1852, 1862, 1871, 1888, 2042, 2048, 2140, 2927

Chambon, Jean-Pierre, 25, 26, 221, $941,1219,1252,1525,1541$, 1575, 1608, 2158, 2938

Chambrun, Gilbert de, 2062

Charvet, Gratien, 2229

Chastel d'Amors, 1381, 1386, 1388, 1389-91

Chaytor, Henry John, 2819

Cherchi, Paolo, 367, 504, 1417, 1739

Cheyette, Fredric L., 298, 369, 661, 698, 699, 2026, 2626

Chiarini, Giorgio, 947, 2569

Chichmarev, Vladimir Federovich, 1490

Cholakian, Rouben, 832, 1576, 1971, 2353, 2544, 2573, 2627, 2628

Cierbide Martinena, Ricardo, 1100, 1584

Cigni, Fabrizio, 1473, 2707, 2708

Cingolani, Stefano Maria, 1169, 1443, 1507, 2058

Ciprés Palacín, María Ángeles, 416

Cirlot, Victoria, 877

Clara d'Anduza, 737, 764, 776, 2010, 2012, 2013, 2015, 2225-31

Clarmon, Robert Lo Vesques de, 2157-58

Cluzel, Irénée-Marie, 1142, 1911, 2226, 2383, 2700

Cocco, Marcello M., 417

Coderch, Marion, 1667, 2079

Codi, 1435-36, 1592

Cohen, Joel, 631, 635

Colby-Hall, Alice M., 1014, 1015, 1514

Collins, Fletcher, Jr., 612

Colón, Germán, 1580

Colrat de Montrozier, Bruno, 1902, 2142, 2565

Coluccia, Rosario, 1717

COM, COM1, COM2, COM3,
COM4, 1, 29-32, 47, 52, 60, 81, 222, 930, 932, 1079, 1948

Comas, Andreu, 2979

Combarieu du Grès, Micheline, 1085, 1086

Combes, Laure, 1627

Compagna, Anna Maria Perrone Capano, 1191, 1194

Comtessa de Dia, 40, 76, 598, 653, 661, 666, 697, 698, 700, 701, 712, 734, 740, 742, 743, 746, $768,774,775,785,852,853$, 858, 1756, 2025-31, 2859

Comunal (pseudonym). See Garin D'APCHIER and TORCAFOL

Comunals Cycle, 589

Concheff, Beatrice Jorgensen, 1660

Corcoran, Mary Cynthia, 878, 2508, 2509, 2846

Cornagliotti, Anna, 1101, 1307, 1340, 1628

Cornilh affair, 244-46, 435, 437, 440, 1128, 1942, 1982-92

Coromines, Joan, 1479, 2959, 2978

Corradini (Bozzi), Maria Sofia, 34, 215, 1594, 1617, 1618

Corral, Esther, 1702

Corriente, Federico, 336, 1793, 2360

Cort d'Amor, 1381, 1385, 1386, 1388, 1392-95

Cossezen, 2232-34, 2731

Cots Vicente, Montserrat, 2435, 2436

Crémieux, Geneviève, 2764

Cremonesi, Carla, 2874

Crespo, Roberto, 1612

Cropp, Glynnis M., 368, 418-20, 487, 974, 2275, 2855, 3010

Cucinotta, Cosimo, 1740

Cullin, Olivier, 624, 2197, 2417

Cummins, Patricia W., 574

Cunha, Viviane, 2725

Cura Curà, Giulio, 421, 1383, 1828, 3020, 3086, 3092 
Cycle of five sirventes from the 1285

France/Aragon conflict, 469, 2043

Cycle of poems centered on Marcabru:

D'aisso lau Dieu / Tot a estru / Sei-

gner n'Andric, 876, 1888-92, 2666

Cyrus, Cynthia J., 552

$D A G, 26$

Dagenais, John, 1376

D’Agostino, Alfonso, 1498, 1679, 1972, 1973, 1985

Dalfin D'Alvernhe, 850, 2021, 2024, 2157, 2158, 2206, 2235-37, 2238, 2817, 2821, 2822, 2942, 2944

DAlfinet, 2238, 2952

Dante da Maiono, 2239-41, 2718, 2719

$D A O, 26$

Daude de Pradas, 1494-96, 1597-

1601, 2242-47, 3011

Daurel e Beton, 1016, 1018, 1070-77, 1129, 1130, 1796

Dauzier, Martine, 73, 2119

Davies, Peter V., 1524, 1641

Davis, Judith M., 41, 281

De Caluwé, Jacques, 1072, 1170, 1515,1642

de Cauna, Jacques, 1447

De Conca, Massimiliano, 52, 505, 811, 1444, 1934, 1946, 1947, 1948, 3085, 3091

De Lollis, Cesare, 2143

Derrer, Félix, 1435

Dewberry, Carol Elizabeth, 1031

D'Heur, Jean-Marie, 587, 1052, 1082

Di Febo, Martina, 1581

Di Girolamo, Costanzo, 48, 230, 231, 319, 523, 528, 1717, 1949, 1974, 2510, 2847, 2848

Di Luca, Paolo, 464, 649, 1138, 2282, 2742, 2745

Dickey, Constance L., 1220
Diekmann-Sammet, Doris, 21

Dieus vos sal, dona . . ., 3063-65

Dijkstra, Cathrynke, 588

Dillange, Michel, 74

Diogo, Américo António Lindeza, 1703

Distilo, Rocco, 1, 4, 28, 3082

DOM, 25, 60, 183

Domna H., 731, 735, 758, 2556-59

Donatz proensals, 1349, 1352, 135558, 3027

Doucelina (Vida de la benaurada sancta), 45, 245, 1562-67

Dragonetti, Roger, 1221, 1237

Dronke, Peter, 700, 780, 1006, 2214 , 2566, 3003

Duby, Georges, 349, 369, 430, 765, 2635

Ducos, Joëlle, 1418

Duggan, Joseph J., 426, 2354

Duhamel-Amado, Claudie, 313

Dujardin, Lucien, 538

Dumitrescu, Maria, 2248

Dupuy, André, 288, 1643

Duvernoy, Jean, 1777

Earnshaw, Doris, 701, 737

Eaten heart, 1912, 2107, 2169, 2435-38, 2441, 2746, 2989

Eble de Ventadorn, 75, 227, 267, $279,859,2215,2216,2222$, 2223, 2224, 2248-50

Eckhardt, Caroline D., 1271, 1272

Economou, George D., 2629

Edwards, J. Michele, 702

Egan, Margarita, 1144

Einbinder, Susan L., 1185, 1809

Elias Cairel, 772, 891, 1759, 2255-58, 2560, 2561, 2880

Elias de Barjols, 2251-54, 2292

Elias D'Ussel, 2261-64

Elias Fonsalada, 636, 2259-60, 3014 
Eliot, Robert, 1684

Elizalde, Ignacio, 394

Elsheikh, Mahmoud Salem, 1622, 1624

Elucidari, 1609-16

Ely, Bernard, 1262

Emmi, Silvia, 1720

Enimia, 1555, 1568-73

Enric II Comte de Rodez, 1899, 2141, 2266, 2680

Ensenhamen alla dama (El termini d'estiu... ), 1451-53, 2289

Ensenhamen au cavayer (Qui comte vol apendre... ), 1306, 1447-50

Ensenhamen au jongleur (Si tot non es enquistz... ), 1473-74, 2706

Ensenhamen de la donzela (En aquel mes de mai . . . ), 1441, 1454-57, 1907

Ensenhamen del escudier (El temps de nadalor... ), 1441, 1454-56

Ensenhamen del guarso (L'Autrier mentre ques ieu m'estava . . . ), 1458

Ensenhamen d'onor (Aissi co.l tesaurs es perdutz... ), 1459-62, 2984-87, 2991, 2996, 2998, 2999

Ensenhamens (general), 929, 1437-41

Espadaler, Anton M., 1133, 1273, 1274

Esperdut. See Gui de Cavaillon

Esposalizi de Nostra Dona, 1336-38, 1512

Espòsito, Anthony P., 979

Esther, 1183-89, 1809

Eusebi, Mario, 1463, 1929, 1973, 1999, 2336, 2630

Evans, Dafydd, 1599-1601, 1613

Exposition (interpretation by Guiraut Riquier of allegorical poem by Guiraut de Calanson), 1407, 1408, 2543. Cf. Gloza

Fabre, Césaire, 2754
Fabre, Claude, 1623

Fabre, Daniel, 395

Fabre, Paul, 39, 232

Faccioli, Emilio, 2986

Fadet joglar, 1442-46, 3085

Falquet de Romans, 522, 2281-86, 2725, 2795

Falvy, Zoltán, 679

Fasseur. See Galent-Fasseur, Valérie

Fassò, Andrea, 82, 268, 353, 422, 874, $879,980,2219,2355$

Faula, 1122, 1190-98, 2965

Fausel, Andrea, 822

Favero, Alessandra, 2162

Fedi, Beatrice, 1361-63

Fedrigucci, Samanta, 2495

Felbeck, Christine, 233

Ferabratz, 61, 1021, 1078-84

Fernandez Campo, Francisco, 2891

Fernandez de la Cuesta, Ismael, 609

Ferrand, François, 228

Ferrante, Joan, 370, 763, 769, 2356

Ferrari, Anna, 184, 200, 1704, 2392, 2810

Fèvre, Mavis, 482, 2237, 2822

Fidalgo, Elvira, 1705

Field, Thomas T., 173

Field, William Hugh, 1140, 2934

Filomena, 1199-1201

Finazzi-Agro, Ettore, 1580, 1582

Finoli, Anna Maria, 2498

Fitzpatrick (Sitarz), Beata, 2959, 2981

Flamenca, 45, 450, 831, 881, 923, 929, 1123, 1125, 1127, 1129, 1136, 1202-40, 1284, 1285, 1662, 2803

Fleischer, Ezra, 327, 1811

Fleischman, Suzanne, 929, 1203, $1230,1275,1590$

Fleming, John V., 2180

Floquet, Oreste, 622

Flynn, St. John E., 3093

Fo, Alessandro, 1975

FolqueT DE LunEL, 2267-72 
Folquet de Marselha, 266, 477, 487, 578, 597, 601, 663, 815, 857, 883, 899, 900, 1485, 1516, 1740, 1760, 1766, 2273-80, 2740, 3024

Formisano, Luciano, 915, 1083, 1685, 1721,2181

Forner, Climent, 2432, 2473, 3015

Frances (Sant), 1574-76

Franchi, Claudio, 493

Franci, Giovanna, 1242

Francis, Scott M., 1467

Frank, Barbara, 935, 942, 968, 1002

Frank, István, 1, 54, 57, 928, 3004

Frank, Margit, 1794

Fraser, Veronica, 582, 770, 852, 853, 975, 1276, 2807, 2811

Fratta, Aniello, 1655, 1722, 1950, 1951, 2599, 2722

Frayre-de-joy et Sor-de-plaser, 917, 1122, 1241-49, 1321

Fuente Cornejo, Toribio, 506

Fuksas, Anatole Pierre, 802, 1308, 1314, 1742, 2107, 2169, 2631, 2746, 2989

Fumagalli (Mezzetti), Marina, 1540, 1853, 2259

Gadea i Gambús, Ferran, 251, 1656

Galano, Sabrina, 823, 1163, 1253, 1686

Galent-Fasseur, Valérie, 1222, 1419

Galley, Claude, 1024

Gallo, Franco Alberto, 603, 1743

Gally, Michèle, 1687

Galmés de Fuentes, Álvaro, 1795, 1796

Gambino, Francesca, 252, 264, 459, 520, 524, 1481, 1585, 1996, 2357, 2574, 3040-43

Gandois, Jean-Lucien, 2696

Ganze, Alison, 2151

Garay, Kathleen, 1563, 1566

Garcia-Aranda, Carlos, 1836
Gardy, Philippe, 1644

Gareyte, Jean-François, 1030

GARIN D'APChIER, 589, 2287-88

GARIN LO BRUN, 1441, 1451-53, 2289-91

Garreau, Joseph, 2448, 2765

Garsenda de Forcalquier, 653, 742, 764, 1903, 2309, 2385-87, 2404, 2415

Gasca-Queirazza, Giuliano, 1915, 1917,2867

Gasperoni, Marianne, 1525, 1541

Gaucelm Faidit, 477, 547, 597, 600, 653, 675, 679, 692, 808, 890, 900, 918, 1824, 1825, 1826, 2023, 2292-2308, 2310, 2386, 2514, 2515, 2679, 2740, 2822

Gaudairenga. See Caudairenga

GAudi, 1866, 1868, 1874, 2315, 2455

Gaunt, Simon, 44, 175, 226, 282, 369, 396, 436, 448, 741, 759, 803, $824,825,833,901,905,1016$, 1090, 1124, 1350, 1555, 1889, 1952, 1953, 2059, 2093, 2358, $2437,2511,2575,2622,2632$ 35, 2639, 2643, 2726, 2727 , 2849, 2898

Gausbert Amiel, 261, 2316-17

Gausbert de Puycibot, 2051, 2052, 2055, 2318-22

GaVAUDAN, 2323-25

Gégou, Fabienne, 2309, 2310

Geneys lo Joglar, 2326-27

Genim d'Urre (En Genim), 2265

Gennrich, Friedrich, 614, 645, 1329, 1514

Gérard-Zai, Marie-Claire, 1319, 3070, 3071

Gerez, Pau, 2576

Ges no m'eschiu nuls . . . , 3068

Ghil, Eliza Miruna, 397, 411, 460, $854,906,1053,1063,1223$, 1224, 2399, 2449, 2766 
Giangrande, Mario, 1874

Giannetti, Andrea, 241, 2905

Giannini, Gabriele, 525, 1525, 1541, 1723-25

Gier, Albert, 1680

Giffen, Lois Anita, 337

Gillioz, C., 200

Girart de Rossilhon, 221, 917, 929, 1016, 1018, 1021, 1085-98, 1796

Giraut De Bornelh, 40, 201, 218, 264, 346, 394, 450, 496, 497, 504, 511, 514, 518, 590, 655, 681, 724, 749, 760, 763, 791, 803, 807, 857, 862, 877, 878, 901, 902, 903, 905, 910, 1011, 1069, 1141, 1468, 1516, 1849, 1861, 1864, 1865, 1878, 1911, 1913, 2021, 2118, 2126, 2210, 2305, 2502-21, 2799, 2803, 2843, 2846, 2847, 2862, 3061

Gîrbea, Catalina, 1277, 1449

Gizzi, Luca, 2728

Glixelli, Stefan, 1491

Gloza (interpretation by Raimon de Cornet of allegorical poem by Bernart de Panassac), 1383, 3086, 3087, 3096

Goddard, Richard N. B., 1482, 2359, 2636

Gómez Moreno, Ángel, 1029

Gómez Redondo, Fernando, 1261

Gonfroy, Gérard, 449, 1359

Gordo, 1442, 1446, 2140-42

GormondA, 709, 721, 725, 740, 781, 788, 794, 898, 1778, 2328-33

Gorosch, Max, 1629

Gosman, Martin, 1054, 1542, 2974

Gougaud, Henri, 1047

Gouiran, Gérard, 83, 242, 253, 294, $465,507,508,513,1055,1056$, 1086, 1104, 1113, 1115, 1202, $1225,1232,1251,1270,1278$, 1315, 1447, 1477, 1573, 1589,
1591, 1706, 1822, 1841, 1954, 2045, 2051-55, 2110, 2120, 2121, 2281, 2283, 2483, 2484, 2543, 2590, 2875, 2912, 2990-92

Gourc, Jacques, 299, 450, 451, 880, 1822, 1823, 1826, 2803, 3044

Gout, Raoul, 1562

Graham, John M., 66, 217

Granet, 2109, 2388-91

Grange, Huw, 662, 1554, 2080, 2438

Gravdal, Kathryn, 742, 759

Graves, Rolande J., 1216, 1226

Green, Edward, 680, 2637

Greene, Virginie, 185

Gresti, Paolo, 570, 1831, 2099, 2743, 2744, 2826, 2868, 3011

Grifoll, Isabel, 1657

Grigsby, John, 583

Grilli, Attilio, 923

Grimaldi, Marco, 1384, 2975

Grimaud, Jean, 1623, 1624

Grimbert, Joan Tasker, 719, 759, 771

Grimoart Gausmar, 2392-93, 2574

Gross, Charlotte, 398, 812

Grossweiner, Karen, 1212, 1227

Gruber, Jörn, 240, 803, 826, 855, 871, 1986, 2577

Grutman, Rainier, 916, 1707

Gschwind, Ulrich, 1202, 1203, 1205 , 1208-11

Gsell, Otto, 571

Guadagnini, Elisa, 1909

Gubbini, Gaia, 399, 400, 2081, 2082, 2578

Gui de Cavaillon, 302, 482, 1057, 1063, 2137, 2385, 2394-2405, 2747, 2953

Gui D'Ussel, 227, 366, 475, 477, 890, 900, 2263, 2264, 2280, 2406-12, 2677, 2679, 2740, 2789

Guida, Saverio, 129, 186, 254, 255, 269, 270, 423, 424, 636, 760, $1057,1146,1151,1152,1356$, 
$1450,1820,1829,1840,1863$, 1877, 1899, 1905, 1907, 1917, 1923, 1924, 2005, 2013, 2023, 2034, 2060, 2068, 2097, 2108, 2137, 2138, 2156, 2192, 2193, 2194, 2232, 2238, 2266, 2298, 2323, 2400-2402, 2421, 2426, 2465, 2466, 2470, 2471, 2680, 2697, 2713, 2715, 2729, 2730, 2731, 2737, 2739, 2747, 2756, 2793, 2831, 2876, 2899, 2907 , 2921, 2933, 2940, 2952, 2953, 2993, 2994, 3005, 3014, 3016, 3024, 3025, 3037, 3075

Guigo de Cabanas. See Gui de Cavaillon

Guilhelma de Rosiers, 764, 241315

Guilhem Ademar, 1936, 2416-20

Guilhem Augier Novella, 554, 2144, 2424-27, 2754, 2755

Guilhem d'Autpol, 2428-29

Guilhem de Cabestanh, 36, 79, 251 , 322, 388, 776, 1656, 2062, 2064, 2435-43

Guilhem de la Barra, 917, 1129, 1250-58

Guilhem de Montanhagol, 42, 260, 262, 802, 1068, 1069, 1288, $1818,2163,2165,2167,2460-64$ Guilhem De Mur, 36, 2266, 2465-67 Guilhem de Peitieus, 40, 75, 176, 213, 264, 267, 268, 293, 303, $317,321,327,328,341,343$, $345,348,352,353,355,363$, 400, 436, 439, 451, 582, 590, 741, 744, 770, 797, 803, 807, $832,837,843,850,856,861$, $871,874,882,886,889,909$, 1152, 1297, 1811, 1847, 1849, 1952, 1953, 1959, 2219, 2288, 2334-82, 2410, 2577, 2582, 2583, 2584, 2644, 2847
Guilhem de Saint Gregori, 531, 1972, 2483-85

Guilhem Magret, 2456-59, 2477, 2480, 2482

Guilhem Peire de Cazals, 270, 2004, 2049, 2138, 2292, 246872

Guilhem Raimon de Gironela, 2432, 2473-75

Guilhem Rainol d’At, 750, 247682, 3004

Guillem Anelier de Tolosa, 10991103, 2422-23

Guillem D'ANDUZA, 255, 2421

Guillem de Berguedan, 36, 251, 462, 466, 589, 1013, 1656, 2430-34

Guillem de Durfort, 275, 2444-45

Guillem DE LA ToR, 2493-97, 2992

Guillem de Saint-Didier (SaintLeIDIER), 1381, 1388, 2021, 2486-92, 2497, 2779-82

Guillem Figueira, 262, 721, 781, 788, 794, 889, 898, 1068, 1069, 1513, 1778, 1788, 1843, 1844, 2329-33, 2446-54, 2765, 2770

Guillem Godi, 2315, 2455

Guionet. See Gui de Cavaillon

Guiraudo lo Ros, 280, 754, 24982501

Guiraut de Bornelh. See Giraut de BORNELH

Guiraut de Cabreira, 1442-46

Guiraut de Calanso, 1381, 1383, 1385, 1388, 1391, 1405-9, 1440, 1443,1446, 2522, 2543, 2546

Guiraut d'Espanha, 566, 2523-26

Guiraut Riquier, 33 ,40, 42, 370, 404, 491, 494, 500, 598, 634, 674, 801, 827, 832, 1381, 1408, 1484, 1516, 1674, 1899, 2171, 2172, 2266, 2267, 2465, 252755, 2593, 2706, 2961 
Gutiérrez-Garcia, Santiago, 425

H., Domna. See Domna H.

Haahr, Joan G., 856

Hackett, Winifred Mary, 1085, 1087

Hagman, Roy, 371, 1364

Haines, John, 44, 67, 502, 604, 610, 617, 625, 626, 681, 907, 1797, 2638

Halevi, Meir Ben Eliezer, 1810

Hancke, Gwendoline, 289, 721, 781, 1778, 2333

Hansen, Mary-Louise, 813

Hardy, Ineke, 814, 924

Harley Lyrics, 934, 938, 939, 990-96

Harris, Marvyn Roy, 23, 931, 1036, 1526, 1543-46, 1552, 1575, 1779,1781

Hart, Thomas R., 1645, 1708

Hartmann, Jörg, 935, 942, 968, 1002

Harvey, Ruth, 256, 290, 478, 483, 484, 887, 1124, 1874, 2024, 2052, 2085, 2086, 2109, 2139, 2148, 2171, 2220, 2252, 2264, 2275, 2295, 2320, 2391, 2394, 2397, 2413, 2472, 2474, 2477 , 2499, 2559, 2560, 2622, 2632, 2633, 2639, 2640, 2643, 2644, 2732, 2733, 2812, 2817, 2818, 2939

Hasenohr, Geneviève, 38, 1508, 1527 , 1528, 1534, 1547

Hauf i Valls, Albert, 1195

Haugeard, Philippe, 1091

Haupt, Hans-Christian, 397, 1036

Heart (the eaten heart). See Eaten heart

Heidenreich Findley, Brooke, 772, 2037

Heintze, Michael, 561, 2199, 2595, 2596, 2788

Henrard, Nadine, 61, 965, 1007 , 1322-24, 1331, 1337, 1341, 1342, 1347
Hérilier, Christian, 2158

Hershon, Cyril P., 1420, 1548, 1635, 1812, 2044, 2427, 2587, 2591, 2682, 2828, 2913

Hilty, Gerold, 936, 937, 949, 953, 955, 956, 962-64, 966, 969, 981, 2360

Hinton, Thomas, 1125

Hishikawa, Eiichi, 35, 1955

Hoby, Otto, 2523

Hoekstra, Dirk, 1058

Hoepffner, Ernest, 976, 1332

Hogetoorn, Corry, 2545

Holmes, Olivia, 827, 2546, 3026

Honorat (Sant), 1038, 1555, 1577-78

Horan, William D., 2176

Horrent, Jules, 1109, 1110

Howie, Cary, 2995

Huchet, Jean-Charles, 715, 761, 834, 843, 881, 1125, 1126, 1134, $1135,1153,1166,1176,1186$, 1206, 1228, 1251, 1254, 1279, 1299, 1365, 1466, 2361, 3094

Huglo, Michel, 1650

Hunt, Tony, 1008, 1280

Huot, Sylvia, 1059, 1688

Hurley, E. Anthony, 773

Hutchinson, Patrick, 1818, 2163, 2167, 2450, 2462, 2850, 2900

Ibáñez Rodríguez, Miguel, 1658

Ibarz, Alexander, 65, 1630, 1659, 1937

Indini, Maria Luisa, 1535, 3045

INTAVULARE, 60, 200

Ippolito, Marguerite-Marie, 75, 2071

IsABELLA, 772, 1871, 2256, 2560-62, 2681

Iselda (Yselda). See Alaisina Yselda

Iseut de CAPION, 700, 735, 740, 764, 1901, 1902, 2013, 2563-66

Ivens, Angelika, 1017, 1107, 1116

Izquierdo, Josep, 1549, 1813 
Jackson, William E., 1754, 2641

Jaeschke, Hilde, 2255

Janzarik, Diether, 1357, 3027

Jaufre, 174, 923, 1124, 1125, 1126, 1129, 1134, 1141, 1259-97, 1404,1676

JAUfRe Rudel, 40, 41, 79, 80, 185, 218, 264, 376, 398, 399, 621, 629, 656, 669, 670, 677, 812, $832,850,859,871,873,874$, $877,882,886,888,892,909$, 924, 1218, 1233, 1516, 1689, 1761, 1951, 1966, 2122, 2219, 2355, 2356, 2364, 2567-86, 2653, 2726, 3012

Jeanroy, Alfred, 71, 1328, 1333, 1338, 1348, 1503, 1579, 1922, 3021

Jeay, Madeleine, 1563, 1566

Jensen, Frede, 166, 167, 234, 1709, 1726, 2276, 2337, 2362, 2757 Jewers, Caroline, 743, 782, 1108, $1125,1281,1987,2027$

Jewish, 1803, 1808-19

Jofre de Foixa (Monge de Foissan), 251, 568, 1374, 1656, 2687-90, 3068

Johan Esteve (Olier de Bezers), 547, 565, 2045, 2535, 2587-94, 2912

Johnston, Mark D., 1455, 1456

Johnston, Ronald C., 1993

Jones, Lowanne, 1127, 1385, 1390, 1392, 1394, 1405, 1409

Jordan de l'Isla de Venessi, 2199, 2595-96

JoRDI DE SANT JoRDI, 1668, 25972603, 3084

Judici d'amor (=So fo el temps; =En aquel temps), 1134, 1135, 1298-1306, 1471, 2934

Jullian, Martine, 198, 722

Jung, Marc-René, 1270, 1282, 1381, 1391, 1395, 1401, 1689, 2409, 2489
Kabatek, Johannes, 1435, 1436

Kaehne, Michael, 2083

Kalenda maya, 574, 575, 650, 671, 682

Kaltenbach, Nikki L., 1283

Karnein, Alfred, 372

Kasten, Ingrid, 774, 1755, 1756, 2635

Kay, Sarah, 282, 328, 775, 804, 805, $811,835,857,858,1018,1073$, 1092, 1229, 1284, 1316, 1380, 1382, 1421-25, 1946, 2512, 2579

Keller, Hans-Erich, 205, 1025, 1037, 1110, 1117, 1200, 1304, 1744

Kelly, Douglas, 1285, 1351, 1366, 2710

Kendrick, Laura, 68, 187, 426

Keyser, Dorothy, 620

Khemir, Nawar, 806

Kintana, Xabier, 1100

Kirsch, Fritz Peter, 83, 1207, 1230, 1690

Klein, Annette, 1017, 1107, 1116

Klein, Karen W., 3006

Klein, Otto, 2159

Kleinhenz, Christopher, 2241, 2719

Klingebiel, Kathryn, 14-16, 29, 32, 53, 84, 276, 277, 930, 2734

Koelb, Janice Hewlett, 2642

Köhler, Erich, 461, 488, 584, 2084

Kramer, Johannes, 233

Kravtchenko-Dobelmann, Suzanne, 1336

Krispin, Arno, 441, 750, 2478, 2701

Krülls-Hepermann, Claudia, 618, 663

Kullmann, Dorothea, 62, 1093, 1094

Kuzmenko, Laura, 1956, 1957

Labbé, Alain, 1095

Labbie, Erin F., 747, 783, 792, 2038, 2617

Laborie, Yan, 1632

Lacan, Jacques, 373, 436, 437, 745, $804,831,834,836,839,1424$, 1953, 1988, 2014, 2353, 2361 
Lachin, Giosuè, 85, 200, 1154, 1932

Lacroix, Daniel W., 1438

Lacy, Norris, 1171

Ladányi-Turóczy, Csilla, 1651

Lafont, Robert, 165, 243, 268, 291, 313, 315, 329, 609, 762, 977, 982-84, 999, 1019, 1020, 1021, 1032, 1038, 1039, 1060, 1074, 1080, 1087, 1096, 1102, 1104, $1113,1201,1309,1445,1623$, 1646, 1647, 2243, 2363, 2410, 2851

Lai on cobra sos dregs estatz . . . , 1381, 1385, 1386, 1388, 1396-1404, 2783

Lalande, Denis, 1833

L'altrier cuidai aber druda . . . , 3069-72

Lambert, Malcolm, 1780

Lamur, Anne-Claude, 3046

Landau, Justine, 1367

Landoni, Elena, 807

Lanfranc Cigala, 188, 807, 2413, 2414, 2607-10

Langdon, Alison, 784

Langlois, Gauthier, 1317

Lannutti, Maria Sofia, 650

LANTELM, 2611-12

Lanza Marques (Manfredi Lancia), 2613, 2807

Larghi, Gerardo, 2145, 2244, 2794, 2867

Lartigue, Pierre, 535

Larzac, Jean, 1550

Latella, Fortunata, 2051-55, 2148, 2287, 2320, 3008

Lavaud, René, 2750, 2759

Lawner, Lynn, 1849, 1878

Lazar, Moshé, 354, 1325, 1342, 2069

Lazzerini, Lucia, 218, 320, 882, 897 , 943, 948, 950, 952, 955-57, 966, 992, 1128, 1259, 1989, 1990, 2633, 2643, 2644
Le Vot, Gérard, 229, 605, 608, 637-39, 1976, 2277, 2299, 2922

Lecco, Margherita, 1286

Lee, Charmaine, 174, 231, 1070, 1259, 1287-90, 2877, 2942

Lefèbvre, Gilles, 1336

Lefèvre, Yves, 1505, 1834, 2777

Legenda aurea, 1146, 1556-58, 1567

Leger (Sant), 935, 937, 938, 970, 975, 1001-3

Léglu, Catherine, 462, 466, 467, 482, 589, 723, 917, 1097, 1245, 1255, 1368, 1506, 1630, 2130, 2295, 2645

Legros, Huguette, 1075

Lejeune, Rita, 1237, 2233

Lemaitre, Jean-Loup, 196, 1509

Léon Gómez, Magdalena, 177

Leonardi, Lino, 178, 194

Lepage, Yvan G., 2943

Leppig, Linda S., 1063

Lesfargues, Bernard, 1632

Leterrier, Sophie-Anne, 69

Leube-Fey, Christiane, 472, 526, 557 , 564, 575, 890, 2411

Leupin, Alexandre, 837

Levron, Pierre, 438

Levy, Emil, 20-22, 51, 2098, 2446, 3076

Lewicka, Halina, 1326

Leys d'Amors, 917, 929, 1352, 135973, 2708

Liborio, Mariantonia, 241, 257, 1145

Limacher-Riebold, Ute, 1210, 2858

Limentani, Alberto, 1033, 1076, 1129, $1177,1231,1256,1291,1318$

Linhaura, 2614

Linskill, Joseph, 1001, 1869, 2529, 2870, 2872

Lioce, Nico, 1373

Locher, Caroline, 815, 2278

Loeb, Ariane, 300

LOMBARDA, 740, 772, 775, 783, 
556 Index

792, 802, 840, 2037, 2038,

\section{5-17}

Lombardi, Antonella, 200

Lomenec'h, Gérard, 301

Longobardi, Monica, 1204, 1483, 1824, 2528, 2547, 2548, 2976

Loporcaro, Michele, 2484, 2485

Lorenzo Gradín, Pilar, 859

Luce-Dudemaine, Dominique, 1136, $1178,1202,1232,1310$

Lug, Robert, 86, 619, 627, 2295, 2580

Lushchenko, Marina, 302

Lusson, Pierre, 1976, 2922

Lütolf, Max, 2686

Macdonald, Aileen Ann, 763, 1345, 1864, 3047

Macé, Laurent, 1633

Mahrt, William Peter, 628

Maillard, Jean, 553, 1850, 2915, 3066

Majorossy, Imre, 1137, 1172, 1179, 1187, 1246, 1300, 1320, 1369, 1402, 1426, 1470, 1516, 2513, 2581, 2852, 2936, 2949

Mala canso, mala domna, 454, 456, 468, 471-77, 563, 880, 890, 900, 1823, 1883, 2091, 2280, 2408, $2411,2679,2738,2740,3030$

Mallette, Karla, 1799

Malm, Ulf ,439, 509, 2054, 2148, 2320, 2418, 2646, 2751, 2977, 3098

Mancini, Mario, 401, 402, 838, 1208, 1233, 1842, 2070, 2122, 2996

Mandach, André de, 1637

Manetti, Roberta, 268, 1204, 1586, 2364, 2582, 2799

Maninchedda, Paolo, 1370

Mantovani, Dario, 258, 883, 26922695

Marcabru, 40, 175, 176, 218, 221, 226, 264, 266, 293, 299, 303, 308, 310, 344, 384, 392, 402,
$410,432,439,455,462,495$, 608, 626, 661, 676, 680, 684, $741,803,807,811,819,825$, $832,850,857,859,862,871$, $874,876,877,889,895,902$, 904, 909, 911, 1129, 1233, 1319, 1388, 1433, 1482, 1516, 1689, 1814, 1849, 1888-94, 1952, 2026, 2058, 2081, 2198, 2224, 2288, 2315, 2507, 2575, 2580, 2622-71, 2726, 2910, 3054

Marcenaro, Simone, 2182

Marchesi, Simone, 1958

MarcoAt, 261, 470, 850, 909, 2672-75

Margolis, Nadia, 710

Maria de Ventadorn, 227, 746, 890, 2408, 2676-79, 2830, 2917

Marinetti, Sabina, 3048

Marinoni, Maria Carla, 1567, 1587

Markiol, Lai, 3066-67

Marks, Claude, 292

Marnette, Sophie, 776, 111

Marques (DE Canilhac), 2142, 2680-81

Marshall, John H., 480, 554, 648, 860, 901, 1350, 1355, 1374, 1464, 1867, 1879, 1880, 1935, 2049, 2055, 2085, 2148, 2221, 2253, 2320, 2647, 2687, 2749, 2767 , 2818, 2823, 3049

Martí, Sadurní, 6, 203, 1666

Martin, Frédéric, 1247

Martin-Chabot, Eugène, 1046

Martindale, Jane, 2365

Martinengo, Marirì, 703, 734

Martinez, Ronald, 1741

Martínez, Vicent, 1173

Martínez Blanco, Carmen María, 1681

Martorano, Antonella, 2492, 2832, 2833

Martos, Josep Lluis, 591

Massip, Fransesc, 1346 
Matrre Ermengaud, 1410-34, 2667,

\section{2-86}

Mayer-Martin, Donna, 620

McCash, June Hall, 46, 1856, 1901, 2329, 2564

McPeek, Gwynn S., 2878

Medina Granda, Rosa María, 816

Melani, Silvio, 278, 1835, 2366, 2648

Meliga, Walter, 188, 200, 206, 219, 293, 303, 1529, 2195, 2293, 2295

Melli, Elio, 1084, 2461, 2604

Ménard, Philippe, 1061

Menegaldo, Silvère, 1077, 1112, 1130

Meneghetti, Maria-Luisa, 87, 189, 266, 316, 884-86, 934, 944, 954, 964, 993, 994, 1009, 1155, 1156, 1691, 1794, 1800, 1814, 1890, 2367, 2368, 2644, 2649, 2650, 2673, 3055

Menocal, Maria Rosa, 70, 324, 338, 339, 1801, 1815

Merlin, 1307

Mermier, Guy R., 972, 1710

Mertens, Volker, 1757

Meschini, Marco, 1044

Meylakh, Michael, 374, 427, 1142

Milani, Matteo, 1595

Millay, S. Lea, 785

Milone, Luigi, 368, 2853-55

Minetti, Francesco Filippo, 2549

Minnesänger, 281, 304, 891, 927, 1727, 1753-68

Mitchell, James G., 1406

Mocan, Mira, 428

Mölk, Ulrich, 314, 321, 347, 403, 737, 995, 997, 998, 2017, 2228, 2300, 2527, 3074

Monari, Giorgio, 651, 887, 2086

Monestier, Jean, 2494

Monge de Montaudon (Pierre de VIC), 42, 571, 678, 883, 1156, 2691-99, 2762

Monroe, James T., 340, 1802
Monson, Don Alfred, 356, 375, 817, 931, 1180, 1386, 1403, 1439, $1446,1457,2904$

Montan, 440, 441, 443, 2700-2705

Monterosso, Raffaello, 1004

Moreau, John, 1234

Morgner, Irmtraud, 76

Morlino, Luca, 271, 1398, 1399, 2010, 2783, 2784

Moscatelli, Roberta, 664

Mouchet-Chamard, Florence, 652, 665

Mouzat, Jean, 2004, 2006, 2292, 2468

Muratori, Emilia, 2490, 2779

Murphy-Judy, Kathryn A., 1211

Mussons, Anna Maria, 429, 2651

Mystery Plays, 1339-44

N'At de Mons, 801, 1366, 1473, 1474, 2706-10

Napolski, Max von, 2832

Nappholz, Carol Jane, 738, 2146, 3050, 3051

Naudeau, Olivier, 1026

Naudieth, Fritz, 2456

Navarra, La Guerra de, 1099-1103, 2422

Negri, Antonella, 1843, 2451, 2493

Nelli, René, 77, 245, 440, 586, 1991, 2170, 2174, 2444, 2923, 3087

Nelson, Deborah H., 1683, 2652

Nelson, Jan A., 1836, 2503

Neumeister, Sebastian, 540

Newcombe, Terence H., 562, 2033

Newman, Jonathan, 2369

Nichols, Stephen G., 190, 744, 861, 2321

Nicholson, Derek E. T., 2802

Nicholson, Francesca M., 724, 745, 786, 1427, 2014, 2152

Nicholson, Helen J., 2956

Nieten, Ulrike-Rebekka, 1803

Nompar, Lai, $\mathbf{3 0 6 7}$

Noomen, Willem, 1181 
Nothingness / dreit nien / devinalh (Cycle of poems), 807, 856, 878, 1847 , 1849, 1878, 1884, 2354, 2356

Noto, Giuseppe, 200, 1071, 1143 ,

1157, 2109, 2390, 2496, 2613, 2929

Notomia, 1627-29

Notz-Grob, Marie-Françoise, 1131, $1175,1183,1257,1301,1311$, 1389, 1397

Noulet, Jean-Baptiste, 3091

Novas, 312, 401, 929, 1123, 1127, 1129, 1131, 1132-37, 1175, $1210,1241,1438$

Novas de l'heretge, 1475-77

Okada, Machio, 1569

Older versus younger women (debate), 2051-55

Olivella Madrid, Pilar, 3095, 3096

Oliver, Sophie, 746

Olivier, Philippe, 27, 941

Olivier lo Templier, 2711

Orlando, Sandro 1499

Oroz Arizcuren, Francisco Javier, 259, 1100, 1517, 1914, 2245, 2284, 2326, 2531, 2589, 2775

Ozil de Cadartz, 255, 2712-13

Pacheco, Arseni, 1165

Paden, Frances Freeman, 235, 946

Paden, William D., 17, 42, 63, 71, $88,89,168,175,191,200,212$, 217, 235, 272, 356, 357, 376, 452, 494, 495, 572, 606, 611, 704, 711, 717, 751, 787, 808, $818,828,925,938,945,946$, 956, 959, 996, 1062, 1063, 1605, 1711, 1712, 1804, 1816, 1936, 2020, 2087, 2111, 2123-25, 2172, 2183, 2208, 2301, 2428, $2483,2550,2753,2785,3052$

Page, Christopher, 640
Palais, 577, 578, 579, 883, 2714-16

Palermi, Maria-Laura, 1503

Pales-Gobilliard, Anne, 1769

Palumbo, Giovanni, 1118

Paolo Lanfranchi da Pistoia, 248, 2241, 2717-19

Papagai (Novas), 525, 1123, 1127. 1129, 1134, 1136, 1308-21

Parducci, Amos, 2188, 2189, 2191, 2388

Pasero, Nicolò, 888, 2338

Passion of Augsburg, 934, 935, 936, 937, 938, 960-66

Passion of Clermont-Ferrand, 935, 937, 938, 967-70, 1004

Passion provençale (Didot), 1324, 1335, 1339, 1345-48

Paterson, Linda M., 256, 294, 310, 311, 355, 358, 478, 481, 484, 725, 739, 862, 908, 1027, 1028, 1034, 1035, 1065, 1619, 1874, 1959, 2052, 2109, 2139, 2148, 2164, 2171, 2252, 2256, 2264, 2320, 2391, 2394, 2397, 2472, 2474, 2477, 2479, 2499, 2559, 2560, 2622, 2653-56, 2733, 2879, 2903, 2939, 2953

Patrici (Viatge al purgatori de Sant), 1579-82

Pattison, Walter T., 2841

Paulet de Marselha, 565, 2720-21

Payen, Jean-Charles, 2061, 2370, 2657

Pegg, Mark Gregory, 1064

Peire II, king of Aragon, 251, 1656, 2043, 2736-37

Peire Basc 464, 2062, 2741-42, 3060

Peire Bremon lo Tort, 269, 2745, 2748-49

Peire Bremon Ricas Novas, 266, 649, 2036, 2107, 2162, 2169, 2400, 2745-47, 2748, 2792

Peire Cardenal, 40, 42, 176, 221, 260, 262, 302, 317, 322, 410, 
432, 462, 466, 467, 470, 577,

578, 589, 656, 665, 677, 860, 893, 1069, 1512, 1516, 2040, 2041, 2132, 2423, 2448, 2724, 2759-74, 2907

Peire Catalan, 2754-56

Peire d'Alvernhe, 36, 305, 307, 344 , 580, 582, 677, 769, 803, 862, 874, 877, 902, 903, 909, 1156, 1313, 1893, 2058, 2081, 2327, 2575, 2650, 2722-35, 2843

Peire de Barjac, 477, 900, 2280, 2738-40

Peire de Blai, 2743-44

Peire de Boussignac, 2750-53

Peire de Corbian, 801, 1417 , 1503-6, 1834, 2775-78

Peire de la Cavarana, 2234, 2757-58

Peire de la Mula, 2793-97

Peire de Ladils, 3089-90

Peire de Lunel (Cavalier Lunel de Мontech), 1439, 1441, 1458, 2618-21

Peire de Maensac, 2787-89

Peire de Valeira, 261, 2804-6

Peire Duran, 443, 2490, 2491, 2705 , 2779-82

Peire Guilhem (de Tolosa, de LUSERNA), 271, 1396-1404, 2471, 2783-86

Peire Milo, 569, 1824, 2790-92

Peire Raimon de Tolosa, 36, 269, $482,623,678,927,1751$, 2798-2801

Peire Rogier, 264, 269, 450, 1218, 1305, 2749, 2802-3

Peire Vidal, 36, 40, 176, 262, 266, 275, 300, 317, 322, 582, 597 , 598, 628, 636, 679, 692, 770, 776, 802, 852, 853, 856, 871, $880,1742,1760,1775,1823$, 1936, 2072, 2094, 2210, 2447 , 2613, 2770, 2807-15, 3014
Peirol, 480, 597, 635, 663, 2085, 2447, 2816-18

Pellegrini, Silvio, 1919

Pellen, René, 31

Pelosini, Raffaella, 541

Pendle, Karin, 707

Pépin, Guilhem, 3090, 3097

Perceval Doria, 188, 2825-27

Perdigon, 269, 636, 2021, 2236, 2237, 2819-24, 3014, 3024

Perkal-Balinsky, Deborah, 2227

Peron, Gianfelice, 889, 2452

Perugi, Maurizio, 52, 220, 221, 810, 1745, 1926-28, 1960-63, 2467, 2622, 2658, 2997

Peters, Ursula, 748

Petrossi, Antonio, 558

Peyrebrune, Georges, 2504, 2514, 2515

Pezzimenti, Sara, 2088

Pfeffer, Wendy, 3, 829, 1066, 1343, 1371, 1387, 1484, 1485, 2279, 2330, 2551, 2684, 2689, 2801

Pfister, Max, 26, 34, 64, 1088, 1182 , $1203,1575,1623$

Phan, Chantal, 653-55, 666, 863, 2028, 2552, 2553

Pic, François, 18, 1644

Piccat, Marco, 976, 985, 2177

Picchio Simonelli, Maria, 950, 2095, 2518

Pickens, Rupert T., 453, 2567

Picone, Michelangelo, 1977

Piemme, Jean-Marie, 1334

Pillet, Alfred, 1, 49

Pinkernell, Gert, 1292

Pintarič, Miha, 285

Pirot, François, 1440, 1442, 1493, $1821,2141,2216,2522$

Pistoleta, 623, 678, 2828-30

Pitombeira, Liduino, 682

Pitts, Monique Bonnier, 1559

Pizzaleo, Luigino, 1471 
Planche, Alice, 2856

plazer, enueg, 272, 446, 470, 568-73, 865, 1936, 1939, 2066, 2688, 2689, 3068

Poe, Elizabeth Wilson, 207, 208, 441, 474, 497, 510-12, 527, 528, 559, 752 764, 1158-60, 1258, 1305, $1377,1388,1472,1886,1903$, 1937, 2105, 2126, 2155, 2230, 2403, 2415, 2516, 2702, 2789, 2834, 2916, 3028-30, 3061

Poli, Andrea, 1832, 1835, 1875

Pollina, Vincent, 542, 683, 684, 685, 909, 1692, 2029, 2089, 2302, 2303, 2659, 2660

Pomponio, Rita, 1588

Pons, Alain, 295

Pons Barba, 255, 2831

Pons de Capduelh, 2199, 2832-36

Pons d'Ortaffa, 251, 1069, 1656, 2839-40

Pons Fabre d' Uzes, 531, 1972, 2837-38

Proverbs, 1066, 1478-89, 1497-1500

Puckett, Jaye, 2957

Pulega, Andrea, 1536, 2371

Pulsoni, Carlo, 192, 200, 265, 536, 1161, 2290, 2291, 2795, 2835, 2930

Quan tu a la taula seras, 1490-93 Quan vei les praz verdesir . . , 3073-74 Quatre vertutz principals, 1494-96

Radaelli, Anna, 200, 566, 1866, 2524, 2525, 2609, 2612, 2911, 2918, 3031

Radatz, Hans-Ingo, 1668, 2600

Raguin, Marjolaine, 1067

Raimbaut D'Aurenga, 40, 218, 221, 264, 266, 368, 398, 399, 400, $410,431,460,470,521,2841-$ 66, 3002, 3003
Raimbaut de Beljoc, 2867-68

Raimbaut d'Eira, 2869

Raimbaut de Vaqueiras, 36, 40, 225 , 269, 590, 649, 682, 686, 731, 741, 841, 890, 891, 913, 918, $1013,1701,1735,1742,1876$, 1877, 1883, 1952, 1998, 2005, 2186, 2257, 2292, 2296, 2397, 2848, 2858, 2870-2902

Raimon Berenguier IV D'ARAgon (Coms de Proensa), 1919, 1920, 2383-84, 2952

Raimon Bistortz d'ArLes, 2938

Raimon d'Anjou, 2903-4

Raimon de Castelnou, 2905-7

RaIMON DE CoRnet, 3091-99

Raimon de las Salas, 269, 2927-33

Raimon de Miraval, 36, 40, 77, 78, 262, 300, 487, 568, 597, 598, $656,776,880,1069,1305,1775$, 1823, 1936, 2028, 2253, 2313, 2736, 2919-26, 3010, 3015, 3017, 3018, 3075

Raimon Escrivan, 455, 2908-10

Raimon Gaucelm de Bezers, 2045, 2535, 2590, 2911-13, 2918

RAIMON JORDAN, 760, 814, 1821, 1863, 2914-17, 3054

Raimon Menudet, 2918

Raimon Vidal de Besalù, 251, 1135, 1174-82, 1274, 1298-1306, 1374-78, 1464-72, 1656, 1748, 1935, 2005, 2934-37, 3017

Rambertino Buvalelli, 522, 1823 , 1844, 1887, 2604-6

Rando, Daniela, 1746, 3022

Raupach, Manfred, 2260

Raynouard, François, 20, 24-26, 51

Razos. See vidas

Razos de trobar, 1059, 1135, 1159, 1349-53, 1374-78, 1748

Razos es e mesura . . , 1463, 1999

Rea, Roberto, 1964 
Reculaire, 2939-40, 2994, 3015-17, 3036

Regina Bruno, Laura, 1451, 1452

Religious lyric, 1512-21

Renzi, Lorenzo, 2857

Resende de Oliveira, António, 1713, 1714

Rey-Flaud, Henri, 839, 843

Reynolds, Dwight, 1805, 1807

RIALTO, 48, 60, 81, 247

Ribeiro Miranda, José Carlos, 1713, 1714

Ribémont, Bernard, 330, 377, 726

Ricau de Tarascon, 2195, 2401,

\section{2-54}

Ricaut Bonomel, 2955-58

Richard I of ENGLAND, 542, 675, 918, 2121, 2297, 2302, 2514, 2515, 2693, 2941-44

Richter, Reinhilt, 1428, 1441, 2685, 2686

Ricketts, Peter T., 1, 29, 30, 47, 222, 577, 930, 932, 1038, 1041, 1393, 1410, 1429-32, 1475, 1495, 1510, 1518, 1530-32, 1546, 1577, 1596, 1614, 1615, 1635, 1758, 1781, 2001, 2050, 2067. 2165, 2269, 2271, 2295, 2395, 2460, 2618, 2661, 2714, 2954, 3036, 3038

Riebold, Ute. See Limacher-Riebold Rieger, Angelica, 40, 63, 78, 79, 90, 279, 304, 378, 442, 475, 560, 705, 706, 735, 753, 765, 788-90, 890-92, 1693, 1759, 1855, 1860, 1865, 1871, 1900, 1912, 2009, 2016, 2031, 2036, 2147, 2149, 2153, 2205, 2206, 2225, 2257 , 2280, 2311, 2312, 2328, 2331, 2386, 2411, 2413, 2481, 2491, 2556, 2561, 2563, 2571, 2615, 2662, 2676, 2679, 2681, 2703, 2740, 2741, 2780, 2830, 2859,
2880, 2901, 2917, 2931, 3002, 3053, 3054, 3057, 3060, 3073

Rieger, Dietmar, 91, 454, 468, 473, 488, 579, 830, 2372, 2433

Rigaut de Berbezilh, 40, 1128 , 1147, 2426, 2945-51

Riquer, Isabel de, 236, 404, 471, 476, 513, 543, 693, 716, 727, 1197 , 1198, 1293, 1669, 2091, 2210, 2517, 2554, 2614, 2720, 2738, 2979

Riquer, Martí de, 199, 227, 236, 248, 447, 693, 754, 1837, 1670, 1851, 1854, 1881, 1897, 1909, 1910, 1920, 1930, 1933, 2000, 2007, 2035, 2043, 2063, 2064, 2134, 2166, 2191, 2210, 2246, 2254, 2258, 2285, 2317, 2322, 2324, 2384, 2393, 2404, 2405, 2420, 2429-31, 2439, 2453, 2458, 2464, 2475, 2480, 2518, 2526, 2534, 2592, 2597, 2610, 2674, 2690, 2699, 2717, 2774, 2797 , 2805, 2827, 2839, 2871, 2909, 2932, 2941, 2978, 3007, 3013, 3017, 3018, 3064

Rivière, Jean-Claude, 2836, 2938

Roberge, Pierre-F., 692

Robert, Lo Vesques de Clarmon. See Clarmon (Clermont)

Robinson, Cynthia, 341, 1806

Roca Ricart, Rafael, 2598

Rochegude, Henri Pascal de, 2837

Rollan a Saragossa, 1017, 1104-12, 1113,1796

Rollo, David, 2373

Roman d'Arles, 1015, 1020, 1036-39, 1201, 1584

Romieu, Maurice, 169, 237, 3089

Romualdi, Stefania, 200, 209

Ron Fernández, Xosé Xabier, 405

Roncaglia, Aurelio, 223, 537, 1328, 1891, 1978, 2374, 2380, 2663, 2722 
Ronsasvals, 983-84, 1017, 1111-12, 1113-20, 1796

Roquebert, Michel, 1782

Rosenberg, Samuel N., 608, 694, 1694, 2678

Rosenn, Eva, 728

Rosenstein, Roy, 46, 80, 280, 489, 754, 2090, 2313-15, 2455, 2500, 2501, 2568, 2583-85, 3012

Rossell (i Mayo), Antoni, 36, 505, 514, 595, 613, 656, 668, 686, 893, 894, 1209, 1671, 1838, 1921, 2294, 2304, 2305, 2881

Rossi, Luciano, 267, 544, 895, 986, 1652, 1844, 2215, 2222-24, 2249, 2250, 2440, 2441, 2735

Rossich, Albert, 2980

Roubaud, Jacques, 238, 819, 1847, 1884, 1976, 2922

Rourret, Robert, 170

Routledge, Michael J., 305, 883, 1022, 1588, 2131, 2691, 2695, 2698

Roux, Jean, 1632

Rubagotti, Tiziana, 2348

Rubinelli, Ezio, 1783

Rubio Flores, Antonio Rafael, 2127

Rüdiger, Jan, 360, 430, 1845, 1913 , 2736, 2924

Ruffinatto, Aldo, 1375

Ruiz-Doménec, José Enrique, 2375, 2376

Runnalls, Graham, 1344

Rychner, Jean, 970, 1003

Sainte Agnes, Jeu de, 1322, 1328-35, 1339

Sainte Foy, Canso de, 182, 850, 914, 929, 935, 975, 976-89, 1019, $1020,1102,1555$

Sakari, Aimo, 729, 791, 2002, 2019, 2021, 2039, 2040, 2486, 2497 , 2781,2882

Sakari, Ellen, 2768
Salvador, Vicent, 2434

Salvat, Joseph, 1049, 1132, 1339, $1372,1437,1512,1513,1553$

Salvatori, Enrica, 306, 1738, 1747, 2883, 2899

Salverda de Grave, Jean-Jacques, 2100, 3021

Saly, Antoinette, 1294

Sánchez Jiménez, Antonio, 307

Sánchez Palomino, Dolores, 2459

Sanguineti, Francesca, 408, 1873, 1882, 1883

Sankovitch, Tilde, 712, 747, 792, 840, 1230, 2111, 2154, 2211, 2813

Sansone, Giuseppe E., 239, 246, 1441, 1448, 1453, 1454, 1458, 1908, $1992,2620,2782,2825$

Santano, Julián, 1100

Santini, Giovanna, 55, 224, 1486

Santomá Juncadella, Luís, 1606

Saouma, Brigitte, 406, 407

Satirical gallery poems, 307, 883, 1156, 2005, 2695, 2732, 2734

Savi, Le (Libre de Senequa), 1497-1500

Saviotti, Federico, 225, 2870, 2884, 2892, 2902

Sayce, Olive, 1760

Scarpati, Oriana, 48, 408, 545, 864, $865,2135,3032,3057$

Schaus, Margaret, 45, 708

Schembri, Marcello, 641

Schima, Christiane, 576

Schippers, Arié, 331, 1817

Schlieben-Lange, Brigitte, 1235

Schmidt, Rolf, 960

Schnell, Rüdiger, 379

Schulman, Nicole M., 2274

Schulze-Busacker, Elisabeth, 382, 546, $1017,1115,1116,1119,1335$, $1462,1487-89,2184,2769$, 2998, 2999, 3099

Schutz, Alexander Herman, 1142, 1597, 2242 
Schwarze, Christophe, 971

Schweickard, Cristine, 383, 926

Scinicariello, Sharon Guinn, 1609

Secor, John R., 1519

Seláf, Levente, 896, 1520, 2295, 2412

Sells, Michael, 1807

Senequa (Libre de). See Savi

Sermons, 1437, 1533-39, 2645, 2773, 2951

Serper, Arié, 1141, 2171, 2860

Sestina, 43, 393, 436, 531-38, 689, 820, 849, 1765, 1928, 1953, 1965-81, 2485, 2838

Seto, Naohiko, 178, 2306, 2327, 2664 , 2665, 2712

Shapiro, Marianne, 431, 547, 767, 777, 1374, 1748, 2687

Sharman, Ruth Verity, 2502, 2503

Sheingorn, Pamela, 987

Shepard, Laurie, 733, 2202, 2328, 2385, 2558

Shepard, William P., 1, 1838, 2318

Shinnick, Julia Wingo, 687, 1979

Shirley, Janet, 1048

Sidrac, 1501-2

Sigal, Gale, 46, 511, 515-17, 2198, 2519

Signorini, Maddalena, 210

Signorini, Rodolfo, 2986

Silberstein, Susan Milner, 1184

Simonnet, Émile-Jean, 1199

Siskin, H. Jay, 793, 2212

Sitarz. See Fitzpatrick, Beata

Siviero, Donatella, 2601

Smets, An, 1593

Smith, Nathaniel B., 171, 866, 1672

Snow, Joseph T., 1682, 1715

Solimena, Adriana, 867, 1749

Solla, Beatrice, 519

Soltau, Otto, 2168

Solterer, Helen, 1236

Sordel, 108, 213, 769, 1156,

1459-62, 1488, 1737, 1842,
2166, 2340, 2391, 2940, 2958,

2984-3001, 3025, 3031, 3055

Souto-Espasandín, Mónica, 425

Soutou, André, 2704

Spaggiari, Barbara, 432, 1513, 1892, 2096, 2193, 2666

Spampinato Beretta, Margherita, 730, 2032

Spence, Sarah, 409, 868, 869, 897, 1297

Speroni, Gian Battista, 2185, 2234

Spetia, Lucilla, 2288, 2944

Splittgerber, Lisa, 3000

Sponsus, 914, 934, 935, 938, 1004-10, 1324, 1520

Squillacioti, Paolo, 2199, 2273, 2286, 2595, 2788, 2824

Stäblein, Patricia Harris, 548, 1750, 2111, 2128

Städtler, Katharina, 380, 736, 759, 794, 898, 2332

Stanesco, Michel, 2377, 2861

Stasyk, Maria, 176, 217, 918

Steel, Matthew C., 667, 2092

Steiner, Patricia Owen, 1791

Steiner, Sylvie-Marie, 1502

Stevens, John E., 688

Stickney, Austin, 1494

Storme, Julie A., 793, 2212

Straub, Richard E. F., 1103, 2422

Stronski, Stanislaw, 2251, 2274

Stussi, Alfredo, 1156, 3055

Sumien, Domergue, 1648

Sunderland, Luke, 1433, 2129, 2667

Supplicatio / Declaratio (Guiraut

Riquier/Alfonso X), 2533, 2546

Sweetenham, Carol, 1028

Swiggers, Pierre, 1352, 1358, 1373, 1378

Switten, Margaret L., 11, 346, 592, 598, 608, 629, 661, 689, 695, 820, 1980, 2026, 2626, 2920

Szabics, Imre, 1295, 1296, 2814 
Ţârău, Paul, 1981

Tato Garcia, Cleofé, 2325

Tausend, Monika, 1557

Tavani, Giuseppe, 919, 1182, 1374, 1716, 1938, 2008, 2186, 2187 , 2270, 2272, 2602, 2744, 2887, 2889, 2893, 2894, 2937, 2982

Tavera, Antoine, 433, 1751, 1846, 2247, 2668, 2810, 2815, 3033

Taylor, Mark N., 84, 212, 216, 226, 2622, 2669, 2670

Taylor, Robert A., 2, 3, 19, 57, 268, 642, 920, 1404, 2378, 2584, 2840, 2950, 3070, 3072

Terry, Arthur, 2606

Teulat, Roger, 939, 1537

Teulière, Gérard, 1818, 2167, 2462

Thezaur, 801, 1503-6, 1834, 2776

Thiébaux, Marcelle, 740

Thiolier-Méjean, Suzanne, 12, 381, 410, 470, 1045, 1131, 1175, 1183, 1188, 1241, 1248, 1301, 1311, 1321, 1389, 1397, 1684, 2003, 2130, 2958

Thomas, Antoine, 2520

Thomas, Patrick Michael, 2442, 2443

Thoss, Dagmar, 1098

Thuillat, Jean-Pierre, 2112

Tibors (Na Tibors), 700, 701, 740, 3002-3

Tischler, Hans, 1694

Togni, Nadia, 1237

Toja, Gianluigi, 1925

Tomier e Palaizi, 3004-7

Topsfield, Leslie T., 2919

TorCAFOL, 589, 3008-9

Tortoreto, Valeria, 1894, 2096, 2215-17, 2671

Tostemps (Raimon de Miraval?), 487, 3010

Touber, Anton, 72, 927, 1695, 1727, 1761-64

Toulouse School, 3080-85

Traeschler, Richard, 1120
Treitler, Leo, 669, 670

Trobar clus, leu, plan, 415, 422, 427, $807,850,857,869,901-11$, 1350, 1926, 1961, 2506, 2843, 2850, 2852, 2862

Troncarelli, Fabio, 2770

Trotter, David A., 1624-26

Trottier, Marc, 921, 2983

Tufano, Ilaria, 1752

Turc Malec. See Cornilh affair, 1982-92

Uc Brunenc, 2244, 2743, 3011-12

UC dE L'Escura, 636, 3013-14

Uc de Mataplana, 251, 754, 1305, 1656, 2312, 2314, 2432, 2940 , 3015-18

UC de Pena, 3019-20

Uc de Saint Circ, 186, 211, 483, 519, 527, 649, 764, 1148, 1149, 1152, 1156, 1158, 1160, 1162, 1355-58, 1840, 1886, 19001903, 1912, 2009-15, 2024, 2099, 2156, 2225-31, 2563, 2565, 2586, 2834, 3016, 302135, 3037, 3075

Uguet (Uc de Saint Circ?), 2939, 3015-18, 3036-37

Uhl, Patrice, 342, 443, 567, 590, 843, 1847, 1884, 2360, 2379, 2705

Uitti, Karl, 37, 988

Unlandt, Nicolaas, 1696, 1765, 2885

Uulders, Hedzer, 529, 530

Vai Hugonet . . , 3075

Vallet, Edoardo, 870, 1728

Vallette, Jean René, 1785

Vallín, Gema, 671, 2380, 2459, 2886

Van d'Elden, Stephanie Cain, 1766, 1767

Van der Horst, Cor H. M., 1164, 1168 van der Werf, Hendrik, 599, 607, 621, 641, 643, 1838, 1931, 2335, 2406, 2568, 3011 
Van Vleck, Amelia E., 795, 2213, 2951

Vanin, Claudio, 672

Varvaro, Alberto, 317, 2945

Vatteroni, Sergio, 1, 57, 60, 222, 260, 455, 578, 932, 1939, 2041, 2064, 2136, 2201, 2307, 2308, 2364, 2423, 2454, 2463, 2582, 2588, 2593, 2759, 2760, 2771-73, 2910

Vecce, Carlo, 1975

Vela, Claudio, 1975

Veltman, Willem Frederik, 1786

Ventura, Simone, 200, 1611, 1616, 2711

Verlato, Zeno Lorenzo, 296, 1521, 1887, 2606, 3001, 3078, 3079

Versus limousins, 938, 1011-12, 1512

Vialle, Colette, 1219, 1252

Vicent Santamaria, Sara, 1190, 1196

Vidal i Alcover, Jaume, 1192, 1353, 3056

Vidas and razos (biographies), 34, 79, 91, 199, 227, 229, 236, 241, 242, $257,381,632,884,1123,1125$, 1127, 1130, 1131, 1142-62, 1589, 1840, 1844, 1912, 2309, 2310, 2415, 2496, 3029

Viel, Riccardo, 261, 1893, 1895, 1904, 2316, 2672, 2804

Vielliard, Françoise, 196, 933, 958, 1592

Vignaux, Alphonse, 1579

Viguier, Marie-Claire, 1189, 2173

Vitale-Brovarone, Alessandro, 327, 1327, 2786

Vitz, Evelyn Birge, 1238

von Gohren, Abbey, 1434

Vuijlsteke, Marc M., 910, 2862-65

Wahl, Angelika, 1511

Walkley, Maxwell, 1239

Warning, Rainer, 644

Washer, Nancy, 899

Wells, Courtney, 1354

White, Sarah, 733, 2202, 2328, 2385, 2558
Widmayer, Jefferey S., 1636

Wilhelm, James J., 1459, 1931, 2985

Wilhite, Valerie M., 1306

Wind, Bartina, 359

Wingell, Richard J., 673

Winter-Hosman, Mièke de, 434,477, 900, 2280, 2740

Wolf, George, 2568

Wolfenbüttel manuscript, 3076-79

Wolterbeek, Marc, 2381

Work, Elisabeth P., 989

Wunderli, Peter, 456, 1546, 1551, 1552

Wüstefeld, W. C. M., 1634

Yearley, Janthia, 539

Zago, Esther, 1242, 1249

Zak, Nancy C., 1240

Zambon, Francesco, 262, 911, 1068, 1476, 1787, 1788, 2065

Zamuner (Candiani), Ilaria, 200, 1620, 1621,3063

Zemp, Josef, 2196

Zemplényi, Ferenc, 1789

Zielkowski, Jan, 37

Ziino, Agostino, 596, 1010, 2440

Ziltener, Werner, 59

Zimei, Enrico, 193, 200

Zinelli, Fabio, 49, 200, 211, 273, 563, 1558, 2094, 3021, 3034, 3035

Zink, Michel, 38, 359, 1263, 1538, 2555, 2895, 2925

Zorzi, Diego, 1539

Zotz, Nicola, 1768

Zuchetto, Gérard, 240, 692

Zufferey, François, 1, 13, 194, 195, $272,490,518,573,755,766$, 1000, 1139, 1162, 1593, 1939, 2200, 2339, 2382, 2521, 2586, 2866, 3059, 3081

Zumthor, Paul, 951 
Typeset in 10/12 Adobe Garamond Pro Composed by Tom Krol

Medieval Institute Publications

College of Arts and Sciences

Western Michigan University

1903 W. Michigan Avenue

Kalamazoo, MI 49008-5432

http:/ /www.wmich.edu/medieval/mip 


\section{Research in Medieval Culture}

MIP's Research/Studies in Medieval Culture series is particularly interested in the idea of the medieval vernacular in all its incarnations, extending beyond language to include literary cultures, vernacular religion, daily life and material culture, social and group identity, the nature of the commons and domesticity, and lay cultures.

Previous volumes in the series have also covered saints and heretics, devotional and popular literature, onomastic and prosopographical research, urban and rural life, and have ranged from the North Atlantic to the Eastern Mediterranean.

Although it seemed in the mid-1970s that the study of the troubadours and of Occitan literature had reached a sort of zenith, it has since become apparent that this moment was merely a plateau from which an intensive renewal was being launched. In this new bibliographic guide to Occitan and troubadour literature, Robert Taylor provides a definitive survey of the field of Occitan literary studies - from the earliest enigmatic texts to the fifteenth-century works of Occitano-Catalan poet Jordi de Sant Jordi-and treats over two thousand recent books and articles with full annotations. Taylor includes articles on related topics such as practical approaches to the language of the troubadours and the musicology of select troubadour songs, as well as articles situated within sociology, religious history, critical methodology, and psychoanalytical analysis. Each listing offers descriptive comments on the scholarly contribution of each source to Occitan literature, with remarks on striking or controversial content, and numerous cross-references that identify complementary studies and differing opinions. Taylor's painstaking attention to detail and broad knowledge of the field ensure that this guide will become the essential source for Occitan literary studies worldwide.

Robert A. Taylor has studied Romance philology and medieval poetry in Germany, France, California, and especially in his native Toronto, where he is Professor Emeritus at the University of Toronto. 